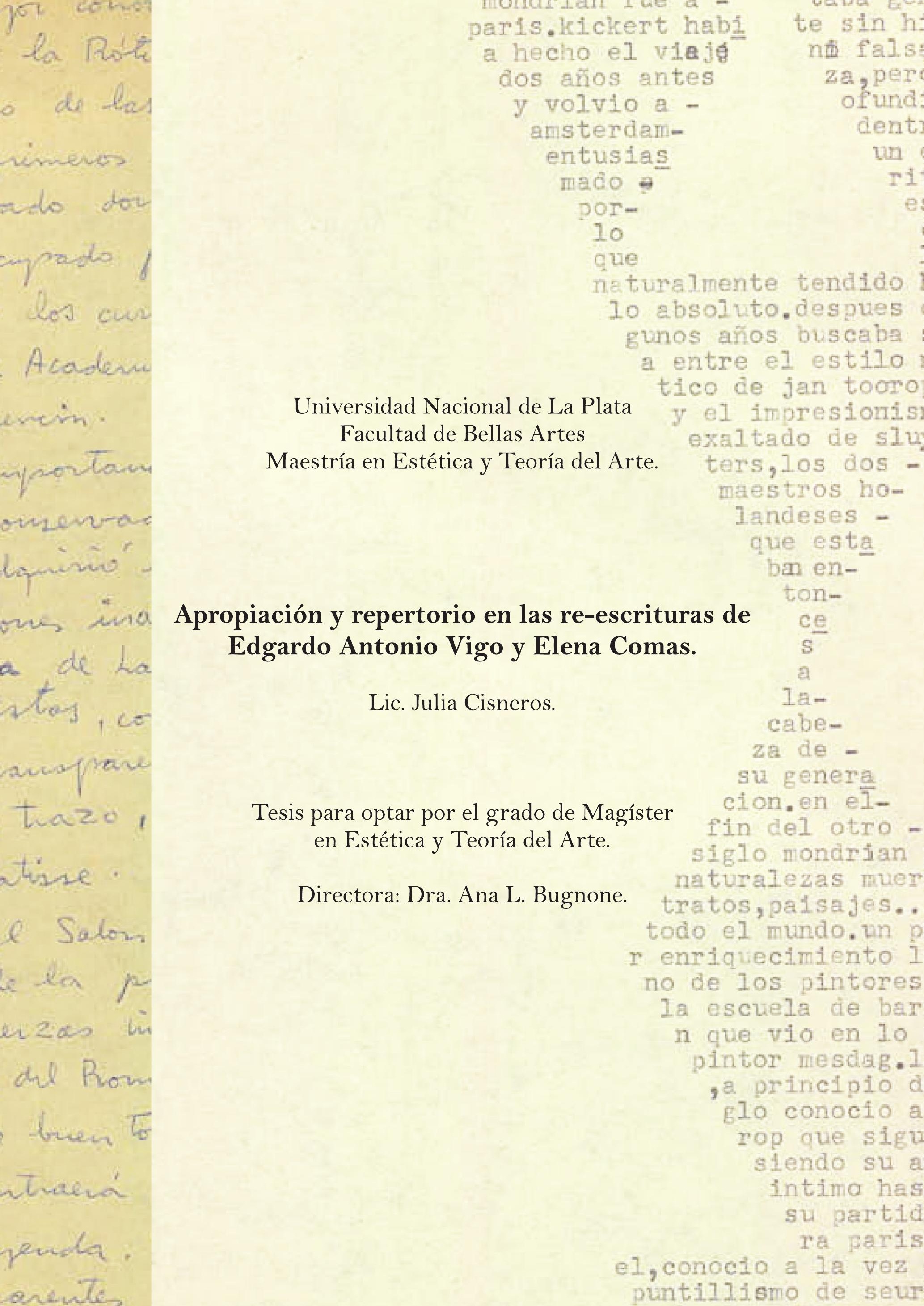




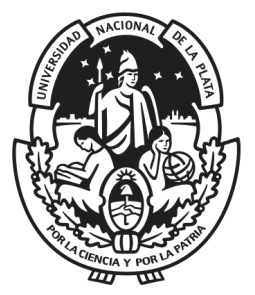

Universidad Nacional de La Plata

Facultad de Bellas Artes

Maestría en Estética y Teoría del Arte.

\section{Apropiación y repertorio en las re-escrituras de Edgardo Antonio Vigo y Elena Comas.}

Lic. Julia Cisneros.

Tesis para optar por el grado de Magíster en Estética y Teoría del Arte.

Directora: Dra. Ana L. Bugnone.

Diciembre 2019. 


\section{Resumen:}

La presente propuesta se enmarca en los estudios de Estética y Teoría del Arte para obtener el título de Magíster por la Universidad Nacional de La Plata. La tesis se centra en el análisis de las re-escrituras de Edgardo Antonio Vigo (1929-1997) y Elena Comas (1934-2006) presentes en el Archivo Centro de Arte Experimental Vigo de la Ciudad de La Plata.

Estudiamos, por una parte, el estatuto de lo que hemos denominado re-escrituras, analizando su incidencia en la obra publicada y expuesta de Edgardo Antonio Vigo así como los procedimientos de apropiación y el concepto de repertorio para analizar estos compendios de lecturas y re-escrituras. Trabajamos con tres grandes ejes, en correspondencia con las temáticas

predominantes en las re-escrituras: vanguardia, poesía experimental e historieta. Atendemos en el desarrollo de estas páginas a la acción como traductora y artista de Elena Comas, así su incidencia en los ejemplares que estudiamos.

Nuestra hipótesis de trabajo se centra en los modos en que las re-escrituras inciden en la producción editorial, plástica y de difusión cultural (en forma de artículos y charlas) de E. A. Vigo a partir de las diversas formas que asume la apropiación en su producción.

En torno a la metodología, trabajamos con un diseño cualitativo, relevamos y organizamos fuentes documentales del acervo CAEV. Seleccionamos para la tesis un corpus de re-escrituras para vincularlas con obras expuestas de Vigo, publicaciones y charlas que dan cuenta de los modos en que la lectura se vincula con la producción del artista platense.

\section{Palabras clave:}

EDGARDO ANTONIO VIGO - ELENA COMAS - RE-ESCRITURAS - LECTURA APROPIACIÓN - REPERTORIO. 


\section{PRIMERA PARTE}

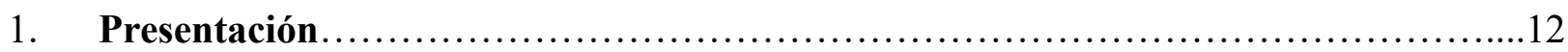

Consideraciones preliminares..................................... 12

1.2 Archivo, Serie Escritos Personales, Sub Serie re-escrituras..................14

Propuesta de tesis................................................

Organización del trabajo...........................................

2. Metodología .............................................................. 18

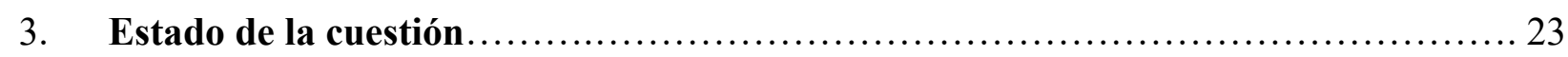

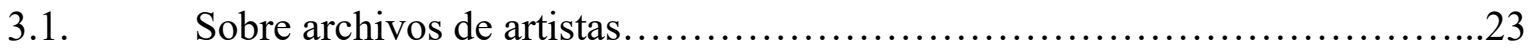

3.2. Archivo E. A. Vigo................................................. 26

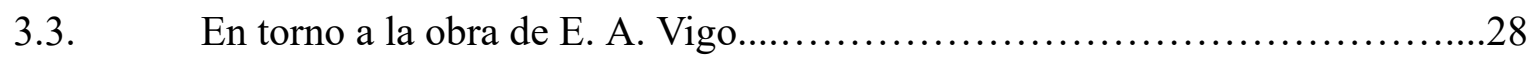

3.4. Re-escrituras..................................................

3.4.1. Antecedentes de Estudio....................................... 35

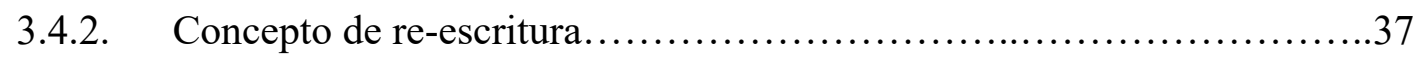

3.4.3 Definición por diferencia.................................... 38

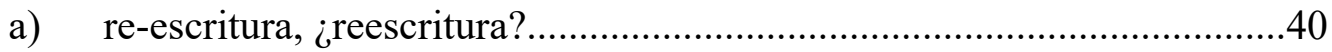

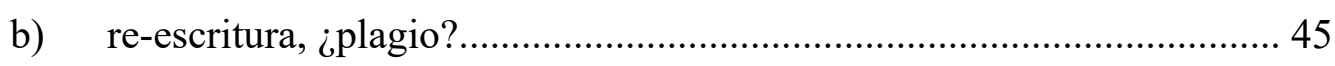

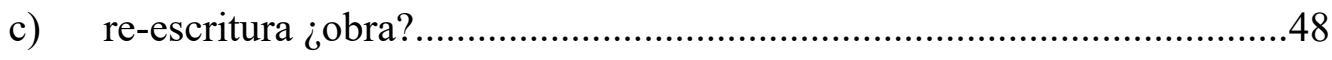

3.4.4 De máquinas de escribir y archivos..................................................48

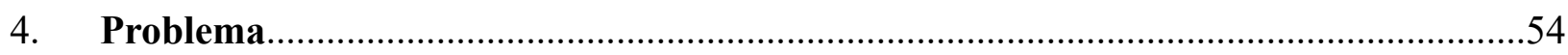

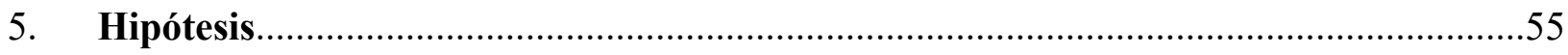




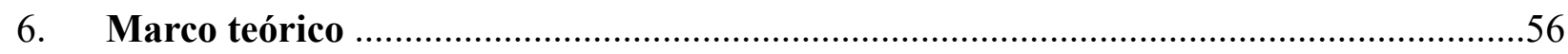

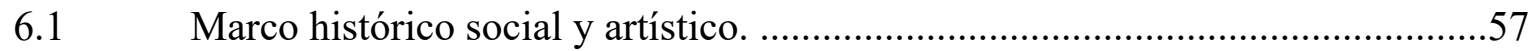

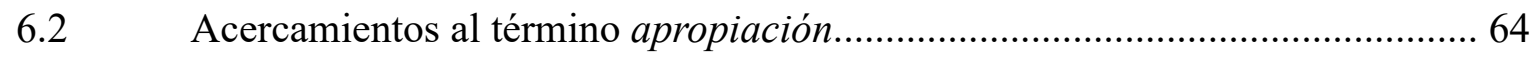

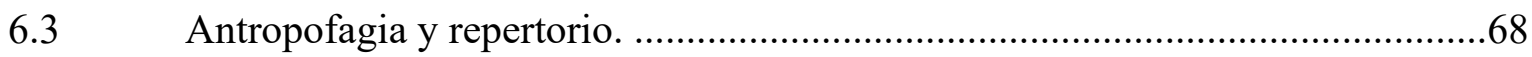

Repertorio y re-escritura........................................................................

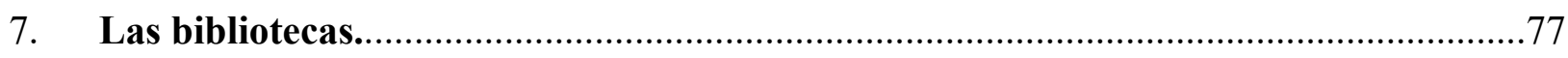

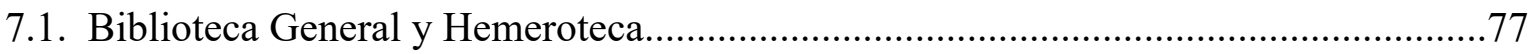

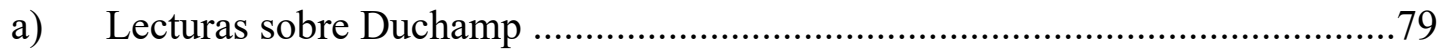

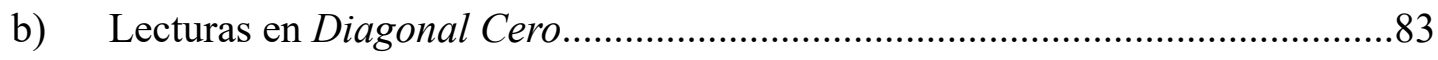

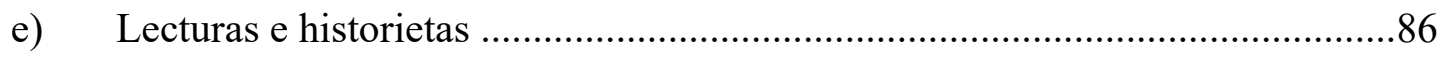

8. Lecturas y re-escrituras: Serie Escritos Personales. ..............................................91

a) Cuadro 2: Libros de referencia para las re-escrituras .................................................93

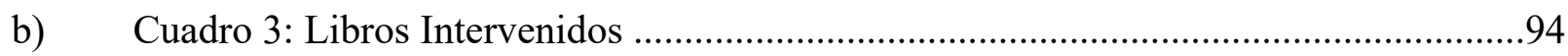

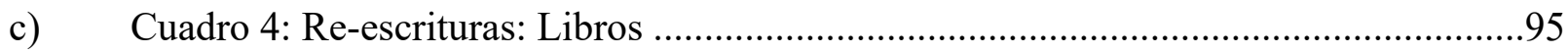

d) Cuadro 5: Re-escrituras: Selección de Artículos ........................................................97

e) Cuadro 6: Charlas, ensayos y textos íntegramente escritos por E. A. Vigo .................103

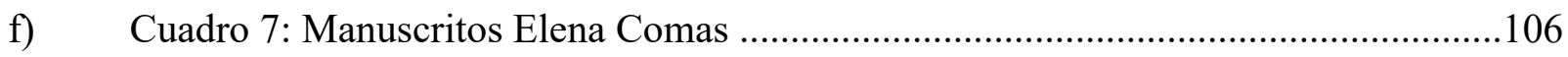

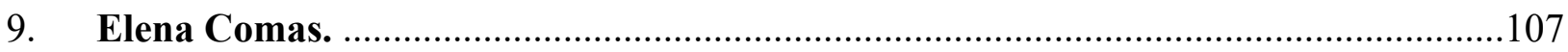

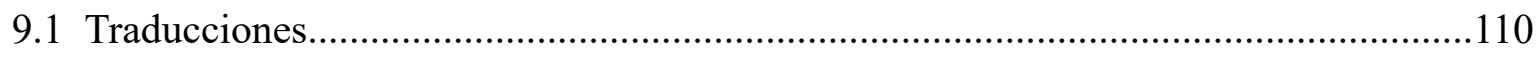

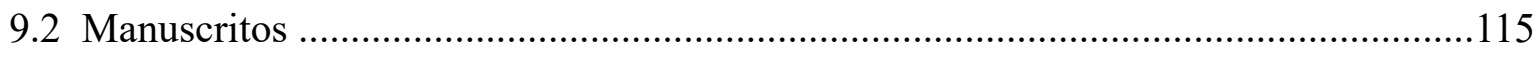

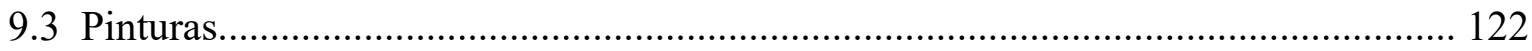

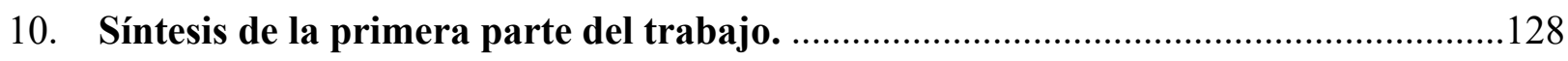


Capítulo 1. Vanguardias.

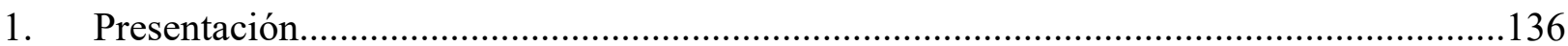

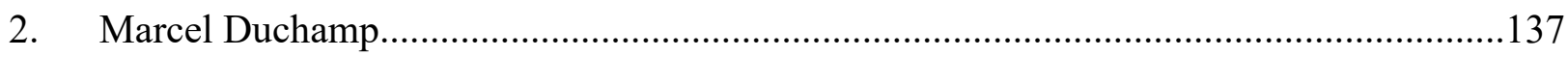

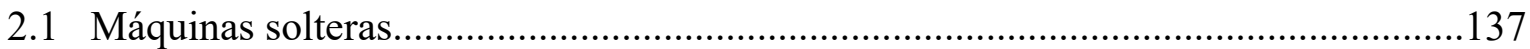

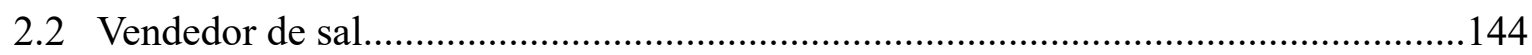

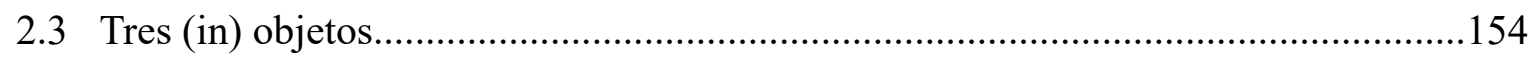

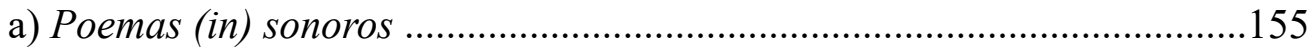

b) Análisis (in) Poético de $1 \mathrm{~m}$. de hilo ........................................................157

c) Poemas matemáticos (in) comestibles .................................................161

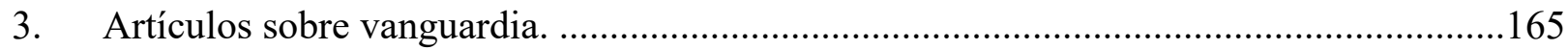

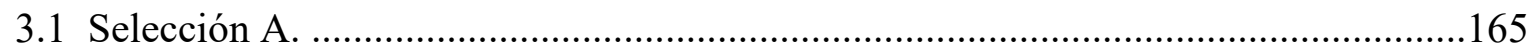

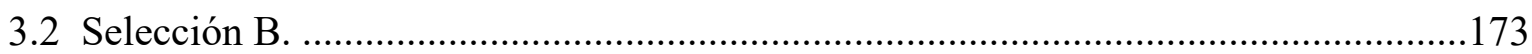

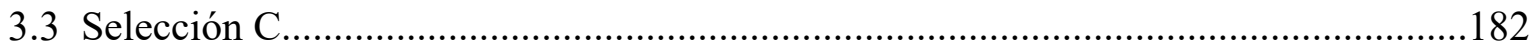

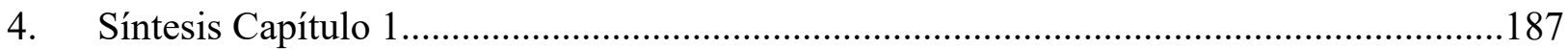

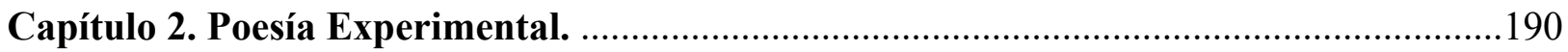

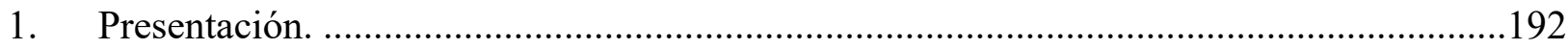

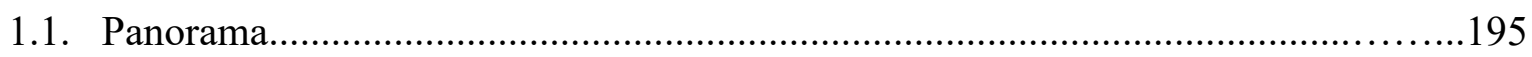

1.2. Poesía Concreta/ Poema Proceso. …….....................................................................198

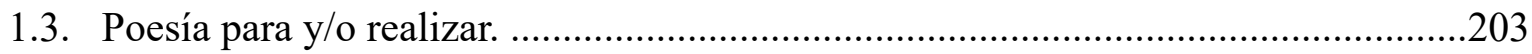

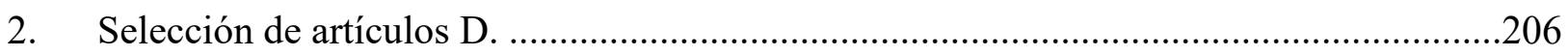




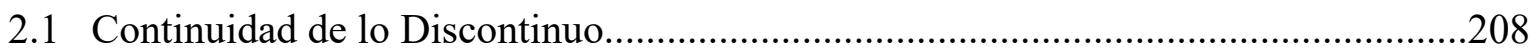

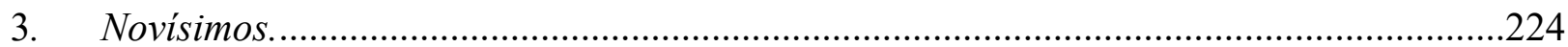

4. Síntesis Capítulo 2 ..........................................................................................249

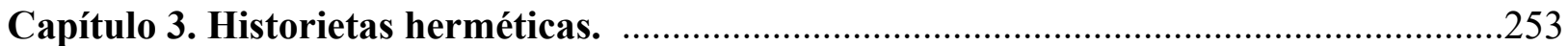

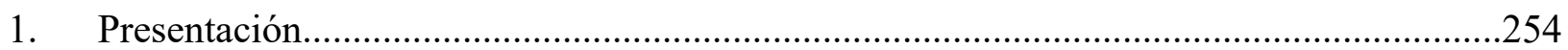

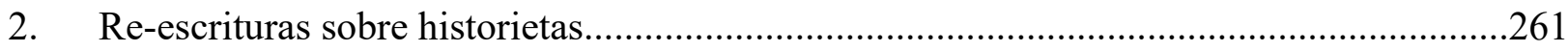

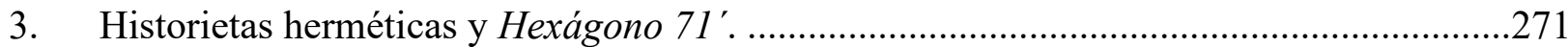

3.1 Grupo de familia, citas y apropiaciones ..............................................................273

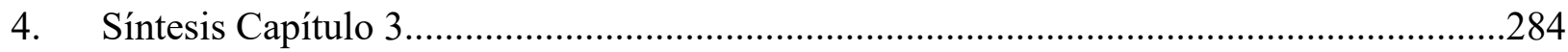

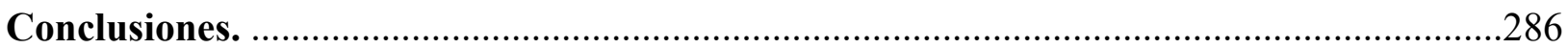

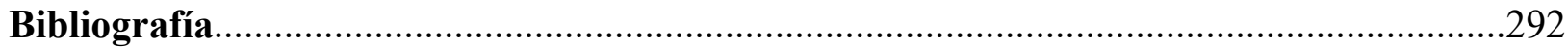




\section{Agradecimientos}

Quiero agradecer en primer lugar a quienes participan y gestionan el Centro de Arte Experimental Vigo particularmente a su directora, Ana María Gualtieri, por haber compartido generosamente su conocimiento, por incentivar y apoyar esta propuesta. A todas las personas del CAEV con las que aprendí más de este universo a partir de conversaciones, muestras, viajes e investigaciones: Mariana Santamaría, Mariana Fuks, Julio Lamilla, Natalia Aguerre, Julia Martinez, Clarisa López Galarza, Federico Santarsiero y Alan Courtis.

Agradecer a Ana Bugnone, la directora de esta tesis, por su lectura atenta, lúcida y rigurosa en cada revisión, la dedicación el proceso que significó este trabajo y su confianza en los proyectos. A mi familia, Gabriela, José y Juan, por estar, compartir y apoyar siempre los mundos que me interesan, gracias por las conversaciones, las preguntas, los viajes y sus miradas otras que aportaron mucho a este trabajo.

Muy especialmente a Mauricio, gracias por nuestro dia a dia, las máquinas y el amor.

A mi abuela Antonia, primera archivista, por su escritura urgente en papelitos parisienne. 
PRIMERA PARTE 


\section{Presentación}

Esta tesis se propone como un aporte de investigación dentro de la Maestría en Estética y Teoría de las Artes enmarcada en los estudios de posgrado que ofrece la Universidad Nacional de La Plata. Comentaré brevemente las motivaciones que llevaron a elegir las re-escrituras de Elena Comas y Edgardo Antonio Vigo como centro de estas reflexiones.

\subsection{Consideraciones preliminares}

Luego de haber culminado la tesina para obtener el título de grado como Licenciada en Letras Modernas en la Universidad Nacional de Córdoba ${ }^{1}$, mi interés se orientó hacia la investigación de sistemas gráficos o escrituras objeto ${ }^{2}$ dentro de la poesía experimental argentina. A partir del estudio de la obra de Xul Solar, particularmente sus Grafías Plastiútiles o Pensilformas, comencé a indagar sobre la producción plástica de otros artistas argentinos que abordaban una problemática similar en torno a la letra y la representación plástica ${ }^{3}(2015$, UNC). Centrando la atención en la producción de este tipo de obras en el período 1960-1970, por sugerencia de la profesora Carina $\mathrm{Cagnolo}^{4}$, comenzó mi introducción lenta pero persistente en la poética de Edgardo Antonio Vigo. En principio conocí la obra del artista platense a partir de internet, (gracias a la digitalización de obras realizada por el equipo del CAEV) y posteriormente, ya radicada en La Plata, participando como voluntaria e investigadora del Centro de Arte Experimental Vigo.

Desde marzo de 2015 asisto semanalmente al Archivo para participar de actividades culturales, investigar y organizar el material de re-escrituras como así también de lo que fuera la Exposición Internacional de Novísima Poesía/69 y otros materiales de archivo.

Ana María Gualtieri, directora del Centro Vigo, fue mostrándome en estos años el patrimonio que alberga este espacio, no solo del artista sino también de otros muchos que participaron en

\footnotetext{
${ }^{1}$ El trabajo lleva por título: Lectura en clave pan-astrológica del Adán Buenosayres: Leopoldo Marechal, Xul Solar y la vanguardia Martinfierrista. Directora: Dra. Cecilia Corona Martínez. Universidad Nacional de

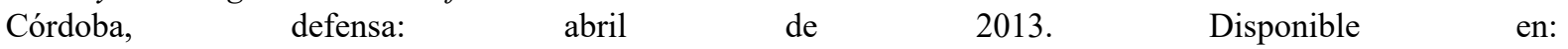
https://www.academia.edu/34100725/Lectura en clave pan-astrol $\% \mathrm{C} 3 \% \mathrm{~B} 3$ gica del Ad\%C3\%A 1 n Buenosay res_Leopoldo_Marechal_Xul_Solar_y_la_Vanguardia_martinfierrista

${ }^{2}$ La denominación pertenece a Tomás Vera Barros (2014).

3 En el marco del proyecto de investigación Heterodoxias y Sincretismos en los márgenes de la Literatura Argentina dirigido por Dra. Cecilia Corona Martínez y Dra. Andrea Bocco. Centro De Investigaciones María Saleme De Burnichon, FFyH, UNC.

${ }^{4}$ Docente de Historia del Arte con quien realice la Adscripción a Historia del Arte III en la Universidad Provincial de Córdoba, Figueroa Alcorta.
} 
sus actividades. Me propuso el trabajo de fichaje de una parte específica del Archivo de E. A. Vigo, me refiero aquí a un conjunto de escrituras con originales particularidades que serían, posteriormente, el centro de mi objeto de estudio para la presente Tesis de Maestría.

Actualmente, mi participación como integrante del proyecto "Cultura y Sociedad en Argentina y Brasil: siglos XX y XXI"5, bajo la dirección de la Dra. Ana Bugnone me ha permitido avanzar y profundizar aspectos de esta tesis, especialmente en relación con la Exposición Internacional de Novísima Poesía/69 y su vínculo con las re-escrituras.

\subsection{Archivo, Serie Escritos Personales, Sub Serie re-escrituras}

Para comprender las características de las re-escrituras que esta tesis se propone analizar, y antes de plantear el objeto de esta, es necesario adentrarse en la organización del Centro de Arte Experimental Vigo. Esta institución cuenta con tres áreas: Biblioteca, Hemeroteca y Archivo. El fondo documental del Archivo se clasifica en series ${ }^{6}$ :

- Serie Documentos personales de EAV.

- Serie de Exposiciones organizadas por EAV.

- Sub Serie: Exposición Internacional de Novísima Poesía/69

- Serie Arte Correo.

- Serie obra artística (objetos, xilografía, poesía visual, arte-correo, arte sonoro).

- Serie Fotografías, diapositivas y videos.

- Serie Publicaciones (revistas experimentales, libros de estampillas, cajas de poesía visual).

- Serie documentos, obras y publicaciones de otros artistas.

- Serie Escritos Personales.

- Sub serie: re-escrituras (A- de libros, B- de artículos)

- Libros de Referencia para las re-escrituras;

- Libros Intervenidos;

- Sub serie: Textos Personales (charlas, publicaciones, ensayos escritos íntegramente por Vigo no publicados)

- Sub serie: Manuscritos de Elena Comas.

\footnotetext{
${ }^{5}$ Código PPID/ H061 acreditado por la UNLP en el Instituto de Investigaciones en Humanidades y Ciencias Sociales de la Facultad de Humanidades y Ciencias de la Educación (IDIHCS, FaHCE, UNLP-CONICET).

${ }^{6}$ Tomamos el relevamiento del trabajo realizado por Ana Bugnone y Mariana Santamaría, agregando las nuevas series clasificadas hasta 2019.
} 
- Sub fondo: Museo de la Xilografía.

Las re-escrituras, por su unidad y materialidad, forman parte de la Serie Escritos Personales dentro del Fondo Documental del Archivo Vigo. Son, materialmente, libros mecanografiados, diseñados y editados por E. A. Vigo que copian otros libros, de manera completa o fragmentaria, en muchos casos traducidos por Elena Comas. Las re-escrituras son piezas que no fueron concebida como obra para ser expuesta y pertenecen, en principio, al ámbito de lo íntimo (Gustavino, 2014). Entendemos que estos materiales dan cuenta de ciertos procesos previos a las obras mostradas y editadas que motivan, como analizaremos en esta tesis, una utilización particular por parte del artista, ya sea como registro, como compendio de conocimientos o bien como pre-texto.

El material estudiado también contribuye a echar luz sobre la figura de Elena Comas, traductora y compañera de Vigo desde 1954, en tanto muchas de las re-escrituras son traducciones inéditas al español realizadas por ella y posteriormente mecanografiadas por Vigo. Se trata entonces de un corpus de libros encuadernados, diagramados y editados que copian otros textos ya publicados por otros autores.

Decimos que las re-escrituras pertenecen a una nueva Serie dentro del Archivo de Edgardo Antonio Vigo denominada Escritos Personales. Esta catalogación permite diferenciar los ejemplares de re-escrituras del fondo documental Biblioteca, si bien están, como veremos en el transcurso de esta tesis, íntimamente vinculados. Se configuran como una nueva serie porque son documentos de estudio, tienen, en principio, una finalidad teórica e intelectual para su formación.

Los libros y artículos que Vigo ha copiado y han sido traducidos por Elena Comas (total o parcialmente) en las re-escrituras se encuentran apartados de la vasta Biblioteca General puesto que dan cuenta de modos particulares de lectura y escritura conformando la serie Escritos Personales. Dentro de esta encontramos tres sub series: re-escrituras, textos personales de Vigo y manuscritos de Comas.

La sub serie re-escrituras contiene: los libros originales han sido denominados "Libros de referencia para las re-escrituras" (estos han servido como base para las re-escrituras de libros completos y una serie de artículos) y los "Libros Intervenidos" (son aquellos ejemplares en los que Vigo ha modificado el aspecto externo del ejemplar original sin transformar el contenido). Encontramos dentro de la Serie Escritos Personales charlas y documentos no publicados de E.A. 
Vigo como así también los manuscritos de Elena Comas. Todos estos materiales serán analizados pormenorizadamente en esta propuesta.

Los textos que se transcriben en las re-escrituras son de procedencia diversa: libros completos, artículos de revista, catálogos o suplementos culturales. Algunas re-escrituras poseen ilustraciones en su interior (en su mayoría realizadas por Vigo, uno ilustrado por Comas); otras, recortes de imágenes que acompañan e ilustran el contenido de lo dicho en el artículo. En cada ejemplar hay un trabajo de edición por parte de E. A. Vigo no solo en lo que respecta al repertorio de autores que se elige, sino también en la disposición del diseño de página, columnas, tipografías y el trabajo de encuadernación.

A partir de las características del material de la Serie Escritos Personales, hemos considerado pertinente dividirlo en las siguientes sub series:

1. "Re-escrituras" (A- de libros, B- de artículos), dentro de la misma 1.1. "Libros de Referencia para las re-escrituras", 1.2 "Libros Intervenidos",

2. “Textos Personales" (charlas, publicaciones, ensayos escritos íntegramente por él no publicados),

3. "Manuscritos de Elena Comas".

Por otra parte, a partir del relevamiento realizado, podemos afirmar que el material de las re-escrituras presenta tres temáticas predominantes: vanguardias históricas, poesía experimental e historieta. Estos ejes serán la columna vertebral de la segunda parte de nuestro análisis.

\subsection{Propuesta de tesis}

El objeto de investigación de la presente tesis está formado por los ejemplares de re-escrituras presentes en la Serie Escritos Personales del Archivo de E. A. Vigo, resguardados en el Centro de Arte Experimental Vigo. Si bien estos ejemplares han sido abordados en los trabajos de Berenice Gustavino (2012, 2015) y Mario Gradowczyk (2008), consideramos que hay una vacancia en la investigación en lo que respecta tanto al vínculo y análisis entre estas re-escrituras inéditas y la obra de E. A. Vigo expuesta y publicada, así como también a la tarea de Elena Comas como traductora y artista.

Expongo en esta instancia de presentación algunas de las preguntas que guiaron la investigación: ¿Cuáles son las particularidades de estas re-escrituras y porqué fueron producidas? ¿Cómo se vinculan las re-escrituras con el archivo? ¿Mediante qué criterios Edgardo Antonio Vigo 
organiza esta gran producción de escrituras previa a las obras? ¿Qué huellas quedan en estas copias? ¿Qué queda de las re-escrituras en la producción expuesta de E. A. Vigo?

Esta tesis considera como hipótesis general que las re-escrituras inciden de manera directa en la producción plástica, editorial y de divulgación del artista. Las re-escrituras aparecen de forma directa a partir de la inserción de estos textos en sus publicaciones o charlas, o bien como cita y alusión en sus obras. Los ejemplares de re-escritura también dan cuenta de modos particulares de lectura y escritura en la apropiación del conocimiento plasmado en los procesos de selección y edición del material por parte de Vigo. Destacamos en este punto el trabajo como traductora de Elena Comas en tanto es ella, con su conocimiento de francés e italiano, quien permite y posibilita una comunicación fluida de Vigo con artistas internacionales, también subrayamos la importancia de sus traducciones pioneras e inéditas, en muchos casos, hasta el momento en español.

El objetivo de este trabajo es por lo menos doble: en primer lugar nos proponemos describir y explicar las particularidades de los ejemplares de re-escritura y, en segundo lugar, atender a la incidencia de las mismas en la obra publicada y expuesta de E. A. Vigo. Se trabajará para ello con la sistematización de las re-escrituras en el archivo y el análisis de obras y publicaciones en el período que comprende desde mediados de la década de 1950 hasta 1975, en correspondencia con los años en que Vigo y Comas producen estos ejemplares.

Consideramos con esta tesis poder realizar un aporte original a la lectura de la obra del artista platense E. A. Vigo y Elena Comas desde el análisis de la Serie Escritos Personales. Se expondrán y problematizarán los procesos de lectura, escritura y producción de obra artística como modos complejos de elaboración y deglución de diversos materiales teóricos y visuales, que, en el caso de Edgardo Antonio Vigo, presentan particularidades originales susceptibles a ser analizadas de manera pormenorizada. Esperamos también poder visibilizar el trabajo de Elena Comas como traductora y artista.

\subsection{Organización del trabajo}

La tesis se encuentra estructurada en dos partes. En la primera desarrollamos la Metodología y el Estado de la Cuestión, centrado en la caracterización de los archivos de artista, particularmente el Centro de Arte Experimental Vigo, así como también acercamientos a nuestra noción de re-escritura diferente a la de reescrituras. 
En el apartado Marco Teórico, analizamos los principales desarrollos en torno a la noción de apropiación y repertorio para comprender los modos en que E. A. Vigo utiliza el material presente en sus re-escrituras. Nos abocamos en los dos últimos apartados de la primera parte de esta tesis a plantear una descripción y ordenamiento de la Biblioteca General y Serie Escritos Personales, así como también a poner en valor la acción como traductora de Elena Comas y su función dentro de los ejemplares que estudiamos, ya que su trabajo no se restringe a la traducción de los textos teóricos sino que también permite profundizar el intercambio de Vigo con artistas internacionales.

En la segunda parte del trabajo, dividida en tres capítulos, nos centramos en el estudio de las tres temáticas predominantes en el corpus de re-escrituras. Nos referimos al abordaje de las vanguardias históricas, poesía experimental e historieta, desarrollando las particularidades de los ejemplares en cada caso y las formas que asume la apropiación en una selección de obras expuestas y publicadas de Edgardo Antonio Vigo. 


\section{Metodología}

Para la presente propuesta de tesis, se efectuó un diseño metodológico cualitativo (Hernández E., Fernández F, Baptista P., 2010; Ruiz Olabuenaga J., 2012). Revisamos y organizamos fuentes documentales del acervo CAEV a partir de un proceso inductivo que comenzó con la organización y descripción de los ejemplares de re-escrituras.

Analizamos las re-escrituras desde su materialidad, atendiendo a sus características específicamente compositivas y plásticas, como en su contenido y proyección. Esto llevó a investigar la función como traductora de Elena Comas y a sistematizar las obras y publicaciones de E. A. Vigo en el período 1954-1975, encontrando correspondencias con nuestros ejemplares de estudio, eje vertebral de esta tesis. Este acercamiento, visibilizó los lazos entre las re-escrituras y los materiales publicados y mostrados de Vigo a partir de los conceptos de apropiación y repertorio.

La investigación se detuvo en el análisis y la descripción pormenorizada de los materiales que conforman la Serie Escritos Personales en vínculo con obra expuesta y publicada de E. A. Vigo.

En torno al análisis de contenidos y documentos, Jaime Andréu Abela (2002) indica que "tanto los datos expresos (lo que el autor dice) como los latentes (lo que dice sin pretenderlo) cobran sentido y pueden ser captados dentro de un contexto" (2002, p. 2). El contexto en este caso de las re-escrituras, sirve para establecer el marco de referencia que atiende tanto a la dimensión temporal como a la simultaneidad en las producciones de Vigo. El recorte cronológico, por lo anterior, ha sido abordado de manera flexible, en tanto, a partir de identificar tres grandes momentos o temáticas (vanguardias históricas, poesía experimental e historieta) dentro de las re-escrituras (que corresponden al periodo 1954-1975), establecimos cruces temporales, que sirvieron para comprender las proyecciones de las re-escrituras en la obra publicada y expuesta de Vigo, así como las complejas formas que asume la lectura en su producción.

En primer lugar, se procedió a organizar e identificar los documentos que conforman las re-escrituras, teniendo como antecedente el archivo Word y un primer relevamiento fotográfico de estos ejemplares presente en el CAEV realizado por Berenice Gustavino. En esta instancia, identificamos tres tipos de documentos: a) aquellos que traducen libros completos, b) aquellos que traducen y transcriben selecciones de artículos, c) documentos que habían sido elaborados por E. A. Vigo para el dictado de charlas y clases, así como poemas y ensayos no publicados. La característica principal de estos documentos, en ese momento del análisis, era su valor estético, plástico, editorial, la referencia a Elena Comas como traductora y la tarea de edición por parte de 
Vigo. Organizamos este material con descripciones específicas a partir de las siguientes categorías: título, autor, año de la re-escritura, características. En el caso de las selecciones de artículos optamos por poner letras, puesto que no poseen título, especificando las características anteriores. Respecto de las charlas, cotejamos en los archivos Biopsia su procedencia en caso de no consignar datos.

En segunda instancia, ante la necesidad metodológica de poner en contexto estas re-escrituras, se analizó la biblioteca del Centro de Arte Experimental Vigo. Se relevaron todos los ejemplares de la Biblioteca General (actualmente los mismos están siendo inventariados por la bibliotecaria Julia Martínez), identificando los originales que posteriormente fueron plasmados en las re-escrituras. En esta búsqueda, pudimos comprobar que, además de las re-escrituras, existían en la biblioteca ejemplares que habían sido intervenidos por Vigo en su aspecto externo. Esto nos llevó a considerar que estos libros se configuraban como una serie especial de consulta, en tanto E. A. Vigo había realizado una intervención personal sobre los mismos. Se procedió entonces a organizar, dentro del espacio de la Biblioteca General del CAEV, una biblioteca "particular" de Vigo, donde se encontraban: los materiales de re-escritura, las charlas, ensayos y poemas, los libros intervenidos y el material de referencia para las re-escrituras.

A partir del análisis de este material y, centrándonos en la hipótesis de que los textos presentes en las re-escrituras había sido difundidos por E. A. Vigo en sus publicaciones, se relevaron las revistas WC, Diagonal Cero y Hexágono 71' editadas por Vigo entre 1958 y 1975. Realizamos cuadros de Excel, donde constan todos los textos y obras que Vigo publicó -tanto en los cinco ejemplares de $W C$ como en los veintiocho números de Diagonal Cero, utilizamos también el índice razonado de Hexágono 71' realizado por Bugnone (2013)-. Pudimos cotejar, a partir de esta sistematización de material, la presencia de algunos textos que figuraban en las re-escrituras en las publicaciones de Vigo, verificando nuestra hipótesis inicial.

Simultáneamente a esta indagación, y a partir del hallazgo de una imagen dentro del libro Panorama des arts plastiques contemporains (1960) de Jean Cassou, que, como analizaremos en el Capítulo 3, Vigo utilizará para la historieta hermética Características eróticas con perforaciones (Hexágono 71' ac, 1971), se amplió el espectro para reflexionar sobre el vínculo de Vigo con los libros y la lectura. Es decir, la utilización por parte de Vigo de esta ilustración en una de sus obras, nos llevó a considerar la siguiente hipótesis: tanto las re-escrituras como los libros de su biblioteca sirven para la difusión mediante las publicaciones que Vigo edita, pero también, funcionan como insumo para la creación artística vía apropiación. Nos abocamos entonces a analizar la obra de E. A. Vigo a partir de los tres ejes fundamentales que comprenden las 
re-escrituras: vanguardias, poesía experimental e historietas, indagando en las distintas formas que asume la apropiación de los libros y las re-escrituras. Para ello investigamos y relevamos los Documentos Personales Biopsia, archivos colaterales, obra expuesta (objetos, "cosas”, xilografías, señalamientos, envíos de arte correo, entre otros), publicaciones teóricas (De la Poesía Proceso, 1970; Continuidad de lo Discontinuo, 1970, publicaciones en periódicos), organizamos la Sub-Serie Exposición Internacional de Novísima Poesía (período 2016-2019) donde encontramos gran cantidad de correspondencias entre publicaciones y re-escrituras. Analizamos también la bibliografía de E. A. Vigo referida a los poetas brasileños, la hemeroteca de poesía y de historieta, reconociendo cruces entre los referentes y periodizaciones que Vigo utiliza en sus charlas con los postulados de los Poetas Concretos y el movimiento Poesía-Proceso. Consultamos las entrevistas realizadas por Mónica Curell (1995) y Osvaldo Nessi (1994) a Vigo, entrevistamos a Ana María Gualtieri (2017) y a Luis Pazos (2018). Se confirmó a partir de esta revisión la segunda hipótesis de nuestra tesis: el material teórico presente en las re-escrituras funcionaba como insumo también para la creación plástica.

Dos grandes dificultades metodológicas, que requirieron mucho tiempo de reflexión y estudio del material teórico, se presentaron en la elaboración del presente trabajo de investigación. Estas se centraron, por un lado, en la manera de conceptualizar los ejemplares que Comas traduce y Vigo transcribe (las re-escrituras), por otro lado, en las decisiones respecto del estatuto archivístico de estos escritos.

En torno a la primer cuestión, comenzamos en 2015, utilizando la palabra rescrituras para referir a estos ejemplares, pero, estudiando este concepto en profundidad, sus alcances no resultaban operativos para comprender los textos presentes en el CAEV, en tanto las re-escrituras no son exclusivamente apropiaciones creativas, ni libros de estudio, así como tampoco podían abordarse como copias ni plagios, no entraban dentro de la categoría "libros de artista", pero, de alguna manera, lindaban conceptualmente con esas caracterizaciones. Decidimos, a comienzos del año 2018, referir a estos compendios como re-escrituras, con un guión entre las dos palabras, como se analizará en el Marco Teórico, entendiendo que las re-escrituras son ediciones que implican procesos complejos de apropiación del conocimiento, donde interviene un repertorio de autores y una propuesta estética que posteriormente se proyecta en distintos formatos (publicaciones, charlas, obras). Las re-escrituras también funcionan como andamiaje de las reflexiones intelectuales de Vigo, en tanto es posible rastrear sus huellas en obras editadas y expuestas. Este concepto inédito, si bien tiene antecedentes "por diferencia", surge como una necesidad metodológica para abordar los ejemplares de este trabajo. 
La segunda problemática, surgió en torno a la ubicación de los ejemplares de re-escritura dentro del Fondo Documental del CAEV. Como ha señalado Patricia Ríos en el artículo La importancia de la organización y conservación de un archivo personal (2008): "La organización documental implica dos procesos vinculados: la clasificación y la ordenación. La clasificación es el proceso intelectual que consiste en agrupar clases o categorías de un conjunto de documentos. La ordenación es la acción de unir de manera coherente los grupos o unidades de un conjunto documental" (2008, p. 53). Cuando comenzamos a indagar en esta parte específica del archivo, entendíamos que las re-escrituras se correspondían con una sub serie dentro de la Biblioteca General, puesto que, a pesar de su rareza y su condición de objeto único, las re-escrituras son libros. Ahora bien, si tenemos en cuenta que entre los materiales mecanografiados y diseñados por Vigo, además de las re-escrituras, encontramos borradores de textos de Vigo (ensayos, poemas de la década de 1950), charlas y manuscritos de Elena Comas, estos documentos no pertenecían a la Biblioteca en tanto poseen características particulares que excedían las características asignadas a esta. Es decir, estas piezas no podían considerarse como una unidad dentro de la Biblioteca, porque, entre otras particularidades, habían sido producidas por Vigo y Comas.

A pesar de que los conceptos que provee la archivística tradicional muchas veces no coinciden con las características específicas de los archivos de artista, particularmente con el Fondo del CAEV (puesto que, como veremos, su condición de existencia es la confluencia de materiales), comprendimos que resultaba operativo entender las re-escrituras dentro de una nueva serie dentro del Archivo ${ }^{7}$. La categoría "serie" corresponde al conjunto de documentos producidos y regulados por la misma norma, es condición que todos los materiales refieran a un tema específico, en tanto "la serie documental la podemos entender como el conjunto de expedientes entrelazados de una misma función o la integración de documentos agrupados de una forma específica que resuelven una actividad o trámite" (CCA, 2011, p. 120). El conjunto de textos que agrupamos bajo la categoría de "re-escrituras", como veremos en el transcurso de esta tesis, dan cuenta de un catálogo (selección de autores y temas), la elección de un repertorio por parte de Comas y Vigo, son además ejemplares que poseen intereses de estudio particulares. Estas consideraciones nos llevaron a proponer dentro del Fondo Documental, la inserción de una nueva Serie denominada "Escritos Personales". La Serie Escritos Personales, dentro del Fondo Documental, posee una unidad específica: son textos pertenecientes a E. A. Vigo y a Elena Comas.

Como hemos señalado, la Serie Escritos Personales contempla:

\footnotetext{
${ }^{7}$ Las series se configuran dentro del Archivo como las divisiones del Fondo Documental.
} 
-Sub serie: re-escrituras (A- de libros, B- de artículos)

-Libros de Referencia para las re-escrituras,

-Libros Intervenidos,

-Sub serie: Textos Personales (charlas, publicaciones, ensayos escritos íntegramente por Vigo no publicados)

-Sub serie: Manuscritos de Elena Comas.

Es importante mencionar, por último, que en el transcurso de estos años trabajando en el Centro, además de los procesos de investigación, relevamiento y organización, participe activamente de las exposiciones del CAEV: E. A. Vigo usina permanente de caos creativo (MAMBA, 2016) Comunicaciones: Envíos vía postal (Museo Provincial de Bellas Artes Emilio Pettoruti, 2017), Presentación de Poemas fónicos de Luis Pazos y exposición de Afiches Novísima Poesía (CAEV, 2018), Taller de revistas ensambladas (Bienal UNLP, 2018) Proyecto Desborde y Biblioteca, Tomo 1: Formatos expandidos (Biblioteca UNLP, 2019). La curaduría para Celebración de la Novísima Poesía/69 en el marco del Festival Internacional de Poesía de Rosario (2019). Junto a Julio Lamilla y Alan Courtis investigamos para el libro Vigo y el arte sonoro, que recopila y analiza los vínculos del artista platense con el universo sonoro.

Haber participado de estas exposiciones y proyectos contribuyeron de manera fundamental para mi acercamiento a la obra de Vigo, en cada una de ellas se abordó una especificidad de este complejo archivo, visibilizando estos materiales a partir de la investigación y las preguntas que los materiales despiertan. 


\section{Estado de la cuestión}

Los dos antecedentes directos en el estudio de las re-escrituras de E. A. Vigo corresponden a los estudios realizados por Mario Gradowczyk y Berenice Gustavino, ellos han sembrado la pregunta por el estatuto de las re-escrituras y han habilitado otras cuestiones por responder: ¿Qué otros artistas han desarrollado un procedimiento similar? ¿Cómo se vinculan las re-escrituras con el archivo Vigo? ¿De qué manera se vinculan las re-escrituras con la obra del artista?. Sin ánimo de pretender en estas páginas abarcar todos los autores que se han explayado sobre los conceptos de archivo y re-escritura, presentamos un panorama que revisa los principales postulados sobre el tema centrando la atención específicamente en aquellos vinculados con nuestro objeto de estudio.

\subsection{Sobre archivos de artistas}

En este apartado queremos acercarnos a la pregunta qué es un archivo de artista, por qué el Centro de Arte Experimental Vigo (CAEV) es un Archivo y no un Museo o una Biblioteca (siendo que su acervo aceptaría estas categorías), qué principios reguladores se utilizan para organizar el material del CAEV.

De manera esquemática, y retomando el trabajo de Bugnone (2013 b), hemos presentado el Fondo Documental del CAEV incluyendo la Serie Escritos Personales, Sub Serie re-escrituras, para ordenar dentro del Archivo los ejemplares que estudiamos en esta tesis, sin embargo, no podemos dejar de mencionar que los cruces entre las distintas series no son la excepción, sino la condición de existencia del CAEV. Así, los materiales artísticos, literarios, museográficos, epistolares -entre otros- se entrecruzan generando nuevas catalogaciones pero al mismo tiempo obligan a pregunta ¿cómo se ordena un archivo en lo múltiple y lo diverso? (Bugnone A. y Cisneros J., 2018) y, particularmente en el caso de las re-escrituras ¿de qué manera el material de re-escrituras se toca con lo expuesto/ publicado? ¿cómo nombramos esas confluencias?.

En Arte y Archivo 1920-2010 (2011), Anna María Guasch indica que además de los dos paradigmas en los que se suele analizar el arte de las vanguardias históricas -el paradigma de la "obra única" y el que refiere a la multiplicidad del objeto, como sería el caso del collage- puede agregarse un tercero que corresponde en su denominación al "paradigma del archivo". Las vanguardias históricas se han estudiado o bien a partir del paradigma de la obra única y el efecto de shock, o bien, a partir la multiplicidad del objeto artístico, por caso el movimiento Dadaísta o el Surrealismo. Guasch propone, retomando los planteos de Benjamin Buchloh, identificar un 
tercer punto de vista para la investigación en artes, que corresponde al "paradigma del archivo". Este implica analizar la creación artística a partir de una secuencia mecánica, "una repetitiva lejanía sin fin de la reproducción que desarrolla con estricto rigor formal y absoluta coherencia estructural una 'estética de organización legal-administrativa"” (2011, p. 9). El "paradigma del archivo" diferencia la acción de coleccionar y la de archivar puesto que el segundo término implica "consignar", es decir, asignar un principio de agrupamiento al material que se resguarda. El archivo contemporáneo ha funcionado a través de dos "máquinas" o modos de proceder: "la que pone en énfasis el principio regulador del nomos (o la ley) y del orden topográfico, y la que acentúa los procesos derivados de las acciones contradictorias de almacenar y guardar, y, a la vez, de olvidar y destruir huellas del pasado, una manera discontinua y en ocasiones pulsional que acentúa el principio anómico (sin ley)” (Guasch, 2011, p. 15).

En esta tensión entre principio regulador del nomos y el principio anómico podemos citar los desarrollos de Derrida en Mal de Archivo una impresión Freudiana (1997). El autor señala que todo archivo es a la vez instituyente y conservador, revolucionario y tradicional (1997). La cuestión del archivo no es una cuestión del pasado sino que "es una cuestión del porvenir, la cuestión del porvenir mismo, la cuestión de una respuesta, de una promesa y una responsabilidad para el mañana. Si queremos saber lo que el archivo habrá querido decir, no lo sabremos más que en el tiempo por venir" (Derrida, 1997, p. 44). La noción de porvenir esta signada por reconfiguraciones en la interpretación y en las lecturas que se hacen del propio archivo; así, la interpretación se inscribe e incorpora como parte del propio archivo: "El archivero produce archivo y es por esto por lo que el archivo no se cierra jamás. Se abre desde el porvenir" (1997, p. 74). En este mismo sentido, Irina Garbatzky (2014) analizando el archivo del artista Roberto Jacoby, señala que:

Nunca dejamos de encontrarnos frente a la noción del archivo como productor: no solo por la posibilidad de reutilización estética de sus materiales sino como producción de conocimiento y de herramientas de análisis intelectual, como dispositivo de democratización del saber y de las formaciones artísticas, como lugar de confección (política) de objetos de estudio (2014, p. 318).

Retomando los planteos de Guasch, Ana Bugnone analiza en el artículo Hacia el paradigma del archivo de artistas y escritores (2018) lo que denomina dos dimensiones en torno al "paradigma del archivo”. Estas nos sirven para reflexionar específicamente sobre el material de re-escrituras 
en tanto su trabajo apunta a sistematizar modos de abordaje de material presente en el archivo de E. A. Vigo. Por un lado destaca en su análisis la "dimensión epistémico-archivística", por otro lado la dimensión "poiética", como modos de ingresar a la investigación en el marco de los archivos de artistas y escritores $(2018$, p. 1). En torno al primer aspecto indica la autora que:

La dimensión epistémico-archivística abarca una concepción de la investigación con archivos que parte del reconocimiento de la importancia de los mismos para el análisis y la interpretación de trabajos artísticos y literarios, pero sin caer en el anhelo de que allí se encuentre la explicación de toda la obra y la intención del autor de un modo lineal y teleológico, sino con una mirada que dude de las certidumbres del documento como objeto transparente que dice todo lo que contiene y que aporta un origen único y fijo de la obra posterior (2018, p. 1).

Esta dimensión se vincula con la institucionalización del archivo $^{8}$, en tanto es la institución la que regula las políticas de hermetismo o democratización de los materiales a partir, por ejemplo, de los usos de la tecnología y los accesos abiertos a internet ${ }^{9}$. En este sentido, para Bugnone, la institucionalización se vincula con los cuatro conceptos derrideanos de domiciliación, poder arcóntico, interpretación y consignación. La segunda dimensión que la autora denomina "poiética", "versa sobre las prácticas creativas y productoras por parte de artistas y escritores que trabajan con el archivo. Implica la creación de obras que surgen de, introducen o producen un archivo, ya sea a partir de la reescritura, la reproducción o la composición de trabajos donde lo ya escrito o elaborado se sitúa en un lugar privilegiado.” (2018, p. 1) Aquí el archivo es utilizado por el artista como material creativo reformulado en su propia obra.

En el artículo Archivo y Vanguardia (2013a) Bugnone ya había analizado las especificidades de la apropiación del archivo en la obra de Vigo profundizando en la dimensión poiética indicando que:

\footnotetext{
${ }^{8}$ En Palabras de Archivo (2013) Mónica G. Pené indica que: "un archivo de escritor sería, en primera instancia, un conjunto organizado de documentos, de cualquier fecha, carácter, forma y soporte material, generados o reunidos de manera arbitraria por un escritor a lo largo de su existencia, en el ejercicio de sus actividades personales o profesionales, conservados por su creador o por sus sucesores para sus propias necesidades o bien remitidos a una institución archivística para su preservación permanente.” (2013, p. 29).

${ }^{9}$ Ver Bugnone A. L. Santamaría, M. (2016) La política de democratización del archivo: el caso del Centro de Arte Experimental Vigo en Actas del I Congreso Internacional de la Asociación Argentina de Humanidades Digitales - AAHD
} 
Una de las particularidades de la obra de Vigo consiste en que cuando realizaba acciones, hacía fotografiar o "certificaba" por medio de documentos muy cercanos al discurso jurídico, lo que allí ocurría. Esos registros se sumaron a una descripción detallada de cada una de sus actividades y formó con ellas un cúmulo de documentos con los que preparó su archivo personal. Colocó allí los recortes de diarios y revistas, catálogos, críticas, cartas, obras, anotaciones personales, textos de conferencias o clases, que exhaustivamente ubicó en el mes y año correspondiente. Desarrolló, así, una obsesión por resguardar, archivar, ordenar $\mathrm{y}$, de algún modo, proteger su producción artística y transformó su archivo en una construcción de sentidos cruzados entre prácticas vanguardistas y registros administrativos (2013, p. 3).

Una revisión de las operatividades del "paradigma del archivo" para analizar las re-escrituras que nos convocan, nos sirve para revisar las prácticas en el seno del espacio que alberga la obra de E. A. Vigo, esto es el Centro de Arte Experimental Vigo, en tanto consideramos que las re-escrituras se vinculan con la dimensión poiética que estudia Bugnone. Partimos de la base de considerar las re-escrituras como materiales que el artista utiliza para su obra de manera creativa, no son meras transcripciones de un material preexistente sino apropiaciones particulares de ese material. Referimos a continuación específicamente al Centro de Arte Experimental Vigo para comprender sus prácticas, funcionamiento y concepción de archivo.

\subsection{Archivo E. A. Vigo}

A partir del fallecimiento de Edgardo Antonio Vigo, en 1997, el Centro de Arte Experimental Vigo dirigido por Ana María Gualtieri y Mariana Santamaría, comienza a difundir y exponer la obra del $\operatorname{artista}^{10}$. Se trata de un archivo autogestivo ${ }^{11}$ que cuenta con participaciones de tipo

\footnotetext{
${ }^{10}$ Ejemplo de la potencialidad del archivo Vigo y su proyección hacia el porvenir en términos derrideanos, citamos la muestra Comunicaciones: Envíos vía postal (Museo Provincial de Bellas Artes Emilio Pettoruti, Noviembre, 2017). El acervo documental del Centro de Arte Experimental Vigo fue revisitado desde los procedimientos vinculados a la comunicación. Se indagó en los artistas con los cuales E. A. Vigo había tomado contacto (plasmado en forma de mapamundi con una "cartografía epistolar"); se expusieron los diversos materiales que los artistas enviaban a Vigo para la realización de la publicación de Nuestro Libro Internacional de Estampillas y Matasellos. Tuvieron su espacio materiales que podrían considerarse secundarios, esto es sellos y tacos de goma; se expusieron las formas que asumió la denuncia por la desaparición de su hijo Abel Luis "Palomo" durante la última dictadura militar. En el catálogo de la muestra, Ana María Gualtieri señalaba que el CAEV "Es una zona de INTERSECCIÓN entre el pasado: historia y memoria, y el futuro: permanencia y proyección." (2017, p. 4).

${ }^{11}$ En palabras de su directora: "Esto no es fundación Espigas, pero tiene una ventaja: el material está a la mano del investigador, tenemos la voluntad de buscar el material a partir de citas concertadas y se pone a disposición del investigador, ¿Qué le falta? Le falta un poco más de orden, porque todo el material está entrecruzado, la
} 
voluntaria -en algunos casos financiadas mediante becas- para fichaje e investigación; está abierto a investigadores e interesados no solo en la obra de Vigo sino también en la poesía visual, la xilografía, el arte correo, arte sonoro, entre otros documentos de arte argentino y latinoamericano.

El único fondo documental organizado en vida por E. A. Vigo es Biopsia, que pertenece al Archivo Personal. Biopsia consta de treinta y cuatro cajas que abarcan desde sus primeros trabajos en 1953 hasta 1997, dispuestas por el artista en forma cronológica. Desde la caja número cinco (1961-1965) les dio el nombre de Biopsia y les otorgó un índice con identificación de trabajos, exposiciones, artículos, catálogos, fotografías, manuscritos, correspondencia, entre otros materiales.

Biopsia podría pensarse como un curriculum pormenorizado de la obra del artista y, muchas veces, sirve como columna vertebral para comprender la simultaneidad de sus producciones. La serie de documentos paralelos recopilados con posterioridad por los archivistas se encuentran ordenados por año y corresponden al Archivo de Documentos Colaterales, Vigo no los incorporó a la serie Biopsia original, por lo que se encuentran apartados de la misma. Estos materiales también contribuyen a la reconstrucción de las trayectorias dentro del archivo.

En torno a la dimensión epistémico-archivistica, en el trabajo presentado junto a Ana Bugnone, Decisiones metodológicas para lo inclasificable en el archivo de Edgardo A. Vigo (2017) analizamos el archivo del Centro de Arte Experimental Vigo en relación con las problemáticas y tensiones que surgen en este archivo vinculadas a la clasificación y a la pregunta ¿cómo ordenar lo múltiple y lo diverso? ¿a partir de qué categorías pensamos la especificidad de este archivo?. Relevamos en esa instancia algunas situaciones problemáticas respecto del orden que el material de archivo propone y las tensiones con los criterios clásicos de ordenamiento del archivo. La noción de desplazamiento ha sido operativa en tanto indica que los materiales en las distintas secciones del CAEV se tocan con otras producciones, oponiéndose a las categorías estancas en las cuales se piensa el archivo tradicional. El material, por sus características, se resiste a ser catalogado de una vez y para siempre.

El archivo Vigo da cuenta de una exterioridad, en tanto alberga producción plástica y visual mostrada, pero también contiene en su acervo un modo de leer y de producir por parte de Vigo que indica procesos de deglusión, en términos antropofágicos, que pertenecen al ámbito de lo no expuesto. Específicamente en el caso que nos ocupa y su vínculo con el archivo, consideramos

poesía visual con el arte correo, con su epistolario personal, es muy difícil a veces recuperar un documento, porque ¿dónde lo pones? ¿qué es esto? ¿arte correo? ¿poesía visual? Las dos cosas.” (Comunicación personal, Ana María Gualtieri, Febrero 2017) 
que no es posible analizar las operaciones que proponen las re-escrituras sin enmarcarlas en determinados procedimientos de lectura por parte de Vigo del material crítico $^{12}$. Dedicamos por ello un apartado a la Biblioteca General y a los Escritos Personales de E. A. Vigo, como así también a las lecturas que inciden en la revista Diagonal Cero, en tanto se manifiestan en estos casos modos particulares de leer y de conocer, configurando así un repertorio de autores, teorías y consumos culturales. En este sentido, consideramos que analizar la dimensión poiética del archivo y el uso creativo de los materiales por parte de Vigo implica comprender y sumergirse en los modos de lectura del artista, las formas en que dialoga con otras poéticas y el modo en que construye sus propios espacios de enunciación.

\subsection{En torno a la obra de E. A. Vigo}

Edgardo Antonio Vigo nace, vive y trabaja en la ciudad de La Plata. La obra del artista, ha sido estudiada por investigadores académicos pertenecientes a la Universidad Nacional de La Plata, tanto del ámbito de la Historia del Arte como desde las Ciencias Sociales y la Comunicación Social, e investigadores y artistas de diversas partes del mundo. Relevaremos algunos estudios sobre la obra de E. A. Vigo específicos que se vinculan directamente con nuestro objeto y se configuran como marcos de referencia para nuestro abordaje tanto de las publicaciones Diagonal Cero y Hexágono 71' como de los discursos que circulan al momento de la elaboración de las re-escrituras. Agregamos, hacia el final, consideraciones en torno a las re-escrituras como un proyecto conjunto entre Elena Comas y E. A. Vigo.

Comenzamos relevando la formación académica del artista y sus estudios en la Escuela Superior de Bellas Artes de la Universidad Nacional de La Plata. Vigo egresa en 1954 como profesor de dibujo de dicha institución ${ }^{13}$ donde conoce a Elena Comas. Como veremos en el desarrollo de este trabajo, si bien la formación de Vigo comprende tensiones con los espacios académicos y

\footnotetext{
12 Ricardo Piglia en Las tres vanguardias. Saer, Puig, Walsh (2016) se pregunta en torno a la tradición de lectura de los escritores: “¿En qué consistiría la lectura de un escritor? Como sabemos, el debate de los críticos está planteado en términos de cuál es el mejor lector y qué instrumentos tiene que manejar el que puede ser considerado el lector ideal. Y uno podría analizar este debate y la historia de la crítica intentando definirlas características que tiene aquel que, por fin, es capaz de leer ya no la verdad del texto, sino aquello que ustedes puedan considerar en cualquier momento como la lectura pertinente. ¿Qué quiere decir leer bien?” (2016, p. 22) Podríamos reformular la pregunta en el marco de este trabajo aludiendo a los modos en que la lectura se proyecta en la producción, de qué modos lee Vigo; qué queda de sus lecturas, ¿Cómo rastrear esos restos?

${ }^{13}$ En la cronología (1928-1962) presentada en el catálogo Maquinaciones se explicita que: “A instancias de magistrados y colegas, Vigo comenzó a tomar cursos nocturnos en la Escuela Superior de Bellas Artes (U.N.L.P.) y más tarde inició el profesorado de Dibujo, también por insistencia de abogados que lo inscribieron y pagaron su matrícula" (2008, p. 111)
} 
formales, la voluntad de informar y difundir el arte contemporáneo y la poesía experimental se manifiesta en charlas ${ }^{14}$, conferencias y artículos que Vigo imparte en distintos espacios. La acción de compartir el conocimiento en instituciones de distintos niveles (Colegio Nacional, Escuela de Periodismo, por ejemplo) resultan una arista importante para abordar las re-escrituras puesto que las charlas se vinculan directamente con sus lecturas. En los ejemplares de las re-escrituras se pone de manifiesto un afán por conocer y sistematizar la información desde abordajes particulares sobre el material teórico, pero también por hacer saber, imprimiendo un carácter didáctico y formativo.

En 1954, Vigo viaja a Europa con Miguel Ángel Guereña y trae ejemplares que serán transcriptos en las re-escrituras formando parte de su Biblioteca General (Gradowczyk, 2008). Se manifiesta en este viaje una ruptura con su formación académica, lo que Vigo ha denominado un "bautismo", "en un año vivimos lo que no vivimos en la academia, en la escuela de bellas artes (...) nuestra cátedra la dieron los café de París"15. Un año después, realiza su primera muestra en la Asociación Sarmiento donde expone junto a su futura esposa, Elena Comas.

Entre 1958 y 1960 publica las revistas $W C$ y $D R K W^{\prime} 60$, realiza sus primeros poemas matemáticos y la serie de máquinas inútiles. Desde 1962 a 1968 edita y publica la revista Diagonal Cero. En una carta presente en el Centro de Arte Experimental Vigo enviada a Stephen Perkins en enero 1996, Vigo escribe un texto denominado "Pequeña historia de mis ediciones". De la epístola transcribimos completo el relato en torno a esta publicación, puesto que será utilizada en distintos momentos de esta tesis para referir a los momentos y virajes de Diagonal Cero:

En el año 1962 fundé y dirigí Diagonal Cero. Revista trimestral que alcanzó la nada envidiable edición de 28 números. Esta publicación tuvo dos etapas muy definidas. Hasta el número 18 la revista difundió personajes o movimientos poéticos y plásticos argentinos, así como brindó información acerca de movimientos poetas y plásticos latinoamericanos. Al margen del material escrito y la reproducción de imágenes, cada

\footnotetext{
14 Además de los registros de charlas que relevamos en esta tesis, resguardados materialmente en la serie Escritos Personales, encontramos en los índices del archivo Biopsia otras charlas impartidas por Vigo. En Biopsia 1974 consta que dió una charla sobre historietas, en Biopsia 1975, una charla titulada "La fotografía en el arte contemporáneo", en 1977: una charla sobre xilografía y otra sobre arte correo. Estas conferencias o discursos todavía no han sido encontradas dentro del archivo, es decir, no sabemos si solo fueron presentadas con diapositivas o Vigo tenía un soporte de escritura donde organizó la disertación.

${ }^{15}$ Extraído del video producido por la cátedra de Análisis y Crítica de Medios UNLP Realización: Juan M. Artero. Equipo: Natalia Aguerre; Lía Gómez; Carlos Vallina "Vigo: comunicación, arte, política y memoria" (2018) https://www.youtube.com/watch?v=7m5Ykz50UQc
} 
número era acompañado por un cuadernillo de separata, dedicado a la xilografía. Esto fomentó un intercambio intenso con distintas publicaciones de las que destaco en forma especial "El corno emplumado" de México, una extraordinaria revista a nivel continental y universal. Gracias a esos contactos surgió un intercambio intenso, sobre todo con grupos o personajes que dentro de sus terrenos investigaban y proponían formas distintas de encarar la solución plástico-poética o propuesta a nivel teórico de tipo refundador.

La segunda etapa comienza con un número experimental, el 19, en el cual participan Carlos Ginzburg, Luis Pazos, Jorge de Luján Gutiérrez, Omar Gancedo y yo. Posteriormente formaríamos, restando a Gancedo, el grupo Diagonal Cero, de cierta vida efímera. Ese número 19 nos abrió la posibilidad de conectarnos con algunos grupos europeos que a su vez editaban revistas. El caso más notorio fue el acercamiento a Julien Blaine y Jean Francois Bory. Quienes a la sazón fundaban en forma permanente revistas con clara tendencia vanguardista, en general comprometidas en todo lo concerniente a la poesía visual y sus distintas expresiones, a la vez todos los terrenos de las demás expresiones creativas como: la plástica, el teatro, el ballet, la música y las investigaciones a nivel experimental. Esta conexión sumada a las del esteta Max Bense (Aleman) Gomez de Liñao, Julio Campal, influenciaron notoriamente sobre nosotros y en cuanto a lo que me atañe personalmente no puedo dejar de resaltar, es que a la colección le falta el número 25, justamente no se imprime por estar "dedicado a la nada" la aclaración del número faltante aparece en 26.

Con la Exposición Internacional de Novísima Poesía que me tocó curar para el Instituto Di Tella de Buenos Aires a comienzos de 1969, la revista a mi entender, cumplió su ciclo y su sentido. En el número 28 sería el último completando así una pretensión de información y una adhesión y modesta ayuda a la renovación de las artes en la argentina. (E. A. Vigo, 1996, mimeo CAEV)

En torno a los trabajos teóricos que han desarrollado la obra de Vigo, destacamos a Fernando Davis, quien ha estudiado las prácticas "revulsivas" en la estética de Vigo (2006, 2007, 2012, 2016). En sus indagaciones analiza objetos, publicaciones y poesía visual en la obra del artista. Señala Davis en Poéticas oblicuas (2006) que la poesía platense joven ocupó un lugar central en el programa de difusión de las prácticas experimentales auspiciado desde las páginas de la publicación Diagonal Cero. Indica el autor en torno a la materialidad de la revista que: 
Las intervenciones en la estructura de la publicación, a través de cortes, troquelados y plegados del papel, introducen, desde el número 20 de DC, una serie de prácticas que fracturan la unidad de la revista y dispersan la página, soporte del poema. Aunque estas diversas intervenciones en la diagramación no son nuevas en la publicación, a partir de $D C$ 20, Vigo multiplica y complejiza los juegos de recortes y superposiciones (2006, p. $3)$.

El ápice del vínculo de Vigo con la poesía experimental sucede en 1969, a partir de la organización de la Exposición Internacional de Novísima Poesía en el Instituto Torcuato Di Tella. En esta muestra se exponen obras de poesía fónica, poemas bidimensionales y tridimensionales de una cantidad importante de artistas nacionales e internacionales. Un año después, Vigo publica un ensayo titulado "De la Poesía proceso a la poesía para y/o a realizar". Davis entiende que es en este espacio donde se plasma el interés por la participación del espectador en tanto: "La poesía para y/o a realizar tensa sus estrategias poéticas y sus tácticas interlocutorias en el descentramiento de los lugares tradicionales del autor y del público en el fenómeno artístico, fracturando la legalidad que trama los procesos de producción, circulación y recepción estéticas" (2006, p. 8).

Por su parte, Magdalena Pérez Balbi (2008, 2010, 2016) en Movimiento Diagonal Cero, poesía experimental desde La Plata, $1966-1969$ (2008), trabaja sobre la condición marginal del Movimiento Diagonal Cero, rescatando la relevancia que tuvo la experimentación en este grupo. Propone una relectura de la historiografía del arte argentino del período de 1960 y 1970 en función de la práctica de la poesía experimental a partir de la plataforma Diagonal Cero como pionera de las mismas. Nos interesa el trabajo de Pérez Balbi en torno al análisis de Diagonal Cero para comprender los modos en que Vigo selecciona y edita determinados materiales poéticos y la circulación de esta revista, también los modos en que Diagonal Cero se configura como una plataforma de edición de trabajos que expanden el formato libro tradicional -como en el caso de Luxan Gutiérrez, Pazos y el propio Vigo ${ }^{16}$ -

También en relación a la poesía de E. A. Vigo, Ornela Barisone trabaja en el libro Experimentos poéticos opacos (2017) los vínculos y articulaciones entre la poesía experimental de la década de 1940 con las propuestas de E. A. Vigo durante la década de 1960, centradas tanto en Diagonal Cero como en lo que significó la ya mencionada Exposición Internacional de Novísima

\footnotetext{
${ }^{16}$ En el caso de Luis Pazos, Diagonal Cero edita La Corneta (1967); de Luján Gutiérrez Diario Edición Sexta de Poesía (1969) y en el caso de Vigo los “(in) objetos”, por caso Poemas matemáticos (in) comestibles (1968).
} 
Poesía/69. La lectura de Barisone propone articular el invencionismo argentino en la década del 1940 y sus proyecciones con la propuesta poética experimental de 1960, especialmente en la obra de E. A. Vigo (2017, p. 13).

En la segunda parte de este trabajo, nos interesa revisar las propuestas de poesía experimental plasmadas en las páginas de Diagonal Cero y la Novísima Poesía, considerando principalmente tres cuestiones en torno a la palabra poética: el interés de Vigo por desarticular la linealidad de la escritura, el trabajo con la materialidad de la palabra y la incorporación del aspecto visual en la escritura. Incorporamos materiales de la Serie Escritos Personales para nuestro relevamiento del vínculo de Vigo con la poesía experimental, estableciendo cruces entre las traducciones de Comas, publicaciones y libros que Vigo lee y transcribe y las formas en que se modifica el perfil de Diagonal Cero y la socialización por parte de Vigo de las experiencias de poesía experimental.

Ana Bugnone (2011, 2013a, 2013b, 2014, 2017, 2018), además de los artículos mencionados, analiza en su tesis doctoral Una articulación entre arte y política: dislocaciones y rupturas en la poética de Edgardo Antonio Vigo (1968-1975) (2013) los complejos vínculos con la política y lo político en la obra de Vigo. Sostiene que:

Vigo al mismo tiempo apunta a cuestionar las estructuras y manifestaciones tradicionales de las Bellas Artes, así como las formas dominantes de la cultura a través de obras y textos que tendían a desestabilizar los roles de autor, espectador y obra, como modos de distorsionar y disentir con las jerarquías, lugares y funciones de los sujetos y objetos del entramado social (Bugnone, 2013, p. 13).

La autora centra su análisis en el cambio en las funciones de los sujetos, objetos, e instituciones artísticas, las influencias del discurso jurídico, las acciones de señalamientos y la revista Hexágono. La hipótesis de lectura con la que trabaja indica que:

(...) es posible pensar la relevancia de su poética a través de las rupturas que plantea no solo con los cánones del arte sino también con las posiciones que ocupan sujetos y objetos, tiempos y espacios en una determinada red de relaciones sociales. En ese disenso invita a un desborde, más allá de las reglas del campo artístico, de las reglas sociales y culturales. Esta politicidad no surge a través de un modelo que intente enseñar sobre las desigualdades, inequidades e injusticias del mundo, un patrón que fue arquetípico en 
algunos artistas de la época (el ejemplo más claro es la obra de Ricardo Carpani), sino de un modo menos explícito y más complejo que Vigo figura a partir de la idea de "revulsión" (2013, p. 21)

La indagación de Bugnone, nos ha servido para enmarcar la complejidad de Hexágono 71'como dispositivo poético-político. Es en esta publicación, como analizaremos oportunamente, donde consideramos, que opera un viraje en el modo de insertar la re-escritura dentro del dispositivo revista. No solo migran a Hexágono 71' re-escrituras sino que se publican composiciones plásticas que Vigo denomina historietas herméticas donde la apropiación de la historieta se genera a partir de la elaboración de obra. El proceso de apropiación, de su sistema de lecturas, como veremos, abandona la copia para producir otra cosa.

Una última consideración en torno a la obra de Vigo que no posee antecedentes de estudio, sin embargo es pertinente para este apartado en tanto se vincula directamente con el tema de nuestra tesis. Como hemos dicho, la dupla Comas- Vigo participa de la exposición en la Asociación Sarmiento en 1954, pero, hasta lo que conocemos, no vuelven en todos sus años de convivencia a exponer juntos. Creemos que las re-escrituras serían la única materialidad de una práctica verdaderamente colaborativa entre ambos, donde Comas traduce y Vigo transcribe y edita los ejemplares. Si bien los procesos de apropiación del material crítico de las re-escrituras, como analizaremos en la segunda parte, se dan principalmente en la obra publicada, expuesta y socializada mediante charlas por parte de E. A. Vigo, Elena Comas es fundamental en ese proceso de conocimiento a partir de su acción como traductora para la conformación de lo que en este trabajo denominamos repertorio. Entendemos que Vigo, hacia el final de su carrera homenajea a parir del heterónimo TANA VIGO a Elena Comas, la incluye como artista en Nuestro Libro Internacional de Estampillas y Matasellos (20 números de 1979 a 1993).

Notemos que en el inicio y en el final de su carrera, Vigo inventa un colectivo, un grupo de artistas. Tanto en WC (1958) como en Nuestro Libro Internacional de Estampillas y Matasellos Vigo forja espacios de duplicidad en, por lo menos, seis nombres. En el caso de sus primeras publicaciones y proyectos Relativuzgir's aparecen heterónimos masculinos bajo la firma de Vhigo, Otto Von Maschdt, Gus Gonzalez e Igor Orit. En el Libro Internacional a partir de dos nombres femeninos: Don Rose Selavi II y TANA VIGO. En el primer caso, en torno a sus proyectos Relativuzgir's, las firmas indican un supuesto colectivo extranjero (podría ser ruso o alemán). Estas identidades inventadas por VIgo aparece, por ejemplo, en los Collages musicales 
(1958) a partir de una escritura insegura (como si una persona diestra escribiera con la mano izquierda); la singularidad en los siguientes nombres presentes en Nuestro Libro Internacional nos lleva a Marcel Duchamp, como analizaremos en el Capítulo 1, y a la figura de Elena Comas. Vigo elabora estas últimas dos firmas a partir de sellos. Las rúbricas están realizadas a partir de letras de molde, en concordancia con la publicación en la que están inmersas destinada a difundir sellos y matasellos, una "filatelia marginal y creativa" de arte postal o comunicación a distancia. Vigo inventa una identidad otra, cuya firma es TANA VIGO para el Libro Internacional, quien vive en $15 \mathrm{n}^{\circ} 1187$ (actual CAEV). La estética de TANA en las Xilografías que aparecen en Nuestro Libro Internacional poseen escrituras, siluetas y planos de color. El hecho de que TANA sea un homenaje a Elena Ana Francisca Comas se confirma en la última obra publicada en Libro Internacional $\mathrm{n}^{\circ} 16$, puesto que es una acción conjunta entre Vigo y TANA en memoria de su hijo desaparecido Abel Luis.

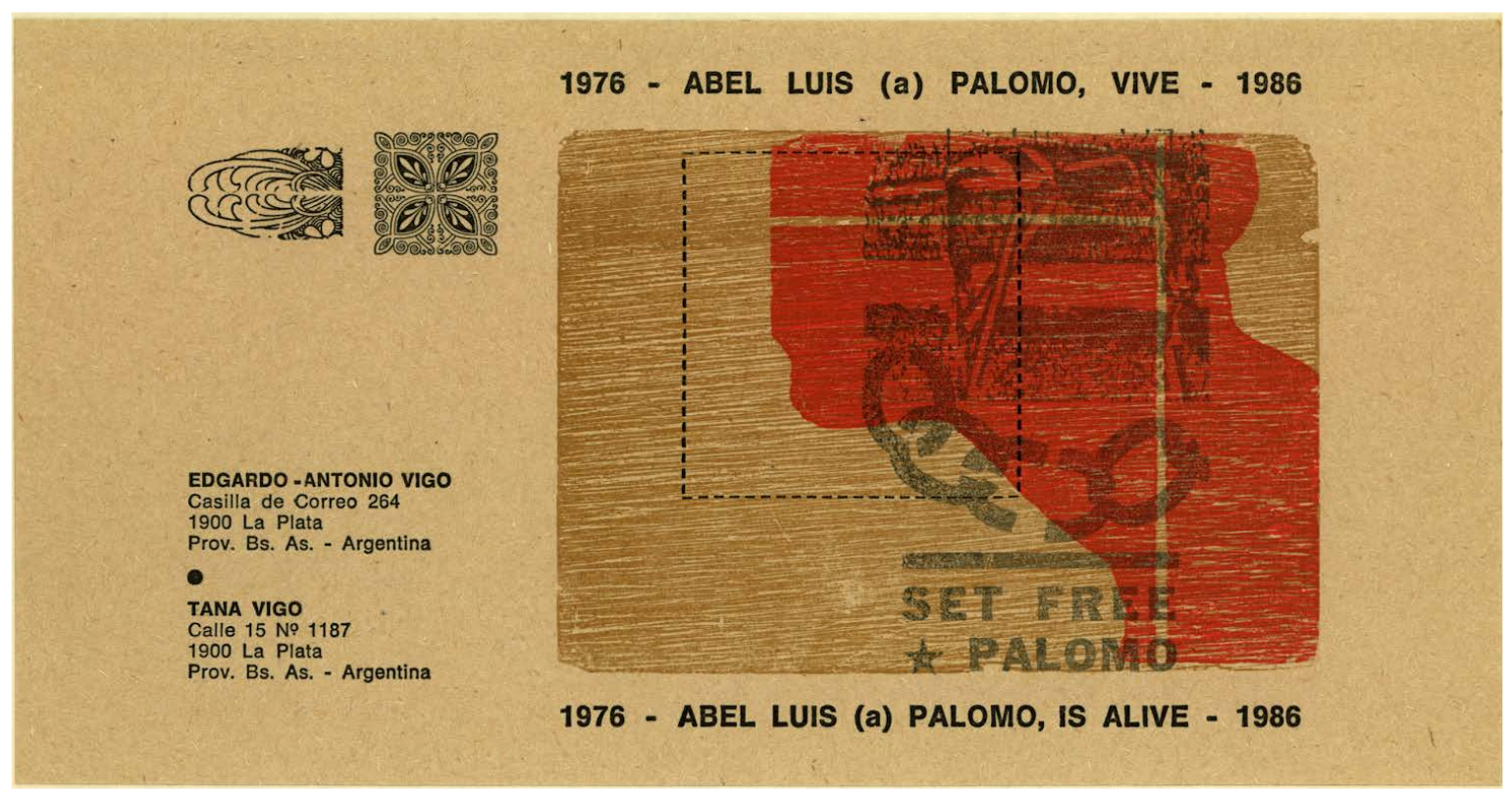

Fig 1. Libro Internacional n ${ }^{\circ}$ 16. Edgardo Antonio Vigo/ Tana Vigo. CAEV

Finalizamos este apartado dedicado a la obra de Vigo reconociendo, en primer lugar que las re-escrituras son ejemplares realizados de manera conjunta entre Elena Comas y E. A. Vigo. Entendemos que sin la contribución de Comas, quizás los repertorios de lectura de Vigo hubieran sido diferentes. Como sostenemos en esta tesis, las lecturas y re-escrituras impactan de manera directa en las publicaciones y charlas de Vigo y de manera indirecta en su producción plástica, la acción como traductora de Comas es fundamental en la elaboración del repertorio de lecturas. 


\subsection{Re-escrituras}

\subsubsection{Antecedentes de estudio}

Como ya mencionamos, los dos antecedentes directos en el estudio de estos ejemplares que han servido para nuestro desarrollo de las re-escrituras en la obra de E. A. Vigo, corresponden a los aportes de Mario Gradowczyk y Berenice Gustavino, primera en sistematizar estos compendios de lecturas. Si bien estos autores no utilizan la palabra re-escritura sino libro de artista en el caso de Gradowczyk y pieza artesanal única en el caso de Gustavino, nos referimos al estudio de los mismos ejemplares ${ }^{17}$.

El trabajo teórico presentado por Mario Gradowczyk en el catálogo para la exposición Maquinaciones. Edgardo Antonio Vigo: trabajos 1953 - 1962 ${ }^{18}$, analiza el período comprendido entre 1953 y 1962 en la obra del artista platense.

Señala el autor, en el apartado "La biblioteca de Vigo: una primer mirada" que, para conocer las etapas en el pensamiento de Vigo y sus fuentes, un indicio esta dado por las lecturas que el artista consumía: traducciones, libros de dadaísmo y surrealismo. Indica que no se disponen las fechas en que ingresan estas obras, sin embargo, muchas son adquiridas en su viaje a Europa y otras en la librería Galatea de Capital Federal. Advierte Gradowczyk que:

Si se ojean esos pulcros volúmenes se observa que, en muchas ocasiones, los textos se transforman: las palabras ya no sólo transmiten contenidos sino también conforman figuras de formas irregulares: rectángulos, sectores circulares, estructuras triangulares. Esta suerte de transformación de texto en ideograma fue realizada por Vigo a su regreso de París, lo que marca su preocupación temprana para que al propio acto de la escritura volcado en el texto se le agregue una conformación formal diferente, por lo que sus textos adquieren el carácter de un juego poético-visual. Estas experiencias comienzan con

\footnotetext{
17 Pérez Balbi, en el relevamiento de la obra de Vigo para el catálogo Edgardo Antonio Vigo Usina permanente de caos creativo obras 1953-1997 (MAMBA, 2016), incorpora los libros que trabajaremos en la presente propuesta, los denomina "reescrituras". Se exponen en el catálogo fragmentos de la compilación de textos de Mondrian, Dewey, Van Doesburg, entre otros. Señala la autora que: "En estos volúmenes se observan ciertas características transversales que Vigo conservará en toda su producción: la articulación entre palabra e imagen, entre lo impreso y el gesto artesanal, y la concepción de la página como espacio plástico (2016, p. 177)

${ }^{18}$ Exposición realizada entre los meses de agosto y septiembre del año 2008 en el Centro Cultural de España en Buenos Aires, Córdoba y Rosario.
} 
la poética de Mallarmé, continúan con los poemas visuales de Marinetti y Apollinaire, y reciben envión final con las intervenciones del dadaísmo (2008, p. 32).

Las hojas mecanografiadas devienen en actos plásticos puesto que, como indica el autor, en muchas de ellas modifica la espacialidad de la palabra y la estructura tradicional respecto del uso del soporte, “con Vigo se inicia en Argentina, a mediados de la década de 1950, ese capítulo del arte titulado 'libro de artista'”, (2009, p. 35). Si bien no coincidimos en considerar los libros de re-escrituras como libros de artista, nos interesa su primer intento por categorizar estas escrituras. Gradowczyk nos deja la pregunta transversal a esta indagación ¿Qué lo lleva a esta reescritura, a esta suerte de apropiación de diferentes relatos?.

Berenice Gustavino en La escritura sobre arte en argentina en los años 60'. La crisis en las referencias extranjeras y la extensión de la perspectiva latinoamericana (UNLP- tesis doctoral, 2014) propone leer las bibliotecas de artistas argentinos desde la modificación de las referencias extranjeras hacia una configuración policéntrica:

Durante la década del sesenta se verifica una progresiva sustitución de autores y teorías tradicionales por nuevas lecturas llegadas del extranjero o elaboradas localmente. Ciertas referencias canónicas perduran sin embargo entre los argentinos. Algunas alternativas a este relato canónico francés ingresan en el medio local, como lo demuestra la biblioteca artesanal y privada del artista platense Edgardo Antonio Vigo. El artista-escritor traduce, con la ayuda de su esposa Elena Comas, varios libros que trae de su primer viaje a Europa y otros que adquiere en librerías de La Plata y Buenos Aires. Esas traducciones, mecanografiadas, son editadas en ejemplares únicos para los que Vigo confecciona tapas y sistemas de encuadernación, e interviene con sus ilustraciones y sellos. Esta biblioteca casera, que el artista compone en paralelo a su biblioteca "tradicional", muestra su interés por las vanguardias artísticas europeas, en especial por Dada y por las tendencias abstractas. Vigo traduce artículos y libros de y sobre Hans Arp, Paul Klee, Piet Mondrian, entre otros. El artista es lector y traductor de Michel Seuphor, autor francófono militante a favor de la abstracción. A través de sus trabajos, Vigo frecuenta otras perspectivas sobre el desarrollo del arte moderno (2014, p. 390).

Coincidimos con la autora en considerar que el hecho de que Vigo sea un artista plástico y un traductor genera piezas artesanales únicas $(2014$, p. 97) con características que indican una 
estética de la edición. Gustavino afirma que las primeras traducciones de los libros serían del 1954, el mismo año en que Vigo realiza su viaje a Europa, y las últimas en 1975. La autora ha señalado que: “Además de frecuentar esta historiografía en la que comienzan a perfilarse nuevos relatos sobre el arte de la primera mitad del siglo, que incorpora la abstracción en una posición central e introduce progresivamente el relevo de 'los viejos', Vigo entra en contacto con otras lecturas sobre el arte moderno elaboradas fuera de Francia." (2015, p. 438) Este estudio nos ha servido para trabajar con el rastreo de esas otras lecturas que inciden en la obra de E. A. Vigo.

Como características formales distingue dos etapas en estos libros artesanales, una primera hacia 1950, donde no hay imágenes en el interior del texto pero sí perforaciones, elemento fundamental en su poética posterior. Hacia la década de 1960, el tema central será la poesía visual y también incorpora la fibra y el collage.

El análisis de la autora nos ha permitido vislumbrar las complejidades en las lecturas y las tradiciones culturales en las cuales se insertan estas re-escrituras, los modos en que estas circulan; así como la posibilidad de acercarnos a complejo estudio de la obra de Duchamp en la biblioteca de Vigo, como se analizará en el apartado correspondiente.

\subsubsection{Concepto de re-escritura}

La dificultad en torno a la conceptualización de las re-escrituras se vincula con la especificidad del material que seleccionamos como objeto de nuestro análisis. Como hemos descrito sucintamente en la presentación de este trabajo, se trata de ejemplares que en algunos casos han sido traducidos por Elena Comas y se presentan mecanografiados y diseñados por E. A. Vigo, se configuran como nuevos ejemplares de ejemplares ya existentes. En el caso de los libros traducidos por Elena Comas, podríamos pensar que se justifica el trabajo de re-escritura de los nuevos ejemplares, pero en el caso de la re-escritura de artículos en la misma lengua nos preguntamos ¿por qué volver a copiar palabra por palabra un material preexistente?, o recuperando la pregunta de Gradowczyk sobre estos libros ¿qué lo lleva a esta reescritura, a esta suerte de apropiación de diferentes relatos?. En el camino de esta investigación nos hemos preguntado continuamente sobre el estatuto de estos ejemplares: ¿son las re-escrituras plagios?, ¿son "libros de artista”? ¿qué tipo de reescrituras son las re-escrituras? ¿qué concepto aglutina está práctica?. Como ya mencionamos, la pregunta por las re-escrituras también implica revisar la producción artística de Elena Comas en tanto resaltamos aquí la acción colaborativa en cada uno de estos ejemplares. 
Decidimos, a partir de la marca textual que aporta el guión (entre el prefijo "re" y "escrituras") hablar de re-escrituras para referir al corpus seleccionado. En las re-escrituras, literalmente la dupla Comas-Vigo vuelve a escribir, pero en esa repetición, a pesar de no modificarse el contenido del texto, se modifica el estatuto del nuevo original, puesto que pasa por el cuerpo de quien, mediante la utilización de la máquina de escribir, duplica el texto y lo reformula en su edición.

Entendemos que el término re-escritura aglutina las características particulares de estos libros, donde la caligrafía maquínica aparece componiendo el nuevo ejemplar, donde la copia pasa a ser una nueva edición. La marca textual del guión sirve para diferenciarnos del concepto de reescritura como lo concibe la crítica literaria puesto que esta centra su atención principalmente en los procedimientos por los cuales un autor reformula determinado texto original con intención creativa.

Presentamos a continuación un estado de la cuestión centrado en algunas definiciones por diferencia, es decir, aquellos conceptos que se acercan a las re-escrituras pero no son operativos para la especificidad de nuestro objeto, nos referimos a las nociones de reescritura, plagio, y libro de artista. Proponemos, posteriormente, una definición más cercana a nuestro objeto.

\subsubsection{Definiciones por diferencia}

a) re-escritura, ¿reescritura? En la poética de Leónidas Lamborghini, la reescritura es una forma de apropiación de diversos relatos que construyen un imaginario a partir de fragmentos, recontextualizaciones, citas o textos canónicos. Gerardo Jorge, en el prólogo a las Las Reescrituras (2016) de Leónidas Lamborghini llama "reescrituras tangenciales" a aquellos poemas que toman un elemento y lo expanden por contraste o semejanza y "reescrituras intrusivas" serían aquellas que parten del texto y lo reformulan:

Hay reescrituras 'tangenciales' y reescrituras 'intrusivas'. Las 'tangenciales' trabajan por contraste y semejanza, tomando un elemento (un tema, un personaje, una estructura; por ejemplo la idea de viaje) (...) Las reescrituras 'intrusivas', en cambio parten de las palabras mismas del texto a reescribir y las usan para formular otro texto, con independencia de la condición estructural e incluso semántica de la fuente. (...) Estas distintas formas de la reescritura tienen diferentes efecto, uno más analógico y otro más deconstructivo, pero se contaminan mutuamente, a la vez que se inscriben en horizontes 
históricos distintos, uno de mayor apertura y participación, otro de repliegue e introspección (2016, p. 10).

Ana Porrúa en su libro Variaciones vanguardistas. La poética de Leónidas Lamborghini (2001) ha analizado pormenorizadamente la obra del poeta y señala que:

Leer y escribir son actividades de igual jerarquía, son operaciones inseparables y éste es un costado novedoso para una figura de escritor que, en la década del '50, aún estaba constituida en relación a una ideología de la originalidad. Aquí, el escritor es el que construye su voz en combinación, en contrapunto con otras voces de la literatura (2001, p. 19).

Porrúa indica que en la biblioteca de Lamborghini los textos citados aparecen bajo la forma de intromisión e incluso de plagio (2001, p. 20), las "voces indirectas", se construyen como artificio, puesto que en esa palabra ajena "el artificio estará en el montaje o en el corte que produce una sintaxis peculiar"' (2001, p. 39).

El concepto de reescritura en los análisis de la poética de Lamborghini puede emparentarse con el concepto acuñado por el post-estructuralismo de intertextualidad (Kristeva, 1969). Como antecedente, pueden rastrearse los trabajos sobre el dialogismo de la escuela de Mijail Bajtin (1986). La reflexión de Bajtín "todo enunciado es un eslabón en la cadena de la comunicación discursiva" (2013, p. 270) intenta dar cuenta de múltiples vínculos y cruces entre esa producción discursiva específica y los textos con los cuales toma contacto. La concepción bajtiniana es germen del reposicionamiento y puesta en valor del receptor como un componente altamente dinámico y activo en la configuración de la obra. Con la figura del "mosaico", Julia Kristeva, propone pensar el texto como un fragmento de un texto donde se leen otros textos, (1967). Por su parte, Roland Barthes señala que la noción de intertextualidad no se vincula con la noción de influencia puesto que todo texto es ya un intertexto (1970), en $S / Z$ dirá: "interpretar un texto no es darle un sentido, sino por el contrario, apreciar el plural del que esta hecho.” $(2004$, p. 3).

En la obra de Genette, Palimsestos se establecen marcos para abordar la transtextualidad. Así, en la estructura que propone el autor interesa destacar tres aspectos sobre el análisis y se configuran como tipos de relaciones transtextuales: intertextualidad (relación de co-presencia entre dos o más textos) incluyendo cita y plagio; paratextualidad, que refiere a los elementos que conforman lo que está "por fuera" del texto: título, subtítulo, interludios, prefacio, notas al pie, fajas, sobre 
cubiertas etc; metatextualidad, corresponde a la relación que une un texto con otro texto que habla de él sin citarlo.

Vemos que el concepto de reescritura desde el análisis literario se toca con el de apropiación crítica, en tanto hay en estas operaciones de escritura una clara intención de transformación respecto del material original, por lo tanto una reformulación del contenido, del cual resulta una nueva obra.

Las re-escrituras que analizamos en este trabajo son copias textuales, no se modifica en ellas el contenido de un texto preexistente. A diferencia de las reescrituras de Lamborghini, las re-escrituras de Vigo son copias, no hay una reformulación del contenido del texto explícita en las re-escrituras.

Decimos que la modificación en las re-escrituras de Vigo se sustenta principalmente en dos aspectos que no inciden sobre el contenido del texto: la selección de textos que realiza para cada ejemplar, es decir el trabajo de edición y la elección de un repertorio, y el aspecto visual que resulta de los nuevos ejemplares.

b) re-escritura, ¿plagio? Si no hay reformulación de la palabra, si las re-escrituras de la dupla Comas-Vigo son transcripciones ¿entrarían estas dentro de la categoría de plagio? Entendemos en este trabajo de tesis que las re-escrituras son apropiaciones y, por lo mismo, nuevos textos donde interviene un repertorio de autores en función de determinados intereses de estudio.

Daniel Schavelzon, en el libro Arte y Falsificación en América Latina (2009) intenta establecer las diferencias entre copia, imitación, plagio y falsificación. La primera implica para el autor "reproducir, imitar, hacer algo de igual manera material o técnicamente" se convierte en delito cuando engaña con fines de lucro. Así:

La falsificación es "un tipo particular de copia" hecha con el objetivo concreto de engañar, con o sin lucro, y puede implicar hasta la copia de la obra completa o de su firma. Es lo más común puesto que intenta pasar algo nuevo por antiguo, o al menos anterior a él, la mayoría de las veces para ganar dinero (2009, p. 79).

Umberto Eco indica que la falsificación se produce cuando el objeto B se usa o expone con la intención de hacer creer que B es idéntico a otro objeto único por lo que "algo no es falso a causa de sus propiedades internas, sino en virtud de su pretensión de identidad" (1990, p. 188). Específicamente sobre el plagio señala que: 
Produciendo un $\mathrm{Ob}$ que copia completa o parcialmente un $\mathrm{Oa}, \mathrm{B}$ intenta esconder la semejanza entre dos Objetos y no intenta probar su identidad. Cuando un Pretendiente dice que los dos Objetos son similares, actúa como Juez y lo dice no para engañar a alguien, sino más bien para revelar la maniobra de B. Cuando B deja transparentar su dependencia de la obra de A, no tenemos plagio sino más bien parodia, pastiche, homenaje, cita intertextual, sin que ninguno de estos sea un ejemplo de falsificación. Una variante de estos ejemplos de pseudoplagio son las obras hechas á la maniere de (1990, p. 190).

En el apartado "Una tipología del préstamo", del libro Sobre el Plagio (2014), Hélén Maurel-Indart distingue plagio directo y parcial. El préstamo sin transformación es calificado como plagio directo, por lo que alcanza la totalidad de la obra original $(2014 ; 253)$; el plagio parcial solo abarcaría una parte de la obra original. Sobre el segundo, desarrolla la parodia ${ }^{19}$ y el pastiche como imitación de obra diferente a la cita (2014, p. 157).

Kevin Perromat (2010, 2014) en el artículo Literatura y plagio en Argentina: formas rentables y no rentables de quebrar los valores del mercado (2014), realiza un recorrido que involucra tanto a la generación de 1880 (Domingo F. Sarmiento, Marcos Sastre) como a los escritores contemporáneos para analizar, lo que podríamos denominar, algunos procedimientos heterodoxos en materia de autoría:

Esta tradición contaría con dos vertientes, no necesariamente coincidentes en sus posiciones frente a la ortodoxia en materia de autoría y modelos de propiedad artística: 1) una serie de propuestas poéticas y programáticas, vinculadas habitualmente a la Postmodernidad y a las textualidades alternativas, que atacarían frontalmente los valores y presupuestos de las definiciones económico-jurídicas imperantes a partir del siglo XIX (Lessig, 2004; Critical Art Ensemble, 1997) y 2) una tradición estrictamente temática, formal o discursiva que - por razones que pueden permanecer implícitas o incluso ser inconscientes- haría del plagio uno de los temas de predilección en la literatura moderna y contemporánea. (2014, p. 15)

\footnotetext{
${ }^{19}$ Linda Hutcheon señala que: "la parodia postmodernista es una forma problematizadora de los valores, desnaturalizadora, de reconocer la historia (y mediante la ironía, la política) de las representaciones" (1993, p. 2).
} 
En la misma línea ha señalado Josefina Ludmer que "uno de los objetivos del plagio es restaurar la dinámica y fluidez del significado, apropiando y recombinando fragmentos de cultura. El significado de un texto deriva de sus relaciones con otros textos" (2007).

El iconoclasta Alberto Laiseca, en su tratado Por Favor ;Plágienme! ([1991] 2013) argumenta sobre la deconstrucción del mito romántico de la creación artística. Dice Laiseca que "El plagio, aparte de ser un homenaje al creador, trae implícita una forma de amor" (2013, p. 53), porque "plagiar es hacer hablar a los muertos" (p. 40). La Tecnocracia es la figura paródica de la legislación argentina en el libro de Laiseca y refiere al Régimen Legal de la Propiedad Intelectual (Ley 11.723) el que en su artículo primero determina que:

A los efectos de la presente Ley, las obras científicas, literarias y artísticas comprenden los escritos de toda naturaleza y extensión, entre ellos los programas de computación fuente y objeto; las compilaciones de datos o de otros materiales; las obras dramáticas, composiciones musicales, dramático-musicales; las cinematográficas, coreográficas y pantomímicas; las obras de dibujo, pintura, escultura, arquitectura; modelos y obras de arte o ciencia aplicadas al comercio o a la industria; los impresos, planos y mapas; los plásticos, fotografías, grabados y fonogramas, en fin, toda producción científica, literaria, artística o didáctica sea cual fuere el procedimiento de reproducción.

La protección del derecho de autor abarcará la expresión de ideas, procedimientos, métodos de operación y conceptos matemáticos pero no esas ideas, procedimientos, métodos y conceptos en sí.

La última modificación (Art. $5^{\circ}$ bis) corresponde al año 2009, mismo año en que Pablo Katchadjian publica El Aleph engordado. Si bien la modificación no es producto del "caso Katchadjian" sino de un reclamo por los fonogramas de Mercedes Sosa, tuvo gran repercusión mediática puesto que María Kodama, heredera de la obra borgeana, en 2011 exige la penalización de la transformación que el autor propone del libro original El Aleph considerando que el agregado de palabras que realiza Katchadjian defrauda los derechos de propiedad intelectual $^{20}$.

\footnotetext{
${ }^{20}$ Nota completa en el diario Página 12 (16 de mayo de 2017) "El autor de "El Aleph engordado", sobreseído". Disponible en: https://www.pagina12.com.ar/38089-el-autor-de-el-aleph-engordado-sobreseido consultado 31/ 6/ 18 .
} 
Por último mencionar algunas consideraciones en torno libro de Goldsmith Escritura no creativa (2015). Inicia su planteo reflexionando sobre los escritores contemporáneos, quienes, según el autor, exploran maneras de escribir que tradicionalmente se consideraban excluidas del campo de la literatura por plagiarias. El autor entiende que:

Esta literatura "no-creativa" esta imbuida de un sentido de celebración, posee una mirada entusiasta hacia el futuro y entiende este momento histórico como lleno de posibilidades. Esta satisfacción es evidente en la escritura misma, donde encontramos momentos de belleza inesperada, algunos de tipo gramático, otros estructurales, muchos filosóficos: los maravillosos ritmos de repetición, el espectáculo de lo mundano transformado en literatura, la reorientación hacia la poética del tiempo, y perspectivas frescas, nuevas, sobre el acto de la lectura por mencionar solo algunos. (2015, p. 25).

Se posiciona en contra de los "manuales de escritura creativa" puesto que estos repetirían modelos caducos en torno a ideas tales como el genio creador, innovación e interioridad del sujeto. El proceso de escritura que propone el autor se vincula con "la toma de decisiones", así: "Si se trata simplemente de cortar y pegar la totalidad de internet en un documento de Word, lo importante es que tú, autor, elijas. El éxito se encuentra en saber qué incluir y más importante todavía qué excluir" (2015, p. 35). En la escritura no-creativa se buscan nuevos sentidos modificando el propósito de los textos ya existentes (2015, p. 67). Si bien algunas de sus reflexiones se emparentan con los desarrollos de Nicolas Bourriaud en Postproducción (2002), creemos que el abordaje de Goldsmith es superficial y no aporta conceptos sustanciales para nuestro trabajo; además no coincidimos con los datos que presenta en su argumentación como 
por ejemplo los antecedentes del Libro de los Pasajes ${ }^{21}$, por lo que no lo utilizamos como marco teórico para nuestro desarrollo.

Es fundamental señalar que las re-escrituras de Vigo son copias de textos preexistentes donde la mención a la autoría original del texto es fundamental. En las re-escrituras, la referencia a la figura del autor del texto de origen a partir de la cita es la forma de apropiarse de las palabras del mismo y posicionarse como sujeto legítimo para decir. La función que hemos relevado de las re-escrituras (proyectada tanto en las ediciones de Vigo como en sus charlas y obras) también indica que para él los textos son un insumo para formar e informarse, acción que no entraría en las múltiples formas que asume el plagio.

Como ha señalado Michel Foucault en El orden del discurso (2005) las instancias de control se encargan de regular las formaciones discursivas en tanto estructuran lo que puede ser dicho en un determinado contexto de producción de enunciados. Las re-escrituras de Vigo no son falsificaciones ni plagios porque el principio básico de estos procedimientos es hacer pasar por propio lo ajeno, en otras palabras, generar un simulacro. A diferencia de este, las re-escrituras se remiten a la autoridad del autor en lo que respecta al contenido del texto, pero lo subvierten

\footnotetext{
${ }^{21}$ En el apartado ¿Por qué la apropiación? Afirma Goldsmith en su lectura de Libro de los Pasajes de W. Benjamin que: "A pesar de la pulverización y la distorsión del lenguaje durante el siglo XX, y los centenares de nuevas formas propuestas para la ficción y la poesía, nunca antes se le había ocurrido a nadie tomar las palabras de alguien más y presentarlas como propias" $(2015,164)$. Esta afirmación puede rebatirse si consideramos los estudios de M. Foucault sobre antiguos hypomnémata. En el apartado "La escritura de sí" de Estética, ética y hermenéutica (1999), Foucault analiza las escrituras personales en la cultura grecorromana siglos I y II. Aquí la "escritura de sí" o "escritura de los movimientos interiores" aparece vinculada a la contemplación y la penitencia, así "la escritura es un operador de la transformación de la verdad en éthos" (1999, p. 292). Las correspondencias y los hypomnémata serán las dos formas en que se manifiesta esa escritura. En palabras de Foucault:"Los hypomnémata, en sentido técnico, podrían ser libros de cuentas, registros públicos, cuadernos individuales que servían de ayuda memoria. Su uso como libra de vida, como guía de conducta parece haber llegado a ser algo habitual en todo un público cultivado. En ellos se consignaban citas, fragmentos de obras, ejemplos y acciones de los que se había sido testigo o cuyo relato se había leído, reflexiones o razonamientos que se habían oído o que provenían del propio espíritu. Constituían una memoria material de las cosas leídas, oídas o pensadas, y ofrecían tales cosas, como un tesoro acumulado, a la re lectura y a la meditación ulterior" (1999, p. 292). Señala también que estos volúmenes no solo debían considerarse apoyos para la memoria, también constituyen un marco para ejercicios de escritura personal que debían frecuentarse: leer, releer, meditar, conversar consigo mismo y con los otros (1999, p. 293). El objeto que persiguen los hypomnémata es captar lo ya dicho, reunir lo que se ha podido oír y leer para constituirse como sujetos herederos de una tradición. "Si la redacción de los hypomnémata puede contribuir a la formación es a través de estos lógoi dispesos, eso obedece a tres razones principales: a los efectos de limitación debidos a la a la ligazón de la escritura con la lectura, a la práctica regulada de la disparidad que determina selecciones y a la apropiación que este efectúa." (1999, p. 294) Si por un lado estos volúmenes corresponden a compendios que intentan huir de la dispersión construyendo en cierto modo un pasado, al mismo tiempo reúne elementos heterogéneos y esto se opone, en palabras de Foucault, al trabajo de los gramáticos o los filósofos de profesión que reivindican la unidad total de la obra de una escuela de pensamiento (1999, p. 295). El desarrollo planteado por Foucault sobre los hypomnémata cuestiona la afirmación de Goldsmith respecto de los antecedentes del Libro de los Pasajes. Así como los hypomnémata son compendios de conocimientos ligados a uno o varios temas específicos, los procedimientos compositivos que utiliza el escriba persiguen un fin: comprender, agrupar lo dicho, producir verdad, generar archivo.
} 
desde la estructura heterodoxa que se propone en los elementos de la comunicación visual. La cita de autoridad en las re-escrituras se vincula, a su vez, con el carácter formativo de E. A. Vigo puesto que este, si bien se desarrolla como docente, no es un teórico académico del arte, tal como ocurre, por ejemplo, con los poetas concretos (como estudiaremos a continuación).

La formación es para Vigo importante puesto que él se desempeña como docente, imparte charlas, entrevistas, cursos y publicaciones periódicas sobre arte contemporáneo como atestiguan los documentos resguardados en Biopsia. También, como veremos en el desarrollo, los textos teóricos funcionan como insumo indirecto en la elaboración de sus obras. Consideramos, entonces, que la transcripción plasmada en las re-escrituras funciona como modelo de aprendizaje y apropiación de ese conocimiento, reconociendo que en esas apropiaciones existen modificaciones en el aspecto visual de los textos que inciden en los modos de leer, pero no el contenido de los mismos ${ }^{22}$.

c) re-escritura ¿obra? Un tercer aspecto a tener en cuenta en relación con el problema sobre cómo categorizar las re-escrituras es el carácter de piezas artesanales únicas (Gustavino, 2014). También Gradowczyk señalaba que estos ejemplares podrían corresponderse con la categoría "libro de artista" (2008). Las composiciones de los párrafos y los aspectos referentes a las imágenes en los ejemplares dan cuenta de un trabajo artístico que incide sobre la edición pero no sobre el contenido de los textos. El trabajo mecanografiado en cada ejemplar, así como las imágenes y la disposición del cuerpo de texto nos ha llevado a indagar en autores que estudian el libro como obra, tanto los denominados "libros de artista", como aquellos casos donde la escritura se transforma en obra ( $\sin$ ser considerada poesía visual), es decir, vinculados al carácter aurático del manuscrito y la escritura como gesto.

El libro de Sergio Chejfec, Últimas noticias de la Escritura (2015) indaga, entre otras cosas, en dos casos donde la escritura es protagonista de la obra visual. El primero refiere obra de Fabio Kacero $^{23}$, corresponde a una instalación realizada en el Museo de Arte Moderno de Buenos Aires donde se reproduce una versión manuscrita del texto de Borges "Pierre Menard, autor del

\footnotetext{
${ }^{22}$ Como veremos en el desarrollo de las historietas herméticas, Vigo no tiene las mismas consideraciones en la apropiación de imágenes y en la de textos; en tanto las primeras son reformuladas desde el montaje configurando una nuevo sentido para la representación y en ellas no se identifica la autoría de la imagen original.

${ }^{23}$ Fabio Kacero (Buenos Aires, 1961) Profesor de dibujo y pintura egresado de la ENBA Prilidiano Pueyrredón. Inicia sus exposiciones individuales en 1991 en la muestra "Las Voces Emergentes" (Harrods), en el ICI, Galería Kravets-Wehby, Nueva York, C. C. Borges y en Ruth Benzacar. También participó de muestras colectivas y ferias de arte internacionales en Argentina, Brasil, Venezuela, México, Japón. Ha publicado su libro “nemebiax", editado por Galería Ruth Benzacar, 2004. Extraído del Catálogo Arte abstracto hoy=fragilidad+ resiliencia (2006) Centro Cultural España en Buenos Aires, Buenos Aires.
} 
Quijote” (2014). En su análisis, Chejfec señala que "el empeño grafológico da como resultado una reproducción no técnica del manuscrito de Borges (...) Kacero conquista la letra del autor; la "saca" como si se tratara de un trazo inimitable de un artista" (2015, p. 32) y se pregunta "¿Qué fantasía o promesa anuncia el ejercicio de Kacero sobre el Menard de Borges? Acaso se trate de la apropiación de lo más evidente: la forma manuscrita, sin el papel que le sirve de soporte: un botín fuera de tiempo que navega por la lengua franca de los originales, y que se sirve de su condición inmaterial para permanecer siempre a flote" (2015, p. 33). La obra se encuentra expuesta en el MAMBA, ordenada secuencialmente en una vitrina.

El segundo caso pertenece a la obra de Tim Youd $^{24}$, quien propone -también en formato de instalación- copiar textualmente un recorte de obras literarias con máquinas de escribir similares a las que utilizaron sus autores. La particularidad de este manuscrito-obra reside en que en el proceso de la transcripción la hoja sobre la que escribe no se cambia. El artista escribe entonces sobre la misma hoja, resultando saturada de tinta, y coloca otra hoja debajo que posee las marcas de la hendidura que las letras de molde han provocado en la primera -podríamos comparar el procedimiento con la técnica del stencil-. En la lectura de Chejfec: "En un punto, Youd materializa el caos potencial inscripto en toda cadena textual, amenazada por el desorden eventual de la secuencia de letras que mantiene unidas (...) las páginas abigarradas de Youd vienen también a representar libros no-abiertos. Son ilegibles como un volumen cerrado" (2015, p. 37). En ambos casos, el problema que le interesa abordar a Chejfec reside en el manuscrito como obra y los desarrollos conceptuales sobre la copia, la reproducción y las escrituras contemporáneas. Vigo, en su acción de transcribir palabra por palabra una lectura, hace pasar por el cuerpo un texto que ya existe. Sin embargo, no hay constancia de que en esta operación exista un deseo de que el nuevo ejemplar, la re-escritura, sea una obra. Es decir, no hay una voluntad explícita de que ese texto salga a la luz en su forma de re-escritura, ya que pertenece, en primera instancia, al ámbito de lo privado (Gustavino, 2014). En ninguna de las exposiciones de Vigo se utilizaron estos ejemplares como obra, tampoco menciona la existencia de las re-escrituras en sus textos publicados vinculados a su obra artística. Siguiendo la definición de Bourdieu, las re-escrituras no fueron puestas a circular como obra ni recibidas como obra, por lo tanto, ni para Vigo ni para Comas, fueron obra ${ }^{25}$.

\footnotetext{
${ }^{24}$ El artísta Tim Youd nace el Massachusetts en 1967.

${ }^{25}$ En este sentido, dice Pierre Bourdieu en El sentido social del gusto (2010): "Todas las relaciones que los agentes de producción, reproducción y difusión pueden establecer entre ellos o con las instituciones específicas (y también la relación que mantienen con su propia obra) están mediatizadas por la estructura de las relaciones entre las instancias que pretenden ejercer una autoridad propiamente cultural: la jerarquía establecida en un momento dado entre los dominios, las obras y las competencias legítimas aparece como la expresión de la
} 
La bibliografía consultada coincide de manera general en la concepción del libro de artista como soporte plástico (Oller Navarro, 2011; Alcaraz, Sabina, 2012; González, 2013; Antón, J. E. y Montero A, 2012; Valente, 2012). Alicia Valente indica que el libro de artista es una ampliación del artefacto libro donde interviene tanto la apropiación como la experimentación desde el lenguaje plástico al considerar el libro como soporte:

De este modo, el Libro de Artista es una obra que explora e indaga las posibilidades del libro; sus elementos constitutivos, tales como la materialidad, la forma y la estructura elemental (lomo, tapas, páginas, formato de códice); su desarrollo espacio-temporal y su lectura secuencial (2012, p. 167).

En su análisis considera los libros de artista según tres ejes: producción, lectura y exhibición. Respecto del eje de la producción indica que en los estudios sobre el libro de artista ha primado la especificidad de la materialidad, centrada en características como el tamaño, percepción sensible, portabilidad y reproductibilidad. El eje de la lectura se vincula tanto a la recepción como a la participación, también al aspecto legible o ilegible del libro (por caso los grafismos de Mirtha Dermisache). Respecto del eje de la exhibición, Valente indica que:

El abordaje del soporte y la relación participativa que propone el LA pone en discusión la idea de exposición de sala y de colección de obra de arte. El LA cuestiona el carácter intocable de la obra de arte y rompe, igualmente, con el aura de la obra de la que habló Benjamin. Son obras concebidas para que sus operatorias de uso puedan ser ejecutadas, aunque impliquen su deterioro (2012, p. 170).

En las caracterizaciones que revisamos anteriormente, tanto del libro de artista como de los casos que presenta Chejfec es fundamental la intención de exhibir el objeto intervenido, es decir, considerar obra esa materialidad. Este hecho se opone a la configuración de las re-escrituras, en tanto estas son intervenciones privadas sobre ejemplares que no tienen la finalidad de ser expuestos a posteriori en su condición de re-escritura.

estructura de las relaciones de fuerza simbólica entre en primer lugar, los productores de bienes simbólicos () y las diferentes instancias de legitimación" (2010, p. 103) 


\subsubsection{De máquinas de escribir y archivos}

A partir del desarrollo "por diferencia" planteado anteriormente, decimos que las re-escrituras son abordadas en este trabajo, en primer lugar, como ejemplares únicos donde interviene un corpus que denominaremos repertorio y un modo particular de incorporar este conocimiento, que será desarrollado a partir de la noción de apropiación.

Destacamos, en segundo lugar, el particular trabajo estético y artístico en la elaboración de cada uno de estos libros. Entendemos que las nociones de plagio, falsificación y escritura no creativa no son operativas para este análisis en tanto, en las re-escrituras, Vigo cita a los autores de los textos originales para, al momento de socializar estos conocimientos en charlas, publicaciones y obras, posicionarse él mismo como sujeto legítimo y conocedor dentro de determinados campos de conocimiento. Las re-escrituras tampoco serán consideradas en este trabajo bajo la categoría libro de artista, puesto que no han sido concebidas por E. A. Vigo ni Comas para ser expuestas sino, en principio, para una utilización privada de ese material.

En las re-escrituras interviene en primer lugar un repertorio, selección de teorías y experiencias que se eligen para ser transcriptas; y en segunda instancia la edición donde se plasman elementos propios de la comunicación visual (diagramación, encuadernación, imagen, entre otros).

A diferencia de Comas, quien traduce los textos a mano, con lapicera y en hojas sueltas, el dispositivo más utilizado por Vigo para la confección de las re-escrituras es la máquina de escribir. Fue inventada con el objetivo de copiar documentos en el siglo XVIII a fin de que los manuscritos llegasen limpios a la instancia de impresión. Piglia, relata de manera anecdótica el encuentro de algunos escritores con este dispositivo:

El primer escritor que la usó con este criterio creativo y no de mera copia fue Tolstói, que estaba siempre muy atento a las renovaciones técnicas. (...) sabrán que sus novelas habían sido copiadas por su mujer, Sofía Tolstói. La guerra y la paz la copió ella siete veces, porque cada corrección de Tolstói suponía una nueva versión que había que volver a copiar, era un trabajo increíble. Tanto que pensaba que la novela era de ella - desde luego, si uno copia siete veces una novela algo comparte con el que la ha escrito - y empezaron los conflictos con Tolstói, que terminaron muy mal. (...) Henry Miller, por ejemplo, hace del canto de la máquina de escribir en los hoteles de París, donde escribía su trilogía de los trópicos, un elemento que forma parte de la 
mística de la escritura. «Todos los vecinos de mi hotel —dice- oían el sonido musical de mi máquina, que no paraba nunca». Ahí esta la idea de que la máquina permitía escribir más rápido. El otro ejemplo es el de Kerouac, el novelista de la Beat Generation, que escribió On the road (En el camino) (...) con una innovación. (...) inventó una bobina: compró un rollo de papel que puso en el rodillo y escribía sin parar siguiendo el ritmo que para él tenía la escritura continua, buscando cambiar la prosa y la narración con esos grandes rush de escritura, a partir de una innovación técnica de la máquina y de la velocidad que se le podía imprimir a la escritura. (Piglia, 2016, p. 86)

En la vida de Vigo, la máquina de escribir forma parte del mundo burocrático en el cual esta inmerso desde 1950 a partir de su trabajo en los Tribunales del Poder Judicial Provincial. Como ha estudiado Ana Bugnone $(2013,2017)$ el vínculo con el universo de los magistrados y la burocracia es un elemento decisivo de la poética de E. A. Vigo que no solo se manifiesta en los procedimientos compositivos, también en aspectos conceptuales de la propia obra del artista. Por lo anterior, el hecho de que las re-escrituras se encuentren mecanografiadas, diseñadas y encuadernadas también nos lleva a la consideración de la propia biografía del artista y la particular reunión que se manifiesta entre arte, técnica y vida en su producción, ligando su obra a un elemento completamente común, usual y cotidiano en determinados hogares de clase media de la época: la máquina de escribir.

Vigo utiliza este dispositivo para sus copias plasmadas en las re-escrituras, en los índices que se presentan en Biopsia, en sus charlas, presentaciones y correspondencias personales, también lo incorpora como elemento a su única obra estrictamente sonora "homenaje a una pensión de estudiantes”26. La utilización de la máquina de escribir le permite diseñar los párrafos de las re-escrituras construyendo una poética y una estética de las re-escrituras, reformulando el uso tradicional que se le otorga a este elemento.

Resulta pertinente retomar el estudio de Anna Maria Guasch sobre Arte y Archivo, puesto que, a los ejemplos que la autora toma para su análisis, podría sumarse el caso de las re-escrituras de E. A. Vigo y Comas. Decía Guasch que, en una de las "máquinas" del paradigma del archivo se pone énfasis en el principio regulador del nomos (o la ley) y del orden topográfico (2011, p. 15). Dentro de este grupo la autora sitúa el Libro de los Pasajes de W. Benjamin y el modelo Atlas

26 Ver: Courtis A. y Lamilla J. (2018) Vigo y el Arte Sonoro Conferencia con Escuchas del Archivo Audiovigoteca del Centro de Arte Experimental Vigo, UNTREF. Simposio Internacional de Arte Sonoro. Actas web: https://untref.edu.ar/uploads/resumenes_de_ponencias-mundos_sonoros.pdf 
Mnemosyne en paneles de Aby Warburg. El primero compuesto de fragmentos, el segundo de imágenes. Respecto de los archivos fotográficos y el vínculo entre el arte y el archivo, estudia el caso de Hannah Höch (1989-1978) en concreto Sammelalbum (Álbum de recortes de prensa) elaborado en torno a 1933. Este “álbum” agrupa imágenes de mujeres, paisajes, flores, máquinas, atletas, bailarines, trabajadores y anuncios "buscando asociaciones iconográficas y ciertas homologías formales en la creación de un continuo flujo visual” (2011, p. 35).
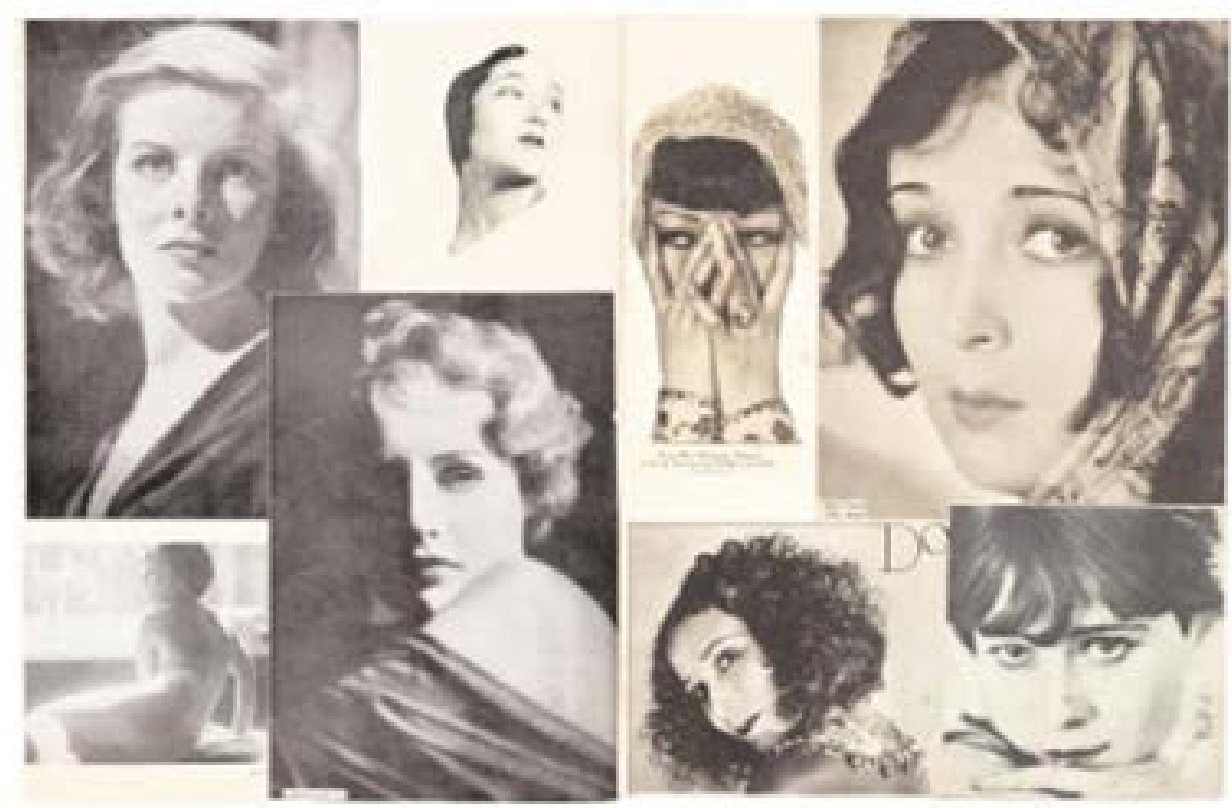

Fig. 2. Hannah Höch. Sammelalbum. 1933.

Indica Guasch que se desconoce si estos álbumes fueron concebidos como obras artísticas independientes o se trataba de un "diario visual". Es importante destacar que se pone de manifiesto en esta incertidumbre la misma tensión para considerar las re-escrituras de Vigo, es decir el problema por el estatuto de estos ejemplares (¿son obras? ¿ “diarios visuales” ?).

Dentro de la caracterización realizada Guasch, proponemos vincular, tanto en lo que respecta a características estéticas como por la rareza de estos ejemplares, las re-escrituras de Vigo y Comas, y sumar las del "poeta, escribidor, pintor y pocas cosas más” ${ }^{27}$ Xul Solar.

En la muestra Xul Solar. Panactivista realizada en 2017 en el Museo Nacional de Bellas Artes, se exhibió un cuaderno de recortes, similar - y posiblemente contemporáneo- al de Hannah Höch, donde se pone de manifiesto el interés archivístico de Xul Solar en relación con el mundo de las imágenes (ejemplares con recortes de catedrales, letras, mapas). No hemos podido tener

\footnotetext{
27 Definiciones que el artistas ofrece de sí mismo compiladas por Patricia Artundo en Alejandro Xul Solar entrevistas artículos y textos inéditos (2006) Editorial Corregidor. Buenos Aires.
} 
acceso a estos ejemplares, sin embargo, creemos pertinente su incorporación a esta argumentación en tanto dan cuenta de un procedimiento acumulativo -de imágenes, en este casoque nos lleva a establecer una analogía con la obra de Höch y las re-escrituras de nuestro trabajo.

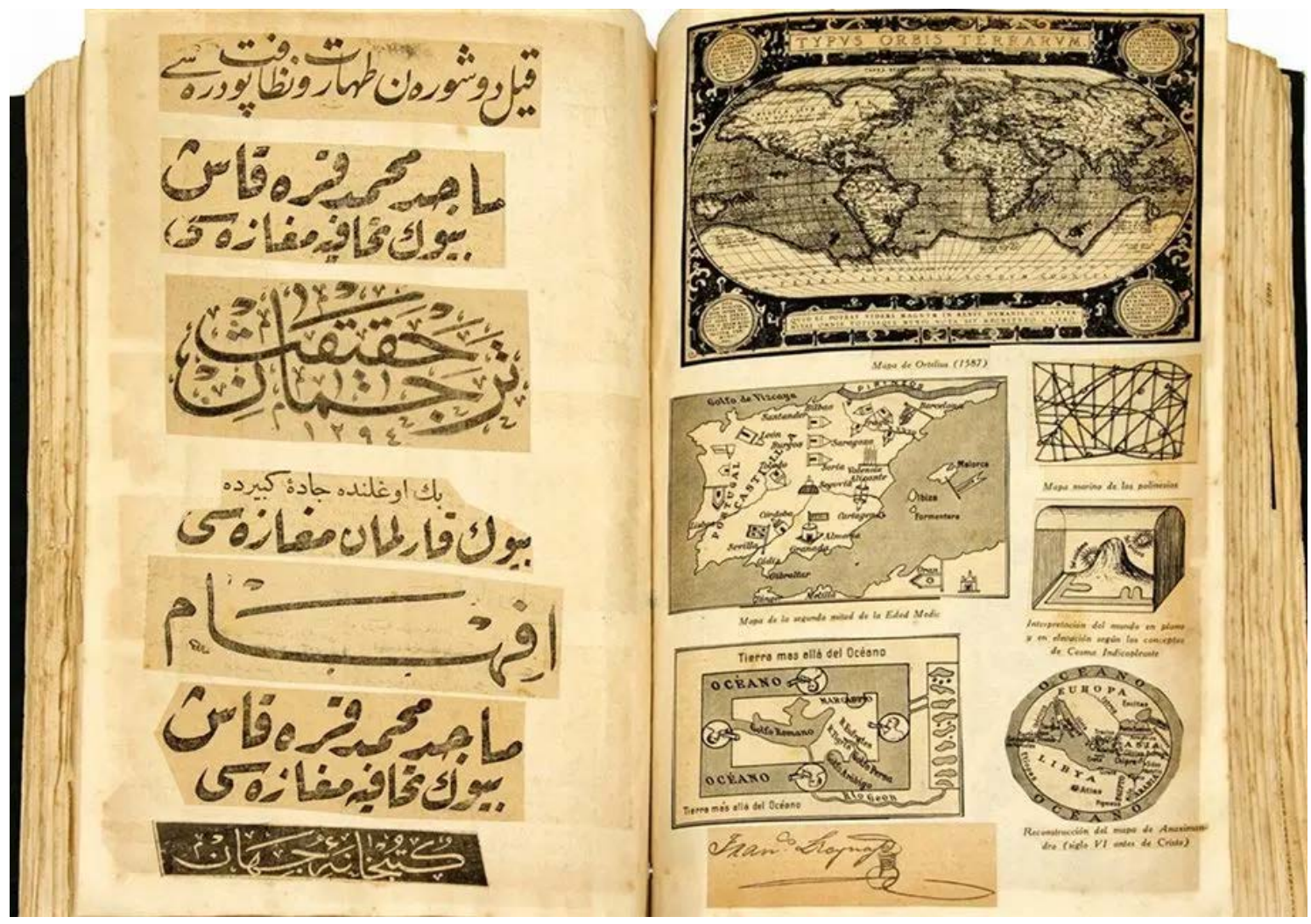

Fig 3. Carpeta de recortes expuesta en Xul Solar. Panactivista. (2017) MNBA, Fundación Pan Klub.

También el libro Los San Signos Xul Solar y el I Ching (2012) ${ }^{28}$ son re-escrituras del Libro de las mutaciones o I Ching a las cuales Xul Solar accede mediante la técnica de clarividencia (Artundo, 2012, p. 33). En la caracterización de Daniel Nelson, corresponden genéricamente a una forma de "prosa poética mística" (2012, p. 45).

Interesa establecer el vínculo entre las re-escrituras de Vigo y los escasos datos que tenemos de los cuadernos de recortes de Xul, puesto que, si por una parte amplían el estudio que presenta Anna María Guasch sumando propuestas locales, contribuye a profundizar los casos de estudio para la categoría que proponemos en este trabajo como re-escrituras, es decir, compendios de conocimiento organizados y editados de manera personal que sirven para estudiar y, mediante la apropiación, plasmar en sus obras y escritos.

\footnotetext{
${ }^{28}$ Corresponde a la materialización del pedido que el mago ocultista inglés A. Crowley realizará en 1924 a Xul Solar: "Reescribir el I Ching describiendo cada hexagrama por medio de una visión pura. Hacer 64 bocetos simbólicos de prosa breve o descripciones poéticas pero con la más cuidadosa atención a un método uniforme de presentación" (Artundo, 2005, p. 49).
} 
Tanto Vigo como Xul Solar re-escriben, en el sentido de agrupar en una nueva materialidad, un compendio de lecturas y transcripciones, copias fragmentaria de una totalidad, registros de la mirada y los intereses de un sujeto - en este caso artistas - sobre el mundo, sus mundos. Soportes materiales que anteceden a los procesos de elaboración "terminada" de una obra, acontecimientos que dan cuenta de una experiencia de estudio, de un proceso de conocimiento, una dimensión creativa que se abre en la utilización a posteriori que estos artistas realizan de ese material.

Se vinculan además (Vigo y Xul) en la indagación por el lenguaje (en Xul las grafías plastiútiles o pensilformas $^{29}$ en E. A. Vigo la poesía matemática barroca, su poesía objetual), los heterónimos y las formas de hacer archivo en términos derrideanos. Los San Signos de Xul Solar presentan también el desplazamiento que opera en las re-escrituras: son apropiaciones de los 64 hexagramas del I Ching, que, posteriormente, Xul Solar transcribe y de las cuales solo se publican tres en vida de su autor ${ }^{30}$. Es posible, al igual que en la obra de E. A. Vigo, encontrar vinculaciones a la luz de Los San Signos con las imágenes de Xul Solar plasmadas en su producción pictórica.

Creemos en esta tesis que las re-escrituras que analizamos, a pesar de su rareza, pueden vincularse con aspectos técnicos específicos -un mundo previo a internet- donde los artistas trabajaban con un repertorio de imágenes y lecturas que sustentan y ofician de andamiaje de sus producciones plásticas pero que no pertenecen al ámbito de lo que consideraron obra para exponer. Revisten importancia en tanto dan cuenta de los procesos de producción y de apropiación de determinados conocimientos, autores, imágenes, movimientos estéticos y consumos culturales que inciden en sus producciones mostradas o editadas.

En el caso específico de las re-escrituras de Vigo, la apropiación en las lecturas no funciona a la manera del plagio o la parodia sino como una cita de autoridad que legitima la palabra y el conocimiento del artista en el medio artístico local. Estos compendios de estudio también sustentan una dimensión creativa puesto que encontramos resonancias de los textos leídos en las producciones visuales, editoriales y de difusión de Vigo. Las re-escrituras dan cuenta de un saber que se construye y que pasa por el cuerpo tanto en la transcripción como en las obras. En este

\footnotetext{
${ }^{29}$ Relacionado con la invención por parte de Xul de nuevos sistemas lingüísticos, es en su retiro al Tigre donde trabaja con las "Grafías plastiútiles" o "Pensilformas", algo verdaderamente novedoso. Los escritos de las mismas, se encuentran a su vez "traducidas" por Xul a su propio idioma: el neocriollo. Las doce técnicas pictóricas sobre las cuales trabaja para la elaboración de las grafías corresponden a doce nuevos alfabetos, de los que llegó a concretar seis.

30 A saber "Poema" (Revista Imán, 1931), “Apuntes en neocriollo" (Revista Azul, 1931) y "Visión sobre el trigrama" (Revista Destiempo, 1936).
} 
sentido, y a la luz de las re-escrituras, una de las etiquetas diseñadas por Vigo "Una lectura aburrida genera un acto creativo" podría pensarse como declaración de principios por parte de su autor, en tanto las lecturas circulan, se modifican, se apropian. Los volúmenes de imágenes de Xul y Höch serían análogos a las re-escrituras en tanto buscan criterios de selección comunes sobre una materialidad, es decir, un repertorio propio e inciden en las obras mostradas. 


\section{Problema}

Los ejemplares de re-escrituras se vinculan con las formas en que Vigo lee (consume, se nutre de teoría y formula su propio repertorio) pero también las formas en que propone ser leído. En este sentido, la función de Elena Comas en las re-escrituras es fundamental en tanto es ella la que traduce textos inéditos al español y permite la comunicación de Vigo con otros artistas internacionales mediante sus cartas.

Los usos que E. A. Vigo efectúa de sus lecturas (tanto del material de las re-escrituras como de los ejemplares presentes en su Biblioteca General) se consolidan en la trayectoria del artista a partir de su obra mostrada y editada. Lo anterior se hace presente en el interés temprano de Vigo por la palabra como material que tiene su correlato en el trabajo con la poesía visual o experimental, en el afán por establecer lazos y generar comunidades artísticas que se materializa en el arte correo-comunicación a distancia, el desarrollo de técnicas como la xilografía que se proyecta en los cuadernos de Xilografía, la conformación de grupos de artistas como Diagonal Cero o el Grupo de los 13, el Museo de la Xilografía, sus reflexiones en torno a la participación del espectador, entre tantos otras obras mostradas, expuestas, archivadas en sus Biopsias. Es posible rastrear a partir del estudio de las re-escrituras las formas en que se materializa la apropiación de determinadas corrientes estéticas y postulados en la obra de Vigo. Estos espacios ocultos, que quedan en la sombra, dan cuenta de modos de leer, conocer y formarse.

Hay en las re-escrituras un programa de conocimiento. Esto significa que no hay improvisación sino compromiso con ese saber para posicionarse como sujeto competente y legítimo para comunicar. Podríamos decir que Vigo produce obra desde donde lee, porque transforma las lecturas materialmente en re-escrituras pero también las reformula e interpreta en su trabajo plástico a partir de la experimentación. Vigo es, tomando una de sus categorías, un lector participante porque hace cosas con palabras.

Por lo anterior, el problema que desarrollamos en este trabajo se enuncia a partir de las siguientes preguntas generales: ¿De qué manera se hacen visibles las lecturas en la obra de Vigo? ¿Cómo inciden las lecturas y las re-escrituras en la producción de E. A. Vigo? Algunas cuestiones que se desprenden de lo anterior: ¿Cuáles son las particularidades de estas re-escrituras y porqué fueron producidas? ¿Mediante qué criterios Vigo organiza esta gran producción de escrituras previa a las obras? ¿Qué huellas deja Vigo en estas copias? ¿Qué hay de estas lecturas en la producción expuesta de E. A. Vigo?. 


\section{Hipótesis de Trabajo}

Esta tesis considera como primer hipótesis de trabajo que las re-escrituras de E. A. Vigo inciden en la producción plástica, editorial y de divulgación del artista y dan cuenta de modos particulares de lectura y escritura en la apropiación del conocimiento.

Para abordar esta primera hipótesis nos abocamos a describir y explicar las particularidades de las mismas atendiendo a la incidencia de las re-escrituras en la obra publicada y expuesta de E. A. Vigo. Se trabajará para ello con la sistematización de las re-escrituras en el archivo y el análisis de obras y publicaciones en el período que comprende desde 1954 a 1975.

La segunda hipótesis de trabajo entiende que las re-escrituras en el periodo estudiado comprenden tres espacios de conocimiento con los que E. A. Vigo configura su repertorio: vanguardia histórica, poesía experimental e historieta.

Trabajamos, para el abordaje de esta segunda hipótesis, con los tres ejes temáticos predominantes en el corpus de re-escrituras describiendolos en función de dos niveles: decisiones y tensiones en torno al corpus y materialización en obras y publicaciones.

En tercer lugar entendemos que las re-escrituras impactan en la producción de E. A. Vigo de forma directa, a partir de la inserción de la re-escritura en las publicaciones que Vigo editó y de manera indirecta, a partir de la reformulación que E. A. Vigo realiza en su producción plástica.

Para abordar la tercera hipótesis trabajaremos con el material del archivo Vigo en relación con una selección de sus publicaciones y obras producidas entre 1954-1975. 


\section{Marco Teórico}

Hemos dicho que las re-escrituras de E. A. Vigo dan cuenta de modos de lectura pero también inciden en la producción del artista, en tanto implican procesos de apropiación del conocimiento. El término apropiación remite, en el ámbito de las artes, a la acción de hacer de lo ajeno algo propio tomando uno/ varios elementos del primero. Como veremos en el desarrollo de esta tesis, la apropiación asume diversas configuraciones (conceptual, iconográfica, entre tantas otras). Entendemos que en la operación de volver a escribir Vigo hace suyas las conceptualizaciones que los autores ponen de manifiesto en sus textos de manera antropofágica: lee, deglute, asimila y genera otra obra.

El modo de hacer propio se configura en las re-escrituras como un montaje donde interviene en primer lugar un repertorio, selección de teorías y experiencias que se eligen para ser transcriptas; y en segunda instancia la edición donde se plasman elementos propios de la comunicación visual: diagramación, encuadernación e imagen. Posteriormente, una selección de esos textos se proyectan en sus publicaciones, en obras, charlas y proyectos de escritura. Ahora bien, ¿Cómo se configura el repertorio de lecturas que se seleccionan para ser traducidas, mecanografiadas y editadas? ¿qué/ quienes se incluyen en ellas? ¿en qué tradiciones se inscriben las re-escrituras de E. A. Vigo? ¿qué elecciones de diálogo mantiene? ¿qué temáticas son transversales en esa apropiación?

Considerando lo anterior, en el presente desarrollo nos acercamos, en primer lugar al marco histórico, social y artístico reseñando los principales hitos de las décadas del 1950, 1960 y 1970 en el campo argentino. Relacionamos determinados temas con problemáticas que le interesan a E. A. Vigo plasmadas en sus re-escrituras de artículos.

Por otro lado, referimos al término apropiación para abordar el procedimiento a través del cual E. A. Vigo hace propio lo otro mediante la transcripción, que supone hacer pasar por el cuerpo a partir de la acción de volver a escribir. El término apropiación nos sirve para reflexionar los modos en que Vigo transforma ese material en otra cosa. Por último, analizamos el alcance que posee el término repertorio para indagar las especificidades de los campos de conocimiento que interesan a E. A. Vigo. 


\subsection{Marco histórico, social y artístico}

Si bien en esta tesis recorremos la producción de E. A. Vigo de manera transversal, centrándonos en las producciones de la década de 1950 hasta mediados de la década de 1970, nos interesa en este apartado reflexionar sobre el contexto de producción de las re-escrituras. Revisaremos las operatividades que presenta el concepto de neovanguardia, específicamente en el caso latinoamericano y argentino en el cual se inserta la producción de re-escrituras de E. A. Vigo y Elena Comas.

Señala Andrea Giunta en Adiós a la Periferia (2013) que desde la década de 1930 el relato de la modernidad artística circuló en textos que ordenaban, caracterizaban y establecían genealogías en torno al arte moderno:

Sin dejar de ser relatos civilizatorios, estas guías pedagógicas que propiciaban la idea de que el arte moderno se gestaba en París, pero era válido para el resto del mundo (éste era el eje de su proyecto colonial), podían usarse de otro modo. Las formas, imágenes y explicaciones del arte moderno se asumieron en su dispersión conformando la idea de un pasado artístico que podía armarse en los nuevos contextos, y también en aquéllos en los que habían surgido, de una manera diferente. Si, como señala Foster, las neovanguardias, más que cancelar el proyecto de las vanguardias, lo habrían entendido y completado, este desarrollo podría suceder en todos aquellos lugares en los que se hubiese asimilado la lección de la modernidad. En todas partes y al mismo tiempo. (Giunta, 2013, p. 111)

En el mismo artículo, la autora indica que las vanguardias históricas fueron "cajas de herramientas" (2013, p. 110) de las cuales los artistas se sirvieron para formular sus propias vanguardias, como veremos, esta caracterización es útil para reflexionar sobre la producción de E. A. Vigo.

Víctor del Río, en el artículo El concepto de neovanguardia en el origen de las teorías del arte postmoderno (2006) indica que la idea de neovanguardia surge para describir la situación artística de la posguerra ante un nuevo contexto social y político. El momento se caracteriza por la emergencia de formas contraculturales vinculadas con los aspectos más radicales de algunas de las prácticas de las vanguardias artísticas -como el dadaísmo, el productivismo soviético o el futurismo-. Señala el autor que: 
(las neovanguardias) pueden definirse como el intento de aglutinar bajo una perspectiva histórica el conjunto de prácticas que desde los 50' hasta los 70', son amparadas, en sus múltiples heterodoxias, bajo el signo pop, el minimal, y el conceptual, fundamentalmente, y que han sido estudiados en contraposición al expresionismo abstracto de la Escuela de Nueva York, en un discurso que hasta la década de los 50' había llegado a ser hegemónico (2006, p. 211).

El término neovanguardia sugiere la idea de retorno y reivindicación de determinados movimientos, se sustenta en la revisión por parte de los artistas de, lo que en esta tesis denominamos el repertorio heredado, seleccionando del mismo tanto conceptos como materialidades. Si bien Vigo no se autodefine en ninguna de sus presentaciones públicas ni obras como "neovanguardista", explícitamente cita determinados referentes como Marcel Duchamp, Kurt Schwitters, Francis Picabia, Nicolás Schöffer, Malevich, entre otros, íntimamente vinculados a los ismos que, como analizamos en la tesis, le interesa rescatar en su producción. Tanto los textos transcriptos en las re-escrituras que estudiamos, como las apropiaciones que realiza del repertorio vanguardista -dada/merz, entre otros- dan cuenta de que estos intereses circulan en el repertorio de E. A. Vigo.

En el ensayo de María de los Ángeles de Rueda, La Nostalgia de las Vanguardias en Argentina (2000) señala que el comienzo en la Argentina de la corriente moderna se inicia en la década de 1920, coincidiendo con el regreso de Xul Solar a la Argentina en 1924, y las producciones de Emilio Petorutti y Pedro Figari. Indica que la crítica considera a Juan del Prete como el precursor de la abstracción. Del Prete, el uruguayo Torres García y las investigaciones concretas europeas dan surgimiento al arte geométrico en la argentina, (entre 1945 y 1947) a partir de tres vertientes: Arte Concreto (representado principalmente por Tomás Maldonado, Lidy Prati), Movimiento Madí (Arden Quin, Gyula Kosice, Diyi Laañ), Perceptismo (Raúl Lozza) y el arte cinético de las décadas de 1950 y 1960 que se expande internacionalmente de la mano de Le Parc. De Rueda indica que cuando Lucio Fontana presenta su "Manifiesto Blanco" (1946) en apoyo a los jóvenes, suscita adhesiones y controversias, como en el caso de Maldonado. En 1968, Vigo festeja a Fontana en la xilografía objeto "Homenaje a Fontana" incorporándolo, por tanto, como referente de su repertorio.

Encontramos entre las re-escrituras de Vigo, particularmente aquellas donde se seleccionan artículos en un mismo tomo, fragmentos de publicaciones periódicas como Kosice: Juegos de 
Agua, publicado en el diario La Nación en 1967, La escultura Argentina: Gyula Kosice de Romualdo Brughetti (s/d), Julio Le Parc artículo del diario La Razón (s/d), y en Diagonal Cero $\mathrm{n}^{\circ} 2$ (1962) el artículo Raúl Loza escribe sobre el perceptismo, Escultura por Lucio Fontana de Flavio Berraute (s/d), la re-escritura por parte de Vigo de estos textos, la mayoría de ellos aparecidos en periódicos de circulación masiva, da cuenta de un interés especial por determinados artistas de los movimientos estudiados por De Rueda. En concordancia con la exposición anterior, ya centrándonos en la década de 1960, Gustavino analiza que:

Desde fines de los años sesenta la búsqueda de formas de legitimación e interpretación del arte se orienta de manera creciente hacia potencialidades nacionales y continentales, y tiende a rechazar las intromisiones tanto europeas como estadounidenses. El debate de los críticos argentinos se ve de este modo atravesado por perspectivas locales y latinoamericanas, y por aquella más general que compromete al arte occidental. (Gustavino, 2014, p. 412)

Una mirada teórica que analiza, contemporáneamente (1962) la condición de umbral entre las artes pertenece a Umberto Eco, quien en Obra Abierta señala que:

El arte contemporáneo manifiesta entre sus características esenciales la de proponer continuamente un orden "improbable" respecto a aquel del que proviene (...) realiza su originalidad al proponer un nuevo sistema lingüístico que tiene en sí mismo nuevas leyes (1962, p. 139).

Nos encontramos frente a un mensaje que se refiere a un código en tanto orden pero que al mismo tiempo lo pone en crisis por la manera intrínseca de articularse. En palabras de Eco, "lo pone en crisis organizando de manera diferente tanto los significados como la naturaleza física de los significantes" (1962, p. 146). El artista, según Eco, busca entonces romper las convenciones de la lengua aceptada y los módulos habituales de concatenación de las ideas:

Para proponer un inopinado de la lengua y una lógica no habitual de las imágenes que dé al lector un tipo de información, una posibilidad de interpretaciones, una serie de sugerencias, que están en el polo opuesto del significado como comunicación de un mensaje unívoco (1962, p. 185). 
Retomaremos estas nociones en la segunda parte del trabajo, al analizar la poesía experimental y las historietas herméticas de E. A. Vigo publicadas en Hexágono'71. Interesan estas consideraciones teóricas en vínculo con las experiencias artísticas argentinas en tanto dan cuenta de la búsqueda por encontrar categorías para comprender en el arte de la década de 1960 en torno a la conceptualización de determinadas experiencias artísticas, la invención de nuevos términos, y el desconcierto que las piezas provocan en la recepción (nos referimos a "arte cosa", la profunda desmaterialización en los señalamientos de Greco, entre otras experiencias).

Citamos algunas experiencias que se dieron en nuestro país a comienzos de la década de 1960 para dar cuenta de los planteos vinculados principalmente a las poéticas informalistas. En la propuesta “Arte Destructivo" (1961) -liderado por Kenneth Kemble-, la unidad conceptual estaba dada por el carácter de investigación en torno a la violencia ejercida sobre los objetos. Por su parte, el “Arte Cosa” de 1963 presentado por Rubén Santantonín propone:

El arte-cosa (...) intenta denodadamente que el hombre no contemple más las cosas, que se sienta inmerso en ellas con su asombro, su inquietud, su dolor, su pasión. El arte-cosa no busca deslumbrarlo, mejorarlo, engañarlo. Busca por todos los medios tocar esa zona de nadie, de la que cada hombre dispone. (citado de GIUNTA, 2008, p. 136)

Los "Vivo Dito" de Alberto Grecco, también son ejemplo de esta ruptura en torno a la materialidad, puesto que sus piezas consistían en señalamientos con tiza de determinados momentos o escenas urbanas firmadas como obras de arte. Marta Minujin, invita en 1963 a quemar sus obras en un terreno descampado de París. En otro orden, la serie de Berni "Juanito Laguna", además de poner de manifiesto una situación social, llevaba a su obra fragmentos de realidad, no representaba sino que presentaba, hecho que pone en crisis el mismo concepto de realidad. En torno a la reconfiguración del lugar del espectador debemos nombrar a los latinoamericanos agrupados en París "Groupe de Recherche d'art Visuel” (GRAV, conformado por Le Parc, De Marco, García Miranda, entre otros) quienes discutieron modos de hacer intervenir al público en la concepción de obra abierta del planteo de Eco.

En los casos nombrados la violencia se ejerce hacia el cuerpo de las cosas, hacia la destrucción de la experiencia conocida, la ruptura con el concepto establecido en torno a representación, belleza, obra, autor. Como ha señalado Andrea Giunta respecto de estas experiencias en Arte, Internacionalismo y Política (2008): 
Para la primera generación de esta vanguardia, en la cual incluimos a los artistas que, entre fines de los cincuenta y mediados de los sesenta, extremaron su indagación en los materiales (...) la problemática principal consistió en explorar todos los recursos que les permitieran fundar un lenguaje nuevo. La definición de su lugar social pasó centralmente, por el compromiso con su propia práctica, que ellos entendían, en sí misma, transformadora de la sociedad. Los rasgos predominantes consistieron en una creciente renuncia al hacer pictórico y en la experimentación con todos los materiales y temas que la realidad circundante les proveía: desde las "villas miseria", hasta las sucesivas citas y apropiaciones de ese depósito de la cultura urbana (...) (2008, p. 126).

La segunda generación, en el planteo de Giunta, descree del internacionalismo, asociando el concepto a colonialismo y dependencia económica. El arte, para muchos creadores, se convierte en un significante ligado a la política $^{31}$. En este marco, Mariano Mestman y Ana Longoni analizan los vínculos entre arte y política en el libro Del Di Tella a Tucumán Arde ${ }^{32}$. En torno al trabajo de E. A. Vigo, Ana Bugnone aporta una mirada original en su libro Vigo: Arte, Política y Vanguardia (2017) sobre la producción del artista platense en relación con lo político y la política, como hemos reseñado.

Breve referencia en esta contextualización general merecen las instituciones artísticas, sobre las cuales volveremos en el transcurso de la tesis. Durante la década de 1960, la crítica sostiene que fue el Instituto Torcuato Di Tella el espacio aglutinador de las prácticas de vanguardia y experimentación:

El escenario de mayor visibilidad del arte de vanguardia que se impuso a lo largo de toda la década del sesenta en Buenos Aires fue, sin lugar a dudas, el ITDT. La creación

\footnotetext{
${ }^{31}$ Señala Giunta: "Nuestra hipótesis es que la decisión de unir vanguardia estética y vanguardia política, cuyos primeros síntomas podríamos ubicar a mediados de la década del sesenta pero cuyas más extremas demostraciones se verán en 1968, no obedeció a una circunstancia única proveniente del campo de la política. Más que los resultados finales, es necesario analizar los sucesivos quiebres y reposicionamientos que respondieron a coyunturas de la política nacional e internacional y a condiciones inherentes a la constitución del campo (...)" (2008, p. 263).

32 "La Experiencia de Tucumán Arde tuvo como objetivo desentenderse de los lugares tradicionales de exhibición de arte; encontrar nuevos marcos de circulación y recepción de las prácticas artísticas articuladas con los sindicatos más combativos; configurar un público más heterogéneo al que asistía a las galerías y museos y la posibilidad de reflexionar, poner en crisis y desbordar los vínculos entre el "arte" y la praxis política definida como contrapoder en la vía de un proceso revolucionario" (2006, p. 133). De: Juan Pablo Perez, Cecilia Ilia, Laura Lina (2006) en Lecturas Problemas y discusiones del arte argentino del último siglo 1910-2010, Ed. $\mathrm{CCC}$, FNA Buenos Aires.
} 
en 1960 dentro de instituto del Centro de Artes Visuales (CAV), y a partir de 1963, dirigido en su nueva sede de la calle Florida por Romero Brest, absorbió el momento de mayor experimentación y transformación de las prácticas artísticas (2006, p. 120).

Vigo muestra gran interés en una de sus re-escrituras que pertenece a las selección de artículos sobre las experiencias del pop y el happening que tuvieran lugar en el ITDT, por ejemplo al transcribir Filosofía del Happening del diario El Día (s/d, 1966), Pop ¿una nueva manera de vivir? de Primera Plana (s/d 1966), Sociología del Pop (s/d), Pop Art: La colocación del mundo occidental escrito por Juan del Valle (s/d), Happening - USA artículo escrito por Dere Ashton (s/d), Marta Minujin (s/d) o La revolución del Happening de Luis Pazos (s/d).

"Experiencias 68" suscita un corte, siendo una de las instancias de mayor conflictividad en el ITDT. Las obras de Jacoby, Carballa, Paska, Bony y Pablo Suárez ampliaron los discursos del arte mostrando sus vínculos con las relaciones de poder, de comunicación, la moral y la libertad sexual. El corrimiento de los artistas de la propuesta del Instituto, considerada ahora elitista, implica la elaboración de obras por fuera de las instituciones consagratorias, Tucuman Arde fué la representación más cabal en este sentido.

Cuando E. A. Vigo organiza la Expo Internacional de Novísima Poesía/69 en el ITDT, la institución ya entraba en decadencia, cerrando sus puertas un año después. Tomamos para la segunda parte de este trabajo la participación de Luis Pazos y Jorge de Luxan Gutiérrez en el programa radial conducido por Víctor Iturralde Introducción a la Cultura Contemporánea. Una Audición del Instituto Torcuato Di Tella de $1967^{33}$. Decimos también que durante la década de 1970, Vigo entra en contacto con el Centro de Arte y Comunicación (CAYC). Como ha señalado Bugnone, no interactúa en el CAYC como miembro del Grupo de los Trece, contribuye con la plataforma a través de envíos y diversas acciones. Volveremos sobre su director, Jorge Glusberg, en el capítulo tres de la segunda parte al referir a la historieta. Interesa para esta contextualización la mención al CAYC porque tanto en sus postulados como en los de Vigo toma fuerza "la calle" como espacio público y político a ocupar-habitar:

Con la aparición del Centro de Arte y Comunicación (CAYC) dirigido por Jorge Glusberg a partir de 1969, se inicia un nuevo momento vinculado a la institucionalidad nacional. Se propició la convocatoria a diferentes artistas a reflexionar e indagar de qué manera interceder, modificar e interactuar en el desarrollo de los procesos sociales,

\footnotetext{
${ }^{33}$ Archivos Sonoros del ITDT. Archivo Fernando von Reichenbach. Universidad Nacional de Quilmes.
} 
culturales y en la aproximación de ciertos vínculos en el campo político, en el cual el arte podía ser un canal potencial para la manifestación y acción transformadora. Las inquietudes de los artistas fueron intensificadas y se abrió un camino de discusión entre los avatares del arte y el sistema capitalista. (...) Uno de los planteos iniciales del CAYC fue llevar a cabo muestras colectivas en diferentes espacios públicos cuya primera intervención fue la muestra de "Escultura, follaje, ruido" en la Plaza Rubén Darío en noviembre de 1970 (Perez, Ilia, Lina, 2006, p. 159) ${ }^{34}$.

Mencionamos antes que la relación de Vigo con las instancias de legitimación y las instituciones es tensa y muchas veces contradictoria. Referimos brevemente a los espacios de consagración como las Bienales puesto que aparecen como temática tangencial en las re-escrituras de E. A. Vigo y Elena Comas.

En la década de 1960 el desarrollo de la industria automotriz fue preponderante en Córdoba, Rosario y Buenos Aires. Las empresas fomentaron iniciativas destinando parte de sus ganancias a la promoción de las artes visuales. Uno de los casos más importantes es el de Industria Kaiser Argentina (IKA) radicada en Córdoba, que llevó a cabo las Bienales Americanas de Arte de los años 1962, 1964 y 1968 35. Las re-escrituras de Vigo presentan interés por estas instancias de consagración recuperando artículos de la Bienal de Córdoba como Córdoba: El apogeo del surrealismo (S/d, 1966) Bienal de Córdoba: Hecho Positivo por Cordova Iturburu, aparecido en El Mundo en 1966.

Para concluir, incluimos a esta caracterización la Charla del 30 de Junio de 1972 ofrecida por Vigo en el Centro Cultural Platense (Cuadro 6). Sintéticamente el artista, en su Archivo Personal Biopsia del mismo año, dice que el recorte de esta esta charla se centró en determinadas figuras del arte argentino: "Partiendo de Pettoruti y Del Prete, pasando por Arturo, y sus sub-grupos, arte concreto invención, madí mensor, perceptismo, hasta cruzar por el Instituto Di Tella y referencia al CAyC" (Biopsia 1972). Se citan en la misma fragmentos de los manifiestos de Invencionista, Madí, Perceptismo y Manifiesto Blanco, junto a diapositivas específicas de las obras de Lucio Fontana y la Nueva Figuración, también obras de Le Parc. En su recorrido por el Arte Argentino, Vigo resalta las instituciones antes mencionadas: el ITDT y CAYC.

\footnotetext{
${ }^{34}$ De esta experiencia Vigo participa con Señalamiento $V$ que consistía en una convocatoria para que el público participe/ programe su obra. Para ampliar, se recomienda Ana Bugnone, 2013.

35 Se recomienda consultar la investigación de Roca, María Cristina (2009) Arte, modernización y Guerra Fría. Las Bienales de Córdoba en los sesenta. Editorial UNC, Córdoba.
} 


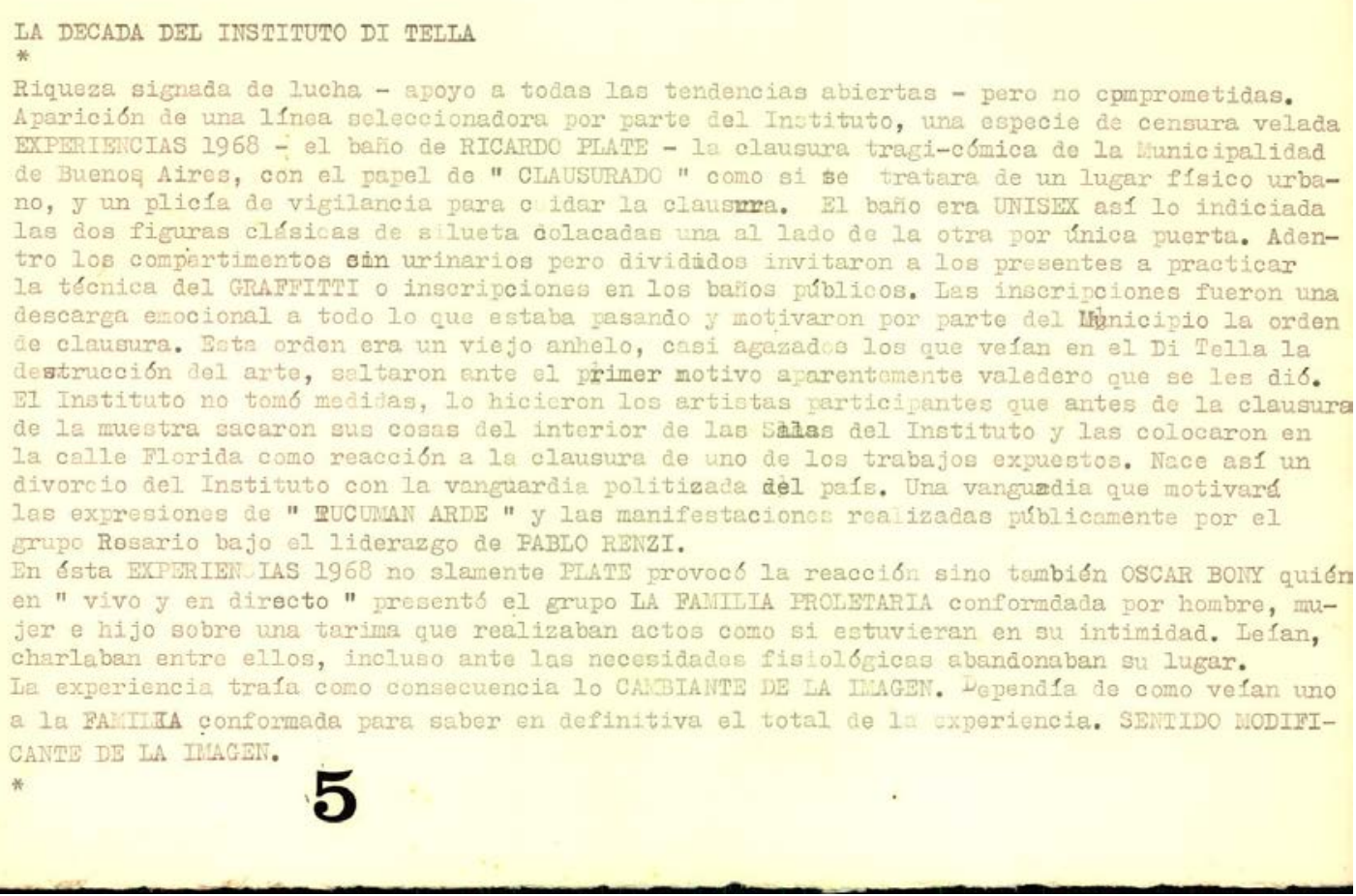

Fig. 4. Charla del 30 de Junio de 1972 ofrecida por Vigo en el Centro Cultural Platense. Cartones mecanografiados con ilustraciones y sellos. Serie Escritos Personales. CAEV.

A partir de esta caracterización histórica nos adentramos en los usos del término apropiación, para revisar los modos en que E. A. Vigo, gracias al conocimiento del medio artístico, de las teorías y conceptualizaciones, elige, selecciona, deglute para generar otra cosa con sus lecturas.

\subsection{Acercamientos al término apropiación}

En la concepción de apropiación, entran en tensión los presupuestos de originalidad, copia y sobre todo, el ya citado, concepto de plagio. En la lectura de Juan Martín Prada (2001) la apropiación crítica es un fenómeno estrictamente postmoderno ${ }^{36}$ que recupera la noción de rebeldía contra las instituciones de las vanguardias históricas:

Como estrategia de lenguaje el apropiacionismo crítico se sitúa en uno de los parámetros fundamentales de lo postmoderno, ya que supone la radicalización de los recursos de la cita, la alusión o el plagio que caracterizan la práctica artística postmoderna, como estrategia crítica implica una actitud de revisión, de relectura de lo dado, de toma de

\footnotetext{
${ }^{36} \mathrm{Si}$ bien los autores citados trabajan desde la postmoderidad consideramos pertinente su inclusión en el presente Marco Teórico en tanto contribuyen a reflexionar sobre las complejidades del término y los procedimientos apropiacionistas.
} 
conciencia de la influencia de los sistemas de exposición y comercialización sobre la obra de arte, su dependencia del contexto institucional y del discurso histórico por el determinado (2001, p. 1).

Señala el autor que una de las características principales de los procedimientos de apropiación radica en la fisura que estos producen en el orden de los discursos puesto que implican una constante dislocación de la linealidad de los mismos. En el mismo sentido, Nicolas Bourriaud en Postproducción (2007) considera que los artistas contemporáneos programan formas antes que componerlas en tanto utilizan lo dado para la elaboración de su propuesta estética $(2007,13)$. La apropiación para el autor sería un modo de recorrer la cultura a partir de su utilización, puesto que "lo que realmente importa es lo que hacemos con los elementos puestos a nuestra disposición" (2007, p. 23). El artista funciona como un $D J$ en la metáfora de Bourriaud, puesto que utiliza material preexistente para re-elaborarlo y configurar de esta manera nuevos sentidos a las obras visuales.

Por su parte, el filósofo coreano Byung-Chul Han, en el libro Shanzhai: el arte de la falsificación y la deconstrucción en China (2016) diferencia los usos de la apropiación en occidente y oriente remitiendo a las concepciones en torno a la idea de originalidad ${ }^{37}$. Explica, aludiendo a la copia, que:

El culto a la originalidad deja en un segundo plano esta práctica esencial para el proceso creativo. En realidad, la creación no es un acontecimiento repentino, sino un proceso dilatado, que exige un diálogo intenso con lo que ya ha sido para extraer algo de ello. El constructo del original borra lo que ha sido, aquello anterior de lo cual se extrae algo. (2016, p. 26)

Señala que los chinos tienen dos modos de referir a la copia, el término fangzhipin (纺织品), refiere a las recreaciones en las cuales resulta evidente la diferencia respecto del original. El segundo concepto para la copia se denomina fuzhipin (复制品), que remite a una reproducción exacta del original, "la cual, para los chinos tiene el mismo valor que el original" (2016, p. 62). Rosalind Krauss en el artículo La originalidad de la vanguardia (1993), ha indicado en torno a las copias de las esculturas de Rodin, que la copia original sería aquella "próxima al momento

\footnotetext{
${ }^{37}$ Indica el autor que "la diferencia del original Chino no se entiende como una creación única sino como un proceso infinito, no apunta a la identidad definitiva sino a la transformación incesante (...) una obra de arte China nunca permanece idéntica a sí misma. Cuanto más venerada más cambia su aspecto” (2016, p. 21).
} 
estético" en tanto sería la representación de determinado "estilo de época"; lo auténtico de la copia estaría dado entonces por la cercanía cronológica en la elaboración del original, así:

Las copias ulteriores se traicionan precisamente porque no han sido producidas en la época: una modificación de la sensibilidad, sobrevenida desde entonces, no podrá evitar que las torpezas se deslicen en el claroscuro, que los contornos no sean demasiado duros o demasiado suaves, que, en una palabra, la coherencia estructural del antiguo orden no sea aniquilada (1993, p. 2).

Benjamin Buchloh en el apartado "Procedimientos Alegóricos: apropiación y montaje" del libro Formalismo e Historicidad (2008) indica, siguiendo a W. Benjamin, que las técnicas de reproducción impactan directamente en la reconfiguración de la perspectiva estética a comienzos del siglo XX. En referencia la obra de Marcel Duchamp, L. H. O. O. Q (1919), explica que el principio alegórico se basa en la apropiación de una pintura canónica (Mona Lisa de Leonardo Da Vinci) donde se produce un desplazamiento que reconfigura la construcción del signo, por el cual:

Duchamp sometió a la imagen a un proceso de confiscación esencialmente alegórico y la inscribió en una configuración textual que solo se actualiza como texto en su ejecución fonética. La imagen mecánicamente reproducida de lo que otrora fuera una obra única y aurática funciona como complemento ideológico de la mercancía manufacturada que el ready-made enmarca con su esquema alegórico (Buchloh, 2008, p. 92).

Según Buchloh, el procedimiento de apropiación duchampeano, inaugurado por el ready-made, se acentúa en los artistas de la década de 1950. El caso que el autor presenta y nos interesa especialmente para nuestro trabajo, es el de Marcel Broodthaers con su re-escritura Un coup de dés jamais n'abolira le hasard (1969). Se trata de la apropiación del libro de Mallarmé Un coup de dés (1897), que será fundamental en el movimiento concreto brasileño así como también en la genealogía sobre la cual Vigo trabaja para la poesía visual:

El Coup de dés de Broodthaers se apropiaba de los detalles de presentación, formato, diseño y tipografía de la cubierta de Coup de dés de Mallarmé tal como fue publicado por Gallimard en París en 1914. El nombre de Mallarmé sin embargo había sido sustituido 
por el de Broodthaers. (...) Broodthaers manipuló las configuraciones escriturales del poema de Mallarmé, así por ejemplo, sustituyó el texto del poema por el prefacio original. Mantuvo la dimensión visual y espacial de la disposición de los versos sobre la página pero la vació de información léxica y semántica. Eliminó las modificaciones tipográficas y las reemplazó por marcas puramente gráficas y lineales que se corresponden exactamente con la posición, disposición, tamaño y dirección de la escritura espacializada de Mallarmé (2003, p. 100).

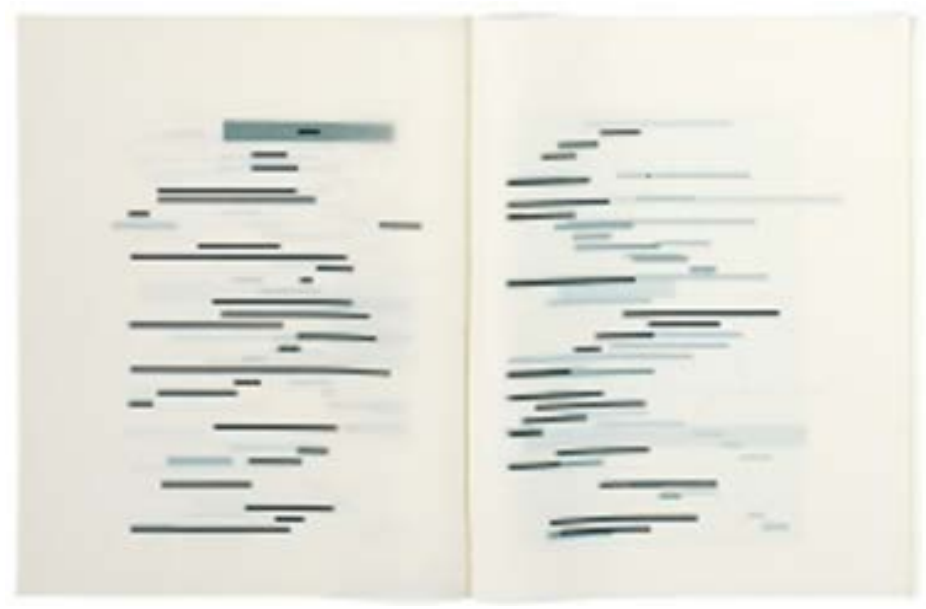

Fig. 5. Marcel Broodthaers. Un coup de dés jamais n'abolira le hasard (1969). MACBA

Si bien la apropiación que realiza Broodthaers se emparenta con los desarrollos que analiza Sergio Chejfec (2015), nos interesa la cita de este artista, puesto que en su obra la apropiación se centra en determinados aspectos procedimentales vinculados con el formato libro. La eliminación de la palabra a partir de líneas tiene el efecto de resaltar el aspecto espacial de la composición en la lectura ${ }^{38}$. El material resultante de esta apropiación dialoga con el libro original como referencia pero lo modifica sustancialmente, es decir, el ejemplar de Broodthaers prioriza el efecto compositivo y la potencia del espacio.

Como ha señalado Mario Gradowczyk, las re-escrituras de E. A. Vigo se asemejan al "Pierre Menard autor del Quijote" de J. L. Borges; porque Menard "no quería componer otro Quijote —lo cual es fácil— sino el Quijote.” (Borges, 1994, p. 22). Se pregunta el autor: “Sería acaso Vigo una reencarnación de Pierre Menard, que reescribe la novela de Cervantes y crea una obra totalmente distinta? Parafraseando a Borges, se podría decir que cada texto de esos autores y el reproducido por Vigo son verbalmente idénticos, pero el del segundo es casi infinitamente más rico...” (2008, p. 33). La repetición y el carácter de duplicidad que presentan las re-escrituras de

\footnotetext{
38 Recordemos que el mismo procedimiento había sido utilizado por Man Ray en Poema Sonoro de 1924 (presente en la tapa del catálogo para la Exposición de Novísima Poesía/69).
} 
E. A. Vigo serán consideradas como apropiaciones en tanto el artista, al transcribir determinadas lecturas, transforma en esa repetición, en otra cosa.

La apropiación se materializa en las re-escrituras a partir de la traducción y la transcripción, así como en la modificación visual que opera sobre el texto sin alteración en su contenido. En el caso de las obras expuestas y publicadas por Vigo, la apropiación se manifiesta en forma de cita o alusión en grados más o menos explícitos como se analizará oportunamente.

\subsection{Antropofagia y repertorio}

En la concepción de antropofagia registrada en el Manifiesto Antropófago (1928) de Oswald de Andrade, la apropiación de lo otro opera en términos de deglución, en tanto lo otro es alimento que se absorbe y se utiliza por las células del organismo que lo recibe. Como ha señalado Francine Regis Goudel en el artículo "Conceito Antropofagia: vanguarda e proliferação" (2008):

A palavra Antropofagia evoca desse modo toda uma idéia trazida das raízes brasileiras do parente índio, a cerimônia de apropriação do outro, uma não submissão, um introduzi-lo e degluti-lo. Sabe-se que o ritual Antropofágico faz parte da idéia de apropriação do outro, "comer" o inimigo para dele abastar-se, assimilar o Outro para dele aproveitar suas virtudes, e nesse sentido, os modernistas foram pontuais na valorização desse conceito e criam a problemática da Antropofagia no sentido da assimilação da arte que vem das vanguardas européias, propondo absorvê-la e recriá-la, não na acepção de "engoli-la" e reproduzi-la (2008, p. 2).

La idea de asimilación para aprovechar las virtudes de lo otro aporta una arista importante en la comprensión del concepto de apropiación al que estamos intentando acercarnos; la antropofagia propone absorber y recrear, no reproducir ${ }^{39}$. En este sentido, las re-escrituras de E. A. Vigo poseen un carácter antropofágico en tanto el artista reformula los postulados que lee y transcribe para generar su propia obra, no reproduciendo sino recreando. Esto será analizado en la segunda parte de la tesis, donde en las re-escrituras vinculadas a las vanguardias históricas, vemos que

\footnotetext{
${ }^{39}$ Suely Rolnik, en su artículo Antropofagia zombie (2006) dice respecto de este movimiento: “¿Cuáles son los elementos constitutivos de esa fórmula? El otro ha de ser devorado o dejado ir. No se ha de devorar a cualquier otro. La elección depende de evaluar cómo su presencia afecta al cuerpo en su potencia vital: la regla es alejarse de los que la debiliten y acercarse a los que la fortifiquen. Cuando la decisión es por el acercamiento hay que permitirse ser afectado lo más físicamente posible: tragar al otro como una presencia viva, absorberlo en el cuerpo de modo que las partículas de su admirada y deseada diferencia sean incorporadas en la alquimia del alma, y así se estimule el refinamiento, la expansión y el devenir de uno mismo" (2006, p. 184).
} 
Vigo copia el contenido de los textos pero subvierte su organización generando párrafos con formas abstractas que generan un tipo de lectura diferente; también Vigo, a partir de las re-escrituras vinculadas a la poesía experimental, publica los textos traducidos por Comas generando así nuevas constelaciones de sentido en tanto establece diálogos inéditos hacia el centro de, por ejemplo Diagonal Cero.

En la “Apostilla Antropofágica”, que Raúl Antelo escribe para Antropofagia y Cultura (2011) de Metraux, dice:

En sus más recientes estertores, la antropofagia, que Métraux estudió como pionero, se deja reconocer, en suma en estos aleteos estructurales de la semejanza obtenida por contacto, una forma de abandonar la altruista fenomenología humanista que solo supo enfocar lo etnocéntricamente coherente. En este rescate de lo trágico, lo poético y lo político como parámetros de la cultura, tales abordajes toman distancia de lo Mismo, desde su linde con lo Otro, desde su in-between. Como postularía la tradición brasileña, de Oswald de Andrade o Alfonso Arinos de Melo Franco a Haroldo de Campos o aun la vanguardia argentina, de Zapata Quesada o Girondo al tardío Borges de "El escritor argentino o la tradición", la historia cultural de la "periferia" esta indefectiblemente ligada a la del "centro" de Occidente pero precisamente lo que le ha permitido a Occidente construirse una imagen de propiedad es la denegación de lo que en su historia y su cultura había de impropio (2011, p. 98).

Como señala Antelo, en la historia de la literatura argentina, el concepto de apropiación se liga íntimamente al de la construcción de una tradición, donde la discutida noción de periferia dialoga, tensiona y re-escribe la -también polémica- concepción de centro ${ }^{40}$. Ahora bien, ¿de qué

\footnotetext{
${ }^{40}$ La construcción de un pasado común supone tensiones en las voces que se incluyen/ excluyen, y desde las cuales se nutre la configuración de la tradición. Referimos brevemente a "El escritor argentino y la tradición" de Jorge Luis Borges, aparecido en el Discusión (1997). El escritor aquí es categórico y señala en torno al género de la gauchesca que: "La idea de que la poesía argentina debe abundar en rasgos diferenciales argentino y en color local argentino me parece una equivocación" (1997, p. 2). Según el autor, en la poesía gauchesca, la operación de apropiación de la voz del gaucho resulta un artificio. Borges se pregunta entonces: “¿Cuál es la tradición argentina? Creo que podemos contestar fácilmente y que no hay problema en esta pregunta. Creo que nuestra tradición es toda la cultura occidental, y creo también que tenemos derecho a esa tradición, mayor que el que pueden tener los habitantes de una u otra nación occidental" (1997, p. 5). En el mismo sentido, Emilio Pettoruti decía en su autobiografía Un pintor ante el espejo (1968) con relación a las críticas que realizaban los medios de comunicación sobre su obra: "Si diese fe a sus crónicas, uno de mis propósitos al pisar tierra argentina, habría sido destruir el arte nacional. Confundían arte nacional con motivo folklórico (...) Manzanas, mujeres y tinas de baño las hay en todas partes del mundo, pero, por encima del motivo, trascendiéndolo, está la inmanencia nacional que no nos dejará equivocarnos sobre el origen de una pintura" (1968, p. 177). La
} 
modos la apropiación se transforma en poética? ¿mediante qué procedimientos compositivos el artista/ escritor, antropofágicamente, hace propio lo Otro?.

\subsection{Repertorio y re-escrituras}

Hemos dicho que en la acción de volver a escribir Vigo se apropia de las de las conceptualizaciones que los diversos autores ponen de manifiesto en sus textos construyendo así un compendio de lecturas que denominaremos repertorio alejándonos de la noción de canon.

Las re-escrituras de E. A. Vigo, se distancian de las lecturas canónicas en tanto indagan en experiencias artísticas liminales ${ }^{41}$. Si la noción de canon se constituye como una formación discursiva configurando un corpus, seleccionando y normativizado lo leído así como las formas de lectura a partir de preceptos que implicarían la inclusión/exclusión de artistas, movimientos estéticos, reivindicaciones políticas y culturales ${ }^{42}$; entendemos que la noción de repertorio posibilita otros abordajes respecto de las lecturas que los autores realizan y los criterios de selección de las mismas.

problemática sobre los temas /asuntos representativos de lo nacional en los dos fragmentos citados, tienen sustento en la pregunta por la tradición y la legitimidad de las vertientes que nutren las apropiaciones que los autores realizan. En este sentido, Macedonio Fernández, en el “¿Prólogo Cuádruple?” de su Museo de la Novela de la Eterna ([1965]1975) entendía que: "La Literatura es precisamente la belarte de: ejecutar artísticamente un asunto descubierto por otros. Esto es ley para toda belarte y significa que el "asunto" del arte carece de valor artístico o la elección es todo el valor del arte. Clasificar asuntos como unos mejores, más interesantes que otros, es hablar de ética: hacer estética es ejecutar artísticamente cualquier asunto. Los asuntos los encuentra todo el mundo fácilmente, superabundan: las páginas de arte son escasísimas y se laboran con desesperación, con lágrimas e iras de Labor" (1975, p. 124). Para Macedonio Fernández entonces, la "belarte" no depende de los temas /asuntos sino de la ejecución artística.

${ }^{41}$ Tomamos la noción de los desarrollos teatrales de Jorge Dubatti, quien entiende que el desarrollo del concepto se vincula con la problematización de los límites entre las disciplinas, aquellas zonas fronterizas donde se produce el intercambio y la combinación de experiencias. Dice el autor: "Creemos que la idea de liminalidad tiene entonces un doble valor: 1) es una herramienta superadora de las categorías taxonómicas modernas que proponían una clasificación racionalista y excluyente (solo es teatro el teatro dramático, o sus variantes más o menos canónicas y aproximadas), poco válida para pensar los fenómenos concretos de la praxis (contra los sistemas cerrados de pensamiento, la idea de liminalidad incluye muchos fenómenos teatrales no prototípicos ni canónicos); 2) permite descubrir fronteras internas en el acontecimiento teatral canónico, incluso en el drama absoluto. De esta manera empleamos el concepto de liminalidad en dos dimensiones diversas, una primera más restrictiva y una segunda más general o abarcadora: la oposición teatro convencionalizado/teatro liminal; la liminalidad interna al acontecimiento teatral en sí, interna al teatro matriz, que descubre la liminalidad tanto en las formas del teatro convencionalizado como las del teatro liminal.” (2017, p. 86)

${ }^{42}$ Decía al respecto Ángel Rama, en 1982, que: "Mientras la literatura culta responde a los núcleos educados de las ciudades y por lo tanto a las coordenadas mentales del proceso de urbanización, la folklórica se expande en la zona rural y pueblerina e invade los arrabales del reciente asentamiento campesino en las ciudades (...) De esta exclusión o inclusión de la urbanización derivan comportamientos literarios diferentes: mientras el creador individual de la literatura culta urbana manejará un amplio y versátil abanico de formas literarias que conceden especial valor a la novación respecto de las formas heredadas, el creador individual de la literatura folclórica mostrará especial conservatismo en lo referente a las formas literarias" (1982, p. 21). 
El canon funciona como un principio regulador y de control (Domenella y Gutiérrez, 2009, 51) Las modificaciones en el canon implican la revisión del corpus y, por tanto, de las tradiciones que lo han sustentado, nunca exentas de complejas reivindicaciones políticas y culturales (Rama A. 1982; Mignolo W. 1991; Cornejo Polar A. 1977; Giunta, 2018).

Por su parte, la noción de repertorio refiere, en primera instancia, al conjunto de obras teatrales o musicales susceptibles a ser representadas o ejecutadas en acto. El concepto de repertorio desarrollado en este trabajo tiene su antecedente en el estudio de Gonzalo Aguilar (2003) en tanto se vincula con la denominación de los poetas concretos brasileños con los cuales E. A. Vigo posee contacto, por lo menos, desde $1967^{43}$. Aguilar, en su estudio Poesía concreta brasileña: las vanguardias en la encrucijada modernista (2003), indica que la noción de repertorio, heredera del paideuma poundiano, remite al "elenco de autores cuyas ideas sirven para renovar la tradición” (2003, p. 65). En la concepción del repertorio los poetas brasileños "suspendieron la idea del archivo como tradición recibida (sobre todo como tradición nacional) y escindieron la noción de vanguardia del corpus que supuestamente le es propio. Una vez realizado esto estuvieron en posición de formar un repertorio que poco o nada tenía que ver con el corpus tradicional de las vanguardias" (Aguilar, 2003, p. 65). La noción de repertorio se opone al de "espíritu de época", nutriéndose de elementos heterogéneos y es, además, una creación y actividad de quien lo utiliza, no viene dado (2003, p. 65).

Haroldo de Campos, en el artículo La Poesía Concreta y la Realidad Nacional ([1961]2004) manifestaba que la poesía concreta a mediados de la década de 1950 se proponía como “devoración crítica de los caminos de la estética internacional: postura antropofágica, matriz generadora de un arte original, de exportación" (2004, p. 163). La elección que realiza el concretismo por la antropofágia de Oswald de Andrade es coherente con la reformulación del elenco de autores renovadores de la tradición que implica la noción de repertorio y con la propia elección de conceptos que se realiza en esta tesis para comprender las re-escrituras de Vigo y Comas. En palabras de Haroldo de Campos:

\footnotetext{
${ }^{43}$ En la biblioteca personal de Haroldo de Campos constan las siguientes publicaciones de E. A. Vigo: Vigo, Edgardo Antonio. "Edgardo Antonio Vigo Y Sus Cosas". São Paulo, 1969. /Vigo, Edgardo Antonio. "Poème Mathémathique Baroque”. Paris, Contexte. (1967)/Diagonal Cero n 1 a n 4. La Plata, Buenos Aires, 1962. /Catálogo Movimiento Diagonal Cero. La Plata, Buenos Aires, 1967. La poesía concreta brasileña ingresa de lleno a Diagonal Cero a partir del ㅇ 22 (1967). En este número, Vigo traduce y publica el ensayo "Poesía Concreta Brasilera" de Haroldo de Campos y el poema de Augusto de Campos "Sem un numero" en la tapa del ejemplar.
} 
Creo que la antropofagia de Oswald de Andrade es algo más serio que lo usualmente sospechado. La antropofagia es un modo de reducción. Es una devoración crítica. No significa eliminar la historia, y partir genialmente tras un "absoluto" vagamente sospechado, tras un "acontecimiento" dominado por el milagro o por la autosuficiencia individualista. Se trata de devorar para comprender y superar (2003, p. 166).

En el artículo citado, de Campos se pregunta:

¿Qué se entiende por nacional en arte? ¿El nacionalismo ha de ser forzosamente un regionalismo temático, y esté, necesariamente una tematización de lo rural? ¿En qué medida es nacional la arquitectura brasileña, sin duda alguna el arte que hoy mejor representa y proyecta a Brasil en el mundo? (2003, p. 166)

Podemos reflexionar sobre tres cuestiones en torno a la noción de repertorio a partir de las preguntas planteadas por Haroldo de Campos.

En primer lugar, la pregunta por la lengua que escriba "lo nacional", será un vector que atraviesa la producción y la crítica tanto en escritores como $\operatorname{artistas}^{44}$ en Latinoamérica -del cual no es nuestra intención, por la complejidad y extensión del tema, ahondar en esta presentación-. Decir aquí que, como analizaremos oportunamente, en la obra de E. A. Vigo según las referencias teóricas que presentan sus re-escrituras hay una convivencia de fuentes y autores diversos, manifestado en la inclusión de editoriales consagradas hasta artículos de diarios y suplementos provenientes de la cultura de masas, desde críticos reconocidos por su trayectoria hasta notas de opinión sin mención de autoría, desde productores legitimados por el campo artístico hasta grupos incipientes. Las vertientes que nutren el repertorio del artista platense resultan bastante autónomas y novedosas respeto del canon de la época. Como hemos visto en el Marco histórico, social y artístico, Vigo se encuentra al tanto de las corrientes artísticas contemporáneas, eligiendo profundizar sobre algunas de ellas como el dadaísmo o la obra Mertz tempranamente, como analizaremos por caso en la traducción del Marchand $d u$ Sel de Marcel Duchamp (re-escrito por la dupla Comas- Vigo en 1966).

Si, como sostiene Piglia (2016), "el debate sobre la tradición es un debate sobre la poética, sobre el modo en que se define el lugar desde el cual se escribe" (p. 164), es en esta

\footnotetext{
44 Ver Marta Cisneros Según decimos en criollo (2000), María Teresa Gramuglio Nacionalismo y Cosmopolitismo (2013); Andrea Giunta Vanguardia Internacionalismo y politica (2008).
} 
configuración, a veces ecléctica y sobre todo original de referencias en las re-escrituras, que detendremos nuestro análisis.

Consideramos pertinente entonces la pregunta por "lo nacional" en tanto se configura en nuestro estudio desde las múltiples voces que E. A. Vigo incorpora a su repertorio de lecturas y re-escrituras. Las formas en que éstas lecturas repercuten en la ejecución desde el planteo macedoniano. Lo nacional, para Vigo no se restringe a términos geográficos, muy por el contrario, su intercambio apunta a la ruptura de estas fronteras. Como señala en la editorial de Diagonal Cero $\mathrm{n}^{\circ} 12$ (1964):

Basta de modas y monigotadas, a lo sumo hagamos nuestras propias modas $\mathrm{y}$ monigotadas. Sin ser serios busquemos la seriedad, sin ser viejo busquemos la madurez, sin ser jóvenes pongamos la bravata y la irreverencia de la juventud. Esto es LATINOAMÉRICA señores no un vulgar terreno operístico-imitativo (E. A. Vigo, DC nº $12,1964)$

Por otro lado, tanto en los artículos La revolución en el arte (15-12-68) como en su ensayo-manifiesto Un arte a realizar (1969), Vigo define las principales líneas de su poética en el período comprendido entre fines de la década de 1960 y principios de 1970. Nos interesa resaltar los cambios con relación a la obra y el público puesto que se utilizan en estos textos términos como "participación activa del espectador", "arte para la comunicación, no para para las élites", "presentación en lugar de exposición" íntimamente vinculado con el "ganar la calle" incorporando trabajos al espacio público. Estos conceptos nos hablan del conocimiento por parte de Vigo de experiencias artísticas vinculadas al happening y la performance que venían desarrollándose en el medio artístico tanto local como latinoamericano, y particularmente en las experiencias de Fluxus, los cuales hace parte de su repertorio para vincularlo con el interés por la participación y la comunicación en sus obras.

En segundo lugar, y retomando las reflexiones de Haroldo De Campos, la pregunta “¿En qué medida es nacional la arquitectura brasileña, sin duda alguna el arte que hoy mejor representa y proyecta a Brasil en el mundo?", deja en evidencia que la noción de repertorio no solamente se concibe desde el campo específico de la literatura sino que será la arquitectura la "mejor representación" del Brasil. Con esto queremos decir que, la noción de repertorio abarca un universo de disciplinas, se concibe desde referencias heterogéneas y liminales, momentos 
“corales", en la denominación de Garramuño (2016). Como ha explicado Gonzalo Aguilar al respecto:

Con las artes de las bienales - la pintura, la escultura, la arquitectura - , los poetas crearon un espacio de diálogo y de performance: al sacar la poesía de su lugar convencional, exigieron que ésta se definiera en relación con las demás artes. La poesía se presentaba como planificación, diseño y construcción, categorías que la acercaban a las artes visuales y a la poética de João Cabral de Melo Neto, pero sobre todo a esa disciplina que en Brasil se había convertido en emblema de la tradición modernista: la arquitectura (2003, p. 72).

Interesa resaltar que, como ya hemos mencionado, la formación de E. A. Vigo pertenece inicialmente al universo de la educación técnica y al ámbito de las artes plásticas. A diferencia de la formación sistemática de los poetas concretos brasileños ${ }^{45}$ y los modos en que estos operaron desde las instituciones, la relación de Vigo con estos espacios es, en muchos casos, tensa. El centro de los intereses que se manifiestan en las re-escrituras de E. A. Vigo se vincula con los diálogos y cruces que pueden establecerse entre las artes plásticas, la literatura, la música principalmente desde la condición experimental es decir, su interés por ahondar en las posibilidades liminales que brindan los cruces entre las disciplinas. Como ha manifestado el propio Vigo y analizaron diversos críticos en torno a su obra (Pérez Balbi, 2008; Gradowczyk, 2008; Bugnone, 2014, 2017) la relación del artista con las instituciones es problemática, no solo con su formación en la Universidad Nacional de La Plata sino también con los museos, las galerías y centros de arte. Las re-escrituras dan cuenta de un repertorio que incide en la formación de E. A. Vigo, estos compendios refieren a intereses por disciplinas en cruce, como veremos en el caso de la poesía experimental.

Por último, nos detenemos en el aspecto de la traducción que será el tercer elemento para reflexionar sobre la noción de repertorio. La traducción funciona como una estrategia de posicionamiento y es un ejercicio de apropiación. Como explica Gonzalo Aguilar en Augusto de Campos: La traducción del nombre ${ }^{46}$ (2015):

\footnotetext{
45 Haroldo de Campos (1923-2003) se doctoró en Filosofía, Letras y Ciencias Humanas. Augusto de Campos (1931) y Décio Pignatari (1927- 2012) estudiaron derecho en la Universidad de São Paulo.

46 Dice Aguilar en el artículo citado que: "Inspirándose en la teoría de Ezra Pound, instituyeron una serie de principios que se refirieron, predominantemente, a cuestiones técnicas del lenguaje poético. Sin embargo, cómo no ver también allí un esfuerzo titánico de reapropiación de las poéticas de estos autores, cuyo efecto más
} 
Desde sus primeros textos programáticos, los poetas concretos han exaltado la práctica de la traducción. Desde la óptica del traslado de una lengua a otra, su trabajo puede verse como la estrategia de un grupo de vanguardia que trata de posicionarse en el campo de la literatura brasileña a través de la importación de un repertorio de autores al que denominaron paideuma. $(2015$, p. 1).

El propio Haroldo de Campos sobre el procedimiento de traducción dirá: "La transcreación, es el modelo por excelencia de traducir las obras de arte verbal, trabaja sobre las formas significantes, en todos los planos (fono-prosódico, sintáctico, morfo-gramatical) buscando una equivalencia paramórfica, del texto de partida en la lengua de llegada" (Entrevista de Víctor Sosa con H. De Campos. 1996, p. 39). Notemos el desplazamiento que opera en el concepto: de traducción a transcreación; traducir no solamente se configura como el traslado de una lengua extranjera a la lengua madre, sino que también es una forma de creación. Como ha estudiado Berenice Gustavino (2014), con relación a la configuración del material crítico en las bibliotecas argentinas y la función de la traducción, la misma opera en los autores de modo compensatorio. Esto se da específicamente en relación con el trabajo de Elena Comas, artista y compañera de E. A Vigo desde 1954, cuyo desempeño es central en las re-escrituras en tanto ella es quien traduce los ejemplares que posteriormente serán mecanografiados y diseñados por E. A. Vigo.

Para finalizar este apartado, retomamos las dos características principales de las re-escrituras expuestas en el estado de la cuestión: son dispositivos que copian otros discursos -presentándose como compendios de conocimientos- y son ejemplares únicos perteneciente al ámbito privado no concebidos a priori para ser expuestos. Agregamos a esta caracterización la noción de apropiación, que refiere en el presente estudio a la acción de hacer de lo otro algo propio, puesto que en la operación de volver a escribir Vigo hace suyas las conceptualizaciones que los diversos autores ponen de manifiesto en sus textos, construyendo así, más que una reproducción

evidente ha sido el hecho de que algunos nombres (como e.e.cummings o el mismo Ezra Pound) se asocien 'naturalmente' al movimiento concreto. En este tipo de traducciones que, para diferenciarla de las mediadoras, podemos denominar posesivas, el poeta busca unir su nombre al del poeta traducido y convertirse en su destinatario 'natural' en la lengua de llegada. Este trabajo de apropiación, que en los momentos de emergencia del movimiento de poesía concreta estuvo subordinado a los objetivos vanguardistas y a la operación de importación (que es también, no hay que olvidarlo, de difusión y democratización), comenzó a adquirir una independencia mayor en los proyectos individuales que encararon Haroldo y Augusto de Campos a partir de Traduzir \& Trovar de 1968" (2015, p. 1). 
la recreación de esas obras a partir de la edición. Las re-escrituras configuran un repertorio de autores y teorías críticas que posteriormente se presentan tanto en publicaciones como en charlas y obras, este repertorio, si bien se presenta ecléctico en su intereses, implica novedades en torno al canon de la época y puede subdividirse en tres temáticas predominantes: vanguardias históricas, poesía experimental e historietas. 


\section{Las bibliotecas}

Creemos necesario realizar un relevamiento de la Biblioteca del Centro de Arte Experimental Vigo puesto que, como hemos señalado en la introducción y en las consideraciones sobre el Archivo, las re-escrituras forman parte del Acervo del CAEV y, si bien son una sub serie dentro de Escritos Personales, los textos que aparecen en las re-escrituras se vinculan con temáticas más amplias de la Biblioteca General, presentando continuidades y núcleos de interés por parte de E. A. Vigo.

Nos detendremos en la segunda parte de la tesis en el análisis de las tres temáticas prioritarias de las re-escrituras (vanguardias, poesía experimental e historieta), sin embargo creemos pertinente en esta instancia comenzar a cruzar los materiales de re-escritura con la Biblioteca General, Hemeroteca y Archivo para compartir la complejidad en la cual se encuentran inmersos los ejemplares de las re-escrituras.

\subsection{Biblioteca General y Hemeroteca}

Nos interesa recorrer la Biblioteca para adentrarnos en las lecturas de E. A. Vigo en relación con los ejes que proponemos para la segunda parte de nuestro trabajo. La importancia de abordar la Biblioteca General como una parte específica dentro de las lecturas de Vigo se orienta, en primer lugar a la comprensión de los modos en que el artista se nutre de estos textos de diversa procedencia; en segundo lugar, buscamos indagar en los modos en que Vigo se inserta en determinados circuitos como un enunciador competente, actualizado y autorizado en los campos específicos.

A partir de los años de publicación, podemos afirmar que parte de los libros de la Biblioteca General ingresan a partir del viaje que realiza Vigo a Europa en 1954, otros han sido conseguidos en librerías (Galatea, por ejemplo) y muchos por correspondencia, como en el caso de las publicaciones de poesía o la temática de arte correo.

En torno a la cantidad de ejemplares presentes en la Biblioteca General que incluye la hemeroteca, hemos constatado la existencia de más de 2000 ejemplares entre libros, revistas de poesía y libros de arte correo. No entran en estos números la cantidad de revistas sobre historieta, cultura general, suplementos culturales de literatura, política y arquitectura que hasta el momento no han sido relevados en su totalidad y que probablemente serían más de 1000. 
La biblioteca del CAEV se configura como una de las más importantes bibliotecas de artistas en la ciudad de La Plata. El siguiente cuadro refleja el relevamiento que hemos hecho de la misma con las temáticas que componen esquemáticamente la Biblioteca General:

\begin{tabular}{|c|c|}
\hline \multicolumn{2}{|c|}{ BIBLIOTECA GENERAL Centro de Arte Experimental Vigo } \\
\hline Artistas/ Biografías & \\
\hline \multirow[t]{6}{*}{ Disciplinas Artísticas } & Artes visuales \\
\hline & Arquitectura \\
\hline & Fotografía \\
\hline & Grabado \\
\hline & Literatura \\
\hline & Historieta/ Comic \\
\hline \multirow[t]{6}{*}{ Teoría } & Historieta/ Comic \\
\hline & Arte \\
\hline & Cine \\
\hline & Estética \\
\hline & Historia \\
\hline & Literatura \\
\hline \multirow[t]{10}{*}{ Movimientos Artísticos } & Abstracción Geométrica \\
\hline & Arte Argentino \\
\hline & Arte Latinoamericano \\
\hline & Bauhaus \\
\hline & Cubismo \\
\hline & Dadaísmo \\
\hline & Expresionismo \\
\hline & Mertz \\
\hline & Surrealismo \\
\hline & Pop \\
\hline \multirow[t]{3}{*}{ Revistas } & Culturales \\
\hline & Políticas \\
\hline & Comics/ Historieta \\
\hline
\end{tabular}




\begin{tabular}{|c|c|}
\hline \multirow{2}{*}{ Poesía Visual } & Arquitectura \\
\cline { 2 - 2 } & Literarias \\
\hline \multirow{2}{*}{} & Revistas \\
\cline { 2 - 2 } & Libros \\
\cline { 2 - 2 } & $\begin{array}{c}\text { Catálogos/ afiches } \\
\text { Libros/ Revistas/ Catálogos de la } \\
\text { Exposición Internacional de Novísima } \\
\text { Poesía 69. }\end{array}$ \\
\hline Arte correo & Libros/ Catálogos/ Revistas/ Fanzines. \\
\hline
\end{tabular}

Cuadro 1. Biblioteca General del Centro de Arte Experimental Vigo. Elaboración propia.

En los apartados que siguen, comenzamos a introducir las lecturas de E. A. Vigo en torno a las tres temáticas predominantes en el corpus de re-escrituras y el contrapunto que ofrece la Biblioteca General sobre estos temas. De los libros presentes en la Biblioteca General referidos a la obra de Marcel Duchamp, nos interesa destacar el prolongado interés de Vigo por la producción del artista francés. En torno a las revistas literarias subrayamos los modos de circulación y las modificaciones en el repertorio de lecturas de Vigo. Por último referimos a teóricos de la historieta presentes en la Biblioteca: Umberto Eco, Oscar Masotta y Moacy Cirne. La selección de estos temas se justifica teniendo en cuenta del análisis que proponemos de las re-escrituras en la segunda parte de este trabajo.

\section{a) Lecturas sobre Duchamp}

Atendiendo a las fechas de edición de los libros de esta Biblioteca General, existen temáticas transversales a la biografía de Vigo que sugieren intereses tempranos. Es el caso de las obras referidas a Marcel Duchamp, en la Biblioteca encontramos los siguientes títulos:

Robert Lebel (1959) Marcel Duchamp Francia. Trianon.

Michel Sanouillet (1959) Marchand du sel. Francia. Le Terrain Vague.

Arturo Schartz (1968) Marcel Duchamp Italia. Fratelli Fabri Editori.

Octavio Paz, Marcel Duchamp (1968)México.Ediciones Era. 
Octavio Paz. (1973) Apariencia desnuda. La obra de Marcel Duchamp. México. Ediciones Era.

Michel Sanouillet (1975) Duchamp du signe: écrits. España. Gustavo Gilli.

Piere Cabanne (1984) Conversaciones con Marcel Duchamp. España. Anagrama.

Manual of Intructions for Etant Donnes (1987) Philadephia Museum art. Gran Bretaña, Balding \& Mansell, Wisbech.

Gloria Mane (1988) Marcel Duchamp. Barcelona. Polígrafa Editorial.

Duchamp (1994) Alemania. Taschen.

Juan Antonio Ramirez (1994) Duchamp el amor y la muerte incluso. España. Editorial Siruela.

AA VV Duchamp (1995) Barcelona. Poligrafa.

Describimos a continuación dos ejemplares sobre Marcel Duchamp presentes en la Biblioteca de Vigo, en primer lugar, porque se presentan como formatos expandidos en torno al objeto libro ${ }^{47}$, son ejemplares singulares tanto en lo que respecta a su edición como a las obras que contienen en su interior. En segundo lugar, y siguiendo la hipótesis de esta tesis, nos interesa el relevamiento de los libros de Duchamp en la Biblioteca puesto que el artista francés funciona como referente en el repertorio de las re-escrituras y en muchas de las obras de Vigo.

El libro -dispositivo participativo- Octavio Paz, Marcel Duchamp (1968), se presenta como un "libro maleta" en palabras de su diseñador Vicente Rojo. Artefacto contenedor de diversos elementos, en la tapa, a partir de una cuadrícula que simula un tablero de ajedrez, se exponen los nombres de los autores Paz y Duchamp. Desplegado, encontramos dos libros en pequeño formato: el primero corresponde a la primera versión del ensayo de Octavio Paz "Apariencia Desnuda" denominada 48 "Marcel Duchamp o el castillo de la pureza”. El segundo es una selección de textos traducidos de Duchamp pertenecientes al libro Marchand du Sel, esta edición sería, hasta lo que sabemos, la primer traducción de los textos de Duchamp de manera oficial ${ }^{49}$.

\footnotetext{
${ }^{47}$ En el mes de mayo de 2019 presentamos el proyecto Desborde y Biblioteca Tomo 1: Formatos expandidos donde, junto a Julio Lamilla y Mariana Santamaría, propusimos un diálogo bibliográfico y poético entre los ejemplares del CAEV y la Biblioteca Pública de la UNLP. En este primer tomo, el objetivo fue revisar aquellos libros de la biblioteca del CAEV que no entran dentro de la categoría tradicional de libro, nos referimos a libros colaborativos, re-escrituras, libros volumétricos, envíos-libros de arte correo entre otros, expusimos el ejemplar de Octavio Paz y Marcel Duchamp que se reseña en esta oportunidad. La intención del proyecto es ahondar y difundir la Biblioteca de Edgardo Antonio Vigo.

${ }^{48}$ Es la primera versión del ensayo de Octavio Paz dedicado a Duchamp titulado: Apariencia Desnuda (1973).

${ }^{49}$ Como veremos en la segunda parte, Comas y Vigo traducen en 1966 el texto de Duchamp Marchand Du Sel en una edición de re-escrituras. El libro de Paz y Duchamp, dos años después de la re-escritura y obviamente sin conocer la traducción de la dupla platense, publican fragmentos de estos mismos textos en español.
} 
El libros cuenta también con una reproducción en lámina claracil de "El Gran Vidrio", tres láminas color de "Dados...", un sobre con nueve reproducciones de los ready-made, un álbum con reproducciones de textos autógrafos y un souvenir-careta de Marcel Duchamp. La disposición de este libro-maleta tiene muchos elementos que serán recurrentes en el formato que trabaja Vigo para sus publicaciones y también con los modos de archivo de obra que el artista propone. Podemos vincular conceptualmente este libro con Boîte-en-valise que contenía un muestrario en miniatura de las obras de Duchamp.

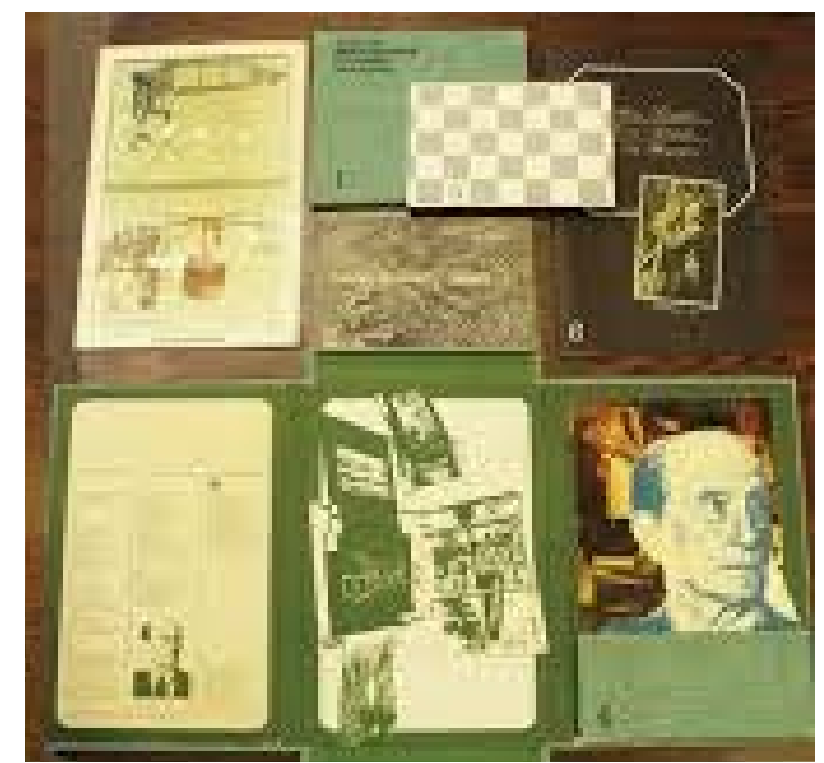

Fig 6. Octavio Paz, Marcel Duchamp (1968), Ediciones Era. México.

Archivo: CAEV.

En segundo lugar, reseñamos la carpeta Étant Donnés (1987) del Museo de Filadelfia, que corresponde a una edición facsimilar del registro donde M. Duchamp trabajaba para obra "La Cascada" emplazada en este Museo. Fue la última pieza que realizó Duchamp, se trata de una instalación en que el espectador se asoma a espiar por una desvencijada puerta de madera, lo que ve es un paisaje bucólico y una mujer yacente con las piernas abiertas. La acción de "espiar", la invitación a que el espectador accione la obra, es un mecanismo utilizado y teorizado ya por Vigo desde la década de 1960.

\footnotetext{
50 Obra que Vigo y Comas conocen desde 1957 a partir de Les Machines Celibataires (1954) de Michel Carrouges en la re-escritura que elaboran a partir del original.
} 


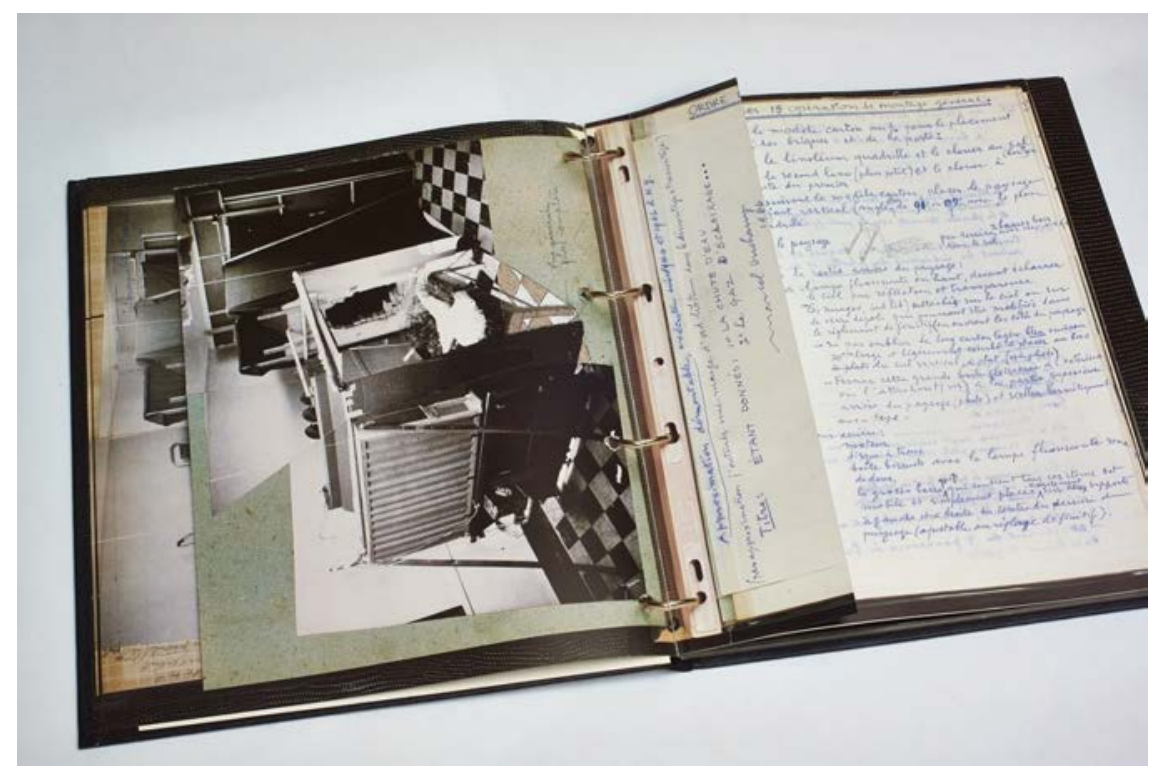

Fig. 7 Manual of Instructions for Etant Donnes (1987) Archivo CAEV.

Es interesante notar, en primer lugar que la carpeta Étant Donnés es la edición facsimilar de un archivo personal, es decir, consta de notas, apuntes y bocetos elaborados por Duchamp el emplazamiento de su obra. En segundo lugar, da cuenta del interés constante de Vigo por Marcel Duchamp puesto que el último libro que adquiere sobre del artista francés es de 1994.

Existe en la obra de Vigo ${ }^{51}$ referencia explícita a la obra de Duchamp, por caso la escultura "El sudario de Marcel Duchamp" o sus envíos postales en Nuestro Libro Internacional, donde firma como Don Rrose Selavi II, aludiendo de manera explícita al heterónimo creado por Duchamp "Rrose Sélavy". Como señalamos, dos de las identidades creadas por Vigo a lo largo de su trayectoria corresponden a "Tana Vigo" y "Don Rrose Selavi II", esta última en claro homenaje al francés.

Por otro lado, encontramos en el archivo papeles dispersos, postales y afiches que remiten a la obra de Duchamp y dan cuenta de un interés sistemático por la obra del mismo. La apropiación de los postulados dadá se verifica cuando analizamos las re-escrituras en vínculo con sus publicaciones y en las operaciones que Vigo realiza e incorpora para su estética, tal es el caso de "Manojo de Semáforos"52 (1968) o "El sudario de Marcel Duchamp" pero también, como

\footnotetext{
51 Como ha señalado Bugnone $(2013$, 2017), si bien la obra de Vigo retoma procedimientos vanguardistas tales como la utilización del objeto manufacturado inaugurada por el ready made, los espacios alternativos para la difusión de la obra y el abandono de los procedimientos y formatos tradicionales, es en la modulación de estos elementos, en vínculo con su contexto de producción, donde la obra de Vigo cobra alcance poético y político (2013, p. 318)

52 Señala Fernando Davis sobre esta obra que: "La intervención de Vigo extiende y complejiza la estrategia desviacionista del ready-made. Pero si la operación de Duchamp traza su densidad crítica en la práctica de descontextualizar el objeto cotidiano, para reubicarlo, al interior de la institución artística, en una nueva trama
} 
argumentamos en la segunda parte de esta tesis, en otras búsquedas poéticas como "Discos para mirar", "Poemas (in) comestibles" y "Análisis (in) poético de un metro de hilo", donde tanto la apropiación como el aspecto "revulsivo", aparece en la pregunta por lo poético y la tensión con las formas canónicas de concebir la poesía.

A partir del relevamiento realizado en el CAEV, la primera referencia explícita a la obra de Marcel Duchamp encontrada pertenece a la caja Biopsia, donde figura "un drama de amor (Leyenda) desarrollo literario de un juego poético" escrito por Vigo en el año 1958. Del año 1957 es la traducción y re-escritura que Elena Comas y E. A. Vigo realizan de Les Machines Célibataires de Carrouges -publicado originalmente en 1954- donde se menciona la obra "E1 Gran Vidrio" de Duchamp-, que analizaremos en la segunda parte. Por otra parte, la re-escritura que la dupla Comas-Vigo realizan sobre el Marchand $d u$ Sel, fechada por ellos en el año 1966, es la primer traducción al español de este texto.

En el desarrollo del primer capítulo de la segunda parte de este trabajo volveremos sobre estos ejemplares y la incidencia de Marcel Duchamp en la obra de Vigo. Hemos querido mostrar que desde los inicios de la producción plástica de Vigo, el artista posee conocimientos que se van profundizando sobre la obra dadá y, particularmente, de Duchamp.

\section{b) Lecturas en Diagonal Cero}

Sostenemos que, a partir de las lecturas que realiza Vigo, tanto en las re-escrituras, los libros de su Biblioteca y las revistas, es posible trazar un camino de análisis para estudiar sus publicaciones y obras. En este apartado nos interesa atender a las lecturas que circulan en torno a la publicación Diagonal Cero, analizando principalmente la hemeroteca de poesía del CAEV.

Si bien, es en la segunda parte del trabajo donde abordamos la poesía experimental y la incidencia de las re-escrituras en la publicación, queremos revisar las decisiones que motivan a su editor, E. A. Vigo, a extender el espectro de lecturas vinculadas a la poesía.

Como hemos leído en la entrevista sobre sus publicaciones -enviada a Stephen Perkins en 1996Vigo divide en dos momentos el devenir de Diagonal Cero. Si desde su aparición en el año 1962

\footnotetext{
de asociaciones y referencias semánticas; el señalamiento invierte esta estrategia: no se trata de alterar o desviar la circulación corriente del objeto, sino de señalarlo en su contexto, con el propósito de instalar la deriva poética en el afuera de la institución arte, en el entorno cotidiano de la calle, donde la presencia del objeto se ha vuelto costumbre." (2007, 2) Pueden consultarse también: De Rueda, M. (2003) "Utopías en la Calle", en Arte y Utopía. Asunto Impreso. Buenos Aires, Argentina, Davis, F. (2008) E. A Vigo, y los reversos del ready-made, Buenos Aires, Vórtice Argentina ediciones.
} 
se centra en la difusión de la poesía tradicional, hacia 1965 se produce un viraje y el centro lo ocupa la poesía experimental ${ }^{53}$. Vigo destaca en la entrevista que, Diagonal Cero logró crear redes de comunicación que motivaron el envío de material diverso, así: “Gracias a estos contactos surgió un intercambio intenso sobre todo grupos o personajes que dentro de sus terrenos investigan y proponían formas distintas de encarar la solución plástico poética o propuesta a nivel teórico refundador" (E. A. Vigo. 1996, mimeo. CAEV) ${ }^{54}$. En este sentido, el afán de Vigo por formar redes y relacionarse, se explicita en el primer número de la revista, donde leemos: "Deseamos el canje con todas las publicaciones de tipo similar" (DC N¹, 1962). Desde el $N^{\circ} 7$ de se sugiere la adhesión a otras revistas de manera propositiva, así: "Suscríbase a: Caballete, Espacios, La Voz en el Tiempo, Eco Contemporáneo, El Fantasma Flaco, Tiempo de Cine y Mediodía", lema que acompañará los siguientes números de la publicación hasta el número 23 (1967). Respecto de los lazos que estableció con otras publicaciones de la época hemos encontrado referencia en los números 3-4 de la revista con orientación surrealista Cero (1964-1967), dirigida por Vicente Zito Lema , así como ejemplares en su biblioteca de la revista platense Teseo.

Además de estos intercambios, la publicación sostiene la importancia de visibilizar los testimonios locales, como queda de manifiesto en la editorial del $n^{\circ} 7$ :

Diagonal Cero sin poner barreras a los testimonios nacionales y extranjeros de vital importancia para el progreso comunicativo, hará especial importancia en la transcripción de testimonios de nuestro acervo local: La Plata (DC N 7, 1963).

La publicación, pone en circulación la obra "Palabras colgadas ante los ojos", del editor platense Denis Krause (DC N $\left.{ }^{\circ} 5-6,1963\right)$, obras de Carlos Pacheco, Luis Pazos, Jorge Ginzburg, también poemas del Grupo de los Elefantes (formado por Lida Barragán, Omar Gancedo, Raúl

\footnotetext{
${ }^{53}$ Silvia Dolinko interpreta al respecto que: "El desarrollo de la publicación de Vigo se puede asociar a los cambios estéticos y a la postura ideológica del propio artista, a la vez que también permite dar cuenta de algunos aspectos de la dinámica y de las transformaciones que atravesaron el campo cultural del período: el avance de las vertientes gráficas experimentales, la creación de redes de intercambios artísticos latinoamericanos, la manifestación progresiva del compromiso intelectual, la eclosión de la poesía visual a fines de la década fueron problemáticas que tuvieron cabida en sus páginas" (2012, p. 104).

${ }^{54}$ Como ha señalado Magdalena Pérez Balbi: "Además de las publicaciones en la revista y las presentaciones en el circuito marginal, la producción del Mov. DC tuvo otra vía de circulación, gracias a la gestión de Vigo, que mantenía una fluida comunicación a distancia con artistas e instituciones de diversas partes del mundo a través del trueque de revistas, publicaciones y obras. Esta práctica - cotidiana para él- y más tarde convertida en disciplina con el arte correo, tuvo un rédito fundamental para el grupo. Mediante intercambios por vía postal, llegaban a Vigo publicaciones (libros, revistas, catálogos, etc.) y convocatorias de todas partes del mundo y, a su vez, la revista DC se distribuía internacionalmente" (2008, p. 34).
} 
Fortín, Roberto Ávila y Yoly Poisneuf). En Diagonal Cero N 9-10 (1964), leemos en el artículo firmado por Vigo titulado Balance de la Plástica platense donde se vislumbra la tensión con las revistas contemporáneas:

Las revistas: casi inexistentes, dan poca importancia a la plástica local, y siguen en su mayoría la línea escapista-europea, (puede ser producto de nuestra Universidad) perdiéndose en el análisis de los movimientos internacionales sin ninguna referencia a la plástica nacional o latinoamericana. Ejemplo la desaparecida o adormilada SIGLO XXI. (DC N 9-10, 1964, p. 3)

En Diagonal Cero, Vigo interactúa de manera polémica no solo con los valores que según él, persiguen los editores contemporáneos platenses, sino también en el modo de concebir el objeto revista y su función. En términos de Vigo, en su publicación se trabaja por una estética participante $\left(\mathrm{DC} \mathrm{n}^{\circ} 23,1967\right)$, contrapuesta a una estética de la observación. El artículo “El artista y la sociedad platense" del n 12 (1964), continúa en la misma línea crítica y apunta que:

El NO PASA NADA lo hemos escuchado tantas veces hasta poder formar un combo masificado de poetas, escritores y plásticos repitiendolo. Y es verdad, NO PASA NADA. Por más que para escaparse de lo antedicho usted haya organizado un festival poético de carácter público, una lectura de poemas en una plaza, expuesto en los barrios, publicado un mural, la sociedad no interpretará el esfuerzo por cambiar el cauce de la política del arte en cuanto a las relaciones artista-sociedad. Entonces se sigue practicando lo permitido. (E. A. Vigo, DC n 12, 1964)

Diagonal Cero, con estas reflexiones, se aleja de manera crítica de las publicaciones platenses de su contemporaneidad considerando que estas mantienen estructuras vinculadas a las formas de lectura y escritura de la poesía tradicional, signado por una estética de la observación (1967). Vigo expondrá mediante el procedimiento de montaje la convivencia de temporalidades en documentos de autores platenses junto a teóricos y artistas extranjeros como modo de resistencia a ese "NO PASA NADA". Encontramos en las páginas de Diagonal Cero traducciones y obras de artistas que publican en revistas extranjeras tales como Les Letters, Phantomas, Los huevos de Plata (posteriormente OVUM 10), Approches, Doc $(k) s$ en convivencia con poetas emergentes 
platenses. Los intercambios teóricos y artísticos operan sobre las construcciones conceptuales y estéticas en el devenir de Diagonal Cero modificando el perfil de la publicación.

Las revistas consultadas y las re-escrituras que analizaremos en el Capítulo 2 de la segunda parte de la tesis, exponen un corrimiento de referencias teóricas con relación a la concepción de la poesía que confrontan con la estructura analítico-discursiva del poema tradicional. Como ha señalado Magdalena Pérez Balbi (2008), “analizando el devenir de la revista, podemos observar que la reflexión sobre la palabra y el rol de la literatura y el arte, se inclina progresivamente hacia soluciones plástico-visuales y da cuenta de una crisis de ciertas convenciones literarias ( $\mathrm{p}$. 19)." En este sentido, las modificaciones en las referencias teóricas y la implicancia de la materialidad en Diagonal Cero, visibilizan tensiones tanto con la estética de las publicaciones de su época como con los repertorios de lectura que exponen.

En concordancia con la hipótesis de esta tesis, nos ha interesado en este apartado reflexionar sobre las lecturas -presentes en la biblioteca y hemeroteca- que inciden en Diagonal Cero, las formas en que los intercambios con otros artistas y publicaciones extranjeras se manifiestan directamente en la revista modificando el perfil de la misma hacia una poesía de tipo experimental.

\section{c) Lecturas e historieta}

Tres críticos contemporáneos al corpus de re-escrituras seleccionado, cuyos pensamientos encontramos en la biblioteca personal de Vigo, plasman versiones sobre este género que sirven para abordar la propuesta estética del artista en torno a la historieta. Si bien es en el tercer capítulo donde abordamos las historietas herméticas en profundidad, nos interesa plantear que, además de las re-escrituras sobre historieta presentes en su Escritos Personales, también, tanto la biblioteca como la hemeroteca, cuentan con un amplio número de publicaciones sobre el tema. Entre las revistas referidas a la historieta relevadas por Julia Martínez, la biblioteca del CAEV cuenta con: Skorpio ${ }^{55}$, Dennis Martin ${ }^{56}$, Cabo Savino $^{57}$, Tit-Bits ${ }^{58}$, El Tony, Nippur de Lagash ${ }^{59}$,

\footnotetext{
55 Skorpio fue una publicación argentina de historietas editada por Récord con Alfredo Scutti como editor responsable. El primer número hizo su aparición el 5 de Julio de 1974. Con una frecuencia mensual, llegó a los 235 números hasta su cierre en Enero de 1996.En sus primeros números, tuvo como guionista a Héctor G. Oesterheld.

${ }^{56}$ Dennis Martin fue una historieta creada por Lucho Olivera y Robin Wood (1967) para la revista D'Artagnan de Editorial Columba de Argentina.

${ }^{57}$ Cabo Savino es una serie de historietas creada por Carlos Casalla en 1954 que apareció de manera semanal en sus comienzos en la contratapa del diario La Razón.

${ }^{58}$ Tit-Bits fue una publicación Argentina editada primero por Manuel Láinez desde 1909 hasta 1957, y retomada por Ediciones Récord entre 1975 y 1982.
} 
Fantasia $^{60}, D^{\prime}$ artagnan $^{61}$, Pif-Paf ${ }^{62}$, Corto Maltes ${ }^{63}$, Hum ${ }^{\circledR}$, Superhumor, Bumerang ${ }^{64}$, Blue Jeans, Intervalo Extra, Maléfico, Chaupinela ${ }^{65}$, Fierro. Además encontramos los siguientes libros: Historia del deporte (Oski), Los deportistas son una risa (Garaycochea), Boogie (Fontanarrosa), Las aventuras de Inodoro Pereyra (Fontanarrosa)Historia del comic español (AAVV), La Aventura del Comic (Lindo), La historieta (Baur), Qué es la historieta (Grassi), Qué es la caricatura (Columba), Historia de la historieta Argentina (Rivera) Charlando con superman (Cáceres), Los comics de Mao (AAVV), Leer Mafalda (Hernández), entre otros.

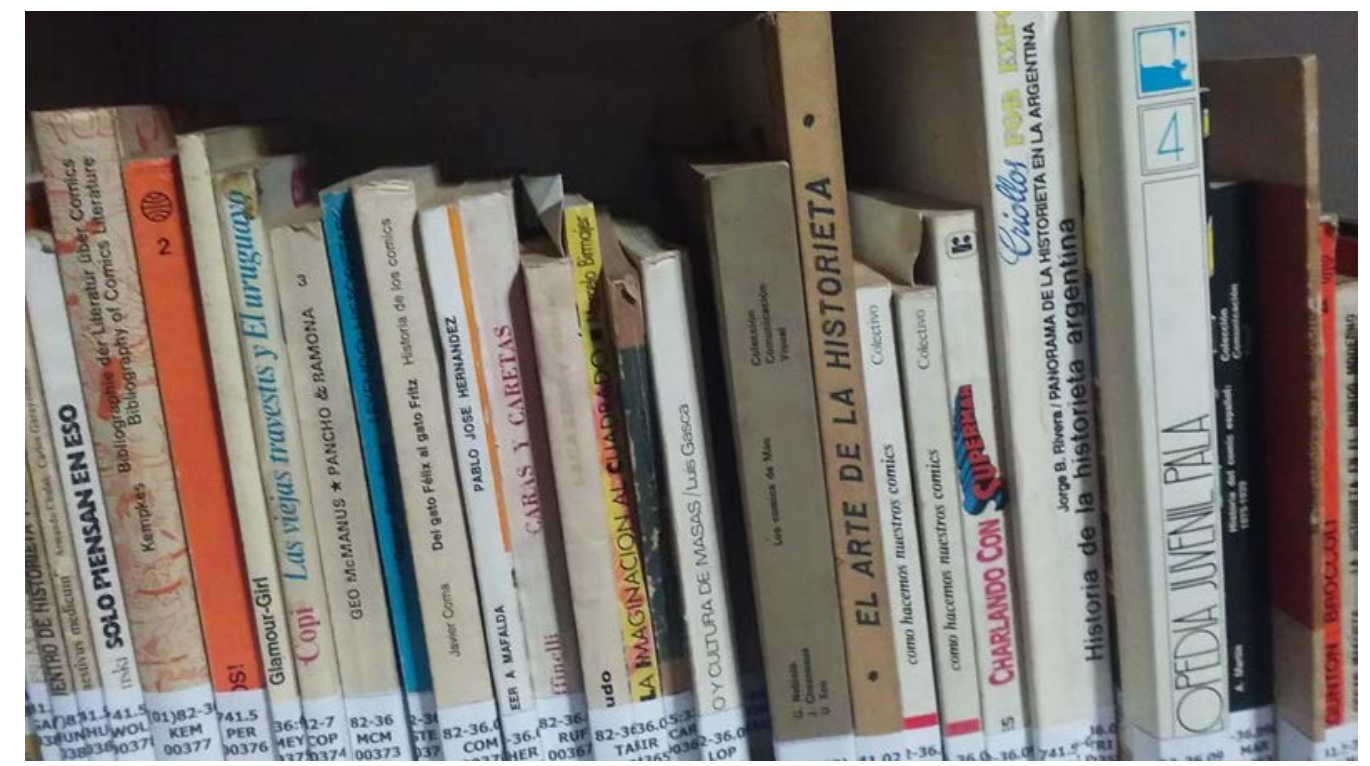

Fig. 8. Detalle de Libros sobre historieta y comic. Biblioteca de Historieta del CAEV.

La mirada de Umberto Eco, en Apocalípticos e Integrados (1968) postula que las críticas apocalípticas surgen de la lectura de textos sobre la cultura de masas mientras que la imagen de quienes se integran a ella surge de las lecturas de la cultura de masas (Eco, 1968, p. 13) ${ }^{66}$. Vigo

\footnotetext{
${ }^{59}$ Nippur de Lagash, historieta argentina creada por Robin Wood y Lucho Olivera, fue publicada entre 1967 y 1998.

${ }^{60}$ Fantasía, revista de historietas publicada en la Argentina por Columba desde 1950 hasta 1959, continuó su edición en forma de álbumes y anuarios hasta 1995.

${ }^{61}$ D'artagnan, revista de historieta argentina publicada por Columba entre 1957 y 2000.

${ }^{62}$ Pif-Paf fue publicada por la editorial Tor.

${ }^{63}$ Corto Maltes fue creado por el historietista y guionista Hugo Pratt en 1967.

${ }^{64}$ Bumerang, revista de historietas española publicada por Nueva Frontera entre 1978 y 1979.

${ }^{65}$ Revista argentina de humor político dirigida por Andrés Cascioli publicada entre 1974 y 1975.

${ }^{66}$ Dice Eco que: "La imagen del Apocalipsis surge de la lectura de textos sobre la cultura de masas; la imagen de la integración emerge de la lectura de textos de la cultura de masas. Pero, ¿hasta qué punto no nos hallamos ante dos vertientes de un mismo problema, y hasta qué punto los textos apocalípticos no representan el producto más sofisticado que se ofrece al consumo de masas? En tal caso, la fórmula "apocalípticos e integrados" no plantearía la oposición entre dos actitudes (y ambos términos no tendrían valor substantivo) sino la predicación de dos adjetivos complementarios, adaptables a los mismos productores de una "crítica popular de la cultura popular" (1968, p. 13).
} 
lee y consume gran variedad de publicaciones de y sobre historieta, su producción entraría dentro de una tercera opción al binomio planteado por Eco, considerando que además de consumir comic como lector, es un estudioso del género y además, productor artístico. Con esto queremos decir que no es un consumidor pasivo ni un crítico acérrimo, indaga en los recursos provistos por el comic para proponer otras experiencias estéticas en torno a las convenciones.

Como lector y hacedor de comic, en su hacer estético, Vigo utiliza los recursos provistos por la cultura de masas como una herramienta para ampliar las posibilidades de las artes visuales, articulando los elementos de la historieta con la poesía visual, proyectos de arte correo y edición. Tomando elementos conocidos, Vigo busca en su producción fisurar los modos establecidos de decodificar las marcas del género apelando fuertemente a los sentidos que puedan despertar en el potencial espectador. En este sentido coincidiría con Eco al considerar que la eficacia de una intervención en la cultura de masas reside en un conocimiento del material sobre el cual se trabaja (Eco, 1968, p. 62).

Eco apunta algunas propuestas de investigación sobre el comic que creemos pertinentes en relación a las novedades formales que interesan para analizar la estética de Vigo:

La sucesión cinematográfica de los strips. Ascendencia histórica. Diferencias. Influencia del cine. Procesos de aprehensión implicados. Posibilidades narrativas conexas. Unión palabra-acción realizada mediante artificios gráficos. Nuevo ritmo y nuevo tiempo narrativo que de ahí derivan. Nuevos estilemas para la representación del movimiento (los dibujantes de comics no copian de modelos inmóviles, sino de fotogramas que fijan un momento del movimiento). Innovaciones en la técnica de la onomatopeya. Influencias de las experiencias pictóricas precedentes. Nacimiento de un nuevo repertorio iconográfico y de standardizaciones que funcionan ya como topoi para la koiné de los fruidores (destinados a convertirse en elementos de lenguaje adquirido para las nuevas generaciones). Visualización de la metáfora verbal. Estabilización de tipos caracterológicos, sus límites, sus posibilidades pedagógicas, su función mitopoética (Eco, 1968, p. 72).

En el capítulo "Lectura de Steve Canyon”, Eco propone una semántica del comic basada en el análisis de determinados estereotipos gráficos que dan cuenta de un código compartido (el espiral de humo, cabeza que da vueltas, lámpara encendida como idea, etc.). Encontramos en esta semántica, las representaciones de la burbuja -que también será abordada en la obra de Vigo 
a partir de los aportes de Moacy Cirne y Robert Benayoun-, la colección de recursos onomatopéyicos trasladados a la escritura; determinada gramática del encuadre que contempla los usos de la perspectiva, ubicación de los personajes y el enriquecimiento o literalidad de la imagen en relación con el texto.

Otro crítico que se encuentra en la Biblioteca de Vigo es el prolífico Oscar Masotta ${ }^{67}$. Masotta organiza en 1968 la Bienal Mundial de la Historieta conjuntamente con la Escuela Panamericana de Arte en el Instituto Di Tella. El mismo año dirige la revista Literatura Dibujada. Serie de Documentación de la Historieta Mundial ( $\mathrm{n}^{\circ}$ 1: noviembre de $1968-\mathrm{n}^{\circ}$ 3: enero de 1969), y en 1970 publica La historieta en el mundo moderno, donde afirma: "En la historieta todo significa, o bien, todo es social y moral" (Masotta, 1970, p. 9). Analiza los elementos y las mutaciones de las historietas en Estados Unidos, Europa y Argentina respectivamente. Masotta habla del "cómic" para referir a la historieta estadounidense mientras que utiliza el término "historieta" cuando refiere al género en Europa y Argentina.

Resulta pertinente resaltar que en el Fondo Documental del CAEV, encontramos los tres ejemplares de la revista mencionada anteriormente Literatura Dibujada. Serie de Documentación de la Historieta Mundial. Esta revista se propone:

(...) reeditaremos las mejores historietas del pasado e invitaremos al lector a conocer las mejores historietas del presente, sorpresivamente dirigidas al público adulto (...) El proyecto de L. D - una actitud de reflexión militante sobre la historieta- puede parecer complejo, más aún contradictorio (...) porque tal vez en ninguna época más que en la nuestra, ni de modo más agudo, las cuestiones del gusto se han hecho más chocantes en relación a aquellas referidas a la política, a la ideología, a la moral (Literatura Dibujada. 1968, p. 3).

Señala María Virginia Castro sobre el contexto de esta publicación:

La aparición de Literatura Dibujada. Serie de Documentación de la Historieta Mundial constituye un primer gran intento vernáculo de promocionar a la Argentina no solo como un país productor de narrativas dibujadas, sino de una producción teórica de vanguardia

\footnotetext{
${ }^{67}$ Además, del mismo autor figura en la biblioteca de Vigo: Masotta, Oscar y otros (1967) Happenings y El pop-art (1967).
} 
sobre este producto específico de la cultura de masas. Las razones de su fracaso (si fue tal) estriban seguramente en que fue un proyecto que quedó trunco demasiado pronto, sin lograr por ello ajustar (su director) las variadas matrices teóricas con las que abordó su objeto, ni resolver las tensiones entre su público ideal y su público posible. No obstante, los tres números de LD, hoy prácticamente inhallables como totalidad en las hemerotecas de consulta pública, no han perdido -creemos- su "poder encantatorio" (Castro, 2017, CeDInCI.).

Por último, mencionaremos los libros presentes en la biblioteca escritos por Moacy Cirne. Este estudioso brasileño del comic o quadrinhos, participante del movimiento Poema Proceso, figura a partir de los libros Bum! a explosão criativa dos quadrinhos (Vozes, 1970) A linguagem dos Quadrinhos (Vozes, 1971), Para ler os quadrinhos (Vozes, 1972) y Vanguardia, um projecto semiológico (Vozes, 1975). En Hexágono bc (1972), como analizaremos en la segunda parte, Vigo traduce el capítulo primero de Bum! (1970), el ejemplar original se encuentra dedicado por Cirne a Vigo ${ }^{68}$. La mirada del Cirne sobre el comic analiza el vínculo del mismo con las técnicas de reproducción, el cine y las técnicas de montaje, la estética de la burbuja o balão, las tradiciones de la historieta, los lazos y las posibilidades entre el movimiento Poema Proceso y los quadrinhos -centrado principalmente en la obra de Alvaro de Sá-.

En el desarrollo de las historietas herméticas planteado en el tercer capítulo, analizaremos las re-escrituras vinculadas a la temática de la historieta y nos detendremos en el adjetivo hermético que Vigo le asigna a sus comics. Entendemos que en esta denominación entran en tensión dos órdenes aparentemente contradictorios. Por un lado, el aspecto masivo que supone el género con sus convenciones y la arbitrariedad de los símbolos, y por otro, el hermetismo, que anularía la posibilidad de una lectura naturalizada de esos sentidos. En la propuesta de Vigo, creemos, el adjetivo no clausura el sentido sino que tiene por objetivo volver porosa la interpretación. Analizaremos también en el tercer capítulo las formas que asume la apropiación en las obras vinculadas a la historieta.

\footnotetext{
${ }^{68}$ Dice la dedicatoria: "Ao /Vigo, /poetamigo/ a admiração/ e a homenagem /de Moacy, /70".
} 


\section{Lecturas y re-escrituras: Serie Escritos Personales.}

Hemos considerado que las re-escrituras de E. A. Vigo configuran un repertorio de autores y teorías de las cuales se apropia en su producción plástica, teórica, editorial, así como también en charlas y artículos periodísticos. Anteriormente, reseñando los caminos de lectura sobre tres temáticas que al artista le interesan y repercuten en las re-escrituras, hemos querido introducir los principales ejes trabajados en las re-escrituras y la selección bibliográfica presente en la Biblioteca General que funciona como complemento paralelo de las lecturas de E. A. Vigo. Seguidamente presentaremos un relevamiento y una caracterización del objeto de estudio de esta tesis que tiene como antecedente el trabajo realizado por Berenice Gustavino en el Centro de Arte Experimental Vigo. 
Serie Escritos Personales: Llamamos Escritos Personales al conjunto de libros que, por su estructura y por la intervención que sobre ellos ha realizado Elena Comas y Edgardo Antonio Vigo, se diferencian material y conceptualmente de la Biblioteca General descripta en el apartado anterior. En el CAEV los libros de esta sección se encuentran apartados conformando un grupo especial de consulta.

La Serie Escritos Personales, donde encontramos las re-escrituras, cuenta de manera esquemática, con los siguientes materiales:

- Libros de referencia para las re-escrituras: corresponden a los libros originales que han sido traducidos o re-escritos de manera fragmentaria en los libros de re-escrituras.

- Libros intervenidos: estos ejemplares han sido modificados en su aspecto externo por E. A. Vigo.

- Re-escrituras: corresponde a los nuevos ejemplares elaborados por E. A. Vigo, mecanografíados y re-diagramados desde 1954 hasta 1975. Pueden sub-dividirse en:

-Traducciones de libros.

-Selección de artículos periodísticos.

-Escrituras personales: Corresponde a material elaborado por E. A. Vigo, contempla charlas, ensayos y manuscritos personales.

\section{- Manuscritos de Elena Comas.}


Presentamos en los cuadros que siguen la referencia específica de la descripción anterior:

\begin{tabular}{|c|c|}
\hline $\begin{array}{l}\text { Serie Escritos Personales: Libro } \\
\text { Estos libros, denominados "de referencia } \\
\text { ejemplares originales presentes en el Ar } \\
\text { encuentran separados de la Biblioteca Gen } \\
\text { de diferencia, comparación y antecedentes e } \\
\text { Los libros "de referencia" son los originale } \\
\text { por Edgardo Antonio Vigo, traducidos en m } \\
\text { re-escritura. Presentamos a continuación los }\end{array}$ & $\begin{array}{l}\text { Ia las re-escrituras } \\
\text { turas", corresponden a los } \\
\text { Arte Experimental Vigo. Se } \\
\text { n para establecer relaciones } \\
\text { rituras. } \\
\text { ha sido transcrito y editado } \\
\text { lena Comas en su versión de } \\
\text { mplares: }\end{array}$ \\
\hline Título & Autor \\
\hline Lo espiritual en el arte & Wassily Kandinsky \\
\hline Mondrian & Michel Seuphor \\
\hline La vida de las formas & Henri Focillon \\
\hline El Surrealismo & Yves Duplessis \\
\hline Arte abstracto, sus origenes, sus primeros maestros & Michel Seuphor \\
\hline Picasso. Estudios biográficos y crítica. & Maurice Raynal \\
\hline Panorama des arts plastiques contemporains & Jean Cassou \\
\hline Marchand du sel & Marcel Duchamp \\
\hline Espacialismo y poesía concreta & Pierre Garnier \\
\hline $\begin{array}{l}\text { La tira dibujada. Historia de las historias en } \\
\text { imágenes de la pre-historia a nuestros días. }\end{array}$ & Gérard Blanchard \\
\hline Banda Dibujada y Figuración Narrativa & Burne Hogarth \\
\hline Las obras maestras de la tira ilustrada & René Goscinny \\
\hline
\end{tabular}

Cuadro 2. Libros de referencia para las re-escrituras. Elaboración propia. 


\section{Serie Escritos Personales: Libros intervenidos}

La sub serie que hemos denominado "libros intervenidos" corresponde a ejemplares que han sido modificados en su aspecto externo por E. A. Vigo con distintas técnicas gráficas, como el collage o la escritura mediante letras de molde. Se los ha intervenido a partir de una funda o sobrecubierta adosada a la cubierta original. No serían, dentro de nuestra catalogación, re-escrituras puesto que solo se ha modificado la apariencia del ejemplar.

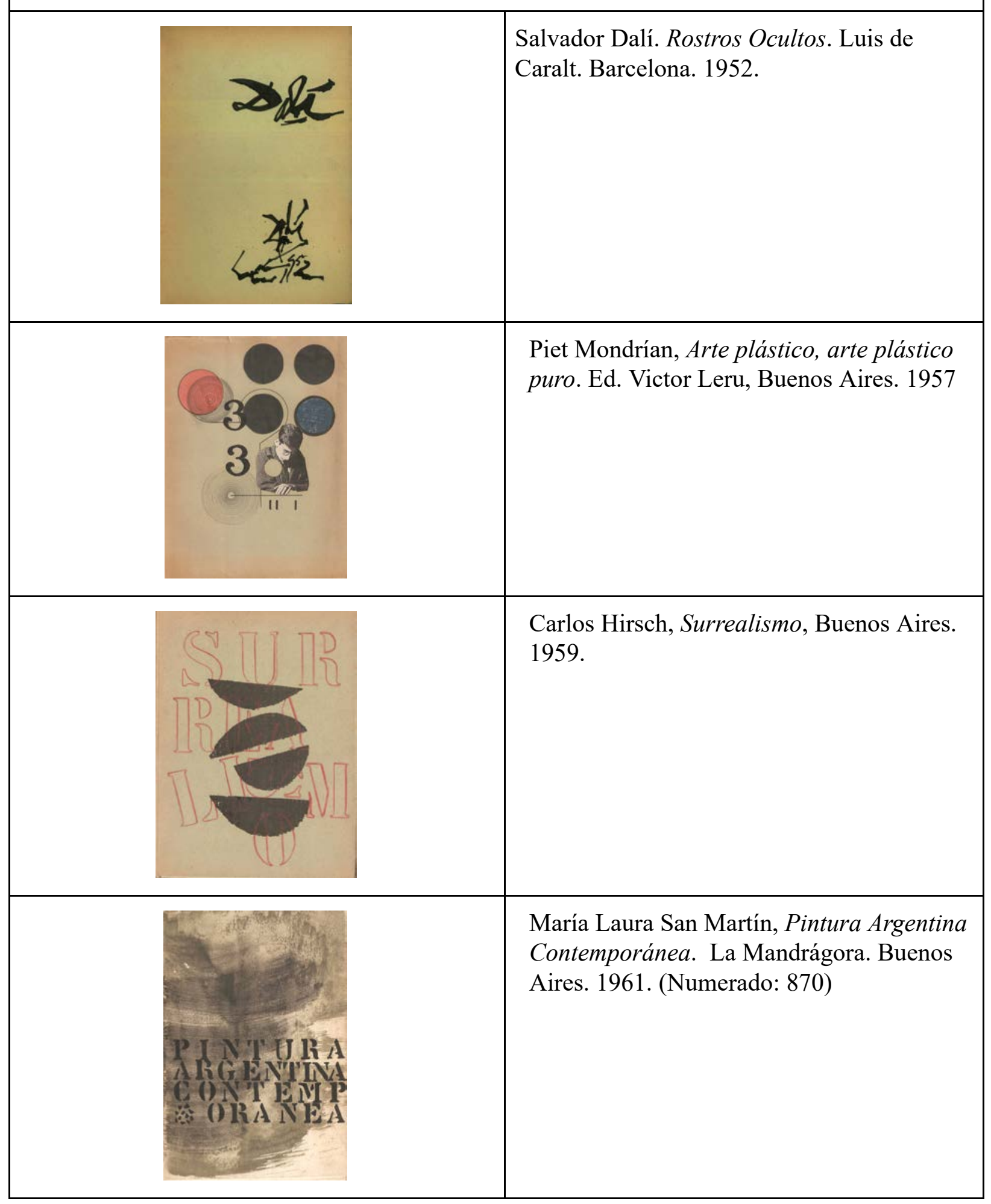

Cuadro 3. Libros Intervenidos. Elaboración propia. 


\section{Serie Escritos Personales: Re-escrituras}

La sub serie re-escrituras, se corresponde con los textos que Elena Comas traduce y E. A. Vigo transcribe y edita. Como vemos, muchos de estos ejemplares están directamente relacionados con los "Libros de Referencia" para las re-escrituras.

En la lista que sigue, se especifica si los años de las re-escrituras son aproximados en caso de que el ejemplar no cuente con los datos precisos. Lo mismo ocurre en el caso de las traducciones de los libros en inglés, donde no se indica quién ha sido el autor de dicha traducción, sin embargo, se trataría de Elena Comas. En "Características" aludimos a una presentación formal de cada ejemplar donde consta la traducción y la edición de $\mathrm{E}$. A. Vigo. Este relevamiento tiene como antecedente el trabajo realizado por Berenice Gustavino en el CAEV.

Dividimos el material, para su mejor comprensión en dos momentos, en el Cuadro 4 se especifican las re-escrituras de libros completos. En el Cuadro 5, las selecciones de artículos que utilizaremos para la presente tesis.

\begin{tabular}{|c|c|c|c|}
\hline \multicolumn{4}{|c|}{ Traducciones de libros completos } \\
\hline Título & Autor & $\begin{array}{c}\text { Año de la re- } \\
\text { escritura }\end{array}$ & Características. \\
\hline Lo espiritual en el arte & Vassily Kandinsky & 1954 & $\begin{array}{l}\text { Traducción de Elena Comas. } \\
\text { Mecanografíada, encuadernada y } \\
\text { diagramada por E. A. Vigo. }\end{array}$ \\
\hline Mondrian & Michel Seuphor & 1957 (aprox) & $\begin{array}{l}\text { Traducción de Elena Comas. } \\
\text { Mecanografíada, encuadernada y } \\
\text { diagramada por E. A. Vigo. } \\
\text { Formato rectangular, hojas sueltas, } \\
\text { tapas negras, contiene reproducciones } \\
\text { a color y catálogo de exposición. }\end{array}$ \\
\hline La vida de las formas & Henri Focillon & 1957(aprox) & $\begin{array}{l}\text { Traducción de Elena Comas. Capitulos } \\
1 \text { a } 4 . \\
\text { Mecanografíada, } \\
\text { encuadernación tapa dura, } \\
\text { diagramación de E. A. Vigo. }\end{array}$ \\
\hline El Surrealismo & Yves Duplessis & 1957(aprox) & $\begin{array}{l}\text { Traducción de Elena Comas. } \\
\text { Capitulos } 1 \text { y } 2 . \\
\text { Mecanografíada, encuadernada y } \\
\text { diagramada por E. A. Vigo. Formato } \\
\text { casi rectangular, hojas blancas. } \\
\text { Estampa de figura geométrica en rojo } \\
\text { y letra "R" en tinta negra. }\end{array}$ \\
\hline $\begin{array}{l}\text { Arte abstracto, sus } \\
\text { orígenes, sus primeros } \\
\text { maestros }\end{array}$ & Michel Seuphor & 1957(aprox) & $\begin{array}{l}\text { Traducción e ilustraciones de Elena } \\
\text { Comas. } \\
\text { Mecanografíada, encuadernada y } \\
\text { diagramada por E. A. Vigo. Formato } \\
\text { cuaderno tapa cartón negro con tres } \\
\text { ganchos y pequeña viñeta en papel } \\
\text { blanco con diseño geométrico en tinta } \\
\text { negra y sellos. }\end{array}$ \\
\hline
\end{tabular}




\begin{tabular}{|c|c|c|c|}
\hline $\begin{array}{l}\text { Picasso. } \quad \text { Estudios } \\
\text { biográficos y crítica. }\end{array}$ & Maurice Raynal & 1959 & $\begin{array}{l}\text { Traducción e ilustraciones de Elena } \\
\text { Comas. } \\
\text { Mecanografíada, encuadernada y } \\
\text { diagramada por E. A. Vigo. }\end{array}$ \\
\hline Bauhaus & Jean Cassou & 1961 & $\begin{array}{l}\text { Traducción de Elena Comas. } \\
\text { Mecanografíada, encuadernada y } \\
\text { diagramada por E. A. Vigo. Fragmento } \\
\text { del libro Panorama de las artes } \\
\text { plásticas contemporáneas }\end{array}$ \\
\hline $\begin{array}{l}\text { Marchand } \\
\text { sel-Vendedor de sal }\end{array}$ & Marcel Duchamp & 1966 & $\begin{array}{l}\text { Traducción de Elena Comas. } \\
\text { Mecanografíada, encuadernada y } \\
\text { diagramada por E. A. Vigo. } \\
\text { Consigna datos de la edición: Le } \\
\text { terrain vague, France, } 1959 \text {. }\end{array}$ \\
\hline $\begin{array}{l}\text { Espacialismo y poesía } \\
\text { concreta }\end{array}$ & Pierre Garnier & 1968 & $\begin{array}{l}\text { Traducción de Elena Comas. } \\
\text { Mecanografíada, encuadernada y } \\
\text { diagramada por E. A. Vigo. En tapa } \\
\text { "Garnier" en letras de molde rojas. } \\
\text { Indica número de referencia de las } \\
\text { ilustraciones. }\end{array}$ \\
\hline $\begin{array}{l}\text { La burbuja en la tira } \\
\text { dibujada }\end{array}$ & Robert Benayoun & 1968 & $\begin{array}{l}\text { Traducción Elena Comas. } \\
\text { Mecanografíada, encuadernada y } \\
\text { diagramada por E. A. Vigo. } \\
\text { Formato oficio tres ganchos metálicos. } \\
\text { Tapa ilustrada con burbuja de diálogo } \\
\text { de historieta, vacía, con texto por fuera } \\
\text { "VROOM...". }\end{array}$ \\
\hline $\begin{array}{l}\text { La tira dibujada. Historia } \\
\text { de las historias en } \\
\text { imágenes de la } \\
\text { pre-historia a nuestros } \\
\text { dias. }\end{array}$ & Gérard Blanchard & 1969 & $\begin{array}{l}\text { Traducción no indicada. } \\
\text { Mecanografíada, encuadernada y } \\
\text { diagramada por E. A. Vigo. }\end{array}$ \\
\hline $\begin{array}{l}\text { Banda Dibujada } \\
\text { Figuración Narrativa }\end{array}$ & Burne Hogarth & 1969 & $\begin{array}{l}\text { Traducción no indicada. } \\
\text { Mecanografíada, encuadernada y } \\
\text { diagramada por E. A. Vigo. }\end{array}$ \\
\hline $\begin{array}{l}\text { Las obras maestras de la } \\
\text { tira ilustrada }\end{array}$ & René Goscinny & 1970(aprox) & $\begin{array}{l}\text { Traducción no indicada. } \\
\text { Mecanografíada, encuadernada y } \\
\text { diagramada por E. A. Vigo. }\end{array}$ \\
\hline
\end{tabular}

Cuadro 4: Re-escrituras, libros. Elaboración propia. 


\section{Serie Escritos Personales: Re-escritura Selección de Artículos}

Los datos que siguen corresponden a re-escrituras donde se compilan artículos periodísticos, de opinión, crítica y ensayos sobre arte. Los volúmenes seleccionados no corresponden con la totalidad de los ejemplares del Centro de Arte Experimental Vigo, solo figuran en este cuadro los que utilizamos para esta tesis, consignados con las letras A, B, C, D y E cada compendio. Todos los textos han sido traducidos por Elena Comas. Como se verá, la procedencia de los mismos muchas veces no figura en la re-escritura, lo mismo sucede con el año en que se publica, entre corchetes hemos recuperado en la medida de lo posible, las fechas y publicaciones.

Las compilaciones de artículos encuadernadas no poseen título, es por esto que los hemos nombrado con letras en el orden que aparecerán en este trabajo.

Las re-escrituras que compilan artículos suman un total de veintiocho ejemplares. Debemos decir también que encontramos 15 artículos sueltos sin encuadernar sobre distintas temáticas (fluxus, cine, comic, entre otras) que no serán analizados en la presente propuesta. ${ }^{69}$

\section{Selección A}

\begin{tabular}{|c|c|c|c|}
\hline Título & Autor & $\begin{array}{c}\text { Publicación de la } \\
\text { cual se extrae }\end{array}$ & Año \\
\hline Documentos Van Doesburg & Camile Bry & - & - \\
\hline La estética de Jonh Dewey & Samuel Ramos & - & - \\
\hline Max Bill & Max Bill & Arte Madi $n^{\circ} 7$ y 8 & 1954 \\
\hline $\begin{array}{l}\text { "El Hogar, la ciudad, la } \\
\text { calle" }\end{array}$ & Piet. Mondrian & $\begin{array}{l}\text { Art d'aujourd'hui } \\
n^{\circ} 5\end{array}$ & 1949 \\
\hline $\begin{array}{l}\text { Piet Mondrian y los } \\
\text { orígenes del } \\
\text { Neoplasticismo }\end{array}$ & Michel Seuphor & $\begin{array}{l}\text { Art d'aujourd'hui } \\
\mathrm{n}^{\circ} 5\end{array}$ & 1949 \\
\hline El Caballero Azul & Will Gronmann & L' oeil n ${ }^{\circ} 9$ & 1955 \\
\hline
\end{tabular}

\section{Selección B}

\begin{tabular}{|c|c|c|c|}
\hline Título & Autor & $\begin{array}{c}\text { Publicación de la } \\
\text { cual se extrae }\end{array}$ & Año \\
\hline El cosmos de arp & Herta Weschler & Cimaise & 1957 \\
\hline Arte abstracto & Maria Rosa Gonzales & La Nación & 1957 \\
\hline $\begin{array}{c}\text { Un doble mensaje de fe, } \\
\text { Piet Mondrian }\end{array}$ & Maria Rosa Gonzales & La Nación & \\
\hline
\end{tabular}

${ }^{69}$ Tomamos la decisión metodológica de incluir en esta tesis una selección de los ejemplares de re-escrituras que compilan artículos en tanto consideramos que son los más representativos para nuestra hipótesis y fundamentación. En la Serie Escritos Personales del CAEV se encuentran diferenciados los artículos suetos que no han sido encuadernados. 


\begin{tabular}{|c|c|c|c|}
\hline $\begin{array}{c}\text { La gran Visión de } \\
\text { Mondrian }\end{array}$ & Ernesto B. Rodriguez & La Nación & 1957 \\
\hline
\end{tabular}

\begin{tabular}{|c|c|c|c|}
\hline \multicolumn{4}{|l|}{ Selección C } \\
\hline Título & Autor & $\begin{array}{l}\text { Revista de la } \\
\text { cual se extrae }\end{array}$ & Año \\
\hline $\begin{array}{l}\text { Marinetti, Vejez de un moderno } \\
\text { Mito. }\end{array}$ & No indica & La Nación & 1959 \\
\hline $\begin{array}{l}\text { La exposición internacional de } \\
\text { Surrealismo de } 1938\end{array}$ & Georges Hugnet & Preuves Paris & 1958 \\
\hline $\begin{array}{l}\text { Concepto moderno sobre museo_ } \\
\text { Sobre San Pablo }\end{array}$ & Leila Marise & $\begin{array}{l}\text { Correo Paulistano } \\
\text { Diario S.P. }\end{array}$ & 1960 \\
\hline El internacional Dada & Michel Seuphor & $L^{\prime}$ oeil n' 24 & 1956 \\
\hline Artículo sobre Kosice & No indica & La Razón & 1960 \\
\hline Schöffer & No indica & Aujour'd hui $n^{\circ} 8$ & 1956 \\
\hline Surrealismo todavía? & Fernando Reyna & La Nación & 1960 \\
\hline $\begin{array}{l}\text { Las cuatro variantes cubistas de } \\
\text { Apollinaire }\end{array}$ & Apollinaire & No indica & No indica \\
\hline Salvador Dalí y el Dalismo & Horacio Estol & Clarín & 1960 \\
\hline El Estilo (tres manifiestos) & Van Doesburg & De Stijl & 1951 \\
\hline Gines Parra & No indica & No indica & No indica \\
\hline $\begin{array}{l}\text { Jorge de Oteiza Escultor } \\
\text { Español (huésped ilustre) }\end{array}$ & No indica & La Razón & 1960 \\
\hline $\begin{array}{l}\text { Las artes plásticas- } \\
\text { Sesquicentenario argentino } 1960\end{array}$ & Julio E. Pairo & La Nación & 1960 \\
\hline $\begin{array}{l}\text { Merz, Zen y consideraciones } \\
\text { sobre Merz }\end{array}$ & $\begin{array}{l}\text { Theodore } \\
\text { Koening }\end{array}$ & $\begin{array}{l}\text { Phantomas } n^{\circ} 6 \\
\text { Traducción Elena } \\
\text { Comas }\end{array}$ & 1956 \\
\hline Once pintores vistos por Arp. & Arp & No indica & 1949 \\
\hline $\begin{array}{l}\text { Dichos, Aforismos de Francis } \\
\text { Picabia. }\end{array}$ & Picabia & $\begin{array}{l}\text { Terrain Vague } \\
\text { Traducción Elena } \\
\text { Comas }\end{array}$ & 1960 \\
\hline Pettoruti Pintor Abstracto & Cordova Iturburu & La Nación & 1960 \\
\hline La Bienal de Venecia 1960. & Ottore Zocaro & La Nación & 1960 \\
\hline
\end{tabular}




\begin{tabular}{|l|l|l|c|}
\hline Sobre Jacques Villon & Nicolas Woff & La Nación & 1960 \\
\hline Paez Vilaro & No indica & La Razón & 1960 \\
\hline $\begin{array}{l}\text { Picasso y Braque } \\
\text { Los aulladores, los ritos } \\
\text { africanos y el surrealismo. }\end{array}$ & No indica & La Nación & 1960 \\
\hline
\end{tabular}

\begin{tabular}{|c|c|c|c|}
\hline \multicolumn{4}{|l|}{ Selección D } \\
\hline Título & Autor & $\begin{array}{c}\text { Revista de la cual } \\
\text { se extrae }\end{array}$ & Año \\
\hline $\begin{array}{l}\text { Panorama de la poesía Moderna. De lo concreto } \\
\text { a lo espacial. }\end{array}$ & $\begin{array}{l}\text { Pierre } \\
\text { Garnier }\end{array}$ & {$\left[\right.$ Les Lettres $\left.n^{\circ} 32\right]$} & {$[1964]$} \\
\hline Poesía Concreta, espacialismo. II parte & $\begin{array}{l}\text { Julio } \\
\text { Campal. }\end{array}$ & Problemática $n^{\circ} 66$. & 1966 \\
\hline Poesía Experimental, crónica a seguir. & $\begin{array}{l}\text { Pierre } \\
\text { Garnier }\end{array}$ & Poesíe Vivante $n^{\circ} 22$ & {$[1967]$} \\
\hline $\begin{array}{l}\text { Campo analógico y Estructura narrativa de un } \\
\text { poema francés. }\end{array}$ & $\begin{array}{l}\text { Francis } \\
\text { Edeline }\end{array}$ & $\begin{array}{l}\text { Correo del } \\
\text { Internacional } \\
\text { estudios Poéticos } \\
59\end{array}$ & No indica \\
\hline Las mutaciones Poéticas & $\begin{array}{l}\text { Henri } \\
\text { Chopin }\end{array}$ & Les Lettres $n^{\circ} 30$ & 1963 \\
\hline $\begin{array}{l}\text { Breve exposición sobre una exposición de } \\
\text { Expoemas Popcretos Acogidos y recogidos en los } \\
\text { Aleatorios del Ready Made. }\end{array}$ & & $\begin{array}{l}\text { Catalogo Popcretos, } \\
\text { San Pablo, Galería } \\
\text { Atrium. }\end{array}$ & 1964 \\
\hline Aspectos de una obra editada o Expuesta & $\begin{array}{l}\text { Julien } \\
\text { Blaine }\end{array}$ & Robho $n^{\circ} 1$ & 1967 \\
\hline Manifiesto Acción & Met ART & No indica & No indica \\
\hline Para una lengua Olorística & $\begin{array}{l}\text { Herman } \\
\text { Damen }\end{array}$ & No indica & No indica \\
\hline El cristo tachado & Emilio Isgró & Ed. Apollinaire & 1968 \\
\hline $\begin{array}{l}\text { Declaraciones para el congreso "Multiples 67" } \\
\text { de Luigi Ferro }\end{array}$ & Brescia & Luigi Ferro & 1968 \\
\hline Segundo Manifiesto para una poesía visual & $\begin{array}{l}\text { Pierre } \\
\text { Garnier }\end{array}$ & {$\left[\right.$ Les Lettres $\left.n^{\circ} 30\right]$} & {$[1963]$} \\
\hline $\begin{array}{l}\text { Poesía Experimental, crónica a seguir. A } \\
\text { propósito de las Vocales. }\end{array}$ & $\begin{array}{l}\text { Pierre } \\
\text { Garnier }\end{array}$ & No indica & 1962 \\
\hline Por una poesía Supranacional: El espacialismo & $\begin{array}{l}\text { Pierre } \\
\text { Garnier }\end{array}$ & No indica & No indica \\
\hline
\end{tabular}




\begin{tabular}{|c|c|c|c|}
\hline Las Letras & $\begin{array}{l}\text { Vincenzo } \\
\text { Accame }\end{array}$ & Las Artes & 1968 \\
\hline Observaciones sobre la poesía Verbo Fónica & No indica & No indica & No indica \\
\hline Artículo de Jochen Gerz & Jochen Gerz & Robho & 1968 \\
\hline Un intermediario de la Visión Escrito-hablada & $\begin{array}{l}\text { Daniela } \\
\text { Palazzoli }\end{array}$ & $\begin{array}{l}\text { Del catálogo Marcel } \\
\text { Alocco }\end{array}$ & 1968 \\
\hline Poesía más allá del Alfabetismo & $\begin{array}{l}\text { Henri } \\
\text { Chopin }\end{array}$ & No indica & 1967 \\
\hline Carta Abierta a los músicos Áfonos & $\begin{array}{l}\text { Henri } \\
\text { Chopin }\end{array}$ & OU n ${ }^{\circ} 33$ & 1967 \\
\hline La revolución tipográfica (después de Mallarmé) & $\begin{array}{l}\text { Jacques } \\
\text { Damase }\end{array}$ & (Libro) & - \\
\hline Verbofonia y Poema Ficción de Arthur Petronio & $\begin{array}{l}\text { Francis } \\
\text { Loyre }\end{array}$ & Mensaje $n^{\circ} 10$ & 1968 \\
\hline Declaraciones de Luigi Ferro & Luigi Ferro & Iconogrammi & 1968 \\
\hline Poesía y Técnica & $\begin{array}{l}\text { Pablo el } \\
\text { Bajo }\end{array}$ & Poesía Vivante $n^{\circ} 27$ & - \\
\hline La poesía de los años 70' & $\begin{array}{l}\text { Miccini } \quad y \\
\text { Sarenco }\end{array}$ & Bo $n^{\circ} 1$ & 1969 \\
\hline Aexplanacion & Ana Etc. & Edición Anna Etcétera & - \\
\hline Estilo Experimental & Max Bense & Il Compasso $n^{\circ} 1$ & 1966 \\
\hline Poesía Concreta & Max Bense & Il Compasso $n^{\circ} 1$ & 1966 \\
\hline Poesía Concreta como Búsqueda Estructural & $\begin{array}{l}\text { Arrigo } \\
\text { Lora- } \\
\text { Totino }\end{array}$ & Il Compasso $n^{\circ} 1$ & 1966 \\
\hline Nota sobre la Poesía Plástica & $\begin{array}{l}\text { Kitasono } \\
\text { Katue }\end{array}$ & Il Compasso $n^{\circ} 1$ & 1966 \\
\hline Cuerpos de Poesía. Poesía Visual. Texto poema. & $\begin{array}{l}\text { Carlo } \\
\text { Belloli }\end{array}$ & Il Compasso $n^{\circ} 1$ & 1966 \\
\hline $\begin{array}{l}\text { Palabras en Libertad. Poesía de tecnicismo. } \\
\text { Manifiesto Futurista. }\end{array}$ & Marinetti & Il Compasso $n^{\circ} 1$ & 1966 \\
\hline $\begin{array}{l}\text { Las imágenes de la Puerta y del espejeo en la } \\
\text { retórica surrealista }\end{array}$ & $\begin{array}{l}\text { Marc } \\
\text { Angenot }\end{array}$ & No indica & - \\
\hline $\begin{array}{l}\text { Introducción al catálogo "La poesía degli anni } \\
70^{\prime \prime \prime}\end{array}$ & Sarenco & Catálogo & 1970 \\
\hline Catálogo Fragmento & $\begin{array}{l}\text { Franco } \\
\text { Vaccari }\end{array}$ & Catálogo & 1970 \\
\hline
\end{tabular}




\begin{tabular}{|l|l|l|c|}
\hline Catálogo Fragmento & $\begin{array}{l}\text { Michelle } \\
\text { Perfetti }\end{array}$ & Catálogo & 1970 \\
\hline Catálogo Fragmento & Sarenco & Catálogo & 1970 \\
\hline Catálogo Fragmento & $\begin{array}{l}\text { Achille } \\
\text { Bonito } \\
\text { Oliva }\end{array}$ & Catálogo & 1970 \\
\hline Catálogo Fragmento & Emilio Isgró & Catálogo & 1966 \\
\hline $\begin{array}{l}\text { Catálogo Fragmento "Letras en el espacio en } \\
\text { Checoslovaquia" }\end{array}$ & $\begin{array}{l}\text { Arsen } \\
\text { Pohribny }\end{array}$ & Catálogo & 1970 \\
\hline
\end{tabular}

\begin{tabular}{|c|c|c|c|}
\hline \multicolumn{4}{|l|}{ Selección E } \\
\hline Título & Autor & $\begin{array}{l}\text { Revista de la } \\
\text { cual se extrae }\end{array}$ & Año \\
\hline Barbarella: la historieta en carne y plástico & No indica & Panorama $n^{\circ} 66$ & 1968 \\
\hline Las nuevas historietas & No indica & El Día & 1971 \\
\hline Historietas, el quinto poder & No indica & Siete Dias $N^{\circ} 204$ & 1971 \\
\hline $\begin{array}{l}\text { Octobriana: historieta clandestina en URSS entre } \\
\text { Lenin y Barbarella }\end{array}$ & No indica & Siete Dias $N^{\circ} 243$ & 1972 \\
\hline Mafalda & No indica & $S / d$ & - \\
\hline El dilema de las historietas & No indica & El Dia & 1972 \\
\hline Al Capp protesta contra la protesta & No indica & Mercado Baires & 1970 \\
\hline El fabuloso mundo del comic & $\begin{array}{l}\text { Felix } \\
\text { Guzman }\end{array}$ & $\begin{array}{l}\text { Imagen } \\
\text { Caracas }\end{array}$ & - \\
\hline Tarzan un mito de nuestro tiempo & No indica & El dia & 1970 \\
\hline Humor made in argentina & No indica & El Dia & 1972 \\
\hline Los superhéroes de Superman a Patoruzú & No indica & El Dia & - \\
\hline 40 años de Blondie y Dawood & No indica & La Razón & 1970 \\
\hline Yo encogí la libertad & No indica & El Día & 1972 \\
\hline Para leer al Pato Donald & $\begin{array}{l}\text { comentario } \\
\text { s/a }\end{array}$ & El Día & 1972 \\
\hline Caricaturas humor dibujado & $\begin{array}{l}\text { Rafael } \\
\text { Squirru }\end{array}$ & $S / d$ & - \\
\hline Para volverse loco de amor y de Alegría y Nostalgia & No indica & Siete Días $s / n$ & 1975 \\
\hline
\end{tabular}




\begin{tabular}{|l|l|l|c|}
\hline $\begin{array}{l}\text { Los Peanuts "aparecieron en un diario ruso } \\
\text { problemas con el Copyright de una historieta yanqui" }\end{array}$ & No indica & La Opinión & 1973 \\
\hline La Explosión de humor en historieta Argentina & No indica & La Opinión & 1973 \\
\hline El boom de los héroes de tinta china & No indica & Siete Dias $N^{\circ} 393$ & 1974 \\
\hline
\end{tabular}

Cuadro 5: Re-escritura Selección de Artículos (sólo se transcriben los que serán utilizados para esta tesis) Elaboración propia. 


\section{Serie Escritos Personales: Charlas, ensayos y textos íntegramente escritos por E. A. Vigo}

Los textos que siguen pertenecen a la producción de escrituras de E. A. Vigo, están datados entre 1954 y 1972 (los que hemos encontrado hasta el momento) corresponden a ensayos, poemas y charlas.

En torno a las charlas: $\mathrm{Si}$ analizamos los registros Biopsia pormenorizadamente vemos que Vigo menciona otras charlas y presentaciones, por ejemplo en 1975 "Charla: la fotografía en el arte conceptual" o 1977: "Charla sobre xilografía" y "Charla sobre Arte Correo". Estos materiales todavía no han sido hallados. Solo presentamos en este cuadro aquellas charlas que se preservan como el ordenamiento material que Vigo le otorgó a la socialización de esas exposiciones (compuesto en su mayoría por textos sintéticos donde aparecen alusiones a diapositivas).

\begin{tabular}{|c|c|}
\hline Título & Descripción \\
\hline Ensayo del 1001 al 1007 y un 10101 (1954). & $\begin{array}{l}\text { Contiene poemas dispuestos en una columna angosta, } \\
\text { sobre la derecha de cada página, algunas hojas varían } \\
\text { de color. El ejemplar se encuentra mecanografíado y } \\
\text { posee tapa dura color celeste. }\end{array}$ \\
\hline Cuadernos 1954. & $\begin{array}{l}\text { Tres carpetas con imágenes en tapa probablemente de } \\
\text { Elena Comas. Todas fechadas en } 1954 \text {. Contienen } \\
\text { hojas sueltas, } 16 \times 22,5 \mathrm{~cm} \text {. mecanografiadas. Títulos } \\
\text { de cada una: 1) Salchichón alemán y un avioncito a } \\
\text { chorro. 2) Teoría y plástica para el plástico. 3) Un } \\
\text { concierto Zuzu. }\end{array}$ \\
\hline Poemas y escritos breves de E.A.V. (1954) & $\begin{array}{l}\text { Carpeta cartón celeste forrado en papel de seda. } \\
\text { Contiene hojas sueltas. Los textos se encuentran } \\
\text { ubicados sobre la mitad derecha de la página. Abajo } \\
\text { de cada uno se indica "ensayo". Al final de la carpeta } \\
\text { encontramos tarjetas con reproducciones de pinturas } \\
\text { de Paul Klee y otros. }\end{array}$ \\
\hline $\begin{array}{l}\text { Charla n }{ }^{\circ} 2 \text { dada el } 11 \text { de junio de } 1955 \text { en la protectora } \\
\text { ciudad de la plata sobre cine }\end{array}$ & $\begin{array}{l}\text { Carpeta cartón celeste-gris pintado con témpera } \\
\text { (imagen abstracta probablemente de Elena Comas). } \\
\text { Contiene } 23 \text { hojas sueltas mecanografiadas. } \\
\text { "Diré// a uds. que tiene delante// de sí// UN } \\
\text { PLÁSTICO// que vé en el //cine a más de la tan } \\
\text { //cacareada //PARTE SOCIAL, //que es un relleno } \\
\text { //VAGINARIO DE ADOLESCENTES; //aquello// } \\
\text { que en un escape// de locuras y furiosidades// se } \\
\text { coloca //en el rótulo temido y buscado// DE LA } \\
\text { VANGUARDIA." } \\
\text { Sobre cine vanguardista, distingue figurativo de } \\
\text { abstracto. Programa de la sesión: films de } \\
\text { Massingham, Bradley, Richter, Kirsanoff, Yvens, } \\
\text { Glober, entre 1921 y 1950. }\end{array}$ \\
\hline $\begin{array}{l}\text { Charla leída en la Escuela de Periodismo de la } \\
\text { Universidad Nacional de La Plata el } 17 \text { de noviembre } \\
\text { de } 1962 .\end{array}$ & $\begin{array}{l}\text { Caja cartón celeste formato rectangular. Contiene } \\
\text { carpeta con tapa calada rectangular y decoración } \\
\text { geométrica, deja ver foto blanco y negro de escultura. } \\
\text { Contiene hojas sueltas mecanografiadas. }\end{array}$ \\
\hline
\end{tabular}




\begin{tabular}{|c|c|}
\hline $\begin{array}{l}\text { Conferencia sobre Artes Plásticas contemporáneas } \\
\text { "Ubicación de la plástica moderna". } 1 \text { de Julio } 1966 .\end{array}$ & $\begin{array}{l}\text { Esta charla, junto con diapositivas tuvo lugar en } \\
\text { I.P.E.N.S.A. La Plata, según consta en Biopsia } 1966 . \\
\text { Es una carpeta tamaño oficio tapas de cartón color } \\
\text { salmón. Con detalle de diapositivas proyectadas y } \\
\text { datos completos de las obras. }\end{array}$ \\
\hline $\begin{array}{l}\text { Charla Panorama de la Poesía Experimental. Círculo } \\
\text { de Periodistas La Plata (1968). }\end{array}$ & $\begin{array}{l}\text { Cartones de } 21 \times 11,5 \mathrm{~cm} \text { cm mecanografíados, en la } \\
\text { tapa xilografía en rojo. Desarrollo sobre la poesía } \\
\text { experimental con aclaraciones hacia el número de } \\
\text { diapositivas que se mostrarían. }\end{array}$ \\
\hline Charla Resistencia Chaco (13 de noviembre de 1969) & $\begin{array}{l}\text { Cartones mecanografiados de } 16 \times 10 \mathrm{~cm} \text {. en caja } \\
\text { contenedora. Se exponen las principales vertientes de } \\
\text { la poesía experimental. El marco de esta charla es la } \\
\text { Jornada JOPOE que gestiona junto a Elena Pelli en el } \\
\text { Departamento de Letras de la UNNE. (Datos } \\
\text { extraídos de Biopsia 1969) }\end{array}$ \\
\hline Charla Continuidad de lo Discontinuo (1970) & $\begin{array}{l}\text { Tarjetón de } 20 \text { x } 5 \mathrm{~cm} \text {, con burbuja calada donde } \\
\text { indica el título de la charla. } 45 \text { hojas mecanografiadas } \\
\text { fotocopiadas del original bajo el mismo título con } \\
\text { imágenes. En Biopsia } 1970 \text { dice: "Continuidad de lo } \\
\text { discontinuo, charla- clase en el Colegio Nacional } \\
\text { sobre la "Poesía Visual y Fónica", sus antecedentes } \\
\text { históricos. Tuvo lugar en el Salón de Actos, una sala } \\
\text { totalmente a oscuras, iba recibiendo a los alumnos que } \\
\text { a la vez se muñían del sobre-tarjeta, una vela de } \\
\text { Suknasky, Andy (canadiense) estaba encendida y era } \\
\text { el único elemento de iluminación, se procedió a pasar } \\
\text { la grabación de poemas fonéticos de Raoul } \\
\text { Hausmann(fragmentos) escritos entre el 918/919. A } \\
\text { mitad del mismo se procedió a iluminar el } \\
\text { "Tendedero" de la americana Dana Atchley, } \\
\text { posteriormente un juego de luces acompañó a la cinta } \\
\text { grabada por Housman y antes de proceder a la lectura } \\
\text { de la charla, una diapositiva como marco de } \\
\text { escenografía tomada en base a un trabajo de Vigo, } \\
\text { inundó el escenario del salón, una mesa ubicada al } \\
\text { revés de punta, tipo ratona pero amplia, fue la base } \\
\text { para proceder a la lectura, previamente Vigo se quitó } \\
\text { el saco". (Biopsia, 1970) }\end{array}$ \\
\hline Tarjeta invitación Continuidad de lo discontinuo & $\begin{array}{l}\text { Tarjeta con hendidura en forma de burbuja. } 15 \text { x } 4,5 \\
\mathrm{~cm} .\end{array}$ \\
\hline $\begin{array}{l}\text { Charla sobre Arte Argentino ( } 30 \text { de Junio 1972, en } \\
\text { Centro Cultural Platense). }\end{array}$ & $\begin{array}{l}\text { Cartones de } 21 \text { x 11, } 5 \text { mecanografíados con sobre } \\
\text { contenedor. Dice Vigo en Biopsia } 1972 \text { sobre la } \\
\text { misma: "partiendo de Pettoruti y Del Prete, pasando } \\
\text { por ARTURO, y sus sub-grupos, arte concreto } \\
\text { invención, madí mensor, perceptismo, hasta cruzar } \\
\text { por el Instituto Di Tella y referencia al CAyC" }\end{array}$ \\
\hline Ensayo sobre arte. Sin Fecha. & $\begin{array}{l}\text { Carpeta blanca con imagen de escultura en tapa. } 27 \\
\text { hojas mecanografiadas. Contiene imágenes, recortes y } \\
\text { realizadas por Vigo. } 25 \text { x } 35,5 \mathrm{~cm} \text {. No posee fecha, } \\
\text { probablemente, por las temáticas que aborda, sea de } \\
1970 \text {. }\end{array}$ \\
\hline
\end{tabular}




\begin{tabular}{|c|c|}
\hline Ensayos y escritos sueltos, sin carpeta. & $\begin{array}{l}\text { Arte y Correspondencia. Introducción. EAV (1975). } \\
\text { Arte Correo, una propuesta novísima. EAV. s/f } \\
\text { Novísima propuesta: el arte correo. EAV. s/f } \\
\text { Arte correo: una nueva etapa en el proceso } \\
\text { revolucionario. Declaración por E. A. Vigo. (enero } \\
\text { 1976). } \\
\text { Arte correo: una nueva propuesta de comunicación. } \\
\text { EAV. s/f } \\
\text { Un proceso de sacrificio. (EAV? s/f) } \\
\text { Panorama sintético de la Poesía Visual. EAV. (s/f. c/ } \\
\text { traducción al inglés) } \\
\text { Plataforma de base para los agitadores de día y de } \\
\text { noche (E. A. Vigo, 1970) } \\
\text { Concepto de Obra, Concepto de Acto (E. A.Vigo s/f) } \\
\text { A manera de introducción: hacia una prospectiva del } \\
\text { Pasado E. A. Vigo (señalamiento) } \\
\text { A manera de Introducción (E. A. Vigo s/f) } \\
\text { Introducción (E. A. Vigo s/f) }\end{array}$ \\
\hline
\end{tabular}

Cuadro 6: Charlas, ensayos y textos íntegramente escritos por E. A. Vigo (no publicados). Elaboración propia. 


\section{Serie Escritos Personales: Manuscritos de Elena Comas}

Los manuscritos que siguen pertenecen a Elena Comas, con traducciones del francés y el italiano de cartas y artículos. Si bien no se han encontrado los manuscritos originales, las traducciones de las re-escrituras fueron realizadas por ella como se detalla en cada una de las re-escrituras. En el cuadro que sigue, sistematizamos los manuscritos encontrados en el CAEV.

\begin{tabular}{|l|l|}
\hline Título & Descripción: \\
\hline Carta a Vigo de Sarenco (1968/1969 aprox) & $\begin{array}{l}\text { Hoja de cuaderno rayado }(16 \text { × } 21 \mathrm{~cm}) \text { escrita con } \\
\text { lapicera azul. }\end{array}$ \\
\hline Traducción Artículo Perfetti (1969) & $\begin{array}{l}\text { Cuatro hojas de cuaderno rayado }(16 \times 21 \mathrm{~cm}) \text { escritas } \\
\text { con lapicera azul. }\end{array}$ \\
\hline Perfetti “La ampliación del decir" (sin fecha) & $\begin{array}{l}\text { Hoja de cuaderno rayado }(16 \text { x } 21 \mathrm{~cm}) \text { escrita en } \\
\text { lapicera azul }\end{array}$ \\
\hline Max Bense Elementos de lo que pasa (sin fecha) & $\begin{array}{l}\text { Hoja de cuaderno liso }(16 \text { x } 21 \mathrm{~cm}) \text { escrita con } \\
\text { lapicera azul. Posee numeración en la parte superior.. }\end{array}$ \\
\hline Picabia Prefacio Ilusión (sin fecha) & 18 Hojas lisas (16 x 21) escritas con lapicera azul. \\
\hline Pintura Metafísica. (sin fecha) & $\begin{array}{l}\text { 6 hojas escritas en anverso y reverso con lapicera azul } \\
\text { sobre prueba de xilografía de E. A. Vigo. }\end{array}$ \\
\hline Poesía concreta (sin fecha) & $\begin{array}{l}\text { Hoja de cuaderno lisa }(16 \text { x } 21 \mathrm{~cm}) \text { escrita con } \\
\text { lapicera azul. }\end{array}$ \\
\hline
\end{tabular}

Cuadro 7: Manuscritos de Elena Comas. Elaboración propia. 


\section{Elena Comas}

Dedicamos este apartado a la figura de Elena Comas (10 de noviembre de 1934 - 12 de octubre de 2006) puesto que, en el contexto actual, centrado en reivindicaciones, reconocimiento y visibilización del trabajo de las mujeres artistas, resulta fundamental incorporar y reconocer su figura y producción. Como hemos indicado, Elena Comas es quien traduce una selección importante de libros completos y publicaciones que posteriormente Vigo transcribe y edita en los libros de re-escrituras que han sido conservados en el CAEV. Analizaremos en el presente apartado algunos de sus manuscritos referidos a obras, su tarea como traductora de artículos y libros como así también de la correspondencia de Vigo.

Es de destacar en este sentido que los papeles manuscritos encontrados no estaban identificados y ordenados en el archivo y tampoco habían sido descritos ni estudiados hasta la presente investigación. La figura de Elena Comas ha quedado en los estudios sobre Vigo marginada en tanto no se había sistematizado la documentación sobre su tarea como traductora, a excepción de la mención de Berenice Gustavino en su tesis doctoral (2014; p. 97, p. 390) quien señala también que probablemente Vigo en su estadía en Francia aprendió esa lengua y ayudó en las traducciones a Comas.

La investigación sobre las re-escrituras ha abierto posibilidades de indagación sobre esta artista platense, los manuscritos encontrados de Comas muestran una faceta que da cuenta de un proceso y una tarea conjunta, un espacio de encuentro en las palabras.

Elena Comas fue una artista plástica de la ciudad de La Plata, compañera de E. A. Vigo desde 1954. A partir de su conocimiento del francés e italiano, ofició de traductora de los ejemplares de re-escritura y de la correspondencia de E. A. Vigo. Hemos relevado a partir del material de re-escrituras que Comas traduce del francés los siguientes libros completos: Lo espiritual en el arte, de V. Kandinsky; La vida de las formas de Focillon, Arte abstracto, sus orígenes, sus primeros maestros de Michel Seuphor; realiza las primeras traducción al español del libro Marchand du sel de Marcel Duchamp en 1966 y de Lo espiritual en el arte de Kandinsky ${ }^{70}$. A partir de los trabajos plásticos de Comas de la década de 1950, podemos afirmar que ella es quien ilustra los primeros libros de re-escrituras que estudiamos.

Elena Comas y E. A. Vigo se conocen en la Escuela Superior de Bellas Artes a comienzos de la década de 1950 cuando ella era estudiante de dibujo en la Universidad Nacional de la Plata.

\footnotetext{
${ }^{70}$ Se anticipa dos años a la publicación que realiza Edgar Baley traducida del francés en 1956 y publicada por la editorial Galatea-Nueva Visión (Gustavino, 2015, p. 436).
} 
Exponen juntos en la Asociación Sarmiento en 1954. Las obras de esta muestra fueron dañadas por el público pero se conservan fotografías de la exposición (Gradowczyk, 2008).

En la entrevista realizada por Osvaldo Nessi a Edgardo Antonio Vigo (mimeo original) ${ }^{71}$, Vigo relata en torno a la obra de Comas, expuesta en la Asociación Sarmiento que:

Elena presentaba unas cosas muy interesantes: superficies de forma rectangular, apaisadas o verticales, fondos muy plenos de textura de óleo. Ella les había pasado por distintas incisiones de distintos colores, como si fuese enlazando los puntos de un dibujo a completar. Ese era el criterio (Nessi, 1994, mimeo original. p. 2. Archivo CAEV).

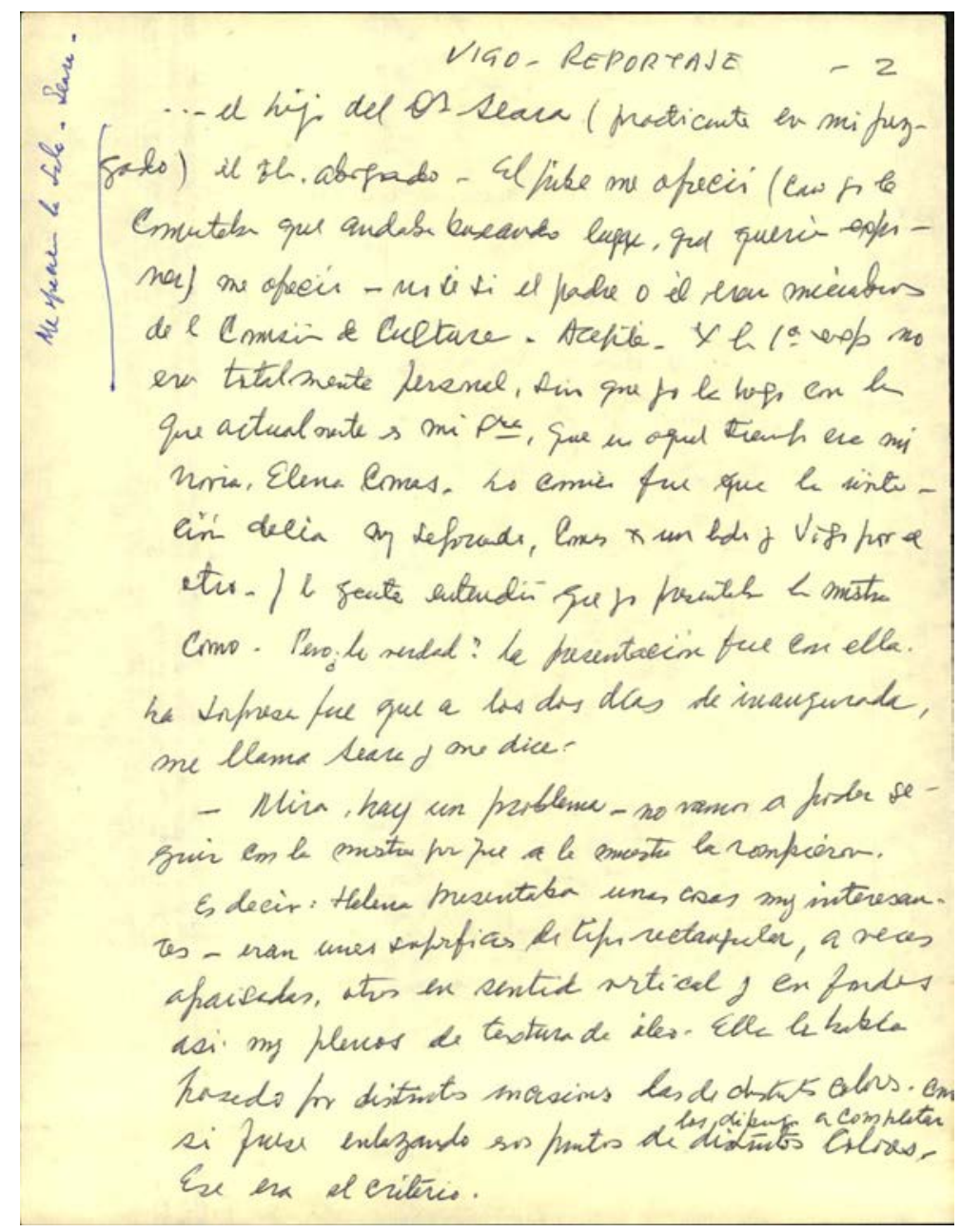

Fig. 9.Osvaldo Nessi, "Reportaje a Vigo". Página 2 de 17. Escrito a mano con anotaciones en color. CAEV.

\footnotetext{
${ }^{71}$ La entrevista se realizó con motivo de la exposición 1954-1994. Los textos que aquí analizamos corresponden a material de archivo inédito, previo a la publicación del catálogo. Ver: NESSI, Á. (1994). "Edgardo-Antonio Vigo. Cuarenta años de (in) obras de arte". En 1954 - 1994. Edgardo-Antonio Vigo. La Plata: Fundación Artes Visuales. Argentina.
} 
En el manuscrito original de Nessi, donde transcribe la entrevista grabada, Vigo cuenta además, otra anécdota sobre esta primer exposición:

Y la primera exposición no era totalmente personal [ilegible] que actualmente es mi señora, que en aquel entonces era mi novia, Elena Comas. Lo cómico fue que la invitación decía por separado Comas por un lado y Vigo por el otro. La gente entendía que yo presentaba la muestra. Cómo, pero ¿de verdad?, la presentación fue con ella. (Nessi, 1994, mimeo original. p. 2. Archivo CAEV).

Comas y Vigo se casan el 5 de mayo de 1956, tienen cinco hijos, uno de ellos, Abel Luis, desaparecido durante la última dictadura cívico-militar argentina.

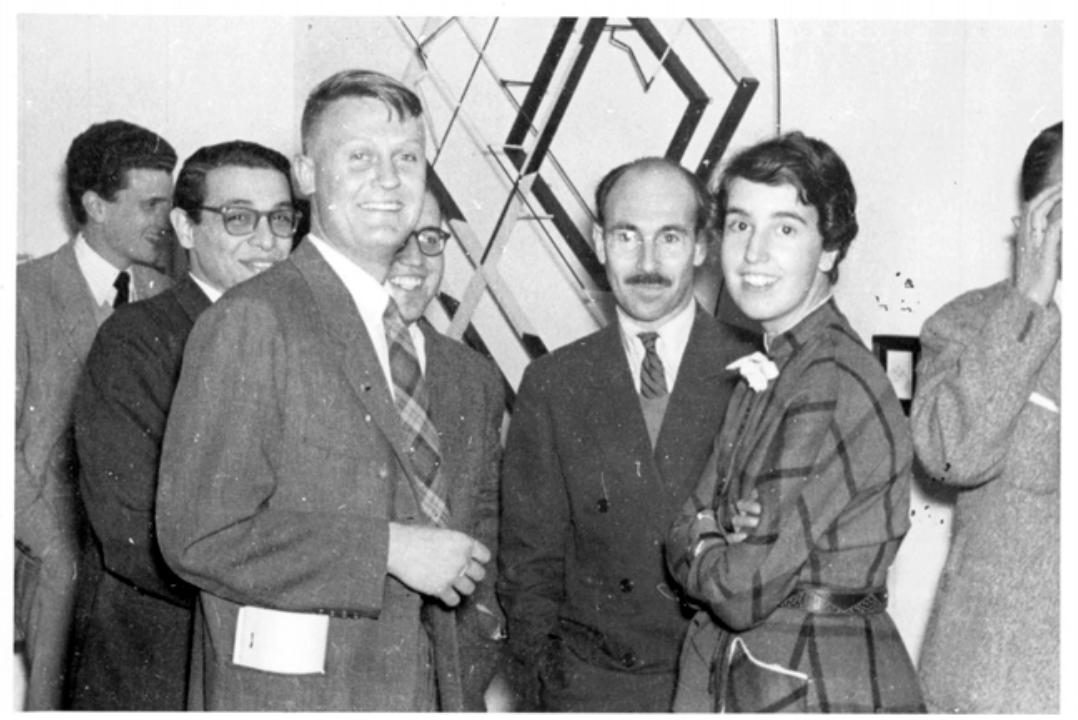

Fig. 10. Elena Comas y E. A. Vigo, Asociación Sarmiento, 1954. CAEV.

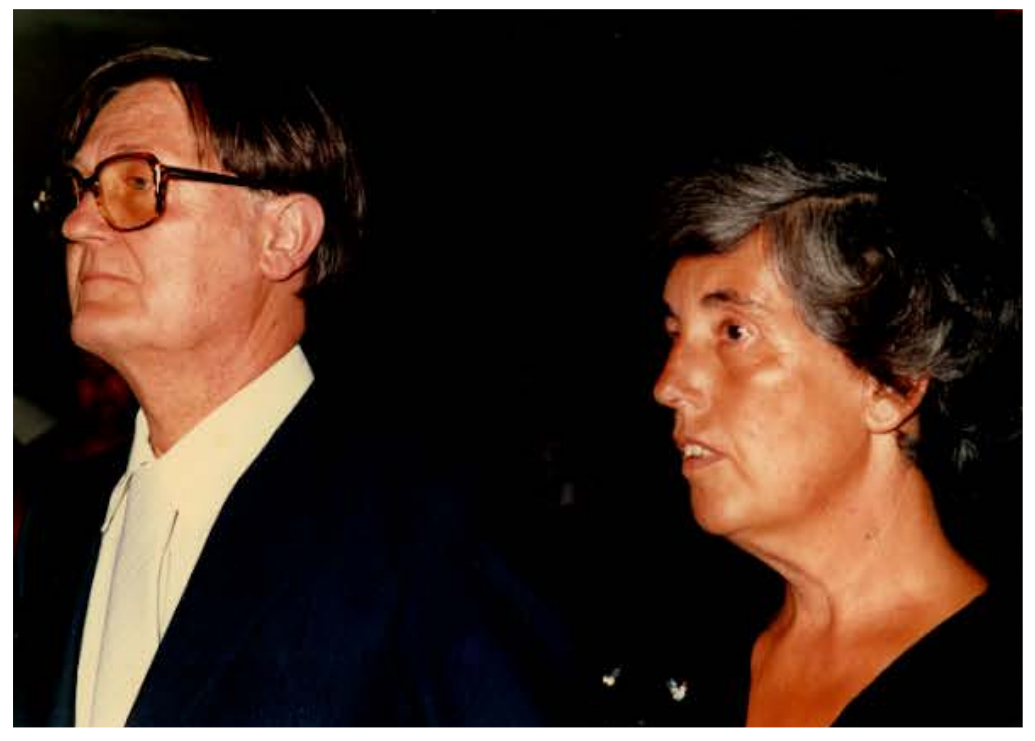

Fig. 11. Elena Comas y E. A. Vigo, 1988-1989, Biopsia, CAEV. 
Analizaremos a continuación la participación de Elena Comas en la producción de re-escrituras reseñando dos aspectos: en primer lugar, su acción como traductora tanto en re-escrituras como en correspondencias o artículos de E. A. Vigo y, en segundo término, las imágenes de que ilustran las primeras re-escrituras pertenecientes a su autoría.

\subsection{Traducciones}

Gustavino indica, en relación con la configuración del material crítico en las bibliotecas argentinas, que la traducción opera como "'mecanismo de compensación' que se activa a partir de la expresión de cierta insatisfacción y los libros traducidos se eligen según pueden completar lo que falta, acrecentar, diversificar lo existente e introducir innovaciones" (Gustavino, 2014, p. 388). En las re-escrituras figura Comas como autora de las traducciones, a partir de distintas firmas: ELENA ANA FRANCISCA COMAS, ELENA COMAS, ELENA COMAS DE VIGO, E. A. Comas. Vigo, como editor, la nombra en todas las traducciones del francés que publica reconociendo su trabajo en los textos que hace circular mediante sus publicaciones $W C, D R K W$, Diagonal Cero y Hexágono 71', así como en el catálogo para la Novísima Poesía. Luis Pazos también reconoce el trabajo de Elena Comas como traductora. Con motivo de la Expo Novísima Poesía, decía Pazos: "Elena Comas, la esposa de Vigo, es un personaje importante para esta muestra, porque ella traducía los textos en francés, yo era uno de los pocos que había leído a Rimbaud, eso circulaba poco.”(Comunicación Personal, 2018). En las palabras de Pazos queda de manifiesto la potencialidad de las re-escrituras desde la noción de apropiación. Los textos presentes en las re-escrituras circulaban entre el grupo Diagonal Cero, y le permitían, a Pazos "citar" a distintos autores, enriqueciendo su acervo de lecturas.

Elena Comas participa en la década de 1950 de las ediciones de WC (1958) junto a Guereña y Vigo. Esta revista, de corte experimental, posee cinco números en sobres contenedores que evocan la estética dadá tanto el título como la imagen que ilustra su portada, que se corresponde con un inodoro como cita explícita a la obra de Marcel Duchamp. En $W C \mathrm{n}^{\circ} 5$ (1958) hay una xilografía donde la tarea es conjunta: "Taco de madera / diseño: elena comas compos. y diagram. / e - a. vigo / 1950 y 8”. Hasta el momento, en todo el relevamiento realizado, es la única pieza plástica que circuló como obra conjunta. 


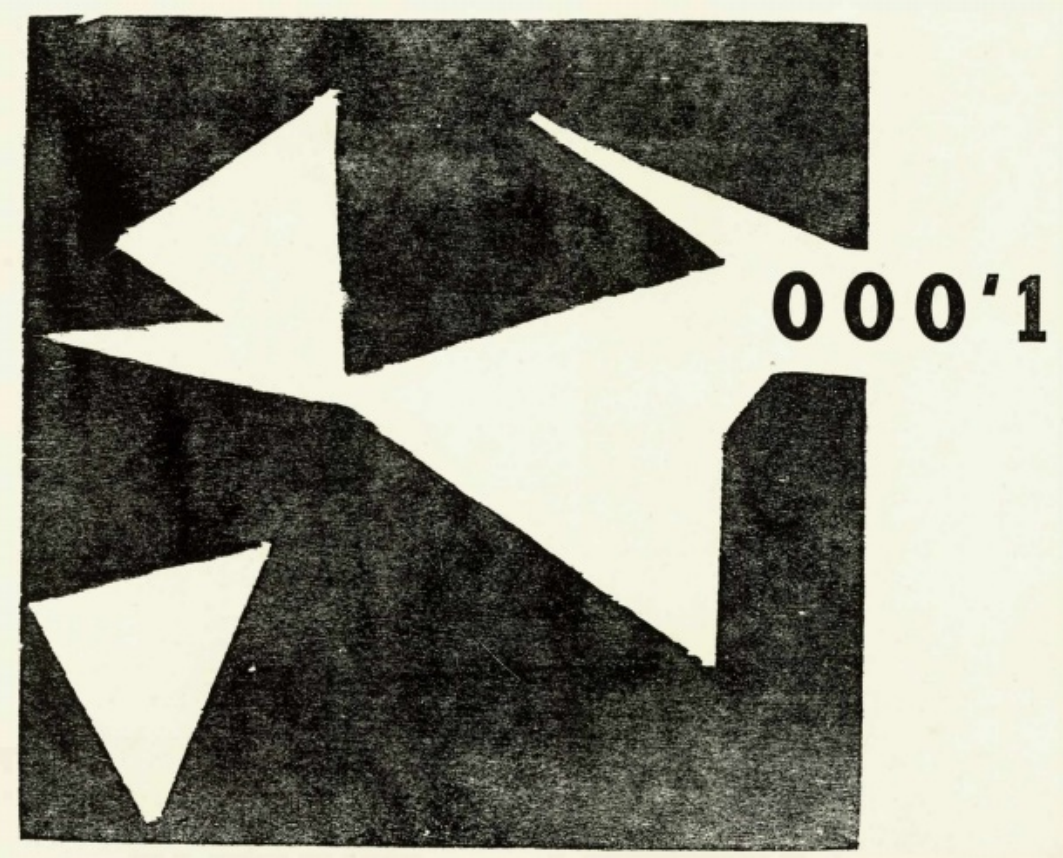

Fig. 12. $W C(1958) n^{\circ} 5 . \mathrm{CAEV}$

Los procedimientos técnicos de las imágenes que contiene $W C$ son el collage, la xilografía y el ensamblado de material. $W C$ posee también textos poéticos y teóricos en sus páginas. En el número 5, encontramos la primera traducción de Comas que conocemos publicada, se trata de "El Dado", texto de Kurt Schwitters y Jean Arp, extraído según se dice en $W C$, de la publicación Phantomas $\mathrm{N}^{\circ} 6$ (1956). No se ha encontrado el manuscrito original correspondiente a éste texto pero si la publicación original de la cual se extrae. 
Une des qualités sublimes de l'ouvre $M E R Z$ siège dans le rejet de l'emploi de la romme a quoi l'auteur opposait un NON délibéré, tait et sans cesse, surajoutait.

L'apport de la prose $M E R Z$ à la littérature insolite et de la poésie $M E R Z$, avec "Anna Mafleur ", ainsi que d'autres textes à I'éflo est bien connu. (La revue $M E R Z$, une des enzymes de léclosion dadaiste, a paru sur 24 numéros. En 1922, Schwitters NATE a 15 a con DADA W'WR Son poeme URSO dont le titre fut vraisemblablement inspiré, enon délice - les lettristes réinventèrent-ils cette pré-appellation? Schwitters rejoint le ZEN par le labeur et la foi immense qu'il plaça dans la confection de ses TABLEAUX SANS TITRE et d'œuvres abstraites sans borne. Procédant de l'illumination abrupte, il a sans doute ressentı pour le futur de son art, ce que l'homme de Lascaux pressentait de nos penchants pour la fresque. Il confine encore au ZEN lorsque, s assimilant à ses propres œuvres, il rejoint a présent, je m'appelle $M E R Z$ ".

Lecteurs, ouvrez donc un bottin; dix ans après la mort de notre héros, vous découvrirez om ters : un MONSIEUR MERZ pour le moins,

Théodore KOENIG.

$$
\text { LE DE }
$$

Deux gisaient à côté en dessous. Ici il y en avait 3 , là 3 , en dessous 2 .

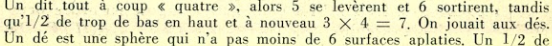
Un dée est une sphère qui n'a pas moins de 6 surfaces aplatites. Un $1 / 2$ de
trop ceest 2 trop peu. Et le vieux à côté dit tout à coup : «A qui trop?

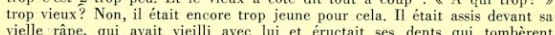
vielle râpe, qui avait vieilli avec lui et eructait ses dents qui tombèren

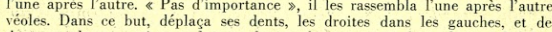
dans sa large main et les renfonca de nouveau dans leurs alvéoles.
Il y en avait 2 trop peu donc $1 / 2$ de trop. Et il éructa à nouveau ses al. devant vers le haut, de derrière vers le bas; alors il grimpa alternative age, lorsque brusquement à gauche dans la petite chambre avant de dessus une feuille tomba sur le dos. Cela claqua, comme lorsqu'on souffle un sac
une papier. Et qu'il claque ensuite. Et qüilil claque ensuite. Le sac claque. Et tandis que le vieillard boucle sa moitie gauche, on entend doucemen assa ses dents au crible et sépara les dents mâles des dents femelle. Comme c'était faux, 2 rentrèrent de nouveau et dirent qư un des 5 devali
ortir. Alors les 5 se rassirent et jouèrent à nouveau aux dés avec la

Alors le vieillard jeta une dent au milieu - et les 2 se calmèrent l'u autre et commencecrent à compter, D'abord eux-mêmes, puis eux et l'autre la dent et les 4 jambes des cinq à table.
Et ils cempterent jusquà 100 . Puis jusquà 101 . Puis jusquà 1000. Reculant toujours d'une unité, jusqua ac co quilis paryinssent au chiffre $2 / 3$. plus jeune et grandit et grandit jusqu'à ce qưilil fut petit comme les deu derrière. Ceux-ci ne pouvaient plus rien voir maintenant et c'est pourquo
ils escaladèrent ses excroissances arrière. ils escaladèrent ses excroissances arrière.
Et ils eurent beau demander la rápe en suppliant : le vieillard resta dur
et mit la râpe dans la caisse sous les quatre - lorsque les cinq furent sortis.
Le vieillard cria : «Halte 》 et signifia dans un discours, qui semblait emboité dans et avec la râpe, que nous devons parvenir à la clarté.
pendant ce temps le sac à papier était très progrom. Sans claquer le sac, pendant ce temps
6 continuèrent leur chemin au dessus de 5 jusquà 4 , jusqu'à ce qưun puisse le lui dire. Il dit deux fois prognom, 3 tois prognom jusqu
quili dise finalement popognom. Et ainsi il était au bon endroit. Le vieillard mit ses dents une après Tantem embôtée.
pleinements

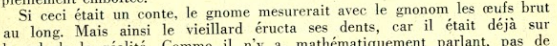
le sol de la réalité. Comme il n'y a, mathematiquement partar
chiffres pairs, il n'y a pas non plus de chiffres impairs. La masse proposa maintenant qu'on multipliât le vieillard par 6 avec le
chiffre-clé. De même qu'il était devenu jeune, il devint maintenant vieux lequel on pouvait maintenant facilement le mettre au carré. On en fit une racine, car la racine est une sphère avec quelques
Puis ce fut un grouillement de vieillards qui extrayaient des racines carrés

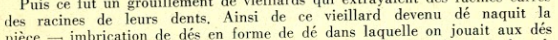

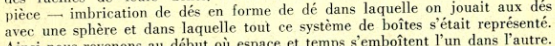
Ainsi

Lorsque 4 quatre heures sont éloignés de 4 ct prétendent atteindre 4 en même temps, alors il vaut mieux que chacun des 4 coure 3 heures et qu'il
porte les 2 antres. Cela ne dure naturellement que 3 heures. Quand il y en a 2 , et 2 heures quand il n'y en a qu'une. C'est très agréable quand ii Kurt SCHWITTERS et Jean ARP. Traduction de Paule Mérisse.

Fig 13. Revista Phantomas $\mathrm{n}^{\circ} 6$ (1956) CAEV.

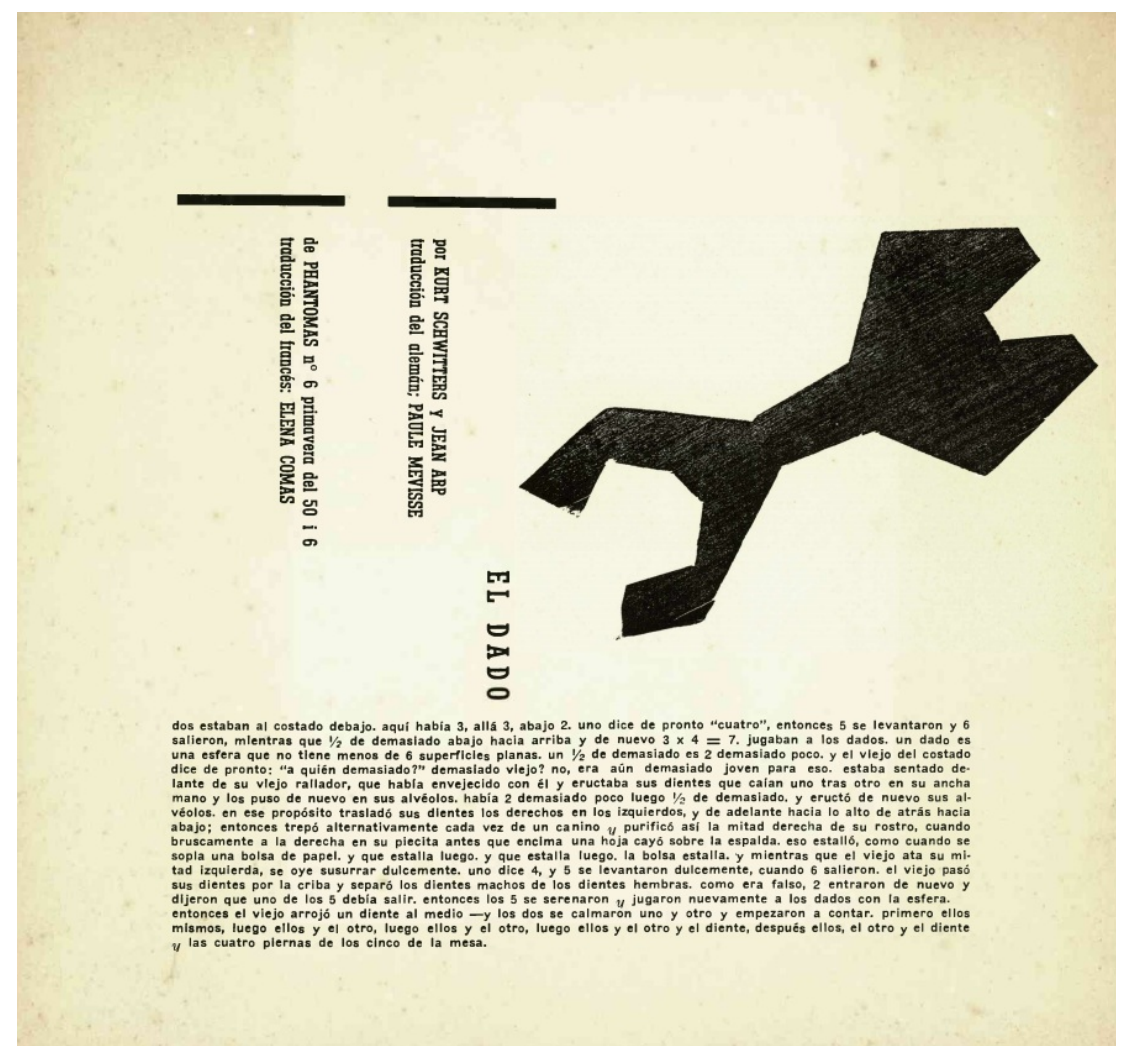

Fig. 14. $W C n^{\circ} 5$ (1958) CAEV 
En la revista Diagonal Cero, se publican seis de las traducciones de Comas. En el $\mathrm{N}^{\circ} 3$ de Diagonal Cero (1962) se difunde la traducción que realiza Comas del texto de Théodore Kooning sobre Kurt Schwitters en la sección "Testimonios". La traducción esta presente en la selección de textos y artículos que conforman uno de los tomos de re-escrituras que en el cuadro anterior identificamos como Selección C.

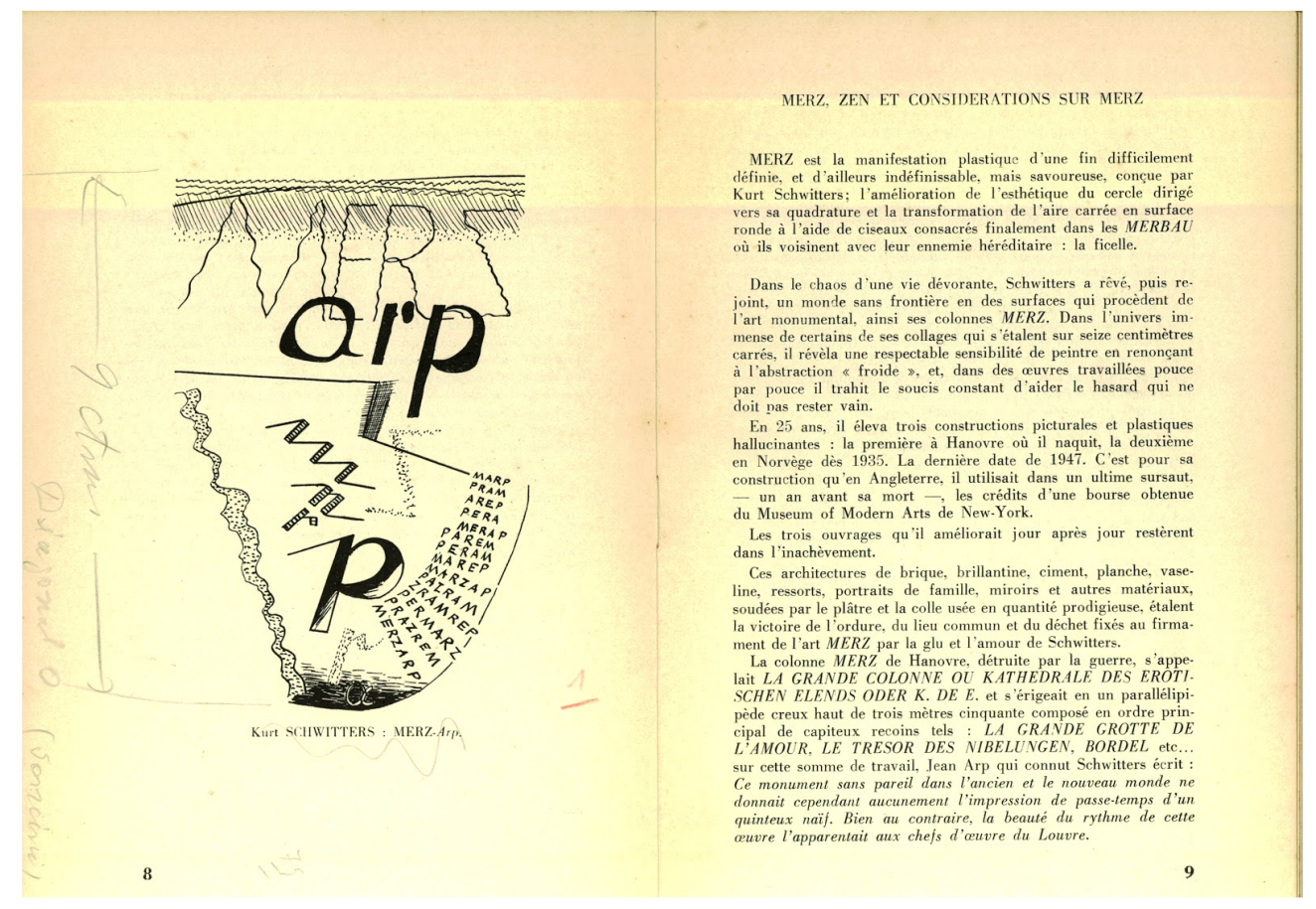

Fig 15. Revista Phantomas nº 6, (1956)CAEV.

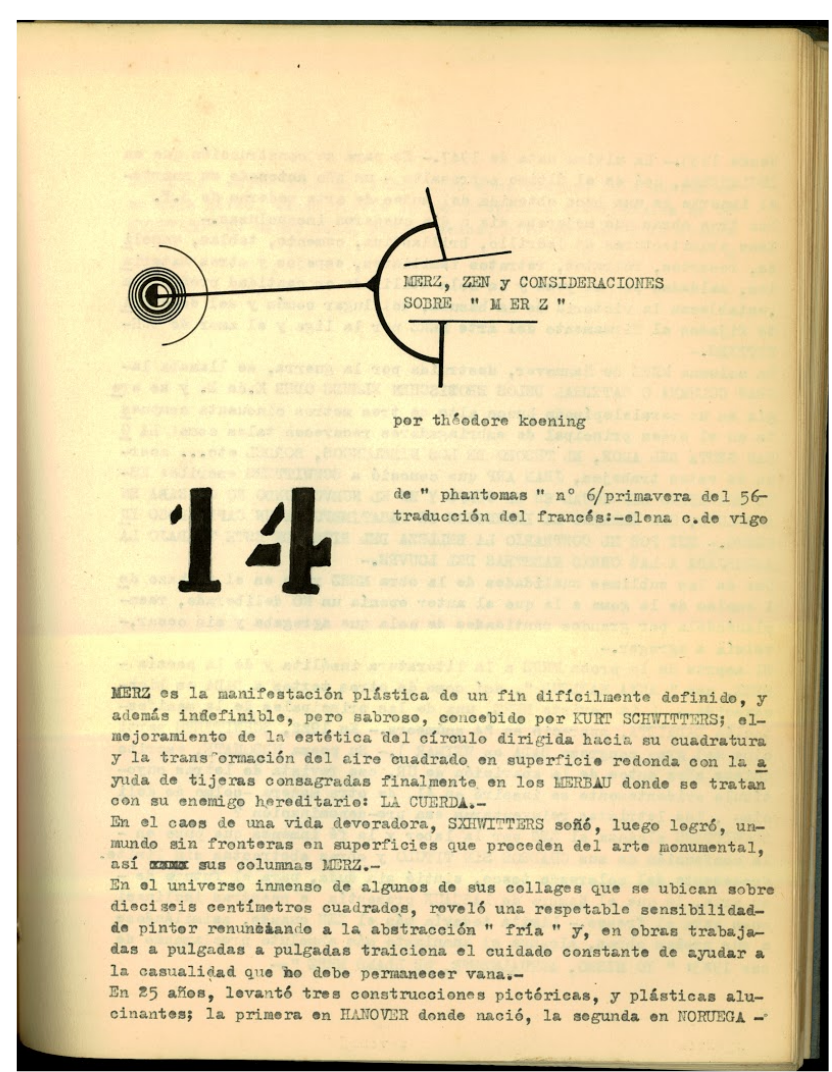

Fig. 16. Re-escritura Selección C. Artículo “Mertz, Zen consideraciones sobre Mertz” CAEV. 
En la re-escritura, el texto de Theodore Kooning, "Mertz, Zen consideraciones sobre Mertz" dialoga con otros artículos tales como "Marinetti, Vejez de un moderno Mito", "Salvador Dalí y el Dalismo", "Once pintores vistos por Arp", entre otros. Como analizaremos en el Capítulo 2, la sección "Testimonios" de Diagonal Cero se configura como una especie de "gabinete de fragmentos" donde aparecen voces de artistas a partir de pequeñas citas. Vemos también que, al momento de estabilizarse el texto, en la publicación Diagonal Cero, Vigo conserva la imagen de la publicación original de la revista Phantomas.

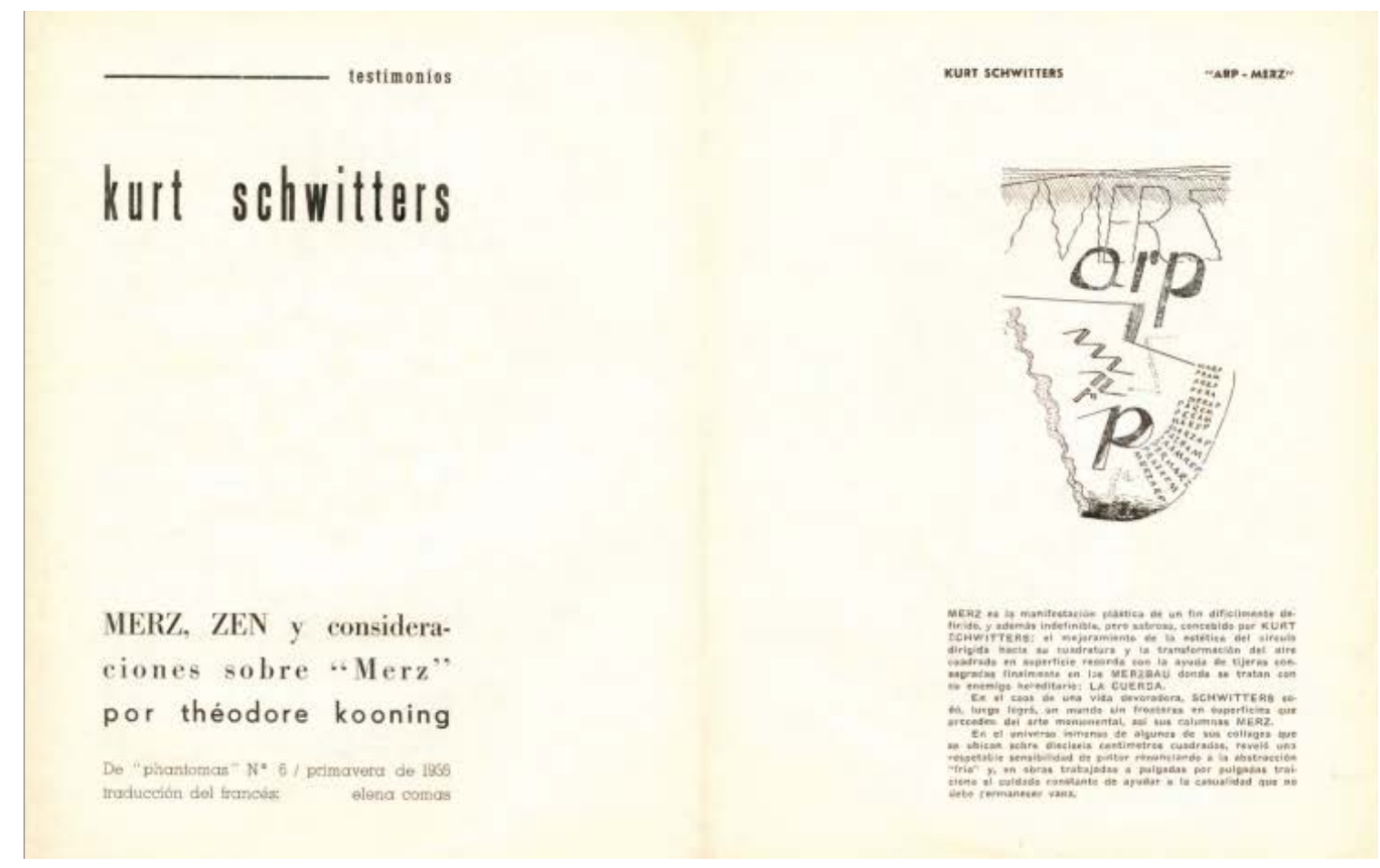

Fig. 17. Diagonal Cero No 3 (1962) "Kurt Schwitters". Trad. Elena Comas.

En el número 21 de Diagonal Cero (1967), Comas traduce una selección de textos del poeta francés Julien Blaine, titulados: "Para empezar con la semiótica”, en el mismo número se publica de J. F. Bory "Hacia un segundo comienzo", donde Comas también oficia de traductora. El "Manifiesto para una nueva poesía Visual y Fónica" de P. Garnier (Diagonal Cero n 23, 1968), así como "Poesía Sonora" de Henri Chopin (Diagonal Cero $\left.n^{\circ} 24,1968\right)$ también corresponden a la traducción de Elena Comas. Debemos decir al respecto que Comas es, hasta lo que sabemos, la primera en traducir al español los textos del poeta sonoro y editor de la revista $O U$, Henri Chopin, nos referimos a los textos de la compilación Selección D: Las mutaciones Poéticas, Carta Abierta a los músicos Áfonos y Poesía más allá del Alfabetismo. 


\subsection{Manuscritos}

Horacio González, en el catálogo de Manuscritos Literarios Argentinos (2014) expresa que:

Todo párrafo escrito, en su última profundidad añora formar parte de una totalidad ausente. Se trazan líneas vinculantes que son un trapecio que se mece de abajo hacia arriba. Son dardos lanzados un tiempo después de lo que parecía definitivo, luchando con la agonía de los escritos como si el escritor tuviese sobre su escritorio unos papeles a los que somete a cirugías, inclusiones y entrecruzamientos $(2014$, p. 7).

La lectura de González permite pensar en los manuscritos de Comas como partes de un sistema complejo, entramado en formas culturales de concebir la lectura y la escritura, en la acción del tiempo como huella en la materialidad de esa palabra. No se han encontrado (hasta el momento) en el archivo los manuscritos originales completos de las traducciones que posteriormente serán plasmadas en las re-escrituras, pero sí hemos podido revisar cuatro de los escritos conservados que pertenecen, en su mayoría, a fragmentos de las traducciones de Elena Comas (presentes en

\section{Cuadro 7).}

Es interesante notar, en torno a la materialidad, que el manuscrito de Comas da cuenta de un proceso en la producción del sentido signado por la huella -en la grafía, en los subrayados, en los espacios en blanco- mientras que, en la mayoría de las re-escrituras vemos una edición "cerrada", que, si bien conserva el gesto artesanal, presenta rasgos planificados en la edición, en la construcción estética que opera sobre la diagramación, la tipografía, la encuadernación.

A pesar de que, como ya señalamos, la re-escritura no tiene por objeto ser publicada tal y como está, en tanto pertenece al espacio de lo íntimo con una circulación más o menos restringida, los elementos de diseño que la componen se alejan del carácter espontáneo que posee el manuscrito. Las re-escrituras que analizamos en esta tesis son consideradas ediciones donde se estabiliza la escritura y la traducción.

Los manuscritos de Comas se presentan en soportes de escritura efímeros, descartables y precarios, hojas arrancadas de un cuaderno, pruebas de obra o trozos de papel que aparentemente ya no sirven más. Las re-escrituras, por el contrario, están encuadernadas y organizadas, en muchos casos por índices y número de página. Si bien, como señalamos anteriormente, Comas tradujo los textos que Vigo utilizó para las re-escrituras, a continuación describiremos solo algunos de los manuscritos de Elena, aquellos que se conservan hasta hoy -y que pudimos hallar- 
en el CAEV. En los casos que siguen las traducciones se realizan del francés e italiano al español.

En el primer caso, Comas traduce del francés al español, "Picabia, prefacio ilusión”, manuscrito del cual se conservan veinte hojas. Se trata de escritos de Francis Picabia emparentados con los aforismos publicados en "Dits" (Diagonal Cero $\mathrm{n}^{\circ} 2$ ), y un artículo crítico, del cual no se menciona el autor, que aborda la trayectoria de Picabia.

En el segundo manuscrito, del francés al español Comas traduce "La pintura metafísica por Marco Valsecchi", texto que presenta un recorrido histórico por la obra de Giorgio de Chirico (1888 -1978) y Carlo Carrà (1881 - 1966). En tercer lugar, traduce del italiano al español, el artículo titulado: "La nueva frontera - la poesía objeto de EAV por Michele Perfetti" del cual se conserva en el archivo Biopsia el artículo original. Por último, la carta dirigida a Vigo enviada por Sarenco y traducida por Elena del italiano al español hacia fines de la década del 60'.

En el manuscrito de la traducción de Comas titulado "Picabia, prefacio ilusión" leemos:

\section{PICABIA PREFACIO ILUSIÓN}

1_Las risas y los besos huelen a tabaco, el arte, la gloria, la belleza, las estrellas, los paseos: cállate, quiero narrar, enciende, si quieres un cigarrillo.

Es preciso atravesar la vida, roja o azul, desnudo con música de pecador sutil, totalmente listo para la fiesta, la vida no tiene más que una forma, el olvido.

No trabajen, no amen, no lean, piensen en mí: hallé la risa nueva que da el dejar pasar. Vive para tu gusto. No hay nada que comprender, nada, nada, nada. Más que los valores que darás de ti mismo a todo. Es preciso ser nómade, atravesar las ideas como se atraviesan los países y las ciudades, comer perruches [sic], [en blanco] y [tachado], colibríes, [ilegible, subrayado], [en blanco], chupar la sangre de las jirafas, alimentarse con los pies de las panteras!, es preciso acostarse con monettes [en blanco], bailar con una boa, hacer el amor con heliotropos y lavarse los pies con bermellón! No hay obstáculos, el único obstáculo es la finalidad, caminen sin finalidad, la tierra es un departamento esférico donde solo deberían estar los beduinos. Los que dieron al infinito la dimensión del metro se equivocaron: la dimensión del infinito es de dos metros cincuenta.

Además, hay que gozar simultáneamente.

2. Le escapo a la felicidad para que no se vaya.

La única manera de hacer que lo sigan es correr más rápido que los demás. (Comas, s/d) 
En el manuscrito hay espacios en blanco que no han sido traducidos (en la transcripción los hemos marcado entre corchetes), subrayados y tachones sobre determinadas palabras que no han podido ser trasladadas al español (identificados en nuestra transcripción como "ilegible").

El manuscrito da cuenta de ese proceso de búsqueda por la palabra justa que le otorgue sentido a la construcción sintagmática. Las hojas de este manuscrito se encuentran numeradas en la parte superior derecha.

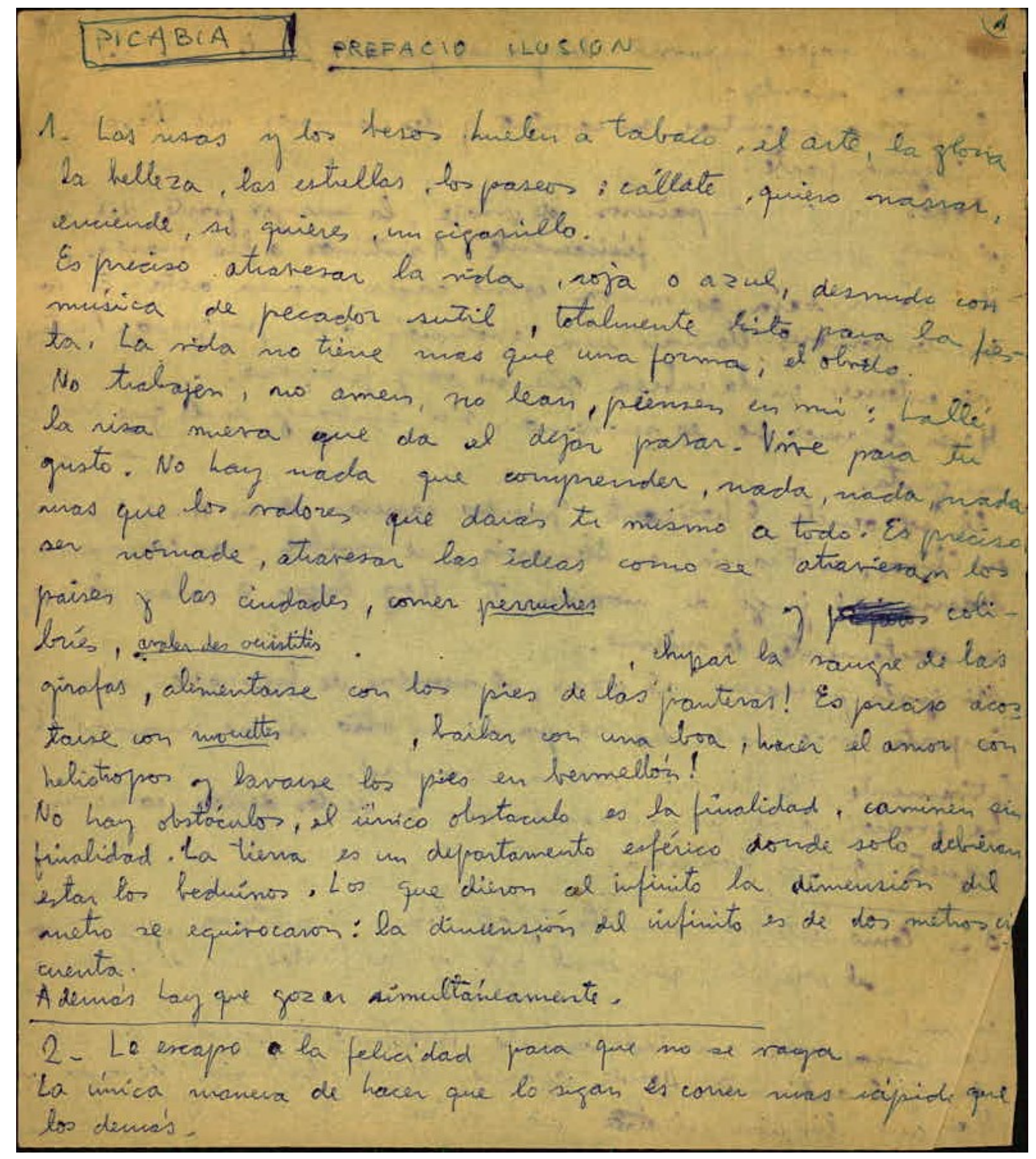

Fig 18. Picabia Manuscrito Elena Comas, traducción sin datos. CAEV. 
Como señalamos anteriormente, la mayoría de los soportes sobre los cuales Elena Comas traduce son papeles improvisados, que se usan porque en apariencia sobran, con utensilios de escritura que muchas veces funcionan mal o con poca tinta, una escritura las veces apurada e intervenida con tachones. De alguna manera, en esta elección de soportes también hay una mirada frente a la traducción, concebida como acontecimiento en proceso o como boceto.

El segundo manuscrito de Comas encontrado en el CAEV, se titula:"La pintura metafísica por Marco Valsecchi”, aborda un recorrido por las principales obras de Chirico y Carrà y un estudio sobre la corriente metafísica en pintura. Llama la atención aquí el soporte sobre el cual se encuentra la traducción, puesto que corresponde a la reproducción de xilografías con taco original de E. A. Vigo fechados en 1965. Se trata en este caso de un total de 12 hojas traducidas. Como se verá, Comas traduce sobre el espacio superior e inferior de la hoja pero no interviene la obra de Vigo en el centro.

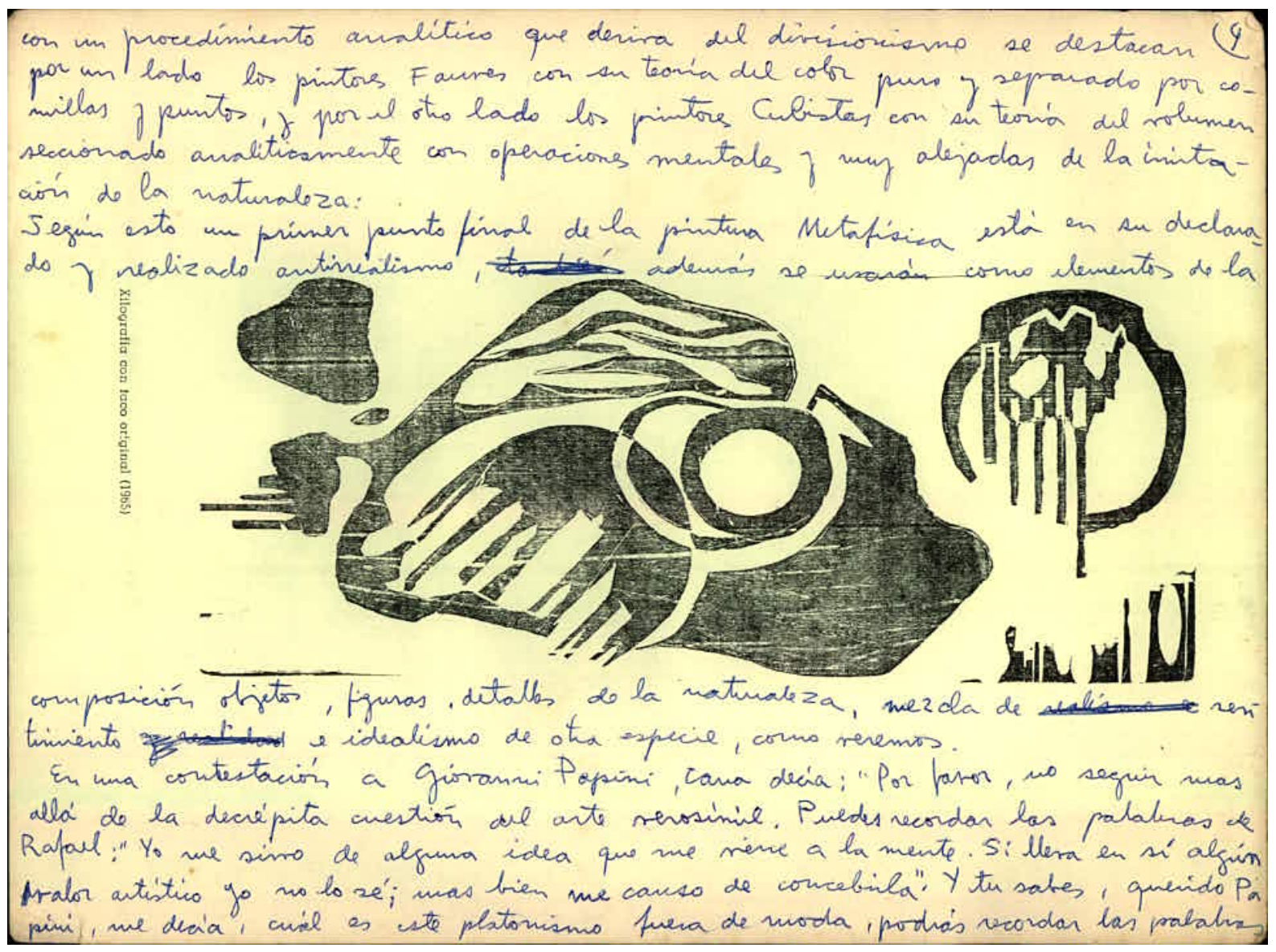

Fig. 19. Manuscrito de la traducción de Elena Comas de "La pintura metafísica por Marco Valsecchi”. CAEV.

En tercer lugar, destacamos el artículo sobre la poesía objetual de E. A. Vigo por Michel Prefetti traducido por Elena Comas del italiano. Este manuscrito, a diferencia de los anteriores, refiere a 
una crítica sobre la obra de E. A. Vigo. Se encuentra traducido sobre hojas rayadas extraídas de un cuaderno. Transcribimos un fragmento de la traducción de Comas donde Perfetti habla de los objetos de Vigo y su propuesta sobre la "inutilidad":

La "bi-tri cicleta ingenua" esta construida con objetos encontrados, usados y recompuestos para nueva, posibles significaciones. $\mathrm{Y}$ el referirnos a las diversas expresiones "pop-neo-dada- nuevo realismo" (en el campo de las artes plásticas) es evidente. Pero aquí, por sobre todo, caduca cada significación de género, el material, así como la mezcla de diversos materiales, se conjuga como poesía. Es en efecto notable, según la teoría de la información, como un objeto (o un signo) quitado de un contexto para un nuevo destino cambia y amplifica su significado. Este proceso de cambio de signo, y a veces de rumbo, en Vigo es bien evidente. El sin embargo afirma que su propósito es llevarlo a la INUTILIDAD (objeto desechado y usado) o aquello que se considera únicamente útil, un juego irónico realizado en una época en las cual (al menos en mi país) el asunto recién estaba en embrión. Una suerte de rebelión, además hacia la sociedad de consumo en la que todo se basa en la utilidad inmediata.

Este artículo ha aparecido en el diario Corriere del Giorno, Roma el 22 de enero de 1969, con el título "La poesía oggetto di Edgardo Antonio Vigo" y se encuentra archivado en Biopsia del año correspondiente. El crítico destaca de la obra de Vigo la utilización de un material pre-existente para la creación de sus objetos poéticos y analiza tanto la "Bi-tri-cicleta ingenua" como los "poemas (in) comestibles" de E. A. Vigo. Recordemos que en la Exposición Internacional de Novisima Poesía se mostraron dos afiches de Prefetti: “Gong” 1968 y “Algo Más" 1968; también participó en Diagonal Cero n 28 (con la obra “In piu”) y en Hexágono 71'. 


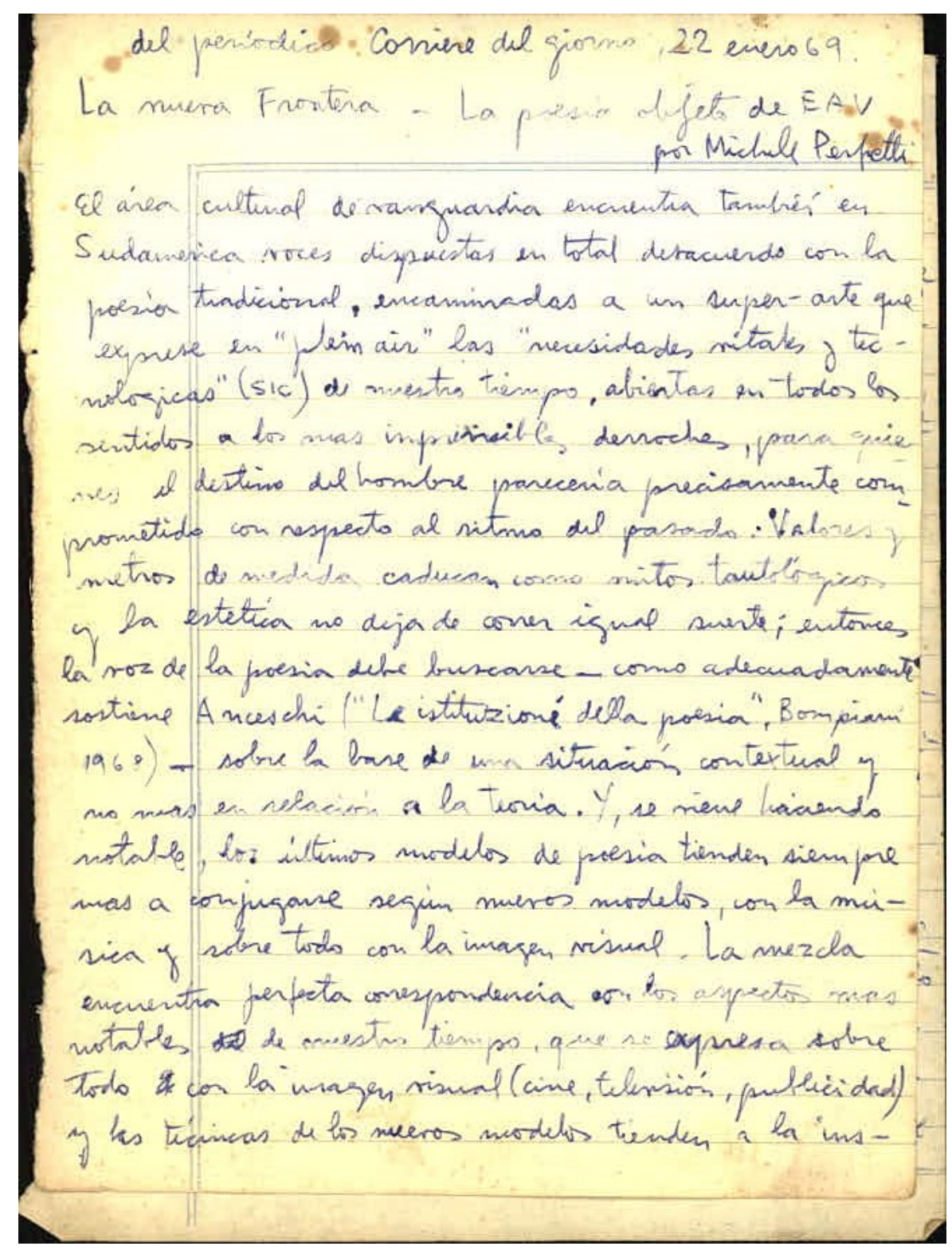

Fig. 20. Manuscrito de Elena Comas, traducción de "La poesía objeto de E.A.Vigo por Michele Perfetti” CAEV

Por último, mencionamos la traducción de la carta de $\operatorname{Sarenco}^{72}$ a E. A. Vigo fechada posiblemente hacia 1968-69. Transcribimos a continuación un fragmento de la misma:

Querido Vigo: perdoname por el atraso en la respuesta, tuve muchas cosas que hacer; Llegó Amodulo 1? Amodulo 2 saldra en algunos días, hay tres poemas mat.-cinemátograficos. Para la Expo 69 hice enviar en estos dias nuevo material lo publicado algo sobre la Expo 69 en el Amodulo 2 (y tambien sobre DC) Espero siempre tus noticias de amistad ciao Sarenco (s/f, Manuscrito Elena Comas. CAEV).

\footnotetext{
72 El poeta visual italiano Isaia Mabellini (1945- 2017), más conocido como Sarenco, participa como artista de la Expo Novísima con el libro Prossimamente y la obra tridimensional "Poemas inflables" (de dos metros de alto, en polietileno, con letras y palabras impresas).
} 


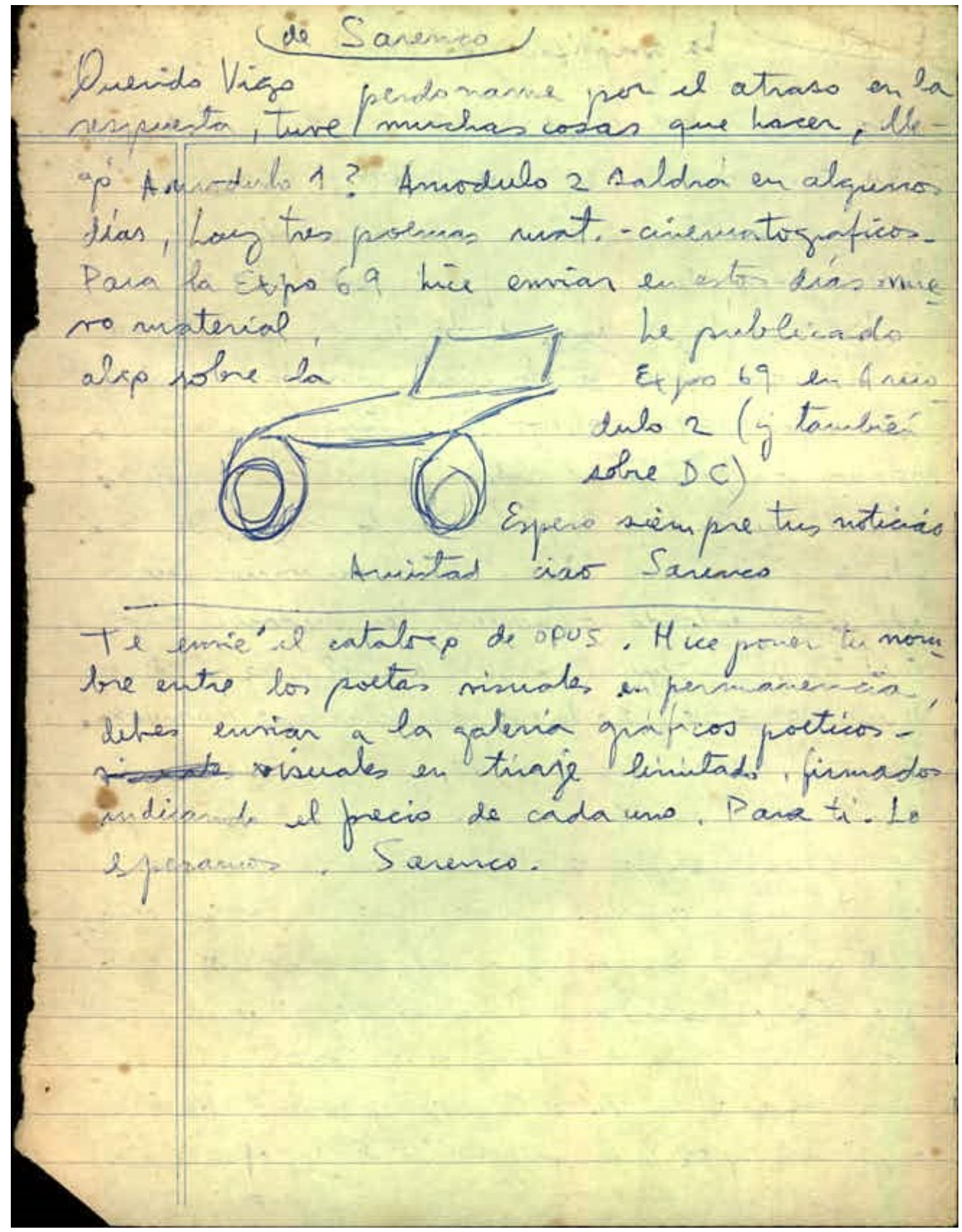

Fig. 21. Traducción de Elena Comas. Carta enviada por Sarenco a E. A. Vigo. s/f CAEV.

En los cuatro manuscritos relevados así como en las traducciones publicadas en las revistas $W C$ y Diagonal Cero, vemos que la acción de Elena Comas es fundamental. No solo contribuye a la configuración del repertorio de autores para las re-escrituras sino que también, en gran parte gracias a las traducciones de Comas, como Vigo se comunica con otros teóricos y poetas para la organización y gestión de lo que será la Exposición Internacional de Novísima Poesía y otros proyectos artísticos. Considerando que las re-escrituras funcionan como insumo teórico e intelectual para la producción plástica y editorial de E. A. Vigo, Elena Comas es, en su acción 
como traductora, una figura clave en la configuración y el posicionamiento de E. A. Vigo dentro del campo artístico y cultural.

\subsection{Pinturas}

Si observamos detenidamente los trabajos plásticos de Comas hacia mediados de la década de 1950, contemporáneos a las declaraciones de E. A. Vigo en torno a la exposición en la Asociación Sarmiento, vemos composiciones abstractas con un uso medido del color. Sus trabajos presentan líneas cortadas, rectas, formas orgánicas, en algunos casos con planos de color, en otras composiciones solo fronteras delimitando el espacio plástico.

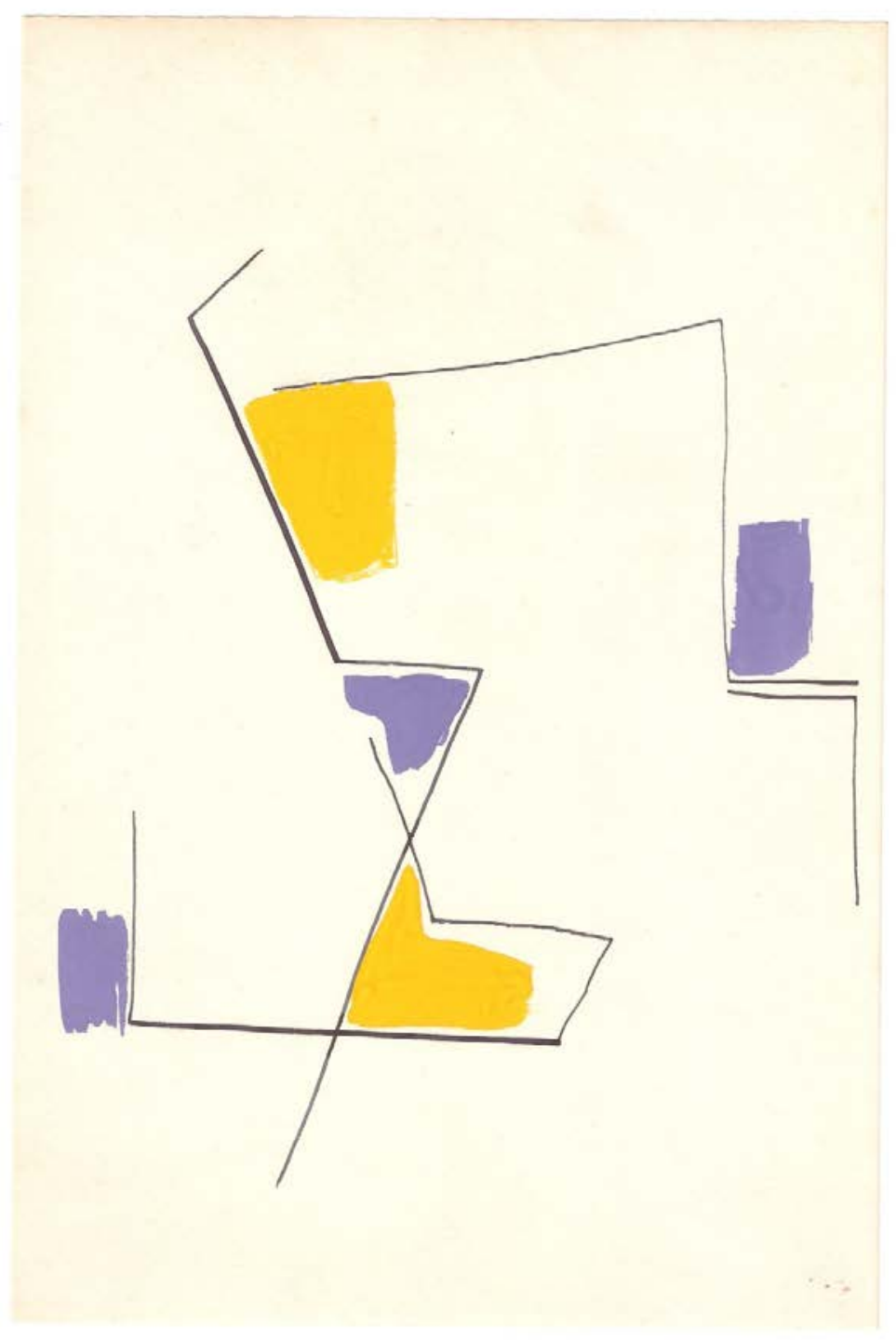

Fig. 22. Elena Comas, trabajos 1954, Archivo CAEV. 


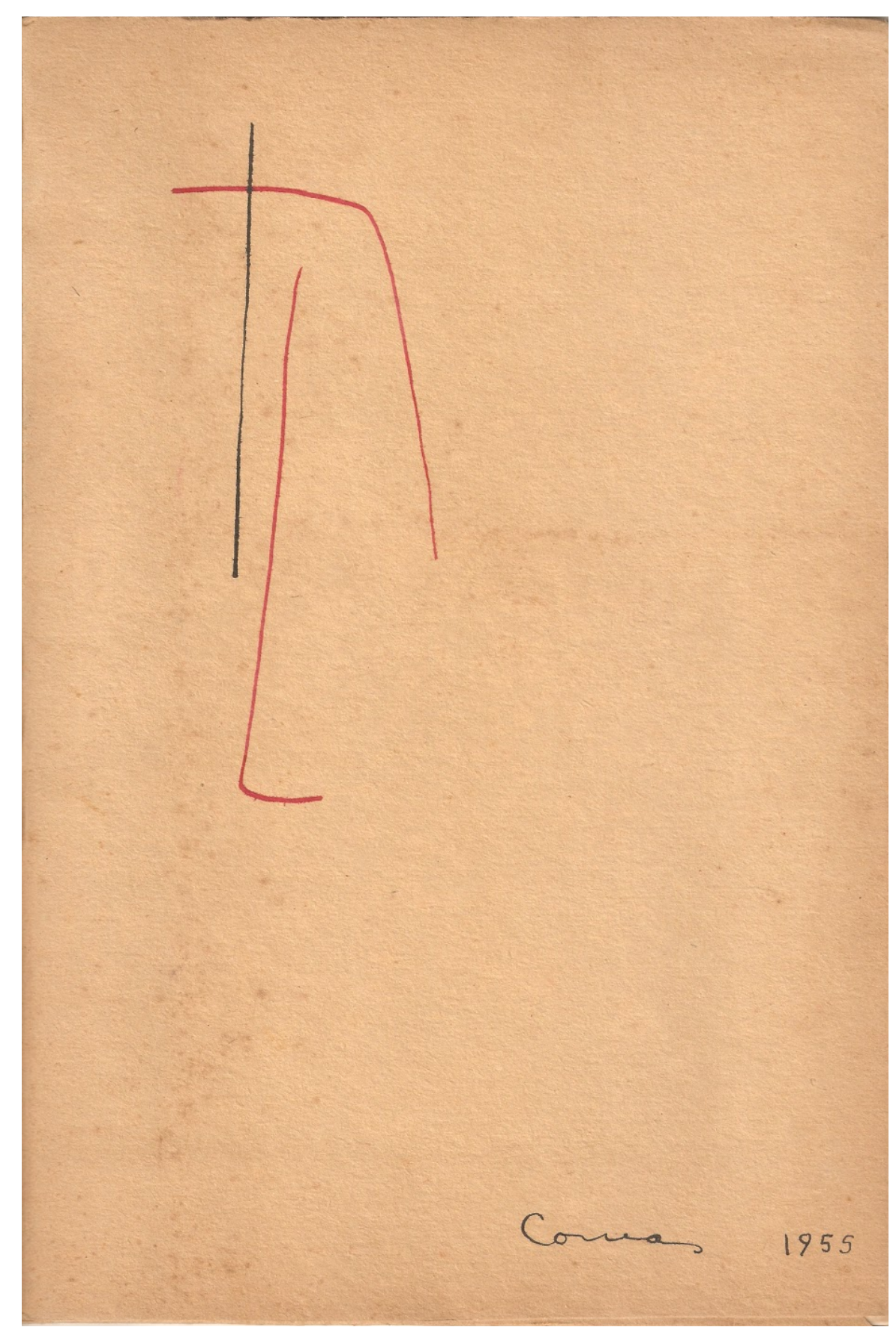

Fig. 23. Elena Comas, Carpeta de Trabajos 1955, Archivo CAEV.

Por lo anterior, podemos afirmar que los trazos que ilustran la re-escritura de Arte abstracto, sus orígenes, sus primeros maestros (1957 aprox.), pertenecen a Elena Comas. Mientras por esta época, en las re-escrituras intervenidas por Vigo -que analizaremos detenidamente en la segunda parte-, prima la tinta y un dibujo más bien técnico, las intervenciones de Comas sobre este ejemplar corresponden a líneas y colores en los márgenes del bloque textual. El trabajo en la re-escritura Arte abstracto, sus orígenes, sus primeros maestros es el único ejemplar encontrado hasta el momento- donde ella, además de traducir, ilustra. 
Del el corpus que configura la totalidad de las re-escrituras es en Arte abstracto, sus orígenes,

sus primeros maestros, donde mejor podemos apreciar el gesto y la participación de Comas.

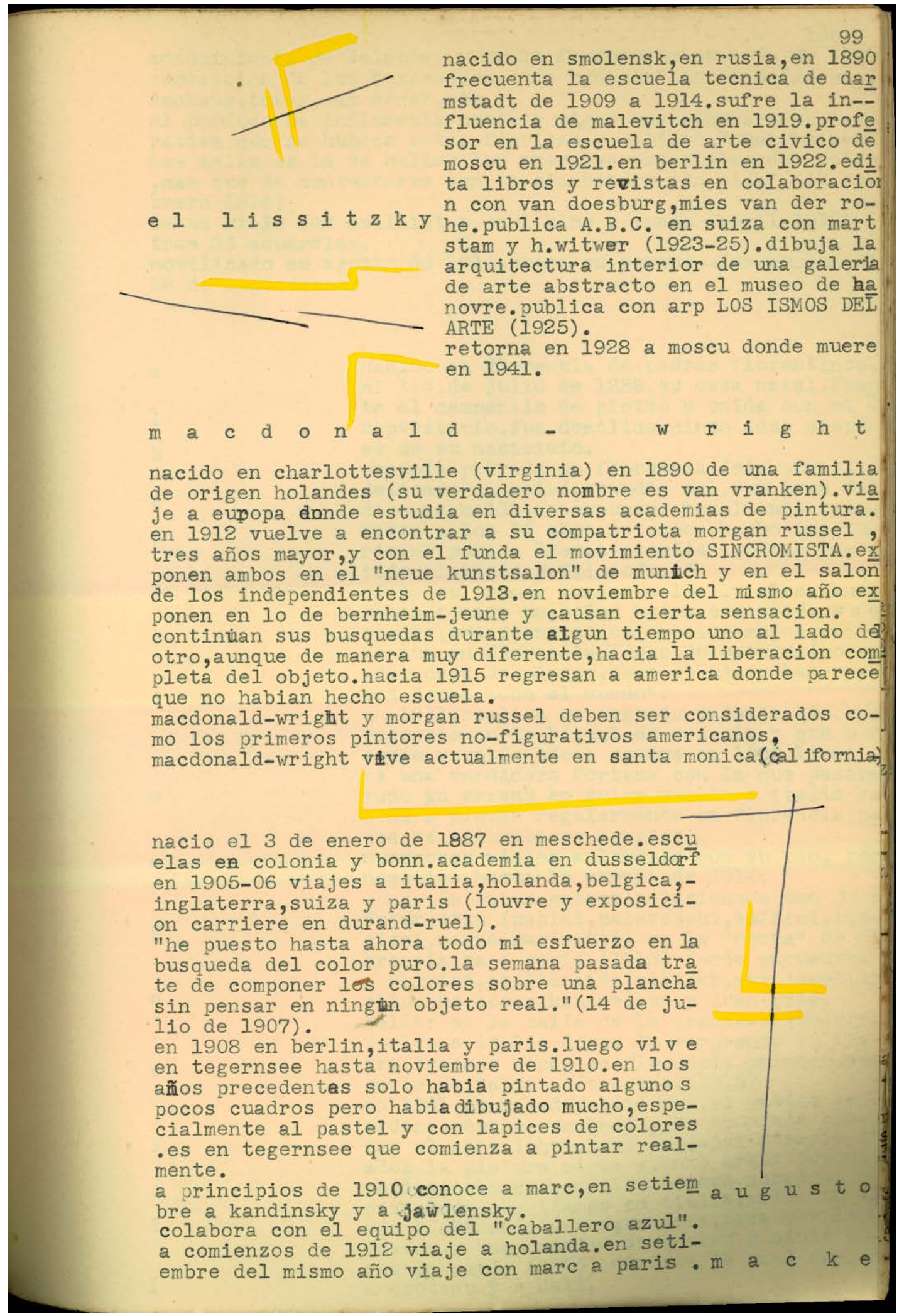

Fig. 24.Detalle de la re-escritura Arte abstracto, sus origenes, sus primeros maestros con ilustraciones de Elena Comas (1957 aprox) CAEV. 


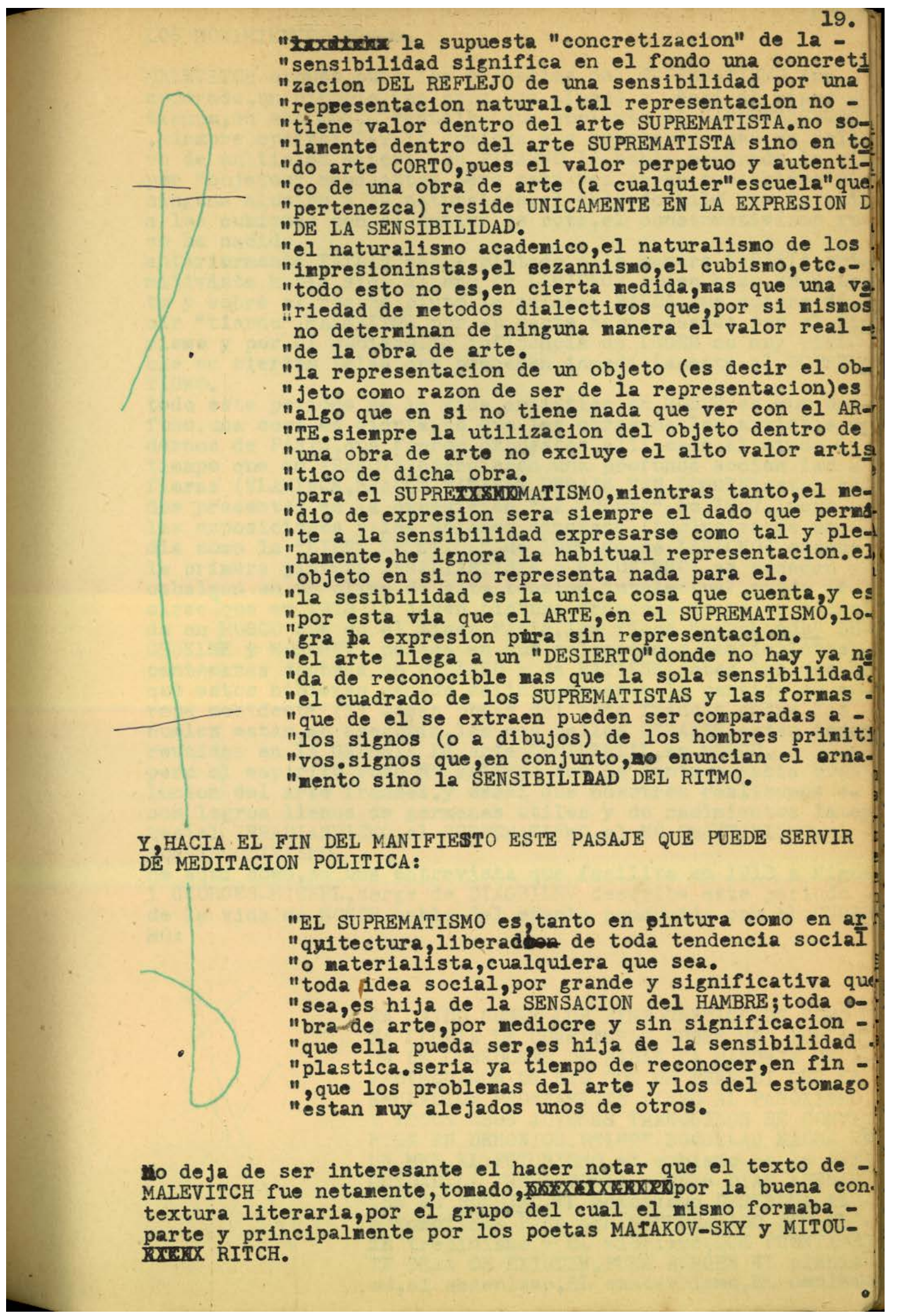

Fig. 25.Detalle de la re-escritura Arte abstracto, sus orígenes, sus primeros maestros con ilustraciones de Elena Comas (1957 aprox) CAEV

Berenice Gustavino con relación a este libro ha indicado que: 
Vigo traduce a Seuphor, un autor francófono defensor de la abstracción y uno de los primeros en proponer una síntesis y una organización de la historia de esta tendencia. En L'art abstrait..., que constituye un corpus de base para libros publicados desde fines de los años cincuenta a los setenta, el autor elabora una historiografía que no pasa necesariamente por París, estudiando artistas y tendencias alemanas, las vanguardias rusas y otros "olvidados" de la historia del arte canónica. Aunque Seuphor ignore las contribuciones del uruguayo Joaquín Torres García, ausencia muy cuestionada por los argentinos, sobre ese libro descansaría, por su apertura relativa en el contexto de la producción historiográfica europea, "la aplastante responsabilidad de haber asumido en Francia la historiografía de la vanguardia internacional". Junto a otros autores francófonos, Seuphor contribuye al cambio de panteón artístico, inaugurando una nueva historiografía que toma distancia de la figura de Picasso, para hacer ingresar en el relato a Kandinsky, Klee y Mondrian. No sorprende que el ejemplar de L'art abstrait... de Vigo haya sido profusamente subrayado por el artista (2015, p. 437)

Retomaremos este tema y las reflexiones de Gustavino en el apartado correspondiente a las vanguardias, en este punto nos interesa resaltar la importancia que le asigna al texto citado en tanto se corresponde con lecturas que configuran un repertorio sobre el arte abstracto que incorpora artistas admirados por Vigo y Comas tales como Kandinsky, Klee y Mondrian.

En resumen, en este apartado hemos querido atender a la importancia de Elena Comas en la configuración de las re-escrituras que estudiamos. Es ella, desde su trabajo como traductora, la que posibilita y transcrea, retomando las palabras de Haroldo de Campos (2000, 2004), el repertorio de autores que conviven en las re-escrituras. Cuando indicamos las operatividades de la noción de repertorio extraídas del concretismo, referimos a la traducción como un elemento fundamental en tanto se concibe como una forma creativa por la cual se da voz a otro tipo de experiencias estéticas por fuera del canon hegemónico. En el artículo De la traducción como creación y como crítica [1963] dice De Campos que:

Los primeros móviles del traductor, que también es poeta o prosista, son la configuración de una tradición activa (de ahí que no sea indiferente la elección del texto que se va a traducir , sino extremadamente reveladora), un ejercicio de intelección y, a través de él, 
una operación crítica viva. Que de esto nazca una pedagogía, no muerta y obsoleta, en pose de contrición o defunción, sino fecunda y estimulante, en acción, es una de sus más importantes consecuencias (2000, p. 197).

De Campos agrega aquí, el nacimiento de una pedagogía de la traducción, que en las re-escrituras puede pensarse desde la difusión que Vigo realiza mediante sus publicaciones de los textos traducidos por Comas. Destacamos en este sentido, las declaraciones de Luis Pazos en torno a las traducciones, las que le permitieron conocer, citar y posicionarse como conocedor del campo artístico. Por su parte, Octavio Paz, en Traducción: literatura y literalidad (1971) indica que:

Ningún texto es enteramente original, porque el lenguaje mismo, en su esencia, es ya una traducción: primero, del mundo no verbal y, después, porque cada signo y cada frase es la traducción de otro signo y de otra frase. Pero ese razonamiento puede invertirse sin perder validez: todos los textos son originales porque cada traducciónes distinta. Cada traducción es, hasta cierto punto, una invención y así constituye un texto único (1971, p. 1).

Traducir, siguiendo a estos autores, no se concibe como el traslado de una lengua extranjera a la lengua propia, sino que es una forma de creación. La acción de Elena Comas resulta fundamental para la configuración del repertorio de lecturas que Vigo difunde, por caso, como hemos visto, en las revistas $W C, D R K W$, Diagonal Cero y Hexágono 71' pero también para la construcción intelectual, teórica y, vía apropiación, en la estética de Vigo.

Las traducciones de Comas, como hemos visto, son centrales para su comunicación con los artistas extranjeros, acercando mediante la lengua los proyectos editoriales y las posibilidades en la gestión de las obras. 


\section{Síntesis de la primera parte del trabajo}

Hemos atendido en las páginas precedentes a la pregunta por los archivos de artista y sus particularidades. Ha sido fundamental el abordaje desde la potencialidad de la dimensión poíetica (Bugnone, 2018) para comprender el acervo del Centro de Arte Experimental Vigo, en tanto las re-escrituras introducen un uso creativo del material de archivo.

Posteriormente, desarrollamos los vínculos entre los compendios de imágenes desarrollados por Xul Solar en relación a la estructura y utilidad de las re-escrituras de E. A. Vigo, considerándolas como un antecedente formal para nuestro estudio.

Respecto del estatuto de estos ejemplares, hemos argumentado que para el análisis de las mismas no resulta operativo el concepto de reescritura como adaptación, tampoco en la noción de plagio ni de libro de artista para referir a las re-escrituras. Preferimos entonces considerar las re-escrituras como espacios de apropiación del material teórico donde funciona un repertorio de autores, críticas y estéticas que sirve de andamiaje en la producción plástica y editorial de $\mathrm{E}$. A. Vigo. Reseñamos los desarrollos teóricos B. Gustavino y M. Gradowczyk sobre los ejemplares de E. A. Vigo y recorrimos algunas "definiciones por diferencia" para acercarnos a las particularidades de nuestro objeto.

En el Marco Teórico, indagamos en los conceptos de apropiación y repertorio tomando reflexiones del Manifiesto Antropófago y de la poesía concreta brasileña. De la noción de repertorio nos interesó destacar la pregunta por lo nacional en torno a la configuración de autores que "sirven para renovar la tradición", la condición liminal donde la poesía dialoga con la arquitectura, la pintura y el diseño, y el trabajo de traducción entendido como una transcreación. En los últimos dos apartados desarrollamos la Biblioteca General de E. A. Vigo reseñando de manera pormenorizada los ejemplares que abordamos en esta tesis a partir de la Serie Escritos Personales y la acción de Elena Comas como traductora.

La segunda parte de este trabajo se presenta estructurada en tres capítulos. Analizamos la incidencia de las re-escrituras en la producción plástica y editorial del artista platense a partir de tres ejes: relectura de las vanguardias históricas; repertorio y poesía experimental e historietas herméticas en Hexágono 71'. 
SEGUNDA PARTE 


\section{Presentación.}

A partir de concebir las re-escrituras como espacios de apropiación y conocimiento que dan cuenta de modos particulares de lectura y escritura, en esta segunda parte de la tesis, analizamos las re-escrituras desde su implicancia en la producción estética y editorial de E. A. Vigo.

En el primer capítulo del presente análisis, estudiamos las lecturas sobre vanguardia, centrado la indagación en las re-escrituras pertenecientes a Marcel Duchamp, Francis Picabia y Piet Mondrian estableciendo posibles relaciones con su obra posterior en lo que respecta al aspecto material de la palabra.

En el segundo capítulo, analizamos las apropiaciones referidas a la poesía experimental a partir de la charla ofrecida por Vigo titulada "Panorama de la poesía experimental" (1968) y la charlaensayo "Continuidad de lo Discontinuo" ([1970], 1992). Buscamos reconocer a partir de las fuentes que Vigo cita como antecedentes, el repertorio de autores del cual se nutre en su trabajo en torno a la poesía experimental. Analizamos la incidencia de la poesía brasileña en la producción de Vigo, referimos a la Exposición Internacional de Novísima Poesía realizada en 1969 en el Instituto Torcuato Di Tella y la participación que sobre esta muestra tuvieron las lecturas y re-escrituras en la configuración del montaje de la misma.

En el tercer capítulo de esta parte, nos centramos en las re-escrituras referidas al género de la historieta considerando la producción de historietas herméticas en el marco de la revista Hexágono 71', atendiendo a la particular reformulación del género que opera en las mismas a partir del adjetivo hermético, tal como Vigo refiere a estas producciones. Veremos en este capítulo variantes en torno a la apropiación de los materiales de re-escritura así como también la incorporación de imágenes (

En las páginas precedentes hemos expuesto -en los cuadros referidos en el apartado Lecturas y re-escrituras-, que el período temporal en que se elaboran las re-escrituras comprende mediados de la década de 1950 (cuando la dupla Comas-Vigo comienza a traducir y transcribir los primeros textos) hasta 1975. Decidimos dividir los capítulos de esta segunda parte en los tres ejes predominantes por orden sucesivo, principalmente en las tres décadas en que se elaboran los compendios de re-escrituras, que corresponden a fines de 1950, década de 1960 y comienzos de 1970. Si bien hay materiales, como la re-escritura de Marchand $\mathrm{Du} S \mathrm{Sel}$, que funcionan de manera transversal y es posible rastrear sus resonancias en obras posteriores, iremos desarrollando en el transcurso de esta segunda parte los cruces temporales si los hubiere. Es 
importante aclarar que esta división por temáticas y años se realiza a los intereses de esta indagación, en tanto no es posible establecer con exactitud el momento en que se realizan las tareas de traducción, transcripción y edición de las re-escrituras. 


\section{Capítulo 1}

\section{Vanguardias}




\section{Presentación}

Las siguientes preguntas serán nuestro horizonte en este capítulo: ¿Qué particularidades estéticas y compositivas poseen las re-escrituras de la década de 1950? ¿De qué manera/s Vigo se apropia de los postulados de las vanguardias históricas, particularmente del dadaísmo? ¿Qué elementos de sus lecturas respecto de las vanguardias resuenan y se visibilizan en su poética? ¿Cómo inciden las re-escrituras en el abordaje y la conceptualización que Vigo realiza de los movimientos de vanguardia?. A partir de estos tópicos proponemos el ingreso al trabajo sobre las re-escrituras vinculadas a la temática de las vanguardias.

La selección realizada se fundamenta en un corpus de cinco re-escrituras que consideramos relevantes por su valor documental: las dos primeras pertenece a la traducción de libros completos, se trata del libro de Marcel Duchamp traducido por Comas y Vigo bajo el título Vendedor de Sal, y Les Machines Célibataires de Carrouges. Las tres siguientes corresponden a selecciones de artículos (A, B, C descriptas en el apartado 8, Lecturas y re-escrituras), donde analizamos aspectos visuales y compositivos así como también los repertorios que se ponen en diálogo en la re-escritura. 


\section{Marcel Duchamp}

La re-escritura del Marchand $\mathrm{Du} S \mathrm{Sel}$, o Vendedor de Sal en la versión realizada por la dupla Comas-Vigo en 1966, se presenta como un espacio para reflexionar sobre las nociones de apropiación y repertorio, las formas en que la lectura incide en la producción plástica y editorial del artista platense. Consideramos como antecedente en el conocimiento de Vigo de la obra de Marcel Duchamp el libro Les Machines Célibataires de Carrouges; analizamos posteriormente diversos artículos de Vigo en torno a la obra de Duchamp y proponemos interpretaciones en torno a la apropiación de los postulados duchampeanos en la obra de Vigo.

\subsection{Máquinas solteras}

Dentro de las vanguardias históricas europeas encontramos cuatro grandes actitudes en torno a la máquina: la exaltación de la misma del futurismo italiano (en el manifiesto de Marinetti), la máquina en función de nuevas relaciones de producción en el caso del constructivismo ruso (Tatlin, Moholy-Nagy), máquina del deseo dadá y el antimaquinismo surrealista que quiere resguardar el deseo simbólico para volverlo contra la máquina ${ }^{73}$. En el caso latinoamericano, las referencias al objeto máquina y sus usos pueden rastrearse desde la década de 1920. La máquina aparece como sistema, por ejemplo, en el constructivismo de Torres García, a partir de su representación en la obra de Tarsila do Amaral y Diego Rivera, en la agrupación Artistas del Pueblo $^{74}$ como Adolfo Bellocq y Abraham Vigo. Algunos Sueños de Grete Stern entran dentro de las formulaciones maquinicas o bien las imágenes surrealistas del joven Berni donde se plantean máquinas-ficciones, dejando al descubierto fragmentos del artefacto descentrado de su función habitual.

El concepto de máquina funciona en la obra temprana de Vigo, entre otros factores desde la posibilidad de obra seriada y su potencialidad conceptual ${ }^{75}$. Como ha indicado Mario

\footnotetext{
${ }^{73}$ Esta caracterización, de manera muy esquemática, tiene como referencia el Apéndice Balance-programa para máquinas deseantes del libro de Gilles Deleuze y Félix Guattari El Anti Edipo Capitalismo y esquizofrenia. (1985, p. 413).

${ }^{74}$ Los artistas del Pueblo (2008) Catálogo Malba- Fundación Osde. Del 10 de abril al 31 de mayo de 2008.

${ }^{75}$ En torno a las potencialidades conceptuales de la máquina en vínculo con la literatura, se sugiere el artículo de Marta Sierra en "Máquinas, ficciones y sociedades secretas: Caterva y La ciudad ausente" (2005), analiza la figura de la máquina vinculada al cuerpo, comenzando por el Adán Buenosayres (1948) -con la aparición del neo-criollo de Xul Solar-, pasando por los vínculos entre anarquismo y técnica en Art, deteniendo su argumentación en Filloy y Piglia. Señala Sierra que "Tanto en Filloy como en Piglia, la incorporación de los residuos de la historia (personajes-residuos como los linyeras de Filloy o residuos de narraciones como en el museo de Piglia) son mecanismos de creación literaria que al mejor estilo de las vanguardias de los años 1920 y 1930 emplean el collage como estrategia de reciclado para crear originalidad" (2005, p. 523).
} 
Gradowczyk las máquinas en la obra de Vigo "responden a un proceso de serialización que se ve reflejado en diversas variaciones temáticas. Las series responden a los conceptos de repetición y de diferencia y se caracterizan por el empleo de soportes, tamaños, motivos y medios similares." (2008, p. 66). Por ejemplo, la obra Máquina inútil aprovechando la fuerza motriz humana (...), presenta su condición paradójica desde su título, por un lado, alude a la inutilidad del uso del dispositivo y, por otro, a la "productividad" y el "aprovechamiento" del trabajo dentro del universo discursivo de la mecánica. La "acción productiva" de esta máquina inútil es cortar las malas lenguas. Se vislumbra en esta obra, compuesta de un collage y una superficie negra con hendidura, el aspecto participativo -que se profundiza en la obra de Vigo- en tanto el espectador para poder observar el mecanismo completo debe develar el plano negro que solo muestra una parte de la totalidad del collage. A diferencia de la utilización del concepto "máquina" en las obras de Berni, o Torres García, en estas piezas prima la paradoja y, sobre todo, el humor. Notemos que en sus primeros trabajos ya aparece el adjetivo "inútil”, referido a lo que no produce provecho o beneficio, antítesis de la idea de progreso que propone la máquina, que será re-utilizado a partir del prefijo "in" entre paréntesis en otras producciones como sus "poemas (in) sonoros" por ejemplo a fines de la década de 1960.
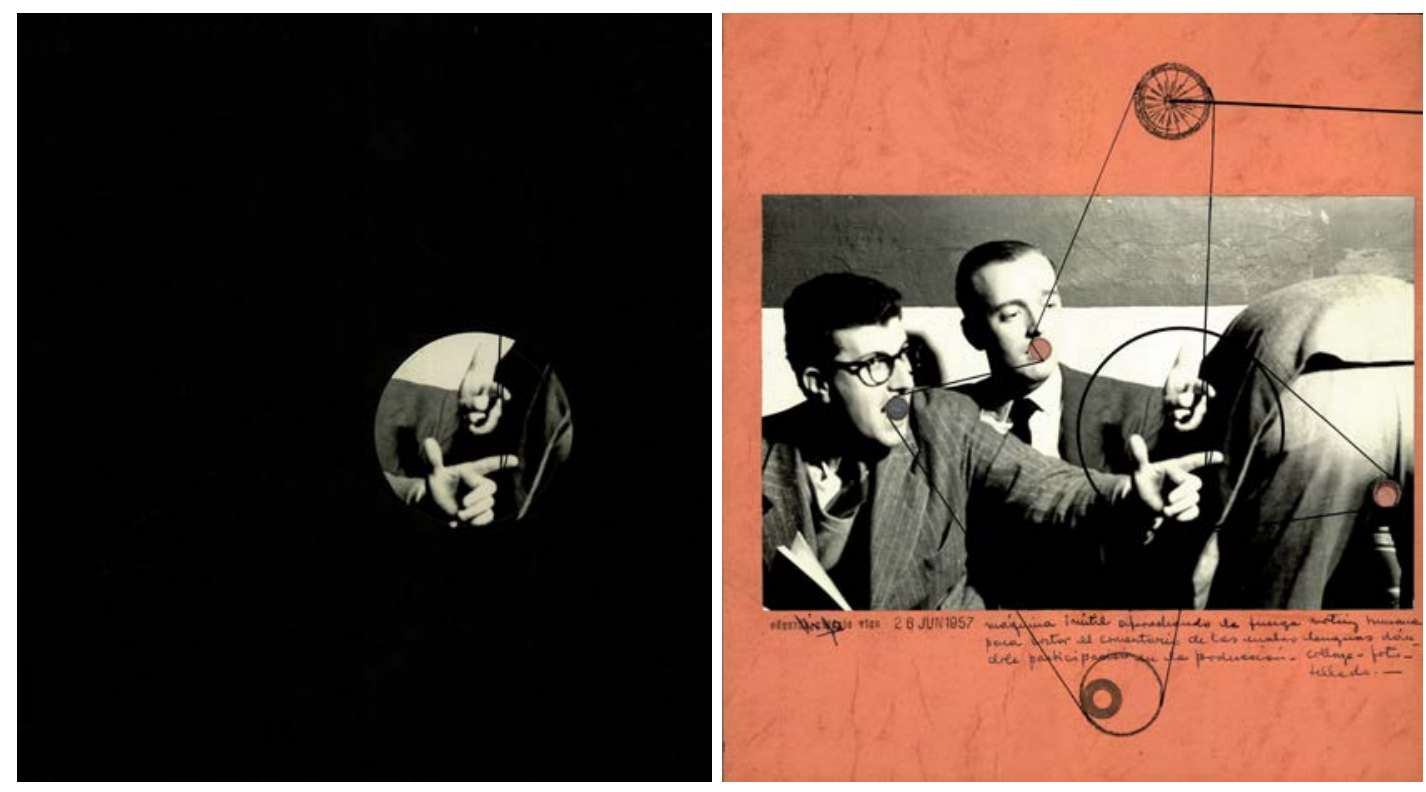

Fig. 26. E. A. Vigo. Máquina inútil aprovechando la fuerza motriz humana para cortar el comentario de las malas lenguas dándole participación en la producción. (1957). CAEV

En las primeras máquinas inútiles elaboradas por Vigo en la década de 1950, dialoga el erotismo, el fetiche, la autosatisfacción, lo extraordinario, el juego, el humor, lo contradictorio y lo irreverente. Conceptualmente se encuentran ligadas a las características de la máquina deseante 
El Gran Vidrio de Duchamp pero también a las máquinas de otro de los referentes en el repertorio de Vigo, Francis Picabia. Vigo escribe tempranamente (1959) sobre la máquina en su artículo Máquinas Inútiles. Solteras imposibles (El Argentino, 19/11/59).

En la producción de Vigo, la idea de máquina es conceptualmente el nombre que antecede a la caracterización del "objeto" en su producción; ligado en este caso a los desarrollos de la década de 1960 y el carácter abstracto con el que llama "cosas" sus obras tridimensionales como analizaremos en el desarrollo de este apartado.

Luego de esta breve caracterización, nos detenemos en la re-escritura de Les Machines Célibataires de Carrouges (1954) en tanto es el primer texto en el que Vigo ingresa, vía máquinas solteras, a la obra de Marcel Duchamp. Este libro data de del año 1957 en la Serie Escritos Personales, debemos decir al respecto que Les Machines Célibataires de Carrouges, no ha sido hasta hoy, traducido y editado oficialmente en español, este hecho da cuenta de la importancia de las traducciones y las re-escrituras del acervo del CAEV. Vigo difunde los conceptos de Carrouges plasmados en esta traducción a partir del artículo mencionado anteriomente, Máquinas inútiles. Solteras imposibles publicado en el diario El Argentino en 1959 y en la revista $D R K W$ “ $C$ ”'de 1960, transcribiendo fragmentos del texto de Carrouges.

Carrouges desarrolla en Les Machines Célibataires reflexiones en torno a los "mitos modernos" y lo que denomina "imágenes-clave" en las construcciones estéticas vanguardistas. Se detiene en el mito de las máquinas solteras concebidas como máquinas del suplicio porque "el mito de las máquinas solteras significa de una manera evidente el imperio simultáneo del maquinismo y del mundo del terror" (1957, p. 18). El corpus analizado por Carrouges se centra en diversas máquinas, ejemplificadas a partir de Impresiones de África (1910) de Roussel, La recién casada o El Gran Vidrio (obra iniciada en 1911) de Marcel Duchamp y Colonia Carcelaria (1914) de Kafka, entre otras. El autor homologa el mecanismo de ficción creado por Kafka y Duchamp destacando el erotismo, la significación del material y su transparencia, el dolor, el suplicio y la soltería. 


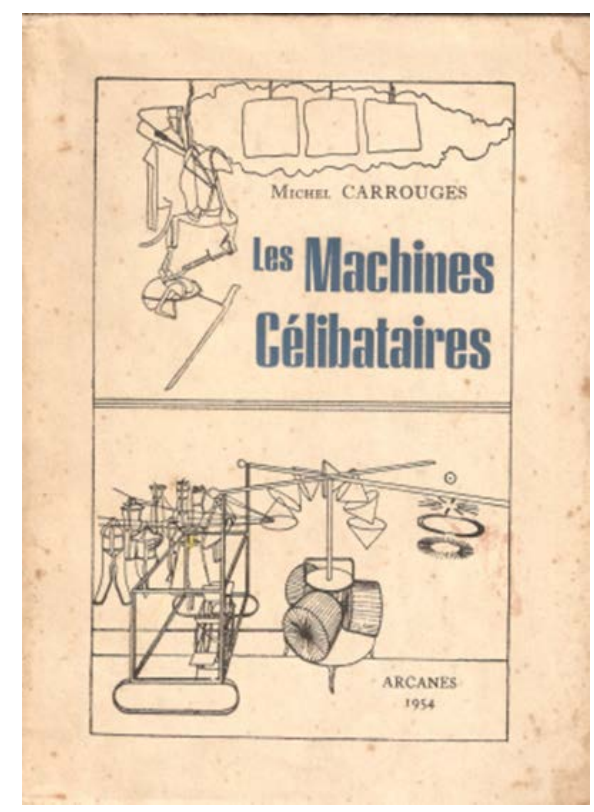

Fig. 27. Tapa de la edición original de Les Machines Célibataires M. Carrouges (1954). CAEV.

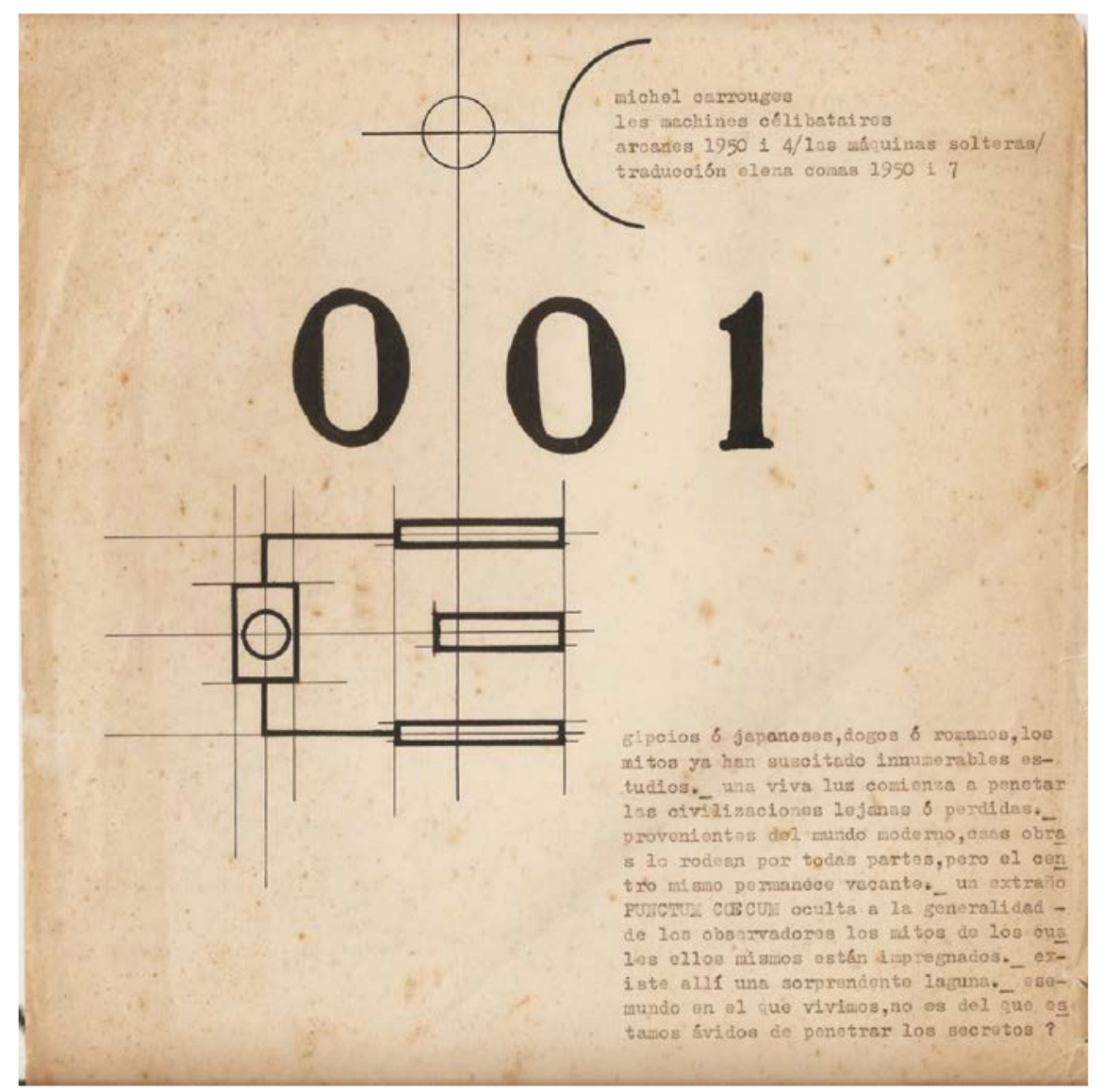

Fig. 28. Página inicial de la re-escritura Las máquinas solteras (Les Machines Célibataires). Traducción Elena Comas, diagramación E. A. Vigo (1957) CAEV.

Como indicamos anteriormente, la re-escritura de Comas y Vigo data de 1957, tres años después de su publicación oficial del francés, probablemente el libro original haya sido traído por Vigo de su viaje a Europa. Se destaca entre los aspectos formales de esta re-escritura la diagramación 
de los párrafos en una hoja cuyas medidas $(23,5 \times 22 \mathrm{~cm})$ no se corresponden con un formato de hoja tradicional, la re-escritura no esta encuadernada, consta de hojas sueltas con números de página elaborados a partir de sellos y está mecanografiada con tinta negra.

El ordenamiento de los párrafos se encuentra en función del desarrollo compositivo de la transcripción agregando aspectos visuales vinculados con un tipo de dibujo más bien técnico y la utilización de sellos en la numeración de las páginas. Respecto de conocimiento por parte del artista de los procedimientos del dibujo técnico, recordemos que Vigo egresa del Colegio Industrial Albert Thomas de La Plata, y posee conocimiento del tipo de trazo utilizado para realizar bocetos de máquinas.

En 1957, Vigo ya se encontraba trabajando en Tribunales, donde mencionamos que la máquina de escribir cumple un lugar fundamental en lo que respecta a los expedientes que cotidianamente manipula y cose. La selección de artículos que analizaremos en el apartado siguiente comparte las características formales de esta re-escritura ya que pertenecen al mismo período, nos referimos procedimentalmente a las líneas rectas perpendiculares y horizontales, el espesor combinado de las mismas así como el uso del compás para los círculos en las composiciones, lo que caracterizamos como circuitos.

Entre los aspectos formales, hasta la página 20, el ejemplar de re-escrituras traducido como Las Máquinas Solteras, esta compuesto por un bloque de texto y números de página (realizado con sello de goma, probablemente marca Norma, $\mathrm{n}^{\circ} 20$ ) en color negro.

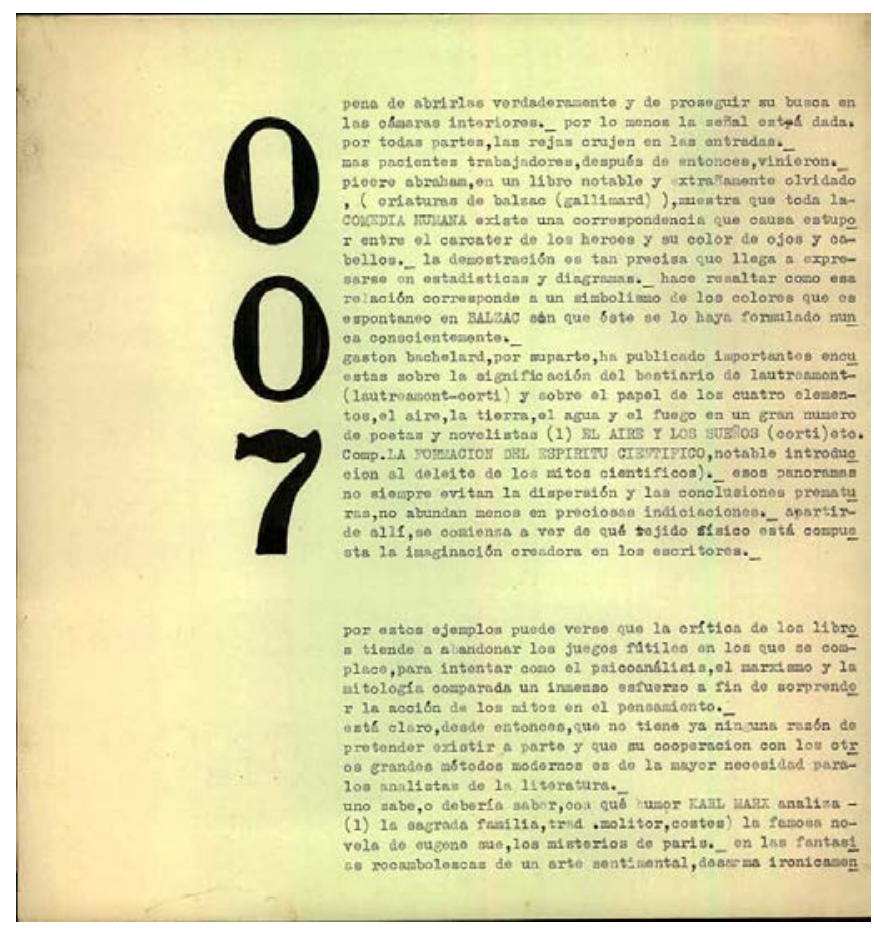

Fig. 29. Página $\mathrm{n}^{\circ} 7$ de la re-escritura Las máquinas solteras (Les Machines Célibataires). Traducción Elena Comas, diagramación E. A. Vigo (1957) CAEV 


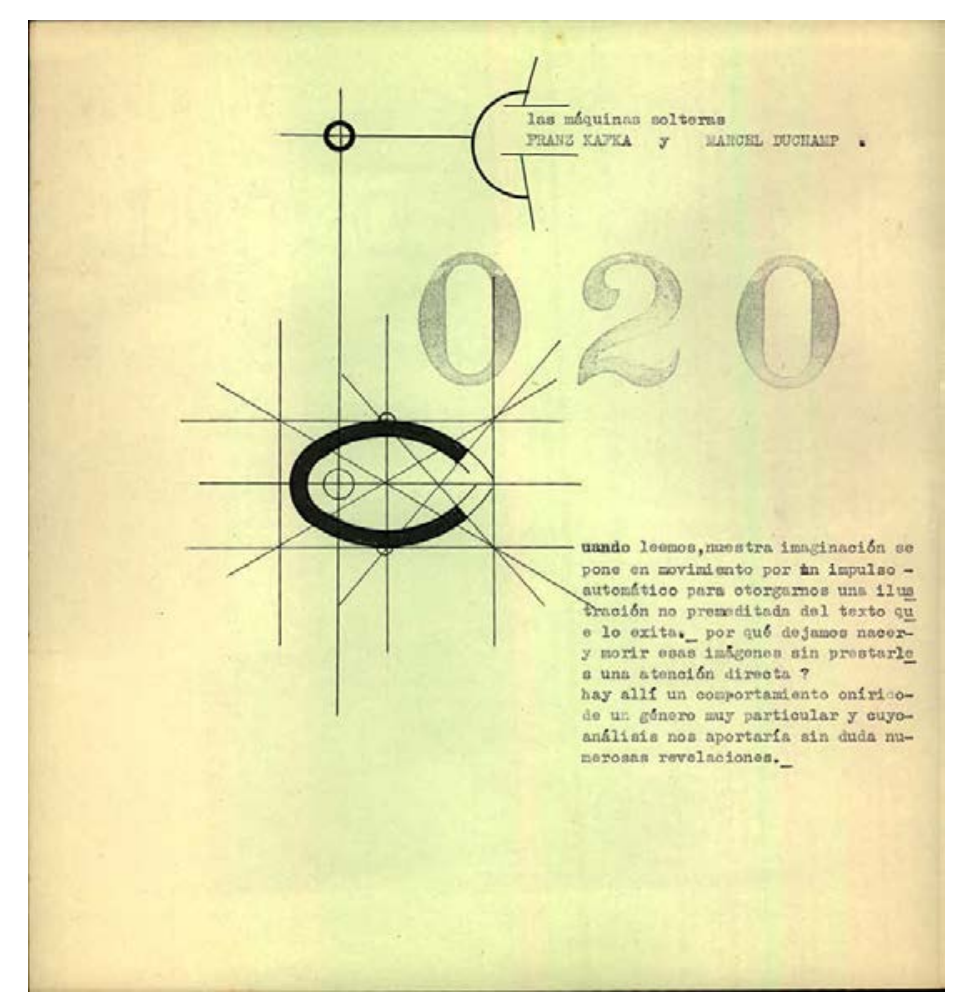

Fig. 30.Página ${ }^{\circ} 20$ de la re-escritura Las máquinas solteras (Les Machines Célibataires). Traducción Elena Comas, diagramación E. A. Vigo (1957) CAEV

La página $\mathrm{n}^{\circ} 20$ de la re-escritura lleva el subtítulo "Las máquinas solteras, Franz Kafka y Marcel Duchamp”. La página $n^{\circ} 21$, contiene una reproducción por parte de Vigo que copia la imagen original del texto de Carrouges. Al igual que en el original, la re-escritura respeta imagen y texto por separado, ocupando cada uno hojas diferenciadas. En las dos imágenes que siguen, vemos el original del libro y la copia por parte de Vigo de "Colonia Penitenciaria de Kafka". En la "copia" de la re-escritura, Vigo agrega la nota: "burda reproducción a ojo".

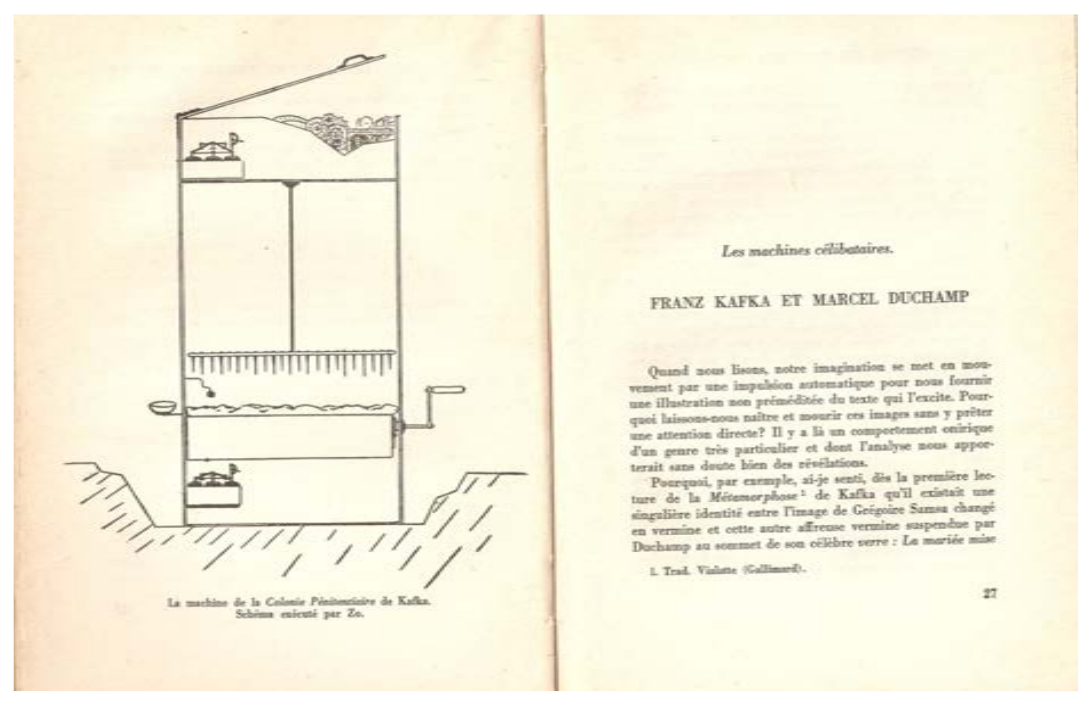

Fig. 31.Página n ${ }^{\circ} 27$ del libro original Les Machines Célibataires M. Carrouges (1954)

en el epígrafe inferior dice "La máquina de la Colonia Penitenciaria de Kafka, esquema ejecutado por Zo" CAEV. 


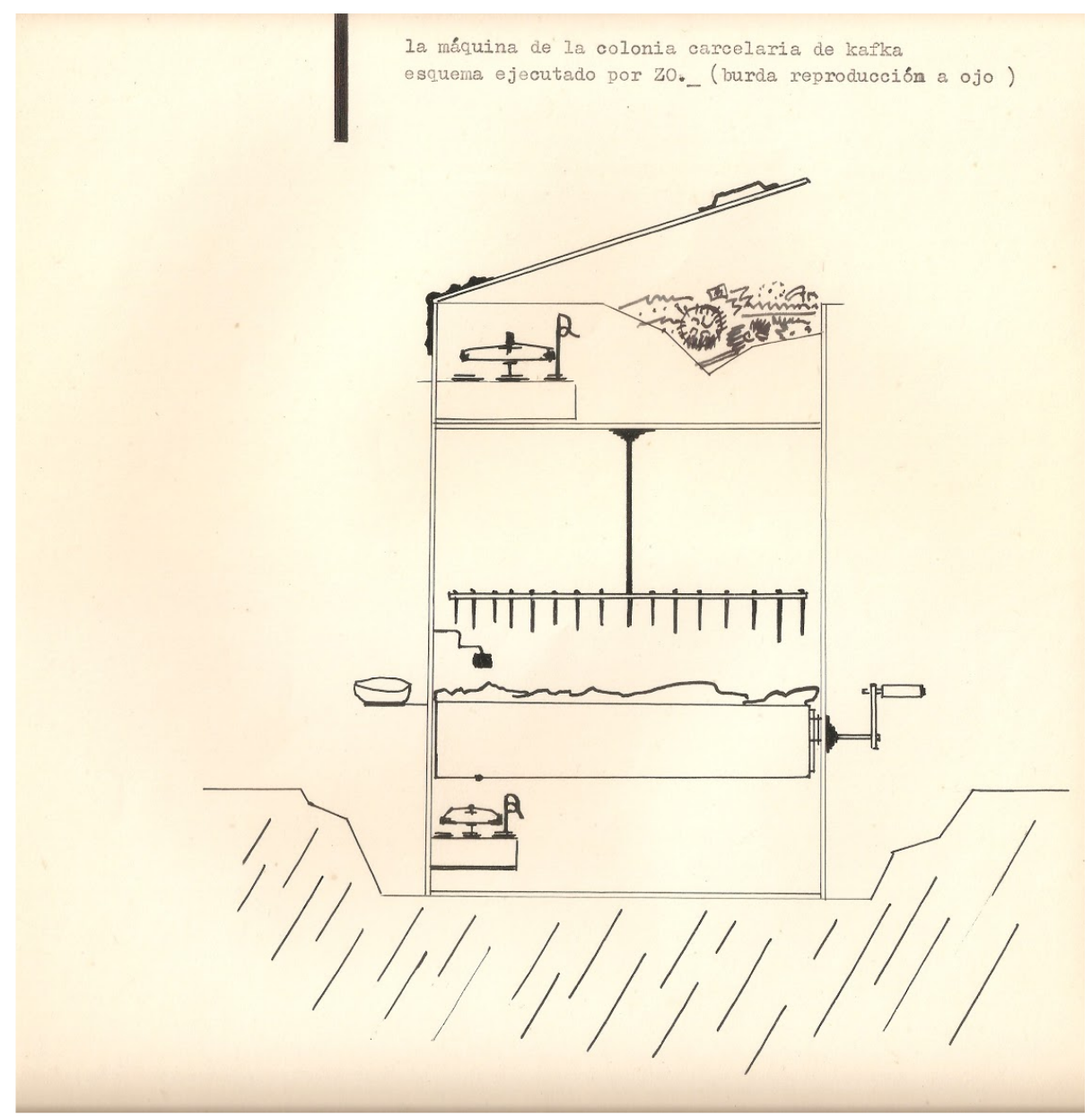

Fig. 32. Re-escritura Las Máquinas Solteras.Traducción Elena Comas, diagramación E. A. Vigo (1957) el epígrafe en la parte superior de la imagen dice "La máquina de la Colonia Penitenciaria de Kafka, esquema ejecutado por Zo._(burda reproducción a ojo)”. La aclaración entre paréntesis es un agregado de Vigo.

Vemos en esta re-escritura que Vigo transcribe con libertad el texto (organizándolo en bloques con números de página sellados sobre el lado derecho de la hoja) pero la imagen que copia es sumamente fiel al original del libro de Carrouges (a pesar de ser una "burda reproducción" según sus palabras). Veremos, en las apropiaciones de la década de 1970 referidas a la historieta, que Los miramientos y la consideración por la autoría de la imagen se modifican, puesto que, como analizaremos en el Capítulo 3 referido a las historietas herméticas, Vigo se apropia de la imagen sin citar autoría ni fuente.

En la entrevista realizada por Mónica Curell ("La marca de Vigo", 1995), Vigo hace alusión a este libro diciendo, con motivo de su desarrollo objetual, "yo las llamaba cosas inútiles (...) también usé el término de Carrouges: máquinas inútiles". Indica que comienza a armar estructuras con el material que le resulta más cálido, la madera, y refiere justamente a la obra "Colonia Penitenciaria de Kafka" como inicio de su búsqueda objetual puesto que advierte en su 
trayectoria que la pintura "no era su camino" artístico. La apropiación funciona aquí como reformulación pero también como insumo para la teorización en su propia obra.

La re-escritura Las Máquinas Solteras, no solo es contemporánea a los inicios en el diseño editorial de Vigo, como veremos en las selecciones A, B y C, sino que también se presenta como el ingreso de Vigo al conocimiento de una de las obras más importantes de Marcel Duchamp, El Gran Vidrio. Este libro entonces aporta reflexiones y conceptos claves para la conceptualización que Vigo elabora sobre su producción.

2. 2. Vendedor de Sal: Como se indicó en la primer parte del trabajo, en la biblioteca de Vigo encontramos ejemplares que dan cuenta de un interés prolongado por la obra de Marcel Duchamp. Analizaremos en este apartado la única re-escritura de libro completo referida íntegramente al artista francés.

En 1966 año, Elena Comas traduce y E. A. Vigo realiza la edición para la re-escritura del libro de Duchamp Marchand $d u$ Sel devenido Vendedor de Sal. Como ha señalado Berenice Gustavino, la reescritura que realiza la pareja Comas-Vigo del libro de Kandinsky De lo espiritual en el Arte, se anticipa dos años a la publicación que realiza Edgar Baley (2015, p. 436), lo mismo ocurrirá en la re-escritura de la obra de Duchamp Marchand du Sel. Gustavino indica que Vigo elige una literatura que privilegia una versión del arte moderno donde predomina la abstracción, sin embargo esto no quita su preocupación por otros movimientos como el surrealismo y el dadaísmo presentes en su biblioteca. Con la re-escritura del libro de Duchamp, Vigo y Comas se adelantan a la primer traducción oficial de los escritos de Marcel Duchamp, en tanto, es en 1975 que bajo la edición de Sanouillet, la editorial Gustavo Gilli publica Duchamp du signe: écrits. Es relevante en este sentido la recuperación que en este trabajo hacemos de las re-escrituras en tanto presenta y analiza estos gestos pioneros en lo que respecta a la traducción e inserción de la obra de Duchamp en la Argentina.

Tanto el libro Marchand $\mathrm{Du} \mathrm{Sel}$ (en la primer edición francesa de 1959) como la re-escritura de Comas y Vigo traducida como Vendedor de Sal (de 1966), y Duchamp du signe: écrits (en la traducción oficial al español de 1975) corresponden a una recopilación de textos de Marcel Duchamp elaborada por Michel Sanouillet. En el prólogo se aclara que "No son creaciones literarias, en el sentido propio del término, sino más bien los jalones de un lento proceso mental" (Sanouillet; 1975, p. 16). Al igual que la carpeta Etant Donnes, reseñada en el apartado 
Biblioteca General, los escritos de Duchamp editados por Sanouillet se asemejan a papeles dispersos de archivo, notas, dibujos, reflexiones, instrucciones ${ }^{76}$ y proyectos.

La primera parte del libro Marchand $\mathrm{Du}$ Sel se titula "El velo de la novia", comprende anotaciones sobre caja 1914, caja verde, sombras proyectadas y caja blanca; en la segunda parte, "Rose \& Cia” encontramos notas de Rrose Sélavy, heterónimo de M. Duchamp; la tercer parte "M. D Criticavit", posee una entrevista a Duchamp por J. Sweeney, un desarrollo sobre los ready made y textos de M. D. sobre otros artistas. La cuarta parte "Texticulos" cuenta con notas dispersas del artista, así como pequeños textos presentes en algunos objetos. No podríamos decir que es un libro de lectura convencional, se presenta más bien como un libro de fragmentos donde conviven instrucciones, notas, imágenes, reflexiones.

Como señalamos en el apartado "Lecturas sobre Duchamp", una selección de las anotaciones presentes en la primer parte sobre caja 1914, caja verde y caja blanca fueron publicadas oficialmente en español en el libro Octavio Paz, Marcel Duchamp (1968) en un cuadernillo cuyo título es Marcel Duchamp: textos. Por su parte, Vigo en 1966 se encargará de publicar en la revista Museo el prólogo de Sanouillet, pero no nos adelantemos.

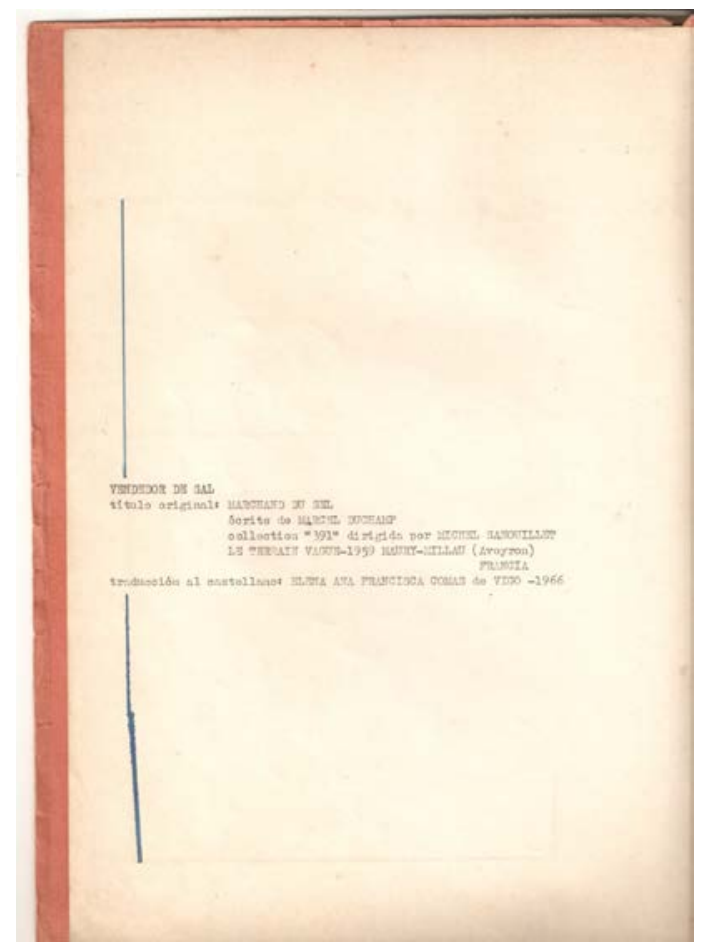

Fig. 33. Re-escritura Vendedor de Sal (1966) segunda hoja con datos, traducción Elena Comas, diagramación y edición E. A. Vigo.

\footnotetext{
${ }^{76}$ En este sentido, podríamos considerar la publicación de Duchamp como un antecedente cercano a las Piezas del libro Pomelo (1964) de Yoco Ono. Por ejemplo dice Duchamp en una de sus notas titulada "Errata musical": "Yvonne: Hacer una huella marcar con trazos una cara sobre la superficie imprimir un sello sobre cera//Magdeleine: Hacer una huella marcar con trazos una cara sobre la superficie imprimir un sello sobre cera// Marcel: Hacer una huella marcar con trazos una cara sobre la superficie imprimir un sello sobre cera" ([1959] 1975, p. 45)
} 
La re-escritura traducida como Vendedor de Sal se encuentra mecanografiada y diseñada sobre hojas de 30 x $25 \mathrm{~cm}$. La tapa y la contratapa son de cartulina naranja, no presentan imágenes ni textos que indiquen al lector de qué traducción se trata, la edición se encuentra encuadernada mediante costura exterior con hilo blanco. Vendedor de Sal presenta, en la segunda hoja, una copia realizada por Vigo de la silueta "Autorretrato de perfil" 77 de M. Duchamp realizada con marcador de fibra, la rúbrica de la tapa también es una copia de Vigo de la firma del artista francés. Si en la re-escritura de Carrouges de la década de 1950, Vigo trabajaba solo con tinta negra, con líneas perfectamente trazadas en la composición de sus re-escrituras, incorpora, a mediados de la década de $1960^{78}$, las posibilidades y colores de la fibra y las letras de molde.

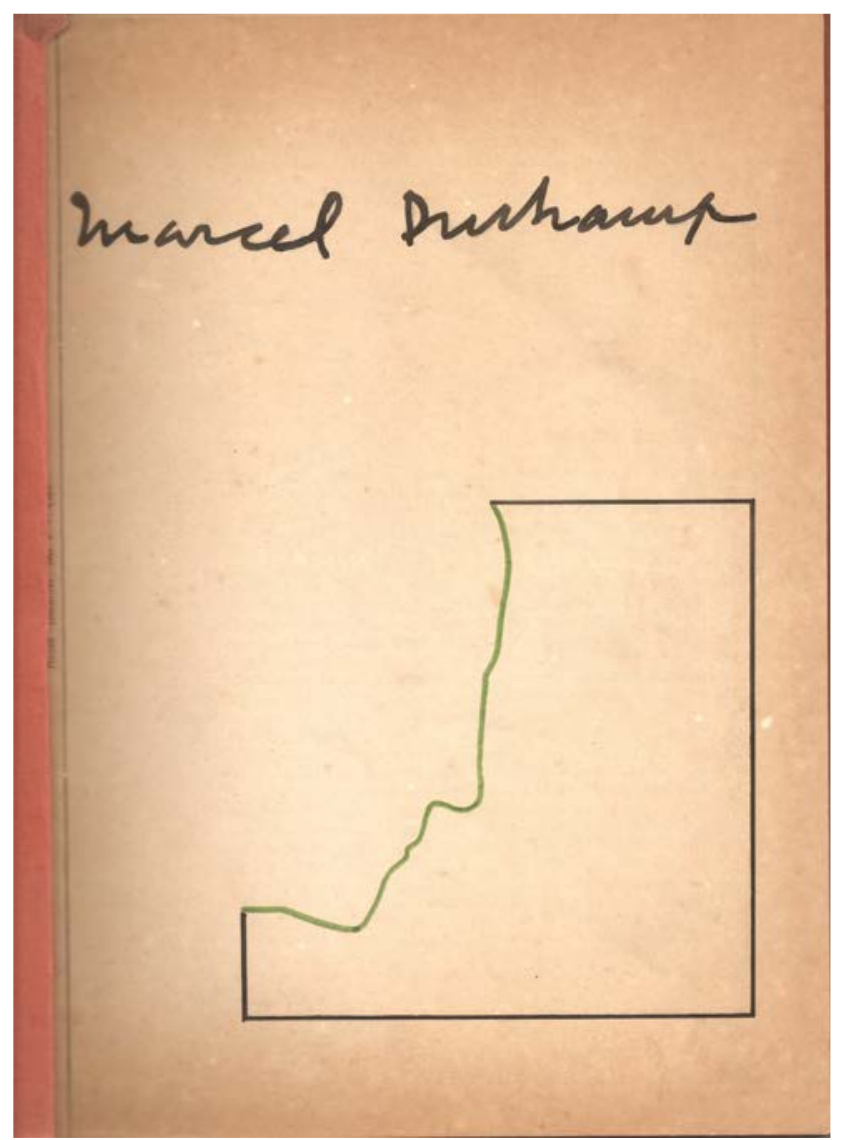

Fig. 34.Vendedor de Sal (1966). Traducción Elena Comas, diagramación y edición E. A. Vigo. Primera hoja del ejemplar. La silueta y la firma de M. D. son copias realizadas por Vigo en fibra color negro y verde.

En el interior de la re-escritura encontramos un poema matemático realizado con marcador titulado “(pseudo) poema matemático a D. 1966”. En los documentos colaterales a Biopsia

\footnotetext{
${ }^{77}$ Vale decir que otra versión "libre" de la silueta de Marcel Duchamp aparece muy posteriormente en el trabajo de arte correo "Perfil imaginario de Marcel Duchamp obra que no nos pertenece" para el catálogo de la muestra OFF OFF (1988), este hecho da cuenta del interés prolongado de la obra del artista entre las producciones de Vigo tal como señalamos al comienzo.

${ }^{78}$ Nótese el cambio también en los registros Biopsia, donde el año 1966 aparece con fibra verde.
} 
presentes en el CAEV del mismo año, hallamos poemas matemáticos ${ }^{79}$ con una estructura similar, donde también utiliza el marcador de fibra.

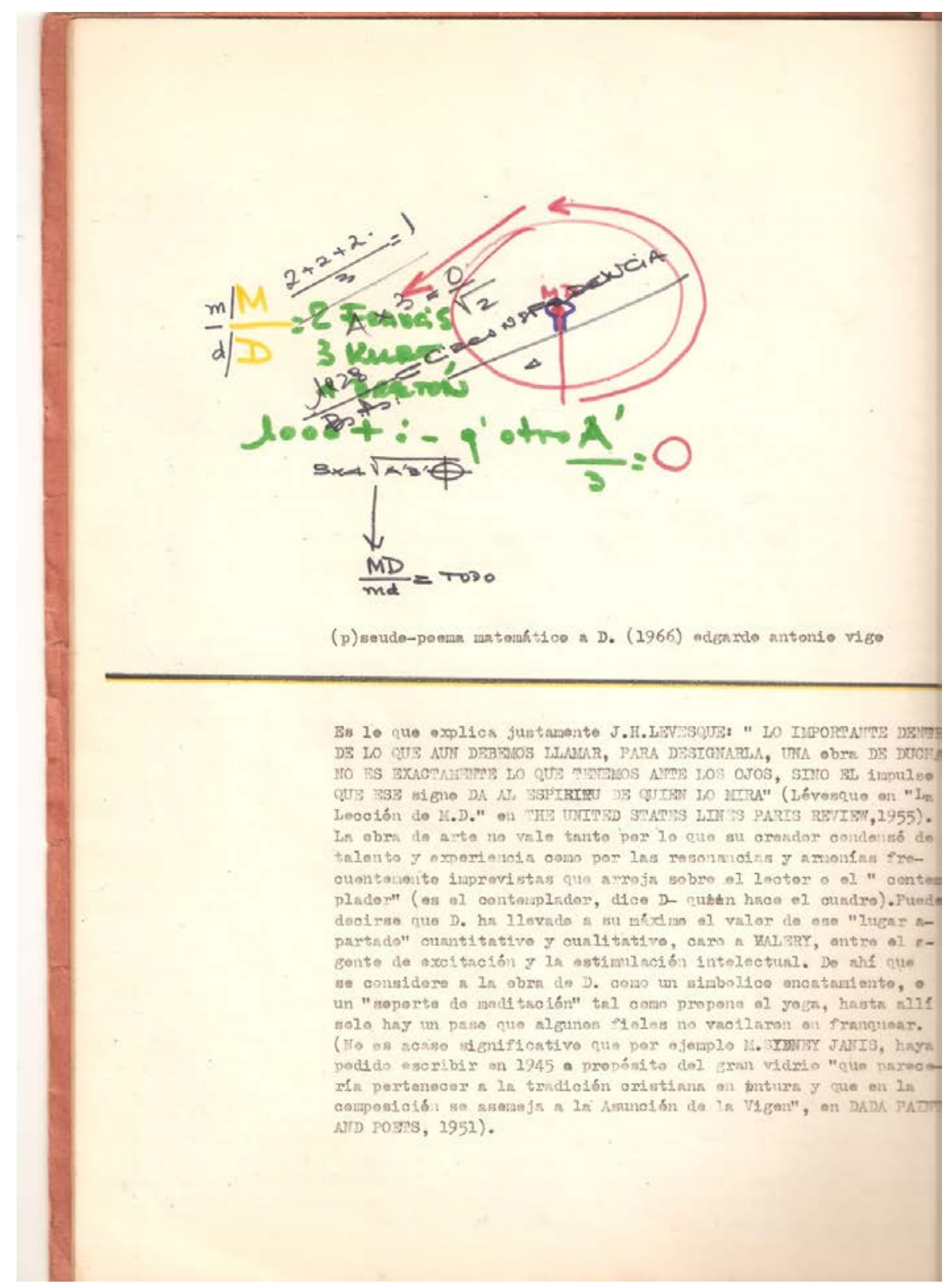

Fig. 35.Vendedor de Sal (1966) Traducción Elena Comas, diagramación y edición E. A. Vigo. Detalle: (pseudo) poema matemático a $D$.

El (pseudo) poema matemático a D cuenta con algunas inscripciones legibles que remiten a su repertorio de artistas: Francis [Picabia], Kurt [Schwitters], [Andre] Bretón, correspondencia, M. $D$ [Marcel Duchamp]. La inclusión de este poema matemático es una muestra más del carácter

\footnotetext{
${ }^{79}$ En la lectura de Gonzalo Aguilar, el procedimiento de los poemas matemáticos de Vigo se vincula con una apertura hacia lecturas críticas novedosas en tanto "Vigo propone el desencadenamiento por medio de números. Los números siempre estuvieron en la poesía: las canciones populares están constituidas por octosílabos, un soneto contiene 14 versos de 11 sílabas, lo que suma 152 sílabas. Un orden perfectamente orquestado que supone una serie de repeticiones, correspondencias y desplazamientos" (2016, p. 87).
} 
antropofágico que posee la apropiación en la obra de Vigo, las operaciones en las que el material leído y transcripto generan otras producciones. En este caso, la intervención estética sobre el ejemplar muestra que la mitad superior de la hoja se encuentra intervenida por Vigo, quien homenajea a sus referentes, mientras que la mitad inferior es la traducción del libro de Duchamp. En la hoja de la re-escritura conviven y se establece un diálogo entre temporalidades y estéticas. Como ha expresado el propio Vigo (1996), es a partir del año 1966 donde se produce un cambio sustancial en la revista Diagonal Cero, que coincide en nuestro estudio, con la re-escritura Vendedor de Sal y, como analizaremos en el capítulo siguiente, con las lecturas e intercambios con otras publicaciones. Silvia Dolinko afirma al respecto que:

Vigo comenzó a incluir páginas recortadas, perforadas y plegadas en la edición de setiembre de 1966. Dos números más tarde, la perforación del papel era trasladada a la portada. Mientras que la materialidad de la publicación se estaba desplazando hacia un diseño visual más experimental, también sus selecciones comenzaron a apuntar hacia la poesía visual. (2012, p. 105)

Un primer acontecimiento que deriva de esta re-escritura es su inserción en la revista Museo. En torno a esta publicación, Juliana López Pascual indica desde el 11 de abril de 1964, coincidentemente con la inauguración del $\mathrm{XXXIV}^{\mathrm{o}}$ Salón Regional de Arte, la dirección del MMBA comenzó a distribuir la revista Museo del Museo Municipal de Bahía Blanca ${ }^{80}$. Se editaron siete números hasta 1966, sin una periodicidad establecida (2009, p. 20). Respecto de las características de la revista, López Pascual explica que:

Las limitaciones materiales incidieron, sin dudas, para que el énfasis de la revista estuviera en lo textual, a pesar de lo cual se manifestó una preocupación por cuidar su presentación visual con los recursos disponibles. El tamaño dado por la mitad de una página oficio, el trabajo sobre asimetrías en el diseño gráfico de la mayor parte de las páginas, la heterogeneidad de la tipografía en los títulos y la inclusión de imágenes dan cuenta de una voluntad de aprovechar al máximo las posibilidades dadas por la elaboración a partir de esténcils para mimeógrafo y máquinas de escribir (2009, p. 20)

\footnotetext{
${ }^{80}$ Museo dirigido en ese entonces por Ubaldo Tognetti.
} 
El $n^{\circ} 7$ de la revista Museo $^{81}$ (1966) fue diagramada íntegramente por E. A. Vigo. Suponemos que algunos textos han sido sugeridos por la dirección de la institución en tanto no pertenecen al repertorio de Vigo. Estos textos serían: Introducción a la música del siglo $X X$ por Gabriel di Cicco, El Genio de Francisco Luisich, Poemas de Gloria Micci y el Discurso Inaugural de Enrique Ferracutti.

Claramente, la marca de Vigo está en el diseño, en la elección de tres textos (Arp, Mondian y Duchamp) y, probablemente, de la imagen de Libero Badii de la página 16. Vigo también es el autor de la xilografía "Mata". En la primer hoja de la publicación Museo, el artista platense compone con la frase "MUSEO NÚMERO SIETE” un bloque textual que, por la disposición del bloque, genera un efecto cinético. Incorpora fragmentos dispersos de textos de Arp, y "pensamientos" de Piet Mondrian, editados bajo una estética similar a las de sus primeras re-escrituras.

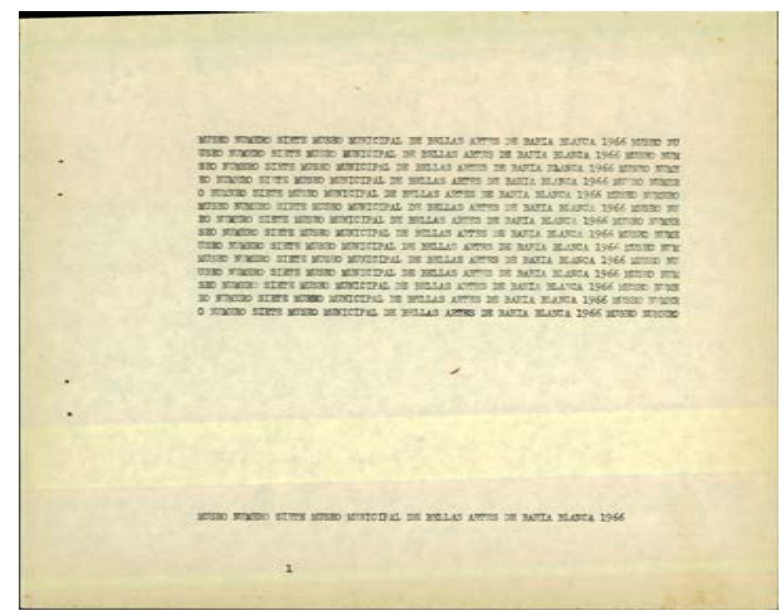

Fig. 36. Revista Museo, página 1, diagramación E.A.Vigo, “MUSEO NUMERO SIETE”.. Biopsia 1966. CAEV.

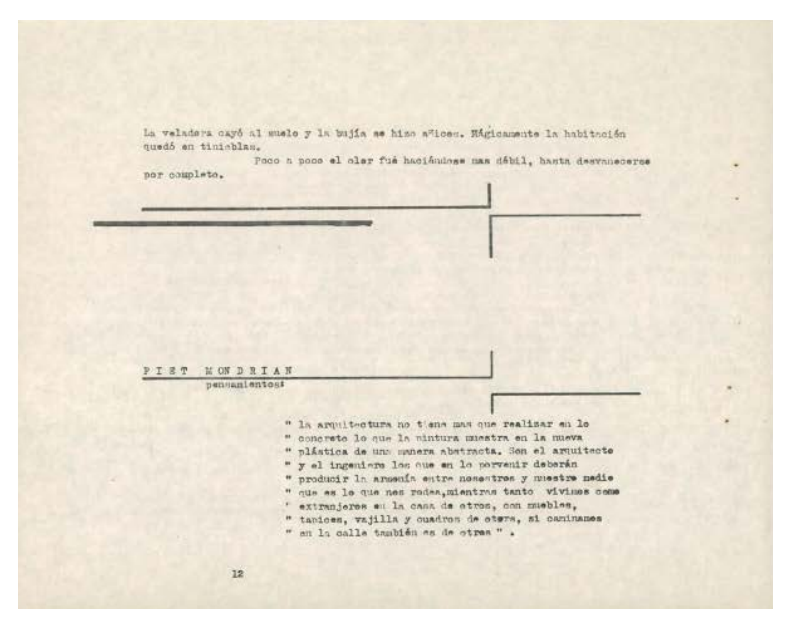

Fig. 37. Revista Museo, página 12, diagramación E.A.Vigo, “Pensamientos” de Piet Mondrian. Biopsia 1966.

CAEV.

\footnotetext{
${ }^{81}$ Biopsia 1966-1967.
} 
Hacia el final de la edición, sorprende encontrar fragmentos de la introducción de M. Sanouillet del libro Marchand $d u$ Sel que han sido traducidos en la re-escritura del mismo año. Atentos a la fecha de la re-escritura sería esta la primer traducción publicada del Marchand du sel en Argentina. Los "fragmentos" que se publican en la Revista Museo no son directamente de Duchamp pertenecen a la nota introductoria de M. Sanouillet.

En la hoja $\mathrm{n}^{\circ} 22$ de la revista Museo, vemos una línea curva, se superpone en letras mayúsculas mecanografíado el nombre Marcel Duchamp (a la manera de las composiciones con sellos de Vigo), los datos de la edición original del Marchand $d u$ Sel y la traducción por parte de Elena Comas.

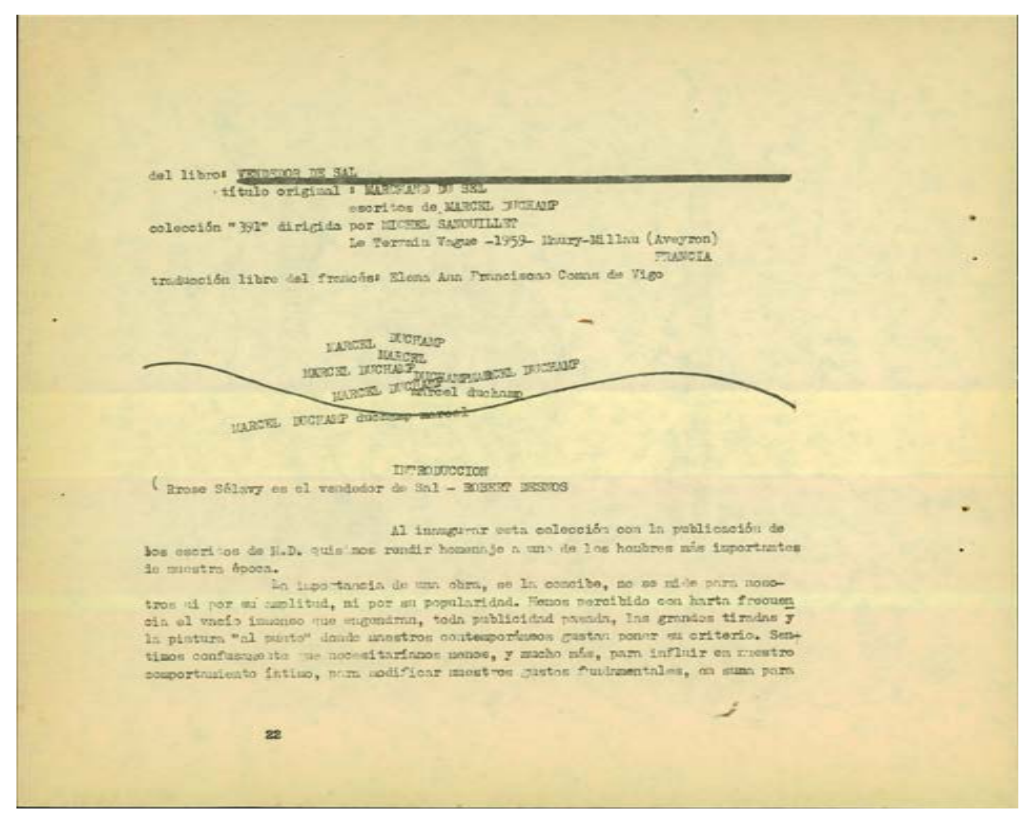

Fig. 38. Número 7 de la revista Museo, página 22, fragmentos del Vendedor de Sal, señala “traducción libre del francés: Elena Ana Francisca Comas de Vigo”, 1966

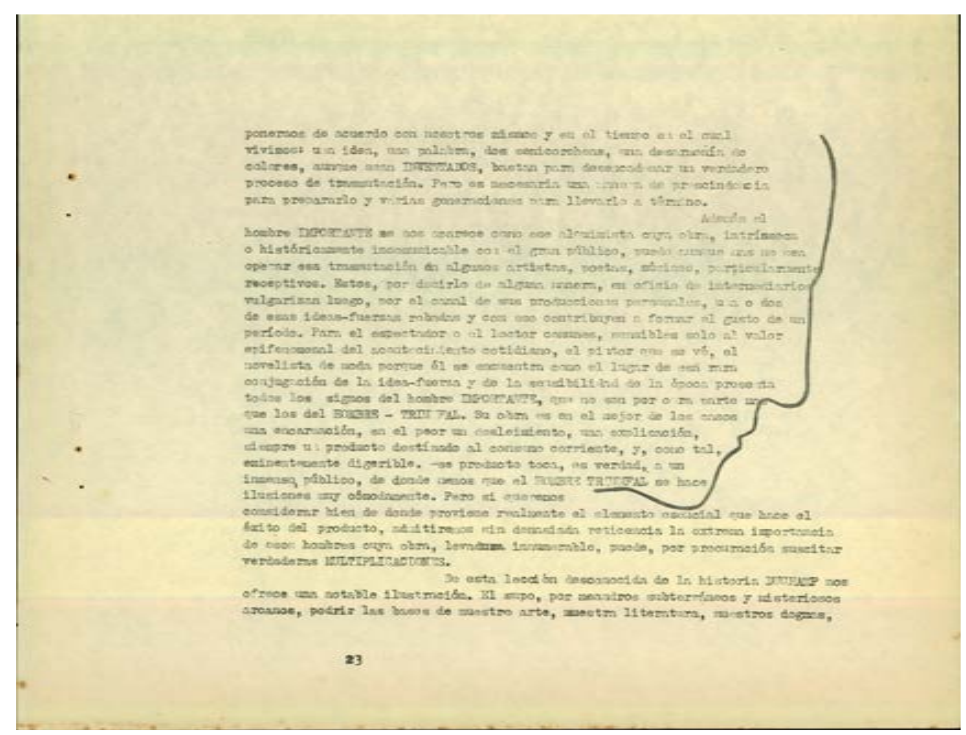

Fig. 39. Número 7 de la revista Museo, página 23. Fragmentos de la nota introductoria del Vendedor de Sal (1966).

Detalle de la silueta que también aparece en la primer hoja de la re-escritura. 
La publicación de la nota introductoria -extraída de la re-escritura Vendedor de Sal- en la revista Museo indica que Vigo pudo elegir qué fragmentos difundir de sus lecturas, de ellos seleccionó a tres de sus referentes: Mondrian, Arp y Duchamp. Además, a pesar de ser una edición con limitaciones materiales, presenta un trabajo compositivo como queda de manifiesto en las imágenes y la disposición de los párrafos.

Una segunda resonancia de la traducción de los escritos de Marcel Duchamp, la encontramos en el artículo publicado por Vigo en 1966 en el diario La Tribuna. El artículo se titula "Hacia un arte del objeto", Vigo menciona aquí la obra de Marcel Duchamp explicando que la preocupación del artista francés por la pintura se experimenta un alejamiento de los materiales nobles. La obra El Gran Vidrio implica una técnica distinta en su ejecución centrada en la conceptualización, el paso del tiempo, la rotura azarosa del vidrio que da por concluida la obra. Vigo establece vínculos entre el procedimiento duchampiano y la obra de Kurt Schwitters, entendiendo que estos fisuran las categorías tradicionales a partir de las cuales se ha estructurado el campo artístico (originalidad, autoría, uso del material, vínculo con las instituciones, entre otros).

La labor de Vigo como difusor continúa y en 1968, en el suplemento del diario El Día, publica una serie de artículos periodísticos. En el primero de ellos "Mitos Plásticos" (3-3-68, Biopsia) se explaya sobre la obra de Schwitters, Metz y la poesía fónica. El segundo, denominado "El Gran Vidrio", comienza caracterizando a Duchamp como un cultor de la innovedad. Afirma Vigo que el conocimiento de la obra de Duchamp a partir del "avance del estudio" sobre su obra, se proyectará hacia el futuro en tanto "M. D. es el MITO del artista actual” (Vigo, 1968), resuenan en estas consideraciones las reflexiones de Carrouges. Vigo señala que:

El avance del estudio sobre lo realizado por M. D. nos irá afirmando sobre estas posibilidades ciertas de proyección hacia el futuro. M. D. es el MITO del artista actual. $\mathrm{Su}$ prototipo. Para llegar a serlo no únicamente se mostró traslúcido, sino que también supo ocultar en "negruras" muchos de sus pensamientos. La puesta a luz de ellos es lo que mueve a los artistas actuales a investigarlo. La develación del misterio, incitación constante para el hombre que avanza (Vigo, El Día, 1968) 


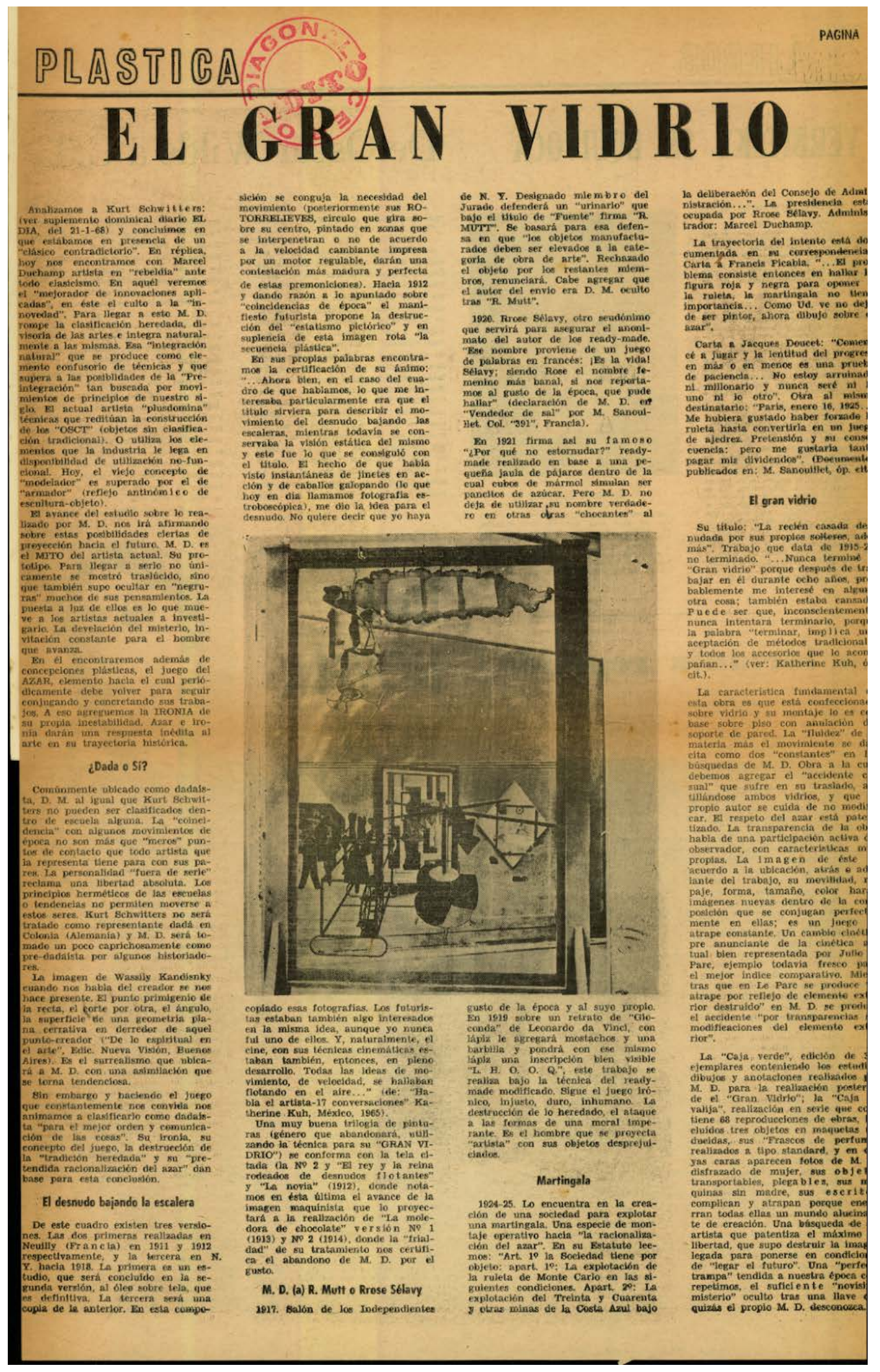

Fig. 40. Vigo, artículo "El gran Vidrio" aparecido en diario El Día, 1968. Archivo Biopsia. CAEV.

La lectura de Vigo de la obra de Duchamp es presentada en el artículo de manera cronológica. Comienza con Desnudo bajando la escalera (1912) y lo interpreta como antecedente de los 
experimentos ópticos utilizados en los rotorelieves ${ }^{82}$. El artículo continúa con el análisis de los heterónimos usados por Duchamp, R. Mutt y Rose Sélavy:

Rrose Sélavy, otro seudónimo que servirá para asegurar el anonimato del autor de los ready-made. "Ese nombre proviene de un juego de palabras en francés: ¡Es la vida! Sélavy; siendo Rose el nombre, femenino más banal, si nos retrotraemos al gusto de la época, que pude hallar" (Vigo, El Día, 1968)

En tercer lugar, en este artículo, Vigo menciona La Martingala, apartado transcripto íntegramente en su re-escritura del Vendedor de Sal. Se trata de la creación de una sociedad para explotar la martingala, "una especie de montaje operativo para explotar la racionalización del azar" (Vigo, El Día, 1968) Vigo transcribe en su nota fragmentos del estatuto de esta sociedad presidida por Rose Selavy ${ }^{83}$.

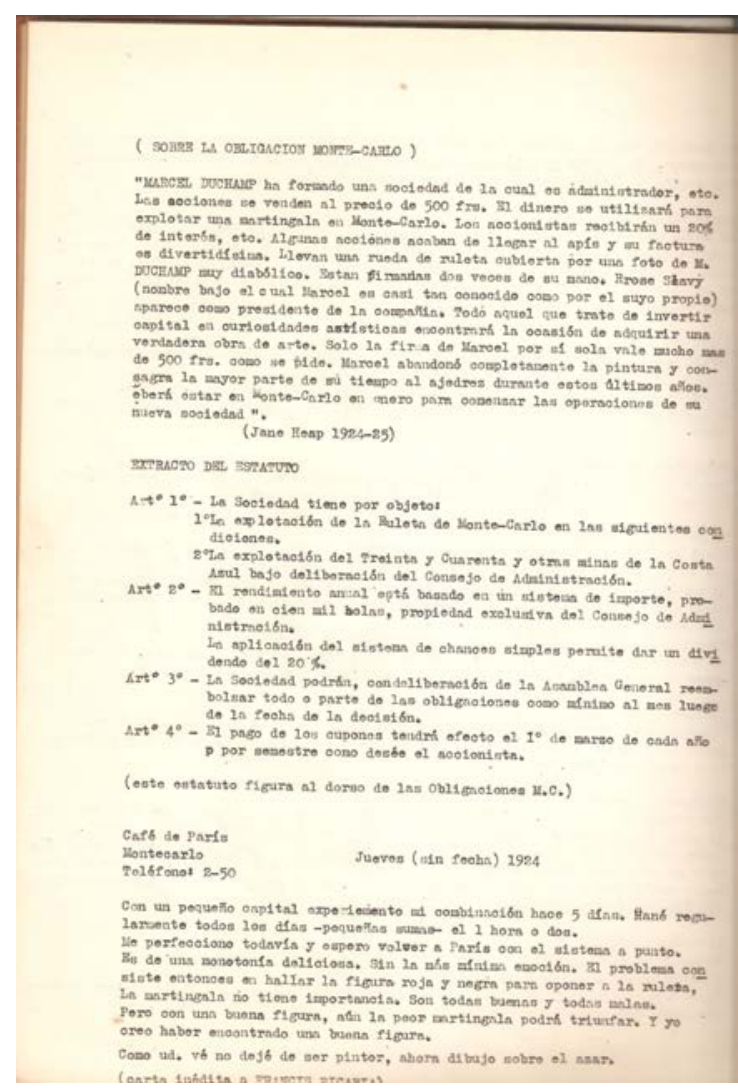

Fig. 41. Vendedor de Sal (1966). Traducción Elena Comas, diagramación y edición E. A. Vigo. Extractos del estatuto.

\footnotetext{
${ }^{82}$ Se trata de una serie de experimentos ópticos realizados por Duchamp en círculos con diversas composiciones que, al moverse generan efecto cinético. Encontramos en la biblioteca general de Vigo reproducciones de los mismos.

${ }^{83}$ Al igual de Duchamp, como señalamos en la primer parte del trabajo, Vigo en el transcurso de su carrera inventa seis heterónimos, uno de ellos es Don Rose Selavi II, que aparece como participante recurrente en Nuestro Libro Internacional de Estampillas y Matasellos.
} 
Por último, se menciona la obra El Gran Vidrio (1915-1923). En la lectura de Vigo:

La transparencia de la obra habla de una participación activa del observador, con características muy propias. La imagen de éste de acuerdo a la ubicación, atrás y adelante del trabajo, su movilidad, ropaje, forma, tamaño, color harán imágenes nuevas dentro de la composición que se conjugan perfectamente en ellas; es un juego de atrape constante. Un cambio cinético pre anunciante de la cinética a actual bien representada por Julio le Parc, ejemplo todavía fresco para el mejor índice comparativo. Mientras que en Le Parc se produce "el atrape por reflejo de clemente exterior destruido" en M. D. se produce el accidente "por transparencias sin modificaciones del elemento exterior". (Vigo, El Día, 1968)

Al referir al Gran Vidrio notemos que Vigo habla de participación activa del espectador, de un "juego de atrape constante", toma esta obra como antecedente de las experiencias ópticas de su contemporáneo, Julio Le Parc.

Creemos que la apropiación en Vigo del discurso de Duchamp podría funcionar por deglución antropofágica. Es decir, si la antropofagia se configura como una experiencia donde se aprovechan las virtudes de lo otro, alimento que se absorbe y re utiliza, cuando Vigo proyecta el "avance del estudio" sobre la obra de Duchamp se propone la misión de difundir y al mismo tiempo refiere a su propio proceso de estudio en torno a su referente. Si las re-escrituras son insumo para la producción intelectual, para su trabajo teórico y de divulgación, también lo son, vía apropiación, para la producción de obra.

\subsection{Tres (in) objetos}

Tres obras de E. A Vigo mantienen a fines de la década de 1960 relación directa con la obra de Duchamp y, sobre todo, con la re-escritura que nos ocupa. Referiremos en este apartado a estos tres (in) objetos poéticos: Poemas (in) sonoros, Un disco para mirar. (Diagonal Cero, 1969), Análisis (in) Poético de $1 \mathrm{~m}$. de hilo (Diagonal Cero, 1969) y Poemas matemáticos (in) comestibles (Diagonal Cero, 1968) ${ }^{84}$.

\footnotetext{
${ }^{84}$ Esta obra estuvo presente en la Expo Internacional de Novísima Poesía/69.
} 
En los tres casos se trata de "cosas" 85 - objetos poéticos donde la operación de apropiación realizada por Vigo se sustenta en la subversión -o irreverencia- respecto de los órdenes que propone la poesía tradicional así como los modos de lectura que esta implica.

Como hemos visto al comienzo, la noción de "máquina inútil”, extraída de Carrouges y con la que refiere a sus primeros collages, es un antecedente para la conceptualización que E. A. Vigo realiza de sus (in) objetos poéticos, en tanto permanece en esta acepción el prefijo de negación que problematiza su "utilidad".

\section{a) Poemas (in) sonoros}

Los Poemas (in) sonoros son ejemplares que Vigo edita bajo el sello Diagonal Cero en $1969^{86}$. El objeto consta de un sobre contenedor de cartulina blanca y en su interior un cartón rectangular negro con un círculo en medio. En el anverso del sobre contenedor, aparece el título en negro y la leyenda "Un Disco para mirar", y en color rojo el prefijo (in) entre las palabras poemas y sonoros, en rojo también el sello Diagonal Cero Editó. En el interior encontramos un cartón de color negro al que se adhiere un círculo de siete pulgadas con una hendidura en el centro. El círculo del centro posee líneas cerradas verdes concéntricas que culminan (o surgen) de la hendidura central. El círculo tiene también el título "Poemas (in) sonoros" en la parte superior del hueco y la inscripción "Edgardo Antonio Vigo" en la parte inferior, ambos textos están escritos en en letras mayúsculas sostenidas con color negro.
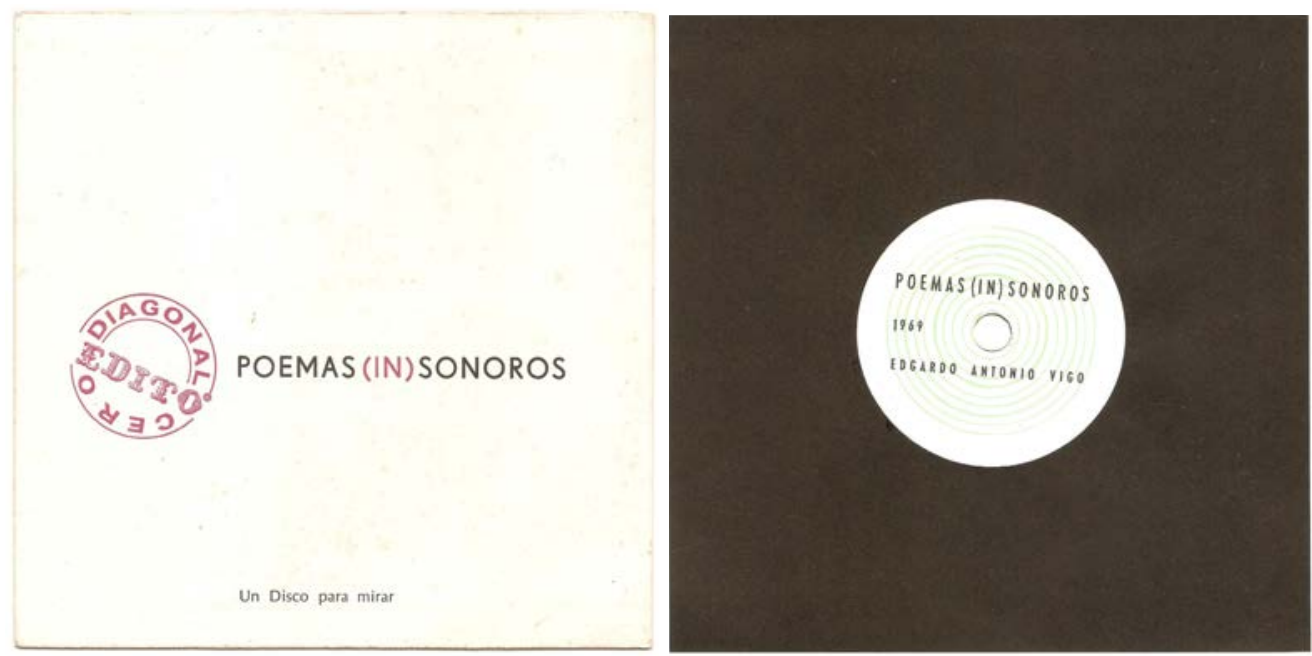

Fig. 42. Poemas (in) sonoros, Un disco para mirar. (sobre e interior) Diagonal Cero, 1969. CAEV

\footnotetext{
85 Se corresponde con la denominación de "Cosa trimestral" para referir a Diagonal Cero a partir del n 24 (1968) en 1968, también refiere a sus xilografías como "cosas visuales" (Biopsia, 1968)

86 De 1969 es también la primera obra sonora registrada de Vigo titulada "Homenaje a una pensión de estudiantes".
} 
Tanto el título como epígrafe de esta "cosa", intencionalmente, desorientan. En el sobre contenedor que funciona como tapa, se aclara que son "Discos para mirar". El epígrafe, que podría funcionar como presentación de la edición, implica una aparente contradicción, un corrimiento de los sentidos que el dispositivo "disco" implica, asociados principalmente a la escucha. Es decir, los Poemas (in) sonoros, se identifican con la palabra "disco" pero su soporte es el cartón, por lo que la palabra "disco" referiría, en este caso, a la forma circular que encontramos en su interior, no al dispositivo que almacena sonidos. Vigo juega, en la tapa de los Poemas (in) sonoros, con la homonimia, desconcertando al potencial lector.

En su interior, como dijimos, encontramos un rectángulo negro donde esta adherido un círculo. Las líneas concéntricas de color verde que se encuentran en el círculo central, podrían ser interpretadas como una representación de los surcos que persigue la aguja del vinilo generando sonido a partir de las irregularidades de las hendiduras del disco. A diferencia de aquellos, los "surcos" de los poemas (in) sonoros están hechos de tinta. En caso de que el potencial espectador participante decidiera reproducir los poemas (in) sonoros en un dispositivo, vería girar el círculo central generando un cuerpo cinético que se mueve sobre su eje.

Volvamos sobre el título y su intención desconcertante. Los poemas (in) sonoros problematizan el estatuto de lo poético, nos interpelan, ¿existe una poesía sin voz? ¿es posible una poesía silente? ¿la poesía es porque existe el sonido?. Si los discos no suenan, se miran, la preguntas también se dirigen al sonido. Mirar, ¿es escuchar?, la escucha ¿potencia la mirada?, el sonido ¿es un círculo que se observa?. Como vemos, estos poemas nos dejan más preguntas que respuestas. Por su parte, Marcel Duchamp produce, junto a Man Ray, "Anemic Cinema"87 (1926). Se trata de discos con composiciones geométricas o frases ordenadas de manera espiralada hacia el centro de la composición. Cuando el disco gira se transforma en un continuum de imágenes cinéticas, estos experimentos ópticos serán denominados por Duchamp como rotorelieves. Existen similitudes constructivas entre los rotorelieves duchampeanos y los poemas (in) sonoros de E. A Vigo en tanto el formato "disco" es análogo en ambos casos.

\footnotetext{
${ }^{87}$ Disponible en: https://www.youtube.com/watch?v=dXINTf8kXCc
} 


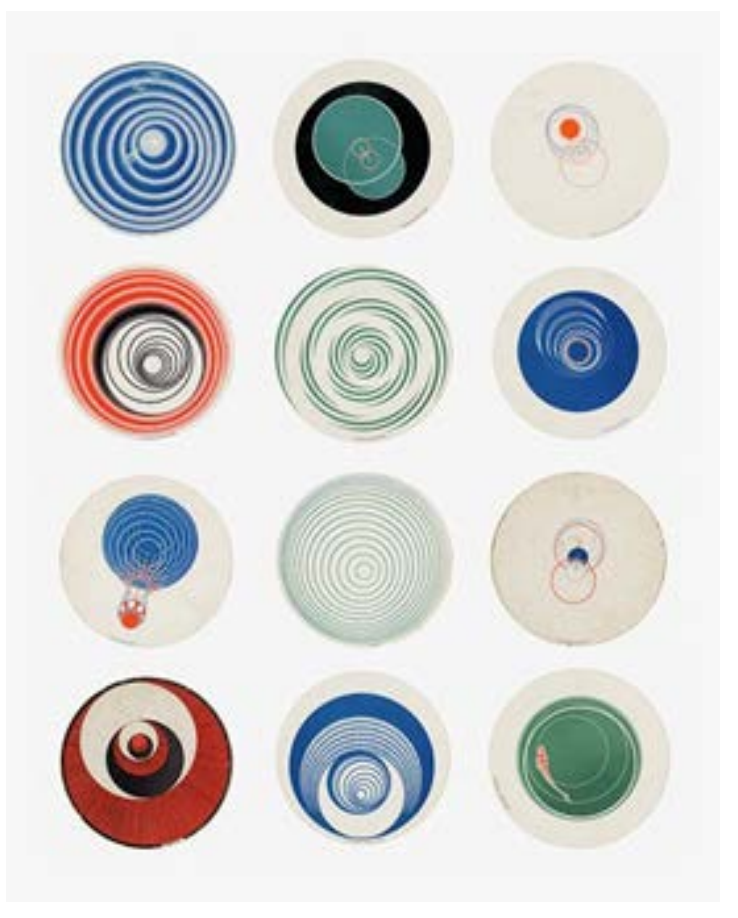

Fig. 43. Marcel Duchamp, Rotorelieves (1935) CAEV.

Recordemos que en los escritos traducidos por Comas y re-escritos por Vigo del Marchand $d u$ $\mathrm{Sel}$, existen imágenes sobre estos objetos y un desarrollo sintético por parte de Duchamp de su interés por las ilusiones ópticas que se generan con el movimiento. Por lo que, además de figurar los discos rotorelieves de Duchamp en su biblioteca, también Vigo tenía conocimiento bibliográfico de su existencia. Ahora bien, si la búsqueda de Duchamp se orienta hacia el movimiento físico de un cuerpo y sus modificaciones mediante la utilización de un dispositivo, Vigo se apropia del dispositivo disco propuesto por Duchamp en su materialidad y forma, para utilizarlo en función de sus propios intereses y preguntas, cuestionar el ritmo del poema, invitar a ese espectador a desnaturalizar la voz, la escucha y la mirada.

\section{b) Análisis (in) Poético de 1 m. de hilo (1970)}

La segunda obra, íntimamente relacionada con la anterior, corresponde a Análisis (in) Poético de $1 \mathrm{~m}$. de hilo $(1970)^{88} \mathrm{y}$ puede vincularse con los experimentos duchampeanos plasmados en “Azar en Conserva" o "Zurcido de Patrón” como aparece nombrado en Marchand du Sel.

En el punto 5 de los textos compilados en el apartado Caja 1914 del Marchand $d u$ sel, , la nota “Azar" dice: "Si un hilo recto horizontal de un metro de longitud cae desde un metro de altura desde un plano horizontal deformándose a su aire y da una nueva figura de la espacialidad de

${ }^{88}$ Consta en Biopsia que se hicieron 180 ejemplares. 
longitud" (1975, p. 43); esto corresponde a la "modificación en la unidad de longitud" puesto que cuando se deja caer el hilo éste adquiere una forma azarosa. Además, en las notas "A propósito de mi mismo" (1975, p. 195), explica Duchamp el proceso de esta experiencia:

(3 Zurcidos-patrón): (...) cada banda propone una línea curva hecha por un hilo de coser de un metro de largo, después de caer desde una altura de 1 metro, sin que la distorsión del hilo durante la caída quede terminada. La forma así obtenida se fijó en la tela por medio de gotas de barniz... Tres reglas... reproducen las tres formas distintas obtenidas por la caída del hilo y pueden utilizarse para trazar a lápiz estas líneas sobre el papel. Esta experiencia se realizó en 1913 para aprisionar y conservar formas obtenidas por mi azar. Simultáneamente, la unidad de longitud: un metro, se transformaba de línea recta a línea curva sin perder efectivamente su identidad en tanto que metro, pero creando, no obstante una duda patafísica sobre el concepto según el cual la recta es el camino más corto entre dos puntos (Duchamp, 1975, p. 195)

Ramírez aporta otras precisiones sobre la obra:

Duchamp cortó después estos lienzos y los pegó sobre placas de cristal, las cuales se encerraron, a su vez, en una caja de madera cuidadosamente elaborada. La obra recibió el añadido de unas reglas de madera recortadas con la forma curva de los hilos: se dice que fueron hechas como patrones para trasladar estas «unidades de medida» a los tubos capilares del Gran Vidrio (1994, p. 35)

Azar en conserva o 3 zurcidos-patrón corresponde al estudio del "fenómeno de alargamiento en la unidad de longitud" (1975, p. 43) en palabras de Duchamp, se corresponde con un fragmento del estudio para el complejo Gran Vidrio. 


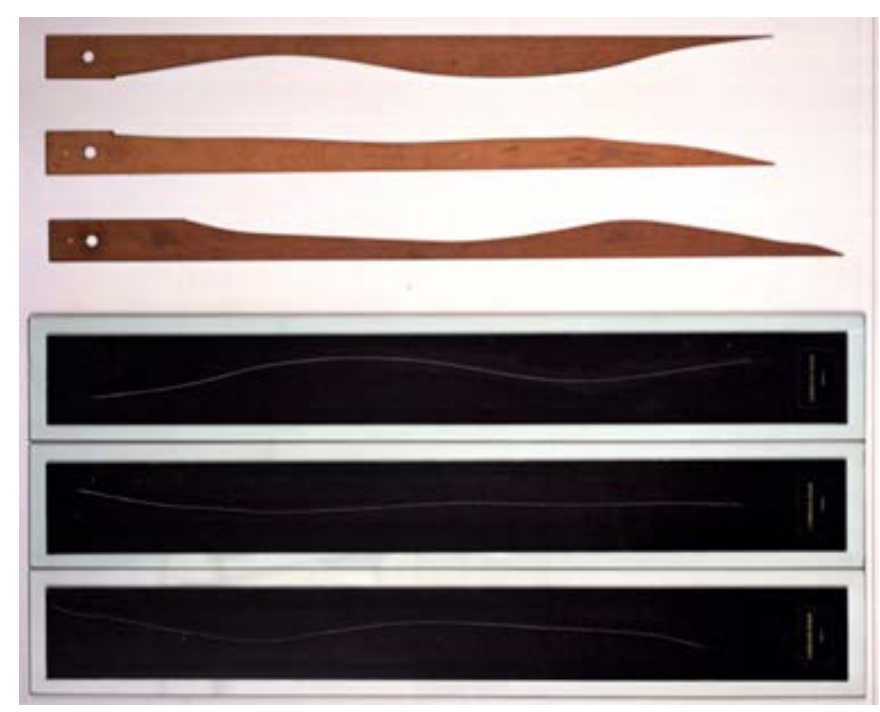

Fig. 44. Marcel Duchamp, Azar en conserva/3 Zurcidos-patrón (1913-1914). En la parte superior de la obra vemos las tres reglas de madera que representan la silueta del hilo cuando cae. En la parte inferior, los tres lienzos de tela azul donde se ha marcado la caída.

La obra de Vigo, Análisis (in) Poético de $1 \mathrm{~m}$. de hilo, consta de 1 metro de hilo ${ }^{89}$ de algodón en cuyos extremos se lee "principio" y "fin". Posee dos variantes: en la revista experimental montevideana OVUM 10 (1969-1975) $\mathrm{n}^{\circ} 10$ (1970) ${ }^{90}$ dirigida por Clemente Padín, fue publicado envolviendo (o atando) la revista con la cuerda que dice "principio" y "fin". En segundo lugar, la obra se presenta rodeando un cartón rectangular de 24 x $10 \mathrm{~cm}$ con dos hendiduras circulares simétricas en la parte inferior. Este cartón, posee en la parte superior un ojal con la etiqueta "La Marca de Vigo" y otra, de forma triangular con el título de la obra “Análisis (in) Poético de $1 \mathrm{~m}$. de hilo" (1970). Decimos que son dos variantes de la misma obra porque en la revista OVUM 10 se respeta el título Análisis (in) Poético de $1 \mathrm{~m}$. de hilo, además, es constante en la publicación de Padín la incorporación, en muchos casos, de objetos (fósforos, curitas, alfileres).

Análisis, es, como los Poemas (in) sonoros, una provocación. Aquí el prefijo “in", entre paréntesis se encuentra adelante de la palabra "poético", sugiriendo el carácter improductivo de

\footnotetext{
${ }^{89}$ Como ha señalado Bugnone (2013) la utilización del hilo en la obra de Vigo fue una constante en su carrera, puede verse como conector de dos elementos o como parte de un montaje. El hilo se convierte "en un aspecto que rápidamente se identifica con la materialidad de su poética. Es otra de las formas por las que Vigo captó una de las prácticas judiciales - también extendida a otros ámbitos, como la archivística- haciéndolas parte de su poética. Si bien son pocos los casos en que Vigo utiliza el hilo específicamente para coser en sus obras, su incorporación a la obra de arte, aún desvinculada temática y discursivamente del mundo judicial, remite a la práctica de los tribunales, hechos en los que asume, nuevamente, un uso dislocado de ese ámbito en el de la creación artística." (2013, p. 240)

90 Dirigida por Clemente Padín, su antecedente corresponde a Los Huevos del Plata (1965 a 1969). Esta última está incluida en la sección de la Novísima Poesía, Vigo publica en ella $(P)$ op matemático en 1968.
} 
medir con un metro de hilo un verso. Como en el epígrafe de los Poemas (in) sonoros, "Un disco para mirar", un metro de hilo apela intencionalmente a literalidad, el extrañamiento y desconcierto se produce en la palabra "poético" del título. Vigo sigue indagando sobre la poesía, en este caso, desde la estructura métrica y sus regularidades formales, su estructura: sílabas, acentos, rimas. Podríamos considerar también, que esta obra, en tanto "Análisis", contínua en la misma indagación de otra arista de sus Poemas Matemáticos Barrocos -con sus medidas y cuentas delirantes-.

Creemos que la apropiación de los postulados duchampeanos se produce en el juego que la obra propone con la métrica del poema y la medida del verso. Como hemos visto, Vigo, a partir de la traducción del Marchand $d u$ Sel, conocía la existencia de Azar y las reflexiones de Duchamp. Notemos las diferencias en los títulos: la obra de Duchamp, Azar en conserva/3 Zurcidos-patrón, responde al caso fortuito, accidente no controlado por el sujeto. Análisis, en cambio, remite a la reflexión, el estudio y la observación de un hecho. La obra de Vigo indaga en la pregunta por la medida del poema, proporcionando al participante programador -en términos de Vigo- un elemento para hacer la experiencia. Si la obra anterior se preguntaba por el sonido, Análisis disloca los sentidos asociados a la medida y la extensión del verso tradicional.

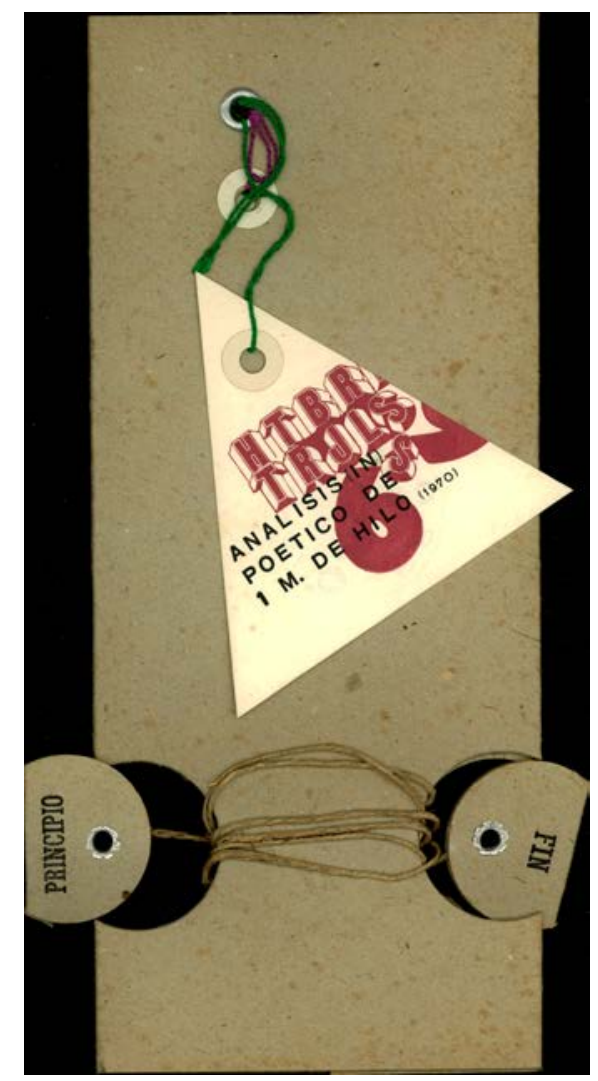

Fig. 45. Análisis (in) Poético de $1 \mathrm{~m}$. de hilo (1970). Edgardo Antonio Vigo. CAEV 


\section{c) Poemas matemáticos (in) comestibles}

Hemos analizado en los casos anteriores, lo que consideramos apropiaciones por parte de E. A. Vigo de algunos procedimientos y dispositivos duchampeanos. Consideraremos a continuación, la obra Poemas matemáticos (in) comestibles (Diagonal Cero, 1968) ${ }^{91}$ en vínculo con el ready made de Duchamp titulado Ruido Secreto (1916) a partir de los continentes propuestos y su concepto ${ }^{92}$.

La obra Poemas matemáticos (in) comestibles consta de una serie de latas de sardina cerrados herméticamente con una etiqueta rodeando la lata. Se encuentran protegidas por una caja de cartón de 11 x 10 × $3 \mathrm{~cm}$. En dos de los laterales, la caja posee aberturas circulares; en la parte superior, lleva impresa la inscripción "Poemas matemáticos (in) comestibles". Las latas están selladas, poseen una etiqueta que consigna el título, acompañando la forma circular y, en su interior, un objeto al cual el espectador - programador no tiene acceso. Este objeto esta “escondido", al sacudir la lata suena.

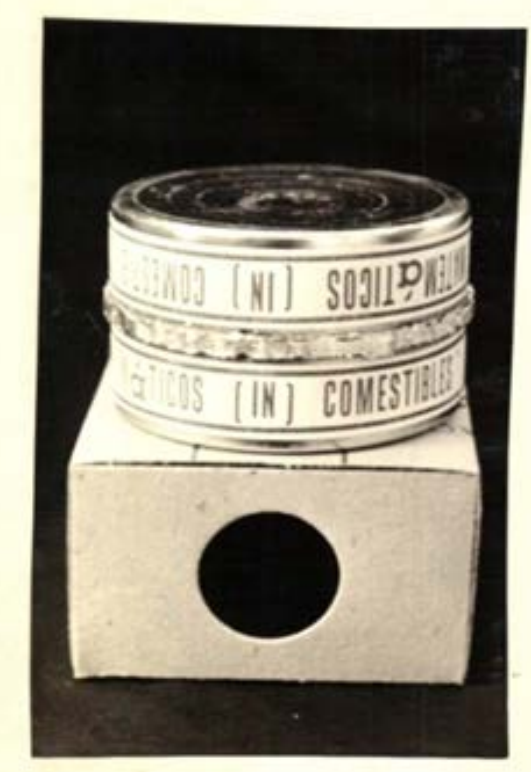

Fig. 46.Poemas matemáticos (in) comestibles, Diagonal Cero, 1968. CAEV

El propio Vigo, en el Catálogo para la Novísima, se explaya sobre la condición expandida de este formato, señalando que:

\footnotetext{
${ }^{91}$ En Biopsia 1968 consta que se produjeron 100 ejemplares de esta obra.

${ }^{92}$ Merda d'artista (1961) de Piero Manzoni, presenta características similares en lo que respecta al envase como continente.
} 
La utilización del "envase" en producción seriada elimina al libro como vehículo de comunicación fundando un Arte Tocable, donde "el objeto seriado" cumple una función estrictamente lúdica. A diferencia del surrealismo que subjetiva el misterio a través de la metáfora, el uso del "envase hermético" objetiva el concepto de misterio. (Vigo, Catálogo Di Tella, 1969)

En el artículo, No tanta Risa publicado en Primera Plana (1968), se conceptualiza de esta manera los objetos-poéticos que nos ocupan:

Poemas matemáticos (in) comestibles, una broma que no lo es tanto al rato de pensarlo. Se trata de tomar dos latas de conserva de pescado, vacías, y soldadas reconstruyendo una nueva lata: en su interior, un objeto indeterminado produce un suave rumor cuando se agita el envase. Obviamente, el contenido de la lata es el contenido del poema: abrirla equivale a destruir el poema, convertir en explícitos sus significados secretos. Vigo espera envasar cien poemas con ese procedimiento y colocarlos en el mercado. (Primera Plana, 1968, Archivo Biopsia.)

Álvarez Martín lee en estos poemas que:

La obra no se niega a ser revelada, por el contrario, determina una posición infinitamente más creativa que la literatura misma. Un solo envase de poemas podría generar una multiplicidad de imágenes mentales vedadas para la poesía escrita por cuanto en esta la imagen ya ha sido fijada con antelación, el envase no permite a priori imagen alguna solo aquella del misterio encerrado" (1991, p. 6)

En el catálogo para la XXII Bienal de San Pablo (1994), Basualdo advertía la cercanía de los Poemas (in) comestibles con la obra de Duchamp, pero no tenía en cuenta en su afirmación el seguimiento preciso que Vigo hace de la obra duchampiana desde mediados de la década de 1950, puesto que en el texto el autor señala que: "cuando en 1968 Vigo realizó sus poemas matemáticos (in) comestibles (...) seguramente ignoraba que el sonido hermético que su trabajo atesoraba ya resonaba con el otro ready-made asistido el del ovillo que Duchamp encerró en 1916 entre dos placas metálicas” (1994, p. 8) en este sentido, creemos, por la bibliografía 
disponible y la argumentación que venimos sosteniendo, Vigo si poseía un conocimiento preciso de la obra de Duchamp desde 1950.

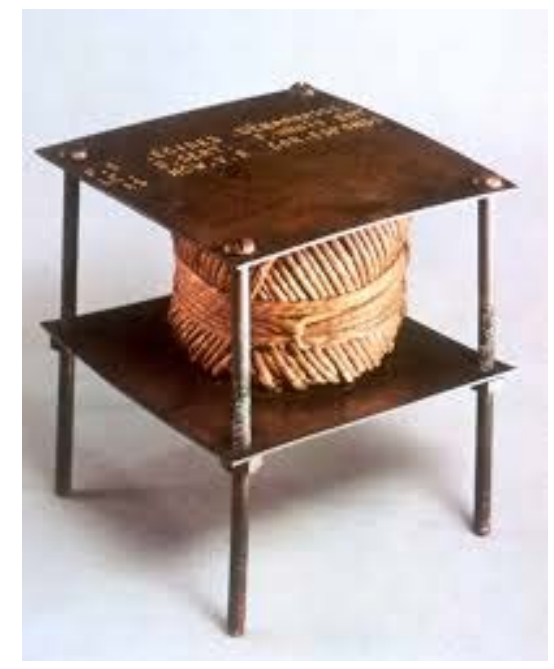

Fig. 47. Marcel Duchamp. Un ruido secreto (1916).

Un ruido secreto (1916) consiste en un ovillo de hilo (que funciona como envase) encorsetado entre dos planchas de cobre mediante cuatro tornillos. Según la descripción de Duchamp, publicada en Marchand $\mathrm{Du} S \mathrm{Sel}$, se trata de:

(Con ruido secreto) Tal es el título de este ready made ayudado: un ovillo de cordel entre dos planchas de cobre unidas por cuatro tornillos largos. En el interior del ovillo de cordel Walter Arensberg, añadió un secreto en un pequeño objeto que produce un ruido cuando lo sacuden. Y desde entonces ignoro de qué se trata, ni yo ni nadie lo sabe. En las planchas de cobre, inscribí tres breves frases omitiendo algunas letras a voleo como un rótulo de neón cuando tiene una letra fundida y convierte la palabra en algo ininteligible (1975, p. 196).

José Luis Brea apunta sobre esta obra que:

Funciona como una máquina construida con la finalidad de producir el secreto en su interior, de producirse a sí mismo como enigma. Su título apunta así a nombrar esta misma condición - de máquina célibe que se autoproduce como máquina enigma- como dispositivo productor de secreto, de un sonido secreto, de un sentido secreto (1996, p. 5). 
Si bien hemos analizado posibles vías de acceso a los objetos poéticos de E. A. Vigo, interpretando los mismos como apropiaciones de postulados duchampeanos, una primer gran diferencia conceptual radica en la reproductibilidad de los mismos. Mientras Vigo realiza ediciones seriadas de sus (in) objetos (se consignan 100 ejemplares de Poemas matemáticos (in) comestibles, 180 de Análisis (in) Poético de $1 \mathrm{~m}$. de hilo en las Biopsias respectivas), las producciones de Duchamp, según la bibliografía consultada, no fueron concebidas para su reproducción seriada como objeto.

Una segunda cuestión radica en que las tres obras analizadas configuran su título por la negativa, el prefijo "in" entre la marca textual que proporciona el paréntesis. Contribuye a lo que otros autores han denominado como dislocamiento en la poética de E. A. Vigo a partir del recurso del oxímoron. En concordancia con lo señalado por Octavio Paz respecto del concepto de ready made, éste "no postula algo nuevo, es un dardo respecto de lo que llamamos valioso" (1968, p. 31), las negativas de Vigo son rupturas respecto del orden naturalizado de las palabras. Así, el prefijo negativo disloca e irrumpe con el modo de experimentar, leer y encontrar sentido en la poesía. Las obras presentadas bajo el sello Diagonal Cero se corresponden con determinados procedimientos de apropiación por parte de E. A. Vigo de los postulados duchampeanos, recuperando de ellos justamente el aspecto lúdico, misterioso y punzante para hacer otra cosa con el poema. En concordancia con el planteo de Andrea Giunta en Adiós a la Periferia (2013), podríamos decir que la lectura de Vigo sobre las vanguardias históricas, particularmente de la obra de Duchamp, no solo revisa y estudia, también lo reformula y lo hace estallar desde su propia poética. 


\section{Artículos sobre vanguardia}

\subsection{Selección A}

En la presente selección analizamos un ejemplar de re-escrituras de mediados de la década de 1950 que figura en el Cuadro 4 de la primer parte de esta tesis. Hemos indicado que dentro de la Serie Escritos Personales encontramos libros completos traducidos y selecciones de artículos compilados por la dupla Comas Vigo en las re-escrituras.

La Selección A esta encuadernada, las hojas se encuentran unidas mediante dos ganchos en el lateral izquierdo. El tamaño del ejemplar es de 27,5 x $21 \mathrm{~cm}$., no posee índice y cuenta con los siguientes títulos:

1) Documentos de Van Doesburg, ensayo de Camille Bryen que plantea un recorrido cronológico por la obra del artista y citas del mismo;

2) La estética de John Dewey por Samuel Ramos;

3) Transcripción en francés y luego en español un artículo de Max Bill extraído de Arte Madi ${ }^{\circ}$ 7 y 8 (1954),

4) El Hogar, la ciudad, la calle textos de P. Mondrian, aparecido en Art d'aujourd'hui $n^{\circ} 5$ (1949),

5) Piet Mondrian y los orígenes del Neoplasticismo por Michel Seuphor Art d'aujourd'hui ${ }^{\circ} 5$, 1949),

6) El Caballero Azul por Will Grohmann (L' oeil n 9, 1955).

Hemos seleccionado está re-escritura porque nos interesa el trabajo estético que propone operando a la manera de muestrario en torno a la disposición y ordenamiento posible de los párrafos. A diferencia de las re-escrituras que siguen, en la Selección A no hay ninguna intervención compositiva con círculos o líneas de tinta, tampoco imágenes. El protagonista de la composición es el párrafo y sus posibilidades. 


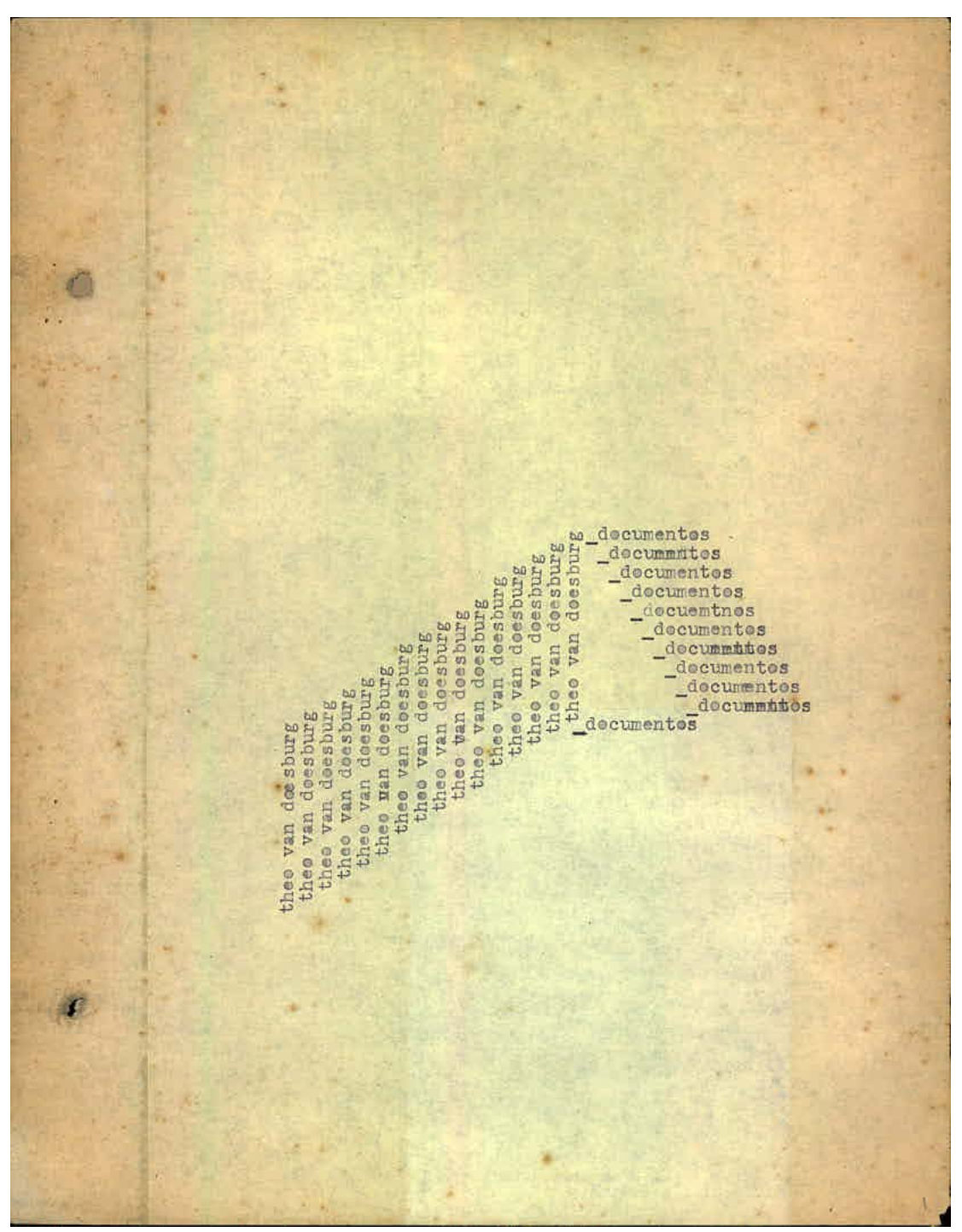

Fig. 48. Theo Van Doesburg, documentos. Re-escritura Selección A. Traducción Comas, edición E. A. Vigo (pag. 1)

Podríamos decir de manera general que, entre los seis artículos que conforman la Selección A, el que resulta más tradicional y sistematizado en forma de "bloque textual" corresponde al texto de Samuel Ramos "La estética de John Dewey”; el más heterodoxo en la construcción sería el desarrollo sobre "Los orígenes del Neoplasticismo". Entre estos dos extremos, la re-escritura indaga tanto en la palabra como materialidad y su espacialidad, como en la potencialidad de las formas de lectura. 


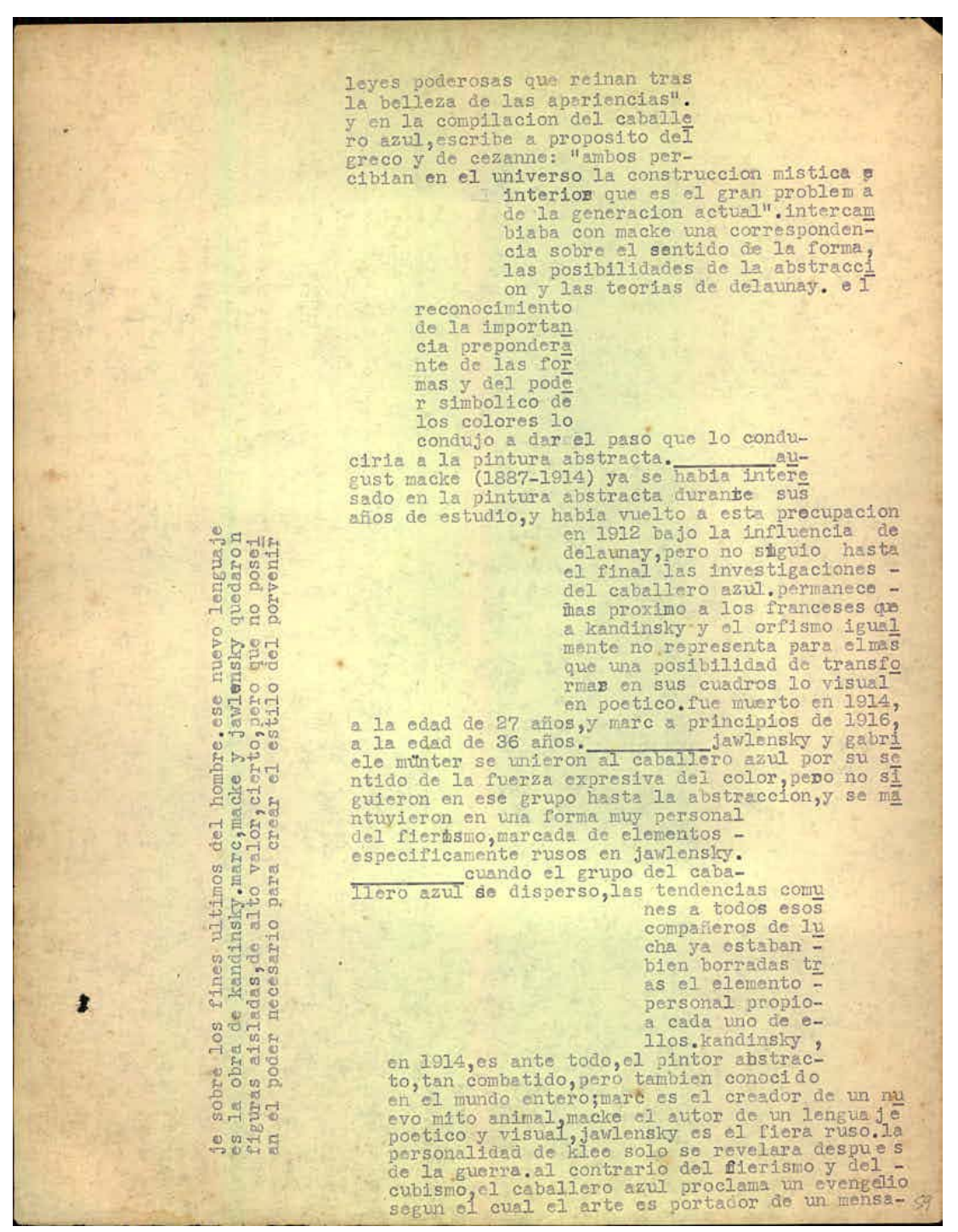

Fig. 49. El Caballero Azul. Re-escritura Selección A Traducción Comas, edición E. A. Vigo (Pag. 59)

\begin{abstract}
Al igual que Carlos Ríos, en su poemario Un shock póstumo ${ }^{93}$, donde se propone en una escritura ligada al dibujo a golpes de enter, la entrada a cada uno de estos textos es, por lo menos, doble; en su visualidad y en el contenido. Los textos de la Selección A están "encorsetados” por una forma orgánica $\mathrm{o}$, si se quiere, conformando una nueva organicidad desde la propuesta de escritura. Se trata del ordenamiento de la palabra a partir de una composición que utiliza el blanco como parte de un sentido a construir. El trabajo que realiza la dupla Comas-Vigo en la presente selección de artículos comparte el golpe de enter (o tabulador, para usar un término contemporáneo a la máquina de escribir que utilizaba Vigo) con el trabajo de Ríos, desde distintas tecnologías de escritura. Como hemos indicado en la primer parte de este trabajo, en ningún caso hay interés por la modificación del contenido del texto, de lo que se dice, la modificación sustancial radica en la forma.
\end{abstract}

${ }^{93}$ Ríos, C. (2017) Un shock póstumo. Rosario. EMR. 


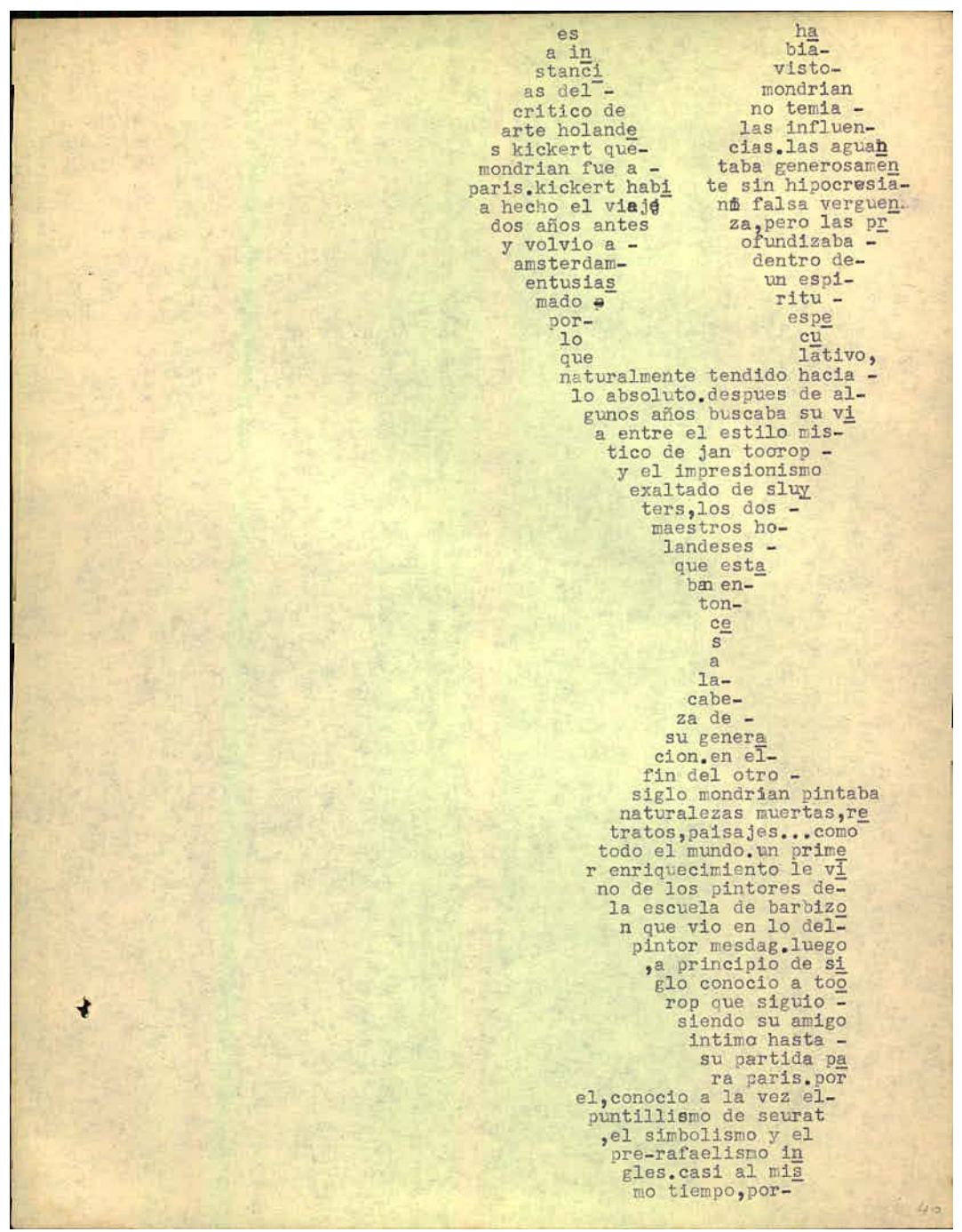

Fig. 50. Re-escritura Selección A Los orígenes del Neoplasticismo.Traducción Comas, edición E. A. Vigo (Pag 39) CAEV.

Los bloques de palabras en los que se organizan los textos más disruptivos de esta re-escritura Documentos, El Hogar, Orígenes y Caballero azul- se distancian del ordenamiento del párrafo tradicional, puesto que en cada hoja se establece una alineación que propone una lógica propia. No es una construcción del párrafo aleatoria sino una matriz concebida intencionalmente, en el sentido en que cada párrafo se adecúa a la silueta de una forma específica no azarosa. A la manera de los antiguos ordenamientos griegos de la palabra en bloques de imágenes aglutinados bajo el término technopaegnia, el ordenamiento heterodoxo de los párrafos que propone Vigo responde al hecho de favorecer el aspecto visual por sobre el contenido del texto. Notemos, sin embargo, que, a diferencia de las composiciones poéticas donde la estructura del texto se ve modificada por la forma del mismo, en el caso de esta selección de artículos, el contenido del texto no es de índole poético, son textos teóricos donde lo que se modifica es la composición del párrafo. 


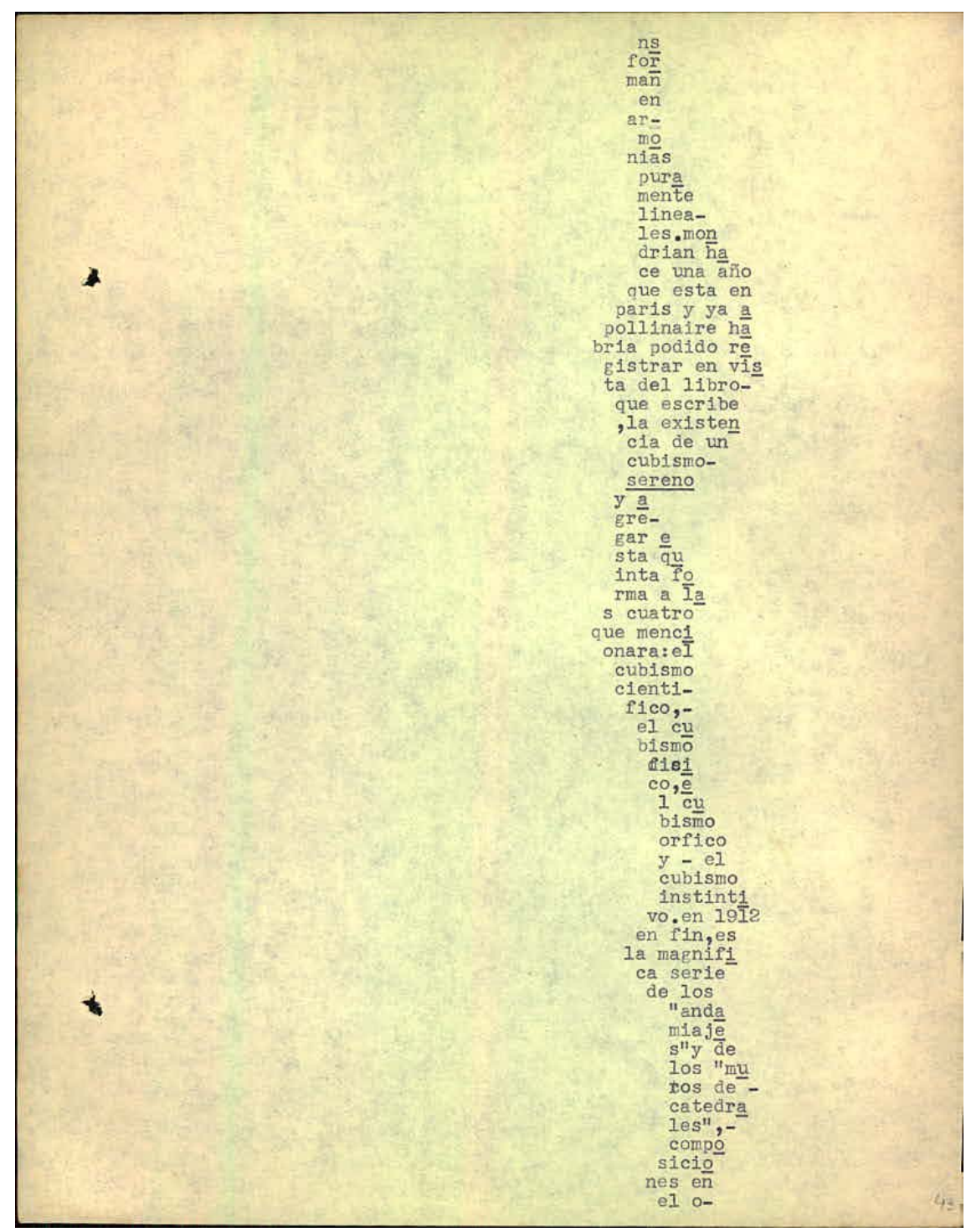

Fig. 51. Re-escritura Los orígenes del Neoplasticismo. Re-escritura Selección A. Traducción Comas, edición E. A. Vigo (Pag 43) CAEV.

El contenido del texto original lee salteado en tanto se encuentra condicionado por el espacio que ocupa el texto, obligando al receptor de este experimento a otro tiempo de lectura. Podríamos considerar que la forma genera un retardo en la lectura, como si recién nos iniciamos en el acto de leer. Lo anterior lleva a preguntarnos qué lectura se construye en esta arquitectura de la palabra, la originalidad que propone esta edificación tiene que ver tanto con el contenido como con la forma en que se presenta y los desafíos que implica para el lector.

En la construcción del caligrama, estructura que podría emparentarse con la forma de esta re-escritura, se desarrolla un poema, sin embargo, en los artículos seleccionados por Vigo y traducidos por Comas, el contenido corresponde a textos sobre historia del arte que no entrarían dentro de la categoría de "poéticos" en tanto su búsqueda es principalmente teórica. En el caso de Los orígenes del Neoplasticismo, Seuphor desarrolla la pintura de Mondrian respecto de a las tres etapas de su producción (Holanda, Paris, N. Y), la retícula, los colores y su aspecto 
carcelario; mientras tanto Vigo hace rombos con las palabras, corta sílabas sin tener en cuenta la gramática, su juego es corresponder la palabra con la forma. El texto debe adecuarse a ella. Está componiendo una obra en esta re-escritura, usando la palabra como bloque, la frase como textura.

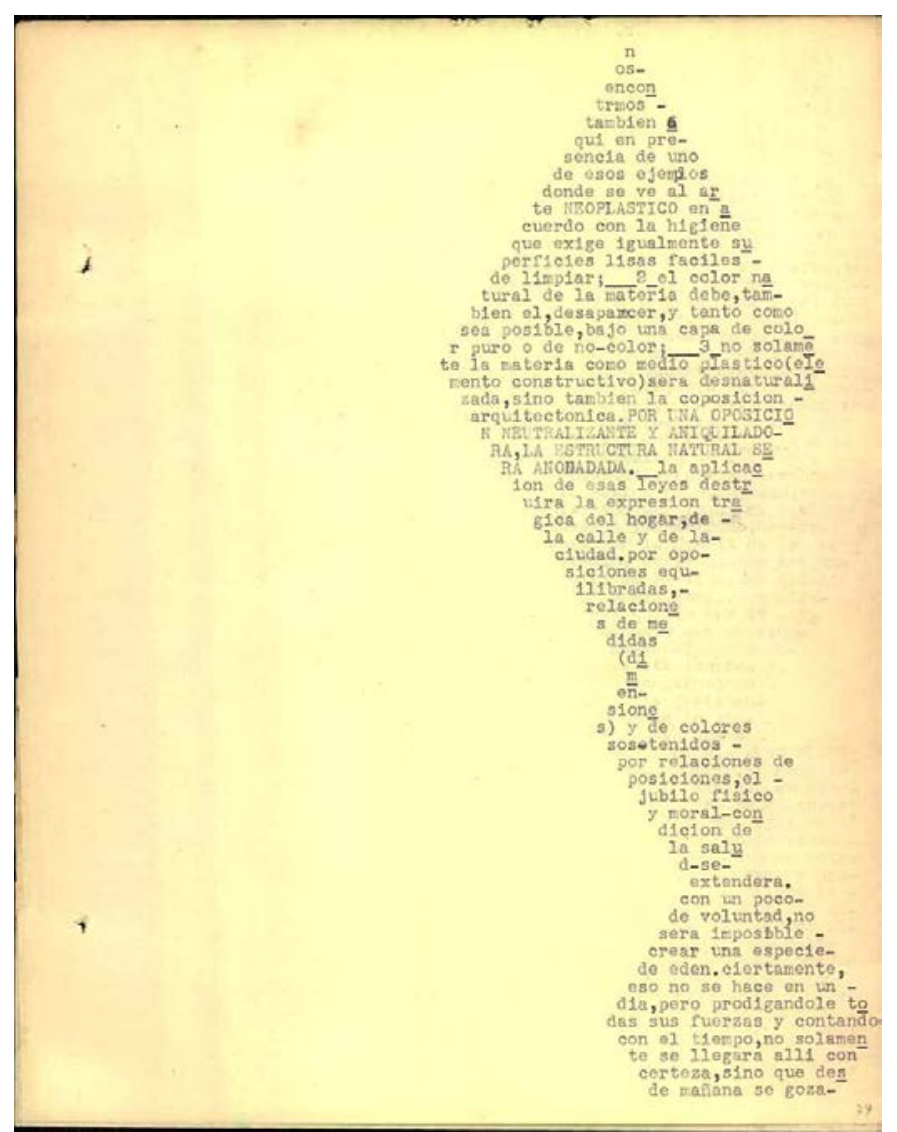

Fig. 52. El Hogar, la ciudad, la calle de P. Mondrian. Re-escritura Selección A. Traducción Comas, edición E. A.

Vigo (Pag. 33)

En la re-escritura lo no dicho significa tanto como lo dicho porque la forma elegida se distancia del contenido del texto, es decir, no funciona de manera ilustrativa. Una tradición historiográfica que se re-escribe, como apropiación, desde su forma. La apropiación funciona aquí como devoración crítica, antropofágicamente haciendo propio lo otro (el texto) mediante su transcripción, acción que implica pasar por el cuerpo esas palabras, elegir una manera de leer. La libertad con la que Vigo aborda la transcripción puede ser irreverencia o negación de lo que se transcribe porque en la distancia entre el texto teórico y su forma pareciera que Vigo, al recrear, estalla lo dicho.

Cuando René Magritte dibuja una pipa e inscribe "esto no es una pipa", reflexiona sobre los vínculos entre el lenguaje y su representación. El elemento real es negado en tanto representación pictórica y lingüística no son el objeto, porque ni el puro dibujo, ni la pura palabra son capaces de asir la pipa. En la lectura de M. Foucault, esta obra tiene como 
antecedente el caligrama, donde la palabra está asociada a la forma que representa. El caligrama, dice Foucault:

Por su doble entrada, garantiza esa captura, de la que el discurso por sí solo o el puro dibujo no son capaces. Conjura la invencible ausencia sobre la que no llegan a triunfar las palabras, imponiendo en ellas, por las astucias de una escritura que actúa en el espacio, la forma visible de su referencia: sabiamente dispuestos en la hoja de papel, los signos apelan, desde el exterior, por el margen que dibujan, por el recorte de su masa en el espacio vacío de la página, a la cosa misma de la que hablan (Foucault, 1993, p. 35).

Si la propuesta de Magritte se centra en el los límites del lenguaje y la representación, la propuesta de Vigo también muestra una frontera que se escapa. Vigo niega la acción de representar como un "volver a presentar" como copia e imitación y parece decirnos "esto no es una copia, es un nuevo original", esto (la re-escritura) no es una copia, es la mostración de un modo personal de leer. La re-escritura reformula el original convirtiéndose en una nueva edición pero también lo interviene desde las formas. El nuevo ejemplar, en su propuesta estética, busca una lógica propia, una forma exenta de correspondencias representadas por una convención social que indica y estabiliza el espacio (y sentido) de las palabras. Desde las formas heterodoxas de ordenar el discurso de los demás, Vigo establece un diálogo, un puente de comunicación que niega la acción de "volver a escribir" como copia.

En la biblioteca general no hemos encontramos la revista de la cual se han extraído los textos de Mondrian Art d'aujourd'hui $\mathrm{n}^{\circ} 5^{94}$ pero si los demás ejemplares de esta publicación. Pudimos constatar en las publicaciones presentes en el CAEV, que no hay en los originales de estas revistas ordenamientos heterodoxos como los que Vigo practica en su re-escritura. Si nos detenemos en el planteo estético de las revistas contemporáneas a esta re-escritura para intentar establecer relaciones de apropiación al respecto con las cuales Vigo podría haber tenido contacto, encontramos que tanto en la revistas argentinas como Arturo $^{95}$ (1944), como la revista

\footnotetext{
94 Según el ordenamiento presente en el CAEV los siguientes números de la revista se encuentran en la biblioteca: de la serie 2 (1951) el $\mathrm{n}^{\circ} 4,6$ y 7 ; la serie tres completa $\left(1951-1952, \mathrm{n}^{\circ} 1\right.$-diciembre- al $\mathrm{n}^{\circ} 7 / 8$ -octubre-); la serie 4 completa (1953, $\mathrm{n}^{\circ} 1$-enero- al $\mathrm{n}^{\circ} 8$-diciembre-) la serie 5 completa (1954, $\mathrm{n}^{\circ} 1$-febrero-, al $\mathrm{n}^{\circ} 8$-diciembre-) A partir de enero de 1955 la revista pasará a llamarse Aujourd'hui art et architecture, modificándose el perfil de la misma. A partir de la modificación del perfil de la publicación figuran en la biblioteca los 31 números de esta revista aparecidos desde 1955 a 1961.

${ }^{95}$ Arturo (1944): dirigida por Carmelo Arden Quin, Rhod Rothfuss, Gyula Kósice, Edgar Bayley; Tomás Maldonado en tapa y diseño;
} 
con orientación surrealista Ciclo $^{96}$ (1948-1949), Perceptismo $^{97}$ (1950-1953), Nueva Visión ${ }^{98}$ (1951-1957) de Maldonado, la palabra no irrumpe rompiendo el párrafo tradicional.

Solo en dos revistas hemos encontrado ordenamientos de este tipo vinculado con un tipo de prosa poética no con textos teóricos como en el caso de Vigo. La primera corresponde a la revista uruguaya Aliverti Liquida ${ }^{99}$, revista inclasificable publicada en 1932, donde prima el trabajo experimental con la palabra, el uso irreverente de la tipografía y el humor. Por su parte en la revista Arte Madí Universal ${ }^{100}$ (1947-1954) hay dos casos en los que la edición juega con el bloque de palabras. En la sección “Autores y Libros” (Arte Madí Universal n 3 [1949], ed. Facsimilar BN 2014) y en "prosa sondable" (Arte Madí Universal n 3 [1949], ed. Facsimilar BN 2014) hay un ordenamiento que podría vincularse con la propuesta de E. A. Vigo donde el párrafo aparece de manera ondulada ${ }^{101}$. Por otra parte, el texto que se transcribe en la re-escritura Selección A sobre arte concreto, perteneciente a Max Bill, ha sido extraído de la publicación Arte Madi Universal ${ }^{102}$. Ornela Barisone ha estudiado los vínculos entre el concretismo plástico y poético en torno a las investigaciones de Vigo vinculadas al invencionismo $(2015,2017)$ e indica en este sentido que: "La "ludicidad" y la "pluralidad" como principios Madí, son criterios que Vigo adopta” (2015, p. 329).

Debemos considerar que, si bien no hay antecedentes directos del ordenamiento de párrafo que Vigo propone para los textos teóricos, como hemos visto en las re-escrituras anteriores, podemos notar en escritos contemporáneos a esta re-escritura, la intención de Vigo por investigar las posibilidades de la letra y la composición plástica. Tomamos como referencia uno de sus ejemplares de poemas / ensayos (presentes en el Cuadro 6) titulado: "Ensayo del 1001 al 1007 y un 10101” (1954). Este ejemplar posee poemas ordenados en una columna angosta sobre el margen derecho de cada página.

\footnotetext{
${ }^{96}$ Ciclo (1948-1949): dirigida por Aldo Pellegrini, E. Pichón Riviere y E. Piterbarg, diseñada por Maldonado e A. Hlito.

97 Perceptismo (1950-1953) dirigida por Raúl Loza.

98 Encontramos en el la biblioteca del CAEV nueve números de la Revista Nueva Visión (desde 1951 hasta 1957).

${ }^{99}$ Consta en el Catálogo para la Novísima Poesía que esta publicación estuvo presente en la exposición sin embargo no ha sido hallada en la biblioteca del Centro de Arte Experimental Vigo.

100 Para una lectura ampliada de los vínculos entre la poética invencionista y la obra de E. A. Vigo remitimos al análisis de Ornela Barisone en Experimentos Poéticos Opacos (2017), especialmente el capítulo: Biopsia 2: Anhelos opacos invencionistas, 1944-1950 y ¿1968?.

${ }^{101}$ Arte Madí Universal n 3 [1949], ed. Facsimilar BN 2014.

102 En el ejemplar original de Madí (correspondiente al $\mathrm{n}^{\circ}$ 7-8), acompañan el texto de Bill esculturas y pinturas de Geraldo de Barros, Moss Marlow y Alexandre Wollner. En la publicación original también encontramos un poema de Diyi Laañ denominado "Postal y todo".
} 


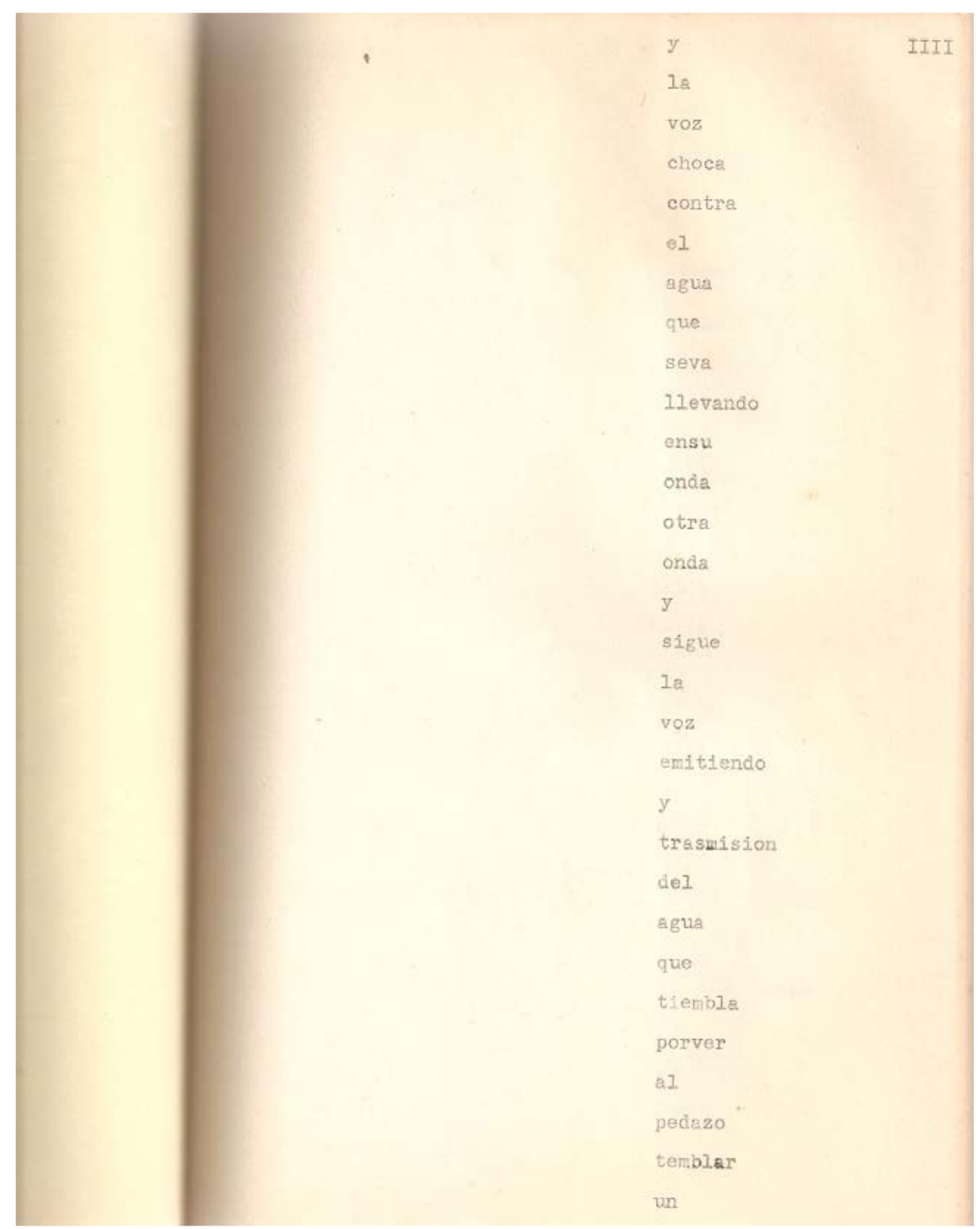

Fig. 53. E. A. Vigo "Ensayo del 1001 al 1007 y un 10101" (1954) Serie Escritos Personales CAEV.

En la re-escritura Selección A, hemos abordado un conjunto de textos teóricos que E. A. Vigo y Comas leen, traducen y re-escriben hacia mediados de la década de 1950, analizando su propuesta experimental en torno al párrafo, como vimos, poco común en la época.

Al considerar las re-escrituras como textos de estudio que permiten acercarnos a un modo particular de conocer y apropiarse de teorías estéticas, corrientes y discusiones, cabe volver a la pregunta por la arquitectura de la palabra que se le otorga a los párrafos en la Selección A. La forma y el contenido del texto invitan, desde formas heterodoxas, a otros tiempos de lectura.

\subsection{Selección B}

Si en la selección anterior nos interesaba analizar la estructura del párrafo, elegimos la re-escritura Selección B por las intervenciones estéticas y las composiciones plásticas que 
acompañan los textos. La segunda selección con la que trabajamos corresponde a textos de fines de la década de 1950, las hojas del ejemplar tienen un formato de 23, 5 x $22 \mathrm{~cm}$. La re-escritura no esta encuadernada y figuran en ella los siguientes artículos:

1) El cosmos de Arp por Herta Wescher (1957)

2) Arte abstracto por María Rosa González (1957)

3) Un doble mensaje de fe, Piet Mondrian por María Rosa González y

4) La gran Visión de Mondrian por Ernesto B. Rodríguez.

A diferencia de la re-escritura anterior -con artículos extraídos de las publicaciones Art d'aujourd'hui, Madi, L' oeil - la mayoría de estos textos pertenecen a un espacio de difusión masivo: el diario La Nación. Otra diferencia entre ambas corresponde a la intervención plástica por parte de Vigo en este ejemplar; si en la re-escritura Selección A, el trabajo estético se efectúa principalmente sobre el cuerpo del texto utilizando la palabra como materialidad; en la Selección B, el trabajo se da en el diseño compositivo, la letra capital, las imágenes que acompañan los textos y la utilización de sellos en el ejemplar. El formato de hoja y las composiciones se vinculan estéticamente con los desarrollados en torno a Les Machines Celibataires, re-escritura contemporánea a la Selección B (1957). 


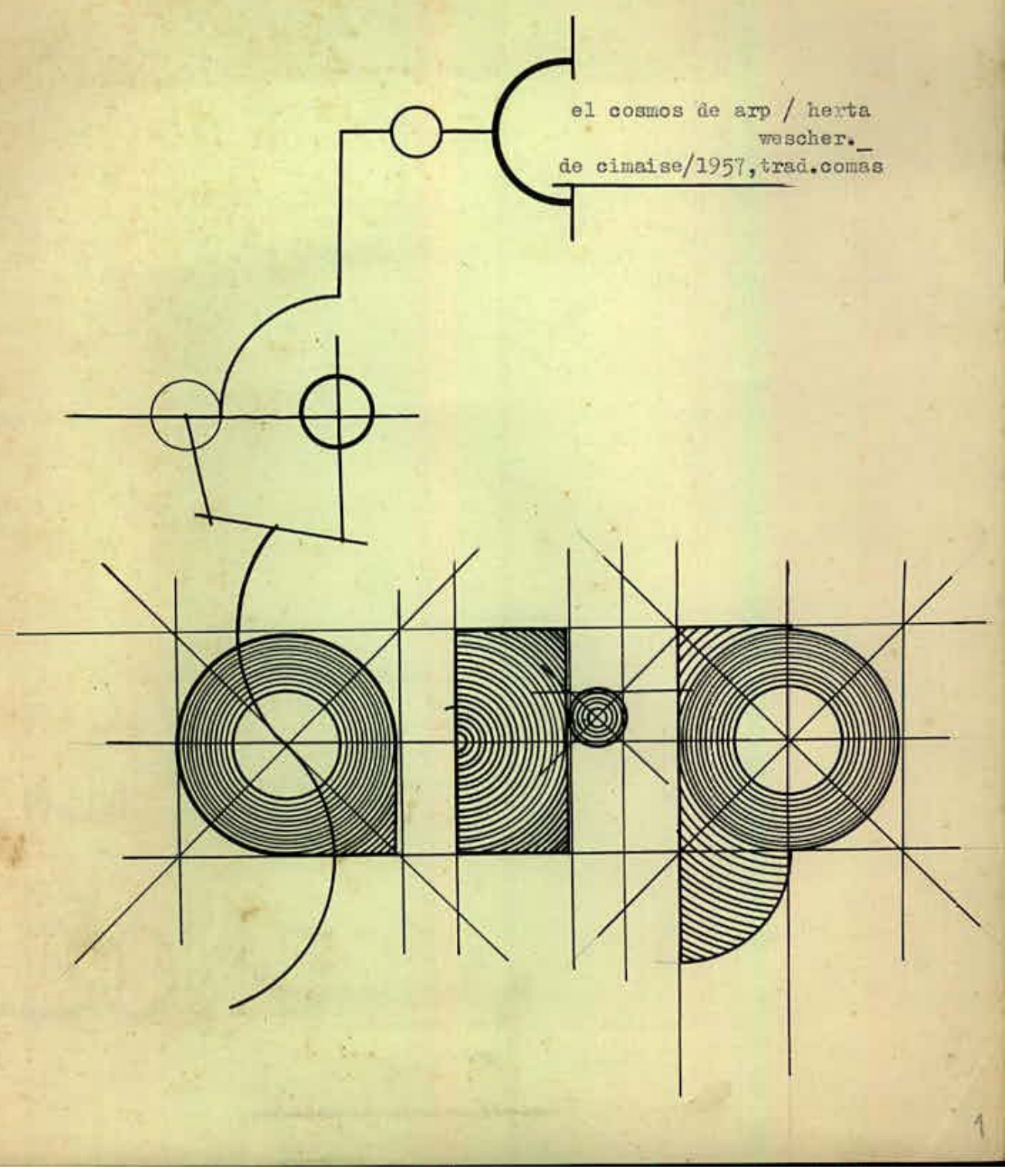

Fig. 54..El cosmos de Arp por Herta Wescher (1957) Re-escritura Selección B.Traducción Comas, edición Vigo (Pag. 1)

Vigo elabora composiciones en esta re-escritura que funcionan como cubierta donde incorpora imágenes vinculadas al dibujo técnico. En el artículo "El cosmos de Arp", respecto de la tipografía para “ARP”, los círculos concéntricos evocan un volumen topográfico en tanto la distancia entre una línea y la siguiente puede ser pensada como superficie vista en planta. Sin embargo, vemos que prima en la composición la utilización de estructuras provenientes del dibujo técnico, determinados símbolos similares a los diagramas eléctricos que conforman circuitos. El medio círculo cortado (junto al título y los datos del artículo) corresponde, en los 
diagramas eléctricos, a un toma corriente. Las líneas que cruzan los círculos indican simetría en torno al centro del mismo. Notemos, además, que la composición se encuentra encadenada y conectada (como una máquina o circuito) desde el medio círculo superior hasta la tipografía inferior. El cuadro siguiente muestra los distintos símbolos gráficos para esquemas eléctricos, similares a los elementos con los que compone Vigo:

\begin{tabular}{|c|c|c|c|c|c|}
\hline & EXISTENTE & PROYECIACON & & EXISTENTE & PROYECTADO \\
\hline $\begin{array}{l}\text { Linea eléctrica área } \\
\text { sfmbolo general }\end{array}$ & , & & $\begin{array}{l}\text { Ifnee área eobre poete de } \\
\text { acero }\end{array}$ & & \\
\hline Ilnes aérea de un circuito & & + & $\begin{array}{l}\text { Linee aeree abre poste } \\
\text { retioulado }\end{array}$ & & \\
\hline $\begin{array}{l}\text { Lnes á́res de un circuito, de } \\
\text { corrlente continue, } 600 \mathrm{v} \text {, pole } \\
\text { rided positive, de un sole oon } \\
\text { ductor de cobre de } 250 \mathrm{~mm}^{2} \text { de }\end{array}$ & $\frac{-\cos *}{\operatorname{trsec} 2}$ & $+\frac{-\infty}{+\pi 50604}$ & $\begin{array}{l}\text { Ifnea ó́rea sobre poste de } \\
\text { horm1 g6n arzado }\end{array}$ & & \\
\hline aecc1ón y $2 \mathrm{~km}$ de largo & & & & & \\
\hline Ĺnes á́res de dos ôlrcuitos & & + & riende & & \\
\hline $\begin{array}{l}\text { Ifnes área de dos circuitos, } \\
\text { de corriente trifásica, } 50 \text { o/s, } \\
60 \text { ooo v: Un oircuito de } 3 \text { con }\end{array}$ & & & $\begin{array}{l}\text { Lines adrea sobre poste con } \\
\text { puntel o contreposte }\end{array}$ & & \\
\hline $\begin{array}{l}\text { ductores de cobre de } 50 \mathrm{~mm}^{2} \text { de } \\
\text { geccibn, el otro cirouito de } 3 \\
\text { conductores do cobro de } 35 \mathrm{~mm}^{2} \\
\text { de geceibn, emboe de } 50 \mathrm{~km} \text { de }\end{array}$ & $+\frac{30}{300}$ & 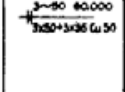 & Linea a remover & & \\
\hline largo & & & & & \\
\hline Linea eérea de tres circuitos & & $-\Perp$ & Armedo en "reck" & & \\
\hline $\begin{array}{l}\text { Línee eléctrice subterránea } \\
\text { S1mbolo general }\end{array}$ & & - - & Armedo en ménsula & & \\
\hline $\begin{array}{l}\text { Linea subterrénea de un } \\
\text { circuito }\end{array}$ & & ++--- & $\begin{array}{l}\text { Armado en cruceta centrel, } \\
\text { en nape }\end{array}$ & & \\
\hline $\begin{array}{l}\text { Ifnes oubterránes de dos } \\
\text { circuitos }\end{array}$ & & +--- & $\begin{array}{l}\text { Armado en oruoeta central, } \\
\text { en triéngulo }\end{array}$ & & \\
\hline $\begin{array}{l}\text { Ines subterrinee de doe cir- } \\
\text { cuitos, de corriente continue, } \\
\text { uno de } 440 \mathrm{v} \text { y el otro de } 110 \mathrm{v} \text {. }\end{array}$ & & & Ménoula a pered & & \\
\hline $\begin{array}{l}\text { E1 primero de } 2 \text { conductores de } \\
95 \mathrm{~mm}^{2} \mathrm{de} \text { eecc16n, el segundo de } \\
240 \mathrm{~mm}^{2} \text { de sección, embos de } \\
0,6 \mathrm{~km} \text { de lergo }\end{array}$ & $-+\frac{-40 \times 10}{2000000000}$ & $-t=440 y+10$ & Ceballete & & $L$ \\
\hline $\begin{array}{l}\text { Poste pere linea éree } \\
\text { Sfmbolo generel }\end{array}$ & 0 & $\mathrm{O}$ & Poste con cruceta central & & \\
\hline Poste de hormigón armado & $\ominus$ & $\theta$ & Poste con cruceta doble & & 0 \\
\hline Pogte de madera & $\theta$ & $\oplus$ & Poste con ménaula & & \\
\hline Poste de ecero & & $\oslash$ & $\begin{array}{l}\text { Ménsula a pared con } \\
\text { rienda }\end{array}$ & & \\
\hline Poste reticulado & & $\square$ & $\begin{array}{l}\text { Mónsula e pared oon } \\
\text { puntel }\end{array}$ & & \\
\hline $\begin{array}{l}\text { Lfnea afrea sobre poste } \\
\text { S1mbolo general }\end{array}$ & & $-\mathrm{O}-$ & $\begin{array}{l}\text { Lámpara de alumbrado } \\
\text { público, con auspention }\end{array}$ & & \\
\hline $\begin{array}{l}\text { Ínea á́rea sobre poste de } \\
\text { madera }\end{array}$ & - & $\oplus$ & $\begin{array}{l}\text { Lúmpera de elumbrado } \\
\text { público, con brazo }\end{array}$ & & \\
\hline
\end{tabular}

Fig. 55. Cuadro "SÍMBOLOS GRÁFICOS PARA ESQUEMAS ELÉCTRICOS”. Extraído de EMPRESA PROVINCIAL DE ENERGIA DE CORDOBA Emisión: 11-11-1986 Oficina de Normalización pag. 2. 
Recordemos que Vigo es egresado de la Escuela Industrial Albert Thomas por lo que seguramente conocía estos simbolos.

Al igual que en la re-escritura Les Machines Célibataires, Vigo reproduce, esta vez a tinta, una imagen. En este caso no se trata de una reproducción técnica sino de una obra de Arp, extraída del libro de Tristan Tzara Cinema calendario del corazón abstracto. Desconocemos, porque no hemos tenido acceso al original del artículo, si la imagen se encontraba ilustrando "El cosmos de Arp” o no.

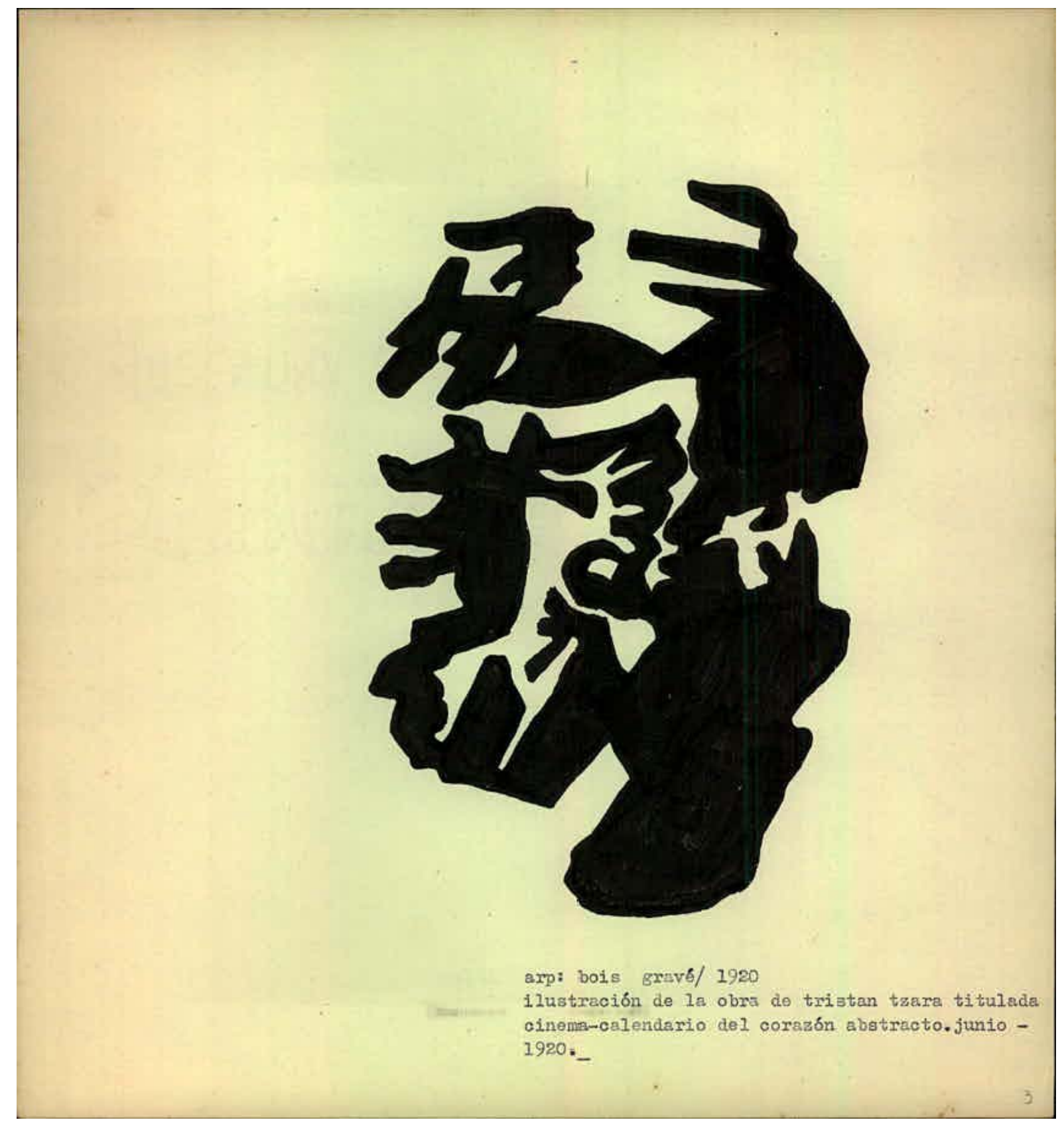

Fig. 56. El cosmos de Arp por Herta Wescher (1957) Selección B. Copia de E. A. Vigo de obra de Arp. (pag. 3) 
El artículo "Arte Abstracto" de la Selección B, también presenta características ligadas a esquemas eléctricos y dibujo técnico. Notemos que título, autoría, año y publicación original se encuentran mecanografíados ocupando en el centro de la composición. Las líneas sugieren un circuito eléctrico. En los diagramas de circuitos los elementos conectado entre sí tienen la finalidad de transportar energía de un lugar a otro. En la imágen, las líneas rectas son las ramas del circuito, en algunos casos encontramos puntos de intersección, en otras partes, las líneas no se tocan y quedan abiertas, evocando también la forma de un laberinto.

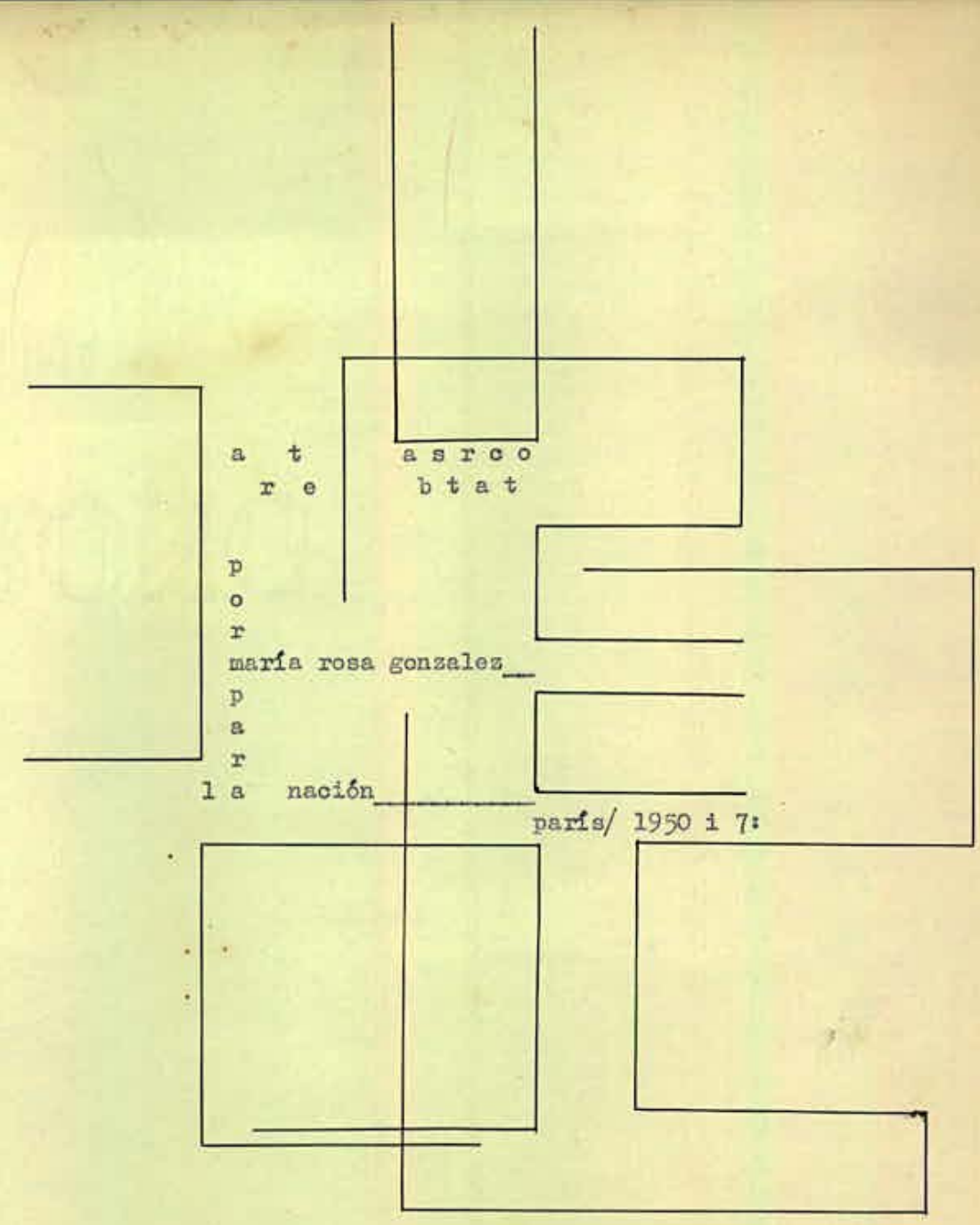

Fig. 57. Arte abstracto por María Rosa González. Re-escritura selección de artículos sobre vanguardias. Edición Vigo (pag. 12) 


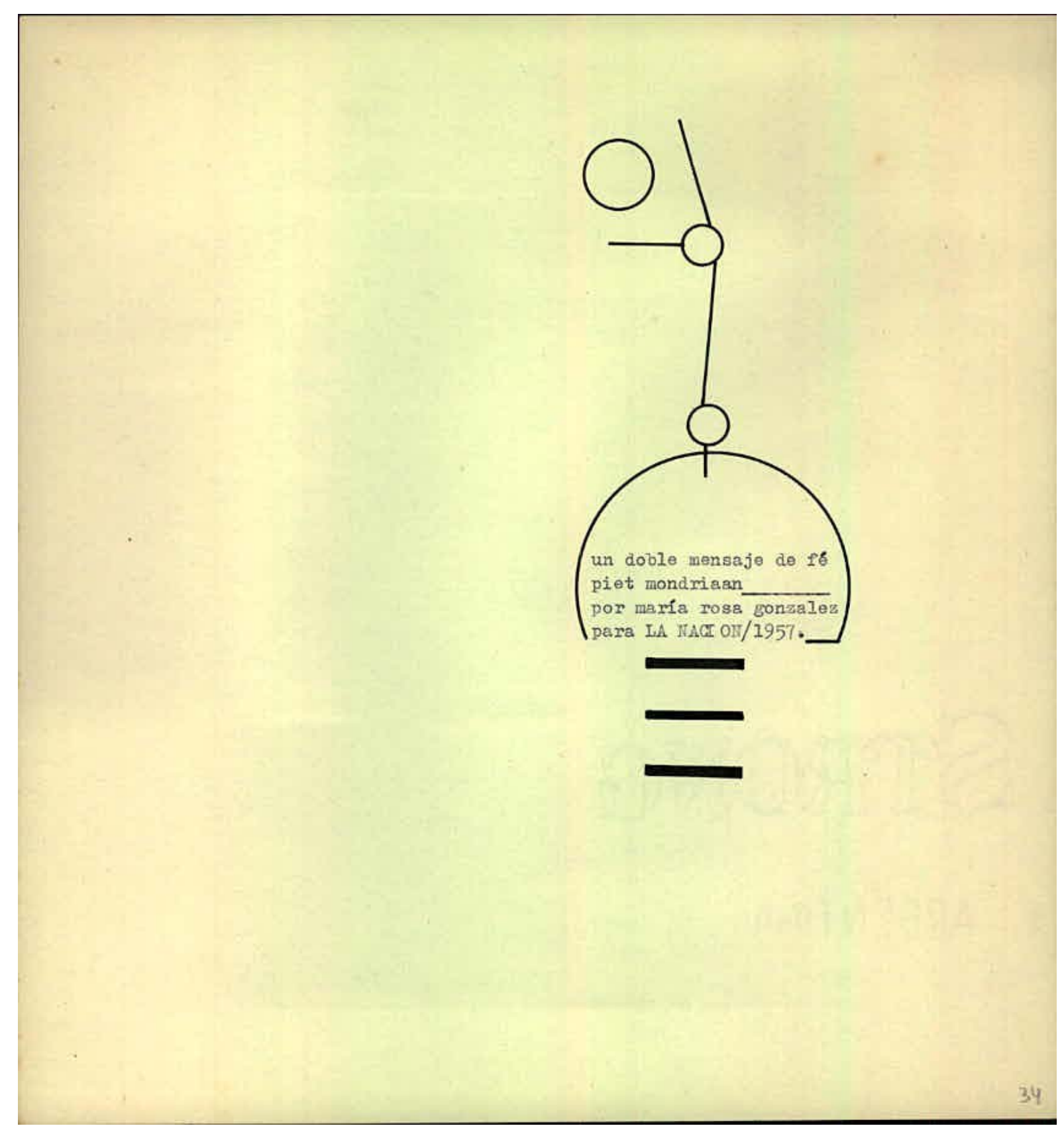

Fig. 58. Un doble mensaje de fe, Piet Mondrian por Maria Rosa Gonzalez. Selección B. Edición E.A. Vigo (pag. 34)

En la edición de la Selección B, los elementos compositivos que priman son el círculo, el medio círculo y la línea articulados por un tipo de dibujo ligado a la técnica y la ilustración de máquinas. Vigo organiza la superficies con pocos recursos, utiliza el negro, varía grosor de la línea, círculos y texturas. En la combinatoria de estos, forma las estructuras o circuitos que acompañan cada hoja, lo que nos hace suponer, por un lado, que el trabajo estético de intervención que Vigo realiza sobre este ejemplar, concibe la Selección B como una unidad (si bien no se encuentra encuadernada como otros compendios, se ha dejado el margen de página 
suficiente que permite considerar su encuadernación posterior). Por otro lado, por el tipo de imágenes que Vigo utiliza, habilita la posibilidad de reflexionar sobre la re-escritura como máquina, sistema, artefacto de lecturas y reformulaciones, mediante la intervención estética que propone en su transcripción y edición.

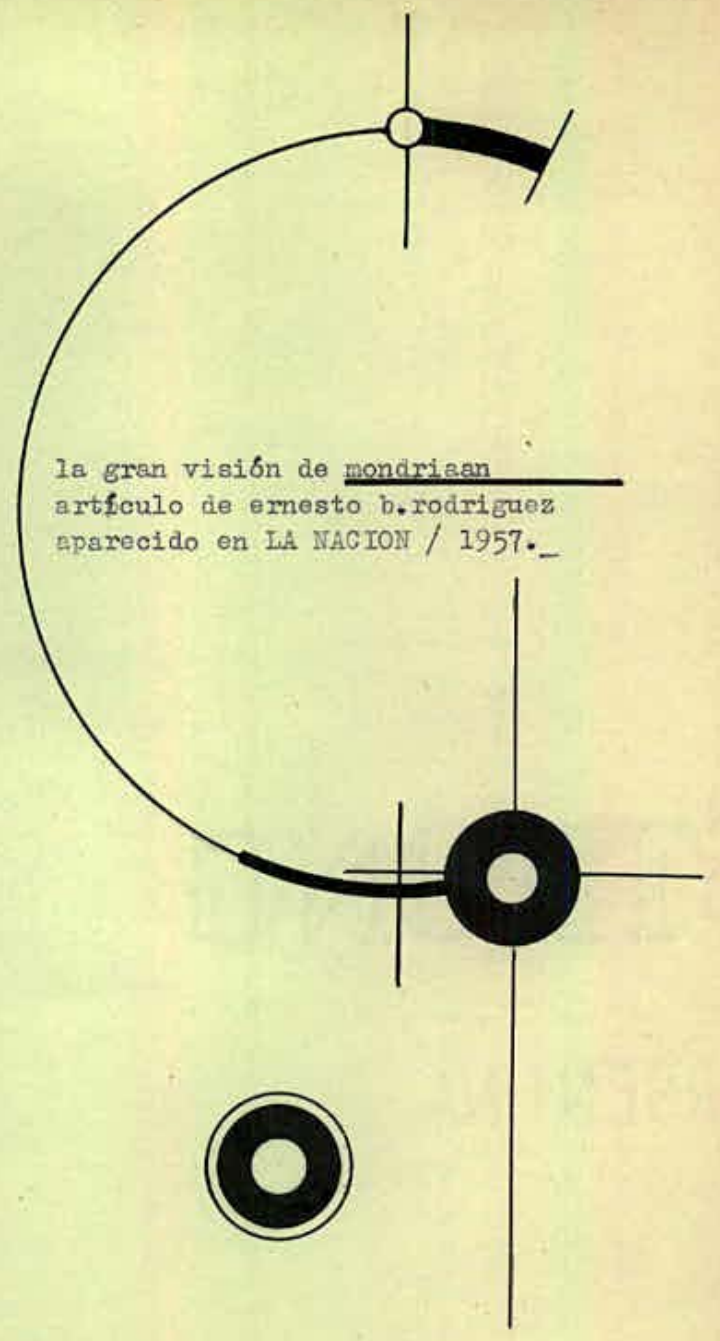

Fig. 59. La gran Visión de Mondrian por Ernesto B. Rodríguez. Selección B. Edición E. A. Vigo (pag. 43) 


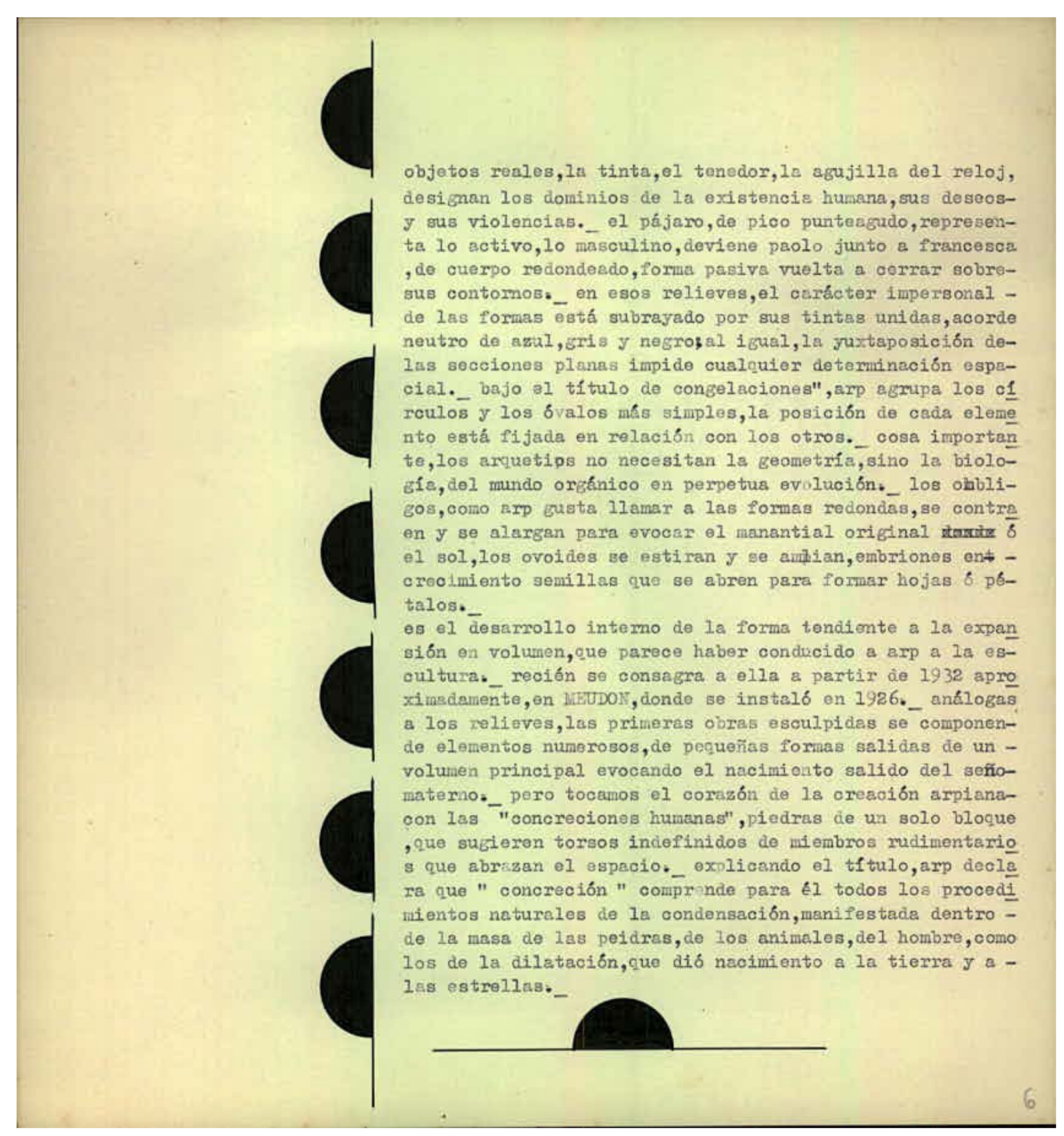

Fig. 60.El cosmos de Arp por Herta Weschler (1957) Selección B. Edición E. A. Vigo (pag. 6)

Por último, la estructuración heterodoxa de los párrafos de la Selección A así como los desarrollos estéticos en la Selección B, pueden vincularse tanto con las experiencias que Vigo realiza por esos años en torno a los desarrollos maquínicos, como con las poéticas experimentales que desarrollará hacia mediados de la década de 1960, ligadas a la espacialidad de la palabra y la indagación sobre el aspecto material del poema. La apropiación funciona aquí a partir de un ejercicio compositivo donde dialogan las diversas vertientes de su formación.

Los desarrollos sobre poesía experimental serán abordados en el capítulo siguiente, aquí interesa dejar planteado el antecedente del trabajo que realiza Vigo en los comienzos de su proceso editorial. Nos detenemos a continuación en la reutilización por parte de Vigo del material de la 
Selección C refiriendo al caso de los aforismos de Francis Picabia aparecidos en Diagonal Cero $\mathrm{n}^{\circ} 2$ para referir al repertorio de autores y poéticas que hace circular en sus publicaciones.

\subsection{Selección C}

En el desarrollo de nuestra hipótesis, hemos indicado que uno de los modos en que Vigo utiliza las re-escrituras es haciendo circular estos textos en sus publicaciones. Si las re-escrituras son un espacio de formación, ese conocimiento se comparte cuando la lectura se difunde, ya sea en forma de charla o publicación. Agreguemos que el texto de re-escritura se estabiliza al momento de ser publicado en la revista; es decir, el texto (traducido por Comas, rediseñado por Vigo) asume una versión final. Operan, en esta versión publicada, modificaciones en torno al haz de relaciones que el texto mantiene distintas a las que sostenía en la selección de artículos de la re-escritura.

La Selección C presenta artículos fechados entre 1951 y 1960. Como hemos mencionado, dos de los artículos presentes en esta la re-escritura han sido publicados en Diagonal Cero, nos referimos a Aforismos (DC n ${ }^{\circ}$ ) y Merz, Zen y Consideraciones sobre Merz ( $\left.\mathrm{DC} \mathrm{n}^{\circ} 3\right)$.

En el repertorio de artistas, figuran los nombres de Petorutti, Kosice, Marinetti, Picasso, Braque, Jaques Villon (seudónimo de Gastón Emile Duchamp), Schwitters, Páez Vilaró, Ginés Parra, Schöffer y Oteiza, Arp. Por su parte, en torno a los críticos, M. Seuphor es el autor del libro citado al comienzo, Arte Abstracto sus orígenes sus primeros maestros traducido e ilustrado por Elena Comas, entre otros artículos citados; G. Hugnet aparece en las re-escrituras con textos sobre Mondrian y el dadaísmo (citado, entre otras, en $W C \mathrm{n}^{\circ} 3$ ), Arp se cita en Diagonal Cero ${ }^{\circ}$ 5/6 (1963) con el texto "Un arte concreto" - en la sección "Testimonios"-. Los artículos han sido extraídos de publicaciones especializadas como Phantomas, L'oeil, Art d'aujourd'hui, pero también de diarios como La Nación, Clarín, La Razón, Correio Paulistano (San Pablo, Brasil), Los textos de la Selección C, aluden a algunas de las trayectorias de los artistas que a Vigo le interesa conocer y apropiarse, en el sentido en que venimos desarrollando el término. El platense Emilio Pettoruti (1892-1971) pintor, activo partícipe de la revista Martín Fierro Segunda época 103 (1924- 1927) director del Museo Provincial de Bellas Artes (1930-1947), G. Kosice

\footnotetext{
103 "El núcleo activo de Martín Fierro (redactores y colaboradores permanentes) es el que sigue: José B. Cairola (fundador), Leonidas Campbell (fundador del Martín Fierro de 1919 y el actual), H Cambarat (redactor del anterior y fundador del presente periódico), Córdoba Iturburu, Luis L. Franco (fundador) Dr. Oliverio Girondo (Fundador, destacado en misión de propaganda y vinculación con las juventudes intelectuales de America y Europa), Luis Góngora, Ricardo Güiraldes, Ernesto Palacio (fundador), Emilio Pettoruti, Dr. Sergio Piñero, Arq.
} 
(1924-2016) co-fundador del movimiento Madí (1946) cuyas experiencias escultóricas y cinéticas resultan renovadoras en el campo de las artes ${ }^{104}$, P. Picasso (1881-1973) y G. Braque (1882 - 1963), iniciadores de la corriente del cubismo analítico ${ }^{105}$, el hermano de Duchamp, Jacques Villon, y Schwitters, dos personajes admirados por E. A. Vigo. Respecto del uruguayo C. Páez Vilaró (1923-2014) creemos que le interesa a Vigo por su exposición junto a Lucio Fontana en 1960 en el Museo Nacional de Buenos Aires. En tanto los españoles Oteiza (19082003) y Ginés Parra (1896-1960) comienzan su obra vinculados con la estética cubista. Por su parte, N. Schöffer (1912- 1992) trabajó con esculturas y arte cinético que podrían vincularse con la obra de Kosice, y también con las esculturas y obras que Elena Comas y Vigo presentan en la Asociación Sarmiento, este artista se menciona como un personaje fundamental en la biografía de Vigo según relata en la entrevista realizada por Mónica Curell (1995).

A partir de los datos anteriores, resulta significativo que, en un total de veintidós artículos presentes en la Selección $\mathbf{C}$ se publican en la primer configuración de una Diagonal Cero, todavía vinculada a las vanguardias históricas, dos de sus referentes: Francis Picabia y Kurt Schwitters.

En segundo lugar y relacionado con la noción de repertorio, en la re-escritura, dialogan espacios del decir legítimos (revistas especializadas en arte y arquitectura, libros publicados, críticos consagrados) y suplementos culturales de opinión donde no se indica ni siquiera la autoría.

\section{Francis Picabia}

Picabia, en la revista $D R K W$ “C" editada por Vigo en 1960, es homenajeado a partir de un “collage biográfico" donde se presenta de manera cronológica la producción del artista francés. Para la realización de esta biografía, Vigo toma datos del libro Arte Abstracto según se afirma en la publicación. Picabia vuelve a aparecer en el universo de sus revistas a partir de la traducción

\footnotetext{
A. Prebisch, Pablo Rojas Paz (fundador), Xul Solar, Gastón O. Talamon (fundador), Evar Méndez(redactor del anterior Martín Fierro y fundador del presente) director del periódico." (MF n ${ }^{\circ} 12 / 13^{\circ}$ : Octubre/ Noviembre 20

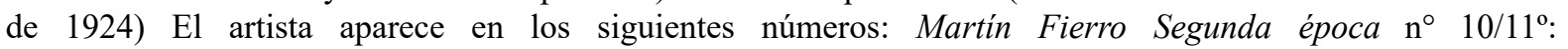
Septiembre/Octubre 9 de 1924: PETTORUTI por Xul Solar; 12/ 13º: Octubre/ Noviembre 20 de 1924: Pettoruti. P. V. Blake; $25^{\circ} 14$ Noviembre 1925: Exposición de E. Petorutti (A. Prebisch); 35 5 Noviembre de 1926: EXPOSICIÓN PETTORUTI (En la Asociación Amigos Del Arte, Por Prebisch); 44/45 31 Agosto/ 15 Noviembre de 1927: reproducción de obra "LA CANCIÓN POPULAR".

104 Para un desarrollo extenso sobre los vínculos entre la obra de E. A. Vigo y los poetas de la década de 1940, BARISONE, Ornela, Experimentos Poéticos Opacos. (2017) Corregidor. Buenos Aires.

${ }^{105}$ RUBIN, W Picasso y Braque, la invención del Cubismo (1990).
} 
de una selección de Aforismos que figuran en Diagonal Cero n ${ }^{\circ} 2$ (1962). Esta selección, como se explicita en la publicación, fue extraída del libro Aforismos reunidos por Poupard, y se encuentra en la sección "Testimonios" de Diagonal Cero. Se especifica que pertenece a la edición Le Terrain Vague, (París, 1960) con traducción de Elena Comas.

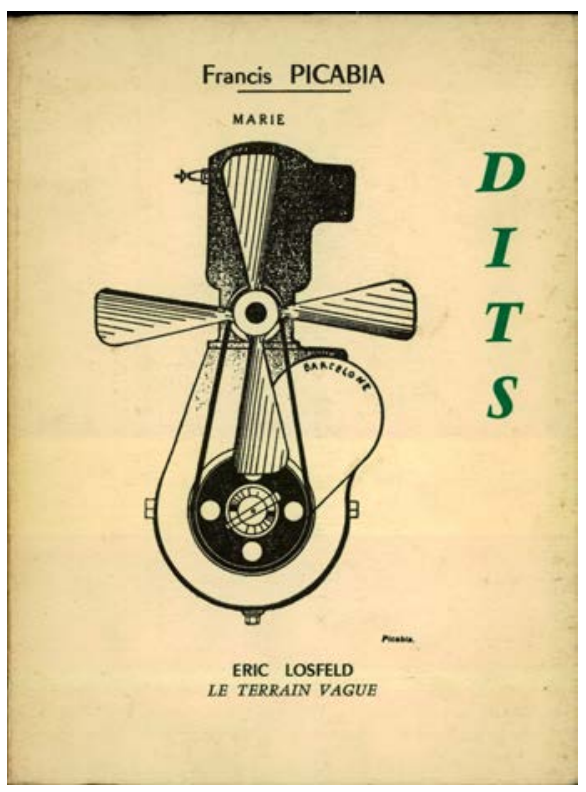

Fig. 61.Francis Picabia, Dits, Le terrain Vague, 1960. Libro de referencia para la re-escritura. CAEV

Recordemos que entre los manuscritos de Elena Comas se encontraba un texto denominado "Picabia, prefacio ilusión" donde se traducen reflexiones del artista similares a las volcadas en esta selección. La silueta de Picabia que acompaña los Aforismos es la misma que Vigo ya utilizó en 1960 en $D R K W$ “C".

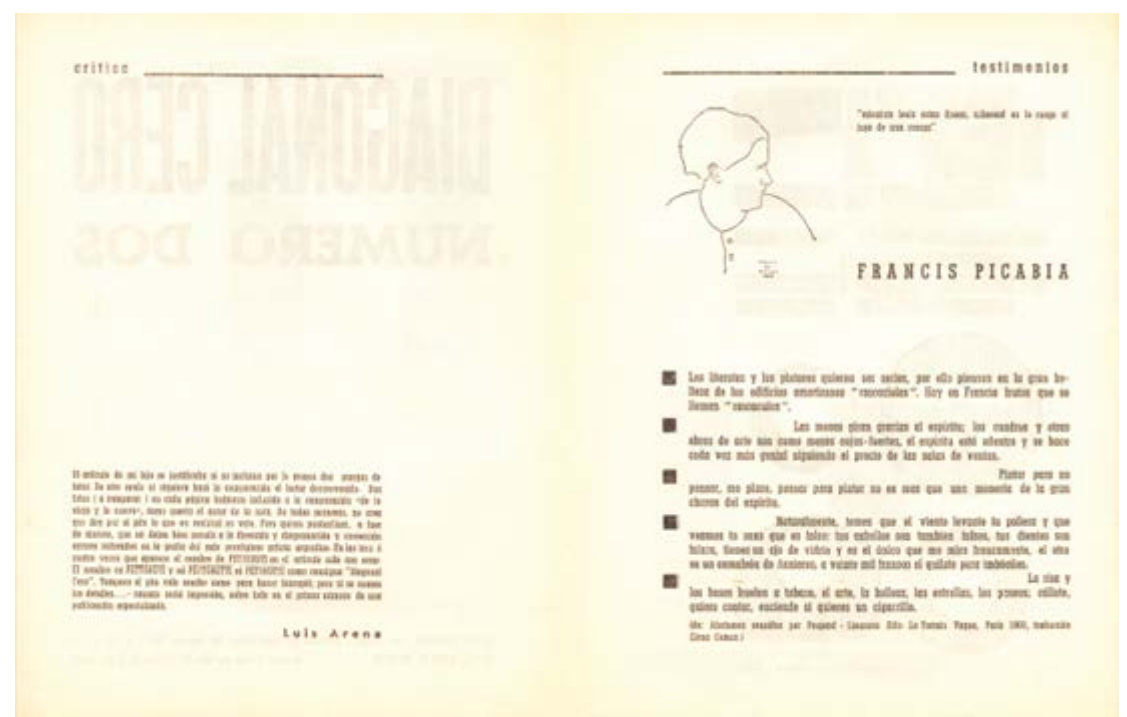

Fig. 62. Diagonal Cero n ${ }^{\circ}$. Sección “Testimonios”. Traducción de Aforismos de Francis Picabia por Elena Comas. CAEV 
Cuando los Aforismos traducidos por Comas, mecanografiados y diseñados por Vigo, se difunden en la publicación Diagonal Cero, se modifica las relaciones que el texto establece con el contexto discursivo de la Selección C. En el nuevo dispositivo, la revista DC, Picabia deja de dialogar con los artistas que conformaban la selección (Kosice, Marinetti, Picasso o Ginés Parra) para formar parte de la propuesta editorial en una publicación destinada a difundir poesía. Vigo, como editor, vuelve a operar sobre el texto con una última modificación: la fragmentación del contenido a partir del montaje.

El nuevo dispositivo, -la revista Diagonal Cero $\mathrm{n}^{\circ} 2$ - compone sus páginas con voces tales como: "Pequeña antología de poetas jóvenes" con textos pertenecientes a Lida Barragán, Raúl Fortín y Omar Gancedo, (1962) y extractos de "Poemas Radioactivos" del Grupo de los Elefantes (1962); el artículo "Francisco Pena Escribe Sobre Dalí” y "Raúl Lozza escribe sobre el Perceptismo".

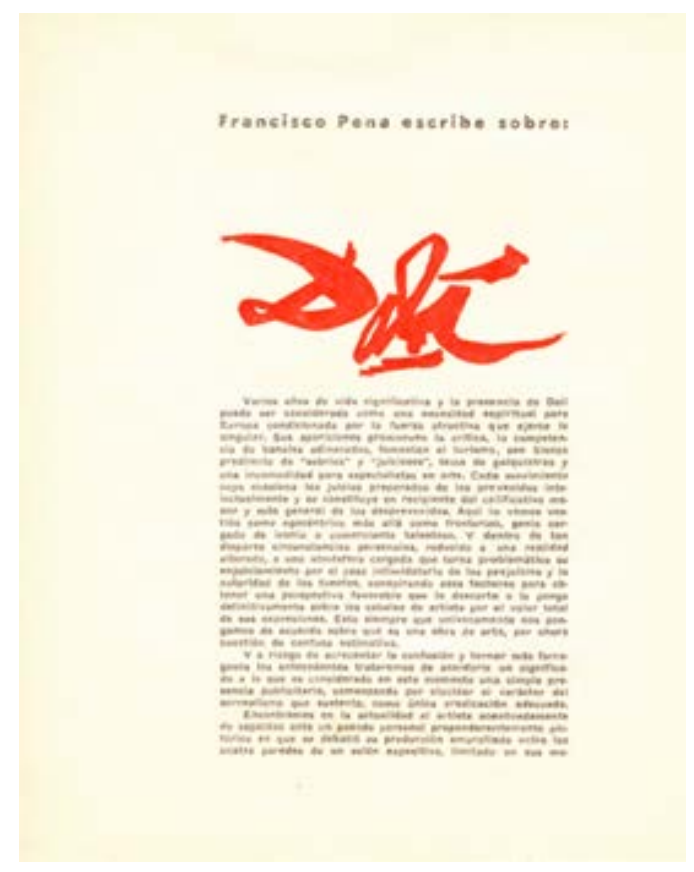

Fig. 63.Diagonal Cero n². "Francisco Pena escribe sobre Dalí” CAEV.

En este número se combinan referentes nacionales y extranjeros, temporalidades y perspectivas que serán una constante en la publicación. Si retomamos las reflexiones de Vigo sobre los dos momentos de la publicación, esto es en la primera etapa (1962 hasta 1966, n 19) vemos que el centro de los intereses se plasma en la difusión de movimientos poéticos y plásticos argentinos y latinoamericanos y determinados personajes dentro de las vanguardias históricas (Picabia, Dalí, Arp, Schwitters) junto a poemas y obras de jóvenes artistas. En este diálogo se visibiliza la 
operación de reconocimiento y difusión de determinados representantes de la tradición pero también de aquellos que se presentan como novedosos y contemporáneos.

La sección "Testimonios", se mantiene hasta el número 8 de la publicación, los autores que figuran son Picabia (Diagonal Cero $n^{\circ}$ ), Schwitters (Diagonal Cero $\mathrm{n}^{\circ} 3$ ) Ernst (Diagonal Cero $\mathrm{n}^{\circ}$ 4) Arp (Diagonal Cero $\mathrm{n}^{\circ}$ 5-6) Iberé Camargo (Diagonal Cero $\mathrm{n}^{\circ}$ 7-parte 2 en $\mathrm{n}^{\circ} 8$ ) y Macedonio Fernández como único representante nacional. ¿Qué comparten estos "testimonios" en los primero números de Diagonal Cero? son frases, aforismos, lecturas críticas de obra o fragmentos de teorías. Si un testimonio es una prueba de verdad, estos siempre se citan de manera incompleta, como partes de un enunciado mayor, por lo que podríamos pensar que la publicación Diagonal Cero se propone como ese enunciado macro. Al observar en detalle, vemos que estas voces también acercan al potencial lector las elecciones que el propio Vigo consume y comparte, aquellas que considera parte de su repertorio estético y poético.

Los "Testimonios" son puentes diversos hacia una concepción poética heterodoxa, no signada por el desarrollo de una vertiente hegemónica sino a partir de una especie de "gabinete de fragmentos" para que el lector reconstruya en el ensamblado de la publicación. El carácter fragmentario que opera tanto en el recorte de referentes como el proceso de edición, configura una nueva unidad de ese material y podría pensarse como un tipo de montaje donde interviene una selección de aquel material pre-existente que se modifica al formar parte de un nuevo contexto.

Cuando señalamos al comienzo que las re-escrituras se configuran como dispositivos de apropiación y conocimiento cuya proyección puede verse plasmada en las publicaciones que Vigo edita, consideramos que la difusión mediante su publicación, no solo se vincula con espacios legitimados, sino también con la posibilidad de generar cruces entre estos y las experiencias poéticas locales emergentes. En los recortes de la tradición y las incorporaciones es donde se visibilizan las apropiaciones que Vigo realiza del material.

Conforme Vigo establece vínculos con publicaciones y documentos teóricos, como hemos visto en el apartado Lecturas en Diagonal Cero, se produce el viraje de la propuesta editorial hacia una poesía de tipo experimental. Creemos, sin embargo, que se conserva en esta publicación el carácter heterodoxo de las referencias en la configuración del repertorio; hecho que será retomado en el análisis de la Exposición Internacional de Novísima Poesía/69 del segundo capítulo. 


\section{Síntesis Capítulo 1}

La revisión por parte de E. A. Vigo de las conceptualizaciones, procedimientos y rupturas de los movimientos estéticos que significaron las vanguardias históricas han sido abordados en estas páginas teniendo en cuenta una selección de obras y publicaciones del artista platense vinculadas con las Selecciones A, B y $\mathbf{C}$ de re-escrituras. Hemos propuesto saltos temporales en la producción de Vigo a lo largo de esta argumentación para notar la persistencia de determinadas temáticas y el nivel de experimentación que se da en sus trabajos tempranos en torno a la materialidad de la palabra plasmados en las re-escrituras.

En el primer apartado trabajamos con la re-escritura del libro de Marcel Duchamp, Marchand du sel - Vendedor de Sal visibilizando mediante las lecturas, el conocimiento preciso que Vigo posee sobre la obra del francés y las particulares elecciones de difusión y reformulación de la obra de este artista. Nos detuvimos en reflexionar sobre la apropiación en torno al análisis de tres (in) objetos editados por Vigo para establecer relaciones posibles entre las obras de ambos. El lugar del espectador y el sentido en propuesta poética de Vigo es fundamental para comprender el carácter conceptual de la apropiación por parte de Vigo de la obra de Marcel Duchamp.

En segundo lugar, consideramos que los procesos de apropiación se ven plasmados en el uso que Vigo le otorga al material crítico (ya sea en forma de cita como en el caso de Picabia) como en las formas en que interviene el material (por ejemplo, en la estructuración de párrafos o la inserción de composiciones). Las composiciones de las re-escrituras más heterodoxas en torno al ordenamiento de los párrafos también nos ha llevado a reflexionar sobre el lugar del lector en las re-escrituras de mediados de la década de 1950, ¿Qué modos de lectura se proponen en esas arquitecturas de la palabra? Siguiendo las reflexiones de los estudiosos de la obra de Vigo, el aspecto participativo se acentúa fuertemente en las décadas de 1960 y 1970, sin embargo, estas producciones dan cuenta de que es una problemática con la que comienza a experimentar tempranamente a partir de los modos de lectura.

En torno a la noción de repertorio, hemos visto que la procedencia de los artículos que se transcriben en las re-escrituras es variada; desde revistas especializadas hasta suplementos culturales de diarios de tirada masiva. En las selecciones de textos publicados vemos la convivencia de fuentes y autores en la primer etapa de Diagonal Cero a partir principalmente de un carácter fragmentario. El repertorio de lecturas de la primer etapa de Diagonal Cero se comparte a partir de un montaje de teorías y lógicas diversas funcionando como un compendio o 
tesauro de los movimientos y experiencias que Vigo considera relevantes sobre su contemporaneidad.

Diagonal Cero hace posible la convivencia de temporalidades en tanto se expone textos de principios del siglo XX junto a jóvenes artistas platenses y latinoamericanos. En este sentido, las nociones de grupo y movimiento repercuten en el repertorio de autores a partir de las selecciones y vínculos que Vigo, como editor y conocedor del campo, decide poner en órbita en sus proyectos.

En el capítulo siguiente nos abocamos al análisis de la poesía experimental en relación con las re-escrituras y otros materiales de la Serie Escritos Personales, centrando la atención en los representantes de este movimiento resaltados por E. A. Vigo, las formas que asume la apropiación en una Diagonal Cero consolidada y la Exposición Internacional de Novísima Poesía/69 que tuviera lugar en el Instituto Di Tella. Entendemos que en el desarrollo conceptual de Vigo sobre la poesía experimental se profundiza el rigor teórico en la mostración de un saber plasmado las re-escrituras. En torno a la circulación, veremos que por un lado se consolida la intención de que los lectores potenciales de la publicación Diagonal Cero comprendan los postulados de la poesía experimental de una manera más directa (exponiendo obras y teorías sobre el tema) y, por otro lado, Vigo reflexiona sobre la participación del espectador buscando informar (intelectualmente) y formar mediante la experiencia y manipulación de obra en sus ensayos, charlas y sistematizaciones del material crítico. 


\section{Capítulo 2}

\section{Poesía experimental.}


1. Presentación: En el análisis realizado en el Capítulo 1, reflexionamos sobre la palabra escrita, las composiciones y reproducciones, los repertorios y los modos de lectura como tema clave de las apropiaciones en la obra de Vigo enmarcado en el estudio de las re-escrituras Selección A, B y C como así también en los libros.

En este capítulo nos centramos en la poesía experimental partiendo de las siguientes cuestiones: ¿qué elementos teóricos, susceptibles a ser rastreados en las re-escrituras, inciden en la propuesta poética experimental de E. A. Vigo?; ¿qué repertorio de autores, movimientos y experiencias conforman el corpus de lecturas que Vigo consume sobre el tema?; ¿de qué manera se proyectan las lecturas sobre poesía experimental presentes en las re-escrituras en la obra de Vigo?.

Como hemos analizado en el apartado Lecturas en Diagonal Cero, en el texto "Balance de la Plástica platense" (DC $\mathrm{N}^{\circ}$ 9-10 1964) se pone de manifiesto la tensión con los espacios editoriales de difusión por parte de Vigo, alejándose de manera crítica de las revistas contemporáneas. Hemos dicho que, a partir de este "balance", se profundiza la intención por parte de su editor de buscar en otros consumos y lecturas, una línea de fuga que vincule la palabra con la plástica, algo que, como vimos, ya venía practicando. Las obras y teorías expuestas en la segunda etapa de Diagonal Cero se vinculan íntimamente con los procesos de lectura que hemos analizado posibilitando la ampliación del repertorio de lecturas y experiencias inclinándose hacia soluciones plásticas y visuales en las páginas de la revista (Perez Balbi, 2008).

Las categorías tradicionales críticas resultan insuficientes para el análisis de la poesía experimental, en tanto este tipo de obra cuestiona las claves de lectura sobre las que históricamente se ha construido el género ${ }^{106}$. Como señalamos en el Marco Teórico, la poesía experimental indaga en los márgenes, es una disciplina liminal, reconoce las posibilidades y potencialidades que surgen del contacto con otras disciplinas -ya sea dándole un uso novedoso a materiales pre-existentes o tomando procedimientos de otras artes para ser aplicados a la poesía-. Magdalena Pérez Balbi en su estudio sobre la poética de Vigo indica que:

\footnotetext{
106 Remitimos a los desarrollos de Jorge Santiago Perednik, Fabio Doctorovich y Carlos Estévez (2016). El punto ciego. Antología de la Poesía Visual Argentina de 7000 a.C. al Tercer Milenio / The Blind Spot. Visual Poetry from Argentina. San Diego: San Diego State University Press. Decimos en esta instancia que en América Latina encontramos distintas manifestaciones hacia la década del 20'/30' que vinculan la escritura con las artes visuales y pueden ser concebidas como antecedente de lo que, a partir de la década del 60', se expande en forma de poesía experimental e impulsa el arte correo como manera de relación: en Perú, Carlos Oquendo de Amat, publica Cinco metros de Poemas (1927), explorando los soportes, la espacialidad y la tipografía. Vicente Huidobro, desde Chile, indaga en la musicalidad del lenguaje como única posibilidad de comunicación a partir de Altazor, temblor del cielo (1931). En Argentina Oliverio Girondo con su propuesta de "jitanjáforas" y caligramas ahonda en las posibilidades de la letra/forma en Espantapájaros (1932). Xul Solar, es un caso especial con sus Grafías Plastiútiles.
} 
La apertura de la poesía a distintas propuestas (provenientes de literatos como de artistas plásticos) permitió que la creación poética se ampliará a soportes que van desde el libro a la cinta magnetofónica, de la página suelta al arte correo, del cuerpo performático al soporte digital, y a técnicas desde el collage a la grabación $(2008 ; 4)$

Los poemas objetuales de E. A. Vigo dialogan con las categorías tradicionales para deconstruirlas o "revulsionarlas", utilizando un término más afín a su poética. Las obras "Análisis in-poético de un metro de hilo", "Poemas (in) sonoros" u "Obras (in) completas", como hemos analizado, se proponen preguntas, no exentas de humor, en torno a la poesía. Para Vigo la poesía es una herramienta, una posibilidad, donde interviene para su formalización tanto el aspecto material-visual como el sonoro del signo y sus potencialidades. A la pregunta ¿Qué es Diagonal Cero?, Vigo responde:

Una intención, una posibilidad. Una encuesta constante y una alerta a todo aquello que uno vislumbra como contestación de futuro como posibilidad de ser testimonio con temperamento. Hoy creo que la COSA TRIMESTRAL en la que se ha convertido también testimonia un devenir: no es más una revista ni una publicación. (Entrevista a E. A. Vigo, La Tribuna, Archivo Biopsia, 1968).

Vimos que el aspecto material y espacial de la palabra están presentes en sus producciones tempranas. Si consultamos los primeros registros de Biopsia de la década de 1950, Vigo resguarda composiciones con sellos que pertenecen al mundo burocrático en el cual está inmerso por su trabajo en el poder judicial. En estos primeros trabajos el juego visual que se produce con el sello, en la repetición del nombre sobre la retícula del papel cuadriculado que se interrumpe con lo aleatorio en la manchas de tinta roja. También en las re-escrituras de la década de 1950, como hemos analizado anteriormente, se vislumbra la preocupación por el espacio en el ordenamiento heterodoxo que Vigo otorga a los párrafos e índices.

Recuperamos en esta instancia la entrevista realizada por Víctor Iturralde en 1967 a Luis Pazos y Jorge de Luxan Gutiérrez, “Introducción a la cultura contemporánea” del ITDT ${ }^{107}$, donde los artistas exponen su versión en torno a las vertientes de la poesía experimental. Transcribimos un

${ }^{107}$ Archivos Sonoros del ITDT. Archivo Fernando von Reichenbach. Universidad Nacional de Quilmes. 
fragmento de la misma donde Pazos señala la importancia del grupo Diagonal Cero y se explaya sobre la poesía matemática de Vigo y sus formas de lectura:

Luis Pazos: En la sección argentina, que la domina el grupo Diagonal Cero, la poesía experimental abarca cuatro partes: Poesía Matemática de Vigo, Poesía Electrónica de Gancedo, Poesía Fonética mía, y Actualidades de Jorge de Luján Gutiérrez.

Víctor Iturralde: ¿Nos puede describir aproximadamente, a la poesía matemática, electrónica, fonética...?

LP: La Poesía Matemática, de Edgardo Vigo estaba hecha en base a números y fórmulas físico químicas de matemática en general. Ahora, básicamente, son ecuaciones fantásticas. El tema es el universo y parten de una base: la ruptura de la lógica aristotélica. La imagen que nos da Vigo del universo es un mundo en el que no hay ningún principio ordenador ni ninguna finalidad determinada. Hay que leerla con la inteligencia. Nos encontramos ante una ecuación fantástica.

VI: Perdón, eso me obliga a preguntarle, ¿es realmente legible la poesía matemática?

LP: Si se la lee teniendo en cuenta de que se está en plena alogicidad es perfectamente legible. Hay que usar inteligencia e imaginación, una mezcla perfecta (Entrevista, 1967).

En esta conversación, tanto Pazos como Gutiérrez dan cuenta de la importancia de sus contactos con el exterior sobre todo a partir de las publicaciones, como hemos visto, todas ellas presentes en la biblioteca de E. A. Vigo. La desconfianza de Iturralde respecto de la lectura de los poemas matemáticos, nos lleva a las tensiones en torno a las formas de abordaje de la poesía tradicional y las propuestas experimentales del grupo. Analizaremos en el transcurso de este capítulo que el repertorio de autores que Vigo lee y transcribe en sus re-escrituras sobre poesía experimental da cuenta de un rigor teórico por parte del artista vinculado con el estudio y la comprensión de las bases de la poética, indagando en las formas de procesar, potenciar y revulsionar los signos y las convenciones.

Nos detenemos a continuación en los registros de la charla (presente en el relevamiento del Cuadro 6) ofrecida por E. A. Vigo en 1968 titulada "Panorama de la Novísima Poesía" (Círculo de Periodistas, La Plata). La intención es adentrarnos en los referentes teóricos y experimentales que Vigo sostiene como precursores de esta corriente. Se evidencia tanto el carácter didáctico en la exposición de Vigo, como el repertorio de autores que selecciona con el fin de establecer una genealogía de la poesía experimental. 
Una versión extensa de esta presentación puede encontrarse en el artículo Continuidad de lo discontinuo ([1970], 1992), como veremos en el apartado siguiente. La charla está organizada a partir de un total de veinte diapositivas que muestran un recorrido por las vanguardias históricas y las experiencias latinoamericanas. Cabe resaltar que la charla corresponde al año anterior en que se organiza la muestra de Novísima Poesía en el Instituto Di Tella, por lo que encontramos paralelismos entre los autores que se citan en la charla y los que aparecerán, con posterioridad, en la muestra.

\subsection{Panorama}

La charla titulada "Panorama de la Novísima Poesía", fue presentada en el Círculo de Periodistas de La Plata el 20 de septiembre de 1968. Materialmente, el registro de la charla corresponde a nueve tarjetas mecanografiadas de $21 \times 11,5 \mathrm{~cm}$, donde presenta un desarrollo de los principales postulados y representantes de la poesía experimental hacia fines de la década de 1960. Al parecer, la charla estuvo acompañada por diversas diapositivas que se encuentran consignadas en el desarrollo de la exposición con números de referencia, no han sido encontradas las diapositivas respectivas a las que refiere. Vigo establece una secuenciación temporal como punto de partida para su argumentación sobre lo que denomina "Panorama de la Novísima Poesía".

Consideramos que este documento es relevante para el presente desarrollo puesto que da cuenta de una de nuestras hipótesis de trabajo, la intención de Vigo por posicionarse como un sujeto conocedor a partir de sus lecturas y re-escrituras a partir de la apropiación de distintas vertientes teóricas. En este caso, la charla se propone hacer conocer la corriente poética experimental en un espacio de formación de comunicadores y periodistas del ámbito local. La relación de Vigo con la difusión en los medios masivos de comunicación platenses es considerable por estos años ${ }^{108}$, por lo que se comprende que haya sido invitado a dar esta charla al Círculo de Periodistas. Por otro lado, si bien no se menciona en este documento, la charla se da un año antes de la Exposición Internacional de Novísima Poesía, importante muestra organizada por el artista sobre

\footnotetext{
108 Vigo tiene una participación importante en lo que respecta a las publicaciones periódicas culturales: entre 1961 y 1963 publica como columnista para el diario "El Argentino"; en 1966 publica el artículo Hacia un arte del objeto (diario "La Tribuna") y durante 1968 los siguientes artículos para "El Día", Madi Kosice I (21 abril 1968), Hidro Kosice II (28 de abril 1968), Punto y espacio en Badii (12 de mayo 1968), Experiencias 68 en el Di Tella (9 de junio 1968), Mi lunática hija libro de Jorge D'Elia (30 junio 1968) Hacia el interior de la Luz (14 de Julio 1968), La pureza de Lido Iacopetti (21 julio 1968) La calidez de un taller (28 julio 1968), La búsqueda del ser (4 de agosto 1968), Con las valijas en la mano (25 de agosto 1968), A manera del Caracol (1 de septiembre 1968), Fontana: agujerear el cielo (15 septiembre 1968) La revolución en el arte (15 de diciembre 1968) y el ya citado en el desarrollo sobre Duchamp, Mitos Plásticos y El gran Vidrio.
} 
la que profundizaremos en el transcurso de este capítulo. La carta enviada por Haroldo de Campos a Romero Brest, recomendando la dirección de la muestra a cargo de E. A. Vigo, está fechada el 22 de agosto de 1967, por lo que, es altamente probable que Vigo ya estuviera al tanto de su intervención dentro de la organización y gestión de la Novísima. La Charla se presenta entonces como un espacio propicio para ofrecer una sistematización de lo que será la muestra y da cuenta del conocimiento profundo que Vigo ya poseía sobre la poesía experimental.

Adentrándonos en el desarrollo de Panorama de la Novísima Poesía, Vigo indica entre los "precursores" de la corriente novísima a los siguientes autores: Mallarmé por "Un Golpe de Dados" (1897), los "Cantos" de Pound "por el método ideogramático" (Vigo, 1968), Joyce por la “interpenetración orgánica de tiempo y espacio" (Vigo, 1968), Cummings por la "atomización de palabras y la valoración expresionista del espacio" (Vigo, 1968) y Apollinaire, por "los caligramas".

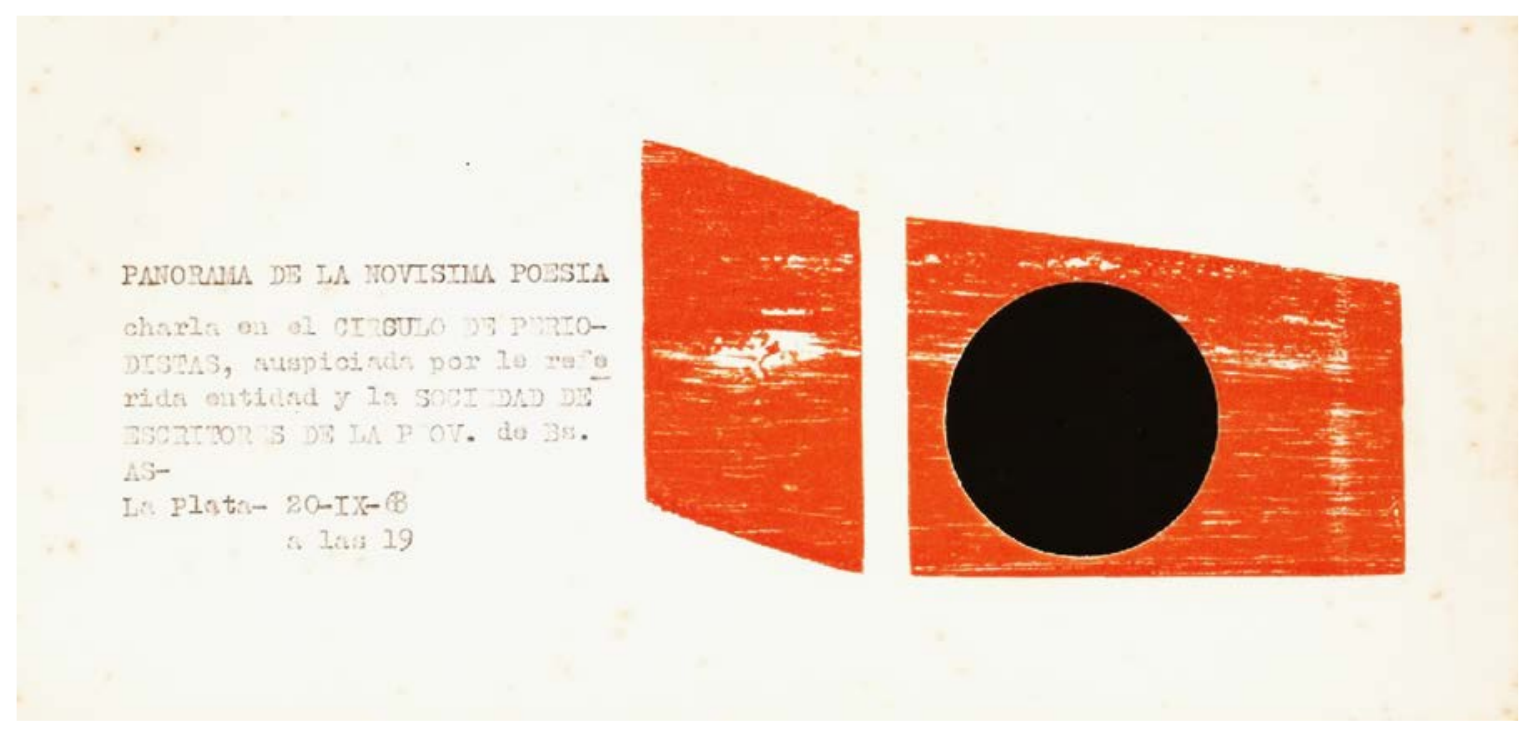

Fig. 64.Tapa de la Charla "Panorama de la Novísima Poesía", 1968 . Serie Escritos Personales CAEV.

Se establece entre estos nombres una correspondencia respecto del repertorio que los poetas concretos postulan y la reconstrucción que realiza Vigo en torno a los precursores de la poesía novísima.

Recordemos que Gonzalo Aguilar señalaba que la primera ruptura de los poetas concretos consiste en la modificación de periodización de los movimientos de vanguardia: los brasileños desplazan el comienzo del legado poético vanguardista a fines del siglo XIX, ubicando "Un golpe de dados" de Mallarmé como inicio de la búsqueda vanguardista (2003, p. 64). El "método ideogramático" al que refiere Vigo se vincula con un aspecto central de la reformulación que los 
concretos realizan del poema. El ideograma se concibe en contraposición al verso, ingresando al repertorio concretista a partir de la lectura que Pound realiza de Fenollosa; "el ideograma es, en los poetas concretos, el camino hacia la materialidad del signo y del espacio en que estos signos se relacionan" (Aguilar; 2003, p. 211).

Vigo comparte los referentes de los poetas concretos y les asigna a los brasileños un lugar privilegiado donde no solo se hace referencia al grupo Noigrandes (Vigo cita a Augusto de Campos y Décio Pignatari), sino también a la Poesía Praxis, el Poema Proceso (cita a Álvaro de Sá) y la obra de Hugo Mund Junior. Remonta los antecedentes de la poesía experimental latinoamericana a la década de 1930 aludiendo a los siguientes poetas y órganos de difusión: la revista nicaragüense Vanguardia (Joaquín Pasos, Pablo Antonio Rocha y Octavio Rocha); Aliverti Liquida (1932) rarísima revista uruguaya de vanguardia (donde se juega no solo con la tipografía sino también con las posibilidades de lectura a partir del formato libro), la pareja Madi Diyi Laañ y Gyula Kosice (sin referencia a una obra en particular y escrito con lapicera aparte); Xul Solar y Oliverio Girondo. De Xul Solar, destaca Vigo "su uso de la letra y el panjuego", de Girondo, el libro Espantapájaros. Hace referencia también a la obra de artista radicado en México, Mathias Goeritz, "Oro" y, posteriormente, al chileno Vicente Huidobro con el poema-caligrama "Paisaje".

Las referencias continúan en una particular lectura de las vanguardias históricas: en las primeras diapositivas se exponen “Canción nocturna del Pez" (1906) de Christian Morgenstern, Man Ray (con la imagen que será la tapa del catálogo de la Novísima Poesía) y Raoul Hausmann con "Poema ortofónico" incorporando de esta manera la poesía fónica.

En las siguientes tres diapositivas, se presentan varias "máquinas" de Picabia, entre ellas "La hija nacida sin madre" y obras Dadaístas. Se menciona la obra de Kurt Schwitters, muestra un collage Metz y acompaña la imagen una cita extensa sobre la "obra universal Metz". Esta "obliga al espectador a leer no a ver únicamente" en el agregado de Vigo. De Schwitters también se presentó un fragmento de la Ursonata (1924-25) y ambientaciones, incluyendo nuevamente la poesía fónica a su argumentación.

De esta primera parte de la charla se evidencian, por lo menos, dos cuestiones: en primer lugar, remonta los orígenes de la poesía experimental recurriendo a los artistas que había denominado "pre-dadaístas" en el artículo aparecido en $W C$ n³ (1958); en segundo lugar, le asigna una importancia fundamental a la vertiente experimental latinoamericana, sistematizando antecedentes nicaragüenses, mexicanos, brasileños, chilenos, uruguayos y argentinos. Sobre los demás movimientos de vanguardia como el surrealismo, el cubismo, salvo el futurismo, se 
detiene brevemente. Se menciona como aporte surrealista una obra de Max Ernst (diapositiva 11) y De Stijl con las innovaciones tipográficas (diapositivas 12 y 13).

La segunda parte de la charla, destinada a análisis del diseño, se centra en las potencialidades del afiche y el "póster" como soportes gráficos "sin sentido propagandístico" dice. Se citan las obras de Nicolás Cassandre y la crítica que éste realizara de los afiches de Toulouse Lautrec. Finaliza la exposición de diapositivas con las obras de los estadounidenses Stuart Davis y Robert Motherwell para aludir al modo en que estos incorporan la palabra a sus obras pictóricas.

En la argumentación planteada por Vigo en la charla Panorama, identificamos tres cuestiones relevantes: por un lado, la referencia a artistas pertenecientes al ámbito de la literatura que realizan innovaciones formales y conceptuales, en tanto cuestionan el verso como unidad para el poema (Mallarmé, E.E. Cummings, entre otros); en segundo lugar, la referencia a artistas plásticos que incorporan la palabra a la imagen (ya sea tomando procedimientos tanto del collage como del universo tipográfico) en soportes diversos (desde Schwitters a Xul Solar); en tercer lugar, la incorporación de la poesía fónica al reservorio de la poesía experimental.

En los casos analizados se desprende la preocupación de Vigo por la participación del espectador en tanto es él quien puede "enriquecer y variar el significado" de la obra. Entre estas tres referencias encontramos el sentido de la organización que Vigo le otorgará, un año después, a la Novísima: poesía y experimentación visual, arte sonoro y espacialidad de la palabra. A continuación profundizamos el análisis de los poetas brasileños que, como vimos, inciden en la producción poética de E. A. Vigo.

\subsection{Poesía Concreta/ Poema Proceso}

Hemos visto la importancia que Vigo le otorga en su charla a la Poesía Concreta no solo como espacio de experimentación sino también a partir de la investigación teórica a la que los concretos se abocan (traducción, elección de un repertorio, carácter liminal de las disciplinas). Analizamos en este apartado las influencias que poseen los poetas brasileños en la obra de E. A. Vigo a partir del concretismo y el grupo Poema/ Proceso.

Los concretos ingresan de lleno a la publicación Diagonal Cero a partir del № 22 (1967), un año antes de la charla de Vigo "Panorama". En este número, Vigo traduce y publica el ensayo "Poesía Concreta Brasilera" de Haroldo de Campos y el poema de Augusto de Campos "Sem un 
numero" en la tapa del ejemplar"109. En el mismo número se publica de Mike Weaber "Poesía Cinética" (Traducción de Diez de Fortuni), y el "Folio Diagonal Cero de Poesía" compuesto por obras de Carlos Raúl Ginzburg (con las obras: "Poesía Atómica", "Signo Convencional Desintegración Total/Signo Convencional Desintegración Parcial”).

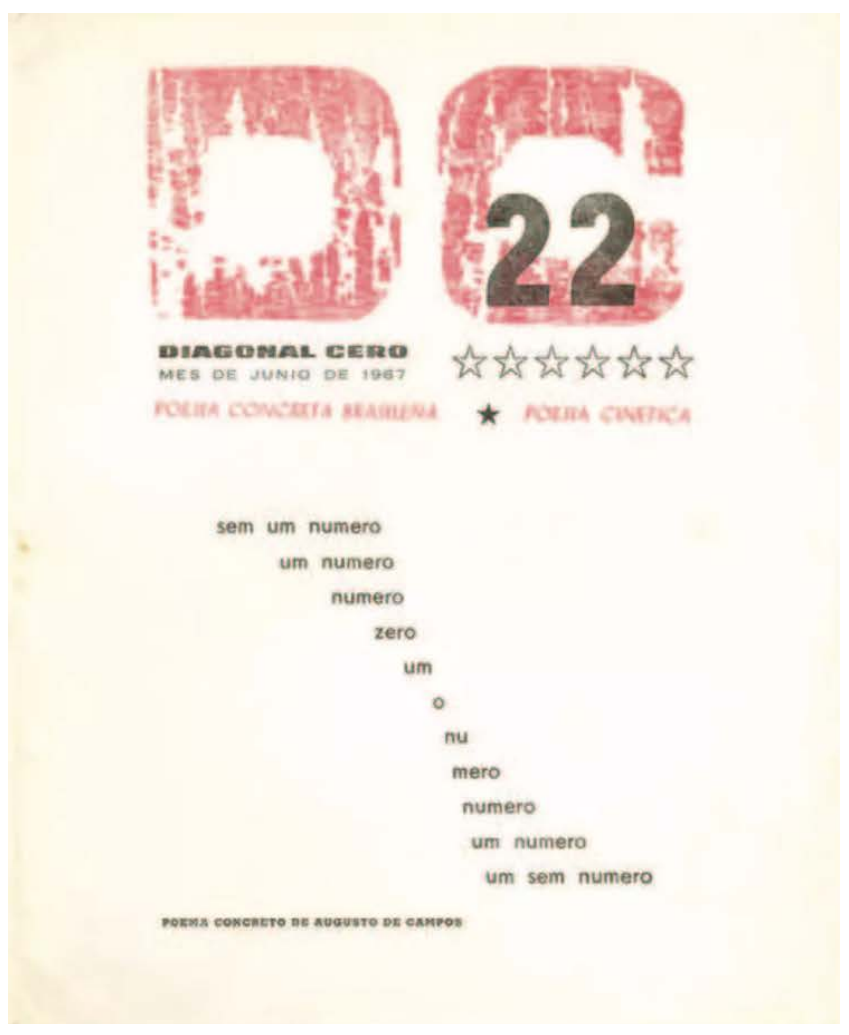

Fig. 65.Diagonal Cero $\mathrm{N}^{\circ} 22$ (1967), CAEV.

De Campos, comienza relatando en el ensayo "Poesía Concreta Brasilera", los inicios del concretismo en 1952 por el grupo Noigrandes (cuyo libro- revista formará parte de la bibliografía presente en la Novísima). Queda en evidencia en esta escritura la trayectoria como ensayista de Haroldo de Campos, quien, como ha señalado Rodolfo Mata, documenta con gran detalle aludiendo con precisión sus fuentes $(2000$, p. 14) para crear un panorama preciso de la poesía concreta. Encontramos aquí el mismo mecanismo que utilizará Vigo en su charla, el rigor crítico como modo de posicionarse como enunciadores competentes. Citamos en extenso el repertorio que De Campos señala para la Poesía Concreta, puesto que se corresponde con los artistas que Vigo retoma como "precursores":

\footnotetext{
${ }^{109}$ En Diagonal Cero N ${ }^{\circ} 26$ (1968) encontramos de Decio Pignatari, "Hombre” y el poema de Alvaro de Sá "Poema de $12 \times 9$ ".
} 
El marco inicial (y genial) está representado por el poema-constelación de Mallarmé ("Un coup de dés", 1897), que Valéry llamó con toda propiedad "espectáculo ideográfico", Mallarmé, es para el Grupo NOIGRANDES, el Dante de la Edad Industrial (...) Se levanta a partir de allí un conjunto básico de ideas que abarcan: a) el método ideográmico de composición de los Cantares de Ezra Pound, inspirados en las lecciones del sinólogo Fenollosa, b) la teoría de los caligramas de Apollinaire; c) las palabras-montajes de Joyce, d) en las atomizaciones visuales E.E. Cummings; e) las contribuciones de los futuristas y los dadaístas. (Haroldo De Campos, Diagonal Cero, 1967)

El artículo de Haroldo de Campos, culmina citando a Pignatari con la frase: "Crear cosas realmente nuevas es crear libertad". De Campos, como adelantamos, será un personaje fundamental para la Novísima, puesto que es quien sugiere a Jorge Romero Brest la coordinación de la Exposición Internacional de Novísima Poesía a cargo de Edgardo Antonio Vigo en 1967. En la epístola ${ }^{110}$, el poeta brasileño señala:

En Argentina, el coordinador de la muestra podría ser Edgardo Antonio Vigo, coordinador de Diagonal Cero que está ya en contacto con los poetas visuales de todo el mundo y empieza a introducir el movimiento en la Argentina (Archivo Di Tella, 1967. Carta de Haroldo De Campos a Romero Brest).

En el Marco Teórico de este trabajo, hemos mencionado la recuperación que hacen los poetas concretos del legado antropofágico de Oswald de Andrade, la operación de devoración crítica que implica "devorar para comprender" (2004, p. 166). De este procedimiento se sirven los poetas para establecer un repertorio y apropiarse, mediante la traducción, de las voces de los distintos poetas con los que buscan identificar su movimiento. La noción de repertorio, si bien no es una categoría utilizada explícitamente por E. A. Vigo para remitir a su formación, es operativa para esta tesis en tanto, como ya señalamos, posee tres características principales que nos permiten reflexionar sobre las lecturas y re-escrituras de Vigo: es una creación y actividad de quien lo utiliza, el repertorio es más amplio que el concepto de canon porque incluye lecturas por fuera de las consideradas hegemónicas y permite cruces disciplinares. Destacamos también el

${ }^{110}$ Se agradece el material facilitado por la Biblioteca Di Tella. 
desarrollo de los concretos sobre la traducción, entendida como transcreación, como hemos analizado en el apartado dedicado a Elena Comas.

El concretismo había desarrollado sus actividades en un contexto de creciente industrialización y urbanización, con la importancia que revistió la construcción de Brasilia, en un contexto de holganza económica para Brasil bajo la presidencia de Juscelino Kubitschek y, posteriormente, João Goulart ${ }^{111}$. El movimiento de Poema/Proceso se inicia en el contexto de la profundización de la dictadura militar que, a partir de 1964, comienza a cercenar las actividades artísticas y culturales en Brasil.

Como señala Marilia Ribeiro (1998), en el artículo "Arte e Política no Brasil: a atuação das neovanguardas nos anos 60", en la primer mitad de la década de 1960, las propuestas artísticas se integran a los proyectos estatales a través de acciones del movimiento concretista; otros se desarrollan en los Centros Populares de Cultura (CPC) que proponían un arte popular revolucionario impulsado por los movimientos sociales durante el gobierno de Goulart. Ya en la segunda mitad, con la dictadura de 1964, se tensionan los vínculos entre las propuestas de la neovanguardia y las políticas del estado, resultando una cultura artística de la resistencia al autoritarismo de la dictadura (1998, p. 403). Los medios masivos de comunicación tienen un papel fundamental en las poéticas de la década de 1960, que oscila, por parte de los artistas, entre la incorporación y la mirada crítica de los mismos ${ }^{112}$.

El Poema/ Proceso, centra su concepción en la noción de experiencia -el poema se lee en tanto se percibe y es tocado ${ }^{113}$-, el material de los medios masivos de comunicación y las reflexiones en torno al lugar que ocupa el espectador. En el caso de Alvaro de Sá, por ejemplo, la utilización de los elementos propios del comic plasmados en Poemics (1967), o el "Poema cordel" (1968) de Neide de Sá, presentados para la Expo de Novísima Poesía/69, son ejemplo de la reutilización

\footnotetext{
111 Señala Aguilar en el apartado "Poesía en tiempos de agitación" que: "El comienzo de los sesenta en Brasil estuvo marcado por dos acontecimientos. Uno tuvo una gran carga simbólica y fue el otorgamiento de la orden del Cruzeiro do Sur al "Che" Guevara en 1961. (...) El segundo hecho fue más significativo y tuvo su inicio durante la presidencia de Goulart: la necesidad de seguir con las reformas modernizadoras pero, a diferencia de lo que se había hecho en el período Kubitschek, buscando consenso y participación popular a partir de lo que se denominó "reformas de base". (2003, p. 93)

112 Recordemos, en el caso argentino, el anti-happening o Happening para un jabalí difunto, que buscó poner en evidencia el engranaje del sistema de comunicación, a partir de la circulación en los medios de un suceso que nunca ocurrió. Puede consultarse el desarrollo en la prensa en http://www.archivosenuso.org/.

${ }^{113}$ En este sentido comparte el aspecto colectivo y participativo con las obras de Lygia Pape, Lygia Clark y Helio Oiticica en tanto se incorpora al otro mediante la acción multitudinaria, la participación y la proposición de experiencias. Ver: Arte e política no Brasil - Os Anos 1960: questões de arte e participação social" Marcondes Ferreira Doares. on line https://periodicos.ufpe.br/revistas/revsocio/article/view/235218.
} 
de un material pre-existente y el montaje propositivo. En el ensayo de Vigo titulado De la Poesía Proceso a la Poesía para y/o realizar (1969), se presentan algunos testimonios del movimiento Poesía Proceso. Neide de Sá y Alvaro de Sá señalaban que el Poema Proceso: “es la toma de conciencia frente a nuevos lenguajes, creándolos o manipulándolos dinámicamente.” (1970, p. 14). En cuanto a las diferencias estructurales de los Poema Proceso con el movimiento concretista, indica Cirne que:

La poesía concreta siempre fue planificada, rigurosa, programática, muchas veces limitando el campo de acción de sus autores. La poesía de proceso, en cuanto a eso, solamente le interesa la creación de nuevos procesos, no exhibiendo ninguna tabla de prohibiciones que reglamente la práctica poética. El resultado es simple: los poetas concretos, últimamente, tienen creados dos o tres poemas; ya ALVARO DE SÁ en estos últimos dos años elaboró cerca de cien poemas, todos bajo el signo de la experimentación. Los poetas concretos alegan que lo importante es la calidad, por eso cuando tenemos calidad más cantidad se abre una perspectiva más sólida para la afirmación de la vanguardia. (Cirne, 1970, p. 12)

En otra reflexión de Moacy Cirne, aparecida en Hexágono 71' bc (1972), si bien el eje es el desarrollo del comic, puede leerse desde sus aportes conceptuales al movimiento Poesía Proceso. El artículo titulado "La importancia de la tira dibujada", establece una genealogía poética a contrapelo del repertorio concretista. Vincula innovaciones estéticas formales en la historieta en relación a los textos que los concretos habían considerado fundantes del movimiento. Así, "Un golpe de dados", en la interpretación de Cirne, comparte las mismas preocupaciones estéticas y formales con Katzenjammer Kids (Los sobrinos del Capitán de Rudolph Dirks) y Little Nemo (de Winsor Mckay). Cirne considera que, si los movimientos de vanguardia implican creación de nuevos lenguajes, si su objetivo es desmitificar la obra de arte, los quadrinhos (o historietas) son la desmitificación de la literatura en su forma de poema y de prosa $(1970,45)$. Cirne concluye que la historieta, por sus innovaciones formales y su capacidad de crear lenguaje "es la literatura por excelencia del siglo XX" (1972, p. 7).

El Poema Proceso tensiona no solo con los autores del repertorio concretista -alejándose de los referentes de la periodización de los concretos- sino que también establece otras preocupaciones en el horizonte poético. Estas preocupaciones están signadas por el contexto socio-político: una crítica al consumo, una apuesta por la participación activa del espectador, la utilización de los 
medios masivos y sus procedimientos compositivos para establecer otros sentidos con materiales pre-existentes. En BOM! (1970) apunta Cirne que las propuesta del Poema Proceso son:

- $\quad$ inaugurar processos informacionais novos

- fundar probabilidades criativas

- $\quad$ lançar projetos que possibilitem versões do consumidor

- criar consciencia crítica para o contra-estilo

- $\quad$ lutar por uma lógica de consumo (1970, p. 55)

Analizamos a continuación la proposición de Vigo en torno a la Poesía para y/o realizar que tiene su antecedente, entre otras lecturas y re-escrituras, en las experiencias brasileñas.

\subsection{Poesía para y/o realizar}

El ensayo de E. A. Vigo titulado De la Poesía Proceso a la poesía para y/o realizar (1969) es una edición artesanal de Diagonal Cero que consta de hojas sueltas ensambladas en un sobre contenedor. Este documento comienza explicitando la voluntad de registrar las últimas tendencias dentro de la poesía experimental:

Dentro del vasto, complejo y contradictorio campo de la "NOVISIMA POESIA" hemos elegido el desarrollo de algunas tendencias que posibilitan su activación. Los antecedentes históricos nos llevarían a re-buscar lo frondoso de los mismos hasta terminar posiblemente en un trabajo de corte "enciclopédico". Presentaremos las últimas variantes que son, por supuesto, el resultado de un cambio de estructuras (cuya quiebra comienza a principios de nuestro siglo) del arte en general y en cada una de sus ramas en particular. Definiríamos a la "POESÍA/PROCESO" como el punto de partida teórico-práctico que permite la iniciación de una "POESÍA PARA ARMAR" que a su vez posibilita una "POESÍA PARA y/ o A REALIZAR" (De la Poesía Proceso, 1969)

Como vemos, Vigo parte de los postulados de la Poesía Proceso para su propia elaboración de las posibilidades de la participación del espectador dentro de la poesía. Indica sobre este movimiento que: 
Es en el poema/proceso, uno de los movimientos más activistas y revulsivos de la poesía, donde nos encontramos con una toma de conciencia ante este fenómeno, desencadenando "imágenes poéticas " por intermedio de "claves " (palabras, imágenes visuales, objetos) que permiten el agregado de otros elementos heterogéneos o el quite de algunas de las mismas por un participante-activo que pasa de recreador (interpretación de la cosa) a creador (modificante de la imagen) (1970, p. 3).

Posteriormente, releva el trabajo de otros artistas a partir de sus búsquedas por articular la poesía con la dimensión visual y constructiva de la palabra como las piezas de Denis Williams, Julien Blaine, Jochen Gerz, Andy Suknasky, el grupo ZAJ, entre otros. Sin embargo, retoma en su argumentación la referencia al Brasil, en tanto considera las poéticas experimentales como “centro-motor" desde los poetas concretos a Poema Proceso:

Los poeta/ procesos desbordan a los concretos y praxistas y ubican sus objetos-poéticos en la tesitura de apertura que permitirá posteriormente el desarrollo de la poesía para armar y posteriormente la poesía para realizar aquí postulada. Ubicamos, entonces, al poema/ proceso con sus objetos-poéticos dentro de una previa etapa de una poesía para $\operatorname{armar}(1969$, p. 5).

La poesía para armar, en palabras de Vigo, opera mediante una activación a la creación del receptor, en tanto "La posibilidad del arte no está ya solo en la participación del observador sino en su ACTIVACIÓN-constructiva, un ARTE A REALIZAR” (1969, p. 8). La propuesta de Vigo encuentra sus raíces en la experiencia brasileña y sería entonces, en sus palabras, una continuación de aquel movimiento. 


\section{Síntesis}

Resaltamos en esta introducción que, a diferencia del trabajo con las re-escrituras en el período de fines de 1954 y comienzos de 1960 (Selección A, B y C), en las re-escrituras que remiten a la poesía experimental, se produce un viraje en torno a la importancia que Vigo le otorga al material bibliográfico.

La relevancia que cobran las lecturas y re-escrituras se hace evidente en los textos que comienza a difundir en la segunda etapa de Diagonal Cero, gracias a sus contactos y las redes de relaciones por las cuales le envían materiales inéditos en argentina. Este corrimiento en las referencias teóricas, impacta de manera directa en su publicación, sus charlas y en el montaje de la Exposición Internacional de Novísima Poesía/69.

El carácter teórico y el conocimiento preciso expresado por Vigo en sus charlas (Panorama, Continuidad de lo Discontinuo [1970]), ensayos (De la Poesía Proceso, Continuidad de lo Discontinuo) y publicaciones visibiliza el afán de posicionarse como sujeto conocedor del campo en el marco de estas corrientes experimentales, sus referentes y postulados. Como venimos señalando, una de las formas que asume la apropiación en la obra de Vigo se vincula con los modos en que la teoría ingresa a su producción editorial, de difusión y en las obras.

Profundizaremos en el apartado siguiente el corrimiento en el perfil de Diagonal Cero a la luz de la re-escritura Selección D, teniendo en consideración las modificaciones que operan en la publicación desde sus inicios hasta 1969 y la incidencia de los vínculos que Vigo mantiene con los poetas brasileños en la construcción de su repertorio experimental. La paulatina pero persistente profundización en la participación como clave del poema.

En los apartados que siguen, ahondamos sobre esta cuestión tomando como corpus la re-escritura Selección D sobre poesía visual en diálogo con el ensayo-charla Continuidad de lo discontinuo ([1970] 1992); y la Exposición Internacional de Novísima Poesía/69. 


\section{Selección D}

La re-escritura, Selección de artículos D, que presentamos a continuación se vincula con las publicaciones con las que Diagonal Cero toma contacto a fines de la década de 1960, nos referimos a publicaciones sobre poesía experimental en las que el diseño, la materialidad de la palabra y la teoría tienen un lugar preponderante. Entre estas publicaciones se destacan: Los huevos del Plata (Uruguay), Ausonia, Amodulo (Italia), Approches, Les Lettres, OU (Francia) Labris (Bélgica), entre otras. Las revistas internacionales con las que Vigo intercambia materiales nos hablan de aquella tensión con las revistas de su tiempo y de las formas en que el contacto con otros artistas incide en la producción de Vigo. A diferencia de las re-escrituras donde se seleccionan artículos, analizadas en el capítulo anterior (Selección A, B, C), todas las publicaciones de las cuales se extraen artículos para esta re-escritura son revistas internacionales que se dedican especialmente a la poesía experimental. Nos interesa poder vincular la presente selección con la charla Continuidad de lo discontinuo y el catálogo de la Novísima, en tanto consideramos que en estos trabajos quedan de manifiesto las formas en que las re-escrituras son utilizadas por Vigo, via apropiación, para ser reformuladas en sus exposiciones teóricas, mostrando repertorios de lectura que se alejan de una concepción tradicional del poema, de lectura y escritura.

Decía Luján Gutiérrez en la entrevista en el ITDT sobre los repertorios de lecturas del grupo Diagonal Cero que:

Víctor Iturralde: Ustedes trabajan en la argentina en poesía de vanguardia, ¿Se puede hablar de movimientos similares o paralelos en otros países?

Luján Gutiérrez: Bueno sí, en Francia el grupo de la revista Approches de Julien Blaine y Jean F. Bory, la revista $O U$, la revista Rinozeros en Alemania, el grupo Invenção que dirige Haroldo de Campos en Brasil, Gronk en Canadá y en Argentina Diagonal Cero que es una revista dirigida por Edgardo Antonio Vigo. Va ya por el número $20 \mathrm{y}$ tiene seis años de vida. (Entrevista ITDT, 1967)

En la re-escritura Selección D, los artículos comparten la poesía visual como tema central. Las fechas de los mismos comprenden de 1962 a 1970. La compaginación de la selección probablemente se haya realizado hacia 1970, en tanto muchos de los artículos presentes en esta re-escritura se corresponden con el periodo previo y posterior a la organización y realización de 
la Exposición Internacional de Novísima Poesía 69. Como veremos, estos textos también se han utilizado como insumo para el catálogo de la muestra. Entre los autores que figuran en el repertorio de la re-escritura encontramos a Julio Campal, Francis Edeline, Henri Chopin, Julien Blaine, Vicenzo Accame, Luigi Ferro, Jochen Gerz, Max Bense, Franco Vaccari, Michelle Perfetti.

De los aspectos formales de esta re-escritura, cuyas medidas son $30 \times 23,5 \mathrm{~cm}$., se destaca su organización. Posee un índice en la primer hoja donde consta nombre del artículo, autor y publicación de la cual se extrae. Salvo en algunos casos donde no pudimos rastrear el original, la mayoría de los artículos poseen los datos completos. Respecto de los procedimientos de diseño, vemos la utilización de fibras de colores y números de molde para referir a los artículos. Algunos artículos de la re-escritura poseen composiciones mecanografiadas en bloque en su interior así como imágenes adheridas de poesía visual.

En el apartado siguiente se analizará el alcance en la producción de Vigo en torno a esta re-escritura. La Selección D se expande de manera directa hacia la charla- ensayo Continuidad de lo Discontinuo y el Catálogo de la Novísima Poesía. 


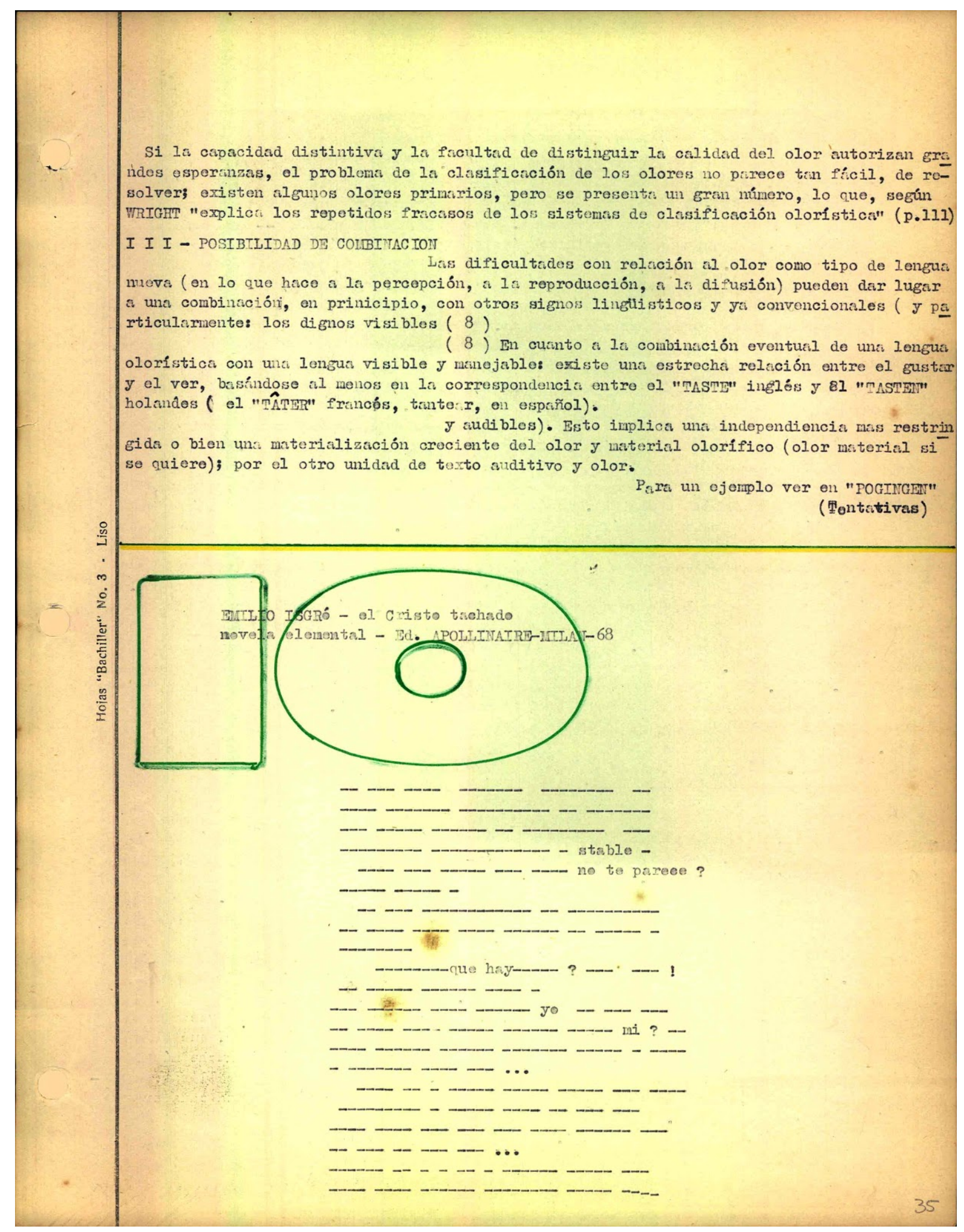

Fig. 66. Re-escritura Selección D. Página 35. Detalle composición mecanografiada de E. A. Vigo. CAEV

\subsection{Continuidad de lo Discontinuo}

Venimos sosteniendo en este trabajo que las re-escrituras sirven en la trayectoria de E. A. Vigo y Elena Comas como espacios de apropiación de conocimiento. Nos interesa analizar en este 
apartado el impacto de la re-escritura Selección D en un trabajo teórico que deviene en ensayo y charla de E. A. Vigo denominado Continuidad de lo Discontinuo. Es interesante notar que aquí el trabajo de apropiación se materializa con el mismo nombre en un trabajo teórico ensayístico y en una charla performática acontecida en el Colegio Nacional.

La charla-ensayo se vincula con el recorrido planteado en la charla Panorama de la Novísima Poesía reseñada anteriormente pero se agregan los referentes expuestos en la re-escritura Selección D. Además, a diferencia de la charla Panorama, cuya presentación en Periodismo no contó (según los registros) con propuestas participativas, Continuidad de lo Discontinuo invitó a los espectadores (alumnos) a intervenir y se generó una espacialidad vinculada con las propuestas de poesía experimental.

El ensayo Continuidad consta de 45 hojas mecanografiadas, en 23 de ellas encontramos imágenes en blanco y negro de distintas obras, como "Velas", de Andy Suknasky, "Poem Kon" de Liliane Lijn o "Poema Gráfico" de Patrizia Viccineli, entre otras. Llama la atención que Continuidad se publica recién en 1992, en la revista En Marcha, a pesar de que el texto haya sido escrito en la década de 1970, como queda documentado en Biopsia. Una explicación posible es que este ensayo haya quedado relegado para su publicación con el proyecto Hexágono 71', otra hipótesis tendría que ver con el contenido de este ensayo, este se presenta como una versión extendida de sus reflexiones editadas en De la Poesía Proceso a la Poesía para y o realizar (1969). Como indicamos anteriormente, otro dato importante es que este trabajo teórico se presentó, según el registro Biopsia, como una charla-clase perfomática en el Colegio Nacional ${ }^{114}$, en el registro Biopsia del mismo año leemos:

Continuidad de lo discontinuo, charla- clase en el Colegio Nacional sobre la "Poesía Visual y Fónica”, sus antecedentes históricos. Tuvo lugar en el Salón de Actos, una sala totalmente a oscuras, iba recibiendo a los alumnos que a la vez se muñían del sobre-tarjeta, una vela de Suknasky, Andy (canadiense) estaba encendida y era el único elemento de iluminación, se procedió a pasar la grabación de poemas fonéticos de Raoul Hausmann (fragmentos) escritos entre el 918/919. A mitad del mismo se procedió a iluminar el "Tendedero" de la americana Dana Atchley, posteriormente un juego de luces acompañó a la cinta grabada por Housman y antes de proceder a la lectura de la charla,

\footnotetext{
114 Ana Bugnone (2013, p. 161) estudia en su tesis doctoral otra conferencia performática realizada por Vigo en el Colegio Nacional titulada "Arte-hoy" acontecida un año antes de "Continuidad de lo Discontinuo" en el mismo sitio. En la charla de 1969, Vigo presenta "Poema demagógico", reproduce una cinta de poesía fónica y presentó su obra sonora "Homenaje a una pensión de estudiantes". La búsqueda de interacción con el público en sus presentaciones teóricas y charlas, por lo tanto, tiene antecedentes.
} 
una diapositiva como marco de escenografía tomada en base a un trabajo de Vigo, inundó el escenario del salón, una mesa ubicada al revés de punta, tipo ratona pero amplia, fue la base para proceder a la lectura, previamente Vigo se quitó el saco (Biopsia, 1970).

Vigo utiliza en esta clase- charla los materiales que estuvieron presentes un año antes en la Novísima para el desarrollo de su conceptualización e incorpora al público en su charla a partir de la participación del mismo entregando el sobre-tarjeta, extrañando el espacio a partir de la penumbra, la vela y la imagen de diapositiva.

El ensayo, Continuidad de lo discontinuo, hace foco en la persistencia de la corriente experimental dentro de la poesía. Tanto la charla impartida por Vigo en el Círculo de Periodistas, Panorama de la Poesía, como Continuidad de lo discontinuo dan cuenta, como venimos sosteniendo, de la importancia del conocimiento bibliográfico como forma de posicionarse como sujeto competente y la manera en que, a partir de ese saber, construye una cierta experticia en el territorio de la poesía experimental. En nuestra hipótesis de trabajo sostuvimos que una de las formas que asume la apropiación en sus desarrollos teóricos radica en el posicionamiento como enunciador dentro del campo de la poesía experimental, agregamos también que en esta apropiación por parte de Vigo se construye una constelación de sentidos que historiza desde distintas vertientes el movimiento. En las "Notas" finales aparecen los textos de las re-escrituras como insumo para la elaboración de Continuidad de lo Discontinuo confirmando nuestra hipótesis en torno a la utilización y apropiación por parte de Vigo de los materiales de las re-escrituras.

El recorrido que propone el ensayo se sustenta en la descripción de las formas clásicas de la poesía experimental pasando por los desarrollos de la poesía concreta y posteriormente centrándose en el lugar del espectador como elemento central en el desarrollo poético. Estructuralmente, el ensayo se divide en los siguientes apartados:

\section{A manera de introducción}

Antecedentes

G. Apollinaire

La poesía visual

Dadaísmo y "De Stijl"

Poesía concreta 
Posters

Poesía cinética

Objetos poéticos

Fenómeno desencadenante: la participación modificatoria

El Poema/ Proceso

El Poema para armar

El poema para realizar

Investigaciones poéticas

La poesía en la calle

El poema publico

Inobjetal

Hacia la mitad del ensayo encontramos el apartado Fenómeno desencadenante: la participación. Se reconocen aquí las tendencias que consideran al sujeto - participante como eje vertebral de la propuesta poética como es el caso de los movimientos Poema/ Proceso; Poema para Armar; Poema para Realizar. El siguiente eje sobre el cual se detiene corresponde al abordaje del espacio. Tanto "La Poesía en la Calle" como "El poema Público" abordan el lugar del espectador en relación con el contexto. Por último, Continuidad de lo Discontinuo, desarrolla la propuesta Inobjetual, donde las reflexiones anteriores confluyen en el vínculo entre el espectador y el espacio. Inobjetual quiere desmaterializar el arte y eliminar el objeto, o bien utilizarlo como pretexto para el encuentro con un otro; un arte inobjetual intenta modificar las relaciones de fuerza en el entorno. Como indica, hacia el final, el ensayo Continuidad, el espectador deja de participar para ser un hacedor del acontecimiento estético. 


\section{CONTINUIDAD DE IO DISCONTINUO}

por

*

BDGARDO-ANTONIO VIGO * poeta visual, fundador y director de las reviatas DIAGONALCERO y HEXAGONO'71. Organizo para el INSTITUTO DI TELIA la " EXPO/ INTERNACIONAL DE NOVISTMA POESIA / 69 " y para el CENTRO DE ARTE Y CONUNICACION ( CAyC ), ambos de Argentina,

- la " EXPO/ INTERNACIONAL DE PROPOSICIONES A REALIZAR - investigaciones poéticas / "7I ". Ha colaborado en la difusión de la poesfa visual en tultilples revistas, asf como dictado charlas y conferencias, habiendo participado como expositor en los eventos de mayor mportancia a nivel internacional. Ha editado su ensayo " DESDE IAA POES\$A/PRCCESO A LA POESIA PARA Y/O A REALIZAR ". Edit. DIAGONAIC ERO, 1969 - La Plata - ARGENTINA .

\section{A MANERA DE INTRODUCCION}

*

Comúnmente se asocia a la POESIA VISUAL con la POESIA CONCRETA. Sin embargo la cor creta originariamente es un solo brazo de aquel gran pulpo que se diversifico en tendencias formales y estéticas que hoy han logrado sepultar a dicha poesla visual, aplastada por tanta habilidad de difusion. No aceptamos tanpoco los " ismos multiples " porque muchos con sagacidad y profundidad pueden concretizarse - valga la redundancia.

*

Desde el punto de vista personal cada realizador " vé " como diferente su creacibn, pero as1 solo se llega a la confusión. Escogemos mas bien el método de " agrupar " bajo un miamo sentido diversas tesis y teorfas particulares y aralizamos luego a aquellos que reforzando o introduciendo modificaciones, enriquecieron una teorla. *

Pero tampoco se nos escapa que debemos cargar el acento en los verdaderos pilares y como consecuencia, hocer un rápido " paseo informacional " de los movimientos - poetas que acunaron con pasión estos cambios. Cmbios que no atacan al otro tipo de poesla ( tradicionalmente literaria) sino que enriquecen a la POESIA sin aditamentos. Y cuando heblanos de ella deberfamos acostuibrarnos a que es tan amplia en su significado y rcalización que, en definitiva nodie debería sentirse con derecho a poseer la verdadera. vujás mucho más modesto y eiectivo, er definitiva ser la hablar de " INTENTOS DE POETIZAR ". Dentro de stos " IWMUVS IS POETLZAR " bien poiemos ubicar, ein deamedro aleuno a la " POESIf VISUA "y ne cometer el error de encontrar en esta postura de " INTENTos " una manera de juaticiar lo que no es, des cendiendo a ese terreno a la " otra poesla " es decir, la radicional que, como tal

Fig. 67. Ensayo Continuidad de lo Discontinuo, Hoja 1. CAEV. 


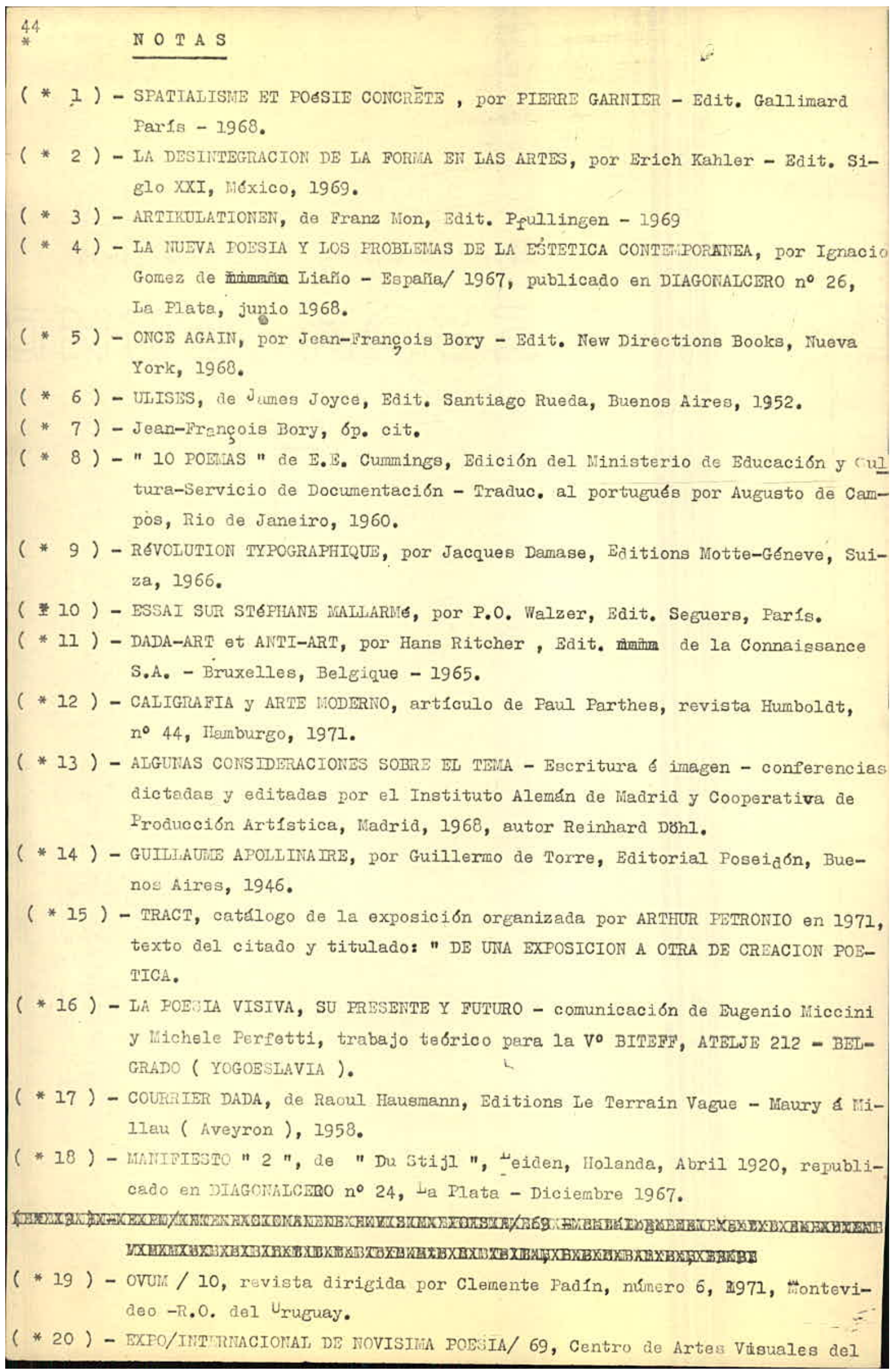

Fig. 68. Continuidad de lo Discontinuo, Hoja 44. "NOTAS" CAEV. 
Seis de los textos transcriptos en la re-escritura Selección D aparecen citados en Continuidad de lo discontinuo, estos son: Poesía Experimental, crónica a seguir, (Pierre Garnier [1967]) Manifiesto Acción (Jean-Claude Moineau), Declaraciones de Luigi Ferro (Luigi Ferro [1968]), La revolución tipográfica (después de Mallarmé) (Jacques Damase [1966]), Poesía Concreta (Max Bense [1966]) y Palabras en Libertad (Marinetti [1966]). Volvemos sobre esta re-escritura en el análisis de la Exposición Internacional de Novísima Poesía en tanto cuatro de los textos que figuran en ella se plasman como citas teóricas en el catálogo de la muestra.

Como indicamos al comienzo, Continuidad de lo discontinuo, presenta, al igual que Panorama un recorrido histórico por la poesía experimental. A diferencia de aquella, este escrito culmina en el apartado Inobjetal, tomado de los conceptos de Clemente Padín, destinado a modificar las relaciones de fuerza en el entorno, tendiente a la creación de un objeto que sirva para crear, generar y sostener vínculos interpersonales.

Dijimos que seis textos de la re-escritura aparecen citados en el desarrollo que el autor realiza sobre la poesía. A continuación, analizaremos la inserción y apropiación que Vigo relaiza de las de la selección de re-escrituras en cada caso. La primer alusión corresponde a Poesía Experimental, crónica a seguir, de Pierre Garnier. En el ensayo de Vigo, aparece la cita en forma de paráfrasis para referir a los antecedentes de la poesía experimental; en el caso de Novalis, refiere al desprendimiento de la función comunicativa de la lengua para volverla autónoma. 


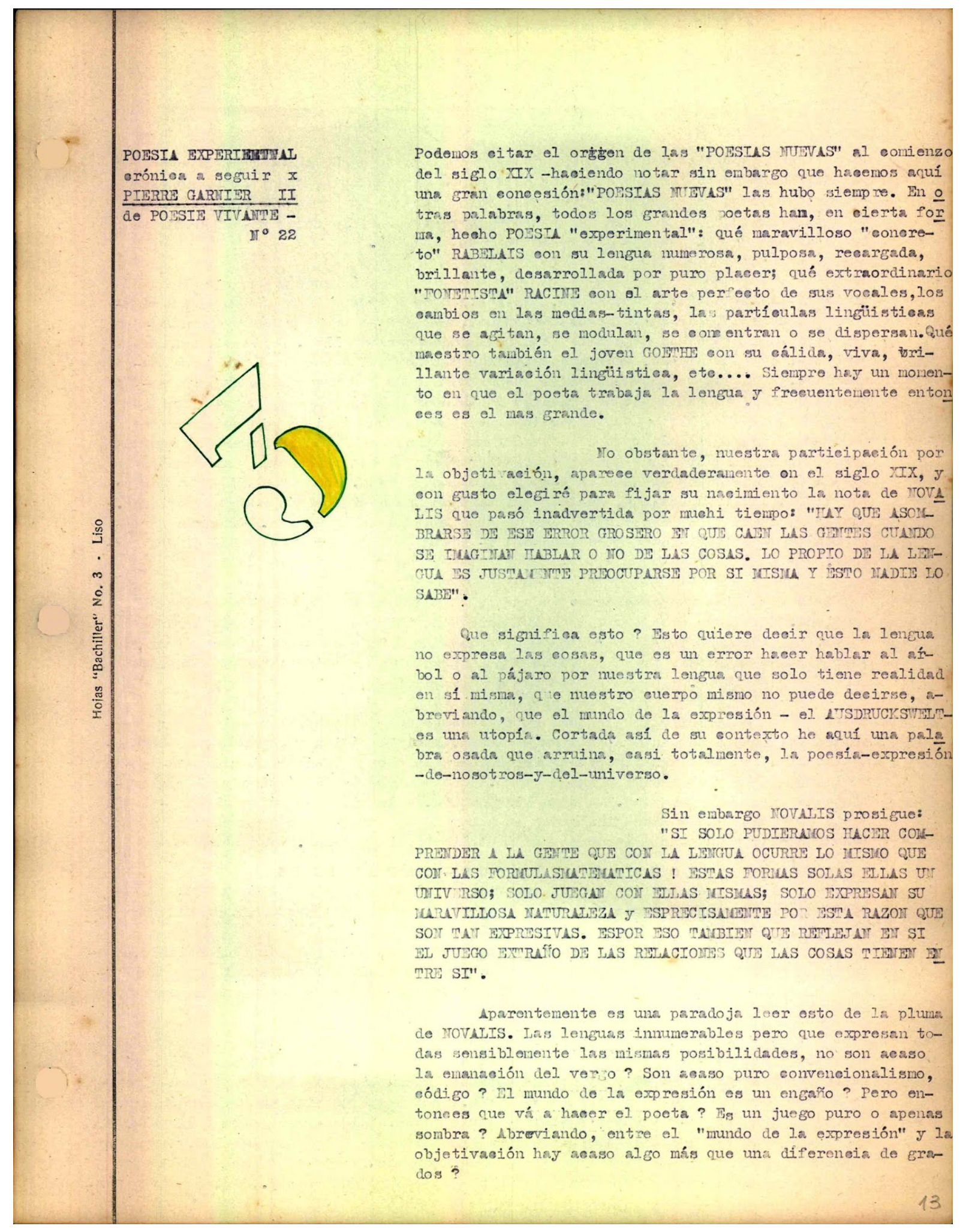

Fig. 69. Selección D, re-escritura sobre poesía experimental. Pag. 13. Poesía Experimental, crónica a seguir, de

\section{Pierre Garnier.}

Continúa el ensayo reseñando Un golpe de dados y el papel que se le asigna al espacio vacío en la composición. 
La segunda cita pertenece a La revolución tipográfica (después de Mallarmé) por Jacques

Damase, se trata de un fragmento del libro presente en la biblioteca de la Novísima Poesía.

son las trismitidas por la SribyARTINE CADIEU en "LES IEMTRTS TRAITGISES" 6 al 13.12.67, donde IUCIATO BFRTO actúi como mísico por el empleo de li voz, porque sirve parib.... P $\mathrm{P}_{0}$ ro citemos mas bien: "Seria neesario hablar del-pero uds. conocen bien a KATHY BIRBERTAIestilo gestual de la cantante. Del aporte visual, de la relación míginca entre la voz y el gesto que llevan a la voza..". Del mismo reportaje citos"Trato de liberar la voz de la que la limitaba, hacer que ya no haya fronteras entre lo "hablado" y lo "cantado". La composición part voz se convierte en la estructura de "signific aci ones articuladas". Pero, Sr. Fleuret y Sra. Cadie u, esta liberación ya estí hecha. Por qué no dir referencias precisas? por qué no aceptar, para convencer mejor al público, que desde hace mas de cien años concientemente deseamos esta liberación? Y en todas liss discippinas ? $\mathbb{B}_{0}$ ten que en nada disminuyo a B BRTO, muy por el contrario, estoy inquieto del empleo deuna cantente en 1967, que por su oficio mísmo, solo conoce "límites" en li voz:

11 - Esas experiencias de la voz son pemanentes, si. Hoy, preflerentemente es la voz quien puede dar a la electrónica un vigor cálido y también todo el cuerpo, este es un rumor constente.

12 - NOUVEL ONSTRVATBUR N $\mathbb{N}^{0}$ 53, del 17.11.67. Selección. A propósito de los discos ACHEIT: "Wn la fronte ra del lenguaje y de la música ( oh ! que no ! ). Ua experiencia que abre singulares horizontes". Destaco el "oh ! que no ! " que es mío. Trmpoco comprendo el empleo de dos líneas solimente para un tema tan amplio y antiguo.

13 - No tengo nada contra la música instrunental, Consta to solamente que sus medios fueron creados para li polifonía, y que pati el arte de hoy, tenemos otros instrumentos.

14 - Gstas lineas las reconocerín uds. mismoss. Ver su carta a la Sribcadieus"Less lettres francai ses" ya citadis: "ITo es a uds. a quienes recordaré la importancia de la exratitud en el oficio que realizamos. Bl pequeño mundo de la' música esté suficientenente trans tornado por toda suerte de querellas para que evitenos agregar algo a la confusión".Aqup estoy de acuerdoy segurimente.

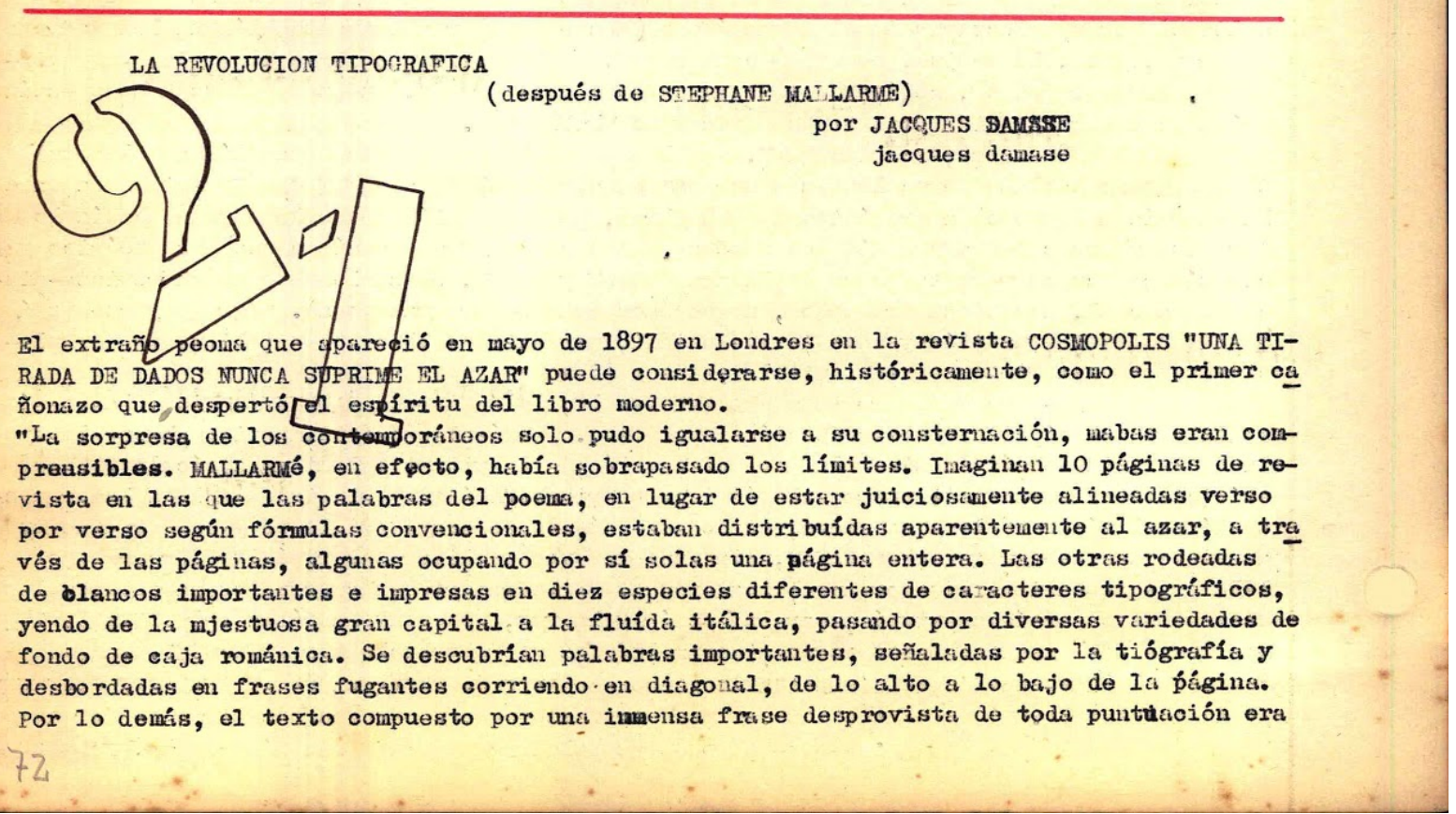

Fig. 70. Selección D, re-escritura sobre poesía experimental. Detalle La Revolución Tipográfica. Pag. 72. 
El ensayo destaca otros precursores como Christian Morgenstern y su Canción nocturna del pez agregandolos a la lista de antecedentes que, como ya vimos, Vigo la utiliza para la clarla

Panorama. La tercera cita pertenece a Filipo T. Marinetti, se trata del Manifiesto Futurista.

$31 / 2-\mathrm{y} \quad 32 / 1$

mas que una revolución etimológica y estructuræl-fonética nosotros proponemos unci evoladión visiva de la estructura semántica, de calidad espiritual absoluta por ser totalmente presen tacional de relaciones palabri-sonido-visualidad.

un cuerpo de poeșia es un objeto de palabris liberadas en el espacio, no colocadas en él: palabras vissivas, en cuento a leerse, que devienen cualitativamente visuales por sustituido ress de sensticiones polisensoriales concretas.

cuerpo de poesía anónima y silenciosa, o asiinvisible : transparencia de palabras liberadas en el vacío.

estructura seméntica orgcunizada en cuerpos platónicos para los grises aposentos de los moteles, de las piezas para alquilar, pero tambien para las mestis de trabajo y las salas de espe ra de las grandes oficinas.

-

hasta para el salón de la abuela leticia para sacudir la proporción de la pemumbra floral so bre el sillón rayado.

los duerpos de poesía incuguran la búsqueda de fonemas elústicos, de palabras hiperacústicáp de elementalidad verbal, impresos en hojas plásticas transparentes ( RODOIDS) o sobre cartón pranamopaco y pegado, de intersecciones ópticas tipovisuales, en el plexiglás 71 íquido o en la resina fenólica a solidificarse para sostenerse en el espacio, glacial, cristalino.

poemas ópticos de letras-formas progiresivmente agrandadas.

la tia parti llegar al poema-objeto a componerse con la intervención del espectador-co autor.

PALABRAS ENT LIBERTAD" POESIA DE TECIICTSIO" POESTA DE PATRIARTE " PILIPPO TOMIASO MARTIETTI de "DESTRUCCION DE IA SINTAXIS

IMAG IVACION SIIn HILOS

PATABRAS EMT IIBERTAD "

manifiesto editado por la dirección del movimiento de

IL COMPASSO $n^{\bullet} 1$, octubre/ 1966 - italia

EXTRACTO

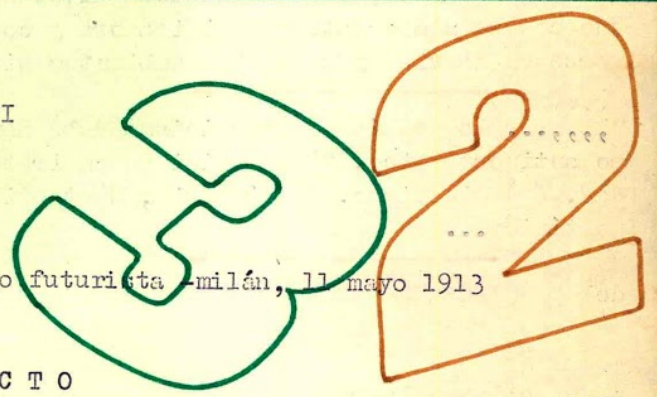

..." Para ayudar de alguna manera a la intuición de mi lector ideal empleo los carcacteres cursivos para todas las palabras en libertad que expressan lo infinitamente pequeño y la vida molecular..."

Mos servimos de muy breves y anónimos si gnos matenáticos y musianles y ponemos entre parénte sis indicaciones como ( pronto) ( mís répido) ( moderado) ( dos tiempos ) para regular la velocidad del estilo. Estos paréntesis pueden hasta cortar una palibra o un acuerdo onomatopéyico...."

Fig. 71. Selección D. Palabras en Libertad. Fragmentos. Pag. 105.CAEV 
En el ensayo explica Vigo que: "los futuristas también se destacan por el interés hacia las investigaciones semánticas. Marinetti, teorizador del movimiento integra las experiencias artísticas bajo un nivel estético y da soluciones universales que debían ser captadas posteriormente por cada género, su individualidad y su proclividad a la totalidad.” (1970, p. 8) Vigo destaca la sonoridad de la palabra como elemento significativo del manifiesto futurista.

En cuanto a Max Bense se cita un fragmento de Poesía Concreta, en la culminación del apartado del mismo nombre. Se trata, según Vigo, de una poesía que "no reproduce el contenido semántico ni estético de sus elementos" sino que juega con sus nexos visuales y de superficie en la composición. Vigo indica el vínculo entre los elementos tipográficos utilizados por el concretismo y el lenguaje publicitario, señala también que el concretismo "ha suscitado una corriente poética verdaderamente internacional" (1970, p. 13)

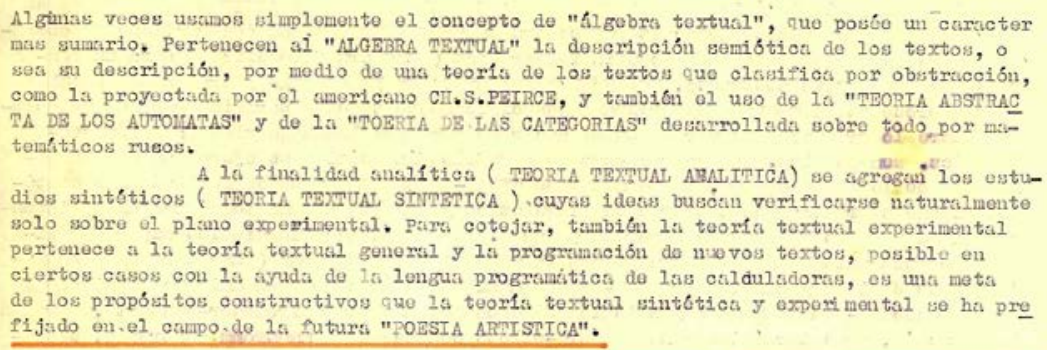

Fig. 72. Selección D, Poesía concreta. Max Bense.Traducción Elena Comas. Pag. 94. 
Adentrándonos en el trabajo teórico presentado por Vigo, la argumentación se detiene en el arte gráfico, particularmente en los posters como medio de difusión de la poesía visual, al igual que en el desarrollo de Panorama.

La cuarta cita extraída de la re-escritura Selección D pertenece a Luiggi Ferro, en Declaraciones. Aquí se rescata del soporte que proporciona el poster o afiche, la posibilidad de producir múltiples copias que permiten determinadas técnicas gráficas en pos de la desauratización de la pieza y gracias al bajo costo de producción para la su elaboración.

Por su parte, en el apartado Objetos poéticos, de Continuidad de lo Discontinuo, refiere al Manifiesto Acción de Met Art. Vigo expone una cita extensa de Jean Claude Moineau, que reproducimos en tanto se vincula con los desarrollos maquínicos que planteamos en el primer capítulo:

"El objeto en el seno de la cultura que lo califica está dotado de una función usual, donde adquieren significado sólo ciertos aspectos del objeto, mientras que en realidad para que exista no solamente el signo sino el objeto percibido es muy necesario que éste esté completamente determinado. Las características que faltan son entonces cuestión de estéticas con los riesgos que sabemos: toda a la estética hacer significar todos los aspectos del objeto (lo arbitrario que precisamente eso incluye)... el objeto más allá de su significación usual, recibe un significado estético global que permite nuevas relaciones de objeto a objeto, nuevas aproximaciones sintácticas de objetos pero además de recibir cualquier significado (de connotación) relacionándose necesariamente con una nueva función (...) "(1970, p. 20).

Notemos que en la re-escritura Selección B, el número ocho se presenta en fibra y letra de molde mientras que se escribe en el lado derecho la palabra "ocho" formando un bloque. 

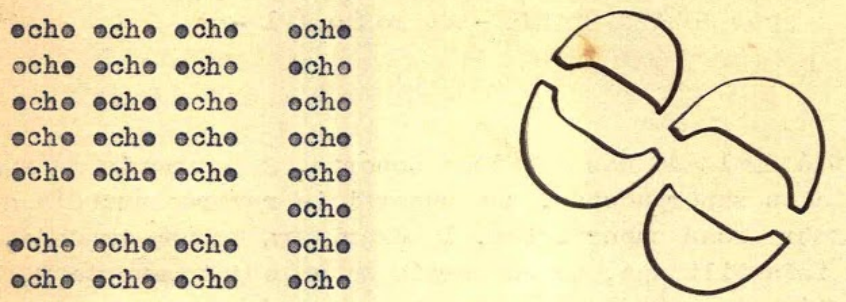

sábado 18 novienbre domingo 19 noviembre HAN IPIBSTO - ACCION IIFTA - ARTE

El objeto on el seno de la cultura que 10 califica esté dotado de una función usual, donde adquieren significado solo ciertos aspectos del objeto, mientras que on realidad, para que exista no solamente el sigmo sino el objeto percibido, os my necesario que ésto esté completamente deterninado. Las caracteristicas que faltan son ontłnces cuestión de estética con los riesgos que sabomoss toca a la estética hacer significar todos los aspoctos del objeto ( con lo arbitrario que procisanente eso in cluye).

Tal vez no "miramos", sin embargo VMrOS.

Tal vez no "escuchamos", sin embargo ormos.

En cualquier parte, en cualquier monento, su/nuestro espiritu "recorta" lo real, lo imaginario.

Ffectivamente, la función de obra no es asumida on sí mismo sino ene cier4. tos aspectos del objeto "obra" lo que señala todavía los distingos habitual mente operados.

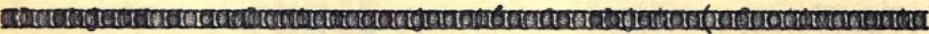

Hirar, escuchar, percibir cualquier cosa, tolerar ( es lo que nos impone cada vez mass la vida de todos los dias), - SEL BCCIOIAR...

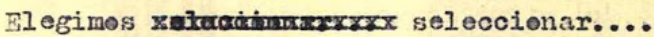

El objeto mas allá de su significado usual, recibe un significado estético global que permite nuevas relaciones de objeto a objeto, nuovis aproximaciones fjintícticss de ob jetos - pero además recibir cualquier nuevo significado ( de conmotación) rolacionán dose necesariamente con una nueva función, lo que hace que todos los aspectos del ebjeto "funcionen", que el objeto se vuelva onteramente "funcional".

Especi Imente conjunción de obrass el programei- la exposición el concierto, etc - esos distingos pueden efectivamente ceder el lugar a un "juego" operando sobre las obras.

Hemos " mecortado", homos pensado "reconstitución" pero uds. lo competarḱn.

Fig. 73.Selección D, Manifiesto Meta Art. Pag. 30 
JEAN-CLAUDE MOINEAU basa sus experiencias de METAart, en poemas donde su escritura no tiene fin o se vo tmpregnada de gráficos que suplantan al termino escrito que los define o clasifica, estos ( dibujos, clisés, sefales) hacen jugar dentro de la escritura códigos visuales diferentes o rafces de palabras con reserva de espacio para que estas sean escritas en su totalidad. La retención visual, el acostumbramiento por lo repetido, el conocimiento, por su disefo, del objeto trangcripto y no

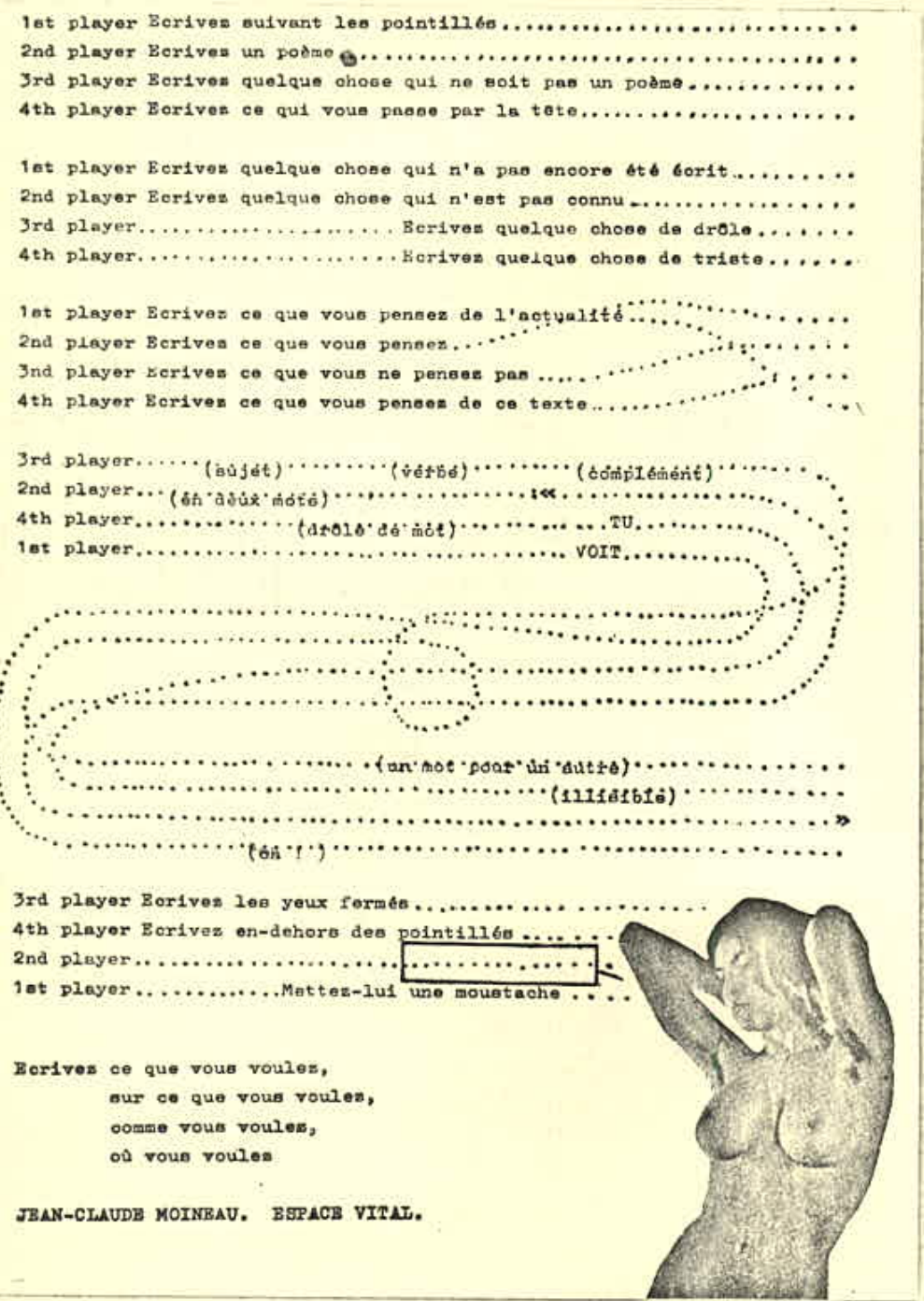

JEAN-CLAUDE MOINEAU " Espacio vital ".

por el concepto caligráfico, la acumulación de información por "seffales cotidianas ( tránsito, lineas peatonales, etc.) producen en una lectura diferente a la maimrarmi habitual - modificada a veces por errores rectificados posteriormente de una idea definitive - torpedean el costumbrismo cotidiano, producen nuevas facetas ( visión caleidoscopica), crean la revulsión. Una activiación del fenómeno de la lectura pero delatando todavía un proceso tradicional o emparentado a los cánones de la herencia recibida.

Fig. 74.Continuidad de lo Discontinuo. Hoja 24. CAEV. 
Vigo no se olvida del dadaísmo, y refiere este movimiento para establecer las primeras experiencias en torno a la modificación del objeto (l'objet-trouvé). Dice que en el objeto está el "porcentaje revulsivo" no ideal para "soluciones institucionalizadas". Recurre al dadaísmo para reflexionar sobre el aspecto revulsivo porque "El dadaísmo es un movimiento que postula la liberación de los géneros artísticos, irrespetuoso con el concepto de obra de arte, postulador de la desaparición del artista" $(1970,20)$. En los apartados siguientes de Continuidad de lo Discontinuo, Vigo continúa refiriendo a citas y experiencias de poetas brasileños como Alvaro de Sá, Dias Pino, Neide de Sá y europeos como Franco Vaccari, Alain Arias-Misson entre otros. Culmina su recorrido con la propuesta Inobjetal, heredera, como ya mencionamos, de las reflexiones de Clemente Padín y extraídas de la publicación Ovum 10. 


\section{Síntesis}

En las reflexiones anteriores nos hemos dedicado al trabajo exhaustivo de rastrear las correspondencias entre los textos que E. A. Vigo retoma de la re-escritura Selección D y la elaboración de un texto personal, teórico y descriptivo sobre la poesía experimental, al que denomina Continuidad de lo Discontinuo. A diferencia de la charla presentada en el Círculo de Periodistas (Panorama de la Poesía) que nos permitió identificar la manera en que Vigo historiza el género, este ensayo presenta una serie de argumentaciones y sistematizaciones del material teórico que nos han permitido vislumbrar las maneras en que el artista, devenido teórico de la poesía experimental, se apropia de diversos materiales para proponer un punto de vista donde confluye un repertorio de autores y artistas diversos. Además de la presencia de antecedentes históricos, Vigo desarrolla un porvenir para la poesía experimental ligada fuertemente a la participación, al sentido de los actos poéticos y al cuerpo en contexto. Es coherente, en este sentido, con la forma de presentar la charla-ensayo, recordemos que tuvo lugar en el Colegio Nacional, se prendieron las Velas de Suknasky, Vigo mostró obra de poesía experimental internacional (como el tendedero de Diana Atchley) y realizó audiciones de poesía fónica. Puso el cuerpo en acto en esta charla, en correspondencia con sus postulados teóricos. En el apartado siguiente, analizaremos la Exposición Internacional de Novísima Poesía/69, considerando que en esta muestra se expone la teoría (a partir de catálogos, libros y revistas) y se habilita un modo de habitar la poesía desde los cuerpos y la participación del espectador. 


\subsection{Novísimos}

Interesa resaltar en este apartado, como ya mencionamos, la importancia que Vigo le asigna al material teórico en esta exposición, a la cual se le dedica una sección dentro de la muestra, también distinguir la incidencia de las lecturas de E. A. Vigo presentes en el catálogo de la exposición que son el andamiaje teórico, deglutido a partir de las re-escrituras, que sustenta la Novísima. La apropiación de las re-escrituras se manifiesta en la Novísima a partir de la inserción de material teórico pero también en los modos en que la teoría invade el hacer, la organización del montaje y las propuestas participativas.

Intervenciones en los medios de comunicación, propuestas poéticas experimentales, lecturas compartidas y acciones artísticas, la Expo Novísima representó el ápice de un proceso de experimentación plástica y literaria sin precedentes en el ámbito argentino de la literatura a fines de la década de 1960.

Como ha señalado Pérez Balbi (2008), Davis (2016) y Barisone (2017) la Exposición Internacional de Novísima Poesía/69, tiene como antecedente las presentaciones en el circuito artístico y espacios no tradicionales de la ciudad de La Plata: Federico V y Bar Mimo. En estos espacios el grupo Diagonal Cero, organizó performances y acciones artísticas. La lectura de Davis sobre la poesía experimental nos ubica en el carácter disruptivo que tuvo esta intervención:

Mucho más que un gesto de provocación como una mera propuesta lúdica y participativa, la poesía experimental apuntaba a movilizar procesos de subjetivación susceptibles de interrumpir la instrumentalización capitalista del tiempo de ocio, para activar la invención colectiva de nuevas estrategias creativas y vitales. $(2016$, p. 14)

La exposición reunió más de 150 obras realizadas por 132 artistas de 15 países y tuvo lugar entre el 18 de marzo y el 13 de abril de 1969, en el Centro de Artes Visuales del Instituto Torcuato Di Tella $^{115}$. Posteriormente, la muestra se trasladó con menos cantidad de material por las condiciones espaciales, al Museo Provincial de la ciudad de La Plata. Ha señalado Bugnone en

\footnotetext{
115 Desde el año 2017, estoy encargada del ordenamiento, recuperación y valorización de las obras bidimensionales y la biblioteca de Novísima Poesía, reuniendo los materiales que estuvieron presentes (catálogos, libros y revistas), relevando los materiales bidimensionales, las formas que asumió el montaje de las obras en volumen. El repertorio sonoro que se mostró en la Tercer Sección esta a cargo de Julio Lamilla y Alan Courtis, investigadores de la Audiovigoteca.
} 
relación con la función de Vigo como coordinador de la muestra que: "La Expo, además de ser coherente con su proyecto "revulsivo", le posibilitaba hacer conocida en nuestro país a la "novísima poesía", en la ciudad más importante tanto por ser la capital como por su rol preeminente en el arte contemporáneo local.” (2013, p. 127). Recordemos que es Haroldo de Campos quien recomienda a Romero Brest la gestión y organización de la exposición a manos de Vigo.

Respecto de la disposición espacial de la Novísima, el montaje fue diseñado en tres secciones, tal como quedó de manifiesto en el catálogo. En la primera sección se exhibieron: libros, revistas, catálogos y libros-objeto; en la segunda, poesía visual impresa y objetos, en la tercera, audiciones de poesía fónica. Las obras tridimensionales, según Luis Pazos ${ }^{116}$, fueron realizadas en Argentina con la coordinación de Vigo a partir de las instrucciones que los artistas enviaron. Ya hemos visto, en el apartado dedicado a Elena Comas, la carta enviada por Sarenco con motivo de la exposición donde indicaba el envío de "nuevo material" para la muestra; probablemente se tratase de los Poemas Inflables expuestos en la Novísima.

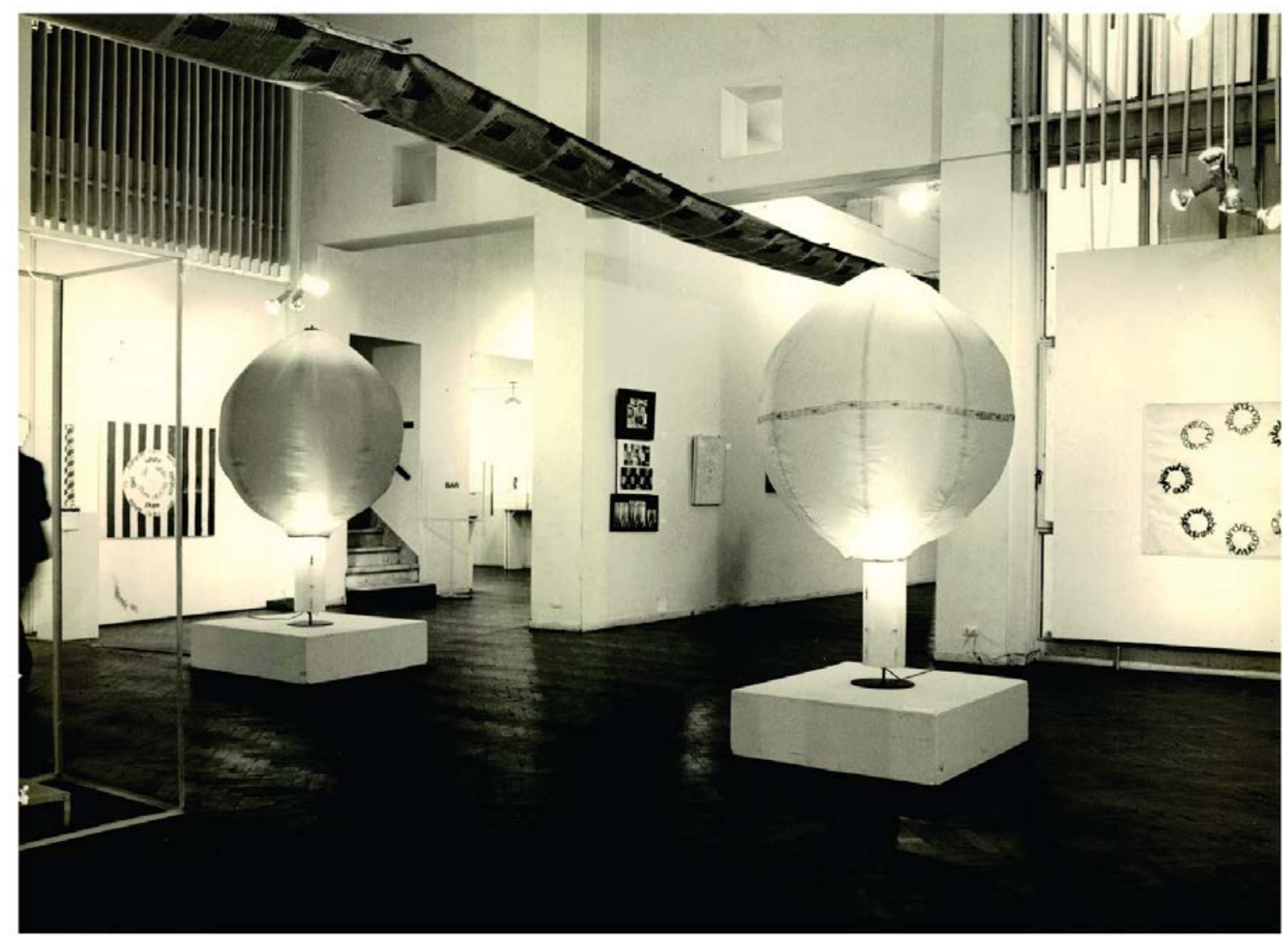

Fig. 75.Sarenco y Ken Cox. Poemas Inflables. De dos metros y medio de polietileno, según las descripciones, inflados con ventiladores. Exposición Internacional de Novísima Poesía/69. CAEV

${ }^{116}$ Luis Pazos, comunicación personal con Mariana Fuks y Julia Cisneros, 2018. 


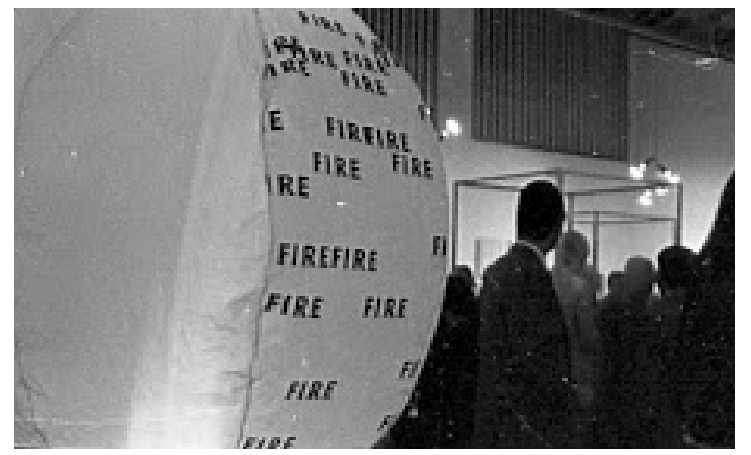

Fig. 76.Sarenco y Ken Cox. Detalle Poemas Inflables.Uno de ellos decía “Fire”, el otro "Earth”. Exposición Internacional de Novísima Poesía/69. ATDT

En la entrevista realizada por Mónica Curell (1995), Vigo cuenta que tuvo inconvenientes en la aduana respecto del envío de las velas producidas por Andy Suknasky: improvisadamente invento que las velas eran para una iglesia metodista de La Plata temiendo que los agentes de seguridad aduanera se las incautaran.

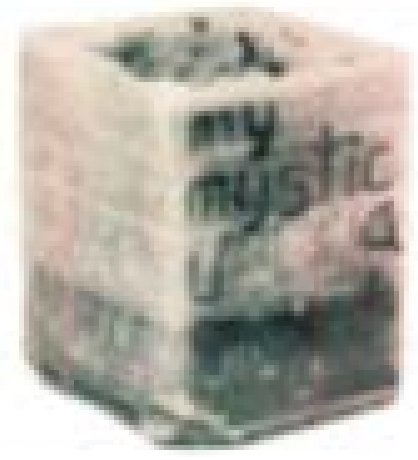

Fig. 77.Andy Suknasky, "Velas” (reproducción extraída del ensayo De la poesía proceso de E.A.Vigo)

Las operaciones de montaje que Vigo organiza no son ajenas a sus preocupaciones por la materialidad de la palabra y la participación del espectador. Las obras seleccionadas representaron un acercamiento al público argentino de expresiones poco reconocidas dentro del ámbito artístico por su carácter liminar. El contacto directo del espectador con la materialidad y recorrido en los formatos diversos que se expusieron significó la mostración de otro tipo de lectura y experiencias respecto de la poesía. El viraje en las referencias teóricas plasmado en la publicación, gracias al trabajo con las re-escrituras y la implicancia de otros referentes teóricos, principalmente brasileros y franceses, se materializa en la Exposición Internacional de Novísima Poesía como un alejamiento de los modos de presentación del montaje tradicional. Como 
venimos sosteniendo, tanto en su biblioteca como en las re-escrituras y a partir de las charlas y ensayos que analizamos (Panorama, Continuidad) Vigo se manifiesta y posiciona como un sujeto conocedor de las últimas tendencias en materia de poesía experimental.

Respecto de las genealogías que inventa la muestra, se visibiliza la herencia de las vanguardias históricas en los cruces temporales que propone la Exposición Internacional de Novísima Poesía: se exponen referentes de la vanguardia argentina martinfierrista, como Oliverio Girondo con Espantapájaros, y la Aliverti Liquida de la Troupe ateniense, junto a los poetas nucleados bajo Diagonal Cero, se escuchan históricos poemas fónicos tipo collage (de Raoul Hausmann) y destrucción del registro natural por medios electrónicos (Arrigo Lora Totino) o los sonidos corporales de Henri Chopin. La noción de repertorio se vuelve operativa en este sentido desde, por lo menos, dos artistas importantes que han sido desarrolladas desde los postulados de Haroldo de Campos en la primer parte de esta tesis: por un lado, en la configuración de lecturas y marcos teóricos para el abordaje de estas producciones liminales y heterodoxas; por otro lado, en los cruces entre disciplinas que se proponen en la Exposición.

Debemos decir que muchos diarios y suplementos nacionales como El Día, Clarín, La Tribuna, Primera Plana, Análisis, La Capital, La Nación, La Razón, e internacionales como El Diario (Uruguay), Jornal dos Escritores (Brasil), entre otros, hicieron eco de la Novísima, desde visiones críticas hasta alabanzas en La Poesía Loca. Todas las repercusiones se encuentran resguardadas en Biopsia 1969, estas voces han permitido reconstruir, mediante sus descripciones y las entrevistas realizadas a sus actores en la época, algunas de las propuestas experimentales que tuvieron lugar en la muestra.

Como venimos sosteniendo en esta tesis, la lectura que Vigo realiza del material crítico incide directamente en su producción, ya sea en forma de cita explícita a partir de su publicación (o inserción dentro de sus charlas/ensayos) y de manera implícita en la apropiación que realiza del contenido teórico en su producción. En la Novísima vemos está apropiación en su doble dimensión: por un lado, la teoría que Vigo y el grupo Diagonal Cero ha leído se muestra, se expone, se comparte (en la Primer Sección). Por otro lado, la selección de obras expuestas esta en línea con las teorías en torno a la poesía experimental, resaltando los umbrales entre las disciplinas lo que generó un cruce interesante e inédito hasta ese momento entre poesía, artes visuales y participación del espectador. 
Reconstruimos a continuación de manera detallada las tres secciones en las que se organizó la Novísima Poesía/69 en el Instituto Di Tella con el fin de visibilizar la envergadura del proyecto como síntesis de la producción de poesía experimental y la acción fundamental que se le asigna al espectador en el recorrido propuesto. Incorporamos al análisis de las secciones, la referencia al catálogo en tanto se visibiliza en este la acción directa de las re-escrituras y las traducciones de Comas.

\section{El catálogo}

Fue diseñado íntegramente por Vigo con traducciones de Elena Comas, el ordenamiento del mismo se corresponde con las tres secciones en las cuales se desarrolló el montaje, junto a imágenes de las obras cuyos originales conserva el CAEV.

Veamos algunas particularidades que dan cuenta de la inserción de las re-escrituras en la presentación de la Novísima, y la función del catálogo como documento donde se presenta un criterio de registro pero también una investigación.

En primer lugar, la imagen de tapa del catálogo presenta, de Man Ray, "Poema Sonoro" (1924), aludiendo al desarrollo histórico ligado a las vanguardias, tema sobre el que trabajamos anteriormente tanto en el análisis de Panorama como en Continuidad de lo Discontinuo.

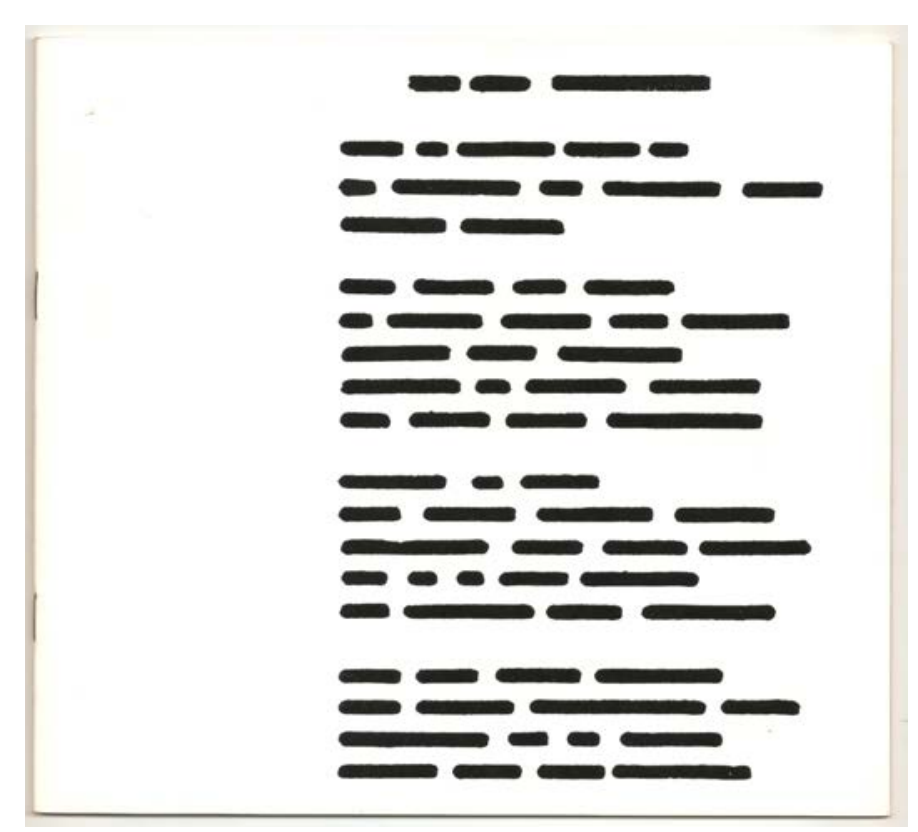

Fig. 78. Man Ray "Poema Sonoro” 1924. Catálogo. CAEV. 
Figuran diez fragmentos teóricos en este documento. El primero es de Romero Brest, el segundo de Vigo y el tercero de Luis Pazos. Los demás pertenecen al corpus de re-escrituras que la dupla Comas-Vigo traduce y re-escribe en los compendios que analizamos desde, por lo menos, cinco años antes del evento. Esto da cuenta de la persistencia e importancia de las re-escrituras en la configuración de las lecturas y apropiaciones por parte de Vigo.

Tres de los fragmentos publicados en el Catálogo de la Novísima Poesía, han sido extraídos de la selección de artículos que analizamos Selección D. De Max Bense, el texto ya analizado Poesía concreta (1966); de J. Damase un fragmento del libro La revolución tipográfica (1966) y Vincenzo Accame, quien se cita a partir de del texto Nuevas técnicas poéticas (1968). La selección para el catálogo se centra en lo que Accame denomina "la figura del lectorespectador". El texto corresponde al artículo n 15 en la Selección D.

El "lector" de Nuevas Técnicas Poéticas no es en realidad ni un verdadero y propio lector, en el sentido al que nos habituamos por una larga tradición literaria, ni un observador, ni un escucha, ni otra cosa, aún cuando de tanto en tanto, en el curso de operaciones (mentales o sentimentales) que realiza para establecer un contacto apropiado con la obra frente a la que se halla, puede asumir una actitud propia a estas categorías (Catálogo, Accame, 1969, p. 47) 


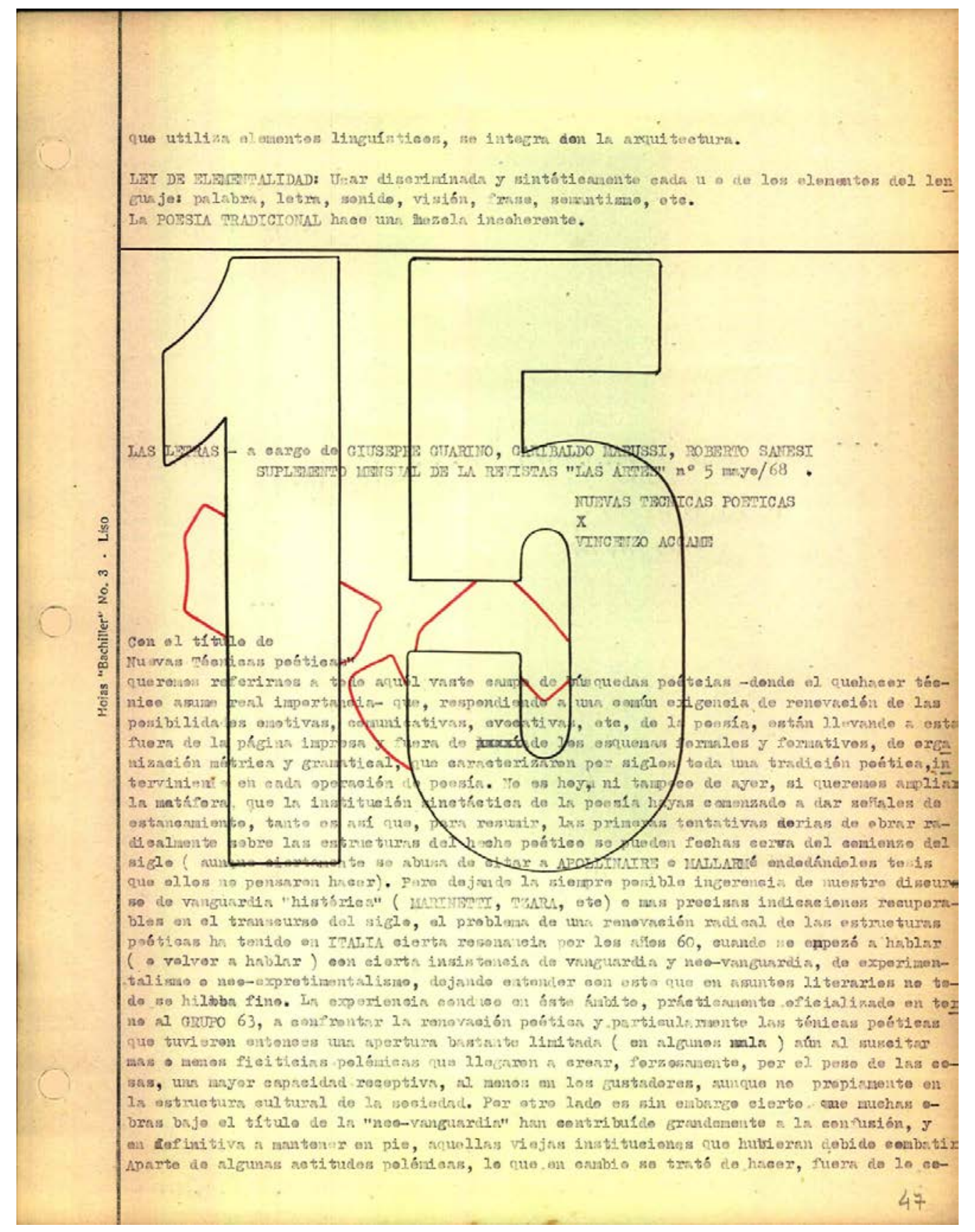

Fig. 79. Selección D. Re-escritura de Nuevas técnicas poéticas. Pag. 47.CAEV

Además, Vigo, en su afán archivístico y administrativo realiza fichas mecanografiadas de más de doscientos ejemplares para la Novísima considerando todos los libros, catálogos y revistas que se expusieron en la Primera Sección. En el catálogo así se explicita:

Cada volumen es acompañado por una ficha bibliográfica conteniendo datos editoriales, pequeño comentario de las características fundamentales de la publicación, artículos que se incluyen en el texto y lista de las reproducciones de los artistas incluidos. (Catálogo Expo Internacional, 1969, p.10). 


\begin{abstract}
Algunas fichas, tienen "pequeños comentarios" delirantes de Vigo, como la ficha perteneciente al libro de J. Blaine donde dice: “en la primera perforación = la penetración, las siguientes perforaciones $=$ la progresión creación". La ficha de Diagonal Cero $\mathrm{n}^{\circ} 25$ dice "No se edita ni se imprime porque esta dedicado a la nada". Es interesante notar que las fichas documentan las propias lecturas y apropiaciones de Vigo sobre el material bibliográfico. Al presentarse como síntesis de otros textos nos permiten adentrarnos en los modos en que, antropofagicamente, Vigo lee y (ahora si) reescribe.
\end{abstract}




\subsection{Primera Sección:}

La primera sección estuvo orientada a ofrecer un panorama general de los estudios teóricos y experiencias de poesía visual en libros, catálogos y revistas. Las consideraciones teóricas que hemos relevado en las re-escrituras, así como en la charla de Vigo y en el ensayo Continuidad de lo Discontinuo vuelven a resonar en el montaje puesto que en la Exposición de Novísima Poesía la teoría se muestra, se expone, se lee. Según las declaraciones de los periódicos, en el artículo "la Poesía Loca” (El Día, 1969, sin autor), la sección Bibliográfica se presentó en vitrinas. Es considerada por el anónimo autor la "documentación histórica de las memorias del porvenir" (El Día, 1969). A continuación presentamos el cuadro con todas las publicaciones de esta sección:

\begin{tabular}{|c|c|c|}
\hline $\begin{array}{c}\text { TIPO DE } \\
\text { PUBLICACIÓN }\end{array}$ & PAÍS & TíTULO \\
\hline \multirow{10}{*}{$\begin{array}{c}\text { Antologías y Libros } \\
\text { teóricos }\end{array}$} & Bélgica & Poezie in Fusle: Lier - 1968 - Paul de Vree. \\
\hline & \multirow[t]{3}{*}{ Brasil } & $\begin{array}{l}\text { Poesía concreta: Embajada del Brasil en } \\
\text { Portugal - } 1962 \text { - Grupo Noigrandes. }\end{array}$ \\
\hline & & $\begin{array}{c}\text { Antología - Noigrandes } 5 \text { - San Pablo - } \\
1962 \text { - Grupo Noigrandes. }\end{array}$ \\
\hline & & $\begin{array}{c}\text { Teoría de la Poesía Concreta - San Pablo -1965 - Augusto y } \\
\text { Haroldo de Campos - Décio Pignatari. }\end{array}$ \\
\hline & Checoslovaquia & $\begin{array}{c}\text { Poezie - Experimentální poezie - Praga - Bohumila } \\
\text { Grogerová - Josef Hirsal. }\end{array}$ \\
\hline & España & $\begin{array}{l}\text { Letras - Texto - Imágenes - Poesía experimental - Madrid - } \\
1967 \text { - Eugen Gomringer y Reinhard Dohl. }\end{array}$ \\
\hline & \multirow[t]{3}{*}{ Estados Unidos } & $\begin{array}{l}\text { Anthology of Concrete Poetry New York - } 1967 \text { - Emmett } \\
\text { Williams. }\end{array}$ \\
\hline & & Once Again - New York - 1967 - Jean- Francois Bory. \\
\hline & & $\begin{array}{l}\text { A World__Look at Concrete Poetry - Universidad de Indiana } \\
\qquad-1968 \text { - Mary Ellen Solt. }\end{array}$ \\
\hline & Suiza & $\begin{array}{c}\text { Révolution Typographique - Géneve - } 1966 \text { - Jacques } \\
\text { Damase. }\end{array}$ \\
\hline
\end{tabular}




\begin{tabular}{|c|c|c|}
\hline \multirow[t]{18}{*}{ Catálogos expuestos } & Alemania & Hansjórg Mayer: Typoems, Ediciones. \\
\hline & Argentina & $\begin{array}{l}\text { Instituto Torcuato Di Tella - Centro de Artes Visuales: } \\
\text { Letras en el Arte Moderno. }\end{array}$ \\
\hline & & $\begin{array}{c}\text { Movimiento Diagonal Cero: Primera Exposición de } \\
\text { Novísima Poesía de Vanguardia. }\end{array}$ \\
\hline & & Edgardo Antonio Vigo: Vigo/ Cosas. \\
\hline & Checoslovaquia & Ladislav Novák: Poemas Alquímicos \\
\hline & España & $\begin{array}{c}\text { Galería Barandiarán: Semana de Poesía Concreta y } \\
\text { Espacial. }\end{array}$ \\
\hline & & $\begin{array}{l}\text { Galería Juana Mordo: Exposición Internacional de Poesía } \\
\text { de Vanguardia }\end{array}$ \\
\hline & & $\begin{array}{l}\text { Cooperativa de Producción Artística: Signo y Forma - } \\
\text { Concordancia de las Artes. }\end{array}$ \\
\hline & & Exp. Rotor - Nuevo Lenguaje. \\
\hline & & Instituto Alemán de Madrid: Letras - Textos - Imágenes. \\
\hline & Inglaterra & Bristol Arts Center: Cavan McCarthy \\
\hline & & $\begin{array}{l}\text { Fulham Gallery: Henri Chopin - Visión } \\
\text { Irónica. }\end{array}$ \\
\hline & Italia & Galería Alpha: Timm Ulrichs. \\
\hline & & Club Turati: Rassegna di Poesía. \\
\hline & & Comuna de Fiumalbo: Paroli sui Muri- Geiger - 1967. \\
\hline & & $\begin{array}{l}\text { Centro Libraría Remagnosi di Piacenza: } \\
\text { Luigi Ferro - lconogramas. }\end{array}$ \\
\hline & & $\begin{array}{l}\text { Comuna di Ferrara - Palazzo dei Diamanti: } \\
\text { km. 149.000.000. }\end{array}$ \\
\hline & México & $\begin{array}{c}\text { Galería Universitaria Aristas: Poesía Concreta } \\
\text { Internacional. }\end{array}$ \\
\hline
\end{tabular}




\begin{tabular}{|c|c|c|}
\hline \multirow{22}{*}{$\begin{array}{c}\text { Libros - Textos } \\
\text { expuestos }\end{array}$} & \multirow[t]{4}{*}{ Alemania } & Ludwig Haring: Das Fussballspiel. \\
\hline & & Ernst Jandl: Laut und Luise Sprech blasen. \\
\hline & & Timm Ulrichs: Beschriebene Blatter. \\
\hline & & Wolf Wezel: Meinsein Geditche. \\
\hline & \multirow[t]{6}{*}{ Argentina } & Carlos Raúl Ginzburg: Sin título - libro objeto. \\
\hline & & $\begin{array}{l}\text { Oliverio Girando: } 20 \text { poemas para ser leídos en el tranvía. } \\
\text { Calcomanías. Espantapájaros. }\end{array}$ \\
\hline & & Jorge de Luján Gutiérrez: Diario - Edic. Sexta de Poesía. \\
\hline & & Luis Pazos: El Dios del laberinto - La Corneta. \\
\hline & & Celina H. Uralde: de Pe a Pa. \\
\hline & & $\begin{array}{l}\text { Edgardo Antonio Vigo: Análisis poético } \\
\text { matemático de una sala de relojes inútiles - Poemas } \\
\text { matemáticos (in)comestibles. }\end{array}$ \\
\hline & Austria & Heinz Gappmayr: Zeichen 11 \\
\hline & \multirow[t]{6}{*}{ Brasil } & E. E. Cummings: 10 poemas. \\
\hline & & $\begin{array}{c}\text { Alvaro De Sá: } 12 \text { x 9. Armando Freitas Filho: Palavra - } \\
\text { Dual. }\end{array}$ \\
\hline & & Camargo Meyer: Carth i la. \\
\hline & & Hugo Mund Jr.: Gráficos. \\
\hline & & José Paulo Paes: Anatomías. \\
\hline & & Decio Pignatari: Life. \\
\hline & \multirow[t]{2}{*}{ Canadá } & Nichal: Scraptures. \\
\hline & & Pierre Garnier: Microcosmique. \\
\hline & Escocia & Stephen A. C. Scobie: Below Zero \\
\hline & \multirow[t]{2}{*}{ Estados Unidos } & Fernbach-Flarsheim: Ediciones varias. \\
\hline & & John Giorno: Poems \\
\hline
\end{tabular}




\begin{tabular}{|c|c|}
\hline & $\begin{array}{c}\text { Ronald Gross: Pop poems - A. Handful of Concrete - } \\
\text { Ediciones varias. }\end{array}$ \\
\hline \multirow[t]{6}{*}{ Francia } & $\begin{array}{c}\text { Julien Blaine: Quinzieme - Essai sur la } \\
\text { sculpturale - Manifeste Mai } 1968\end{array}$ \\
\hline & $\begin{array}{l}\text { Pequeño manual de Erotomanía - Jean } \\
\text { François Bory (original) - Ouverture } \\
\text { pour un intronaute - Requiem pour un } \\
\text { intronaute - Arithmetic Texts - Height } \\
\text { Texts One - Plein signe - }\end{array}$ \\
\hline & $\begin{array}{c}\text { llse y Pierre } \\
\text { Garnier: Poèmes Mécaniques - Prototypes }\end{array}$ \\
\hline & $\begin{array}{l}\text { Jean Claude Moineau: La lecture est } \\
\text { un parcours d'obstacles: Roman }\end{array}$ \\
\hline & $\begin{array}{c}\text { Seiichi } \\
\text { Niikuni - Pierre Garnier: Poemes } \\
\text { Franco-Japonais. }\end{array}$ \\
\hline & $\begin{array}{l}\text { Edgardo Antonio Vigo: Poeme Mathéma- } \\
\text { tique Baroque }\left(1^{\circ} \text { ed. }\right) \text { - Contexte - } \\
\text { Poeme Mathématique Baroque }\left(2^{\circ} \text { ed. }\right) \\
\text { Agentzia. }\end{array}$ \\
\hline \multirow[t]{3}{*}{ Inglaterra } & $\begin{array}{l}\text { Distintos autores: Gallery Number Ten } \\
\text { Edic. }\end{array}$ \\
\hline & Kurt Schwitters - Raoul Hausmann: Pin. \\
\hline & John J. Sharkey: Poem Blanc. \\
\hline \multirow[t]{3}{*}{ Italia } & $\begin{array}{l}\text { Vincenzo Accame: (original) } 4 \text { Aleacon- } \\
\text { cretpoems - Ricercari. }\end{array}$ \\
\hline & $\begin{array}{l}\text { Ugo Carrega: Sketchs relativiste - } \\
\text { Causa Effeto Causa (original) - } 11 \text { Violino } \\
\text { Eroticomatemático - Libro transparente - } \\
\text { Mikrokosmos. }\end{array}$ \\
\hline & Pedrotti: Produzione. \\
\hline
\end{tabular}




\begin{tabular}{|c|c|c|}
\hline & & Sarenco: Prossimamente. \\
\hline & & Tobas: Questo. \\
\hline & & C. A. Sitta: i-n/ finito. \\
\hline & Suiza & $\begin{array}{c}\text { Eugen Gomringer: } 5 \text { mal } 1 \text { Konstellation - } \\
\text { Las Constelaciones. }\end{array}$ \\
\hline & Uruguay & $\begin{array}{l}\text { Mario Ferreiro, Garet y Ortiz Saralegui } \\
\text { (?): Aliverti Liquida. }\end{array}$ \\
\hline & Venezuela & Gerd Leufert: Visibilia. \\
\hline \multirow[t]{15}{*}{ Revistas expuestas } & \multirow[t]{4}{*}{ Alemania } & $\begin{array}{c}\text { Futura: } 1,2,3,4,5,6,7,8,10,11,12 ; 14 \\
\quad 15,16,18,19,20,21,22,23 .\end{array}$ \\
\hline & & Klactoveedsedsteen: 4, 23. \\
\hline & & Rhinozeros: 6, 9, 10. \\
\hline & & Rot: $26,28,29,30,31,32,33,34,35,36,37$ \\
\hline & Argentina & Diagonal Cero: 20, 21, 22, 23, 24, 26, 27. \\
\hline & \multirow[t]{2}{*}{ Bélgica } & $\begin{array}{c}\text { De Tafelronde: } 213 \text { (1966). 1/2 (1967). } \\
3 \text { (1967). } 4 \text { (1967). 1/2 (1968). } 314 \text { (1968). }\end{array}$ \\
\hline & & Labris: 4. \\
\hline & \multirow[t]{3}{*}{ Brasil } & Invenção: $2,3,6$. \\
\hline & & Ponto: $1,2$. \\
\hline & & Revista de Cultura Brasileña: 15, 18, 19. \\
\hline & \multirow[t]{2}{*}{ Canadá } & $\begin{array}{c}\text { Gronk: } 1,2,4,5,6 / 7,8 \text {, primera serie - } \\
\text { 1, segunda serie. } \\
\text { Spanish Fleye: } 1 .\end{array}$ \\
\hline & & Quoi: 1,2. \\
\hline & \multirow[t]{2}{*}{ Checoslovaquia } & Dialog: 1, 2, 3, 4, 5, 6 . \\
\hline & & Sesity: 19. \\
\hline & Francia & Agentzia: 1,2 . \\
\hline
\end{tabular}




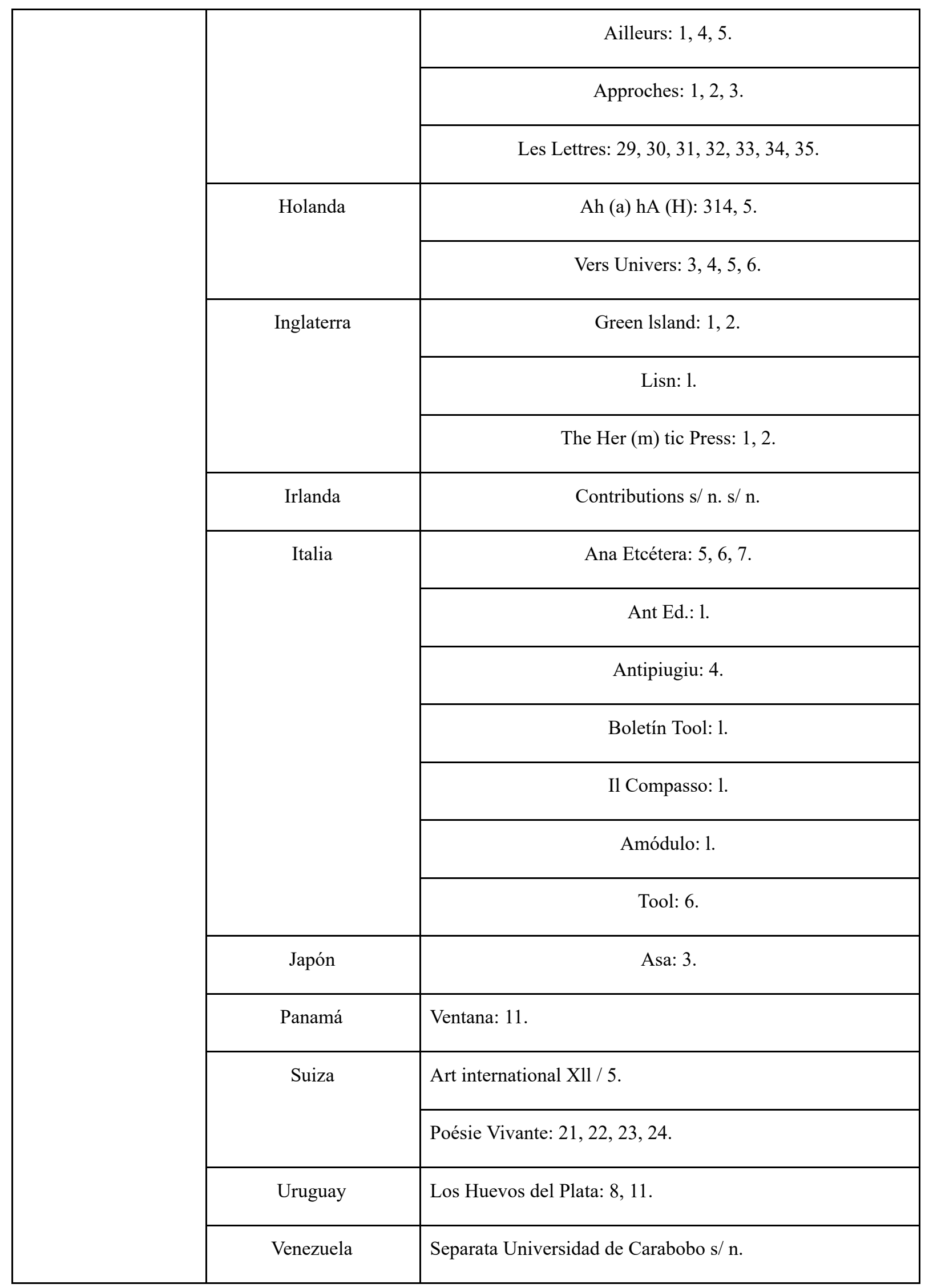

Cuadro 9: Sección Libros, catálogos y revistas. Exposición Internacional de Novísima Poesía/69. Elaboración propia. 
Como queda en evidencia en el cuadro anterior, las publicaciones, catálogos, libros y textos teóricos expuestos abarcan bibliografía de más de veinte países. Señalamos al comienzo que, los cruces temporales y genealogías que Vigo pone en funcionamiento se presentan, por ejemplo, en la sección de libros argentinos, donde conviven de Oliverio Girondo: Veinte Poemas para ser leídos en el tranvía (1922) Calcomanías (1925) y Espantapájaros (1932) junto a los platenses: Luján Gutiérrez, Pazos, Vigo y Ginzburg; con poemas fónicos en el caso de Pazos, el tacho para patear de Ginzburg, las obras (in) completas de Vigo y la llamativa propuesta experimental de Celina Haydee Urralde con el poemario $\mathrm{De} P$ e a $\mathrm{Pa}^{117}$ cuya imagen de tapa y presentación corresponden a G. Kosice. En torno a los poetas latinoamericanos, se exponen libros y revistas de Brasil, México, Uruguay, Venezuela, y Panamá. Como señalamos anteriormente, cada ejemplar posee una ficha mecanografiada del contenido de la publicación elaborada por Vigo. Desconocemos el modo en que se montó esta sección, puesto que en el archivo fotográfico de la exposición no se encontraron registros de esta sección.

En torno a las publicaciones expuestas podemos decir que los formatos expandidos de las revistas y muchos de los libros representan búsquedas editoriales y compositivas que incluyen el tamaño afiche (como las revistas Futura de Alemania), ensambladas y libros objeto en concordancia con el planteo experimental de la muestra en general.

Las revistas de Diagonal Cero mostradas en la Novísima corresponden al viraje que venimos analizando en la publicación en tanto se exhibe desde la $n^{\circ} 20$. En la entrevista realizada a Luis Pazos, el artista entendía en torno a los criterios de selección del material que:

[Julien] Blaine era un contacto que teníamos en París y tenía una revista hermosa: Aproches y no había muchas más. Es correcto cuestionar que había pocos argentinos en la muestra pero había pocos que lo hacían acá. [Clemente] Padín es un pionero, ojo, muy humilde, muy simple, y Vigo se manejaba con cartas, reunimos lo más que pudimos. (Comunicación personal, 2018)

Evidenciar la teoría para ofrecer al espectador herramientas de lectura y genealogías temporales, es una forma de incluirlo, informarlo y formarlo en estas prácticas experimentales. Vigo contempla para el montaje la certeza de que el artista debe propiciar espacios, instrumentos y claves de lectura, operar como un "programador" (De la Poesía Proceso, 1969, p. 8; también

\footnotetext{
${ }^{117}$ La Oficina Perambulante y el Centro de Arte Experimental Vigo realizaron una selección de estos poemas y los reeditaron en edición limitada y artesanal en 2019.
} 
referencias en Continuidad), un creador atento a la estética de la participación (Diagonal Cero $\mathrm{n}^{\circ}$ $23,1967)$.

\subsection{Segunda Sección}

La segunda sección de esta exposición es la más importante en lo que respecta a la cantidad de obras, estuvo referida a poesía visual impresa y objetos. Vigo confeccionó soportes rígidos de madera de 35 x 50 con cuatro ojales en las esquinas para exponer las obras y unificar el formato de los afiches. Sin embargo, encontramos en el CAEV una importante cantidad de afiches con un formato superior, a partir de las imágenes de archivo, estimamos que los mismos fueron adheridos directamente a los paneles de la sala.

Los poetas visuales internacionales que exponen en esta sección, han transitado por las páginas de Diagonal Cero. Es el caso, por ejemplo, de la italiana Mirella Bentivoglio (1968), Timm Ulrich (1968), Eugen Gomringer (1968), Luiggi Ferro (1968), entre otros. Este hecho da cuenta de los diálogos y proyecciones temporales que se presentan entre la publicación y la muestra, presentándose Diagonal Cero como plataforma (expositiva) previa a la Novísima.

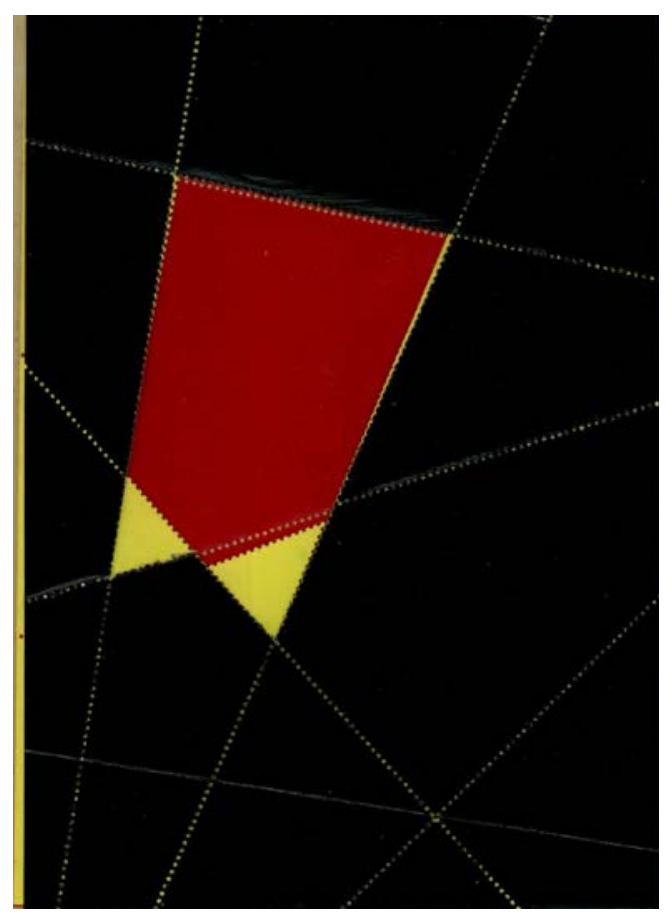

Fig. 81. Moacy Cirne, Poema Proceso (1968). Afiche que utiliza como procedimiento el troquelado de la hoja, posee tres papeles superpuestos (rojo, amarillo y negro) que pueden cortarse. Exposición Internacional de Novísima Poesía/69. CAEV 
Se conservan fotografías de esta sección, de la muestra en general y de las intervenciones tridimensionales en la Caja Biopsia 1969 conforme al afán archivístico de Vigo; como indicamos anteriormente, el registro de "Velas" de Andy Suknasky figura en el ensayo De la Poesía Proceso. En las anécdotas que Pazos recrea, se evidencia la tensión entre el arte tradicional, donde el espectador es un observador, y la propuesta de montaje de la Novísima que invita a la participación. Pazos relata respecto de su propia obra, la Torre de Babel ${ }^{118}$, en el artículo "La Poesía Loca", que:

Mi obra es un poema volumétrico, hecho en base a onomatopeyas espaciales y de lectura activa. El volumen (espacio real) es un superdesarrollo del concepto literario del espacio gráfico. Mientras que el uso de la onomatopeya obedece a una de las leyes de creación de la poesía experimental, la valorización de los desechos del lenguaje. El lector, al tener que realizar la acción física para leer el poema, cambia radicalmente su actitud. se produce el fenómeno de la llamada lectura activa” (El Día, 1969)

El grupo Poema Proceso estuvo representado por: Neide de Sá, Alvaro de Sá, Wlademir Diaz Pino y Moacy Cirne. Presentaron sus creaciones en una mesa participativa según documentan las fotografías y relatos de la época (ref. 9 ay b). Segun las referencias del artículo La Poesía Loca, Neide, expuso una caja de plástico con recortes de periódico, fotografías, titulares para ser colgados en una soga. Sobre la mesa participativa, un soldadito de plomo, botones, una cuerda y broches. Alvaro, una caja de madera con cinco bolitas. Wladimir Diaz Pino, hongos de madera, rectángulos y esferas y cordones que podían trenzarse sobre clavos. Creemos que la imagen de un libro con volumen, carente de referencias, pertenecería a Julio Plaza (ref. 7). Alvaro también presenta el libro $12 x 9 \mathrm{y}$ afiches.

\footnotetext{
${ }^{118}$ En la entrevista realizada agregaba que: "Ginzburg hizo sus aviones y yo una torre. Esa obra nació como teoría, yo quería hacer la torre ponerle un motorcito y que girara. No llegué porque nos gastamos la plata. A quien fui a ver? A mi papá, necesitaba plata para una obra de arte. Imprimí unos papeles diciendo que hicieran una ronda, para que la gente girara agarrada de las manos, ahí apareció la obra política, porque no sé cómo, no me acuerdo bien apareció la ronda hacen rin hacen ran los maderos de san juan piden pan no le dan piden queso le san hueso y le cortan el pescuezo, era una metáfora, una puesta en escena de los cañeros en Tucumán. La propuesta de Luján era el diario más largo del mundo, después pedimos bobinas blancas para que la gente escribirá, Luján hizo una obra impensada y lo logró; cambio mi obra de ser un juego a ser un cuestionamiento" (Pazos, comunicación personal, 2018)
} 


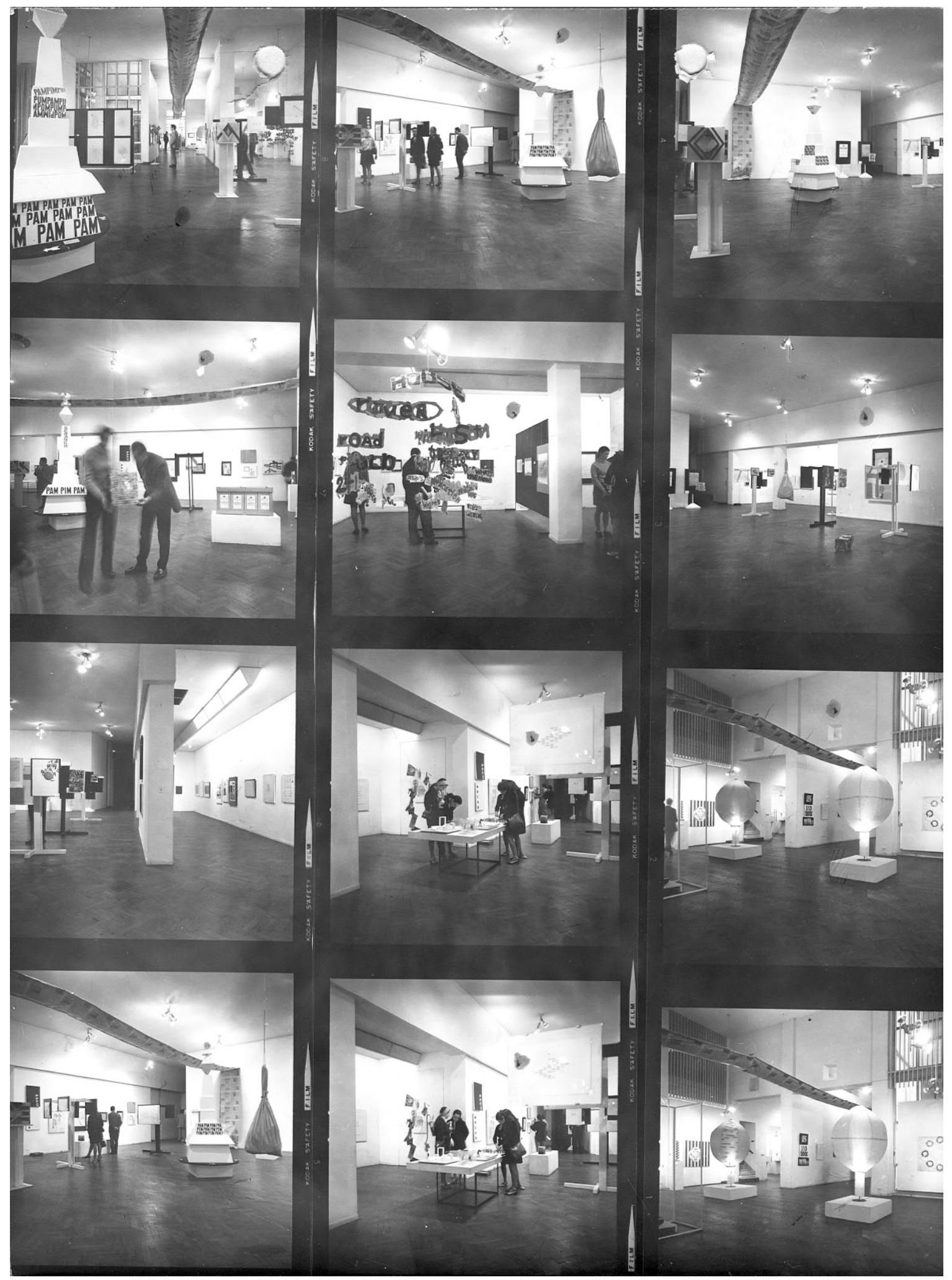

Fig. 82. Fotografias de la Exposición Internacional de Novísima Poesía. Archivo Di Tella ${ }^{119}$

Algunos documentos periodísticos mencionan obras que no poseen registro fotográfico dentro del CAEV. En el artículo La Poesía Loca, por ejemplo, se habla de una pieza de Herman Damen

${ }^{119}$ Se agradece al Archivo Di Tella las imágenes. 
que consistía en una mano de nylon con letras en sus dedos y seis bolsitas con cintas magnetofónicas para armar un poema fónico. Algunos cronistas afirman que los avioncitos de Ginzburg eran diez mil, otros menos. En el artículo Donde Mueren las Palabras (El Dia) se dice que Dennis Williams presenta un "televisor a manivela" que no pudimos confirmar mediante el registro fotográfico. También se dice que había una jaula de bambú suspendida del techo, realizada por Ronald Gross, con 28 letras de metal (El Día), que Tom Edwards “ofrece 125 letras de un abecedario inasible que propone la posibilidad de recrear la estructura del lenguaje a partir del dado" (La Poesía Loca, El Día, 1969). Estas obras, como señalamos no tienen registro fotográfico, tampoco pudimos encontrar referencias a ellas en otros documentos del archivo CAEV.

Presentamos a continuación una reconstrucción de la ubicación de las obras que pudimos identificar, realizada a partir de un exhaustivo relevamiento fotográfico cotejado con las declaraciones del catálogo y los artículos de Biopsia. En algunos casos, no hemos encontrado la referencia de autoría de la obra.

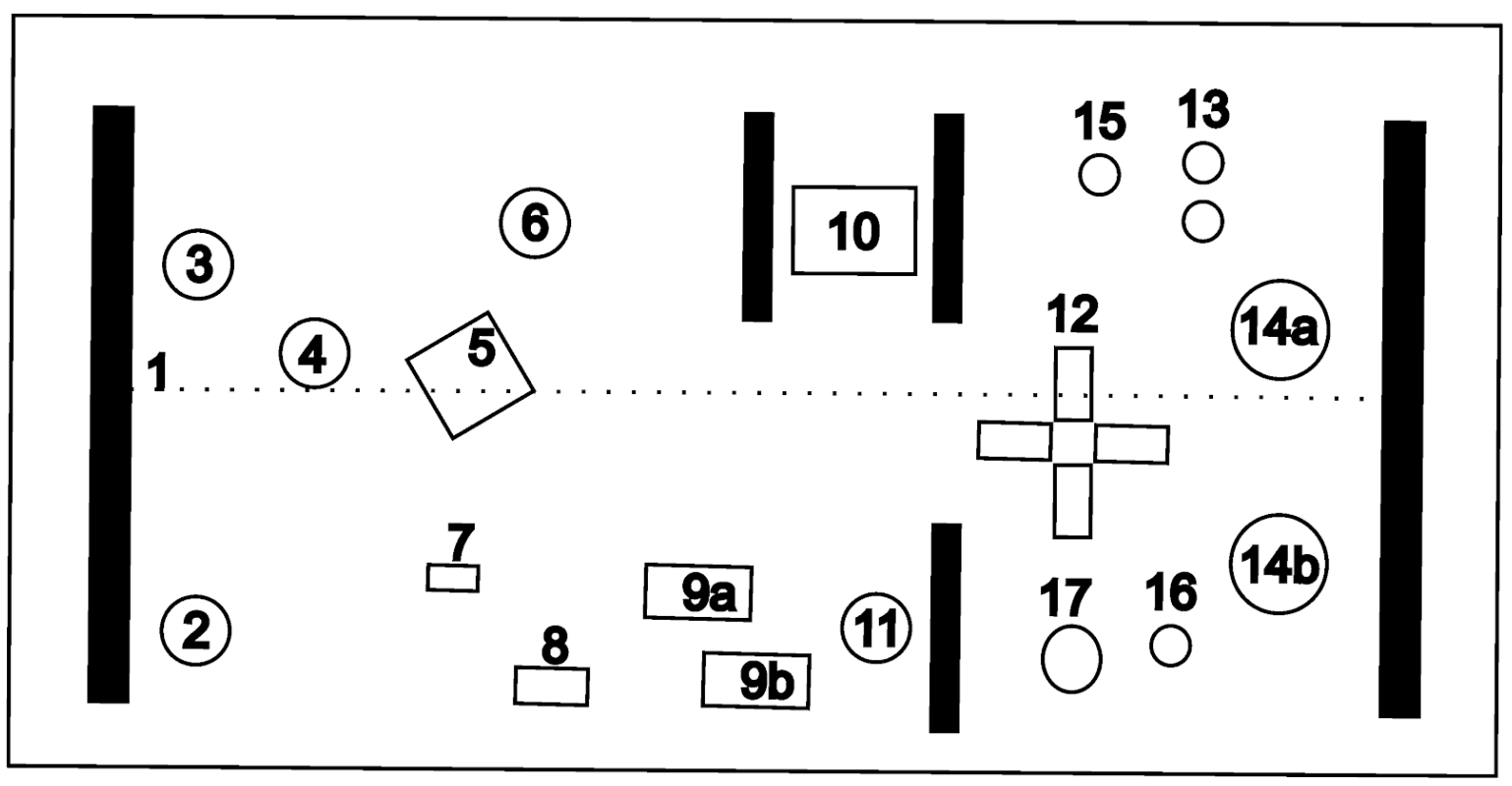

Fig. 83. Planta de la Exposición Internacional de Novísima Poesía. Ordenamiento de obras tridimensionales.

Elaboración propia.

\section{REFERENCIAS:}

1: Luján Gutiérrez, Diario sin fin

2: Julien Blaine, Poema para armar (?)

3: Luis Pazos, La Corneta 
4: E. A. Vigo, Obras (in) completas

5: Luis Pazos, Torre de Babel

6: Bolsa suspendida (?)

7: Libros con volumen (¿Julio Plaza?)

8: Andy Suknasky, Velas

9: Poema Proceso (a-b)

10: Diana Atchley, Clothesline (Tendedero)

11: Denis Williams, Móviles Poéticos

12: Ana María Gatti, A propósito de Mallarmé

13: Tubos con palabras (?)

14: Sarenco- Ken Cox, Poemas Inflables (a decía "Earth"-b decía “Fire")

15: Carlos Raúl Ginzburg, Avioncitos

16: Carlos Raúl Ginzburg, Tacho para patear.

17: Liliane Lijn: Poem Kon.

No hemos encontrado referencia de autoría de las obras 6, 7 y 13, cuyas imágenes presentamos a continuación:

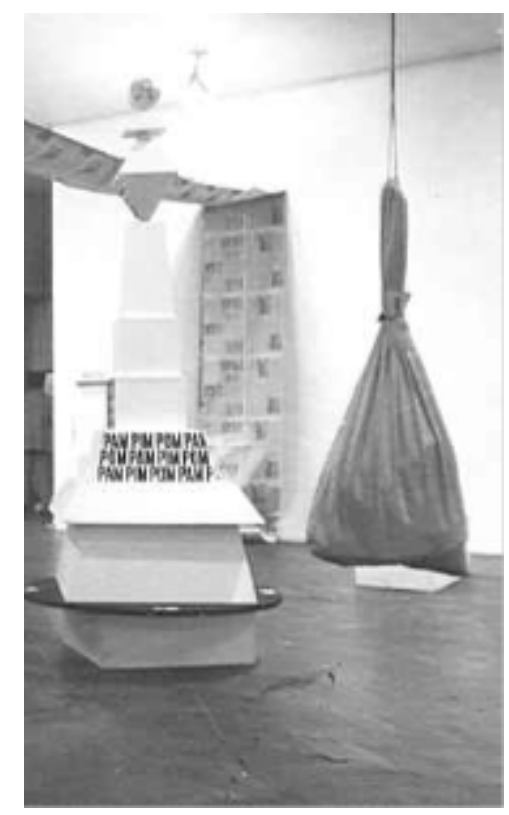

Fig. 84.Sección 2: Exposición Internacional de Novísima Poesía/69, bolsa suspendida, obra sin referencia (6) 


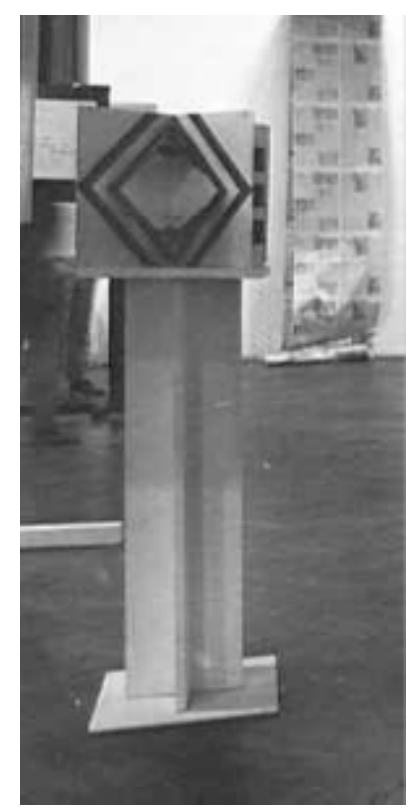

Fig. 85. Sección 2: Exposición Internacional de Novísima Poesía/69, obra sin referencia, por las descripciones extraídas de los diarios podría tratarse del libro volumétrico de Julio Plaza. (7)

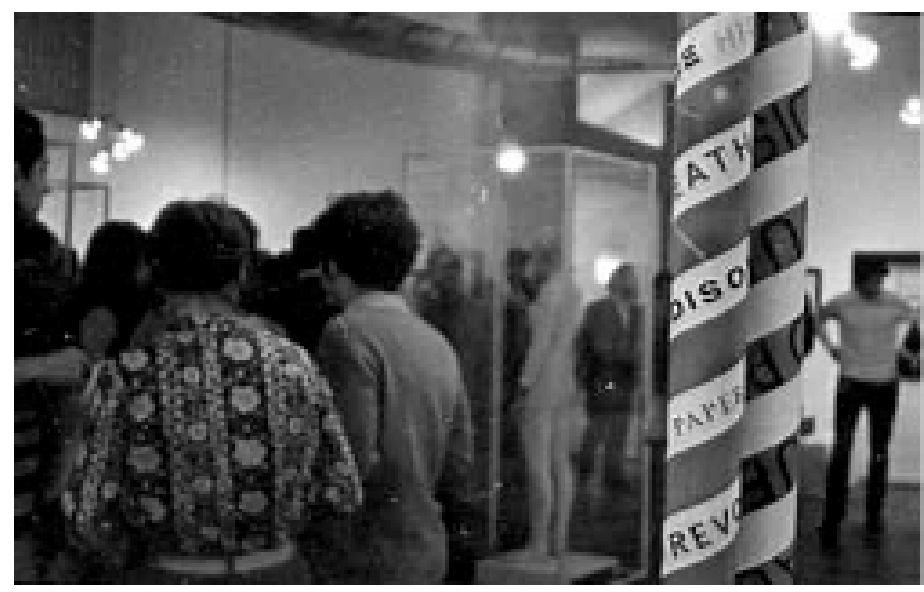

Fig. 86. Sección 2: Exposición Internacional de Novísima Poesía/69, tubos con palabras, obra sin referencia (13)

Nos detenemos brevemente en la obra A propósito de Mallarmé de la argentina Ana María Gatti. Se configura como una de las propuestas experimentales más interesantes a nuestro criterio. En esta pieza, dialoga no solo la obra considerada fundante de la poesía experimental, según la periodización de los concretos, Un golpe de dados, sino que también se incluye la tecnología, el sonido, el carácter de instalación y la participación del espectador. Resulta un tanto misterioso el recorrido de esta artista en la escena poética y visual argentina perdiéndose sus rastros después de la Novísima. Según los documentos conservados en Biopsia, el artículo de Hugo Enrique Sáez (Diario Los Andes, 23/3/69), dice que Ana María Gatti es oriunda de Tres Arroyos, Provincia de Buenos Aires, se recibió de escribana en Buenos Aires, incursiona en la plástica y en la literatura y luego viaja a París. En la entrevista realizada por Alvaro de Sá para Jornal dos Escritores, a la 
pregunta ¿qué objetivo pretende alcanzar con su trabajo?, Gatti responde: "Mi ambición máxima es trabajar con las conexiones cerebrales del espectador" (traducción propia), cuenta que participó de la Bienal de París en 1967, presentando cuadrados de azúcar que el espectador podía comer, agitar. Después produjo bloques de acrílico con hojas de papel que debían manipularse como un libro.

Según las descripciones extraídas de diarios de la época y registros fotográficos, la obra presentada por Ana María Gatti consistió en la instalación de cuatro cabinas de acrílico transparentes rectangulares (de 1,80 m. x $80 \mathrm{~cm}$ aproximadamente) enfrentadas. Dice Gatti en la entrevista de Alvaro de Sá, que: "las columnas de A Propósito de Mallarmé son grandes proposiciones linguisticas que multiplican la idea de paralelípedo creando un arte total" (Jornal, 1969).

En su base, las cuatro columnas transparentes, contenían reproductores conectados a un parlante ubicado en el centro de la instalación. Dicho parlante poseía un péndulo, un sensor de movimiento. Según la hipótesis de cómo podría haber funcionado por parte del investigador Julio Lamilla, cuando el péndulo pasaba por el sensor se activaban una de las cintas donde se reproducían en distintos idiomas (dinamarqués, francés, castellano y japonés) palabras que, según relata el cronista de diario Clarín, eran en su mayoría sustantivos, en los cuatro idiomas. En el artículo Estalló la Revolución de la Poesía, Gatti le explica al cronista: "Usted juega con las palabras y las recibe del modo que quiere. Por que el sonido esta unido al péndulo de luces sensibles y entonces todo se une y se separa al mismo tiempo. Lo único que hice fue darle elementos a los espectadores, todos del lenguaje y ellos deciden el destino" (Análisis, 1969) La obra de Ana María Gatti ocupa, despliega, fisura el espacio físico y sonoro: el día de la inauguración de la Exposición Internacional de la Novísima Poesía/69, cuatro performers vestidos con trajes blancos pegados al cuerpo que, en nuestra interpretación remiten al vacío del poema de Mallarmé, habitaban y recorrían las cabinas activando el mecanismo sonoro propuesto por la artista. Recordemos que el principal factor que advierten tanto los teóricos de la poesía concreta como el propio Vigo sobre Un golpe de dados se vincula con la ruptura que propone respecto del aspecto espacial del poema, la utilización del blanco de la página y el silencio.

En la reconstrucción, mediante fotografías, de la ubicación de las obras tridimensionales de la muestra, la obra de Gatti se presenta en el extremo del salón; a su lado, como heraldos, los "Poemas Inflables" de Sarenco y Ken Cox, y sobre ella, el "Diario sin Fin” de J. L. Gutiérrez. 


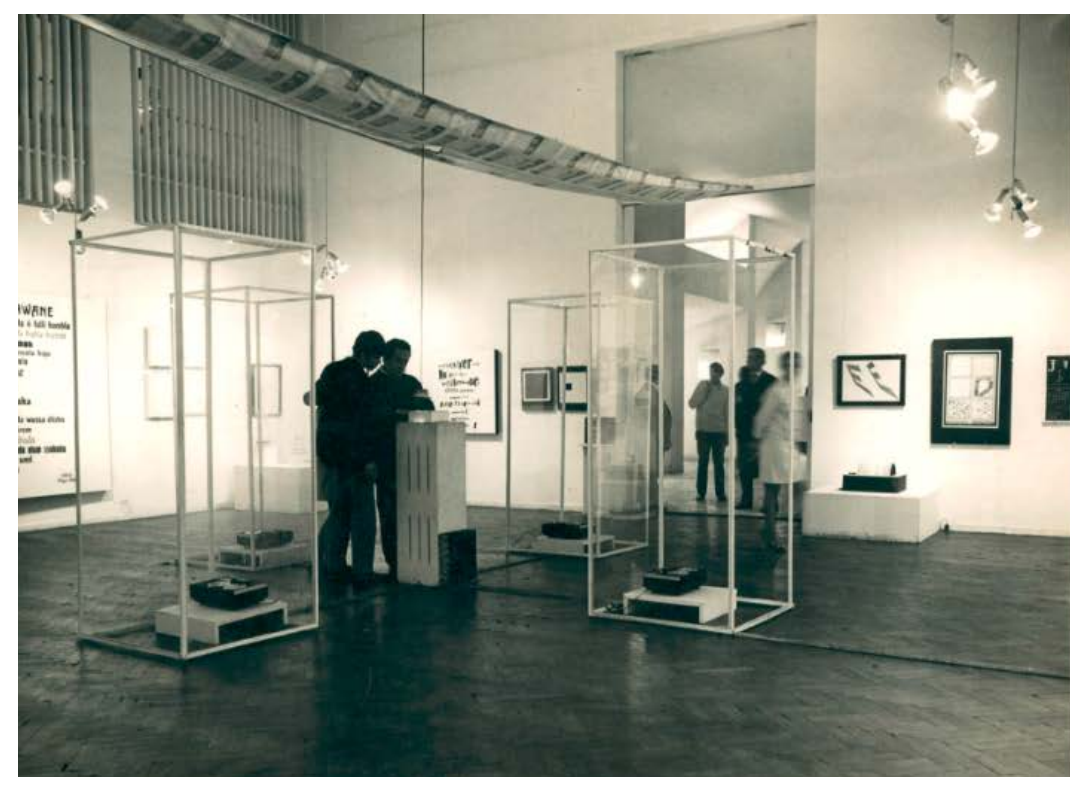

Fig. 87.Sección 2: A propósito de Mallarmé de Ana María Gatti Exposición Internacional de Novísima Poesía/69. CAEV

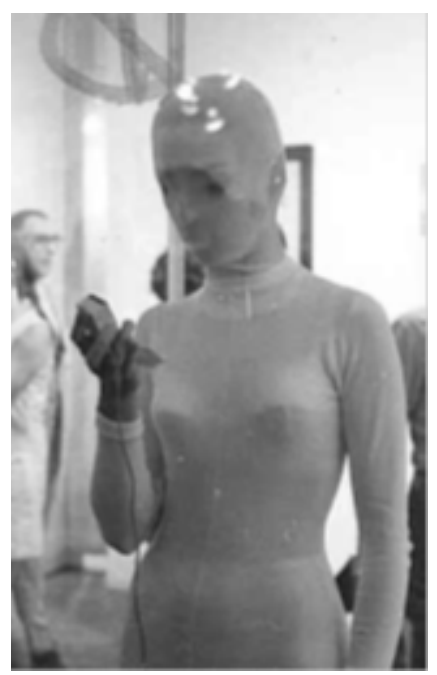

Fig. 88.Sección 2: A propósito de Mallarmé de Ana María Gatti Exposición Internacional de Novísima Poesía/69. Detalle del día de la inauguración. CAEV

\section{Tercera Sección}

Participaron de la tercera sección los siguientes poetas fónicos: Bob Cobbing, Henri Chopin, Herman Damen, Raoul Duguay, Francois Dufrene, John Giorno, Raoul Hausmann, Bernard Heidsieck, Dick Higgins, Ernst Jandl, Kitaeff, Arrigo Lora-Totino, Jackson Maclow, Carl Weissner, Gil J. Wolman. Además del catálogo, Vigo realizó un programa en el que se detalla el cronograma de la audición de Poesía Fónica, bajo el título "A manera de introducción a los Poemas Sessions”. En este programa, Vigo decía: 
El panorama comprende desde los históricos poemas fónicos, provenientes de las composiciones tipo collage y de carácter visual (...) hasta el aprovechamiento de las reverberaciones, ecos, superposiciones de texto y voces, destrucción del registro natural por medios electrónicos, pasando por la poesía líquida, también escucharán los poemas pornográficos de John Giorno, quien ironiza al decirlos en tono de oración colectiva en templo religioso (...) (E. A. Vigo, "A manera de introducción a los Poemas Sessions", 1969, CAEV)

Dialogan, en el recorte propuesto por Vigo, experiencias sonoras de las vanguardias históricas y obras de su contemporaneidad. Resulta interesante que, en la carta enviada por Haroldo De Campos a Romero Brest, se indican como referentes para la exposición poetas del campo de las experiencias visuales (Mathias Goeritz, Jasia Reichardt, Max Bense, Grupo Noigandres) sin hacer mención a la posible inclusión de poetas fónicos, como hemos visto en los desarrollos anteriores sobre las re-escrituras, es una vertiente sobre la que Vigo indaga tempranamente.

En relación con la circulación de estos poemas y el modo en que llegan a Vigo, se especifica en el programa de los Poema Session, que la mayoría fueron extraídos de la Revista- Disco $O U$ de H. Chopin. Esta publicación está presente en la biblioteca de Vigo y los textos de $O U$ han sido traducidos por Comas en las re-escrituras. Así, la introducción de Chopin, citada en el programa de los Poema Session, pertenece a la Selección D, corresponde a "Las mutaciones Poéticas", del cual transcribimos un fragmento:

Fué entonces que supimos que una palabra como silbido llevaba el silbido mismo. Que la palabra salto era la propia acción. Que la palabra resorte prefiguraba su acto. Que la palabra bola podía rodar sola. Que la palabra hervir conocía todos sus borbotones. Hemos sabido también que en nuestro tiempo en que todo acciona una poesía como la de ALAIN BOSQUET carecía de acción no bien escribía: 'Así es como las palabras se echaron a volar'. Con este ejemplo conocimos la diferencia que hay entre la CONSTATACIÓN y la palabra VUELO en sí misma que no tiene ninguna necesidad de ser escrita. Es una palabra...Y vuela...Es su acto.

Y la palabra vuelo se convierte en acto por los aires. Se hace fonética apenas se canta. Pudo transfigurarse a sí misma no bien salieron de ella sonidos. De esta manera VUUUEEELOOO fué un canto que no pudo traicionar su propio sentido, de "V" o disipación sonora el aliento pudo pasar; pudo por la “O” prolongarse aún más, fué por 
"L” líquida una acción total (1). En una sola palabra se resumía el sentido, la acción, el juego, las armonías, y todo esto sirvió para dar el extremo calor de una OBJETIVACIÓN TIMBRAL que no conoce dimensión alguna. Estos ejemplos solo tienen una consecuencia, la de saber que las palabras, los sonidos, los fonemas, las letras, se convierten en "notas" para el interior de un poema. Que esta consecuencia nos obligue a abandonar la escritura y sus cinceles para hacer un poema “componiendolo". Y esta "composición" ya lo hemos dicho, se debe a la vida del Universo donde todo trata de hacerse visible, objetivamente sonoro.... (Cita introductoria de H. Chopin al programa de los Poema Session, Trad. Elena Comas. 1969. CAEV)

Mencionar, por último, que, si bien en el programa se dice que comenzaba a las $18 \mathrm{hs,} \mathrm{en}$ algunos registros como el artículo La Poesía Loca, se dice que las sesiones de poesía fónica se daban en un espacio apartado "una sala en penumbras" (El Día, 1969), mientras que otros cronistas dice que cada treinta minutos se escuchaban los poemas en toda la sala. 


\section{Síntesis Capítulo 2}

Hemos analizado en este capítulo la incidencia de las re-escrituras en los lineamientos de la publicación Diagonal Cero y el viraje de la misma hacia una poesía de tipo experimental hacia mediados de la década de 1960. La modificación en el perfil de la publicación se corresponde con los años en que determinadas revistas de poesía experimental ingresan a la biblioteca y a las lecturas de Vigo mediante sus re-escrituras. Si bien no podemos afirmar de manera taxativa que fueron solamente sus lecturas las que modificaron la revista, mostramos en esta argumentación la íntima relación que se establece entre ambas cosas. Recordemos además dos cuestiones, la primera, vinculada con el descontento por parte de Vigo con las publicaciones de su tiempo, la segunda, en torno a la importancia que Vigo le asigna a la influencia de los contactos con el exterior, los intercambios a partir de los cuales ingresan otras lecturas y experiencias estéticas a su repertorio.

Este corrimiento de intereses, se pone de manifiesto según el artista (como queda de manifiesto en la entrevista de 1996) a partir de los números 18 y 19 de Diagonal Cero, donde Vigo señala la importancia de la separata de Xilografía para los contactos con latinoamérica, y las influencias de las publicaciones de poesía experimental de los grupos europeos sobre su publicación.

Resaltamos en este apartado la importancia en el proceso de conocimiento sobre la poesía experimental que poseen los poetas brasileños sobre la biografía teórica de Vigo. Tanto con los Concretos, como con Poema Proceso, Vigo comparte autores de referencia y posturas estéticas en torno, por ejemplo, a la participación del espectador.

La charla impartida en el Círculo de Periodistas Panorama, el ensayo-charla Continuidad de lo Discontinuo, la Exposición Internacional de Novísima Poesía son algunas de las formas en las cuales se materializa la apropiación de determinadas lecturas en la producción de Vigo. Comenzamos planteando en el Capítulo 2, las correspondencias que se producen entre las revistas y libros que la dupla Comas-Vigo re-escribe en la Selección D, en relación a los textos que finalmente se publican y, podríamos agregar se estabilizan, en la revista Diagonal Cero. En el apartado Biblioteca General, y siguiendo la propia cronología que Vigo establece, dijimos que en la primera etapa de Diagonal Cero, la publicación toma postura respecto del reconocimiento de autores y artistas locales. En el texto Balance de la plástica platense, realiza una crítica a determinados espacios culturales de la ciudad así como de las revistas contemporáneas. Trabajamos con el corrimiento en las referencias teóricas estableciendo un 
contrapunto entre las presentaciones de Vigo y las re-escrituras remarcando en cada caso la inserción de las mismas dentro de las publicaciones y charlas de Vigo.

Analizamos la re-escritura Selección D referida íntegramente a la Poesía Visual estableciendo lazos entre seis de esos artículos y el desarrollo teórico de E. A. Vigo en Continuidad de lo Discontinuo, así como también en el catálogo de la Novísima. La Novísima no solo significó la coronación del proceso que venía llevando adelante Diagonal Cero con un tipo de poesía alejada de las tradiciones hegemónicas de lectura; también representó la visibilización de un campo de experiencias vinculadas a la participación del espectador que venían postulándose en las páginas de la revista. En la muestra de libros, revistas, afiches, así como en las intervenciones performáticas y sonoras, y las decisiones de montaje, la Expo abrió un campo de posibilidades donde la poesía salía del soporte libro para ser manipulada, re-organizada, compartida y el lector se transformaba en programador.

La apropiación de los postulados sobre poesía experimental por parte de Vigo presente tanto en sus re-escrituras como en obras, charlas, y publicaciones nos ha llevado a considerar la experticia como factor determinante para posicionarse como sujeto legítimo a partir de sus lecturas. El campo de sus intereses hacia mediados de 1960, se profundiza en lo que respecta a las posibilidades de la poesía experimental en vínculo con la participación del espectador y la lectura potencial que éste realiza del material. Entendemos que Vigo se preocupa por formar al lector en un sentido doble: por un lado, en lo que refiere al aspecto teórico; por otro lado, en las posibilidades que brinda la experiencia con el material, "un arte tocable" en tanto se propone al espectador participar de forma activa en las investigaciones poéticas.

Una diferencia entre las formas de apropiación de los postulados de la poesía visual y los desarrollos sobre las vanguardias históricas se presenta en la forma de mostrar ese material. En lo que respecta a las vanguardias, la atención está puesta en una exhibición de fragmentos referidos al arte moderno en diálogo con producciones locales; por su parte, la propuesta poética de mediados de 1960, se orienta a la sistematización de ese material visual y teórico, pero también, como venimos sosteniendo, a la paulatina y persistente incorporación del otro como activo partícipe de la creación poética.

En el tercer capítulo de este trabajo proponemos indagar en las historietas herméticas presentes en la publicación Hexágono 71', donde desarrollamos la apropiación como absorción y recreación del material crítico. En las historietas herméticas se vuelve imprescindible la colaboración del lector, dispuesto, en palabras de Bugnone, "a reflexionar y prestar atención frente a la sorpresa, la ironía o el dislocamiento" (2013, 269). La apropiación en las historietas 
herméticas funciona, en lo que respecta a las imágenes, de manera más cercana a los conceptos desarrollados por Bourriaud en la primer parte de este trabajo, en tanto opera la utilización de lo dado para la elaboración de una propuesta estética que tensiona con la fuente original. 
Capítulo 3:

Historietas herméticas. 


\section{Presentación}

Hemos visto en los capítulos anteriores la articulación entre los conceptos de repertorio y apropiación en la obra de Vigo a partir de las diversas proyecciones en publicaciones, charlas $\mathrm{u}$ obras de las re-escrituras con las cuales trabaja el artista.

En primer lugar, referido al abordaje de las vanguardias históricas, resaltamos el carácter fragmentario que asumen las incorporaciones de lecturas extraídas de las re-escrituras en las publicaciones de $W C$ y en la primera etapa de Diagonal Cero, (por ejemplo, en el caso de los “Testimonios"). Vimos que la experimentación con los párrafos incide en la composición visual del nuevo texto y propone una forma de lectura heterodoxa para sus transcripciones y re-escrituras. En el caso de Duchamp, indagamos en las re-escrituras a partir de una selección de obra de Vigo.

En segundo lugar, referido a la poesía experimental, en el Capítulo 2 señalamos que se consolida la experticia y sistematización en las presentaciones que Vigo hace del material que consume como lector, tanto en la incidencia que estos textos tienen en sus publicaciones como en las charlas y textos de su autoría. Destacamos como función principal una clara intención didáctica que posiciona a su enunciador como sujeto conocedor de esta corriente experimental en sus exposiciones teóricas. Un caso particular de reformulación del material crítico se da en la organización que le otorga a la Novísima Poesía donde interviene la teoría como material a ser observado y leído así como la noción de espectador participante, elementos fundamentales en la configuración y montaje de la exposición.

Nos interesa en este capítulo poder comprender el desarrollo que E. A. Vigo le otorga a sus lecturas y re-escrituras en una selección de obras denominadas por el artista historietas herméticas. Como desarrollamos al comienzo de esta tesis, la temática de la historieta es el eje central de las re-escrituras de la década de 1970 y se proyecta en algunas obras de su producción posterior vinculada al arte correo-comunicación a distancia.

Los ejemplares de re-escrituras que refieren a la historieta, como hemos visto en en Cuadro 4 (referido a libros completos dentro de la Serie Escritos Personales), corresponden a: La burbuja en la tira dibujada (Robert Benayoun), La tira dibujada (Gerard Blanchard), Las obras maestras de la tira dibujada (René Goscinny), Banda Ilustrada y Figuración narrativa (Burne Hogarth) y una selección de diecinueve artículos de procedencia diversa que poseen ilustraciones en su interior y se encuentran compilados por Vigo. Podemos decir, de manera general que, salvando 
la selección de artículos sobre historieta, las demás re-escrituras que conforman el corpus no presentan un grado de intervención estética disruptivo en lo que respecta a la organización de los párrafos, como sí ocurre en los casos de las re-escrituras del Capítulo 1 vinculado a las vanguardias.

En esta introducción cabe preguntarnos cómo Vigo llega a la historieta o bien cómo llega la historieta a Vigo. En nuestra hipótesis de trabajo consideramos que las lecturas y las re-escrituras sobre las cuales la dupla Comas/ Vigo trabajan, sirven como insumo para la producción plástica, editorial y de divulgación por parte de Vigo. Analizaremos a continuación el perfil de las lecturas sobre historieta en diálogo con el desarrollo del género en nuestro país para adentrarnos en los modos en que el repertorio repercute en las operaciones de apropiación que realiza Vigo.

Las lecturas de Vigo en torno a la historieta se vinculan con las características que hemos indicado posee la noción de repertorio. Vigo se nutre de la cultura de masas, los postulados de la Poesía Proceso, la gran cantidad de revistas de y sobre la historieta, textos teóricos especializados, poesía experimental y las indagaciones sobre la participación del espectador. Dos referentes para Vigo (como queda en evidencia en sus textos y la presencia de estos en su biblioteca) son Moacy Cirne y Alvaro de Sá del grupo Poesía/ Proceso. Estos desarrollan un pensamiento teórico y estético sobre los quadrinhos ${ }^{120}$ en relación a los procedimientos de la poesía experimental, es decir, indagan en los cruces y desbordes de las disciplinas artísticas. Recordemos que De Sá, en su poemario $12 \times 9$, incorpora uno de los elementos más característicos del género para expresar el pensamiento, nos referimos al globo o burbuja propia de las convenciones de la historieta. Moacy Cirne, como resaltamos en el apartado Lectura e Historietas, escribe tres libros dedicados a los quadrinhos: Bum! a explosão criativa dos quadrinhos (Vozes, 1970) A linguagem dos Quadrinhos (Vozes, 1971), Para ler os quadrinhos (Vozes, 1972) y Vanguardia, um projecto semiológico (Vozes, 1975) todos ellos presentes en la Biblioteca General. También sus compañeros de Diagonal Cero, Luis Pazos y Luján Gutiérrez, trabajan con productos de la cultura de masas tanto en lo que respecta al imaginario sonoro como a las composiciones visuales de la publicidad o de la historieta como fuente para sus creaciones de poesía experimental (Entrevista a Pazos y Luján Gutiérrez, ITDT, 1967). Recordemos que Pazos indicaba que el uso de la onomatopeya en su obra "obedece a una de las leyes de creación

\footnotetext{
${ }^{120}$ En Bom! (1970) explica Moacy Cirne, las diferentes denominaciones para el género según las regiones: "Os quadrinhos, nos Estados Unidos são conhecidos por comics - pois suas primeiras aventuras eram tôdas cômicas e daily strip (tiras diárias: as tiras do jornal, que ocupam áreas variadas), entre outras denominações. Na França, são as bandes dessinées; na Itália, os fumetti, na Espanha, historieta e tebeo, em Portugal, quadradinhos." (1970, p. 1)
} 
de la poesía experimental, la valorización de los desechos del lenguaje" (El Día, 1969). La indagación sobre la historieta, en lo que respecta a las lecturas, es coherente con las búsquedas liminales y de cruces entre las disciplinas artísticas por parte de Vigo.

Retomando lo señalado en el desarrollo del apartado Biblioteca General, y atendiendo al desarrollo histórico del género en la Argentina, explica Lucas Berone que:

En nuestro país, el discurso sobre la historieta, como un caso particular dentro del conjunto de los estudios sobre comunicación masiva, describe un movimiento curioso, que va desde su fundación semiológica, hacia 1968, en los textos iniciales de Oscar Masotta y Oscar Steimberg; pasa por un momento de explosión y expansión, en el que la historieta aparece como un objeto teórico central, disputado por corrientes críticas que ensayaron en él sus apuestas y diferentes políticas de intervención en el campo intelectual; hasta llegar, a fines de los setenta, a un momento de relativa dispersión y/o una segunda fundación (2009, p. 2).

En torno a la segunda fundación, durante la década de 1970, señala Berone que los trabajos de Eduardo Romano y Jorge B. Rivera (1972) “trazan los lineamientos teóricos y epistemológicos más importantes del nuevo acceso a la historieta y el humor gráfico: por un lado, respecto de las relaciones entre historieta, política y sociedad; por el otro, acerca de las relaciones entre texto escrito e imagen en el interior del mensaje.” (Berone, 2009, p. 3). En la Biblioteca del CAEV, a partir de la gran cantidad de revistas y libros relevados, seleccionamos los aportes de dos críticos contemporáneos al corpus de re-escritura sobre historietas, además del desarrollo sobre Moacy Cirne. La mirada de Umberto Eco, en Apocalípticos e Integrados (1968) postula que las críticas negativas surgen de la lectura de textos sobre la cultura de masas mientras que la imagen de quienes se integran a ella surge de las lecturas de la cultura de masas (13). La cantidad de revistas y libros sobre el género de la historieta que encontramos en la Biblioteca, demuestra que fue un lector asiduo del género, en este sentido y vinculado con sus historietas herméticas, Vigo coincidiría con Eco al considerar que la eficacia de una intervención en la cultura de masas reside en un conocimiento del material sobre el cual se trabaja (Eco, 1968, p. 62). Tomando elementos conocidos para subvertirlos, Vigo busca fisurar los modos establecidos de decodificar estas producciones a partir de un hacer estético en tanto, además de lector es un creador.

Otro crítico que figura en la Biblioteca de Vigo es Oscar Masotta, quien, como ya señalamos, organiza en 1968 la Bienal Mundial de la Historieta conjuntamente con la Escuela Panamericana 
de Arte en el Instituto Di Tella. El mismo año, dirige la revista Literatura Dibujada. Serie de Documentación de la Historieta Mundial, y en 1970 publica La historieta en el mundo moderno. Resulta pertinente resaltar que en el Fondo Documental del CAEV, encontramos los tres ejemplares de la revista mencionada anteriormente Literatura Dibujada. Serie de Documentación de la Historieta Mundial ( $\mathrm{n}^{\circ}$ 1: noviembre de 1968 - n 3: enero de 1969) así como el catálogo de la muestra realizada en el Di Tella y el libro mencionado. Señala Pablo Turnes en torno al abordaje masottiano de la historieta que:

Podríamos identificar los dos movimientos simultáneos que componen la aproximación masottiana a la historieta de la siguiente manera: 1) la historieta como lenguaje específico, y por lo tanto la necesidad de desarrollar herramientas de análisis que den cuenta de esa especificidad; 2) la redefinición del público de la historieta, es decir un sujeto social mucho más complejo, que lejos de sufrir los efectos de los dispositivos culturales de forma directa y sin filtro, utiliza todo su trasfondo cultural para resignificarlos en su lectura que implica a su vez el contacto directo y material con el objeto producido (2011, p. 18).

Consideramos que las historietas herméticas de E. A. Vigo no son ajenas a las reflexiones postuladas anteriormente, donde la historieta se va consolidando como un campo experimental a partir de las historietas de autor, vinculado a los medios masivos de comunicación pero también a la renovación en las formas de lectura.

Desde la década de 1970, como señalamos al comienzo de esta tesis, Vigo toma contacto con el Centro de Arte y Comunicación (CAyC) dirigido por Jorge Glusberg ${ }^{121}$, autor de Retórica del Arte Latinoamericano (1978). Si bien este libro es posterior a nuestro estudio sobre las historietas herméticas y Vigo no conforma el elenco estable del Grupo de los Trece, si participa de las intervenciones colectivas del CAyC y difunde el Arte de Sistemas en las páginas de Hexágono $71^{\prime 122}$. Interesa la mención a Glusberg en tanto en el libro Retórica del Arte

\footnotetext{
121 "Hacia fines de la década de los sesenta, cuando Jorge Glusberg creó el Centro de Arte y Comunicación, pensó en un espacio interdisciplinario que pudiera generar un movimiento de arte experimental. Por un lado, buscó articular una red de comunicación entre artistas y críticos latinoamericanos y sus pares argentinos; por otro, proyectarse internacionalmente para la configuración de un nuevo arte regional" (Catálogo Arte de Sistemas, 2013, p. 5).

${ }^{122}$ Vínculo analizado en nuestro Marco Teórico. Se recomienda: Ana Bugnone Una articulación de arte y politica: Dislocaciones y rupturas en la poética de Edgardo Antonio Vigo (1968-1975), apartado "Maniobras Estratégicas: intervenciones en el Di Tella Y El CAYC".
} 
Latinoamericano, dedica un capítulo completo a la historieta ("Las historietas y el arte latinoamericano") e indica que:

La historieta precede, como género, a las manifestaciones a las que hoy se integra estilísticamente en el arte latinoamericano (...) La historieta funciona así como signo anticipatorio de una convergencia que no es mera colección de elementos ni suma mecánica de técnicas, sino producción de algo estéticamente nuevo (...) Al afirmar que todo cambio estilístico implica un cambio semántico, queremos subrayar el carácter específico de la alianza entre la historieta y el arte futuro de Latinoamérica. (Glusberg, 1978, p. 171)

Pablo Turner señala al respecto que "El acierto de Glusberg fue haber interpretado la desmitificación que la historieta hace de sí misma al mostrar su soporte constantemente (...) como compuesto ideológico y político de la producción artística latinoamericana. Es decir, el vanguardismo pop podía ser subversivo en el norte como en el sur. Pero si bien había recursos plásticos en común, los usos y motivos eran diferentes.” (2013, p. 69). La historieta es un campo que explora Vigo tempranamente desde sus participaciones en el CAyC como vemos, por ejemplo en la convocatoria para Art of System in latin America' 74. Bruselas, Bélgica.

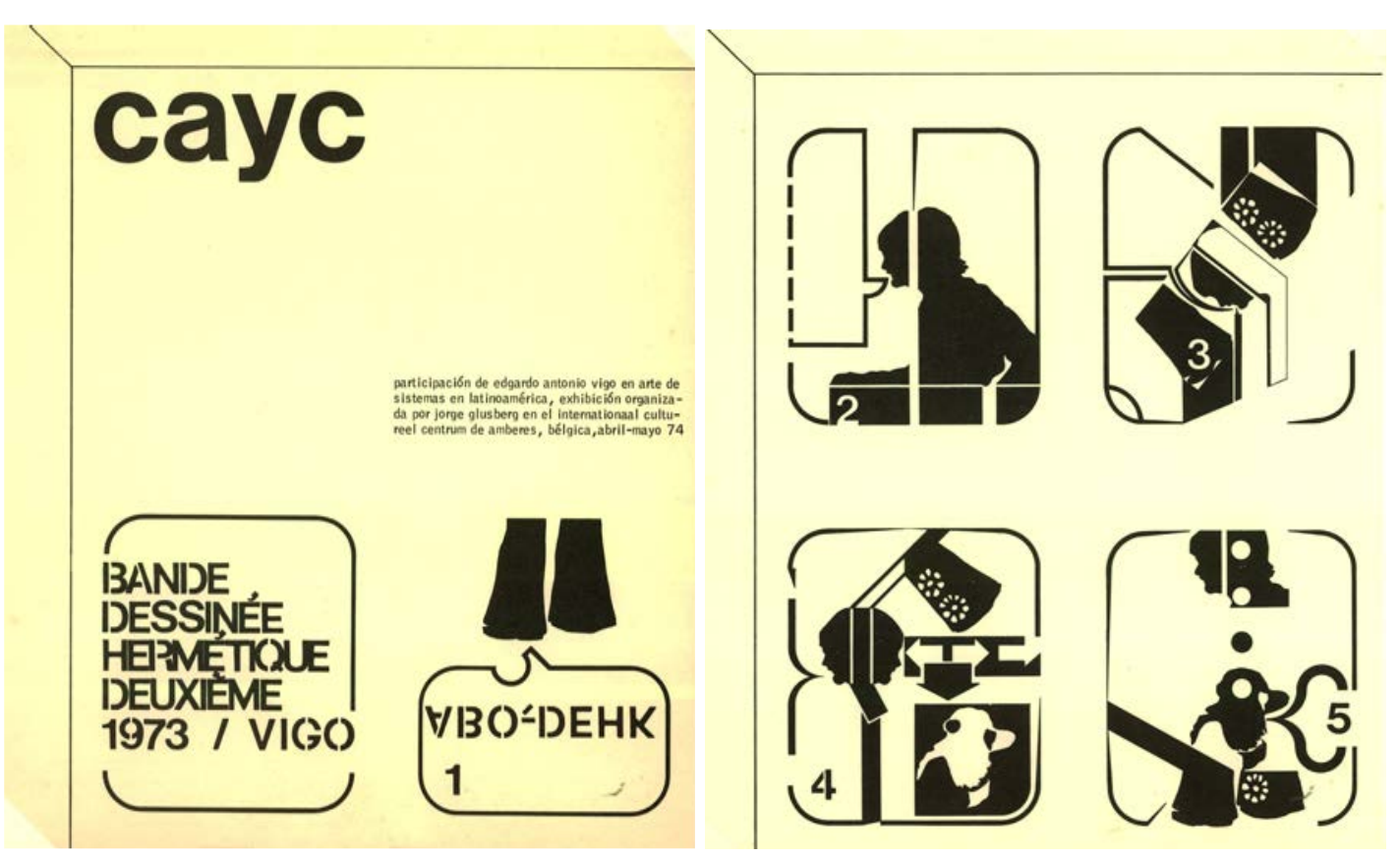

Fig. 89.E. A Vigo, Band Dessinée Hermetique Premiere, (páginas 1 y 2) Biopsia 1974 A. CAEV. 
Sostenemos en el desarrollo que sigue, que el género de la historieta profundiza el trabajo de Vigo en torno al borramiento de las disciplinas y la participación del espectador. En correspondencia con las consideraciones tradicionales sobre la historieta -que ya venían siendo socavadas por la crítica especializada y los autores representativos del género- Vigo, a partir de sus lecturas y re-escrituras elabora un pensamiento sobre el género que transgrede las convenciones del mismo, utilizando elementos propios del comic para elaborar sus historietas herméticas.

Destacamos dos elementos transversales la trayectoria de Vigo que servirán para el análisis de las historietas herméticas: por un lado la indagación por parte del artista en los cruces de las disciplinas característico en la elección de su repertorio. En segundo lugar, las formas que asume la comunicación con el espectador, plasmado en el carácter participativo que se le asigna al mismo en sus diversos proyectos. Veremos en el transcurso de este capítulo los modos en que, desde la producción, Vigo se apropia de los elementos del comic para revulsionar su sentido establecido y desnaturalizar los estereotipos propios del género.

Podemos decir en torno a las historietas herméticas que, en primer lugar, tomando elementos conocidos, Vigo busca en su producción plástica fisurar los modos establecidos de decodificar las marcas del género apelando fuertemente a los sentidos que puedan despertar en el potencial espectador. En segundo lugar, destacamos la transformación que sufre la apropiación por parte de Vigo en este proceso. Vigo deglute antropofagicamente, a partir de las lecturas, re-escrituras e imágenes que consume, ese material para elaborar obra.

Si la mayor parte de las apropiaciones analizadas anteriormente se centraban en la cita y la plasmación en sus publicaciones y charlas de sus lecturas y re-escrituras, en este caso la operación de apropiación se visibiliza en las rupturas que genera en torno al género plasmado en nuevas obras denominadas historietas herméticas. Veremos que, en el caso de estas historietas y Hexágono 71' muchas veces se incorporan imágenes provenientes de otras publicaciones sin nombrar autoría. Recordemos que en la primer re-escritura analizada, Les machines Célibataires, Vigo realizaba una copia sumamente fiel de "colonia penitenciaria" de Kafka y escribía al lado "burda reproducción a ojo". En los casos que presentamos a partir de la década de 1970, las reproducciones carecen de fuente, funcionan a partir del montaje con otras imágenes generando nuevas composiciones plásticas. Vemos que el interés por la historieta es una constante en obras muy posteriores donde por ejemplo combina la historieta con los poemas matemáticos o las incorpora a las convocatorias de mail-art (Off Off, por ejemplo). Es el caso del envío a Lisboa 
con motivo de una convocatoria de Arte Correo donde aparece una "filatelia marginal" denominada "Análisis poético matemático de una historieta hermética".

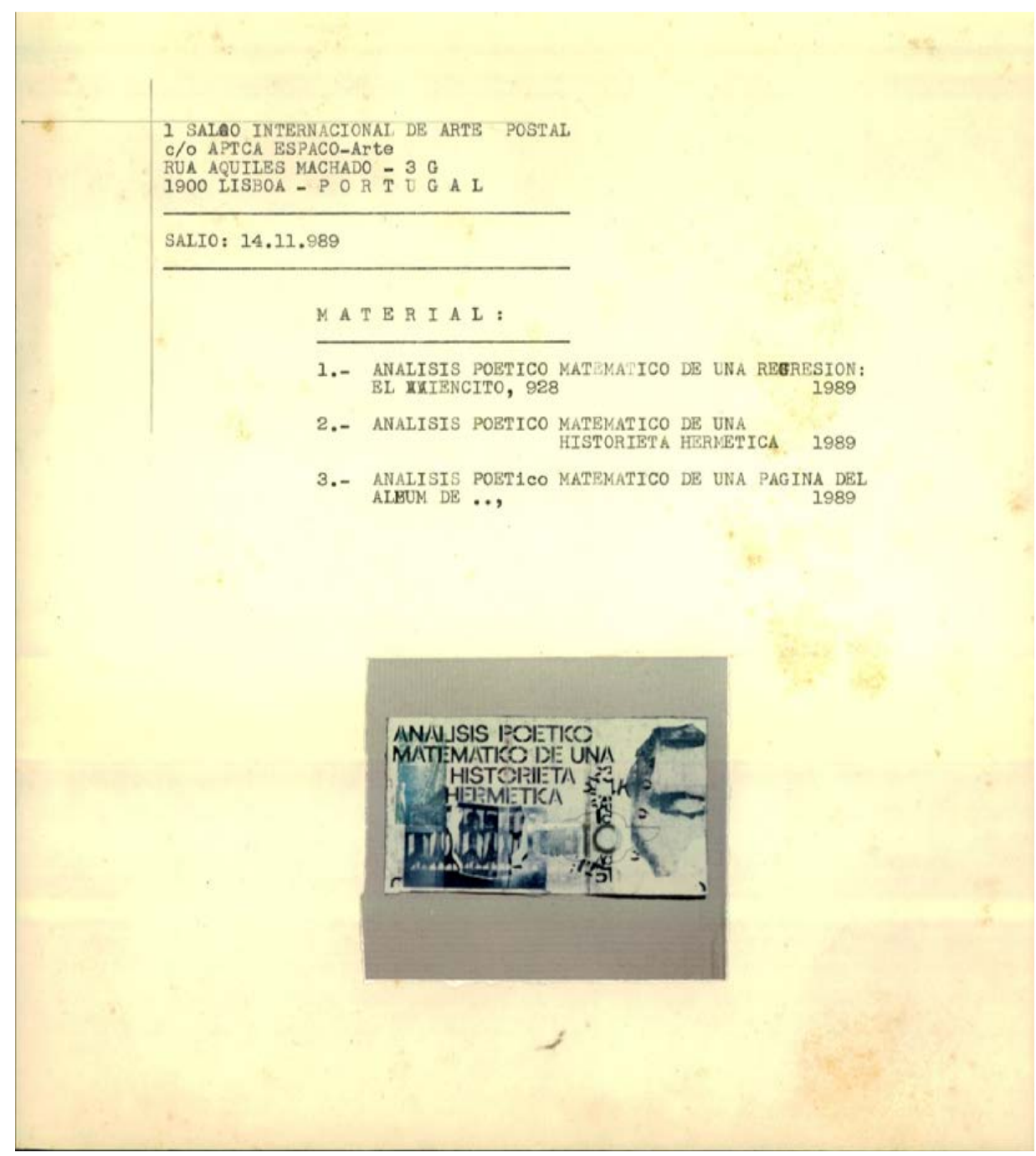

Fig. 90. Envío. Registro Biopsia 1989. CAEV. 


\section{Re-escrituras sobre historietas.}

Como ya adelantamos, las re-escrituras que refieren al cómic y la historieta en la Serie Escritos Personales, corresponden a: La burbuja en la tira dibujada, La tira dibujada, Las obras maestras de la tira dibujada, Banda Ilustrada y Figuración narrativa y una selección de diecinueve artículos de la revista Panorama, Diario El Día, entre otros. Este último cuenta con imágenes, recortes e ilustraciones del propio Vigo.

A continuación desarrollaremos brevemente las temáticas de las re-escrituras para detenernos posteriormente en el análisis de las historietas herméticas presentes en Hexágono 71'.

La burbuja en la tira dibujada, de Robert Benayoun, es un ensayo publicado inicialmente en el año 1963 en la revista Bréche-Action surréaliste n4, bajo el título "Le ballon dans les bandes dessinées". En la re-escritura de Vigo figura la edición posterior, fechada en 1968 con la traducción de Elena Comas, no encontrándose el original al que remite en su biblioteca. La re-escritura posee imagen de tapa diseñada por Vigo con el texto "VROOM" debajo de una burbuja de diálogo vacía. Se encuentra encuadernada con dos ganchos en el lado derecho, no hay imágenes en su interior y mide 30 x 23,5 cm. Como señalamos al comienzo, la organización de los párrafos se presenta de manera tradicional en bloques, consta en la primer página que fue traducido por Elena Comas.

Según Benayoun, la burbuja en la tira dibujada no es solo la manifestación de un sentir, ni es solamente una manera de animar a los personajes; es una forma de visibilizar el pensamiento. En el globo de la tira dibujada, tanto la palabra escrita como la imagen devienen en expresión y materialización de convenciones icónicas para la comprensión de ese discurso. El autor sostiene que estas convenciones dan cuenta de los grados de acuerdo, apelando a unos sentidos culturalmente construidos y cristalizados en estereotipos.La noción de estereotipo para referir a la burbuja, alude a la repetición de modelos o fórmulas que se perciben de manera acrítica por haber sido naturalizados culturalmente. Sin embargo, como ha indicado Cecilia Bajour:

El reconocimiento de los estereotipos en el acto de leer pone de manifiesto que la estereotipia implica una relación intertextual, ya que para reconocer una frase manida o una imagen que cae en el lugar común, se vuelve necesario conocer de antemano el objeto, idea o estilo que se manifiesta en modo recurrente y cristalizado (2017, p. 103). 
Retomando el desarrollo sobre la significación de la burbuja o el globo en la historieta, decimos que corresponde a convenciones para un determinado sistema de notación del pensamiento basado en lo icónico. Transcribimos las burbujas que enumera Benayoun en la re-escritura de la dupla Comas-Vigo:

\begin{tabular}{|c|c|c|}
\hline ilegible & de exageración & agresiva \\
\hline murmullo & de ambición & buñuelo \\
\hline manchita & de insultos & fugitiva \\
\hline censurada & de melancolía & meta-fuego \\
\hline super aguda & de especulación & onomatopeya \\
\hline personalizada & foránea & traductora \\
\hline formando parte & papiro & suspiro \\
\hline trastornada & afiche & de desprecio \\
\hline precoz & silbada & interrogativa \\
\hline obliteradora & rectificativa & snob \\
\hline onírica & de reflexión & mosca \\
\hline somnolienta & atómica & martillo \\
\hline de deseo, provista de & con retardo & amnesica \\
\hline sus ondas vibratorias & glacial & musculosa \\
\hline simultánea & sésamo & exhibicionista \\
\hline muda & geográfica & $\mathrm{cu}-\mathrm{cu}$ \\
\hline jeroglífico & políglota & infantil \\
\hline vacía & áfona & sánscrito \\
\hline de iluminación & estéril & bollo \\
\hline de interjecciones & discursiva & papelote \\
\hline rumor & eructada & cuco \\
\hline desvestimiento & pop & compensación \\
\hline de desilusión & perforada & caridad \\
\hline de frustración & con fugas & péndulo \\
\hline
\end{tabular}

La cantidad de posibilidades, no exentas de humor, para nombrar un código compartido implican la complejidad de estabilizar en un signo esta convención. En las obras de Vigo, vemos que 
utiliza la potencialidad de la burbuja (como estereotipo) para distintas propuestas y objetivos, por ejemplo, en una de las convocatorias de arte correo de la década de 1980 denominada Off Off, tiene como motivo el globo vacío de la historieta para ser re- intervenido por los participantes de la experiencia. De esta manera, vemos como la utilización de este elemento se proyecta en la obra posterior, resemantizando su sentido estereotipado inicial e indicando usos diversos de la convención. La apropiación se materializa aquí en forma de propuesta participativa.

Es interesante, en este sentido, volver sobre la obra del poeta brasileño, Álvaro de Sá, y la forma en que emplea la burbuja en sus composiciones poéticas.
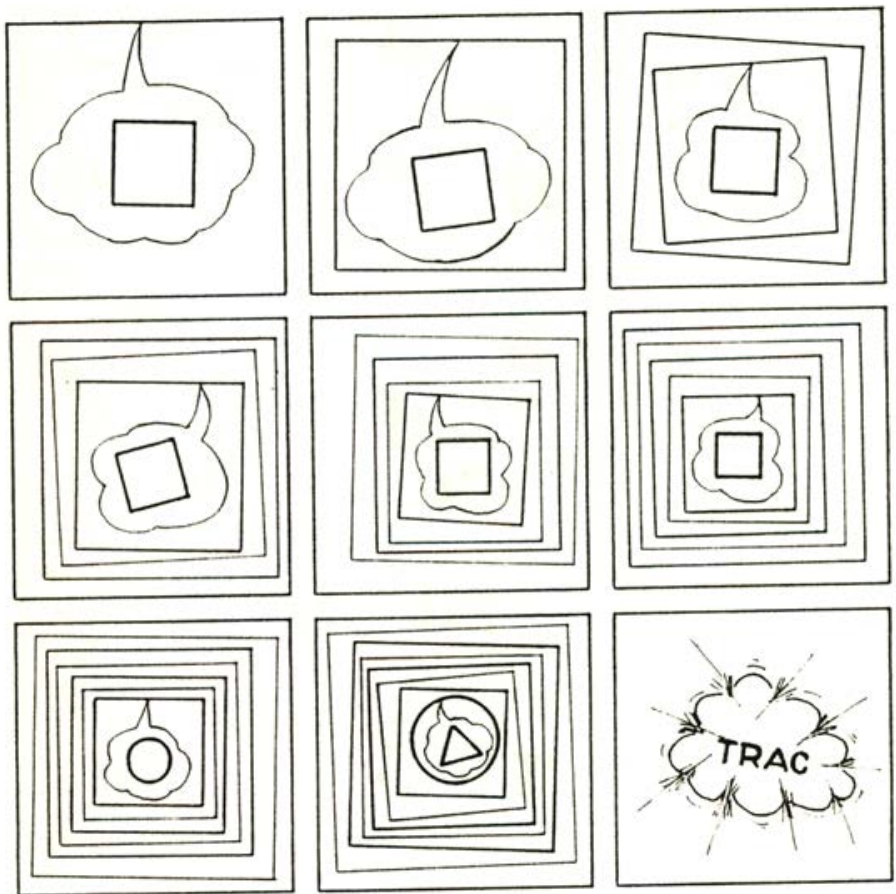

Fig. 91. Álvaro de Sá, Cuatro poema proceso. Fragmento. Archivo CAEV.

La burbuja, en la imagen anterior, aparece vacía de palabra (podría ser la burbuja amnésica de Benayoun) pero conteniendo signos geométricos. Eliminar del interior de la burbuja su contenido convencional sugiere una supresión de la información con la que el lector espera elaborar un discurso narrativo, vinculado a una expectativa de lo que debería contener. Lo que dice, en este caso, es una forma abstracta (cuadrado, círculo, triángulo). Parece en esta tira no haber sujeto de enunciación. El signo, protegido por distintas burbujas, paulatinamente va encerrándose hasta que en las dos últimas viñetas cambia su composición geométrica y, al quedar ahogada, explota utilizando el recurso de la onomatopeya. 
Dijimos que la burbuja o el globo forman parte de convenciones que indicarían la presencia de un discurso directo o una onomatopeya por parte del personaje para referir a determinado paisaje sonoro que se busca recrear en la expectativa de una lectura tradicional. En las obras de Vigo a analizar, el elemento que aparece dentro de la burbuja no es convencional, no hay palabras de las cuales podamos extraer un diálogo o un sentido narrativo. Vigo utilizará, por ejemplo, como contenido de burbujas, una serie de televisores, recortes de otras imágenes, bien burbujas vacías u onomatopeyas ilegibles.

La segunda re-escritura vinculada con la temática de la historieta, corresponde a La tira dibujada, Historia de las Historietas en Imágenes de la Pre-historia hasta nuestros días, de Gerard Blanchard. La re-escritura presenta en la tapa, diseñada por Vigo, una pistola apuntando al espectador (tomada, como veremos, Roy de Liechtenstein), la letra "H” y una serie de estrellas en la parte superior. Está encuadernada del lado derecho con tres ganchos y mide $30 \mathrm{x}$ $23,5 \mathrm{~cm}$. Al igual que en la re-escritura analizada anteriormente, fue traducido por Comas, editada por Vigo. La organización de los párrafos tiene un diseño tradicional y no posee imágenes en su interior. En el archivo se encuentra el libro de referencia que data de 1969. Transcribimos del primer párrafo de la traducción de Elena Comas:

Hay numerosas definiciones posibles de la tira dibujada. La más común restringe el término a designar solamente las historietas en imágenes de estilo americano que vieron la luz a fines del último siglo en los periódicos de allende el Atlántico y se perfeccionaron bajo la influencia del cine y mucho más gracias a algunos dibujantes de muy alta calidad. Nos daremos cuenta al hojear este libro que queremos adoptar un punto de vista más amplio, una definición más literaria que nos permita comprender tanto los bajo relieve de la columna de Trajano como la tapicería Bayeux, los frescos de Assis, como algunas imágenes de Epinal, los álbumes de Töpffer, como los de Tarzán y Asterix.

El desarrollo histórico que propone Blanchard, ubica la historieta como un género híbrido entre la literatura y las artes visuales, además expone vínculos con movimientos como el futurismo y el pop-art. Como venimos analizando, el carácter liminal, de umbral entre las disciplinas artísticas es un interés que lleva a Vigo a indagar en la poesía experimental, específicamente en lo que respecta al carácter secuencial de las historietas herméticas como elementos propios de la 
narrativa visual cinematográfica están presenten en los intereses de Vigo. Consideramos que la labor del artista se orienta justamente a la ampliación de los límites entre los géneros y veremos cómo en su estética operan desplazamientos respecto de los parámetros que establece la historieta tradicional.

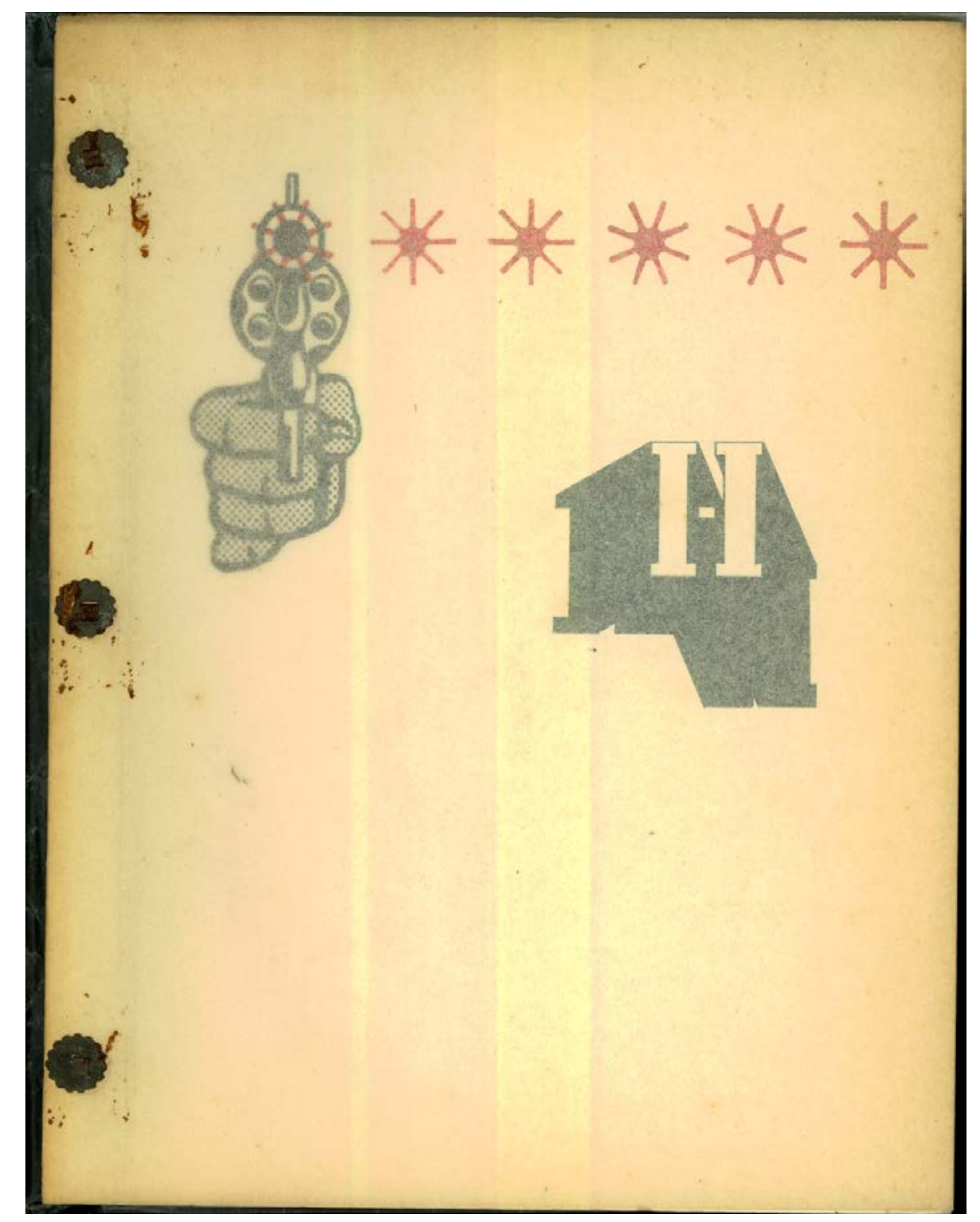

Fig. 92. Tapa de la re-escritura "La Tira dibujada, historia de las historias en imágenes de la prehistoria hasta nuestros días" de Gerard Blanchard. CAEV.

Tanto el desarrollo histórico que se transcribe en la re-escritura y como el contrapunto que ofrece la crítica visibilizan el interés, que ya hemos analizado en los capítulos anteriores, de Vigo por conocer aspectos y fundamentos teóricos del desarrollo de los géneros.

La tercer re-escritura corresponde a Las obras maestras de la tira dibujada. Con prefacio del guionista y editor René Goscinny, quien narra en este prólogo su tarea como productor de historietas. El libro original, publicado por Editorial Planeta en 1967 está presente en la 
biblioteca del CAEV, cuenta con una amplia selección de historietas. En el acervo del CAEV encontramos números de la revista Pilote de R. Goscinny, y el libro original sobre el que se realiza la re-escritura. Al igual que las re-escrituras anteriores, "Las obras maestras de la tira dibujada" no posee imágenes en su interior tampoco en la tapa, se encuentra encuadernada a partir de dos ganchos en el lado derecho y fue editada por Vigo probablemente hacia la década de 1970.

Por su parte la re-escritura de Banda Dibujada y Figuración Narrativa de (1967) de Burne Hogarth -cuyo original se encuentra en la biblioteca personal del artista- se corresponde con el catálogo para la muestra realizada en 1967 Musée des Arts Décoratifs del Palacio del Louvre. Como Señala Laura Vázquez la Primera Bienal Mundial de la Historieta ${ }^{123}$ organizada por Masotta y la Escuela Panamericana retoma los objetivos de esta exposición (Vázquez; 2011, 47). La re-escritura, editada por Vigo y sin datos de la traducción, cuenta con una imagen adherida a la tapa del ejemplar que muestra edificios desde una perspectiva oblicua sobre un soporte de color naranja. Posee una etiqueta mecanografiada con el título, y tres ganchos del lado derecho, mide $30 \times 23,5 \mathrm{~cm}$. En Hexágono 71' a, Vigo incorpora un fragmento de esta re-escritura, con el título: "Prefacio, Banda Dibujada y Figuración Narrativa" fechado en enero de 1967:

Por algún motivo oscuro, existe, entre los círculos informados, en particular aquellos que determinan la apreciación de las artes, antiguas y aceptadas o nuevas y aceptables, una indiferencia, y hasta una ignorancia voluntaria, hacia la tira dibujada. Para algunos mandarines, cuando se discute de arte y de gusto, por solo mencionar las palabras "cartón" o "tira dibujada", desencadena una reacción de desdén, sino de desprecio. (Hexágono 71'a, 1971)

Sugiere Hogarth que la tira dibujada encontrará su lugar en las Bellas Artes, cuando se la defina en relación con las artes tradicionales. No es menor, a la luz de estas palabras, que en el mismo número aparezcan las declaraciones del "Arte Pobre" de Celant (1968). Por otra parte, en la revista Hexágono 71'bc, Vigo traduce y realiza notas sobre el artículo de Moacy Cirne, "La importancia de la tira dibujada", aparecido en BLUM! La explosión creativa de las tiras dibujadas. En las notas, Vigo vuelve sobre el artículo de Hogarth. En el trabajo con la re-escritura de Hogarth vemos el doble proceso de apropiación, por un lado Vigo utiliza el texto

\footnotetext{
${ }^{123}$ Se desarrolló entre el 15 de octubre al 15 de noviembre de 1968 en el Instituto Di Tella.
} 
para volver a publicarlo en Hexágono $71^{\prime}$ y por otro lado, contribuye incorporando datos al texto de Cine.

La última re-escritura a la que aludimos corresponde a la Selección E, los artículos que componen este volumen poseen diversas fechas desde 1968 hasta 1974. El ejemplar cuenta con ilustraciones de Vigo (caso Mafalda) y diversos recortes de historietas argentinas.

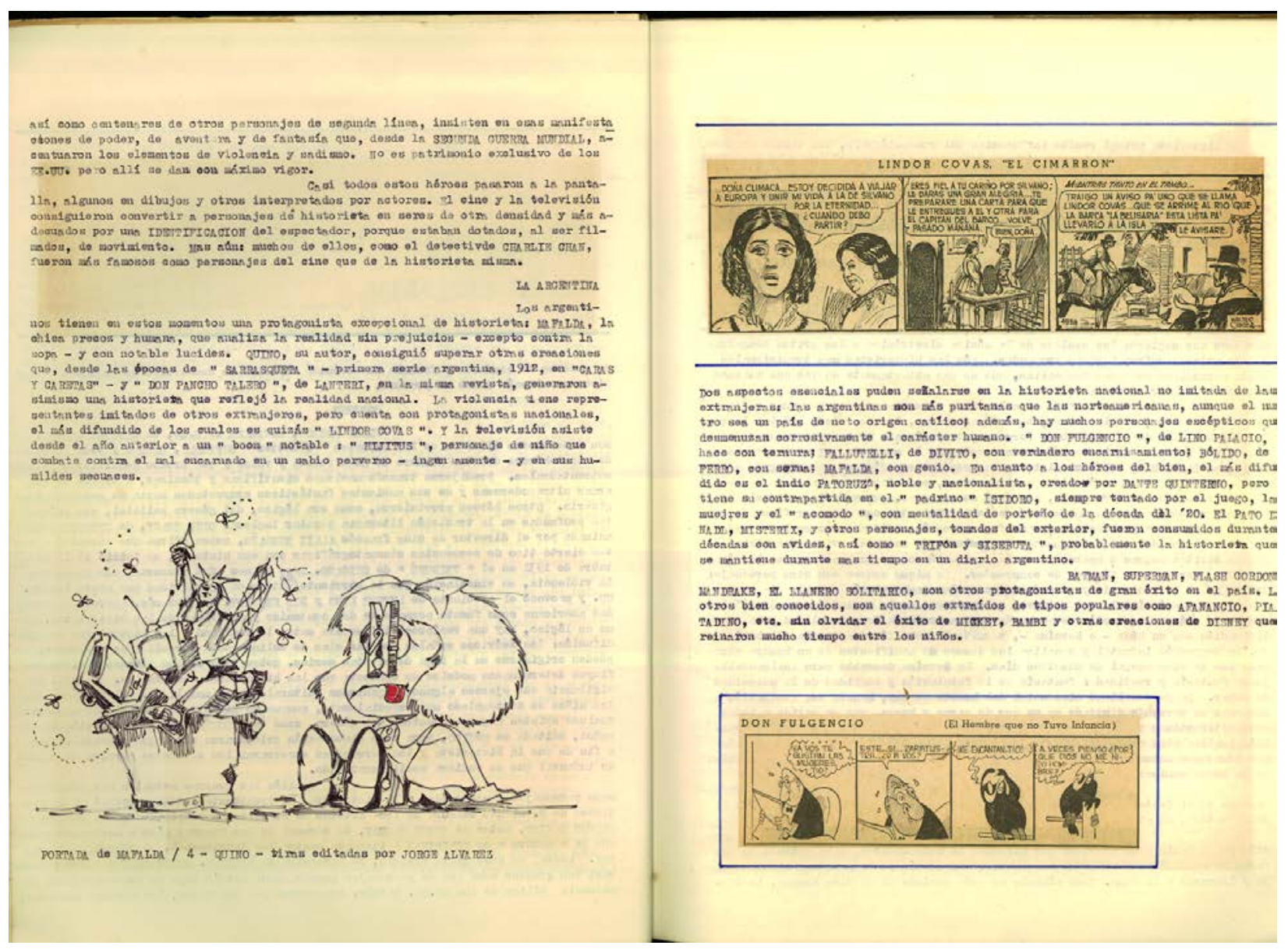

Fig. 93.Re-escritura Selección E. En la hoja derecha posee ilustración de E. A. Vigo del personaje de Mafalda, en la izquierda recortes de "El cimarron" y "Don fulgencio". CAEV

Se destaca esta re-escritura el diseño, la construcción de un catálogo y el trabajo estético de Vigo en su edición. Figura, entre otros, una semblanza del libro Para leer al Pato Donald extraído del diario platense El Día con la fecha del 13 de Agosto de 1972. La crítica marxista que postulan Dorfman y Mattelart (1972) sobre las tiras de Disney se orienta a desmantelar las formas de dominación plasmadas en las historietas. Encontramos también artículos sobre Mafalda, Tarzan, Superman, Patoruzu. Notemos algunas diferencias entre la Selección E y el repertorio de la Selección D sobre poesía experimental. En primer lugar, la mayoría de los textos y artículos de la Selección E, no poseen autor y fueron extraídos de periódicos de circulación masiva: 
Panorama, El Día, Siete Días, La Razón, La Opinión, entre otros. La Selección D, por el contrario, cuenta con autores reconocidos dentro del campo de la poesía experimental, los artículos han sido extraídos de revistas y publicaciones especializadas. Como venimos analizando, desde su Biblioteca y Hemeroteca, Vigo da cuenta un conocimiento amplio y diverso sobre la historieta a partir de libros y revistas nacionales e internacionales que abordan la temática, incorpora, mediante esta selección las voces de la cultura de masas a su repertorio personal.

Como hemos indicado, solo uno de los textos de las re-escrituras aparece publicado en Hexágono 71', nos referimos a Banda Dibujada y figuración narrativa. Creemos sin embargo que, de manera similar al desarrollo sobre Marcel Duchamp, el procedimiento de apropiación se manifiesta aquí como una deglución del material leído y una proyección en obra que genera una estética particular vinculada al comic. Así, podemos afirmar que en las re-escrituras no solo operan desplazamientos textuales, esto es de un original a la particularidad de una copia en su diseño y en la selección de un catálogo, lo que vemos, tanto en los postulados duchampeanos, como en la exposición de la Novísima y, particularmente, en los casos que presenta Hexágono $71^{\prime}$ sobre la historieta, es una apropiación particular de los contenidos de las re-escrituras que decantan en proposiciones estéticas. Sostenemos que en este camino, la re-escritura deja de presentarse (por medio de la cita o la transcripción de fragmentos para su difusión) para dar paso a la representación por medio del lenguaje plástico, como una segunda forma que asume la apropiación. En el caso del comic este corrimiento se efectúa mediante la creación por parte de Vigo de una serie denominada historietas herméticas.

Interesa recapitular brevemente en este punto el desarrollo histórico del género en Argentina puesto que podría pensarse la propuesta de Vigo dentro de lo que los críticos denominan historieta de autor. Laura Vázquez señala que:

El período denominado como la "edad de oro" de la historieta concuerda con un punto de expansión de la industria cultural en el país. En el transcurso de las décadas del cuarenta y cincuenta la historieta no solo se posiciona como un producto masivo en la industria de la cultura sino que consigue conformar su público, consolidar su sistema profesional, imponer una ideología y definir una estética gráfica propia. Durante esta etapa, las editoriales Abril, Códex, Columba, Dante Quinterno, Frontera y Manuel Láinez conforman en el mercado de ediciones semanales una oferta clave (2011, p. 9). 
Javier Comas sostiene en torno a las rupturas que presenta la historieta desde la década de 1950 que:

La sistematización de los hechos que convulsionaron los comics desde los años 50, reemplazando poco a poco el mito del héroe por el del autor, se presta a muy diferentes perspectivas e interpretaciones históricas y a múltiples ángulos de análisis. En cualquier caso, resultan fundamentales aspectos como los siguientes: ocaso de los personajes fijos, concepto de comic de autor, adquisición de mayor libertad expresiva mediante el enfoque hacia los adultos, vitalización de las producciones autóctonas. (1984, p. 12)

Decíamos en el Marco Teórico que, el concepto de apropiación, a diferencia de la noción de plagio y copia, es operativo en esta tesis para abordar la complejidad de las re-escrituras porque permite abordar estos compendios de conocimiento y el uso que Vigo le otorga a los mismos. Analizamos en los Capítulos 1 y 2 la relación entre las re-escrituras y las publicaciones y charlas de Vigo, sin embargo, en el trabajo de Vigo para con la historieta se agrega una nueva dimensión a la apropiación: la producción de obra. Es decir, la re-escritura deja de ser texto para convertirse en nueva obra. Las re-escrituras dejan de difundirse en forma literal y explícita para volverse obra visual, reformulación, concepto que se expande en una apropiación estética.

\section{Historietas herméticas}

La serie historietas herméticas alude a un conjunto de producciones de E. A. Vigo que comienza a principios de la década de 1970, en cuyo nombre explícitamente indica su pertenencia al género de la historieta. En la trayectoria artística de Vigo, como analizamos en el Capítulo 1, los títulos de sus obras poseen un lugar preponderante, indican no solo situaciones paradójicas sino también juegos con el lenguaje -oxímoron-, homenajes y señales o guiños al potencial espectador-lector. En la denominación historietas herméticas entran en juego dos órdenes aparentemente contradictorios: por un lado, la masividad en los códigos que supone el género y por otro, el hermetismo que, podríamos pensar, anularía lo anterior. El adjetivo no clausura el sentido, más bien, como vemos en las series, vuelve porosa la interpretación. Notemos que en otros títulos, por ejemplo "poemas (in) sonoros", también se destaca el género al cual pertenecen estableciendo un primer código de referencia o apelando a una convención difundida: la poesía. Este código inicialmente compartido se fisura cuando aparece el adjetivo, en el caso de las 
historietas, su condición hermética. El título entonces parece sugerir al lector-espectador la imposibilidad de efectuar generalizaciones en torno al sentido, en el caso de los "poemas (in) sonoros" Vigo busca el desconcierto, en las historietas herméticas, la polisemia. Como ha señalado Ana Bugnone:

Las historietas de Vigo -nunca del todo claras-, las comunicaciones y poesía visuales publicadas en Hexágono 71' tienden a hacer imprescindible un público que esté dispuesto a reflexionar y prestar atención frente a la sorpresa, la ironía o el descolocamiento. Esto se debe al criterio utilizado por Vigo al escoger los trabajos para publicar, en el que prima un interés por desechar la lectura o mirada convencional. Propone un receptor que pase a ser también productor o intérprete más o menos libre tanto de las imágenes como de la manipulación del artefacto revista, quitando páginas o ubicándolas en otro lugar. Esto último no implica desistir de la incorporación de trabajos -especialmente en la segunda etapa- cuyo mensaje permanece relativamente inalterado luego de su encuentro con el lector y donde la comunicación política se ha privilegiado sobre otras funciones. En la heterogeneidad que permitió esta combinación, Vigo ha conciliado la presencia de intervenciones radicales del receptor con otros casos en los que este se mantiene - tanto en los trabajos más explícitamente políticos como en los textos teóricos- en un rol menos activo y en una relación menos incierta con el sentido. El resultado son revistas en las que se tensiona o distorsiona el rol de receptor, en tanto pasa por distintos momentos de mayor y menor participación en un mismo número (2013, p. 269)

En el análisis de las re-escrituras realizado en el Capítulo 2, hemos dicho que los postulados de la poesía visual se visibilizan en el corrimiento del perfil de la publicación Diagonal Cero y en las decisiones montaje para la Expo Internacional de Novísima Poesía/69 como un trabajo teórico sobre la palabra pero también como una experiencia particular que invita al lector a ser un programador. Vemos, en el caso de la revista Hexágono 71', la plasmación de las lecturas y re-escrituras desde otras operaciones de deglución, en tanto se utiliza el género del cómic como una propuesta singular donde también se le exige al lector que complete el sentido pero dotándolo de menos herramientas teóricas. Es decir, a través del objeto plástico -que, en el caso de Hexágono 71', es la historieta pero también el dispositivo de revista ensamblada - y con códigos mínimos, Vigo propone un encuentro "en un diálogo silencioso el trabajador plástico de investigación y el espectador" (Vigo, Hexágono 71'ce, 1973). 
La propuesta en las historietas herméticas, toma elementos tradicionales del género para subvertirlos: si en la historieta tradicional el espectador espera encontrar las peripecias de un héroe o heroína, una acumulación de narraciones con un esquema progresivo, un código compartido en la viñeta; en las historietas herméticas, por el contrario, se presentan situaciones, especies de fotogramas no acumulativos, como se puede ver, por ejemplo, con los personajes de "Grupo de familia": siendo evocado, disparado, embelesado. Sobre la utilización de letras y números en las historietas herméticas podemos establecer lazos con los poemas matemáticos y las composiciones xilográficas de Vigo pero tampoco corresponde una asignación de sentido directo en tales manifestaciones. Las historietas de Vigo, a pesar de no haber narrativa en el sentido tradicional, son historietas. No solo porque su nombre las incluye dentro del género, sino porque comparten las tres convenciones específicas (pero no exclusivas) que, siguiendo a Román Gubern (1972), constituyen la marca distintiva del género: el ballon (burbuja), las onomatopeyas y los signos cinéticos (1972, p. 139).

El desplazamiento por parte de Vigo en al abordaje de las re-escrituras vinculadas a la historieta también se visibiliza en la operación de edición: si antes la edición se circunscribía a la traducción, diagramación y composición de un nuevo original (la re-escritura como dispositivo), vemos en Hexágono $71^{\prime}$ que la edición también forma parte de la apropiación de imágenes para nuevas composiciones, se profundiza el aprovechamiento y la reutilización de los materiales, otorgando nuevos sentidos para representaciones ya existentes. Es el caso, por ejemplo, de la incorporación a Hexágono 71' de varios elementos de la revista dirigida por Masotta, Literatura Dibujada, Serie Documentación de la Historieta Mundial.

De Literatura Dibujada, Vigo extrae material considerado secundario (como analizaremos en el caso de la publicidad) y material gráfico (caso Little Nemo).

\section{Historietas Herméticas y Hexágono 71'.}

Hexágono 71'es una "revista ensamblada" en la denominación de Ana Bugnone. Corresponde a una publicación donde prima "el montaje de trabajos de diversos artistas que un editor se encarga se aunar, similar al libro de artista y cuyas estrategias comunicativas se separan de las limitaciones del mundo editorial.” (2014, p. 7) En este tipo de publicaciones, los vínculos y colaboraciones entre artistas son fundamentales: 
A diferencia de las revistas normativas, basadas en parámetros industriales y masivos y centradas en el deber de ceñirse y atenerse a unos cánones editoriales estandarizados por la industria — no digo sin ciertas libertades_-, para llegar eficazmente a consolidarse en el mercado — sea cual sea su temática, tipo de consumidor, nivel de experimentación gráfica o distribución - , las ensambladas transgredieron esas normas y habilitaron la creación experimental, lo que permitió tanto la transformación del formato como del contenido, pero limitadas en la tirada y la difusión (Bugnone, 2014, p. 8 ).

Entre las características específicas que señala la autora, subrayamos en primer instancia, la carencia de numeración de las revistas; Vigo modifica el número por una letra, así, las primeras tres letras del alfabeto se combinan en a, ab, ac, bc, bd, be, cd, ce, cf, de, dg, df, y e conformando los trece números publicados de 1971 a 1975. Por otra parte, respecto de la materialidad, la publicación apela a un dispositivo distinto respecto de la revista tradicional, puesto que las hojas se encuentran sueltas dentro de los sobres respectivos y no poseen numeración, por lo que el espectador también es un hacedor que re ordena y participa en cada accionar este dispositivo. En torno al carácter poético-político de esta publicación, señala que:

Se trata de un artefacto cuya politicidad se encuentra en el entrecruzamiento de vanguardia estética y política radicalizada, las que obtuvieron diferentes pesos a lo largo del tiempo: los modos y proporciones en que se combinaron invalidan cualquier interpretación lineal que identifique el aumento del compromiso político con el abandono de las prácticas específicamente artísticas o de la estética vanguardista (Bugnone, 2014, p. 4).

En la lectura de Bugnone, Hexágono 71' puede dividirse en dos etapas, una primera que comprende los primeros cuatro números (a/ be) y un segundo momento, del número ce a e. La división no solo se efectúa respecto del logo que emplea y la ilustración de tapa sino también al contenido de la misma, puesto que, entre otras, en la segunda etapa se da un viraje hacia autores tanto argentinos como latinoamericanos, adquiriendo un perfil más comprometido políticamente. Relevamos a continuación seis números de Hexágono 71' atendiendo a las formas en que aparecen las historietas herméticas como reformulaciones de lecturas y re-escrituras que Vigo realiza. El corpus de obras seleccionadas para el presente capítulo se corresponde con: Historieta (1971), Características eróticas con perforaciones (1971), USA Versus Latin America (1972), La 
in-comunicación de los medios masivos de comunicación. Por caso la TV (1972) e Historieta con automóvil (1973). Las cinco producciones comparten el montaje como procedimiento constructivo. La cita y la apropiación de materiales pre-existentes se evidencian en las historietas a partir de los fragmentos con los cuales Vigo compone sus propuestas estéticas. En torno a los procedimientos propios del comic se retoma la burbuja y el carácter secuencial que proveen las viñetas así como también la repetición.

Dividimos el análisis en dos momentos, por un lado, aquellas historietas que toman el "Grupo de familia" como icono recurrente; por otra parte, los procedimientos de cita y apropiación en los casos en que la revista modifica el sentido de la imagen recontextualizándola.

\subsection{Grupo de familia, citas y apropiaciones}

"Grupo de familia" corresponde a una tribu con cuatro personajes aparentemente prehistóricos reunidos de forma circular, como veremos, esta figura será recurrente pero no tiene un sentido único en la producción de Vigo puesto que las secuencias en las que participan varían en cada historieta.

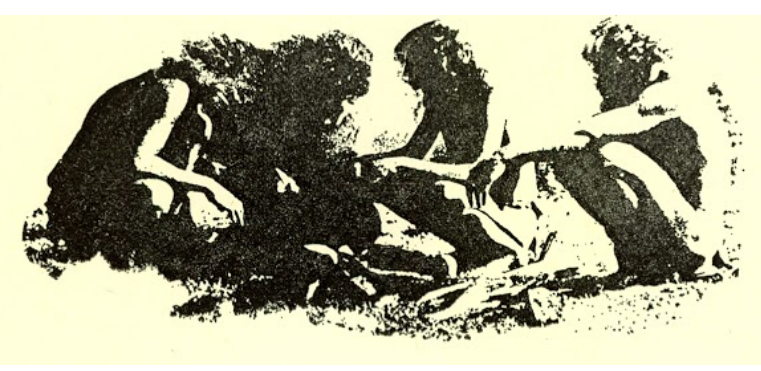

Fig. 94. Grupo de Familia, CAEV.

En Hexágono 71' a figura, como ya señalamos, Prefacio: Banda Dibujada y Figuración Narrativa de Burne Hogarth única re-escritura que se publica en forma de transcripción en las páginas de la revista. En este número, por primera vez encontramos el "Grupo de familia", en la obra titulada Historieta de Vigo. La tira a la que aludimos consta de cinco cuadros-viñetas, dos en la hoja uno, tres en la siguiente. En la primera vemos una especie de viñeta con la letra "T" en la parte inferior y por sobre esta, una burbuja hecha de puntos que contiene una superposición de nubes yuxtapuestas. La letra " $\mathrm{T}$ " se repite en imagen $3^{\circ}$ y $5^{\circ}$, en la $4^{\circ}$ una letra " $\mathrm{S}$ " o "N" compuesta geométricamente. En la segunda imagen encontramos una mixtura entre la estructura de los Poemas Matemáticos Barrocos (1967) y el sello de Vigo en la composición. La tercera es 
igual a la primera viñeta, la cuarta posee dos flechas en orden ascendente y en la última encontramos el "grupo de familia" emergiendo, a la manera de "nube" de pensamiento de la letra “T". Podemos decir que hay una secuenciación del contenido, signado por la repetición, la utilización de las dos viñetas de transición orientadas hacia la izquierda, pero no podemos afirmar un mensaje único, legible de una manera determinada. Notemos que la burbuja toma tres aspectos en esta historieta: en forma de puntos, en forma de nube (o flor) y como globo, entre las tres letras "T" de las cuales salen estas burbujas, la viñeta que podríamos llamar "de transición", está compuesta por números, letras y flechas.
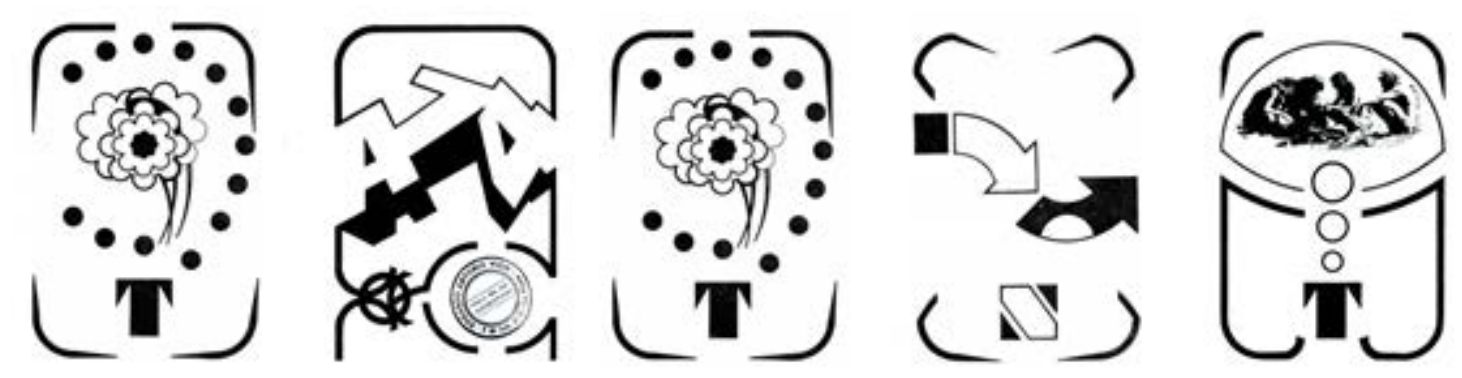

Fig. 95. Historieta. Hexágono 71' a. CAEV

En Hexágono 71' ac (1971) Vigo publicó Características eróticas; con perforaciones. Está compuesta de un solo cuadro, donde aparece nuevamente el "Grupo de familia" en el centro de la composición. De ellos se desprenden tres perforaciones ascendentes hacia la imagen de dos personajes en una relación erótica.

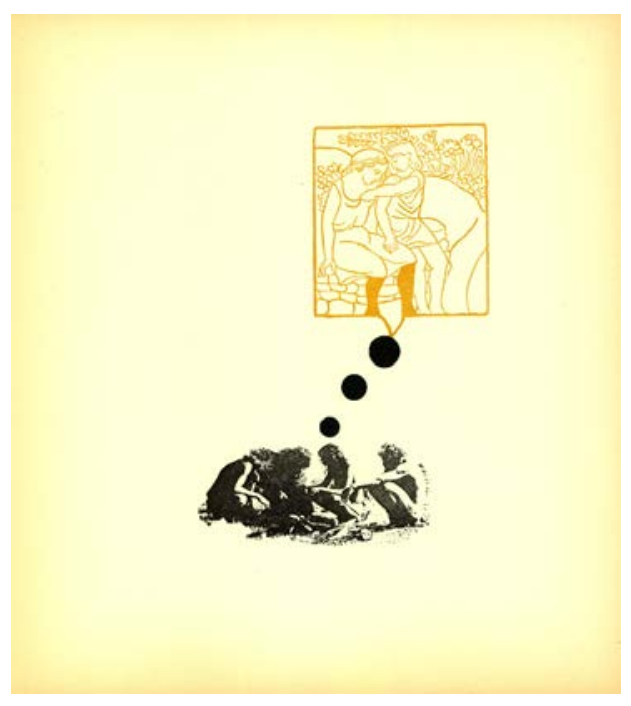

Fig. 96. Hexágono 71' ac “Características eróticas; con perforaciones”. CAEV 
A partir de un relevamiento de la biblioteca hemos encontrado que la imagen de los personajes dentro de la burbuja fue extraída del libro presente en la Biblioteca de Vigo, Panorama des Arts Plastiques Contemporains (1960) de Jean Cassou, página 73.

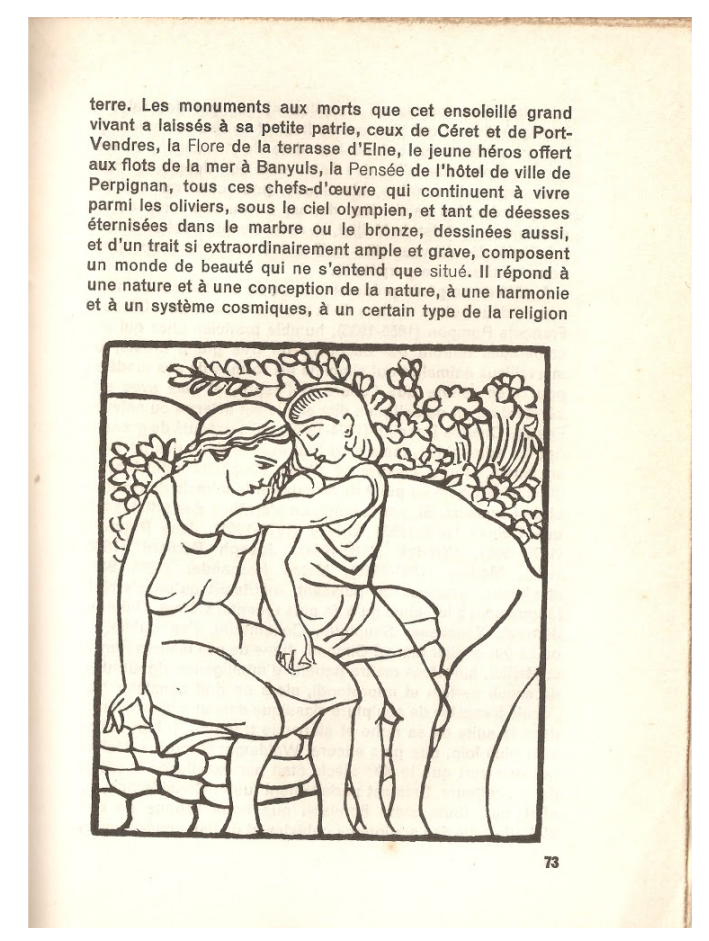

Fig. 97.Jean Cassou, Panorama des arts plastiques contemporaines, (1960) página 73.

El libro también aparece reseñado en el artículo que Vigo escribe para El Argentino, titulado Artes plásticas. Panorama, como apunta Gustavino:

La atención de Vigo a las narrativas divergentes de la propuesta por la historiografía del arte "a la francesa" se confirma en una reseña de 1961 del libro de Jean Cassou, Panorama des arts plastiques contemporaines, traducido y publicado en España. El artista platense objeta que el título no aclare "en Francia", ya que el supuesto "panorama" se restringe a ese país e ignora la pintura española, la italiana, la holandesa, omisiones que Vigo considera "inaceptables en un crítico y figura de prestigio" en las artes plásticas internacionales (2015, p. 441).

Este ejemplo da cuenta de las múltiples formas que asume la cita en el trabajo de Vigo: apropiación, re-escritura, elaboración de un texto crítico, collage, edición. Aporta indicios para reflexionar sobre el diálogo que se establece entre los materiales como insumos, acción presente de manera continua en la producción del artista, pero además, coexistencia de múltiples temporalidades y acciones sobre ese material. Notemos que en el caso de esta imágen, como así 
también en las apropiaciones de la revista Literatura Dibujada que analizaremos a continuación, no hay referencia al autor de las obras. En el caso de la apropiación por parte de Vigo de determinadas imágenes, no aplica el desarrollo sobre la cita y la legitimidad que aporta el reconocimiento de la autoría que desarrollamos en el Marco Teórico en relación con las re-escrituras. Es decir, en la apropiación de textos, Vigo como editor se encarga de citar tanto fuente como autoría (del texto y de la traducción en caso que la hiciera Comas), no sucede lo mismo frente a las imágenes, donde el montaje funciona como apropiación generando un nuevo original donde interviene una copia que se modifica en el contexto de la composición.

"Grupo de familia" aparece por tercera vez, en este caso en la historieta U.S.A. versus Latin America en Hexágono 71' bc. Se trata de una hoja doblada longitudinalmente, donde encontramos una hendidura en forma circular - emulando una huella de bala- que traspasa las tres hojas que conforman la historieta. En la lectura de Bugnone, el texto en inglés puede vincularse con el uso de la lengua a la que se juzga: “Al abrir la hoja, se observa que el calado coincide con el caño de un arma de fuego que apunta directamente hacia el espectador, con un tratamiento pop de la imagen extendido en los Estados Unidos, lo cual también puede emparentarse con el uso del inglés en el título." (Bugnone, 2014, p. 24) El "grupo de familia" aquí aparece con un signo de exclamación en la parte superior, en el medio el calado y abajo la leyenda "llegó la ayuda hermanos!".

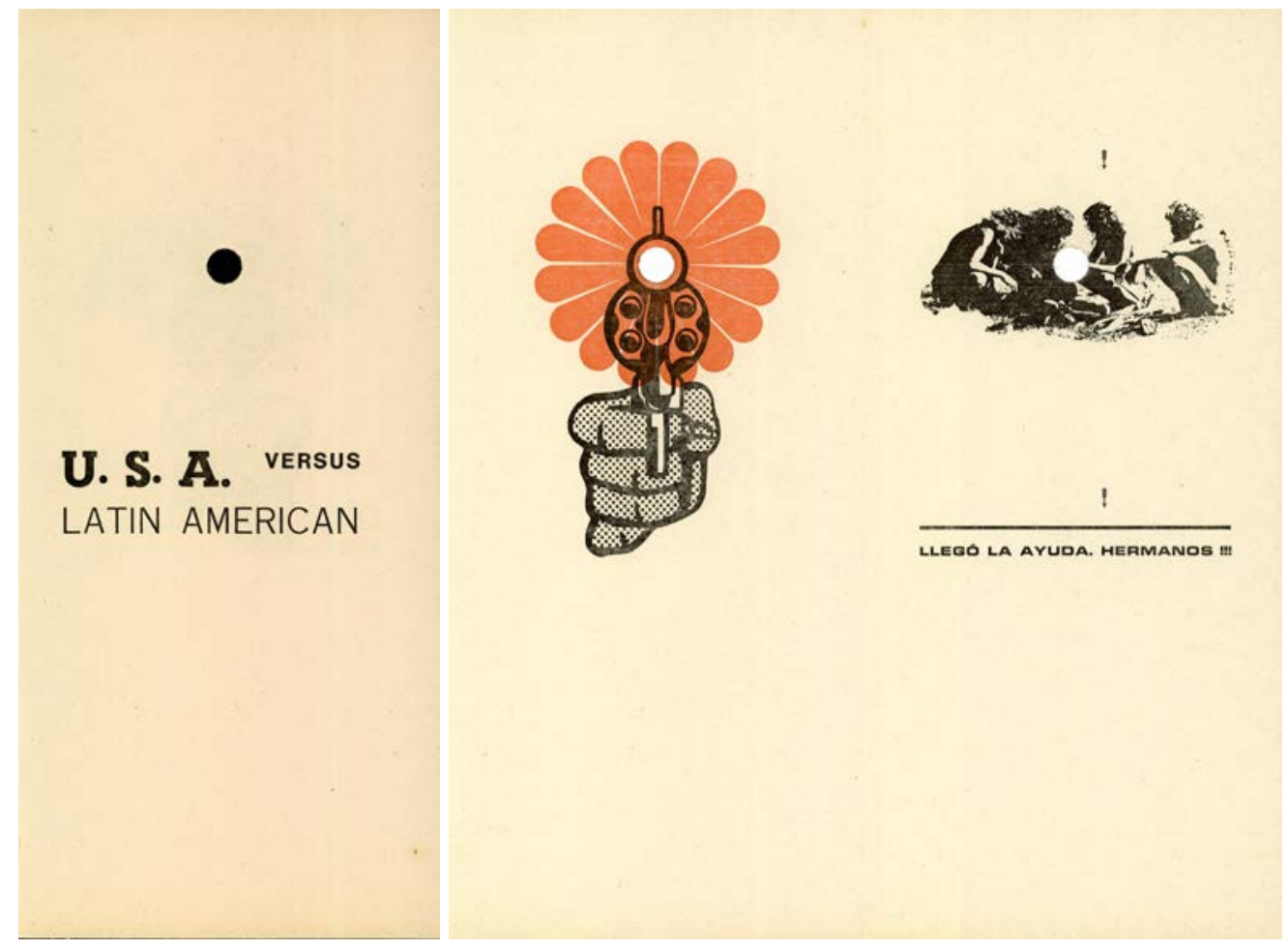

Fig. 98.U.S.A. versus Latin America Hexágono 71' bc. CAEV 
La pistola que utiliza Vigo para la composición es una reproducción de la imagen de Lichtenstein "Pistol" de 1968. La cita, en este caso, se vincula directamente con un artista que utiliza la estética del cómic para su producción y que, con variantes en la representación de la mano que sostiene el arma, ha publicado la misma obra, en la tapa de la revista Time de 1968, bajo la leyenda "THE GUN IN AMERICA". La misma arma aparece en la tapa de la re-escritura sobre Blanchard y en la obra de Vigo "Soluciones económicas ofrecidas por el systema al pueblo" (1972)

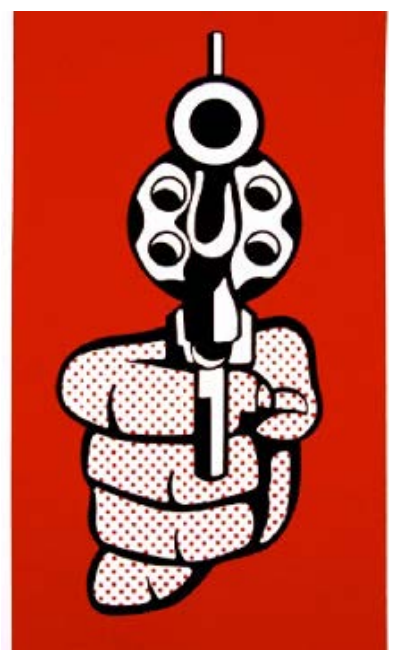

Fig. 99. Roy Lichtenstein, Pistol, 1968, 210.7 x 110.6 cm, Colección Christies Galery.

En la misma publicación se expone el texto La importancia de la tira dibujada de Moacy Cirne, participante, como señalamos en el Capítulo 2 del grupo Poema- Proceso y teórico del comic. Expone Cirne que la historieta ha sido juzgada como una "sub literatura perjudicial para la infancia”. Retoma el ensayo de Benjamin (La obra de arte en la era de la reproductibilidad técnica, 1936) haciendo énfasis en la idea de que las técnicas de reproducción aplicadas a la obra de arte modifican la actitud de las masas frente a la obra y la historieta no queda exenta por su grado de masividad. Repercuten en este ensayo las proposiciones de Poema-Proceso en tanto se refiere a las composiciones del movimiento como "Narraciones de historietas y humor, sin leyendas". Culmina el artículo señalando que: "Poco importa saber que las historietas son — o no - un arte, conforme hace notar RUY CASTRO, precisamente porque - hoy — ¿qué es realmente lo que sería arte? Lo que importa es su poder de comunicación y su capacidad de revitalizar formas expresivas" (Hexágono 71' bc, 1972). En el Capítulo 2, cuando analizábamos el ensayo de Vigo, De la Poesía Proceso (1969), referíamos a Moacy Cirne como referente teórico de Vigo al postular las diferencias entre la Poesía-Proceso y la Poesía Concreta en Brasil. 
Resaltamos en este punto la importancia que Cirne le asigna a la historieta postulando que es el género por excelencia del siglo XX.

En Hexágono 71' be (1972) encontramos La (in) comunicación de los medios de comunicación masivos. Por caso la TV, Comic Strip.

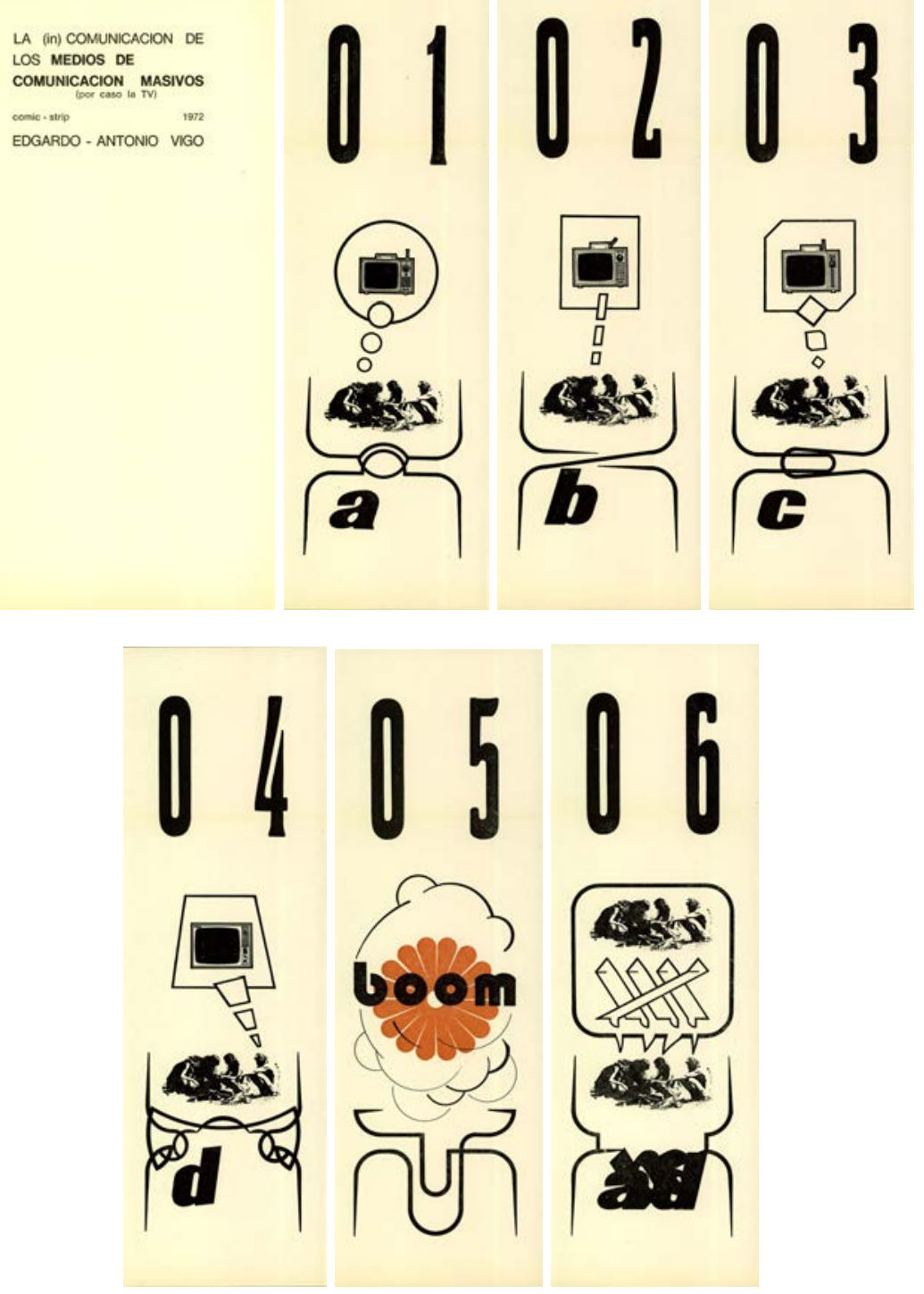

Fig. 100. La (in) comunicación de los medios de comunicación masivos.

Por caso la TV, Comic Strip. Hexágono 71' be (1972) CAEV

Compuesta de seis cuadros, cada uno de ellos numerado y consignado con una letra (a, b, c) en la parte inferior, a excepción de 5 y 6 . Esta doble secuenciación sugiere la continuación de la lógica de la publicación en la que está inmersa, reforzando la secuencia lineal, notemos que utiliza la misma tipografía que la revista en las letras inferiores. Compositivamente en todas se repite el esquema de división en tres espacios, en la parte superior el número $01,02 \ldots$ en medio de la imagen (en 01, 02, 03, 04) un televisor dentro de una burbuja con diversas formas geométricas, y 
en la parte inferior el "grupo de familia" enmarcado en una viñeta con una de las letras del abecedario. En la imagen 5, con tipografía redondeada, (tipo sturm blond) se lee "boom", con la flor que ya ha sido utilizado en U.S.A. versus Latin America. En la imagen 6, en el lugar del televisor está el "grupo de familia", sugiriendo un espejismo entre aquello que miran y ellos mismos. Además en la viñeta número 6 ya no hay letras legibles, se yuxtaponen las anteriores formando un enjambre en la parte inferior. En "La in-comunicación", estos personajes son su duplicado exacto.

De Hexágono 71' ce destacamos por una parte el artículo firmado por Vigo titulado Por qué un arte de investigación donde señala la importancia de reflexionar sobre el lenguaje y la función del espectador. En el arte de investigación los "lenguajes herméticos o demasiado simples han alimentado la existencia de esas dos actitudes frente al arte. Pensamos no para anular (estamos en total acuerdo en la coexistencia de ambas posturas) pero así para que exista comprensión de esa coexistencia y con un real sentido pedagógico, establecer un lenguaje accesible y a la vez cargado de problemáticas nuevas" (E. A. Vigo, Hexágono 71'ce, 1973). Vigo resalta también la utilización de códigos conocidos sin perder la profundidad de las ideas. En este número encontramos obras de: Zabala, "Explotación es terrorismo"; "Afiche de Artistas Plásticos en Lucha" diseñado por Romero, "Fusilados en Trelew el 22 de agosto de 1972. Tribunal popular para los asesinos", Nicholas Zurbrugg, poema visual, "Large \& far. Small \& near”, "Envíe una idea en 200 copias a: G. Deisler"; de Vigo, "Souvenir de dolor" e "Historieta con automóvil".
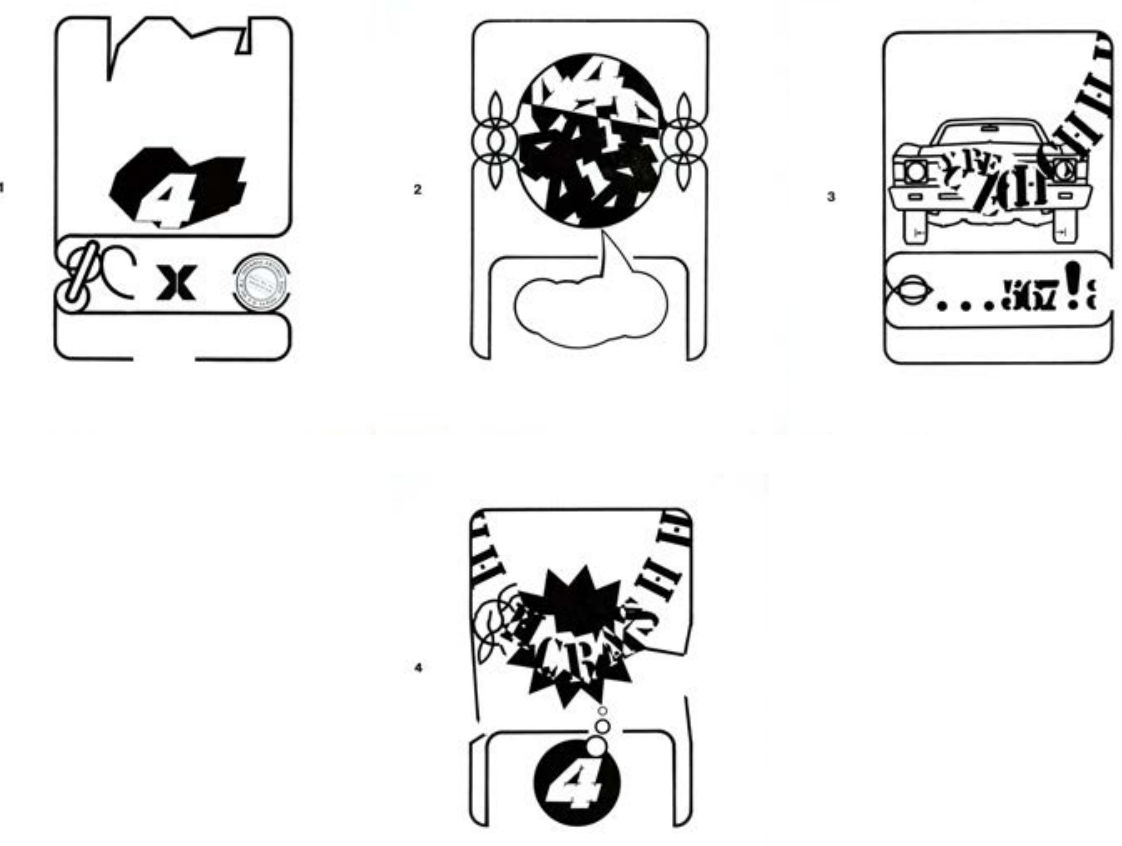

Fig. 101. Historieta con automóvil. Hexágono 71' ce. CAEV. 
Historieta con automóvil se compone de una secuencia de cuatro cuadros. En el primero de ellos, una viñeta con el número 4 con sombra en perspectiva hacia ambos lados, la parte superior de la viñeta sigue ese contorno. Una letra " $X$ " y el sello de Vigo enmarcado de forma circular aparecen en la parte inferior. En el segundo cuadro vemos una viñeta rectangular, en los costados, hacia la mitad de la composición, dos hélices de avión vistas de frente y en medio, enmarcado por un círculo, números 4 formando una composición, la mitad de ellos en blanco y la otra mitad en negro. Debajo de ellos, una burbuja invertida vacía, que también puede leerse como humo saliendo del caño de escape. En el cuadro número 3, vemos un coche Ford Falcón -¿referencia a la huida que fue masacre de Trelew?- de frente, de donde salen letras ascendentes, parece formarse la onomatopeya "SCRECHH", debajo, una especie de viñeta con tres puntos suspensivos y los números “567” con un signo de exclamación. En el último cuadro, una estrella en forma de explosión donde se lee "CRASH", debajo de ella, el número 4 enmarcado en una burbuja negra -¿sugiriendo que lo anterior es pensamiento de ese número?-, llama la atención la ruptura en la forma de esta última viñeta, ya que no es una composición cerrada como las anteriores. Notemos que las características constructivas de Historieta con automovil (utilización de la línea, composición en viñetas con marco, utilización de números, burbujas y letras) son similares a la primer obra, Historieta, aparecida en Hexágono 71' a.

En relación con las apropiaciones nos detenemos en dos imágenes que Vigo incorpora a Hexágono 71' tomadas de la revista Literatura Dibujada de Oscar Masotta. En Hexágono 71'cd (1973) el editor modifica la portada del sobre contenedor e intercala una imagen, sobre esta se lee "Eso sí, la más peligrosa", en el extremo izquierdo el sello "arte argentino de vanguardia". 


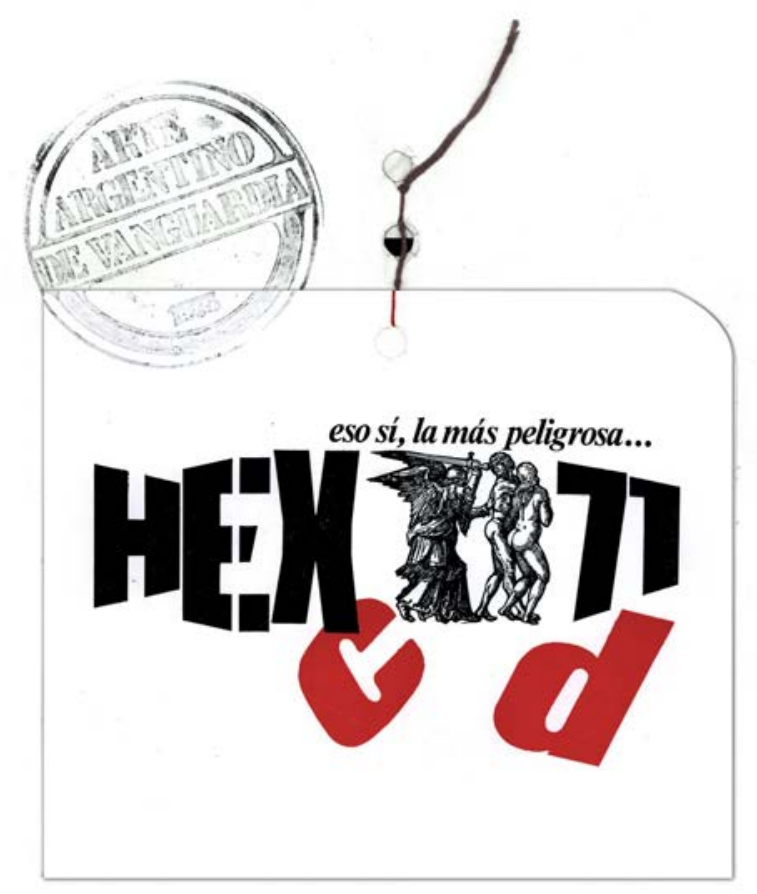

Fig. 102. Tapa Hexágono $71^{\prime} \mathrm{cd}$. CAEV

La imagen original de Adán y Eva pertenece a un grabado de Alberto Durero fechado en 1511, titulado "La expulsión del Paraíso" 124 . Según hemos podido relevar en el archivo, la misma ha sido extraída de la publicación editada por Oscar Masotta, Literatura Dibujada. Serie de Documentación de la Historieta Mundial. La imagen sale de un elemento absolutamente marginal de la publicación de Masotta: la publicidad de la editorial Sudamericana. En la publicidad se lee: "Fabricamos una nueva forma de Paraíso... eso sí, la más peligrosa...”. Vigo fragmenta el contenido de la publicidad y lo vuelve a significar en un nuevo espacio: la tapa de su publicación. En este caso, la apropiación de la publicidad es un procedimiento que transforma la imagen en un elemento estético significativo para la composición de tapa: evoca el texto bíblico de manera crítica y refuerza el carácter político de la revista. Indica Bugnone en torno a la frase "Eso sí, la más peligrosa" que:

(...) invitaría a pensar -al receptor de la época- en una revista vinculada al momento de radicalización política que se estaba viviendo. La idea de "peligrosidad" de algo o de alguien, más que una relación con la ruptura estética, aludía, en ese momento, a

\footnotetext{
${ }^{124}$ La misma imagen será utilizada de manera crítica por León Ferrari en la serie "L'osservatore Romano" (2001), que presenta como título "Conclusiones del Congreso Teológico-Pastoral organizado por el Congreso Pontificio para la Familia".
} 
militantes u organizaciones políticos, sindicales, sociales que se disponían a luchar -de distintos modos- contra el "sistema". ¿Qué implica, entonces, esa leyenda en una revista de arte? Puede interpretarse como una señal de interpenetración más evidente con la situación política y social: la revista se ha vuelto "peligrosa" porque a partir de ese número la masacre de Trelew, el Che y la represión son los temas por excelencia de los trabajos allí publicados. (Bugnone, 2013, p. 282)

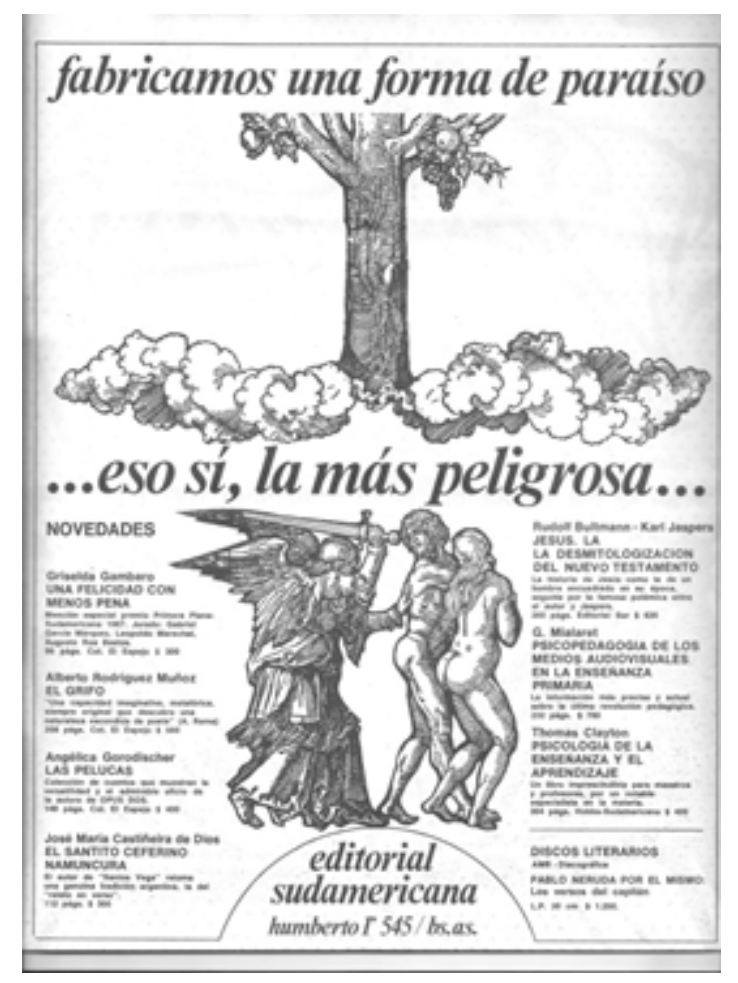

Fig. 103. Publicidad Sudamericana. L. D $n^{\circ}$ 1. Página 43. Archivo CAEV.

En segundo lugar, Vigo toma de la revista de Masotta para incorporar a su publicación, dos páginas de la mítica tira Little Nemo in Slumberland. En el número 2 de Literatura Dibujada. Serie de Documentación de la Historieta Mundial (1968, pp. 14-15) aparece la tira de Little Nemo que es reproducida sin modificaciones en Hexágono df(1974) junto a la transcripción del párrafo de presentación escrito probablemente por Oscar Masotta. 

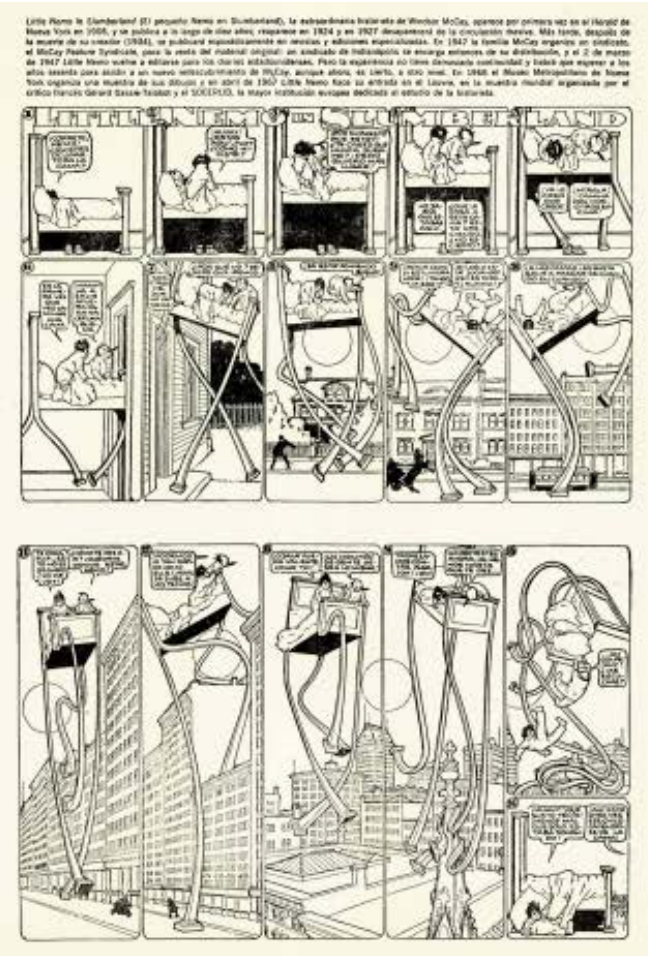

Fig. 104. .Little Nemo in Slumberland (Hexágono 71' df, 1974) comic extraído sin modificaciones de la revista Literatura Dibujada. (1968, pp. 14-15)

Creemos que la incorporación de Literatura Dibujada a Hexágono 71' es otra forma de apropiación por parte de Vigo. Es notable, como mencionamos anteriormente, la diferencia de criterios en la utilización por parte del editor de Hexágono $71^{\prime}$ en torno a la apropiación de textos y de imágenes. Mientras la cita a los textos se realiza de manera precisa consignando autoría del texto, la traducción, editorial o publicación de la cual se extrae y año, en el caso de las imágenes es nula la referencia a la autoría de las mismas. En la apropiación y difusión de textos, Vigo como editor se encarga de citar tanto fuente como autoría, no sucede lo mismo frente a las imágenes, donde el montaje funciona como apropiación, generando un nuevo original donde interviene una copia que se modifica en el contexto de la nueva pieza a partir de su vínculo con otros recursos gráficos en función de su proyecto.

Obviamente, por carecer de referencias, la tarea de rastreo de las imágenes ha sido más dificultosa y azarosa, por ejemplo en el caso de Panorama de las Artes Plásticas, o en la indagación en torno a Literatura Dibujada. 


\section{Síntesis Capítulo 3}

En el desarrollo de este capítulo, hemos estudiado las lecturas de E. A. Vigo en relación a su Biblioteca y a una selección de Escritos Personales donde encontramos las re-escrituras referidas a la historieta. Entre estas re-escrituras, cuatro pertenecen a libros completos y solo una corresponde a selección de artículos. Una sola de ellas, Banda Dibujada y Figuración Narrativa aparece publicada en Hexágono 71'. Por otro lado, en la Selección E, todos los artículos han sido extraídos de periódicos de circulación masiva, generando un nuevo compendio con imágenes recortadas y algunas elaboradas por Vigo. Podemos pensar que, así como Vigo buscaba publicaciones especializadas internacionales para elaborar su repertorio de lecturas sobre vanguardia y poesía experimental, con la selección de artículos sobre historietas pasa lo mismo. El medio del cual Vigo extrae artículos de su interés es el idóneo, en tanto el espacio de mayor circulación del comic es el periódico. Como hemos analizado, hay una gran diferencia entre las apropiaciones vinculadas a la historieta respecto de las que Vigo realiza estudiadas en los Capítulos 1 y 2. La mayoría de las re-escrituras se utilizan a partir de su inserción en las publicaciones y charlas de E. A. Vigo, sin embargo en las historietas herméticas y en Hexágono 71' hay otras operaciones vinculadas al uso de las imágenes y a la composición plástica. Tampoco hemos encontrado registros materiales de charlas de Vigo sobre el comic, pero si diapositivas sobre el tema.

En el análisis de la revista Hexágono 71', hemos considerado las re-escrituras de E. A. Vigo no solo inmersas como presentación de textos en un nuevo dispositivo sino ya como imágenes y composiciones que manifiestan lo leído en la representación de las historietas herméticas. El procedimiento de la apropiación ha generado una modificación sustancial en la estructura de la re-escritura y en los procedimientos creativos que utiliza Vigo. Ya no es necesario visibilizar el texto de referencia, copiandolo, editandolo para posicionarse como conocedor de las últimas tendencias en materia artística; el procedimiento ya es parte de Vigo en tanto deja de utilizar la cita textual para explicar el modo en que otros consideran que es el género sino hacer el género. En Diagonal Cero se citan 28 textos teóricos, de los cuales 17 son extranjeros; en Hexágono 71' ${ }^{125}$ hay un total de 13 textos teóricos, de los cuales seis son extranjeros (Brasil, Canadá, EE UU, Italia, España) y los demás del propio Vigo o autores argentinos. ¿A qué se debe esta

\footnotetext{
125 Remitimos a la matriz de datos sobre la Revista Hexágono 71'realizado por Ana Bugnone (2014) en La revista Hexágono '71: 1971-1975 La Plata, Buenos Aires, Argentina. Biblioteca Orbis Tertius. Universidad Nacional de La Plata; Centro de Arte Experimental Vigo. Disponible en: http://bibliotecaorbistertius.fahce.unlp.edu.ar/09-bugnone
} 
modificación en torno a la incorporación de textos en la publicación? Como hemos visto, Vigo no deja de leer ni de realizar las transcripciones de re-escrituras, el movimiento se dá en la incorporación de experiencias plásticas en la publicación.

En el transcurso de este desarrollo hemos querido indagar las formas en que Vigo opera como editor no solo en sus libros de re-escrituras, donde, como venimos analizando, selecciona un catálogo de artículos de su interés, en muchos casos traducidos por Comas, y los transforma de manera novedosa por las formas de reorganizar esa escritura -así como también en la selección que proyecta para su posterior publicación-, sino también en la práctica del montaje, puesto que aquí la tarea de editor aparece en la elección de las imágenes, en la composición de nuevos sentidos para representaciones ya existentes. 


\section{Conclusiones:}

En la Bienal de Cuenca del año 2014, la artista turca Meric Algün Ringborg, presentó una instalación denominada Biblioteca de libros no leídos compuesta por 470 ejemplares que en los últimos 7 años no habían sido ni pedidos ni prestados en la Biblioteca Juan Bautista Vásquez. Presenciar esta instalación, tan cotidiana en su montaje como biblioteca y sumamente potente en las preguntas que despierta, resuena en mi memoria para estas conclusiones sobre las re-escrituras.

El criterio de selección de Ringborg para aquella biblioteca es la ausencia: de público lector, de huella, de circulación, de afectación. Quizás, en el deseo por dar cuenta de los nuevos modos de lectura, de recolección de información, de tecnologías, la artista elige desenterrar, visibilizar aquellos ejemplares no consultados para hablarnos de las fuentes, del original, de la materialidad. Podríamos pensar que en las páginas que componen esta tesis la hipótesis es la contraria: subyacen aquí preguntas por las formas en que conocemos, en qué lengua, cómo aparece ese conocimiento en la vida de una persona, cómo las lecturas forman parte y construyen la trayectoria artística de un sujeto en particular. La Biblioteca de los libros no leídos es el opuesto a la Biblioteca del Centro de Arte Experimental Vigo, en esta última cada ejemplar se ve afectado y afecta a quien lo lee.

Ringborg en su instalación, cuestiona no solo las maneras contemporáneas en en que se lee sino las formas en que la información circula, los modos en que los medios de comunicación modifican el acceso a la documentación, y también, porque no, las lecturas sintéticas y despolitizadas; por ejemplo, las lecturas que se realizan de Wikipedia sobre El Capital que superan las que se hacen sobre el libro original, generando una lectura sesgada que impediría los procesos de hermenéutica y sentido propio homogeneizando las interpretaciones.

En primer lugar, el abordaje transversal que hemos propuesto en este trabajo de los documentos del Centro de Arte Experimental Vigo permitió lecturas inéditas del fondo puesto que pudimos analizar los cruces y tensiones en la diversidad de este archivo. Vinculamos Archivo Personal (en los relevamientos de Biopsia, los artículos periodísticos), ediciones (WC, Diagonal Cero, Hexágono 71), obra expuesta, Biblioteca y Hemeroteca en relación a la Serie Escritos Personales. Sistematizamos y ordenamos por primera vez en el archivo, no solo las re-escrituras sino también los documentos referidos a charlas y ensayos no publicados de E. A. Vigo así como manuscritos y obras de Elena Comas. 
Mostramos que las re-escrituras son materiales que dan cuenta de procesos previos a las obras mostradas, editadas y que motivan una utilización particular: ya sea como registro, como compendio de conocimientos o bien como pre-texto. En este sentido, hemos intentado leer la biblioteca en clave de huella, como indicio. Partiendo de los libros y re-escrituras, recorriendo la obra de Vigo, analizamos los modos en que la lectura invade la dimensión práctica. Estudiamos los modos en que la información circula, se apropia y configura un repertorio personal en su dimensión poiética.

En segundo lugar, a partir de este trabajo de Tesis, hemos propuesto una nueva Serie dentro del Centro de Arte Experimental Vigo: La Serie Escritos Personales. La misma, como hemos visto, está compuesta por libros de referencia para las re-escrituras, libros intervenidos, re-escrituras, charlas y escritos de Vigo no publicados y manuscritos de Elena Comas.

Analizamos las dificultades metodológicas en torno a la caracterización del concepto de re-escrituras y las decisiones en torno al ordenamiento del material. A partir de un trabajo exhaustivo de investigación pudimos poner en vínculo el Fondo Documental de la Biblioteca de Vigo y la Serie Escritos Personales con las proyecciones que se ponen de manifiesto entre estos documentos y las ediciones y obras de E. A. Vigo, relevando tanto publicaciones como charlas y obras del artista en relación a sus lecturas y re-escrituras.

En la expansión por la pregunta por los dispositivos de escritura y lectura, nos topamos con la dificultad de no encontrar un término que aglutine y logre acercarse con su nombre a estos compendios. Esto llevó a la invención del concepto de re-escritura, con la marca textual del guión y su correspondiente argumentación. Obligó también a considerar las formas en que la crítica utiliza el concepto para establecer una definición propia de estos ejemplares a la que nos acercamos por diferencia. Analizando los usos del archivo y aquella dimensión poiética y creativa de la que habla Bugnone, pudimos vincular este dispositivo de trabajo que denominamos re-escrituras, con otros compendios, como el de Höch y Xul Solar, para acercarnos a modos de estudio, formas heterodoxas de ordenar y disponer de un material que resulta valioso pero permanece en las sombras de lo mostrado. Analizar las re-escrituras permitió pensar la potencialidad del archivo como productor de sentidos a partir de las preguntas que los materiales proponen, sus cruces y tensiones.

Los conceptos desarrollados en la primer parte del trabajo vinculados a repertorio, apropiación, antropofágia y traducción fueron relevantes para los desarrollos de la segunda parte de la tesis, donde se articularon estas operaciones en relación a los procedimientos que Vigo utiliza en su obra expuesta y publicada, como así también con sus charlas. 
Indagamos en la Biblioteca del CAEV, a partir de las temáticas predominantes en las re-escrituras, aquellos ejes que se presentan como insistentes y transversales en la producción mostrada de Vigo. Analizamos lecturas sobre vanguardia, poesía experimental e historieta, organizando esta información mediante cuadros que sistematizan los materiales. Dijimos también, en torno al recorte propuesto, que las re-escrituras comienzan a medidos de la década de 1950, coincidiendo con el encuentro entre Elena Comas y E. A. Vigo en la Escuela Superior de Bellas Artes de la UNLP. El material de las re-escrituras ha contribuido a la visibilización de la figura de Elena Comas, traductora y compañera de Vigo desde 1954, pero también nos lleva a considerar la producción de re-escrituras como un trabajo colaborativo conjunto. Esta acción se pone de manifiesto en el acto de transcrear, tomando, como dijimos, el término de Haroldo De Campos, que invade las re-escrituras. Trabajamos en el apartado dedicado a Elena Comas sus traducciones, manuscritos y pinturas de la década de 1950, así como la importancia de sus traducciones para configuración de la Exposición Internacional de Novísima Poesía/69 plasmada en el catálogo de la muestra.

En la segunda parte del trabajo analizamos en tres capítulos las temáticas predominantes en las re-escrituras. Realizamos un recorte de libros sobre vanguardia, poesía experimental e historietas afirmando que es posible encontrar en las re-escrituras claves para reflexionar sobre un programa de conocimiento, donde no hay improvisación sino compromiso con el saber.

En el Capítulo 1, mostramos que la revisión por parte de Vigo de los procedimientos de las vanguardias históricas plasmado tanto en sus lecturas como en sus re-escrituras, permitió la apropiación de algunas particularidades del discurso duchampeano a partir del conocimiento preciso que Vigo tempranamente posee sobre la obra del artista francés. Analizamos tres (in) objetos donde establecimos cruces entre los postulados de Duchamp y la obra de Vigo.

Señalamos que las re-escrituras que analizamos en este primer capítulo son las más disruptivas estéticamente en lo que respecta al diseño de los bloques textuales y la edición, en concordancia con sus propios escritos y ensayos hacia la misma época. Identificamos estas composiciones como circuitos y máquinas donde se indaga en la potencialidad del espacio en vínculo con la palabra. En torno a la difusión que Vigo le otorga a estas primeras re-escrituras analizamos las publicaciones WC y Diagonal Cero, en su primera época. Identificamos que las voces de las re-escrituras se filtran de manera fragmentaria en las publicaciones a partir de "Testimonios".

En el Capítulo 2, analizamos la poesía experimental en función de charlas y ensayos (Panorama, Continuidad), la segunda época de Diagonal Cero y la Exposición Internacional de 
Novísima Poesía vinculando estos materiales con la Selección D de re-escrituras. La incidencia que sobre el viraje de Diagonal Cero poseen los intercambios con publicaciones extranjeras y sobre todo la poesía brasileña, tanto concretos como poema-proceso. La noción de repertorio sirvió en este sentido para identificar qué lecturas y re-escrituras posibilitaron una modificación en el perfil de la publicación y en las conceptualizaciones que Vigo realiza sobre la poesía y la participación del espectador. Detalladamente, a partir de los relevamientos realizados en el archivo, nos adentramos en la Exposición organizada por E. A. Vigo en 1969, en las tres secciones que conformaron la muestra Novísima Poesía, mostrando la importancia que se le otorga a las lecturas en esta exposición. Estas lecturas se comparten el catálogo, en la Sección 1 y en la Sección 3, dedicada a la poesía fonética, puesto que, como analizamos oportunamente, la mayoría de las obras presentes en las audiciones han sido extraídas del libro-disco $O U$ de Henri Chopin.

En el Capítulo 3, estudiamos las re-escrituras sobre historieta y las modificaciones en torno a la noción de apropiación. Si en la mayoría de los casos anteriores la apropiación de las re-escrituras se da mediante la inserción de las mismas en distintos órganos de difusión, con el fin de mostrar determinada experticia en el campo artístico, las historietas herméticas incorporan otra dimensión al concepto de apropiación en la obra de Vigo. En las historietas, la deglución antropofágica se produce a partir de la elaboración de una obra plástica donde la lectura vibra en forma de cita o alusión. Analizamos las historietas en Hexágono 71' y la inserción de determinadas imágenes provenientes de otras publicaciones lo que genera nuevos sentidos para composiciones ya existentes, por ejemplo en el caso de las imágenes tomadas de Literatura Dibujada. Destacamos la diferencia fundamental entre la apropiación por parte de Vigo de textos, donde la cita de autoridad tiene un papel fundamental y la apropiación de imágenes donde no se menciona la autoría.

Hemos comprobado que la intención formativa le permite a Vigo posicionarse como sujeto conocedor, resguardando en su afán archivístico, no solo el registro de sus pasos artísticos en Biopsia, sino también sus propios recorridos de lectura. Así, pudimos corroborar lo que se presentaba como primer hipótesis de trabajo, donde sosteníamos que las re-escrituras inciden en la producción plástica y editorial del artista dando cuenta de modos particulares de lectura y escritura en la apropiación del conocimiento.

Los acercamientos propuestos a las categorías de apropiación y repertorio permitieron analizar la producción de Vigo con relación a las re-escrituras. Las maneras en que, a partir de determinados intereses, se generan compendios de conocimiento, en muchos casos traduciendo de manera 
pionera textos inéditos al español, posibilitando cruces teóricos, acercando a los lectores en forma de fragmentos y citas las propias lecturas que el artista consume y considera valiosas. En torno a la segunda y tercera hipótesis de trabajo, entendemos que el análisis de las tres temáticas predominantes en el corpus permitió leer la producción expuesta de Vigo en diálogo con sus lecturas, nos referimos al análisis presentado tanto en proyectos editoriales, de gestión, charlas y una selección de artículos periodísticos de su autoría. En el análisis de la obra de Duchamp, por ejemplo, recorrimos el conocimiento preciso que sobre el artista poseía Vigo, los aspectos conceptuales de los cuales se apropia en sus obras. En relación con las selecciones de artículos de re-escrituras, analizamos compendios que refieren a las tres temáticas predominantes, haciendo referencia en cada caso a: procedimientos estéticos y compositivos; migración en torno al repertorio de autores cuando se estabiliza la re-escritura en la publicación, la utilización de las re-escrituras en textos teóricos, catálogos y charlas en el caso de la Novísima Poesía; reformulación y apropiación en el caso de las historietas.

Algunas líneas de investigación que se abren a partir de este trabajo podrían ser la continuación del rastreo de re-escrituras en las publicaciones, charlas y obras de E. A. Vigo, puesto que en este trabajo hemos realizado una selección de estos compendios de lecturas operativos para nuestra hipótesis. La indagación en la biblioteca de Arte Correo y en la biblioteca de Xilografía también son espacios para continuar trabajando en torno a las lecturas de E. A. Vigo. Hemos trabajado en esta tesis algunos artículos periodísticos elaborados por E. A. Vigo pero no trabajamos con la totalidad de los textos que escribe y publica en los periódicos de la época por lo que este relevamiento podría ser otra temática para profundizar dentro del CAEV.

Por último, hacer referencia al Centro de Arte Experimental Vigo y la política que éste lleva adelante en torno a la organicidad del Archivo. Como ha señalado Ana María Gualtieri, parte de la mística de este espacio radica en los cruces entre materiales, en su forma de red. Serían muy diferentes las posibilidades de investigación si los materiales de Vigo, y de tantos otros artistas que el Centro de Arte Experimental conserva, se encontraran dispersos en otras instituciones o, como ha sucedido recientemente con el archivo de Juan Carlos Romero, subastado a capitales extranjeros. Por esto mismo, reconocer el trabajo de custodia del Centro de Arte Experimental Vigo que ha permitido con su política orgánica, despertar las preguntas de esta investigación. 


\section{BIBLIOGRAFÍA}

\section{A- BIBLIOGRAFÍA TEÓRICA GENERAL:}

Agamben, G. (2015). ¿Qué es un dispositivo?. Barcelona: Anagrama.

Aguilar, G. (2003). Poesía concreta brasileña. Rosario: Beatriz Viterbo.

Aguilar, G. (2015). Augusto de Campos: La traducción del nombre. Revista Qorpus, Universidade Federal de Santa Catarina, $N^{\circ} 16$.

Altamirano C. y Sarlo B. (1997). Ensayos Argentinos. Buenos Aires: Ariel.

Álvarez Marín, R. (1991). “El circuito marginal. La vivificación del verdadero arte”. En Helft, J. (Ed.). Anteproyecto de proyecto de un pretendido panorama abarcativo. Buenos Aires: Fundación San Telmo.

Andrade, O. (1928). Manifiesto Antropófago. Brasil: Revista de Antropofagia, Año 1, № 1.

Artundo, P. M. (2005). "Papeles de trabajo. Introducción a una exposición retrospectiva de Xul Solar" en Xul Solar Visiones y Revelaciones, Fundación Eduardo Costantini, La Stampa Editorial, Buenos Aires, Junio. P. 21 - 22.

Artundo, P. M. (organiz.) (2006). Alejandro Xul Solar Entrevistas, artículos y textos inéditos. Buenos Aires: Corregidor.

Aumont, J. (1992). La Imagen. Barcelona, España: Paidós.

Barreiro López P. y León A. M. (2015). Modernidad y vanguardia: rutas de intercambio entre España y Latinoamérica (1920-1970) Madrid: Museo Nacional Centro de Arte Reina Sofía.

Benjamin, W. (2004). Libro de los Pasajes [Edición De Rolf Tiedemann], Madrid: Akal.

Berone, L. (2007). "De la historieta en la literatura popular: negaciones, determinaciones, segmentaciones, filiaciones" V Jornadas de Encuentro Interdisciplinario "Las ciencias sociales y humanas en Córdoba" (Universidad Nacional de Córdoba).

Berone, L. (2009). El discurso sobre la historieta en Argentina (1968-1983) Revista Académica de la Federación Latinoamericana de Facultades de Comunicación Social.

Borges, J. L.(1994). Ficciones. Buenos Aires: Emecé.

Borges, J. L. (1997). Discusión. Madrid, España: Alianza.

Bourdieu, P. (2010). El sentido social del gusto. Buenos Aires: Siglo XX.

Bourriaud, N. (2007). Postproducción. Buenos Aires: Adriana Hidalgo, 
Bourriaud, N. (2008). Estética relacional. Buenos Aires: Adriana Hidalgo.

Brea, J. (1996). Un ruido secreto el arte en la era póstuma de la cultura. Murcia, España: Mestizo.

Buchloh (2004). Formalismo e Historicidad. Madrid, España: Akal.

Bürger, P. [1987] (2010). Teoría de la Vanguardia. Buenos Aires: Ed. Las Cuarenta.

Byung-Chul Han (2016). Shanzhai: el arte de la falsificación y la deconstrucción en China. Buenos Aires: Caja Negra.

Cabanne, P. (1984). Conversaciones con Marcel Duchamp. España: Anagrama.

Castro, M. V. (2017). "Literatura Dibujada: el desafío de comprometer la historieta", en Américalee. El portal de publicaciones latinoamericanas del siglo XX. ISSN: 2545-823X. Disponible en: $<$ www.americalee.cedinci.org $>$ Consultado 21 Agosto 2017.

Castro, M. V. y Sik, M. E. (Coomp.) (2018). Actas de las II Jornadas de discusión / I Congreso Internacional. Los archivos personales: prácticas archivísticas, problemas metodológicos y usos historiográficos Buenos Aires: CeDInCI. Disponible: http://www.cedinci.org/pdf/jornadas/Actas-Archivos-Personales.pdf. Consultado 12 de marzo 2018 .

Cipolini, R. (2003). Manifiestos Argentinos Politicas de lo visual 1900 - 2000. Buenos Aires: Adriana Hidalgo.

Cirne, M. (1970). Bum! a explosão criativa dos quadrinhos. Rio de Janeiro: Brasil Vozes.

Cirne, M. (1971). A linguagem dos Quadrinhos Rio de Janeiro: Brasil Vozes.

Cirne, M. (1972). Para ler os quadrinhos Rio de Janeiro: Brasil Vozes.

Cirne, M. (1975). Vanguardia, um projecto semiológico. Rio de Janeiro: Brasil Vozes.

Cisneros, M. (2000). Según decimos en criollo. Río Cuarto, Córdoba: Editorial UNRC.

Coma, J. (1984). El ocaso de los héroes en los cómics de autor. Barcelona, España: Península.

Cornejo Polar, A. (1977). «El indigenismo y las literaturas heterogéneas: su doble estatuto sociocultural». Revista de Crítica Literaria Latinoamericana 7-8, 7-21.

Cortázar, Julio. (1967). La vuelta al Día en ochenta mundos. Madrid, España: Siglo XXI.

De Campos, H. (2000). De la razón antropofágica. España: Siglo XXI.

De Campos, H. (2004). Brasil transamericano. Buenos Aires: Cuenco de plata. 
De Sá, A. (1967). Poemics 12x9. Brasil. Edición de Autor.

De Sá, A. (1975). Vanguarda produto de comunicação. Rio de Janeiro. Brasil: Vozes.

Deleuze, G. “¿Qué es un dispositivo?”, en Dos regímenes de locos. Textos y entrevistas (1975-1995), trad. José Pardo, Valencia, Pre-Textos, 2007, p. 305

Deleuze G. Y Guattari F. (1985). El Anti Edipo Capitalismo y esquizofrenia. Paidos. España.

Derrida J. (1971). Firma, acontecimiento, contexto. Comunicación en el Congreso Internacional de Sociedades de Filosofía de lengua francesa (Montreal, 1971). «La comunicación». Traducción de C. González Marín.

Derrida J. (1995). Archivo y Borrador Mesa Redonda del 17 de junio, 1995 en Pourquoi la critique génétique? Méthodes, théories. Paris, CNRS Éditions, 1998; 189-209 (Traducción de Anabela Viollaz)

Derrida J. (1997). Mal de Archivo Ed. Trotta: Madrid.

Dorfman, A. y Mattelart A. (2005). Para leer al Pato Donald. Buenos Aires. Siglo XXI.

Dubatti, J. (2017). Teatro-matriz y teatro liminal. La liminalidad constitutiva del acontecimiento teatral. Revista Conjunto Casa de las Américas. № 185. Oct. Diciembre 2017

Duchamp, M. (1995). Duchamp Barcelona: Polígrafa.

Duchamp, M. (2008). Una obra que no es una obra de Arte Fundación Proa. Buenos Aires.

Eco, U. (1968). Apocalípticos e Integrados. España: Lumen.

Eco, U. (1992). Los límites de la interpretación. Barcelona: Lumen.

Errata $\mathrm{n}^{\circ}$ 1. Arte y Archivos. Abril 2010. Colombia.

Especificaciones Técnicas Símbolos gráficos para esquemas Eléctricos. (2019) recuperado de: https://www.epec.com.ar/docs/educativo/normasT/ET20.PDF

Fernández Mallo, A. (2009). Postpoesía. España: Anagrama.

Fernández Moreno, C. (1960). Introducción a Macedonio Fernández. Buenos Aires, Argentina: Talía.

Fernández, M. (1961). Borges, Macedonio Fernández. Buenos Aires: Ministerio De Educación,

Fernández, M. (1964). Papeles de Macedonio Fernández. Buenos Aires: Editorial Universitaria. 
Fernández, M. (1966). Papeles de Macedonio Fernández. Poemas. Buenos Aires: CEAL.

Fernández, M. (1967). No toda es vigilia la de los ojos abiertos. Buenos Aires: CEAL.

Fernández, M. (1972). Cuadernos de todo y nada. Buenos Aires: Corregidor.

Fernández, M. (1977). No toda es vigilia la de los ojos abiertos. Buenos Aires, Argentina: CEAL.

Fernández, M. (1989). Obras Completas tomo IV. Papeles de recienvenido y Continuación de la nada. Buenos Aires: Corregidor.

Ferreira Soares, M. Arte e Política No Brasil - Os Anos 1960: Questões De Arte E Participação Social. Disponible:

Https://Periodicos.Ufpe.Br/Revistas/Revsocio/Article/View/235218

Fleisner P. y Lucero G. (2014). El situacionismo y sus derivas actuales. Buenos Aires:

Prometeo.

Foucault, M (2005). El Orden Del Discurso. Buenos Aires: Tusquets.

Foucault, M (1999). Estética, ética y hermenéutica. España: Paidós.

Foucault, M (1993). Esto no es una pipa España: Anagrama.

Foucault, M. (1998). ¿Qué es un autor?. Córdoba: Revista Litoral N²5/26

Foucault, M (2012). Arqueología del saber. Buenos Aires: Siglo XXI.

Garbatzky, I. (2014). El archivo como productor: el lugar del uso en el deseo nace del derrumbe, de Roberto Jacoby En Revista Anos 90 - Revista Do Programa De Pós-Graduação Em História Da Universidade Federal Do Rio Grande Do Sul. N 40

García G. (Coomp) (1968). Hablan De Macedonio Fernández, Buenos Aires, Carlos Pérez Editor.

Garramuño F. (2016). Todos Somos Antropófagos. Sobrevivencias de una vocación internacionalista En La Cultura Brasileña. Cuaderno 60, Centro De Estudios En Diseño Y Comunicación. Up.

Gerbaudo, A. (2013). “Archivos, Literatura Y Políticas De La Exhumación”, En Palabras De Archivo. Santa Fe: Ediciones Unl- Crla, Pp. 57-86.

Giunta, A. (2008). Vanguardia Internacionalismo Y Política. Buenos Aires: Siglo XXI. 
Giunta, A. (2013). Adiós a la periferia: Vanguardias y Neovanguardias en el arte de América Latina; V. Tell; Blanco Sobre Blanco; 5; 8-2013; 9-20

Glusberg, J. (1978). Retórica Del Arte Latinoamericano. Buenos Aires: Nueva Visión.

Goldchluk, G. (2013). “Nuevos Domicilios Para Los Archivos De Siempre: El Caso De Los Archivos Digitales", Palabras De Archivo, Santa Fe, Ediciones UNL- CRLA, Pp. 33-56.

Goldsmith K. (2015). Escritura No-Creativa. Buenos Aires: Caja Negra.

Gómez De La Serna R. (1943). Ismos. Buenos Aires: Poseidón.

Gonzáles H. (et al.). (2014). Manuscritos Literarios Argentinos. Buenos Aires, Argentina. Biblioteca Nacional. Sala Leopoldo Marechal.

Goudel, F. R. (2008). "Conceito Antropofagia: Vanguarda E Proliferação.". Revista Da Pesquisa, 3 (1).

Gramuglio M. T. (2013). Nacionalismo y Cosmopolitismo. Rosario, Argentina: EMR.

Groys, B. (2014). Volverse Público. Buenos Aires: Caja Negra.

Guasch, A. M. (2011). Arte y Archivo 1920-2010. Madrid, España: Akal.

Herrera, M. J. (2013). Catálogo Arte de Sistemas 1969-1977. Fundación OSDE. Buenos Aires. Recuperado de: https://www.fundacionosde.com.ar/backend/upload/files/img_\$271.pdf

Hernández, E., Fernández F. y Baptista P. (2010). Metodología De La Investigación. México: Ed. Mcgraw-Hill.

Hutcheon L. (1993). La politica de la parodia postmoderna Criterios, La Habana, Edición especial de homenaje a Bajtín, Julio 1993, Pp. 187-203.

Jitrik, N. (Ed). (2007). Macedonio: Historia crítica de la Literatura Argentina (Tomo 8) Buenos Aires: Emecé.

Krauss, R. (1993). La Originalidad De La Vanguardia: Una Repetición Postmoderna. En Arte después de la Modernidad, Madrid, España: Akal.

Lafleur, H., Provenzano, S. y Alonso, F. (1968). Las Revistas Literarias Argentinas. Buenos Aires, Argentina: Centro Editor De América Latina.

Laiseca, A. (2013). Por Favor ;Plágienme! Buenos Aires: Eudeba.

Lamborghini L. (2016) El Genio De Nuestra Raza. Las Reescrituras. Buenos Aires. Mansalva.

Lebel R. (1959). Marcel Duchamp. Francia: Trianon. 
López Pascual, J. (2009). Trincheras: El Campo Cultural En Bahía Blanca, Entre 1963 y 1968. (Tesis De Licenciatura). Universidad Nacional Del Sur. Departamento De Humanidades, Bahía Blanca, Argentina.

Ludmer, J. (2007). “Sobre el plagio” Página/12. Edición electrónica del 27/05/2007:

http://www.pagina12.com.ar/diario/suplementos/radar/subnotas/3843-615-2007-05-27.html

Mane, G. (1988). Marcel Duchamp. Barcelona, España: Polígrafa.

Masotta, O. (1970). La historieta en el mundo moderno. España: Paidós.

Métraux, A. (2011). Antropofagia y cultura. Buenos Aires: El Cuenco De Plata.

Muñoz, M. A. (et al.) (2008). Los artistas del Pueblo Catálogo Malba - Fundación OSDE. Del 10 de abril al 31 de mayo de 2008.

Mignolo, W. (1991). Los Cánones y (más allá de) las fronteras culturales (o ¿de quién es el canon del que hablamos?). En El Canon Literario, E. Sullá (Ed.), 237-270. Madrid:

Arco-Libros, 1998.

Mink, J. (1994). Duchamp. Alemania: Taschen.

Padin, C. (2006). Catálogo Clemente Padín. Montevideo, Uruguay. Banco Central del Uruguay

Paz, O. (1971). Traducción: Literatura y Literalidad. Barcelona, España: Tusquets.

Paz, O. (1973). Apariencia Desnuda. La Obra De Marcel Duchamp. México: Ediciones Era.

Paz, O. y Duchamp M. (1968). Octavio Paz, Marcel Duchamp Ediciones Era: México.

Perednik, J. S., Doctorovich F. y Estévez C. (2016). El Punto Ciego. Antología De La Poesía Visual Argentina De 7000 A.C. Al Tercer Milenio / The Blind Spot. Visual Poetry From Argentina. San Diego: San Diego State University Press.

Pérez, J.P; Ilia C. y Lina L. (2006). Lecturas Problemas y discusiones del arte argentino del último siglo 1910-2010. Buenos Aires: CCC, FNA.

Perromat, K. (2010). El plagio en las literaturas hispánicas: Historia, Teoría y Práctica. Tesis doctoral. París: Université Paris-Sorbonne - Paris IV, 2010. Versión electrónica:

http://www.esorbonne.fr/theses/el-plagio-las-literaturashispanicas-historia-teoria-practica.

Perromat, K. (2014). "Literatura y Plagio en Argentina: formas rentables y no rentables de quebrar los valores del mercado". Cuadernos Del Cilha, Vol. 5. N. 2.

Pettoruti, E. (1968). Un pintor ante el espejo. Buenos Aires: Solar.

Piglia, R. (2016). Las Tres Vanguardias. Saer, Puig, Walsh. Buenos Aires: Eterna Cadencia. 
Porrúa, A. (2001). Variaciones Vanguardistas. La poética de Leónidas Lamborghini Rosario, Argentina: Beatriz Viterbo.

Prada, J. M. (2001). La apropiación postmoderna. Madrid: Fundamentos.

Queneau R.; Perec, J. y Calvino I. (2016). Oulipo. Buenos Aires, Argentina: Caja Negra.

Rama A. (1982). Los gauchipolíticos rioplatenses. Bueno Aires: CEAL.

Ramírez, J. A. (1994). Duchamp, el amor y la muerte incluso. España: Siruela.

Régimen Legal De La Propiedad Intelectual (Ley 11.723)

Ribeiro, M. (1998). Arte E Política No Brasil: A Atuação Das Neovanguardas Nos Anos 60. En Fabris, A. (Org.). Arte \& Política-Algumas Possibilidades De Leitura. Belo Horizonte: C/Arte.

Ríos, C. (2017). Un Shock Póstumo. Rosario, Argentina: EMR.

Rivera, J. (1992). Panorama De La Historieta En La Argentina. Buenos Aires: Libros Del Quirquincho.

Roca, M. C. (2009). Arte, modernización y Guerra Fría. Las Bienales de Córdoba en los sesenta. Córdoba: Editorial UNC.

Romero, J. C. Davis F. y Longoni, A. (2010). Romero, Fundación Espigas. Buenos Aires.

Rolnik, S. (2006). Antropofagia Zombie, Madrid. Brumaria $\mathrm{N}^{\circ} 7$.

Ríos, P. (2008). La importancia de la organización y conservación de un Archivo Personal. Revista Universidad De Sonora, (23), pp. 52-55.

Ruiz Olabuenaga J. (2012) Metodología De La Investigación Cualitativa. Bilbao, España: Deusto.

San Signos: Xul Solar y El I Ching. (2012). Buenos Aires: El Hilo De Ariadna.

Sarmiento, J. A. (et al.) (2009). Catálogo. Escrituras en Libertad, poesía experimental Española e hispanoamericana del siglo XX. Madrid, España: Ed. Instituto Cervantes.

Sánchez Noriega, J. L. (2000). De la literatura al cine. Teoría y análisis de la adaptación. Barcelona, España: Paidós.

Sierra, M (2005). "Máquinas, ficciones y sociedades secretas: Caterva y la Ciudad Ausente" en 
Revista Iberoamericana Volumen XXI Número 211 Abril- Junio 2005. Pp.521- 537.

Schartz, A. (1968). Marcel Duchamp. Italia: Fratelli Fabri Editori.

Schavelzon D. (2009). Arte y falsificación en América Latina. Buenos Aires: Fondo De Cultura Económica.

Schwartz, J. (2002). Las Vanguardias Latinoamericanas. México. Fondo De Cultura Económica.

Scott, R. (1970). Fundamentos Del Diseño Buenos Aires: Victor Leru.

Szurmuk M. y Mckee Irwin R. (Coomp.). (2009). Diccionario de estudios culturales latinoamericanos. México: Siglo XXI.

Trillo C. y Saccomanno G. (1980). Historia De La Historieta Argentina. Buenos Aires. Record.

Turnes, P. (2011). Viñetas Subversivas. La experiencia estética de la historieta en Alack Sinner (1975 - 1986) De José Muñoz y Carlos Sampayo. Tesis de Maestría. Universidad Nacional De San Martín. Buenos Aires.

Vázquez, L. (2011). Historieta, Cultura de Masas y Política. Herramientas de la red de historia de los medios $\mathrm{N}^{\circ} 6$.

Vera Barros, T. (coomp) (2014). Escrituras Objeto. Buenos Aires. Asunto Impreso. Wolf, S. (2001) Cine/Literatura. Ritos de pasajes. Buenos Aires. Paidós

\section{B- BIBLIOGRAFÍA SOBRE E. A. VIGO Y SU OBRA.}

Barisone, O. (2012). Vigo y la Expo Internacional Novísima Poesía/69 (CAV-ITDT, 1969) como materialización del intercambio. Posibilidades del concretismo. Actas VIII Congreso Internacional de Teoría y Crítica Literaria Orbis Tertius. Facultad de Humanidades y Ciencias de la Educación Universidad Nacional de La Plata.

Barisone, O. (2017). Experimentos Poéticos Opacos. Buenos Aires: Corregidor.

Basualdo, C. (1994). " "Prólogo a la Novela de Vigo". En Helft, J. (Ed.). Argentina. XXII Bienal Internacional de São Paulo. Buenos Aires: Fundación Banco Crédito Argentino.

Bugnone A. (2012). Poesía descentrada en los sesenta: El 'Grupo de los Elefantes'. Boletín de Arte; año 13, n 13. UNLP. (En línea). 
Bugnone A. (2013 a). Archivo y Vanguardia VI Jornadas Internacionales de Filología y Lingüística y Primeras de Crítica Genética "Las lenguas del archivo" La Plata, 7 a 9 de agosto.

Bugnone A. (2013 b). Una articulación de arte y política: Dislocaciones y rupturas en la poética de Edgardo Antonio Vigo (1968-1975) Tesis Doctoral. Universidad Nacional de La Plata Facultad de Humanidades y Ciencias de la Educación.

Bugnone A. (2014). La revista Hexágono '71: 1971-1975 La Plata, Buenos Aires, Argentina. Biblioteca Orbis Tertius. Universidad Nacional de La Plata; Centro de Arte Experimental Vigo.

Bugnone A. (2017). Vigo: Arte politica y vanguardia. La Plata, Argentina: Malisia.

Bugnone, A. (2018). Hacia el paradigma del archivo de artistas y escritores. Escritural. Écritures d'Amérique latine (en prensa).

Bugnone A. L. Santamaría, M. (2016). La política de democratización del archivo: el caso del Centro de Arte Experimental Vigo en Actas del I Congreso Internacional de la Asociación Argentina de Humanidades Digitales - AAHD.

Courtis A. y Lamilla J. (2018). Vigo y el Arte Sonoro Conferencia con Escuchas del Archivo Audiovigoteca del Centro de Arte Experimental Vigo, Untref. Simposio Internacional de Arte Sonoro. Actas web:

https://untref.edu.ar/uploads/resumenes_de_ponencias-mundos_sonoros.pdf.

Davis, F. (2006). Poéticas oblicuas. Diagonal Cero y la poesía "para y/o a realizar” en Edgardo Antonio Vigo (1962-1970) II Jornadas de Investigación en Disciplinas Artísticas y Proyectuales. La Plata FBA, UNLP.

Davis, F. (2007). Señalar y revulsionar. Edgardo Antonio Vigo en los márgenes de la poesía. Publicado en V Jornadas sobre Arte y Arquitectura en Argentina (La Plata, Instituto de Historia del Arte Argentino y Americano, FBA-UNLP)

Davis, F. (2012). Luis Pazos, fabricante de modos de vida. Acciones, cuerpo, poesía. Buenos Aires, Argentina. Document-art.

Davis F. y Romero J. C. (2016). Catálogo Poéticas Oblicuas, Fundación OSDE, Buenos Aires, Argentina.

De Rueda M. A. (Coomp). (2003). Arte y Utopía. Asunto Impreso. Buenos Aires, Argentina

De Rueda M. A. (2007). Preludio a la avanzada artística en La Plata 2: E. A. Vigo Vanguardia y reacción en III Jornadas de Investigación en Disciplinas Artísticas y Proyectuales. Facultad de Bellas Artes. Universidad Nacional de La Plata. 
De Rueda M. A. (2008). El campo artístico visual en La Plata (1958-1968). Pp 88-90.

Revista: Arte e Investigación; año 12, nº 6 . FBA, UNLP.

De Rueda M. A. (2010). Las artes visuales en La Plata Un recorrido por los años 70 y 80 Boletín de Arte; año 11, no. 12. FBA, UNLP.

Dolinko, S. (2012). Edgardo Antonio Vigo, vanguardia y contracultura en los años sesenta Pós: Belo Horizonte, v. 2, n. 4, p. 98 - 113, nov. 2012. (101-114) Recuperado de:

file://C:/Users/Administrador/Desktop/Downloads/54-75-2-PB.pdf . Consultado: 16 de mayo 2018 .

Gradowczyk M. (2008). Maquinaciones. Edgardo Antonio Vigo: Trabajos 1953-1962. Catálogo CCEBA, Argentina.

Gustavino, B. (2014). La escritura sobre arte en argentina en los años sesenta. La crisis de las referencias extranjeras y la extensión de la perspectiva latinoamericana. Tesis Doctoral (UNLP, Université Rennes 2-Ueb)

Gustavino, B. (2015). Relatos sobre el arte moderno en las bibliotecas argentinas. Pistas halladas en el archivo y la biblioteca Antonio Vigo En História da arte: coleções, arquivos e narrativas Urutau Ltda. Brasil.

Gustavino, B. (coomp) Paula La Rocca ... (et al.) (2019). Órbita Vigo: Trayectorias y Proyecciones. Universidad Nacional De La Plata. Facultad De Bellas Artes.

Gutiérrez Marx, G. (2002). "Un Teorema No Formulado = La Marca De Vigo”. En A. M. Gualtieri (Ed.). Record-Ando A Vigo. Buenos Aires: Fondo Nacional De Las Artes - Espacio Ojo Al País.

Nessi, Á. (1994). “Edgardo-Antonio Vigo. Cuarenta Años De (In) Obras De Arte”. En 1954 1994. Edgardo-Antonio Vigo. La Plata: Argentina. Fundación Artes Visuales.

Noorthoorn, V. (et al.) (2016). Edgardo Antonio Vigo Usina permanente de caos creativo obras 1953-1997, Museo de Arte Moderno de Buenos Aires.

Padin, C. (1997). Edgardo Antonio Vigo: Vocación Libertaria, Montevideo, Uruguay. Recuperado De: Http:/Www.Merzmail.Net/Edgardo.Htm. Consultado 16 Mayo 2018.

Pérez, Balbi M. (2008). Movimiento Diagonal Cero: Poesía Experimental Desde La Plata (1966-1969) Recuperado De: Http://Sedici.Unlp.Edu.Ar/Handle/10915/46011.

Pérez, Balbi M. (2010). Poesía experimental desde la plata. Crónica del movimiento Diagonal Cero (1966-1969) Boletín De Arte; Año 11, No. 12. Facultad De Bellas Artes, UNLP. Disponible: Http://Sedici.Unlp.Edu.Ar/Handle/10915/18593. Consultado 11-3-17. 
Pérez Balbi, M. y Santamaría, M. (2008). Vigo (In)édito nuevos relevamientos e investigaciones en el Archivo Vigo. En: VI Jornadas Nacionales De Arte En Argentina, Facultad De Bellas Artes. UNLP.

Santamaría, M y Parodi, A. P. (2005). Índice de señalamientos de Edgardo A. Vigo. CAEV. Disponible en: http://sedici.unlp.edu.ar/handle/10915/46574.

Zabala, H. (1987). " 'Las Obras De Edgardo-Antonio Vigo: Transgresión, Irregularidad, Incertidumbre”. En E. Vigo (Ed.). Off; Off... La Plata: Fundación Artes Visuales.

\section{C- PUBLICACIONES CONSULTADAS:}

\section{1 EDITADAS POR E. A. VIGO.}

Revista $D R K W$. A, B, C. 1960.

Revista $W C .1,2,3,4,5.1958$ - 1960

Revista Diagonal Cero. (28 números), 1 al 28, 1962 - 1968.

Revista Museo n 7 . Bahía Blanca.

Revista Hexágono 71'.(13 números), a al e, 1971 - 1975.

Nuestro Libro Internacional de Estampillas y Matasellos. (20 números), 1 al 20, 1979-1993.

\section{C.2. DE LA HEMEROTECA DE E. A. VIGO.}

Revista Skorpio,

Revista Dennis Martin,

Revista Cabo Savino,

Revista Tit-Bits,

Revista El Tony,

Revista Nippur de Lagash,

Revista Fantasía,

Revista D'artagnan,

Revista Pif-Paf,

Revista Corto Maltes,

Revista Hum ${ }^{\circledR}$,

Revista Revista Superhumor,

Revista Bumerang,

Revista Blue Jeans,

Revista Intervalo Extra,

Revista Maléfico,

Revista Chaupinela,

Revista Fierro.

Revista Literatura Dibujada,

Revista Les Letters, 
Revista Phantomas,

Revista Los huevos de Plata

Revista OVUM 10,

Revista Approches,

Revista Doc(k)s,

Revista OU,

Revista Phatomas.

\section{3. PUBLICACIONES DE E. A. VIGO EN PERIÓDICOS.}

Vigo, E. (1959). Máquinas Inútiles. Solteras imposibles. "El argentino"

Vigo, E. (1966). Hacia un arte del objeto. "La Tribuna".

Vigo, E. (1968). Madi Kosice I. "El Día"

Vigo, E. (1968). Hidro Kosice II. "El Día"

Vigo, E. (1968). Punto y espacio en Badii. "El Día"

Vigo, E. (1968). Experiencias 68 en el Di Tella. "El Día"

Vigo, E. (1968). Mi lunática hija libro de Jorge D'Elia. "El Día"

Vigo, E. (1968). Hacia el interior de la Luz. "El Día"

Vigo, E. (1968). La pureza de Lido Iacopetti. "El Día"

Vigo, E. (1968). La calidez de un taller. "El Día"

Vigo, E. (1968). La búsqueda del ser. "El Día"

Vigo, E. (1968). Con las valijas en la mano. "El Día"

Vigo, E. (1968). A manera del Caracol. "El Día"

Vigo, E. (1968). Fontana: agujerear el cielo. "El Día"

Vigo, E. (1968). La revolución en el arte. "El Día"

Vigo, E. (1968). Mitos Plásticos. "El Día"

Vigo, E. (1968). El gran Vidrio. "El Día".

\section{4. EXPOSICIÓN INTERNACIONAL NOVÍSIMA POESÍA/69".}

Carriere del Giorno (21/1/1969). "L' "expo internacional" di Buenos Aires" 
Carriere del Giorno (22/1/69). "La poesía oggetto di Edgardo Antonio Vigo"

Primera Plana (21/1/1969). "El fin del comienzo".

La tribuna (11/03/1969). "Exposición Internacional de poesía”.

El Día (16/03/1969). "Donde mueren las palabras".

Análisis (18/3/1969). " Estalló la revolución en poesía”.

Clarín (20/3/1969). "Exposición Internacional Novísima Poesía 69””.

La Nación (22/3/1969). "Poesía, a pesar de todo".

Los Andes (23/3/1969). "Expo de novísima poesía”.

La Capital (23/3/1969). “Caducidad de la 'Novísima Poesía 1969’”.

Esquiu (30/3/1969). "La poesía de patear una lata y escuchar ruidos".

Análisis (7/4/1969). "Voces y avioncitos".

El Día (13/04/1969). "La poesía loca".

El Diario (22/4/1969). "Maestría en el impacto".

Jornal do Escritor (octubre 1969). "Poesía de vanguardia na Argentina".

Catálogo Exposición Internacional Novísima Poesía 69’. Buenos Aires: ITDT

Catálogo Exposición Internacional Novísima Poesía 69. La Plata: Museo Provincial de Bellas Artes.

\section{D- TEXTOS PUBLICADOS DE E. A. VIGO.}

Vigo, E. (1969) A manera de introducción a los Poema Session. CAEV.

Vigo, E. (1970). De la poesía/proceso a la poesía para y/o a realizar. La Plata: Diagonal Cero.

Vigo, E. (1992) Continuidad de lo Discontinuo. En Marcha. 


\section{E- ENTREVISTAS CITADAS:}

Nessi, Á. (1994). "Edgardo-Antonio Vigo. Cuarenta años de (in) obras de arte" [entrevista a Edgardo Vigo]. En 1954 - 1994. Edgardo-Antonio Vigo. La Plata: Fundación Artes Visuales. (manuscrito y edición)

Entrevista a Vigo realizada por Mónica Curell, 1995. CAEV.

Entrevista a Ana María Guatieri, 2017. (inédita)

Entrevista a Luis Pazos, 2018. (Mariana Fuks y Julia Cisneros)

Comunicación: Stephen Perkins, E. A. Vigo (1996) "Pequeña historia de mis ediciones”.

\section{F- ARCHIVOS CONSULTADOS:}

Archivo Centro De Arte Experimental Vigo.

Archivo Instituto Di Tella, Universidad Torcuato Di Tella.

Archivos Sonoros del ITDT. Archivo Fernando Von Reichenbach. Universidad Nacional De Quilmes. 
